

anterts
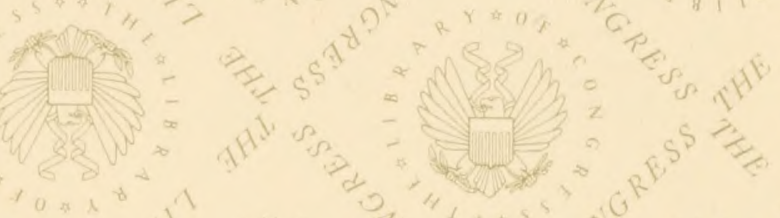

$=0$ com

ations

$\mathrm{AO}^{\mathrm{O}}$

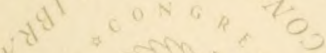
原

?

(t)

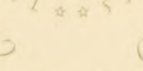

$00^{\circ}$

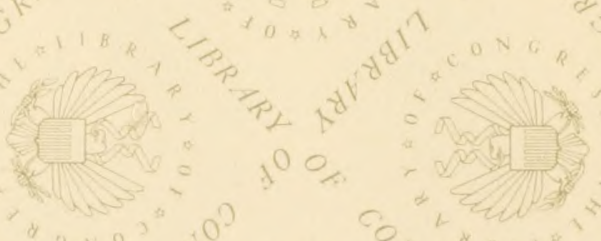

(n)

(Ant)

(a)

100

(स) tक

-

"0 $0^{\circ}$

$\left.R^{2}\right)^{2} / 2$

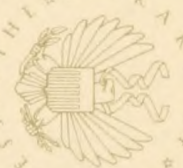

100

(1)

Can $=0$ sto

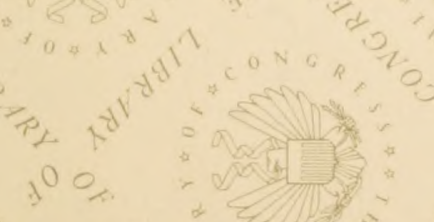

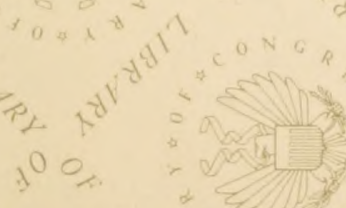

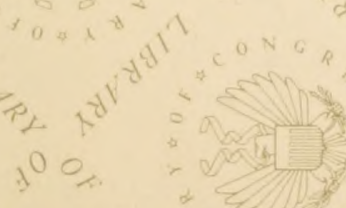

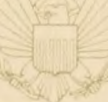







\title{
GARDENING FOR PROFIT;
}

A GUIDE TO THE SUCCESSFUL CULTIVATION

\author{
OF THE
}

MARKET AND FAMILY GARDEN.

ENTIRELY NEW AND GREATLY ENLARGED.

BY

PETER HENDERSON,

JERSEY CITY HEIGHTS, ז.. J.

ILLUSTRATED WITH NUMEROUS NEW ENGRAVINGS.
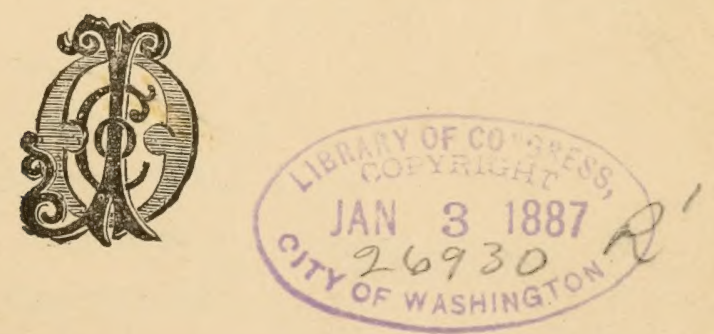

NEW YORK :

O. JUDD CO., DAVID W. JUDD, PRES'T, 751 B R O A D W A Y.

$188 \%$. 
Entered, according to Act of Congress, in the year 1886, by the O. JUDD CO.,

In the Oftice of the Librarian of Congress, at Washington. 


\section{CON'TE NTS.}

Introduction

vii

Preface to Second Edition ................................... $x$

Preface to Third Eaition ....................................... xi

Chapter I.

The Men Fitted for the Business of Gardening

Chapter II.

The Amount of Capital Required and Working Foree per Acre 17

CHAPTER III.

Profits of Market Gardening

CHAPTER IV.

Location, Situation and Laying Out

Chapter V.

Soil, Drainage and Preparation 25

Chapter VI.

Manures 33

Chapter VII.

The Use and Management of Cold Frames 44

Chapter VIII.

Formation and Management of Hot-Beds 56

CHAPTER IX.

Forcing-Pits for Greenhouses 63

Chapter X.

Wide Greenhouses for Forcing Vegetable Crops 73

Chapter XI.

Seeds and Seed Raising 89 (III) 


\section{CHAPTER XII.}

The Use of the Feet in Sowing and Planting-

Chapter XIII.

How, When and Where to Sow Seeds ....................... 103

CHAPTER XIV.

Transplanting

Chapter XV.

Vegetables-Their Varieties and Cultivation

CHAPTER XVI.

When to Sow and Plant in the Southern States

CHAPter XVII.

Packing Vegetables for Shipping 816

Chapter XVIII.

Preservation of Vegetables in Winter.

Chapter XIX.

Insects

Chapter XX.

Culture of Small Fruits 325

Chapter XXI.

Implements 344

Monthly Calendar 359 


\section{L L US T R A T I N S .}

Asparagus Beetle ............ 128

Asparagus, Manner of Planting 123

Drains, Board.............. 31

Flat Stone ........... . 30

Rubble ................ 30

Tile, Horseshoe _... . . . . . . 29

Forcing-pits, Heated by Flue_ 71

Forcing-pits, Heated by Water

Pipes . . . . . . . . . . . . . 64

Greenhouse Heated by Flue _. 86

End Section _............. 87

Greenhouse for Forcing Vege-

tables.

Cross Section

Glazing, Improved Method of IMPLEMENTS.

Asparagus Buncher .......... 355

Asparagus Knife.......... 355

Dibber . . . . . _ _ _ . . . . . . . 356

Drill, Wheel-hoe, Cultivator

and Plow Combined....... 351

Fork, Digging _..._._..... 346

Garden Line Reel ......... 355

Harrow, Acme . . . . . . . . . . 348

Dise _... . . . . . . . . . . 349

Garden ..... . . . . . . . 346

Triangular Adjustable ... 347

Hoe and Cultivator, Horse,

Planet $\mathrm{Jr}$.

357

Jouble-wheel

354

Prong:

350

Scuffle

350

Horseradish Grater- . . . . . . . 356

Marker, Double

352

Rapp's Adjustable _... . . . . 352

Plow, Miner's Subsoil _....... 345

Roland Chilled.......... 344

Skeleton _............. 347

Slip Share for

345
Rake, Steel .... . . . . . . . . . 350

Roller, Garden . . . . . . . . . . . . . 351

Spade, Ames First Quality . . _ 346

Pump, Force, Douglas ....... 66

Straw-mat, Making a _........ 61

SMALI FRUITS.

Blackberry, Kittatinny . _..... 335

Wilson _... . . . . . . . . . 335 .

Gooseberry, Houghton's Seed-

ling . . . . . . . . . . . . . . 340

Grape, Niagara ............ 341

Raspberry, Cuthbert ......... 337

Gregg ............... 338

Hansell _... . . . . . . . . 338

Strawberry, Jersey Red_._... _. 331

Sharpless ............... 332

The Jewel _... _. _ _._._. 333

The Henderson _......... 329

VEGETABLES, VARIETIES OF :

Artichoke, Green Globe . . . . . 129

Jerusalem . . . . . . . . . . 130

Bean, Earliest Red Valentine - 133

Golden Wax . . . . . . . . . 135

Lima, Jersey Extra Early - 137

Beet, Egyptian Turnip _...... 140

Beet _......... 140

Eclipse .............. 140

Long Smooth Blood ...... 141

Borecole, German Greens . . . . 143

Brussels Sprouts ............ 146

Cabbage, American Drumhead

Savoy …_.......... 167

Early Jersey Wakefield... 162

Henderson's Early Summer -............... 164

Late Flat Dutch ..... _ _ 166

Carrot, Danver's ............ 172

Long Red Stump-rooted _. 172

Orange Improved ........ 172 
Cauliflower, Hender'son's Early Snowball .................. 168

Celery after Handling . . . .... 1 17 Earthed up _........... 178 Stored for Winter........ 181 Henderson's Golden Dwarf 185 Henderson's Half Dwarf _ 188 White Plume _........... 186

Celeriac _................ 188

Dwarf Apple-shaped ..... 190

Corn, Sweet, Marblehead _... 198 Minnesota _............. 198

Stowell's Ever@reen ...... 198

Cucumber, Early Russian _... 202 Gherkin _............... 202

Improved White Spine _ _ 202

Egg Plant, Black Pekin _. . . . _ 205

New York Improved _. . . . 205

Endive, Green Curled _....... 207

Horseradish. . . . . . . . . . . . . 211

Set _............... 209

Kohlrabi_............... 212

Leek, Musselburg............ 214

Lettuce, Black Seeded Simpson 220

Farly Curled Simpson _... 219

New York _............. _ 222

Paris White Cos......... 222

Salamander _............ 221

Melon, Musk, Baltimore_... . . 229

Golden Netted Gem ..... _ 228

Hackensack ............ 228

Montreal Market........ 2:29

Melon, Water, Icing _......... 232

Scaly Bark_.............. 232

Striped Gypsy _. . . . . _ _ 231

Nushrooms _.................. 23j

Onion, Extra Early Flat Bed 251
Onion, Giant Rocea_........ 253

Large Red Wethersfield _ - $\$ 51$

Southport Large Yellow

Globe _............... 252

White Portugal _......... 253

White Tripoli .......... 2jt

Yellow Globe Danvers. . . - 25๊2

Parsley, Emerald _..._....... 256

Pea, American Wonder..._._. 262

First of All _............ 260

Stratagem _... . . . _. 263

Potato, Clark's No. 1......... 269

Empire State............ 268

Perfect Peachblow _..._._. 270

Radish, Beckert's Chartier.... 276

Early Round Dark Red. _ 277

French Breakfast _....... $27 \%$

Long Scarlet Short-top _. 275

White-topped Turnip _. _. 287

Yellow Summer Turnip . - 2rr

Rhubarb, St. Martin's . . . . . . . 281

Salsify _.....

Sea Kale _................. 284

Spinach, Long Standing ..... _ 289

Norfoll Savoy-leaved _. . 288

Thick-leaved ........... . 289

Squash, Essex Hybrid _. . . . . . 293

Hubbard_ . . . . . . . . . . . . . 284

White Bush Scalloped._._ 293

Tomato, Mikado _. _. . _. _. _ 302

Perfection - . _..._. 303

Turnip, Extra Early Milan _. _ 305

Purple-top White Globe_. 306

Ruta Baga, Improved

American Purple-top_._ 307

White Egg.............. 305

Wagon, Market ............. . . 353 


\section{INT IIODUCTION。}

I hope it is no egotism to state that in both the Floral and Vegetable departments of Horticulture, in which I have been engaged for the past eighteen years, I have been entirely successful. Now, we know that success only is the test of good generilship, and it follows that, having been successful, I have thus earned my title to merit. From this stanapoint, I claim che right to attempt the instruction of the student of horticulture in the tactics of that field.

We have very few works, either agricultural or horticuitural, by American authors, whose writer's are practical men, and fewer still of these who are men that have "risen from the ranks." The majority of such authors being ex-editors, lawyers, merchants, etc., men of means and education, who, engaging in the business as a pastime, in a year or two generonsly conclude to give the public the benefit of their experience.

The practical farmer or gardener readily detects the ring of this spurious metal, and excusably looks upon all such instructors with contempt. To this cause, perhaps more than any other, may be attributed the widespread prejudice against book-farming and book-gardening, by which thousands shut themselves off from information, the possession of which might save years of useless toil and privation. 
I have some pride, under present circumstances in saying that I have had a working experience in all departments of gardening, from my carliest boyhooil, and eren to-day am far more at home in its manual operations than its literature, and have only been induced to write the following pages at the repeated solicitations of friends and correspondents, to whose inquiries, relative to commercial gardening, my time will no longer allow me to reply individually. I have endearored, in this work, to be as concise and clear as possible, aroiding all abstruse or theoretical questions, which too often serre only to confuse and dishearten the man who seeks only for the instruction that shall cnable him to practice.

Although the directions given are mainly for the market garden, or for operations on a large scale, yet the amateur or private gardener will find no difficulty in modifying them to suit the smallest requirements. The commereial gardener, from the keen competition erer going on in this ricinity of large cities, is, in his operations, taxed to his ntmost ingenuity to get at the most expeditious and economical methods to produce the finest crops-methods that we believe to be superior to those in general nse in private gardens, and which may, with profit, be followed.

Onr estimates of labor. I trust, will not be orerlouked ; for I know it is no uncommon thing for gentlemen to expect their gardeners to do impossibilities in this way. The private garden camnot be properly cropped and cared for with less labor than can our market gardens, and these, we know, require nearly the labor of one man to an acre, and that, too, with every labor-saring arrange- 
ment in practice. When the care of greenhouses, or graperies, is in addition to this, extra labor must be given accordingly, or something must suffer.

The greatest difliculty that has presented itsclf to me in giving the directions for operations, has been the dates; in a country having such an area and dirersity of temperature as ours, directions could not well be given for the extremes, so as the best thing to be done under the circumstances, I have taken the latitude of New York as a basis, and my readers must modify my instructions to suit their locality. The number of varieties of each vegctable described here is rery small in comparison with those that are known, or the seeds of which are offered for sale. I have given only such as I have found most serviceable. 'Those who wish for a more extended list are referred to the seed catalogues.

Jersey City Heights, N. J., December 1st, 1866. 


\section{PREFAOE TO SECOND EDITIOA.}

It is now soren year's sines I wrote " (iardening for Protit." ant. although it has met with a reseption that hus ben exededingly flatiering. I have erer sinee felt that it was too hurriedly done. and far from complete. The sugatitions and yuteries mate to me by some of the many thensands of its readers. have been the mesus of dereloping many new ideas and plans lerbetter enltiration, which I have the pleasure to embody in this adition. I new edition of at work of this kind heemes neessary erery fow years. to enable it to keep paee with the improsement in rarieties, as well als in modes of culture. In the present edition, the part of the work treating of rameties hats been caredully revise.t. and we helieve the linds deseribed to be. as a whole, the best in their respective clatsis's this day in use, cither for prisate or eommereial purposes. It is aratifying w know, ly letters from erery section of the country, that the publication of this work hats been the

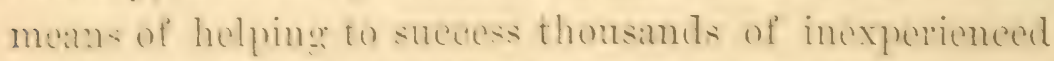
cultirators of the soil, of both classe:- those * Gardening: for Pleasure," as well at those ". Gardening for Profit." It is true that some that hate been induced to engage in the husiness by ratuling my hook have failed. Such must erer be the ens-less or :nore-in erery-business: but I have gocd reatson to believe that the perentage of failures an gamening is less than that in almost any other business.

\section{Peter Hexdelsor.}

Jersey City Heights, N. J., Jamuary, 18\%4. 


\section{PREFACE 'TO 'TIIIII) EIITION.}

It is twenty yoars since " Gardening for Profit" was first written, and twelve years since the second edition

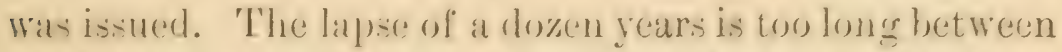
cditions of a work of this character, for new methods of collure, new and improverl varieties of regetal)les and fruts are yearly coming into use, but my life has been more than an orrinaril; busy one, and I have never been aible, until now, to find suficient time to set ont another erlition as full and complete as the necestics of the widely extending nature of the business demands. The present edition, it will he seen, has a much wirler seope than either of the former editions, embracing as it does not only the forcing under glats of some important fruits and rergetables not lefore touched upon, but also detailing the methods of colture of the Jarling small fruits, which properly come under the head of " Gardening for Profit."

At the present writing, the business of gardening in such large cities as New York, Philadelphia, Boston or Chicago, is by no means so profitable as formerly, mainly owing to the vasc competition from the Sonthern states, but that it is yet far more plofitable than farm operations for the caprital and labor employer-in almost every section of the comntry-cimnot be doubted. There are thonsands of firmers adjacent to the smaller towns, villages, hotels, watering places, and summer boardinghomes, where the want at the fable of fresh regcotables and fruits is most conspicuous. In many such places it is unquestionable that if the farmer would devote a few 
aderes to the culcivation of lruits or regetables, or both. the chaness are more than equal that he would find it to be more protitable tham ten times the amount of land entivated in the ordinam farm erops. I have had hetters from thousands of men, who, following the instructions of the formere editions of " Gardening for Profit," have thanked me for indueing them to start in this salle and profitable business.

Jersey City Heights, N. J.,

Peter Henderson.

December 15th, $18 s 6$. 


\section{GARDENING FOR PROFIT.}

\section{I A P ' $\mathrm{T} E \mathrm{R}$ I. \\ THE MEN FIT'IED FOR THE BUSINESS OF GARDENING.}

Although we shall here show the business of gardening to be a profitable one, lot no man deceive himself by supposing that the profits are attainable without steady personal application.

Having been long known as extencively engraed in the business, I am applied to by seores every seatson, asking how they can make their lands available for garden purposes. 'The miljority of these are city merchants who, for investment or in anticipation of a rural retreat in the antumn of their days, have purchased a country plake, and in the meantime they wish to make it pay. They have read or heard that market gardening is profital)?e, and they think it an ensy matter to hire a gardener to work the place while they attend their own mereantile duties as before. They are usually gentlemen of horticultural tendencies, reat all the magazines and borks on the subject, and from the knowledge thus obtaines, plume themselves with the conceit that they are able to guide the machine. 
Many huncireds from our large cities delute themselres in this way erery season in different departments of horticulture-perhilps more in the eulture of fruits than of regetables. I have no doubt that thousands of acres are anmually phanted, that in three years afterwards are abandonel, and the golden dreams of these sanguine gentlemen forever dissipated. Although the workers of the soil will not, as a class. compare in intelligence with the mercantile men of the cities, it is a mistake to suppose that this want of education o" intelligence is much of a drawback when it comes to enltivating strawberries or cabbanes. 'True, the untutored mind does not so readily comprehend theoretical or suintific knowledge, but for that rery reason it becomes more thoroughly platedical. and I must say that, at far als my experience has gone (without being thought for a moment to derogate aganst the utility of a trite scientific knowledge in all matter's pertaining to the suil), that any common labo:er with ordinary sagaleity and twelre months working in a garden would have a far better chance of slicess, other things being eyual. than another withont the practice, even if he hat all the writings, from Liebig's down, at his fingers ends. Not that a life-long practice is ahsolutuly necessary to sucess, for I can see from where I wrice the homes of at least half a dozen men, all now well to do in the world. not one of whom had any knowledge of gardening. either practical or theoretical. when they started the business, but thes were all active urorling men, "actuil settlers" and depended alone on their own hearls and hands for success, and not on the doubtful judgment and industry of a hired gardener. who had no further interest in the work than his monthly salary.

"D. H." writes me thus: "I am a book-keeper with a salary from which i can sare but little: but 
by rigid ecoiomy during it series of years, I have scraped together \$2,000. My health is only ordinary. With that capital can I snceed as a market gardener by hiring an experienced gardener?" This inquiry is a type of hundreds 1 now receive annually, and to which may be given this general reply: From the nature of the question, no very definite answer cam be given, though I would say that the chances are two to one against success. It is a well-known fact that the chances of success in mereantile business are even far less than this. "D. H." may be a capital book-kecper, yet it is doubtful if he has the necessary endurance to stand the wear on the constitution that market gardening inrolves. If he concludes to start at gardening, he is more likely than not to select a soil entircly unsuited to the purpose. In most sectioas of the country there are fewer soils suitalle for the eultivation of regetables than there are those that are unsuitable. Again, he is an educated man, and this rery fact would be rather against him than otherwise, as it would naturally incline him to refined society and associations, in which, I am sorry to say, the beginner in market gardening camnot afford to indulge. The hiring of an "experienced gardener", would take all the cream off of the profits. Experienced market gardeners are exceedingly scarce. Our laborers in the market gardens are generally an ignorant class with very little ambition, and not one in a hundred of them is fit to mannge. T'hough employing serenty hands myself, I have often been sadly at a loss to select from them a suitable man as foreman, though many of them had been with me for year's. When one shows the necessary ability, his services are much sought after, and he readily commands $\$ 500$ or $\$ 600$ a year and board. Clerkis, bookkeeper:, and eity-bred men generally wo not the ones 
Iikely to be successful as workers of the soil. Few of them have any eonception of the labor required to be done to insure suceess. I started business in Jersey City, at the age of twenty-three, with a call)ital of \$.50), which it hat taken me three rears to make as a working gariener. For the first five years that I was in business, I can safely say that we worked, on an arerage, sixteen lours a day, winter and summer, with scarcely a day for recreation. Now, the majority of clerks. hook-keepers or salesmen do not mork much more tham laalf that time, and few of them conld endure this lengthened strain in a summer"s sum, and without this endurance suceess is out of the question; for all lecginners to-clay must do as I did, until they get their heals above water, or else, such is the competition, they must go to the wall in the business. I therefore caution all such who are not in robust health to aroid either farming or gardening if their neesexties require them to males a living therely. That the work of the garderer is conducive to hcalth, when that has not bern impaired, there is no question; but the long hours of labor and the exposure necessary to suceess, must toll agrinst a feeble constitution.

Whe busincs of market gardening, though pleassnt, healthful, and profitable, is a laborious one, from which any one not areustomed to manual labor would quickly shrink. The labor is not what mily be termed heavy, but the hour: are long:-not less than an arerage of twelve hours a day, winter ant summer. No one should begin it after passing the meridian of life; neither is it fitted for men of weak or feeble physical orgunzation, for it is empluatically a business in which one has to rough it. In summer planting, when it is of the ulmost importinee to get the plants in while it rams, we repeatedly work for hours in 
drenching rains, and woe be to the "boss" or ioreman who would superintend the operation under the protection of an umbrella. He must take his chances with the rank and file, or his prestige as a commander is gone.

\section{H A P T E R I .}

\section{THE AMIOUNT OF CAPITAL REQUIRED AND WORKING FORCE PER ACRE.}

The small amount of capital required to begin farming operations, creates great misconception of what is necessary for commercial gardening; for, judging from the small number of acres wanted for commencing a garden, many suppose that a fow hundred dollars is all sufficient for a market gardener. For want of information on this subject, hundreds have failed, after years of toil and priration. At present prices (1886), no one would be safe to start the business of regetable market gardening, in the manner it is carried on in the neighborhood of New York, with a capital of less than $\$ 300$ per acre, for anything less than ten acres; if en a larger scale, it might not require quite so much. The first season rarely pays more than current expenses, and the capital of $\$ 300$ per acre is all absorbed in horses, wagons, glass, manures, etc. If the capital be insufficient to procure these properly, the chance of success is correspondingly diminisher.

I can call to mind at least a dozen cases that have occurred in my immediate neighborhood within the last ten vears, where steady, industrious men have utterly failed, and lost erery dollar they possessed, merely by attempting the businese with insufficient capital. A few rears 'n a man called npon me and stated this he was about 
to become my neighbor ; that he had leased a place of twenty acres alongside of mine for ten years, for $\$ 600$ per year, for the purpose of growing regetables, and asked me what I thought of his bargain. I replied that the place was cheal, enough, only I was afraid he had got too much land for that purpose if he attempted the working of it all. I further asked him what amount of capital he hard, ame he told me that he had about $\$ 1,000$. I said. that I was sorry to discourage him, but that it was better for him to know that the amount was entirely inalequate to begin with, and that there was not one chance in fifty that he would succeed, and that it would be better, eren then, to relinquish the attempt ; but he had paid $\$ 150$ for a quarter's rent in adrance, and conld not be persuadea from making the attempt. 'The result was as I erpected ; he hegan operations in iarch, his little capital was almost swallowed up in the first two months, and the few crops he had put in were so inferior that they were hardly worth sending to market. Without money to pay for help, his place got enreloped in weeds, and hy September of the same year he abandoned the undertaking.

Ind the same amount of caphital and the same energy been expended on three or four acres, there is hardly a doubt that suecess would have followed. Those who wish to live by gardening, camnot be too often told the danger of spreating orer too lare an area, more particularly in starting. IVith a small capital, two or three acres may he profitibly worked: while if ten or twelre were attempted with the same amount, it would most likely result in failure. Many would suppose that if three arces

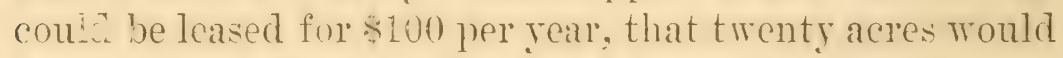
be cheaper at $\$ 500$; nothing can he more elroneons, nuless the caterpuiso be backed up with the necessary capital-\$300 per acre. For be it known, that the rental or interest on the ground used for garlening operations is usualiy nnly about ten per cent. of the woring expensos, 
so that an apparently cheap rent, or cheap purchase, does not very materially affect the result. It is very different from farming operations, where often the rent or interest on purchase money amounts to nearly half the expenses.

The number of men employed throughout the year on a market garilen of ten acres, within three miles of market, planted in close crop, averages seven ; this number is varied in proportion. somewhat, according to the quantity of glass in use. I have generally employed more than that-fully a man to an acre-but that was in consequence of having in use more than the ordinary proportion of sashes. This may seem to many an munecessary force for such a small area, but all our experience proves that any attempt to work with less will be unprofitable. What with the large quantity of manure indispensable, serentyfive tons per acre; the close planting of the crops, so that every foot will tell; the immense handling preparatory for market, to be done on a double crop each season, one marketed in mid-summer, another in fail and winter, a large and continued amount of labor is required. On lands within a short distance of market-say two milestwo horses are suflicient; but when double that distance, three are necessary. When three animals are required it is most profitable to use a team of mules to do the plowing and heary hauling of manure, etc., and do the marketing by a strong, active horse. Erery operation in cultivating the ground is done by horse labor whonever practicable to do so; but it must be remembered that the crops of a garden are rery different from those of a farm ; the land is in most cases (particularly for the first crops) planted so close that nothing will do to work with but the hoe or hand cultivator (See Implements). 


\section{H A P T E R I I .}

\section{PROFITS OF MARKET GARDENING.}

This is rather a diflicult if not a delicate matter to touch, as the protits are so laree in some instances as almost to exceed belied, and so trifling under other conditions as to be hardly worth niming. These hatter conditions, howerer, are generally where men hare stalled on unsuitalile soils, too far from malliet. or without moner enough to hate erer got thoroughly under way. But as the object of this work is to endearog to show how the business cam be male a protitable one. I will endearor to approximate to our a!eraye protits pere acre. As a rule it may he premises

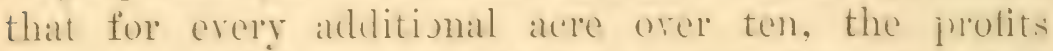
per acre will to some extent diminish, from the fact that a litroce arear camnot he so thopoughly worked as a smaller one: hesides, there will often he al loss in price by having to crowel larerer quantities of produce into matret and to leave it in the hands of inexperienced salesmen. The majority of our produets are quickly perishable and must he solel whon reaty.

'The arerage profits for the past ten reals on all well cultivated market gardens in this riemity have only been about $\$ 200$ per ace. For the five years from 1 shi to 1 sibto they were perhaps twice that amount: hut those were years of "watr plices," such as we will be well (e)tltent nerer to see again. These profits are for the moducts of the open gardens only, not of the frames or forcine-pits, which are alluded to elsewhere. These amounts are for the neighborhood of New York, and, I think. from the rast competition in business. are now a low arerage for the majority of towns and eities thromghout the comotry. Certam it as that from one 
lands, even at at value of from 81,000 to 5,000 pis acre, we can (and do) profitably grow and supply the majority of towns within fifiy miles around New York with fresh regetables. In these cases, no doubt, the consumer pars full double the price that the raiser receives, for they generally pass through the hamrts of two classes of "middlemen" before they reach the consumer, besides which, there are extra charges for packing, shipping and freight. Thus the coisumer in a country town, where land often is not as much in value per acre as it is here per lot, pars trice the value for his partially stale regetables or fruits, which he receives rarely sooner thin twenty-four hours after they are gathered.

In most of such towns market gardening, carried o: after our mamner, would minquestionably be highly remunerative; for if these articles were offered to the consumer fresh from the gardens, he would certainly be willing to pay more for his home-grown products than for the brisised and battered ones that are freighted from the metropolis. Take, for example, the article of Colery, which pays us rery well at two cents per root. There is hardly a city or town in the country, except New Ycrk, but where it sells for twice, and in some cares six times, that price per root; ret the great bulk of this article sold in Philadelphia is sent from Neiv York, for which the consumer must pay at least double the price paid here, for it is a bulky and expensive article to pack and ship, and must of a necessity pay a profit both to the agent hrre and in Philadelphia, which of course comes out of the pocket of the consumer. This is only one of many such articles of which the culture is imperfectly understood, and which the great market of New York is looked to for a supply.

The following will show the rate of receipts and 
expenditures for one alede of a lew of the leading articles we entivate, taking the arerage of the past ten years, from the arounds that hare been brought up to the proper standard of fertility necessary to tise market garden :

EXPENDITURES FOR ONE ACRE.

Labor $\$ 480$

Horse-labor …

MIanure. 75 tons . . . . . $\ldots 0$

Rent _...

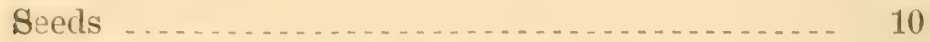

Wear and Tear of Tools, etc. .................. 10

Cost of Carriage to Market and Selling.......... 100

$\$ 800$

RECEIPTS FOR ONE ACRE.

12,000 Early Cabbages, at 4 eents per head . . . . . 8480

14,000 Lottuce, at 1 cent per head . . . . . . . . . . . 140

30,000 Celery, at 2 cents per head............ 600

$\$ 1,220$

800

$\$ 420$

The rotation erops of Early Beets or Onions, follomed by ITorseratish or Sircet Iferbs as a second erop, give nearly the sume results. 


\section{H A P T E R I V.}

\section{LOCATION, SITUATION AND LAYING OUT.}

Locatron.-Before deciding on the spot for a garden, too much caution camnot be used in selecting the locality. Mistakes in this matter are often the sole cause of want of success, even when all other conditions are farorable. It is always better to pay a rent or interest of $\$ 50$, or even $\$ 100$, per acre on land one or two miles from market than to take the same quality of land six or seren miles distant for nothing; for the extra expense of teaming, procuring manure, and often greater difficulty of ol,taining labor, far more than counterbalance the difference in the rental of the land. Another great object in being near the market is that one can thereby take adyantage of the condition of price:, which often in perishable commodities like garden produce is rery rariable. It not infrequently happens that, from scarcity or an unusual demand, there will be a difference of $\$ 15$ or $\$ 20$ per load, even in one day; hence, if near a market, larger quantities can be thrown in than if at a distance, and the adrantage of higher rates be taken.

This disadrantage in distance only holds good for perishable articles that are bulky. The lighter and valuable crops, sucli as Tomatoes, Cucumbers, Lettuce, Radishes, cte., from more southern and earlier Iocalities are grown often hundreds of miles distant and freighted to market at a handsome profit. So with the less perishable articles, such as dry roots of Cilrrots, Beets, Parsnips, Horserarlish, etc. But the necessity for nearness to market for the bulky and perishable crops, such as Cabbage, Lettuce and Celery, is of importance. 
SITLATON AND LAYIXG-OCT.-It is not always that choice can be made in the situation of or aspect of the ground; but whenever it can be made, a level spot should be selected, but if there be any slope, let it be to the south. Shelter is of great importance in producing early crops, and if a position can be found where the wind is broken off by woods or hills to the north or northwest, such a situation would be very desirable. In the absence of this we find it necessary to protect, at least, our forcing and framing grounds, with high board iences, or, hetter yet, be'ts of Norway spruce. The most convenient shape of the garren is a square or oblong form; if square, a road twelve foet wide should be made through the center, intersected by another road of similar width ; but if oblong, one loal of the same width rumning through the center in a plot of teu acres will be sufficient.

Tegerable IIotse, Wells, Etc.-Connected with crery market garden is a regetable homse, usually about twenty-fire feet square, having a frost-proof cellar, over which is the regetable or washing house. In the second story is a loft for seeds, storage, ete. Immediately outside the regetable house is the well, from which the water is pumped to a tub in one corner of the building, on each side of which are erected benches of convenient height, on which the workmen tie and wash the regetables preparatory to sending them to market. 


\section{II A P T E R V.}

\section{SOIL, DRAINAGE AND PREPARATION.}

In the course of an experience of nearly forty years as a market gardener, in the neighborhood of New York, I have had, in the prosecution of the business, the opportunity of reclaming large tracts of very different varities of soil. Some of these, almost the first season, yielded a handsome profit, while with others, the labor of years, and the expenditure of large sums in extra manuring and draining, have never been able to bring these uncongenial soils up to the proper standard of productiveness.

On many occasions I have referred to the great importamce of selecting a proper quality of soil for all gardening and farming operations, and the fact cannot be too often nor too forcibly impressed that success hinges more directly upon this than on anything else. 'Thousands are every year ruined by a bad selection of soil. I have scores come to me in the course of every season for advice in this matter of soils, but in most instances the advice is asked too late; the majority of the applicants having been unfortunate enough to buy or rent land that they had been led to believe was excellent, but only "run down." In my opinion this widespread notion of "exhausted lands" is, to a great extent, a fallacy, and that most of the lands said to be so exhausted never were good, and nothing short of spreading a good soil over them a foot thick wonld ever make them available.

The practical tẹst of the importance of a good soil for market garden operations is clearly shown in a score of cases in my vicinity. Wherever a man of ordinary industry and intelligence has been fortunate enough to locate on land that is naturally good, his success has been certain, while others that have not been able to procure such land have had to struggle far harder for less returns; in 
some few instances entire failure has been the case, for the reason that the soil started on was unlited for the purpose.

The variety of soil that we value above all others is an allurial saline deposit, rarely found orer more than a mile inland from the tide mark. It is of dark heary loam, containing throughout a large mixture of decomposing oyster and other shells; it arerages from ten to thirty inches deep, overlaying a subsoil of yellow sandy loam. 'The next kest rariety is somewhat lighter soil, both in color and specific gravity, from eight to fifteen inches deep, having a similar subsoil to the abore. 'Then we have a still lighter soil, in both senses of the term, in which the sand predominates over the loam, and laying on a subsoil of pure sund; this rariety of soil is well adapted for Melons, Cucumbers, Swert Potatoes, Raldjishes and 'Tomatres, but is almost useless for growing (arops of Onions, Cabbages or Celery. We have still another kind of soil, which I place last, as being of the least value for the purpose of growing regetables; this variety, singularly enough, is found on the highest points only, its color being somewhat lighter than that of the variety first mentioned: it is what is termed a clayey loam, averaging ten inches in depth, under which is a thick stratum of stiff bluish clay. IIth a subsoil of this nature it is almost useless to attempt to grow early regetables for market purposes.

I have just such a soil as the last mentioned, thoronghly drained three feet deep, the drains only eighteen feet anart. and ret in another garden that I work, haring the two fist nimed soils and only one mile distant, manured and eultivated the same in all respects, fruts and regetables are ready from fire to ten dars earlier. But for the succession, or second crops, such as Celery, ete., this stiff, cold soil is just what is wanted; earliness with these is not the object, and its "coldness" is congenial to the 
roots of the lise crop. But if selection can be marle for general purposes, choose a rather dark-colored loamy soil, neither "sandy" nor "clatyey," as deep as can be found, but not less than twolve inches. If it overlay a sancly loam of yellowish color, through which water will pass freely, you have struck the right spot, and abundant crops can be raised under proper mamagement. When selecting land, do not be deceived by any one who tells you that if not naturally good, the soil may be made so hy enltivation and manure, 'These will help, certainly, but only as education improves the shallow minrl. Luxuriant crops can no more be expected from a thin and poor soil-no matter how much it is cultivated-than fertile ideas from a shallow brain, ellucate it as you will. The best guide in the selection of land for garden purposes is to closely examine and compare the erops on lands adjacent; if, under ordinary culture, you see these lands producing good crops of Corn, Wheat, or Potatoes, or where the meadows give two or three tous of Hay to the acre, it is reasonable to expect that land on the same level as that in question will be of similar quality. But should the land to be selected for garden purposes be in a region where there is nothing but timber or the natural grasses to guide, then the best thing to do is to carefully dig in different parts of the land to ascertain the depth and quality of the top soil, and above all the textmre of the subsoil, which, if it be of stiff, adhesive claly, such as brickis could be made from, turn back at once and let that soil alone, if desired for garden work. To the entirely inexpericuced person, who is about to lease or purchuse land for garden work, I would advise lim to get, if possible, an entirely disinterested practical farmer or gardener to examine the soil and general surroundings of the locality before entering on the undertaking; for, as before said, the quality of the soil is all important to success. 
Drasage. - Every oprerator in the soil concedes the importance of drainage, yet it is really astonishing to observe how men will work wet lands, year after year, wasting annually. by loss of cropse twice the amount required to thoroughly drain. A most industrious Gorman, in this ricinity, cultivated about eight acres for three years, barely making a living; his svil was an excellent juam, but two-thirds of it was so "sponer." that he could never get it plowed until all his neighbor's had their erops planted. Driving jast one day I hailed him, asking him why he was so late in getting in his erop, when he explained that if he had begm sooner his horses would have "borged" so he might never have got them out again. I suggested draining. but he replied that would never pay on a leased place: he had started on a ten years" lease, which had only seven rear's more to rmo, and that he would only be improring it for his landlord, who would allow him nothing for such improrement. After some further conversation I asked him to jump into my wagon, and in ten minutes we alighted at at market gallden that haul, six years before. been just sueh a siramp hole as his awn, but now (the midlle of Mray) was luxuriant with vesetation. I explained to him what its former condition hat heen, and that the inresting of $8.5(4)$ in drain tiles would, in twelre months, put his in the same condition. He, heing a shrewd man, acted on the anviee. and at the termination of his lease purehaned and paid for his eight acres $\$ 12.000$, the saring of six years on his drained garden. 'Tlis was in war times, when prices for all products were double what they are now. I honestly helieve that had he gone on without draining he would not have made $\$ 1,200$ in twelve years, far less $\$ 1 ?, 000$ in six years. Mry friend attributes his whole sucess in life to our accidental meeting and conversation that May mornmg, and consequently I have no stauncher friend on earth than he. 
The modes of draining must be guided to a great extent by circumstancis. Wherever stones are abundant on land, the most economical way to dispose of them is to use them for drainage. I have also nsed with great suceess in a wet, sindy subsoil, where digging was easily done, brush from adjacent woods, cut off and trodden firmly two feet deep in the buttom of drains five feet decp, overlaying the brush with straw or meadow hay before covering in. Drains so made hare answered well for nearly a dozen rear's, and in sitnations where no other material offers, they will at least answer a temporary purpose. But unquestionably, when at all attainable at anthing like reasonable cost, the cheapest and most thorough draning. is by tile. We nse here the ordinary horeshoe or

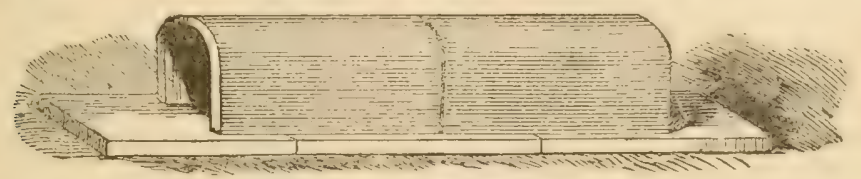

Fig. 1. - Forseshoe tile.

round tile-three-inch size for the laterals, and from fire to six inch for the mains. On stiff, clayey soils we make onr lateral drains three feet deep and from fifteen to eighteen feet apart; on soils with less compact subsoils, twenty to twenty-five fect distant. We find it cheaper to use the horseshoe than the sole tile. In lien of the sole we cut common hemlock boards in four pieces-that is, cut them through the middle-and split these again, making a board thus cut run about fifty feet. These are placed in the bottom of the drains and prevent the agging of the tiles in any particular spot that might be soft (figure 1). We are particularly careful to place, after setting, a piece of sod, grass down, orer the joinings of the tiles to prevent the soil from getting in and stopping up the drainsge.

The manncr of constructing stone drains is gor- 
erned by the character of the stone on hand: if round, they are best made as rubble drains (figure 2), but if that. Which is much the best, they are made as represented by figure :3; but in either case the same care must be exercised in covering orer the top thoroughly with sod, shavings, straw or some similar material, in quantity sufficient to prevent the soil from washing in and filling up the cavity.

Cheap drains of lsemlock boards are found to be very useful for wet lands and can often be obtained when the regular tiles cannot. They are usually less costly and are more quickly laid. Such drains are usu-

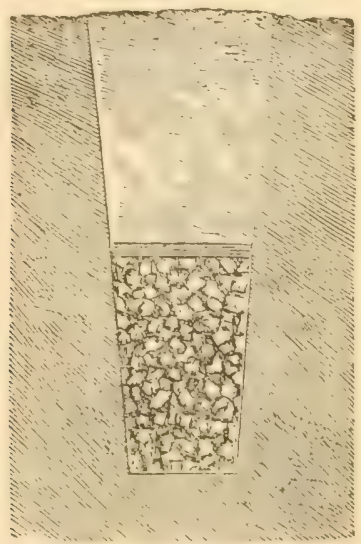

Fig. 2.-TUBBLE DRAIN.

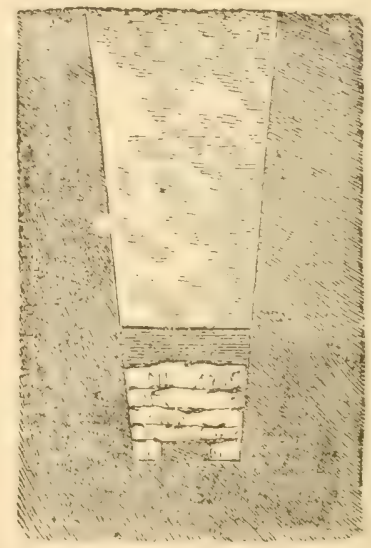

Fig. 3.-FLAT STONE DRATN.

ally made triangular, with three boards three or four inches wide, nailed edge to edge, or the better way is to put the cover on the top of the drain crosswise (fig. 4). This gives mole openings through which the water maty enter the drain, and also makes them stronger. Where roads cross a drain of this kind, it is safer to make them in this way and also to lay a plank upon the drain to distribute the pressure. Every precaution shouid be taken to have the work of draining thoronghly done. It is costly work, and if one little blunder is mate. everything may be spoiled, for a drain 
is like a chain, and if an obstruction occurs it is like a link broken-the drain is rendered useless, like the chain.

Preparation of tie Ground.-Assuming that the ground on which the garden is to be formed is in sod, the best time to begin operations is in september, October, or Norember. If draining is necessary, that should be first completed. Before the sod is plowed, it would greatly assist its rotting, if horse manure can be oltained, to spread it orer the surface to the depth of two or tnree inches. In plowing the sod under, care should be taken to have it laid as flat as possible. This can be best done by plowing shallow; and at this time there is no particular necessity for deep plowing. After plowing we

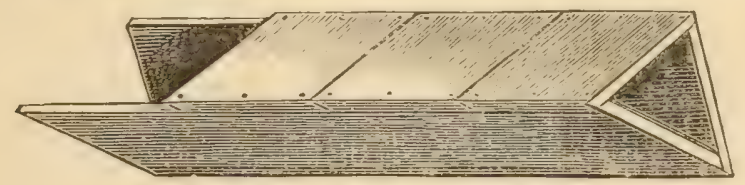

Fig. 4.-BOARD DRATN.

find it adrantageous to flatten down the furrows by running over with the back of the common harrow, or, better yet, with the shortened blades of the Acme harrow (see implements). This mellows the soil, so that it fills up the crevices left between the furrows, and hastens the decomposition of the sod. If the plowing has been done early enough in the fall, so that the sod has had time to rot the same season, it will facilitate the operations of next spring to cross plow and thoroughly harrow; but if too late, this had better be deferred until spring. After the ground has been well broken up by this second plowing and harrowing, it should again be manured orer the whole surface with rough stable manure, as much as can well be procured-there is rarely danger of 
getting too much-and the third plowing takes place, followed this time by the subsoil plow if time will permit. I have always found it best in breaking in new ground, to crop with Potatoes, Corn, or late Cabbages the first season, unless by preparation in early fall it has acquired the proper mellow state necessary for crops of garden regetables or small fruits; but it rarely happens that any amount of labor or manuring can so prepare the ground the first secson as to bring it to that high degree of tilth necessary for growing garden regetables as they should be grown, and any attempt to do so will result in a meagre crop, which will not pay-at least 11 such districts as Nerr Iork, where there is always abundance of products of the first quality. It must not be expected that the crops of Potatocs. etc., will give much profit for this unusual outiay in preparation and manure, for they certainly will not, and the begimner must be content to wait for his profits until the second season. These are certain to he realized if these preparations have been properly makle. Hence will be seen the necessity for capital in this insines, for the returns, though highly remunerative, are not always quick. 


\section{H A P'T E R VI.}

\section{MANURES.}

The quantity, cuality, and proper application of manures is of the utmost importance in all gardening operations, and few have any conception of the immense quantity necessary to produce the heary crops seen in our market gardens. Of stable or barn-yard manure, from fifty to one hundred tons per acre is used, and prepared, for at least six months previously, by thoroughly turning and breaking up to precent its hating unduly. The nsual method is to hare the manure yard formed in a low part of the garden, but if there is no matural depression, one may be made by digging out an area fifty by one hundred feet and from eighteen to twenty-four inches deep, and enclosing it by a fence about six feet in height. The wagons are driven alongside, and the green manure thrown juto the enclosure, care being taken to have it spread regularly: hogs are usually kept ujon the manure in numbers sufficient to break it up, they being fed in part by the refuse regetables and weeds of the garden.

The manure of horses is most ralued, as we consider it, weight for weight, worth about one-fourth more than that of cows or hogs; on stiff soils it is of much more benefit as a pulverizer. There are many articles-the refuse of manufactures-that are still wasted, that have great ralue as manures. Among others, and of first importance, is the refuse hops from the breweries. It is twenty years ago since they first began to be used in our gardens about New York; at first they were to be had at almost every brewery without cost, but the demand has so increased that the price to-day ranges even higher than that of the best stable manure. Aside from its high fertilizing properties, it is excellent for breaking up and pulverizing the soil, and as a top-dressing or mulching, 
cither to protect from the sun in summer, or from tho frost in winter. it has no epual. From my experieneo with this fertilizer, I consiler it to be of nourly double the ralue of that of stahle manure. It repuires to he (e)mplested in the same mamer as other manmes: it heats

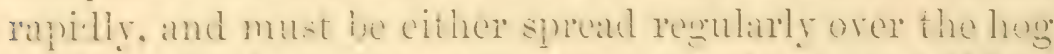
rard. or clse turned ance in fwo weaks to prevent " firefang" from riolent heating:

Another valuable refuse from our mamulatories is liho shavings and seraping from horn or whaldbone mantlfactories. The best way to render these most araibable is to empo-t them thorom proportion of one tan of sharings to hifech of manuro; the heated minure extracts hie oil from the sharings, whish is intermingled with the whole. I have on sereral accilions sen the mixture of tive tons of whildebone shaving with one orinaly stable manure make stod per arere difference in the ralue of the crop; but of comrse ste? mannfactories are not common, and it is only in cortain localitios that this fertilizer can be hat.

Inothor valuable fortilizer from munufuctories is

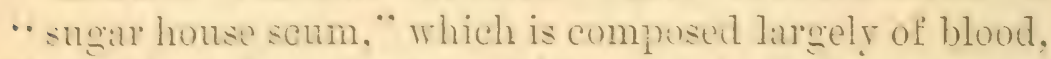
chareonl, and sareharine refuse: as it heats riolently, insteat of boing thrown in heaps hy itself. it should he compostorl with repual quantities of soil or muek, and tumed frepunty, so that the whole is thoroughly mixed : when thus composted. it malics an excellent matnure at trenty tons per acle : it is host apulied by lightly plowing, or deeply harrowing-in.

Of ancentrated manures. perhaps the best for general purposis is pure Permyian guamo : this for enelal crops. when used without the a hition of stahle manures. is put on at the rate of from 1.000 to 1,200 pounds per acre : it is first pismucd to powiter, so that it can be regularly sown orer the surface after plowing : it is then thoroughly harrowed in, and the erop is somm or planted at ones. In 
my cxperience, the next best concentrated fertilizer is

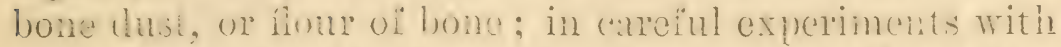

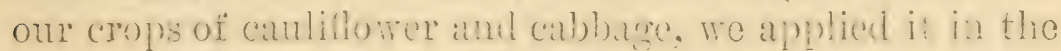

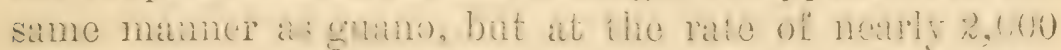

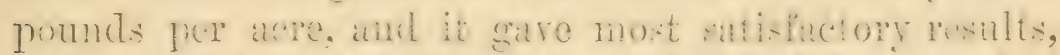

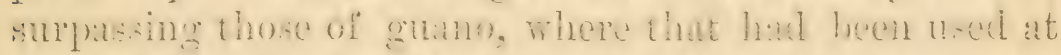
the rate of 1 , the pounds par atere. In apylyme manneses

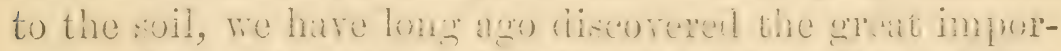
tance of an allernation of diferent kind: Whon I first

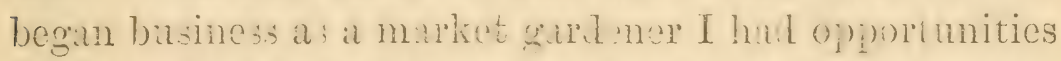
of getting lare quantitiss of night soil from the walrengers of Jersey City; this mas mixed with stable manure,

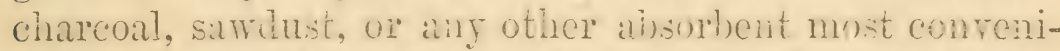
ent, and applied, so mixed, at the late of abont thirty tons per acre. The crops ruiset with this manure were enomous, for two or linee years, but it opalually began to lose cfiect, and in fire years finm the time we began

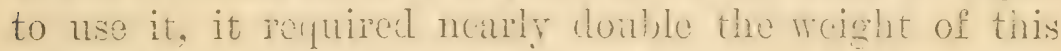
compost to problue eren an aremge crop). I then aluandonet the nec of night soil and applicel refuse hops instead, at the rate of alout sisty tons lor arm, with matied improvement; but this was for the first and second rears only, the third year showng a falling oif. About this timo onp prejulices against the nse of concentrated manmes lor marlict girdening began to gire way, and at first we applied gumo together with manne at the rate of 300 pounds per acre, which we fom to pity : and the next season cuano was nocil at the rate of 1.200 pounds per acre with rery satisfudory results. Since then onr practice has been a stratematic alternation of manures, which I am convinewl is of quite ats much importance to the protuction of miform erope of firat quality. no is the altemation of rarictios of the dificrent kinds of regetables.

It is a criare lilunder to attempt to mon remetable crops withont the use of manures of the ravion: kinds in 
about the proportions I hare named. I never yet saw soil of any kind that hat borne a crop of rewetables that would produce as gool a crop the next salson without the nese of manuere, no mattir how " rich" the soil may we thought to bo. An illustration of this came under my ohecration a few years ago. One of my neighbors, a maket gatrdener of nearly twonty yars experienee.

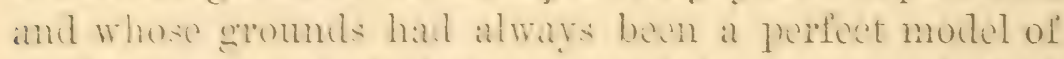
productiremess. hat it in prospent to rum a sixty-foot strot through his gronuls. Thinking his lami suffieintly rich to carry through a crop of Cabhages withont mainure. he thonght it useles to waste money by using guane on that portion on which the strect was to be, but on each side. sowed sulno at the rate of 1.20) pouncis pere are, and planted the whole with Early Cabbages. 'The cffeet was the mest marked I erer saw. 'That portion on which the gumo hat heen used sold of readily at $\$ 1$ : per hundred, or about $\$ 1,400$ per acere, both price and crop lowe more than an aveme-this was the erat of high prices-but the portion from which the entmo

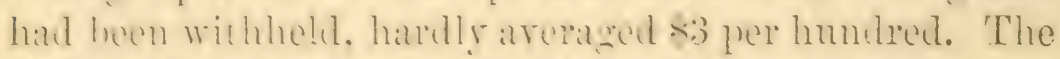
street wecupid fully an alere of ground, so that my friend

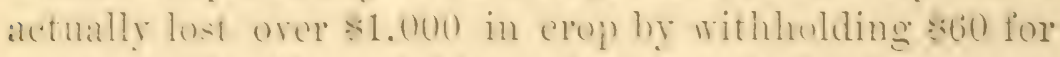
manure. Another neighbor, whose leate had only one year to run. and who also unwisoly concluded that it would be forlish to waste mamure on his last erop, planted and sowed all without it. The result was. at his experience should have taught him, a crop of inferior quality in crery article grown and loss on his eight acres of probably sesoou for that seatson. The comparative value of mamires must be regulated by the eost. If rotted stable manure, whether from horses or cows, ean be delivered on the ground at $\$ ?$ per ton. it is about as valuable for

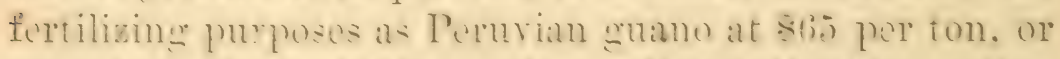
pure bome dust at 840 pere ton. It is better than cither of these or ans oflere encentrated fertilizer, from the 
fact of its mechanical action on the land-that i.', its cifect, from its light, porous natme, in arerating and pulrerizing the soil. Guano, bone dust, or other fine conmereial fertilizers act only as such, without in any way assisting to improve what may be called the nechanical condition of the soil.

All experienced cultivators know that the first year that land is broken up from sod, if proper culture has been given by thorough plowing and latrowing (provided the land is drained artificially or naturally, so ats to be free from water and relieve it from "sourness"), the land is in better condition for any crop than land that has been continnously cropped withont a rest. The market gardeners in the vicinity of New York are now so well convineed of this that when twenty areres are under cultivation at least five acres are continually kept in grain, clover, or grass, to be broken up successively every second or thind ycar, so as to bring the land into the condition that nothing else but rotted, pulverized sod will accomplish. This is done in eates where land is as valuable as $\$ \tilde{5} 00$ per are, experience having proverl that with one-puarter of the land "resting moder grass" more profit can be made than if the whole were under culture.

When the rotation by placing a portion of the land muder grass cannot be done, then it is absolutely neecessiry to use stable manure, at least to some extent, if the best results are desired, for continuous cropping of the soil. Where concentrated fertilizers only are userl, they will not eontinne to give satisfactory resultis after the grats roots or other oreanic matter has passed from the soil, all of which will wsually he entirely gone by the thire or fonth year after broaking up. I have long held the opinion that the idea of lands having been permanently exhausted by tobaceo or other cropes is a fallacy. What give rise to this belief, I think, is the 
fact that when hank are list inoken un from the forest or meatow lands, for there or four yatre the orgmie

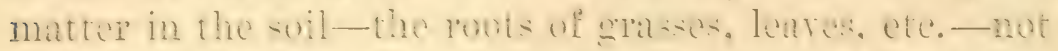

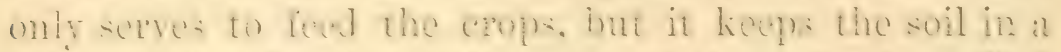

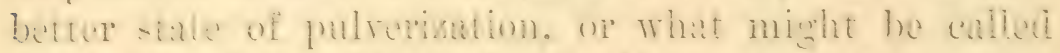

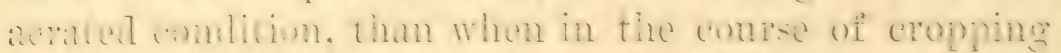

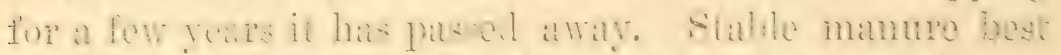

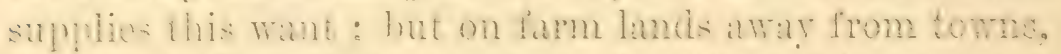

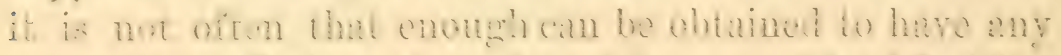

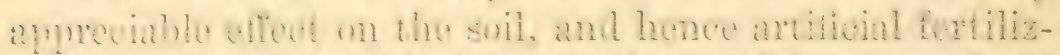

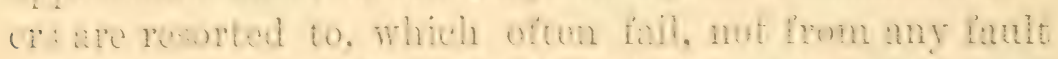

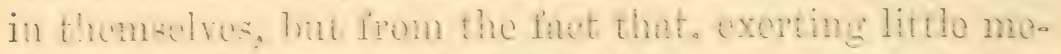

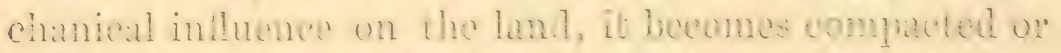

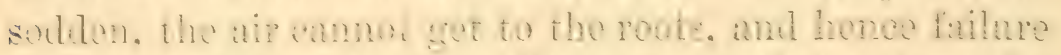
or partial hather of crop. Thus we sees that to have the

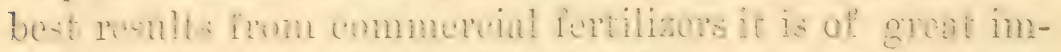
pormune to have the land reated by a crop of gruin or grass etery three or four years.

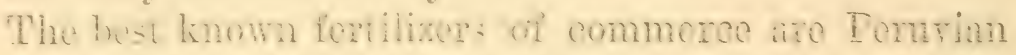

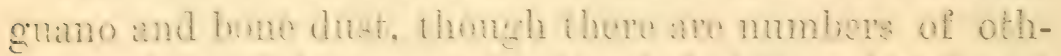

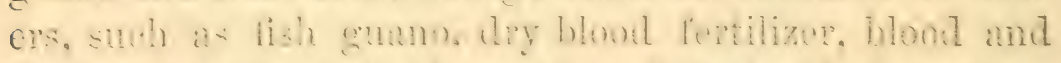

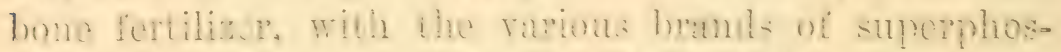

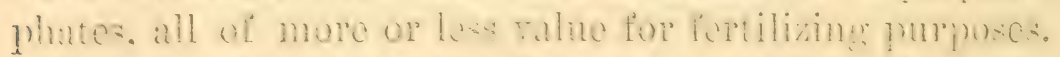
1t is uceless to go over the likt, and we will condine our-

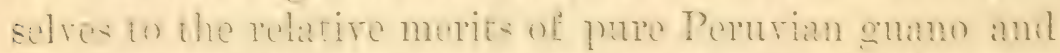

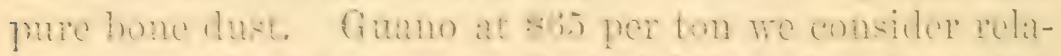

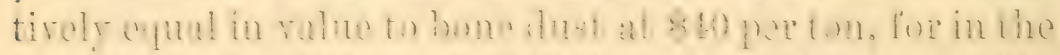
lower priced andele we lind that we have to increas the

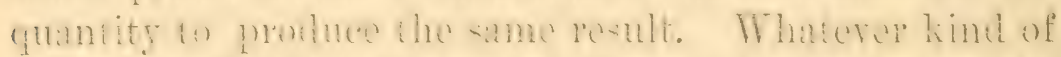

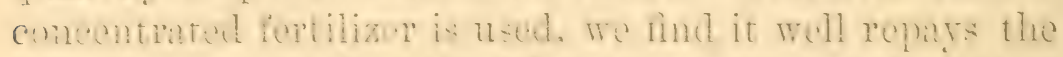

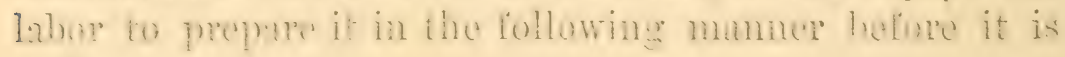
used on the lind :

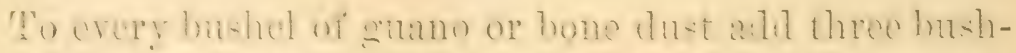

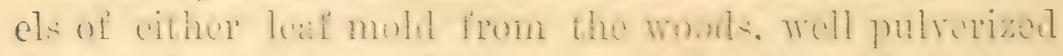

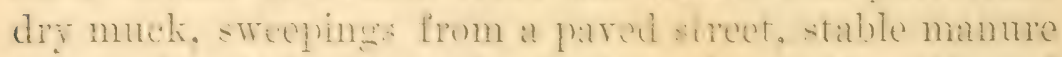
so rotted as to be like pulverized muck, or, if neither of 
these can bo obtained, any loamy soil will ro) but in erery case the material to mix the fertilizers with must be farly dry and never in a condition of mud, the moning of the operation being that the material uset is to ac: as a temporary absorbent for the fertilizer. 'The compost nust be thoronghly mixel, and if guano is used, it being sometimes lumpy, it must be broken up to dust before being mixed with the absorbent.

The main object of this opration is for the better separation and division of the fertilizer, so that when appiled to the soil it ean be more readily distributed. Our experiments have repeatedly shown that this method of using concentrated fertilizers materially increases their value-probably twenty per cent. The mixing should be done a few months previous to spring, and it shonld, after being mixed, be packed away in barrels and licpt in some dry shed or cellar until wanted for lise. 'Thus mixed, it is particularly beneficial on lawns or other grass land. The quantity of concentrated fertilizer to bo used is often perplexing to beginners. We give the foliowing as the best rules we know, all derived from our own practice in growing fruits, flowers and vegetables:

Taking guano as a basis, we would recommend for all regetable and fruit crops, if earliness and good quality are desired, tho use of not less than 1, 200 pounds per acre (an acre contains 4,810 square yards), mixed with two tons of either of the materials before recommended. Of bone dust about one ton per asre should be used, mixed with three tons of soil or of the other materials named.

For market garden regetable crops in the vicinity of New Iowlis, this quantity of guano or bone dust is harrowed in, after twenty-five or thirty tons of stable manure liave first been plowed in, so that the actual cost of manuling each acre is not less than $\$ 100$, and often $\$ 150$.

When fertilizer's are used alone, without being nixed with the absorbent, they should be sown on the soil, after 
plowing or spaling, abont thick enomgh to just color the surlatere or about ats thick as samel or satwelust is strewn on

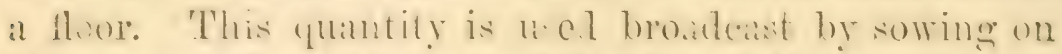
the gromend alter plowing and deply and thorounhly hat rowing it in: when applied in hills or drills, form 100 to Bi). poumds should be msed to the ance, aceording to the distame of these apate mixime wetl with the soil.

IIhen well-pothel siable mamme is procurable at a cost

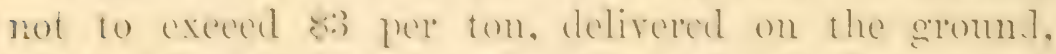

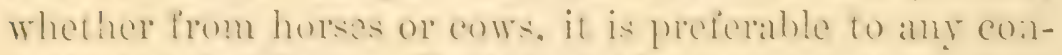

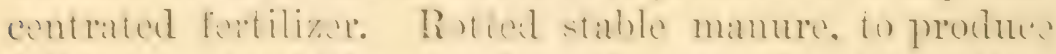

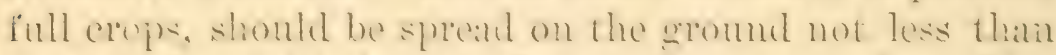

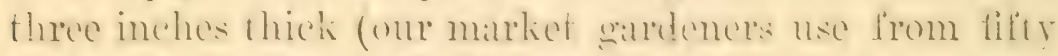
to serenty-ibe toms of well-lotfed stable mamule per alele. when no coneontratol fertilizer is necil), ame should he thoroughly mixed with the soil by plowing:

The mamme from the chicken or pieren honse is ve?

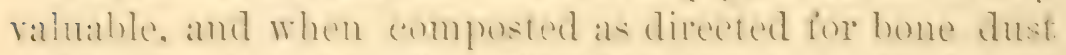
and guano, has al leat ome-third their value. Castor-oil pomate is also valualule in about the same propertion.

Potnk iare is the name grom to a commeredal fortilizer, the complustion of which is night soil, amel dricel swamp muck or charcoal dust as an absorbent. It is sold at

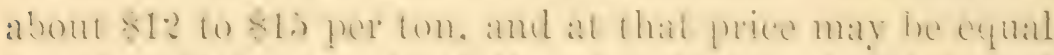
in ralue, if wo much of the ahsorhing material is not msed, to bone dust at $\$ 40$ per ton.

Sit.t has little of no value as a fertilizer, exepte as a milimm of uhsorhing moisture: for expremes shows that soils impremuted by saline matter are no mone fertile than thowe inlant ont of the reach of such an atmo:pliere.

Meck is the name given to a deposit nsually meren?

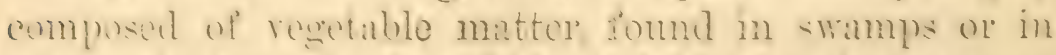
hollums in lorest lands. Of itsolf ft has memally but litite of fortiling property, but from its monen nature. whin 
dry, it is one of the best materials to use to mix with other manures as an absolbent. It can be need fo gereat adrantage if dug out in winter and piled up in narrow ridger, so that it can be part!y drical and "swertened" in summer. 'Thus dried, if mixed witl stable manure, or, better yot, thrown in latyersof thee or four inches thick in the cattle or hog yard, where it can be trodelen down and incorporater with the mann!e, the ralue of the manure thus treated will be noariy doubled.

In reply to questions that I receive by the hundred cach season, asking whether or not it is worth while to use the so-caller special fertilizers claimed to he suited to the wants of particular plants, suctl as the "Potato Fertelizer," "Cabluare Fertilizer," "Strawbery Fertilizer," "I?ose Fertilizer," etc., I can only give this gencral answer, that while these manures may suit the plants they a"e clained to bo "special" Ior, I have little doubt that either one would suit equally well for the others, or if abl were mixed together, the mixture would be found to answer the purpose for each kind of crope just as well as if kept separate and ajplied to the crop it was named for. These hatr-sp) litting distinctions are not recognized to be of any ralue by one practical farmer or gardener in a hundred; for a little experience son shows that pure bone dust or well-rottel stable manure answers for all crops nourly alike, no matter what they are. These suctal frotilizers for special crops are gradually increasing in number, so that some dealers now offer fify kinsls, diflerent brands bering offerer for plants belonging to the same family. There is an ignorant assumption in this, and any contivatop of ordinary intolligence camnet fail tos sor that the motive in so domg is to strike as hroad a swath at ponsible, so that a larecer number of customers maty be reached and a higher price obtained.

One of ny neighthors called the other day and informed no that his lettuce (or), in his groculower, was faling: 
and asked me what I thought of the " Lettuce Fortilizer" that was ollered in a circulare that contained some fifty ot her "suncials." An inquiry dereloped the fact that he

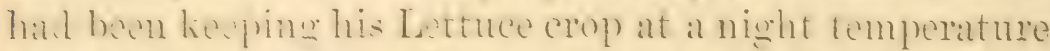

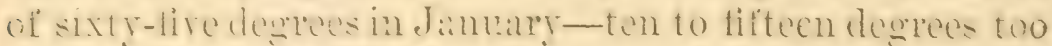
hish for the whelere of the elop-so that there was just. nbout at much chame of the special " Lettue Fertilizer" ledping the crop as there wouhd be of giving health to a man in the last stanges of consmmption by fouling him bet-sicak. I morely mention this incilent to show how, and in when mumer, the sellers of thess special fertilizers ohtuin custumers, cren among pratetical gardeners.

List: on Mori. - I hare alwars held that lime and

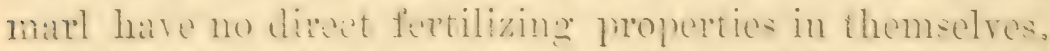

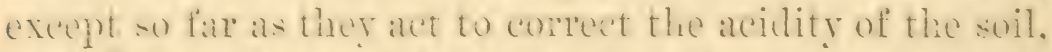
or to lighen heary soils, or to grive alhesirenes to soils that are too light. In fart, I believe they are raluahle

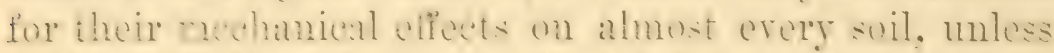
silch as lie along the sea const, ant in some catses a considerable distance inlant: on such subls there is no benefit to he derived from the anplieation of lime. In applying lime dust-whether from limestone or oyser shellsit should bo put on alter plowing. at the rate of not les than 100 basels ler are, and then woll harrowed in, so as to thoroughly mix it with the soil for foter or fire inches below the surface.

Gis Lrye is often rery librially oftered by the gits companies: it is a dangerous material and had better

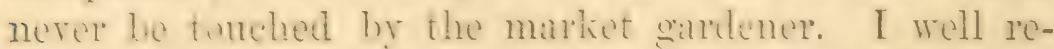
momher applying it to a plece of groumd. which was so poisomed hy the noxions wass that it dibe not rewan its fertility for three years.

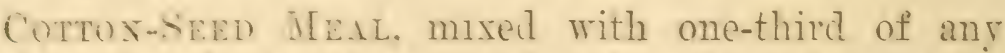
high prute of phosphate. is almost exolusirely used hy the market garlens's of Charleston and Sarannah. where 
the mixture costs about son per ton. Plowel in broatcast, at the rate of from two to three tons per acre, it is baliered to be, for that section, the best and cheapest fertilizer of any kind.

PLAster is one of those fertilizers which have a remarkable effect upon some soils, while in other places it, has no efferet at all. Where the soils are benetited by it, it is of combe adrisable to use it. Its greatest effect is upon choser, and where clover is nocd as a means of improving land, plaster is indispensable. It is one of the cheapest of all fertilizers and should by all means be used where it is beneficial.

Wrood Asmes are largely used by filmers as a topdressing for mealows, spreat on at the rate of fifty bushels per acre. The leached ashes that are brought to New York hy the boat load, are sold at from fifteen to twenty cents per bushel, and, of late rears, some of our gardeners have been using them instead of bone dust or gmano as an addition to stable manure, harrowing them in after plowing at the rate of from 150 to 200 bushels per acre; a lesser quantity (say one half) of unleached ashes would answer the same purpose.

Greex Manuriat. - The practice of growing crops for the purpose of plowing them nnder to fertilize the soil is often turied to rery great adrantage. 'To procure an adequate supply of manure is often a very costly plocess. But a crop that may be casily grown in a few weeks, and then turned under, may furnish to the soil as much fertilizing matter as eight or ten tens of manure; and the process may often be repeated two wo three times in one year. For instunce, if land is plowe? in October and sown to rye, the rye may ba turned under in May or June, and corn may be planted. This will be in full growth early in August, when it may also be trmed under, furnishing ten or twelve tons more of 


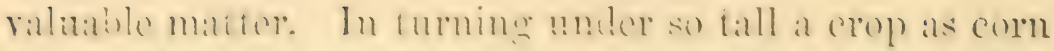

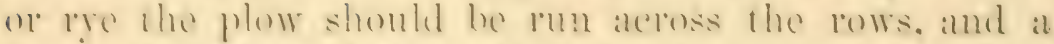
heary cham looper form the plow heam, just aldeal of the stamdand, to the land side ond of the immer whithetree. This loop drate in the furrow. so as to ateh the

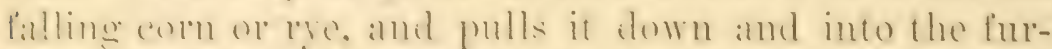
row so that the soil eorers it. It shombl then he smoothed

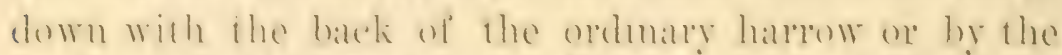

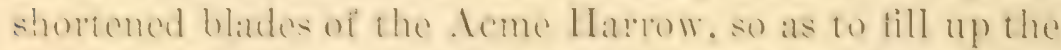

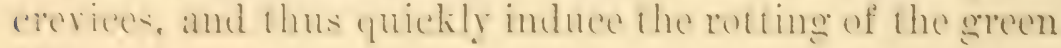
erope.

\section{II A P T E R Y I I.}

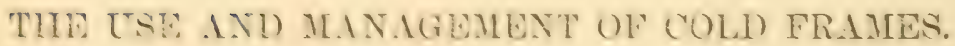

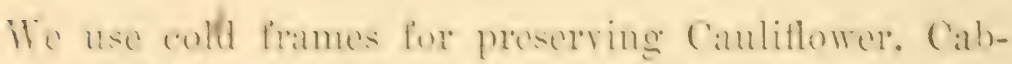
hage and lexthe plants during the winter. and the forwarding of Lettuce and cueumbers in spring and summer.

The malue the mather as clear as pusible. we will sup-

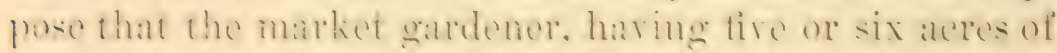

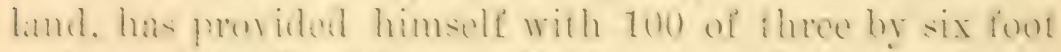

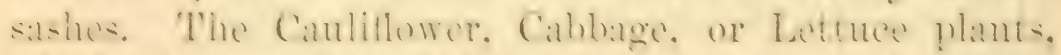

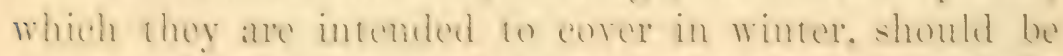

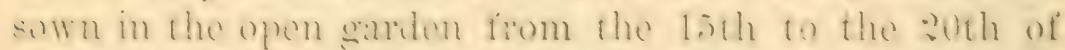

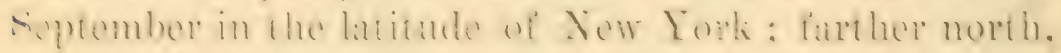
carlicr: farther sonth. later. 'This matter of time of

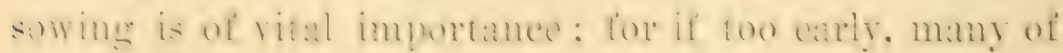
them will rum to seed mul of comrse are useless: agin. if soming is done two late. cold weather sets in and the piams hase mot time to got strome eimole fo stamel the winter. The Early dersey Hatiofold is the variety usod

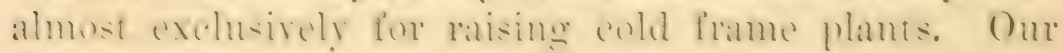
famous "Early simmer Cabbage" is nerel so safe to 
carry over in cold frame: molese indeed, it is sown very late; for example, when wo sow the Wakefield leree on the 15 th of september, Hee Liarly summer is not solvo until ten or fifteen days later.

diellions of this favorite sariety for the Somb have been lo-t by running toseed from having bech sown fon cally. ()n this suljeget I will give my views al lenesth in another portion of this chapter.

When the young (jab)age plants are of sulfirome size, which they will be in alones a month from the time of

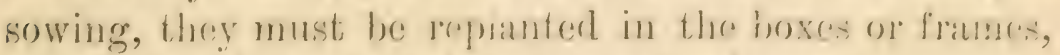
to be covered by the sathes ats winter arlvances.

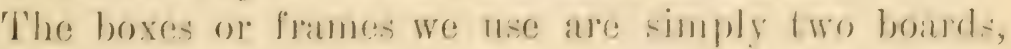
rumning patrallel, and nailed to posts to secure thom in line. The one for the back is ten or twelve inches wirle, and that for the forout soven or eight inches, to give the sdshes, when plared lifon them, pitch emongh to carry

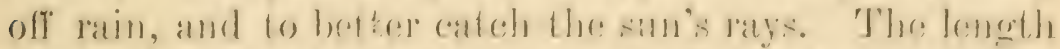
of the frame or hes may loe reculated by the position in

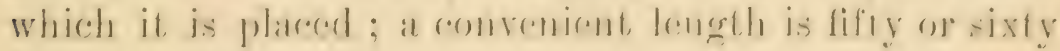
feet, requiring eighteen or twenty sashes.

Siledter from the northwest is of ereat importance, and if the gromerl is not sheltered natmatly, a beatrl formere six feet in height is almost indispensable. Thesa-hes should face sonth or southeast. Each three hy six fort sa-h will hold five hundred plants of Cabbage of Cauliforer, and abont cight hundrest of Lutuce. These numbers will determine the proper distance aptart for those who have not had exporionce. It should never bo lost eight of that these plants are almost laardy, and consorfuently will stand severe freeging withont injury. but, to insure this condition they mont be treated as fherip mature demands; that is, after planting the Cabbage, Lethere of Cauliflower-which will he alont the middle or end of october-the sashes need not be put on for a month or sis

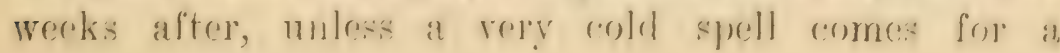


lay or two. which smmetimes happons: but if they

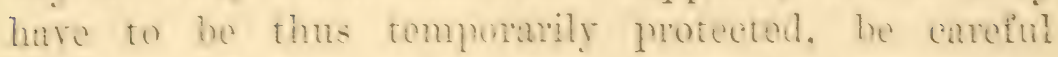
to strip off the sashes again, so as to harden the plants for cold weather. In cold weather, eren on

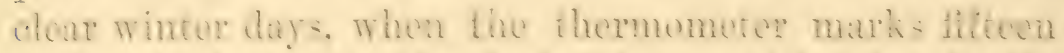
or twonty deques in the shate, they must be ahumdandly

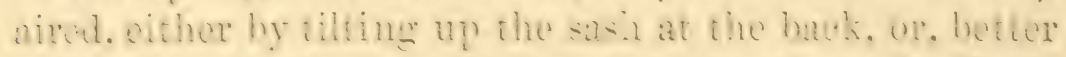
still. when the day in mikd, by striphing the sush ori untirely. With this hardenimg proess there is no necesily for any other eoreme hut the sash. In our bocality we

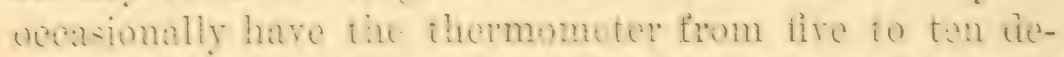

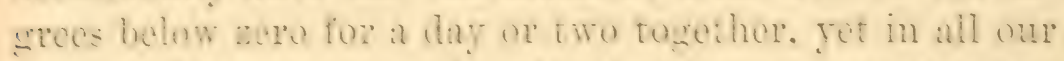
time we hare meror usel mets. shutters. or any corering excopt the eluse, and I wh not think we lowe nore than two prer cant. although in sections where the thermompere dalls to twonly or thirty derew helow aro. mats or shutere will be newsary. They rarely pase through a winter, howerer, without having the stoms split hy the frust. even with ws. hut that does no injury. piovided when plantinz ant in the open tiuld they are so set that the slit part is in the groment. ('anliblower is more ten-

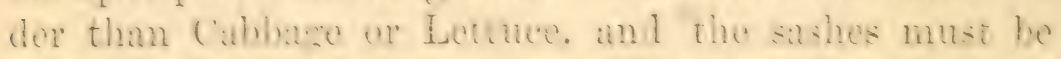
corevel will mats. Fome may think that the raising of plants in this mamer mut involve con-ikleroble trouble. but when they are immmont that the cabbage ami Lattuce plans so mai-ed and planted out in Mareh or April. not intrepuently hring 8900 per a re helowe the midllo of July. giring us cimo on hollow up with Celery for a second

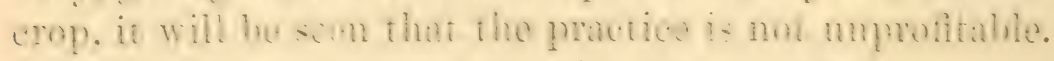

But we have not ret done with the use of the sashes: to muhe them sill available. Funce hoxes of tranes are male, in all regrets similar to there in ure for the Cabbare plants. There frames should be covered up turing

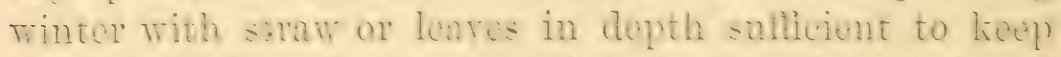
the groumd from frenmes, as that they may he gut at and he in conditum to be planted will Exttues by the and of 
February or the first of March. By this time the weather is always mild enough to allow the sathes to be taken off from the Calblage and Letture plants (if they have been properly hardened), and they are now iran ferred to the spare frames to cover and forward the Leturer. Ender each sath we plant litty Letince plants, having the ground firet well enricherd by digging in about theer inches of well-rotted manure. 'The manatgement of the Letence for heading is in all respects sinilar to that used in preserving the plants in winter: the only thing to be attended to being to give abmutance of air, and on the occasion of rain to renowe the sashes entireiy, so that the ground may receive at gond soaking, which will tend to promote a more rapid and luxuriant growth.

The crop of Lettuce is fit for market in alont six weeks from time of planting, which is always two or three weeks sooner than that from the open gromm. The arerage

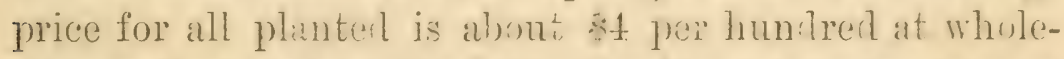
sale, so that again, with little trouble, our crop gives us \$2 per sash in six weeks.

I believe this second use of the sasi is not much practicod outside of this district, most gardeners having the opinion that the winter plants of Caljbage or Lettuce would be injured by their complate exposure to the weather at as carly a date as the first of March. In fact, here we have still a few old forgies among us, whose timidity or obstinacy in this matter prevents them frem making this double use of their salshes, which thereby causes them an annual loss of $\$ 2$ per sash, and as some of them have orer at thousand sashes the loss is of some magnitude.

In my own practice I hare made my sushes do (iouble duty in this way for fifteen years; the number when I first started being fifty, increasing until at one time I had 3,000 sashes in use. Yet in all that time $I$ hare only once had my plants so exposed injured, and then 
only a limited number. which I had neglected to sufficiently harden by airing.

We huve still unother use of the sashes to detail. Omr Lettuce boing ent out by mialde of liar, we then plant five ur six soeds of the Improved IThite spine Curmmber in the center of each sash. It that siason they come un at onee, protected ly the eowring at night. The sashes are leit on until the milale of June. when the eron begins to be sold. The management of the $\mathrm{C}_{11-}$ cumber erop as regards airing is hardly difterent from that of the Letenee, exeept in its carly stage of srowth it repuires to be kept warmor. Ihing a tropical plant, it is rery impatient of bing chillod. but in warm dars airing should never b? neglceted. is the coneentration of the sun s rays on the gluss would raise the temperature to an extent to injure, il not entirels destroy, the arop. This third we of the cathes I hare never yet made so profitable as the sceomd, heeanse the crop has to compets against Southern frown Cnemmbers, although it has alwars been suthicient to make it well worth the labor.

Where are a few men here who make a probitable linsiness from the use of sashes only, haring no ground except that oceupied by the frames. In this wat the winter erep of Canliflower or (nbbige plants is soli at an averagro of $\$ 3$ persah in March or April : the lettue at $\$$ per sash in May, and the Cucumbers at $s 1$ per sash in June, making an arerage of so per silk for the season : and it must be remembered that these are wholesale prices, and that, too, in the market of New York, where there is great competition. There is no doubt that in hundreds of cities aud town of the Union the same nse of sashes would double or treble these results.

Cold frames are also used for sowing the sodts of Cabbage. Canlitlower and Lettuce. instem of hot-bods. If the framos are closely shut up and corered at night by mats, the plants mul be but little later than those from 
the hot-beds, and are raised with far less trouble. 'The time of soring is about February 1st. In sections of the country where these plants cannot he set out before May it is useless to raice them in hot-hedts. (In the other hand, in the Southern States, where in the months of Febriary and March there are no frosti, by adoping the same care in corering up at night, the seeds of fomatoes, Peppers and E, geplints, and the spronts from siweet Potatoes, can be forwarled with much less trouble in the cold frames than in the hot-ber.

I am sometimes asked the question, how mucin freezing and thawing plants of Lottuce, Cabhagen, etc., will stand withoat being destroyed. I have always taken the pround that the freczing and thawing, insteal of being injurious, is a necessity for their alety. In doing so I know I run in direct opposition tes a large majority of my brethren, lut the experience of orer a cumeter of a century, yearly increasing in extent, astires me that I am correct, and I am further confirmed in my opinion liy knowing that there is not a market gardener in this ricinity but whose practice in the manarement of cold frames is the same as my own; thongh if the prestion was asked some of them if thawing and freczing did not injure plants, the answer might be in the aliirmative, so universally has the dogma been acepted.

Again: "How long can frozen plants be kept from the light when covered up with snow?" Mich would depend on atmospheric conditions. If the plants were hard frozen when the snow covered up the sasher, then they might andy remain thee or four wecks then corcred, without light; but if the ground was not firozen when the snow fell, then the snow must be removed from the sashes in three or four days. inless the fill hats been so slight that light can get through to the plants. 


\section{PROTECTING CLOTH IN LIEU OF SASHES.}

In mainy sections of the country it is difficult to get sashes, and with many, too, their cost is such as to make them unattainable. 'T'o such the use of this new protecting cloth will be a sreat boon, particularly in the sonthcrm sitates. where only a slight protection is necled to warl on frost for a few nights. In the wiater of 1886 millions of Cabhare and Cambiflower plants were lost in Georegil. Fouth Carolina and Floridat that might hare been saved by the nes of this cloth for protection. In om experiments with it the past winter. we found that while the themometer stood at twenty-tive decrees above zero, under this errering the temperatme was thirty degrees above zero, while miter the protection of salies it was thirty-two dereres. or but two degrees more. All experienced culcivators know that the ditference of five degrese in temperature in most calces would sire nearly all the plants exposed in the open air from the danger of injury by frost. Could the orange trees of Floriba the past winter have been enveloped in protecting cloth. I douht if a hud would hate heen injured. Ot conrse, in that case, it would have hecu impracticable to do so: but it is easily practicable to protect bowgrowing plants. such a Cahbate plants or fruting strawbury crops. I gentleman from Florida told me list winter that he has repeatedly salved his crop of strawberries-coverimg an acre while in hloom-liom carly flost. by the use of ordinaly cotton cloth, theroby rastly increasing the ralue of his crop. This protecting cloth, while boing no cheaper than ordinary grales of cottom cloth. has the adrantage in boing so prepared that it is mildew-proof, and with ordinary care will last for fire years. It is made in yard ridths and can be shaped for use acending to cireumstances. Probahly the simplest plam is to tack it to a light frame three by six 
fect and use it just as sashe are usel. Such "rathes." made of proteding cloth. would cost not mole than twenty cents calch, while glass salshes eott (fosiry unthing of expense in frephling) so cach. Bexides in the hands of inexperiencert cultivaters. the protecting doth. is saliest. for if this covering is left on in the day-time when the sun is shining, there is complatulively bittle rise of temperature molemeath it, while it is well linom that if rentilation of flames eorered hy ghass suthes is not carchully attended to, the crop beneath may be quickly ruined hy the sun's lays acting on the glass and raising the temperature.

The past spring (beginning aljout miadle of March), we corered a lot of Cabbare plants with the protecting cloth for thece weelis-nerer once taking it of night or day-and the plants were noarly as goon as those corewed by sashes, where daily attention had been griven to rentiation. Not only will this cloth be fonmel most neeful in the winter in the rumthern sitates, to suard

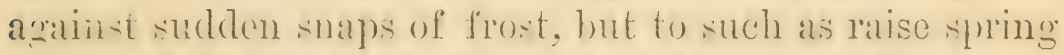
plants of Cabluges, Lettuce, Cauliffowers or Tomatoes, repuiring protection in spring at the Nortln, it will be found an excellent substinte for sashes. I lon not recomment the ne of the protecting cloth in lien of asthes in the wintel months: it would not answer in heary snow. But for all suring work, irom Marele to June, it will in most cases answer every purpose.

SPRING RAISING OF CABBA(RE, (ALLIFIOIIER ANT) LETTUCI.

The question is put to me many hundreds of times every scason as to what is the best methou to produce plants of Cabbage, Cauliflower and Lettuce for carly spring planting. Although we still grow sereral humrred thousands of fill sown plants amoually (which are wintered orer in cold frames). ret increased expericnce 
appar: to show that plants grown in the manner below describer. which we have practiced for the past five reats, all be dome cheaper, and, at the sime time, will pulue neaty a: good plants as by the old method of wintering orer in cold frames.

For oui latibute, we make our first sowing on February 1st in our oremhouses. where the temperature will averace about serenty degrees ; that is, ahout sixty degrees at night, and about eighty degrees duriag the day. Where theme is not the convenience of a greenhouse, a hot-bed will answer the same purpase. I hot-her. made with manure, about two feet deep, in a proper manner, produces just about the same temperature and genelal eonditions al: will a well-appointed gremhouse. We find it more convenient to sow the seod in shalle; bexes, which are made hy entting the ordinary soatp boxes into three piceses. which grives us a depth of about two inches for soil in calch hox. We lise any light, rich soil for the purposes sowing enough seed in each box to produce 1,000 or 1.jog plants. or, if grown in the hot-hed without the box, abch thee hy six loot sash should grow about 5,000 plants: but we lind it more convenient to use the boxes than to sow in the soil put direct on the hench of the Erevilhouse, or on the manure of the hot-hed. The plants

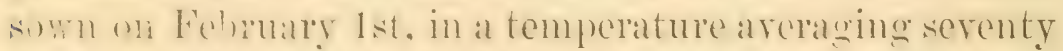
clereses. will give plants fit to transplant in about thee of fonl weeks. We then use the same shatow boxes, putting in the bottom of each about one inch of wellgotted stoble mansure. Orel that we plate an inch of any ordinary light. rich soil. smoothing it so as to have it as lovel als po-ainle. In these boxes, which are fonteen by twenty inches. we put an arerage of about 150 plants. 'ilhe hoves are then talien direct to the ortinsmy cold frames, which, howerer, have been protected with matnure, as it would not do to put the hoxes of tender plants (1) a lowere surface. It is very casy to keep the frost 
out of these cold frames by putting on three or four inches of dry leaves or manure before the soil frewzes 11$]$, and placing the sash on the frames two or three weeks before they are to be used. In this way they will ke(e) perfectly free from frost, and can be userlat any time during the winter. The boxes shomld be placed as clowe to each other in the cold frames as they will stand; about eight boxes fills a satsh, thus holding about 1.20)(0) plants. If the sum is bright, it is well to shade them for a few arys until they take root; but the most imprortant point of all is to cover the sashes with straw mats at night so seculely that no frost will reach them in the cold irames. For the past three rens we have carth seatson grown about half a million of Calbbage. Cauliflower and Lettuce plants in this way, and have had no trouble to keep them from freezing by carcully mating ul, even when the thermometer has reached zero.

Plants sown on the 1 st of Fobluary are transplanter into the boxes abont the 1 st of March, ard are at once placed in the cold frames, and will he finc io trabsplant to the open ground any time after the 1 st of April if they have been carefully attended to by watering, airing and protection from frost. As I have hefore said. these dates refer particularly to the ricinity of Jew Lork City, where we can usually plant out in the open ground all kinds of Cablage, Caulifower and Letsuce plonts about April dst. If in districts where they cannot le planted. nut sooner than the middle of April, then the sowing should not be made hefore the 15 th of Felruary, and the process of transplanting, etc., gone through as before stated, so that the plants will be in condition to sec in the open ground by the 15th of April. Il in sections where Cabbages cannot be planted in the open ground before the 1st of May, then the sowing should he delared until nearly the list of March, and the process of transplanting in the frumes the same. 'Thore are some sec- 
tions in the Southern state, of course, where these directions would not anply, where the sowing would need

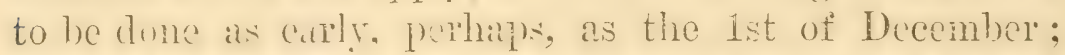
and as it takes alyout tro months from the time of sowing until they are fit to plant in the field, plints sown the 1st of Inecenber in Fathern states would he fit to set ont hy Fabruary 1st. It will bo malerstood that there womld be no necesity for sowing in hot-hed or greenhouse in such a climate as Florida. The protection of glass in an ordinary cold frame would give about the same arelace of e'mprature there in the winter months as we would hare in the north by artificial heat. In most of the suntheru states in my opinion, the protecting eloth before alludel to wouled answer all the purposes of glass sushes-and cren in the North, when mats are used. "sashes" made of protecting cloth misht he used instead of glas.: There is another and simpler

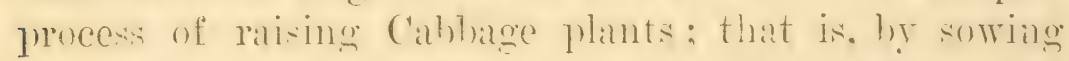
the seed in the cold frames dirert. This is lone here

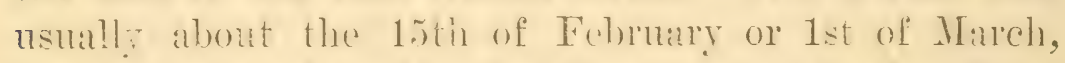
in at warm and sheltered a place as can be fomnd for the france. I sat one of my neighing have a fine lot grown in that way last yeir. Ife hat taken a crop of IIead idettuce out of his frames about the 15 th of Febluary, dug and ralied the ground and sowed his Cabbage sechls in lows about fire inches aplart, sowing enough to gire about 1 , rom plant mudereach three by six sash. Tromatted up carrinly, giving rentilation to the salshes whenerel the weather would permit, and about the lst of April he had fine plants. fit to go into the open ground right from where ther were som ; not quite so gend. of conese as if they had been transplanted, but still mach better than the ordinary hot-bed plants, which are gen rally too much drawn and too tender to stand colel weather until quite late in the season. If care is used to so cover up these cold frames when tho plants 
have been tramsplanted in the boxes, or sown as described abore, there is hardly a chance but that excellent plints will be produced, as there is far lees risk in the handing of them than those from the hot-ber. A rery important point to always observe is, to eover them so that the rirent will not get to them. In come secions it might be neceswiry to use a light shitter placed over the sash, and then throw over them the heary straw mats, at the same time covering up the alleys between the frumes to the top of the board with dry leares er ordinary stable manure, so as to prevent the front striking through the bon'is into the plants. It is dificinlt to explain these operations as clearly by writing as we wonld like, and if any of our customers would take the time to come and see our operations when we are at work, during the months of Tebruary or March, they can get a betier knowledge by seeing them done on the spot. Our greenhonses and grounds are witlin forty minutes time of our store, at Nos. 35 and $3 \%$ Cortlandt Street, New York, and if any one wishing to see our operations will call there, they will be given a card giving directions how to reach the pluce, which is located on the Jersey City Heights, two miles from the Jersey City Ferry. 


\section{OIIAPTER VIII.}

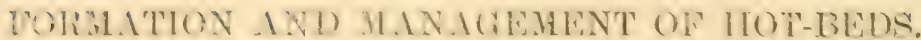

Although wo do not emsider hot-heds so somvoniont or

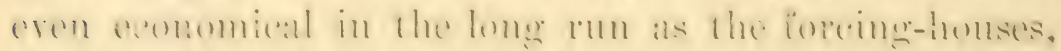
clsow bere deseribed, yot, as begimers in the business are nsuall! no! over-supplied with means. and as hot-heds are to be had at mueh hes tirst eost than the foreing-houses, We givo a diseription of their lormat ion and manatement. 'The most conventent sath for the hot-hed is the thre hy six lout sath. mate ont of one imeh and a hall pine, cost-

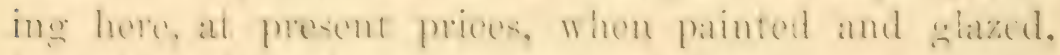

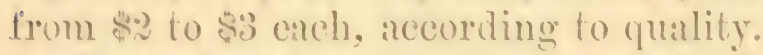

The Prame for the hot-hed is msually mad mon:thle, in lengths which three sashes will eover, making, when

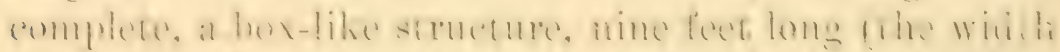

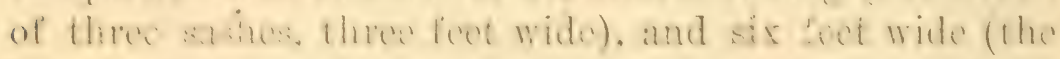
length of the sashes) : at the bottom or lower part the

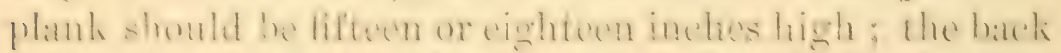
(3) top. twent;-four inches so that when the fashes are

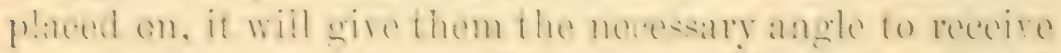

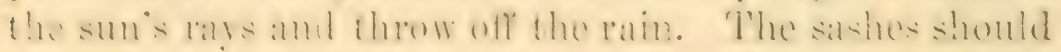
be mate as light litume as they will eatsily work, and the plank forming the sides of the box should bo high

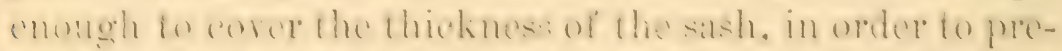

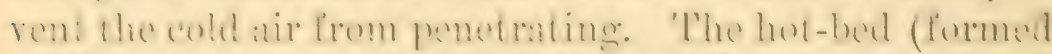

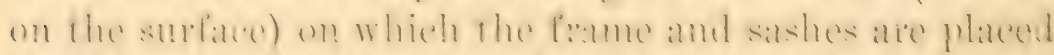
should not bo lese than four feet in depth of hot manume.

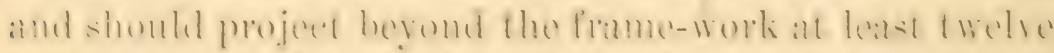
inches on all sides: that is. if the thres shsh-frame work

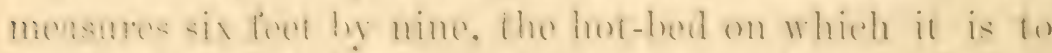

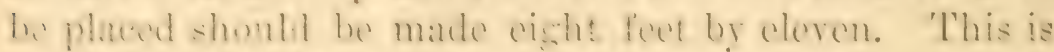
ome slyte of hol-hed frame, and the whe most exmmomly

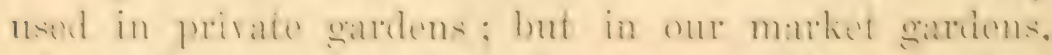

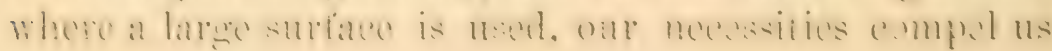




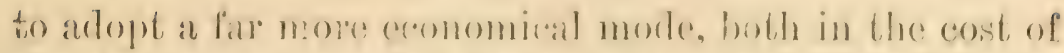
the frame-work and heating material. This is done?

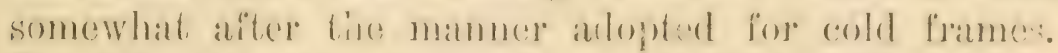
Parallel excatations alle mate, usually in lomeths of sixty

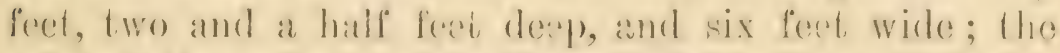
sides of these pits are hourded up with any romeh hoallit-

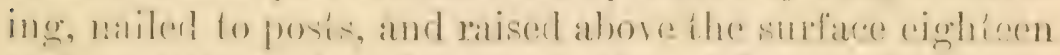

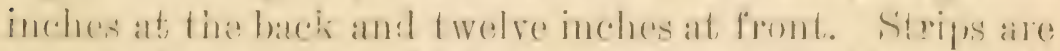

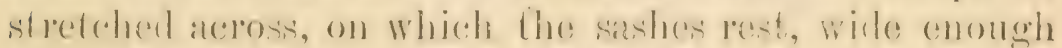
to recerive the erlges of the two sidues where they med, and allow of a piece of ahout an inch in willh betweren them, so that the sals can he shoved has ward and iojward and be kept in place in giving air, etc.

The heating material to form the hot-bed shomld be lasse dumg, fresh from the stables, adcling to which, when

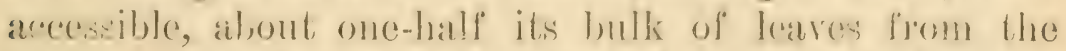
woods. The maitare and labes shombl he well mixed

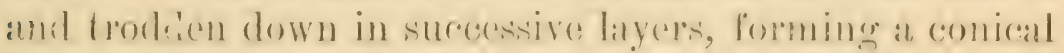

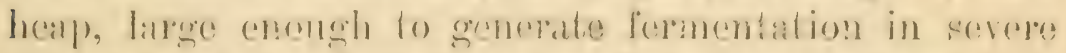
wintor woather. (are must le takon that the matroval is

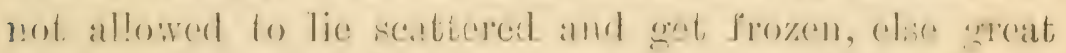
delay will ensue befine heat can be gromerated. $\Lambda$ few

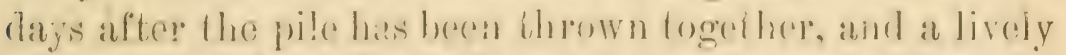
fermentation has taken place, which will be indicated hy the escalpe of steam from the heap, it slonld be arain tmoned over and andefully shaken out, formed asain into a pile, and lelt until the second fementation occurs, which will be usually in two or throe days. It may now lis placed in the pit, or on the surfaces for the hot-bed alraty alluded bo, haing regularly betien down by the batck of the fork, an l trolden so that it is moformly of

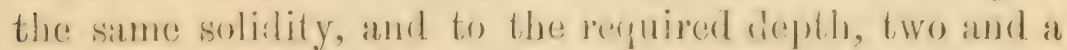
half feet. The sabhes are now placed on the frames and kept chose until tho heat rises; at this timo a therenometce, plumger in the heating material, stonld indicate about 1 (n) degioes but this is tan hot for almast, any rog- 
(ctable growth, and besides the ramk steam given ont by the fermentation should be allowed to escale before operations of sowing or planting begin. Buginners are very apt to be impatient in the matter of hot-beds, and often lose the first (reng by planting or sowing before the violent heat has subsided, which it generally will do in about three days, if the heating material has been sufilciently prepared. As soon as the thermometer in the frame recedes to ninety degrees, soil should be pliced on to the depth of five or six inches. This soil must be previonsty prepared, of onc-third well-rotted manure (or, if procurable, rotted refuse hops from breweries), and two-thirds good loim, spread regularly orer the surface of the manure in the hot-bed.

We nee hot-berts for rarions purguess. One of the most important reses is the forenge of Lettues ; this is platated in the hot-beds (from plants grown in the cold frame:), fify unter each sash, the first erep by serend weck in Jamuary ; it is corered at night by straw mats, and is usually marketable hy the first of Mareh. At that season Lettuce is always seatree, and will atrerage, if properly grown, si per hundred, or s:3 per salsh. The erop is cut out by the first week in March. giving plenty of time to plant the same bed again with lettuce; but now it is no longer a hot-bed, for hy this time the heat. from the dung in exhamsted, and it is reated exactly as described in the chapter on Cold Frames.

Another use for the hot-hed is the raising of 'Tomato, and Egre. and Peprer plants. "The bed should be prepared for these not sooner than the seend week in Milr.h, with the temperature about the same as licfore describud. In sowing. it is we!l to cover the secd, not more than a quarter of an inch, whit some rely light mol.1: nothing is better than leaf mold and sand, patting it gently with the back of the spatie. From the time the swal is sown. attention to arring, during the hot part of 
the day, and covering $n_{1}^{\prime}$ at night, is essential, and also that the soil be never allowed to get dry. Water, howcrer, must he applied with julgment, as there is just as much dangere from soaking the soil tor mich. Water should be applied with a fine rose watering pot, and if the water is heated to a temperature of eighty or ninety degrees, all the better. 'The temperature at nigint may range from fifty-fire to sixty-fire degrees, and during the day from serenty to cighty degrees. As soon as the secelling plants are an inch or two high, which will be in foul or fire weeks, they mest be taken up and re-planteal in a more extensive hot-bed, for they now require room. Tomatoes should be planted of a width to give serentyfire or 100 in each sash. Pepper and Erag Plants do better if planted in small flower pots (thre-inch), as they are more difficult to transplant; they may now also be liept a little closer in the hot-bed than the Tomatses, as they repuire more hait. After transplanting, great care is necessaly that they always be immediately watered, and sharled from the sun until they hare struck root, which will be in two or three days after transplanting.

The hot-bed is also the merlium for procuring us (aib)bage, Cauliflower and Lettuce plints for carly outside planting, when not convenient to winter them orer as described in the uses of cold frames. The secds of these are sown about the last week in February, are treated in all respects as regurds corering up at night as the Tomattoes, etc., but, being plants of greater hardiness, require more air during the day. They will be fit to plant in the open garden by the midille of April. The berls they are talicn from are msually employed for re-planting Tomatoes, which it is not safe to plant in the open ground here before the midille of Mav. $\Lambda$ more derailed account of how to raise Cauliflower and Lettuce plants will be found in the Chanter under that head. 
Suovt Potate plants are almost universally maso in hot-buts : but, as this is a plant that humerines in a high tempermates, the hos-hed shende not be tomed to start them until the midale of April. The soll should be a mixtme of sand and leat mold. laid on of the usual thickuess on the hor-bet. six inches. The rovts are plaved vlose rogether, and the sume samd sompost sifted orep them to the ispeth of two inches. Scme split the large anes lengetowioe and plues thum flat side down. They should not be watered until they start to grow. They ave tit to plant out ubout six weoks afwes starting.

Wwo most esential points in working hot-buds aro in covoring up at night aud in riving an during the das. It often hampons that a fow mild nights in Mareh or April delude us inco the belinet that all the cold wouther

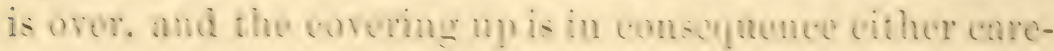
lessly proformed or abmalomol. Erery senson shows us sentes of rietims to this mistake, who by one cold night lose the whole labors of the season. It is alwars salfest to cover up tender plants. such as Tomatoss. Sweat Potatons. ete. mil the 10th of Mar in this latitude. and the more hamb plants. such as Cabbage. to the list of

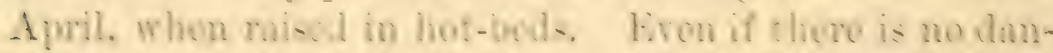
gur from freange. it will! give a more uniform temperature. and comsentently comber to a more healtily geow bir. The waut of close attontiou in airing is tqually dungerous. Often an homrs delar in raising the sashes will resule in the ecoreling np of the whole contunts of the lot-ind, and imegularity of airing will always puthere "Urawn " and spindline plants. owo when they are not

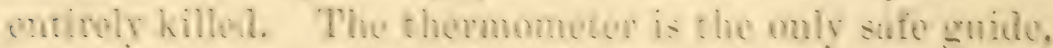
and sliould bo rezularly con-ulod, and whenorer it mulcutes soventy-live degreus, it is sufe to almit more or less of the onwe air. proportioned of course to the condition of the acme-phere. If there be hright smu-hime and cold wime, rory little will suthes : if colm, mild, and sumny, 
admit larger quantities. If the days are warm, say sisty in the shade, in Mareh or April, the sables cosering Cabbage, Candiflower or Lettuce plants maty be stripped entirely off, and also from Tomatoss in April and May when the thermometer is at serenty degrees in the shade, covering up at night, of course.

Coversngs for Protecton dratnet Frost.-To cover up hot-berl sashes we use either light pine shutters or straw mats. The shutters are made the exact size of the sash. There is no necessity of their being more than

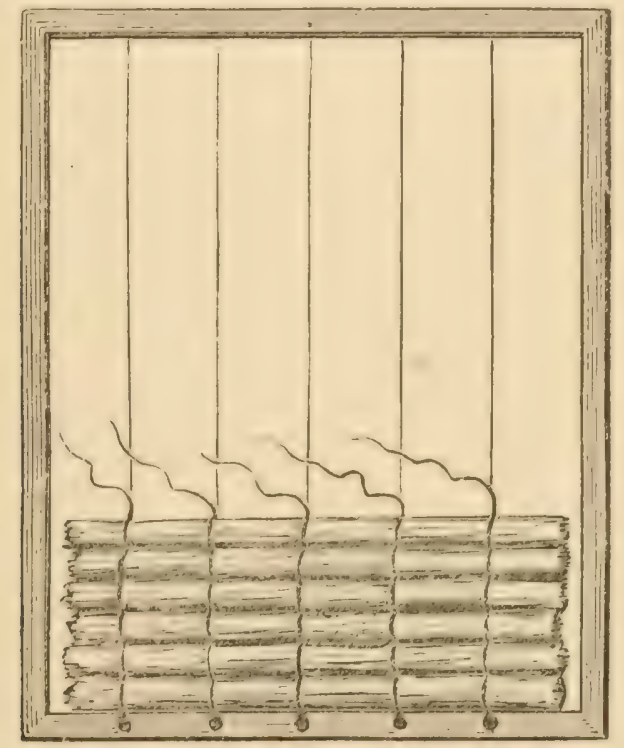

Fig. 5.-MAKING A STRAW-MAT.

Thalf an inch in thickness, as that is quite as effective in keeping out the cold as two inches would be, and they are much cheaper and more convenient to hamdle. Straw mats are, howerer, by far the warmest covering, and in hot-bed culture are almost indispensable. 'They are always mate at home, during wet rlaysor in stormy weathere in winter. The manner of making them is very simple, and will reatily be learned at the first attempt. The 
"uprights" or warps are formed of five strands of a tarred atring linowa as " marline." These are tightly strained ten inches alpart hy bung attalched to dire strong nails at bottom of a wall, corresponoing with the same number wron fiet from the bottom. Aqainst these string (beginning at the bottom) are haid small hamelfuls of rye straw, the butt onds out a long and straight as can be procured. This is serured to the uprights hy a liwher lind of tared string by taking a single tum aromed the mpright and the straw, and so continued until the nat is finfised. Sume use a trame to which the string forming the walli are attachet, as shom in tienre i. This allows the operator to have his work wpright or horizontal. as may he most comrenient. 'Two workmon will make about fire mats in a day. When finished. the mats should he seren feet in leneth and four and a half fow in widh. two boing sufficient to

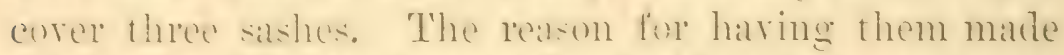
one fout honere than the sish is that there mat be six inches to orellap at folp and hottom. Which are the most necessiry points to secure from frost. In making theses

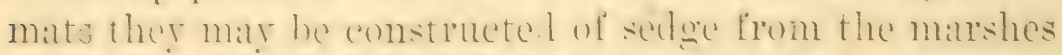
or salt matho hay when rese strat cammot be procured. It is important, howerer. that they may he matle as light as pusilhe, one inch in thickness being quite sufficient. Ly calne ili hambling them, these mats will last for six or eight years. 


\section{H A P T E R I X.}

\section{FORCING-PITS OR GREENHOUSES.}

In another chapter it will be found that we now recommend using wider greenhomses with fixed roofs for growing regetalbles, but as many have loose sashes that they may wish to utilize in constructing ereenhonses, we will still retain the description given in the carlier editions of this work.

Forcing-pits and greenhouses of the style about to be described, whenever the greater expense in their erection is not a consideration, are, in our experiones, far superior, and in the conrse of fire or six years more ceonomical for all purposes of foreing or forwather vegetalbles than the hot-bed or cold frame. Figure 6 represents the end section and ground plan of the style we have in mse, and which may he arlapted to any plant that requires artificial heat and protection of pliss. The pits reperesented by this plan are 100 feet in length, and each eleven feet wide inside. The heating is aceomplished by one of ICitching's patent boilers, (y, heating ahout 1,200 feet of four-inch pipe. The glass roof, $E$, is formed of portable sashes, six by three feet. Each alternate sash is screwed down, the others being movable, so as to give adundance of air. The movable sash is clevated, to adlmit air, by a flat iron bar fifteen inches long, attached to the sash by a staple. Into this har is punched three hole., so as to regulate the armision of the air as required. When the sash is shut down the bal is booliorl on to a pin which secures it in place, so that the sash cannot be mored by wind. I am thus particular in describing what may secm a simple matter, but this system of airing is not common, and we marle some stupid blunders before we hit on our present plan, which is cheap. simple 


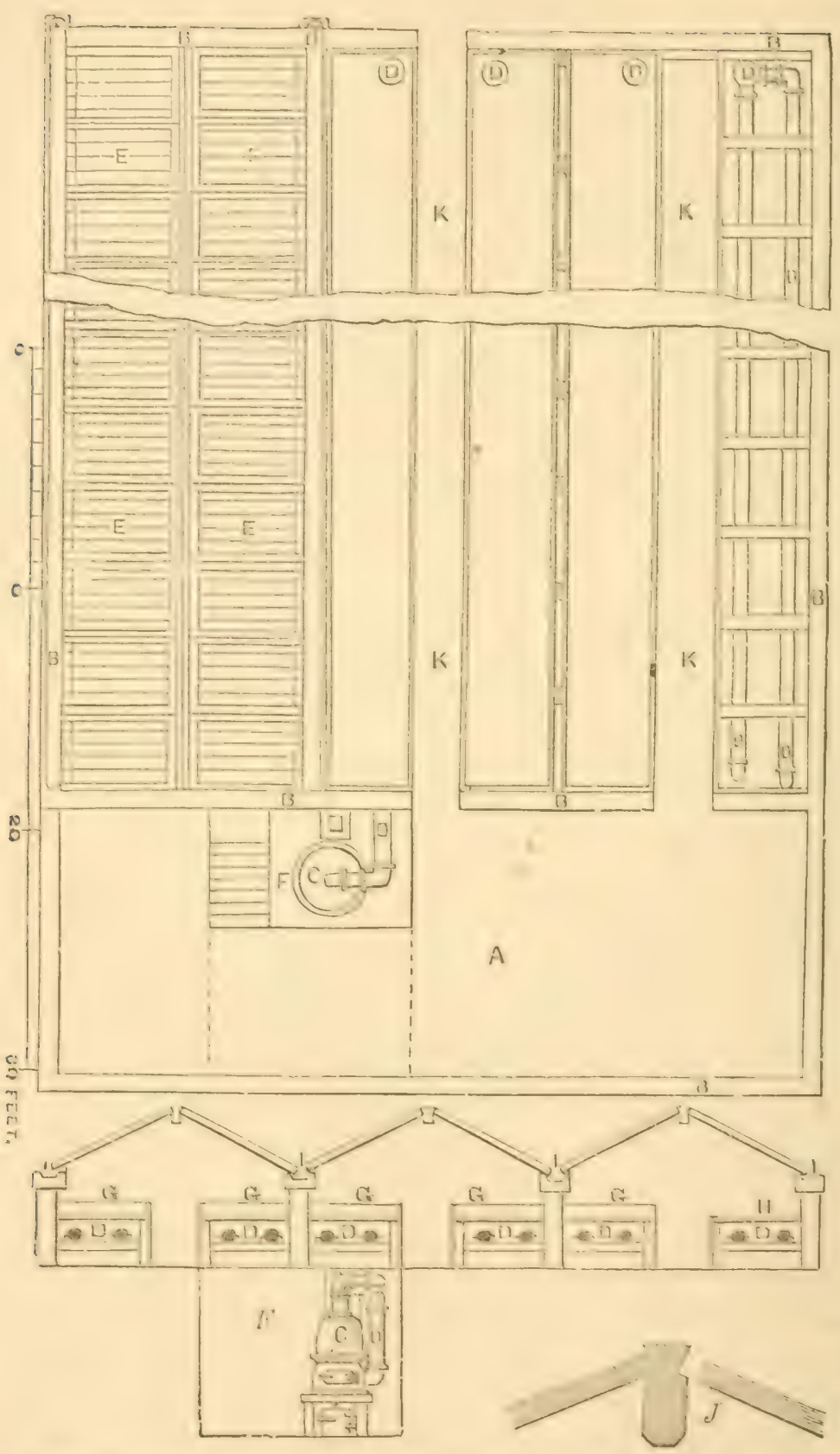

Fim 6. -ENT SECTION AND GROUND PLAN OF FOIRCING-PITS IEATED BY WATEL pil'ls. 
and very effective. The movable sish is not hingerel at the botton, but is held in place by two small plates of iron screwed on the sutter plate. The rielge-poles are cut out of the shape shown at $J$, and the satshes lie on

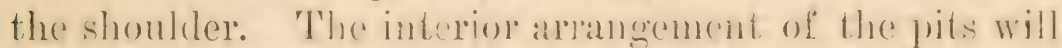
be adsily understond by the end secelon. Gi shows the bench or tahle at it is completed, wheh is filled with dise or six inches of soll, in which the Lethuce, ete., are to be grown. This shows the boxing-in of the pipes, $D$, to give "bottom heat" to the cuttings, seeds ol plants that are placed on the bench; but on the sistes of the bench, along the walk, one plank is hinger throughout the louse, so that it may he let down when leepuired and permit the escape of heat into the greenhouse. The wallis thro:lgh the house, $K$, ale two fect wir? A brick shed, $A$, covers the boiler-pit, $F^{\prime}$, and is attached to the north end of the pits. Besides breaking the wind at this vulneralile point, we find this sherl a mo:- excellent place for many purposes, as it is kepte from freczing by the heat that escape: from tho boilerpit, which would ofherwise be lost. This heat may be turned to a rery profitable account in forcing Mushrooms or Rhubarh, if desired for that purpose.

The system of attaching three pits together is now almost unirersally adopted by commercial gardenses in all houses erected during the pat twenty-five years in the neighborhood of New York; it has graat adrantages over the detathen system, heing less expensive in heat ine. more saring of space, and, above all, far more ceonomical in cost of construction. I nefer having onily three together, for the rason that when we have the smow to clear away it is quickly done by being shoveled from the two ralleys or furrows over the ridges; although we have one grower in this neighborhood who has twelve comnected houses, and finds but, little trouble with snow. Our snow heing mostly from the north, the sherl breakis 
them off in an wat mensule, and what blows orer blows mostly off through the valley between the sashes. The water from the gritter is led into a cistern, at the south end of the greenhouses, of a cupacity of not less than 3,000 cubic feet - if o, 000 , all the better: to this is connected a Douglas Force Pump, figure \%, with 150 feet of one and a half inch hose. and to the end of the hose is attached a heary sprinkler. One man pumps, and another regmlates the water and sprinkles it orer the plants. My establishment. in 1866 contained over an acre of glass, and yet. by this labor-saring arrangement, all the plants were thoroughly drenched with water by two men in four hours. Before adopting this method of watering, at least four of the hanks were muloyod the whole day danding the spring months in watering. and then the work was not done half so well. There is nothing that I have erel dome, commeded with hortioultural operations. that has been so cutirely satisfactory at this 
mothod of watering. Now, 1886, we are fortunate enough to have the rity water, and cain drench four acres of plants grown under glass in ten hours.

In these pits may be propreated and grown leseses and

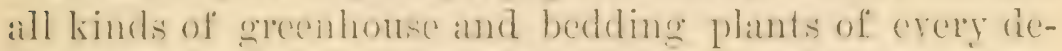
scription, in the hest posible mammer. But als onl present purpose is only with recotal)les, I will andeavol to describe our mote of operations with some of these. Lettuce, from the ereat quantities comsumed in all laree cities, is now, and will he likely to be, one of the most profitable veretables to foree, for the reason that from its soft and bulky character it cannot be so salelyor cheaply shipped from the hionth as many other kinds of vegetables. We brom, for our first (opol), by sowing the seed about the doth of August, in the open eroment, of the

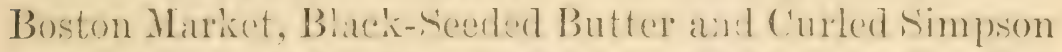
sorts, using hy far the greatest propontion of the first named. es it forms a solid head quicker and can be planted closer. These are planted on the henches of the forcing-Jouse in live or six weeks after, at about six or eight inches apart calch way, on well (miched soil, placed on the benches to the deyth of tire or six inches. It this scason no "foreing" is requirerl, and the sashes should be lient maicer to admit air, night and day, until frosts begin to be serere; then they shomld he shut up at night, lout no fire heat should be applier wntil the weather has becn severe enough to indicate thirty-eight or forty derrees inside the pits, and even then very shightly, for if they can he bronght to maturity at this scason withont the temperature exceding fifty degrees at night (by fire heat), the crop will he all the hetter. The great thing in forcing all plants of this hardy nature being to aroid a high femperature, the temperature when steady firing is begun in the winter months, should average fifty degrees as near as possible.

Of late years, Lettuce plant.: when grown under glass, 
halve onarionally beome affected by a speres of mildew (1) rust. which. hewming in the contere of the plant. quickly sproals oret the whole and lestroys it. I am

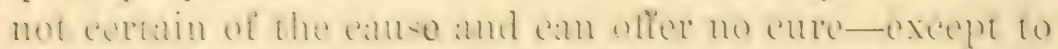
alvise that great eare should be tahen to have the plants

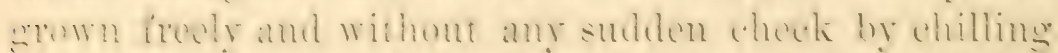
or by the extromes of drouth and moisture. No thel in

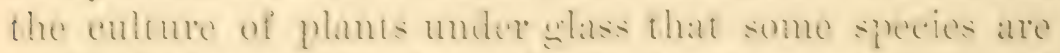

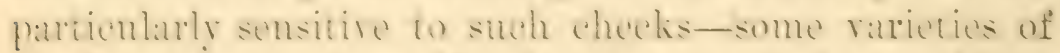
the hose, for instame. if, when in a particular condition of gremth. the comperature for a tew homs is rotued from sixty-five to forty deneres at niwhe or if a thesty sombleast wimd is allowed to play on the leares for wem wom winutes or if allowed to dry so that the plant wilts. mildew wibl to a certainty be derebped in twonty-four

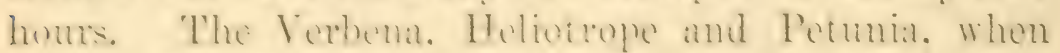

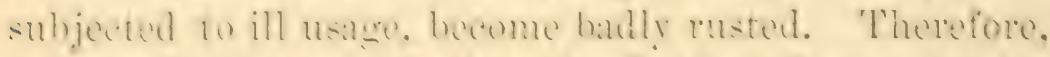
I am incined to think that the betmee discase is also camed by sume ill usenge at some period of its growth. for we tind that it is rarely sen when the erop is grown

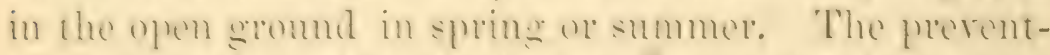
ine stereosted is that ylants io be fored should be pre-

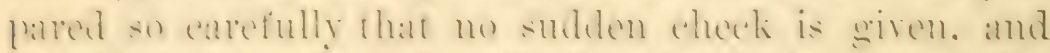
alse that the soil now on the benehes be fresh, and the memure new be thoroughly rocted and well mixed through the soil.

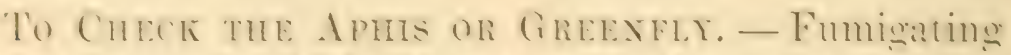

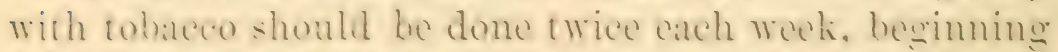
the very day the plants ate planted in the bench. In fumigating we nse refuse tobaten stems, about two pounds

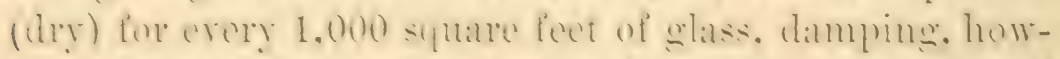

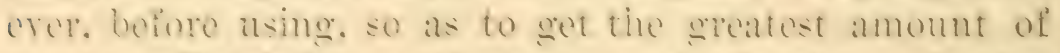

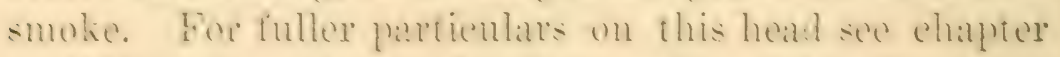
on " Vide Greenhouses for Forcing Tegetables."

The first crop is ready about Norember 1st. and is

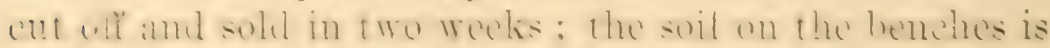


shightly mannred, dug up, and again planted (from plants sown in eold frames, or in boxes in the same pit) about Septemberesolh. 'This second, or winter corep, reopuires more attention in growing, both in firing, watcring, and airing, as it matures about Jannary 1st, and conserpuently has hat to be carlend for dering a cold part of the year. The thirl crop, treated exactly ats the second, is planted ats soon as the other is cut ofl, and matures about $\Lambda_{\text {pril }} 1$ st. We now vary the use of the pit, by planting at distances of about three feet alpart along the entere of the bench, plants of the White spine Cucumber, from seed sown about $\Lambda_{\text {pril }} 1 \mathrm{st}$, in a corner of the pit that hats been liept closer and warmer than ihat for the Lethere; these are planted in pots alont three inches in diameter, and by the time the benches are cleared in May are fine strong plants, that give a full crop during the month of June-fully at month sooner than from the open ground. The combined value of these four cropses will arerage about \$400, for a structure 100 feet in length by cleven feed in width. The estimated expense of cultivation is :

Interest on soo, cost of construction, at 10 per econt. \$ 80.00

Coal, five tons. 30.00

Labor, Manure, ete 100.00

Recoipts $\$ 200.00$ 4111.09

Net Profit

$\$ 200.00$

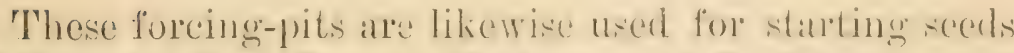
of 'Tomato, Egge, Pepper, Cabbage, and Cauliflower, and sprouting sweet Potatoes, which is done with far lesis risk and in a much better manner than can be alecomplished by the hot-bed. One great ardrantage is, that by heing able to walk inside of them, these pits are aceesible in all weathers, while with the hot-hed or frames we are in winter often debalred from examination for whole datys together: 


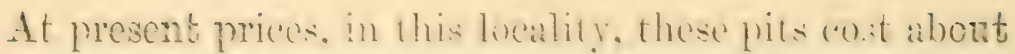
si pre linest foot. orerthing complete. put up in the way indieated hy the plan in a plain sulstantial mamner. But these whose circumstances do not atmit of the expense of hatheg hy hot watel (wheh is nearly hall the cost of

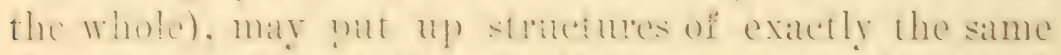
charatere and he:at them hy the eommon smoke flue at an expente of lam $\because 4$ (1) \& per lineal foot. in the manners show hy the phat, liwnes. It will he seen hy this

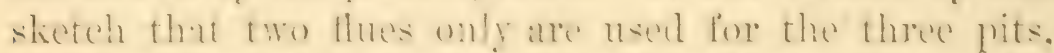

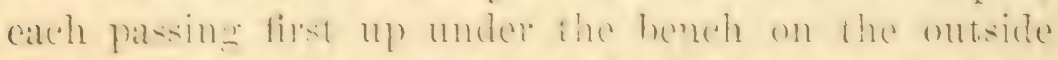

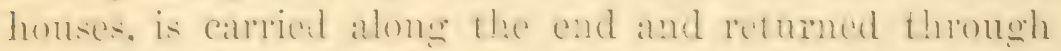
the midalle houses: this equalize: the limperature in al!

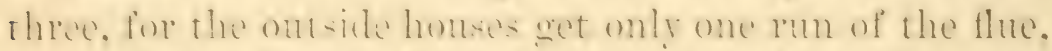

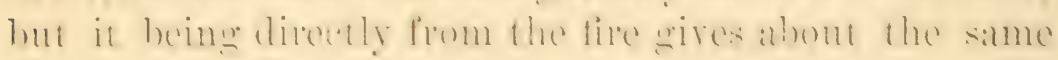
heat to the outside houses as two runs in the middle house, which, hing a greater distance brom the tire, are? much colder. 'Throe attacheil houses, heated thus,

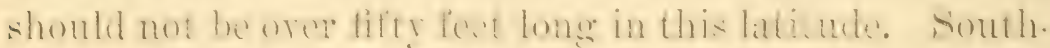
watrel they may he sixty hes and northwath forty fect.

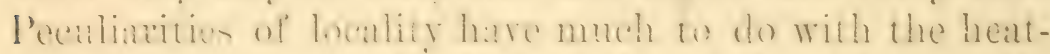

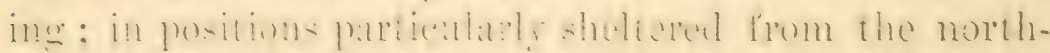
wert. the same amomut of the will heat sixty feet quite as earily as in expeced platers it will herat forry. 'The popele way of construeting the furnace and the is of im-

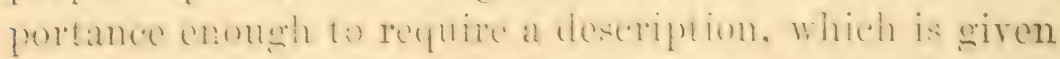

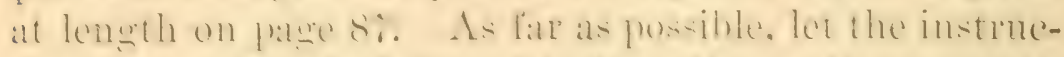
tions there grien he followed to the hetter. ats they alre such

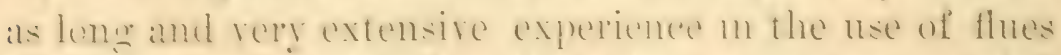

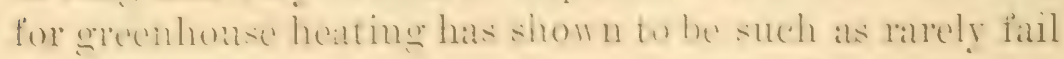
to give the rery best results. 'Lwenty-five years ago

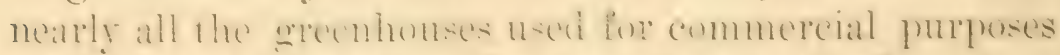
were heated hy hles. In my own practice I nsedel no other moite of heating until 1stit) and grew plants ynite as well there as we de fo-day. One of the lareces roseQrowing lirms in this comintry still uses fluse only, with 
TORCING-PITS OR GREENHOLSES.
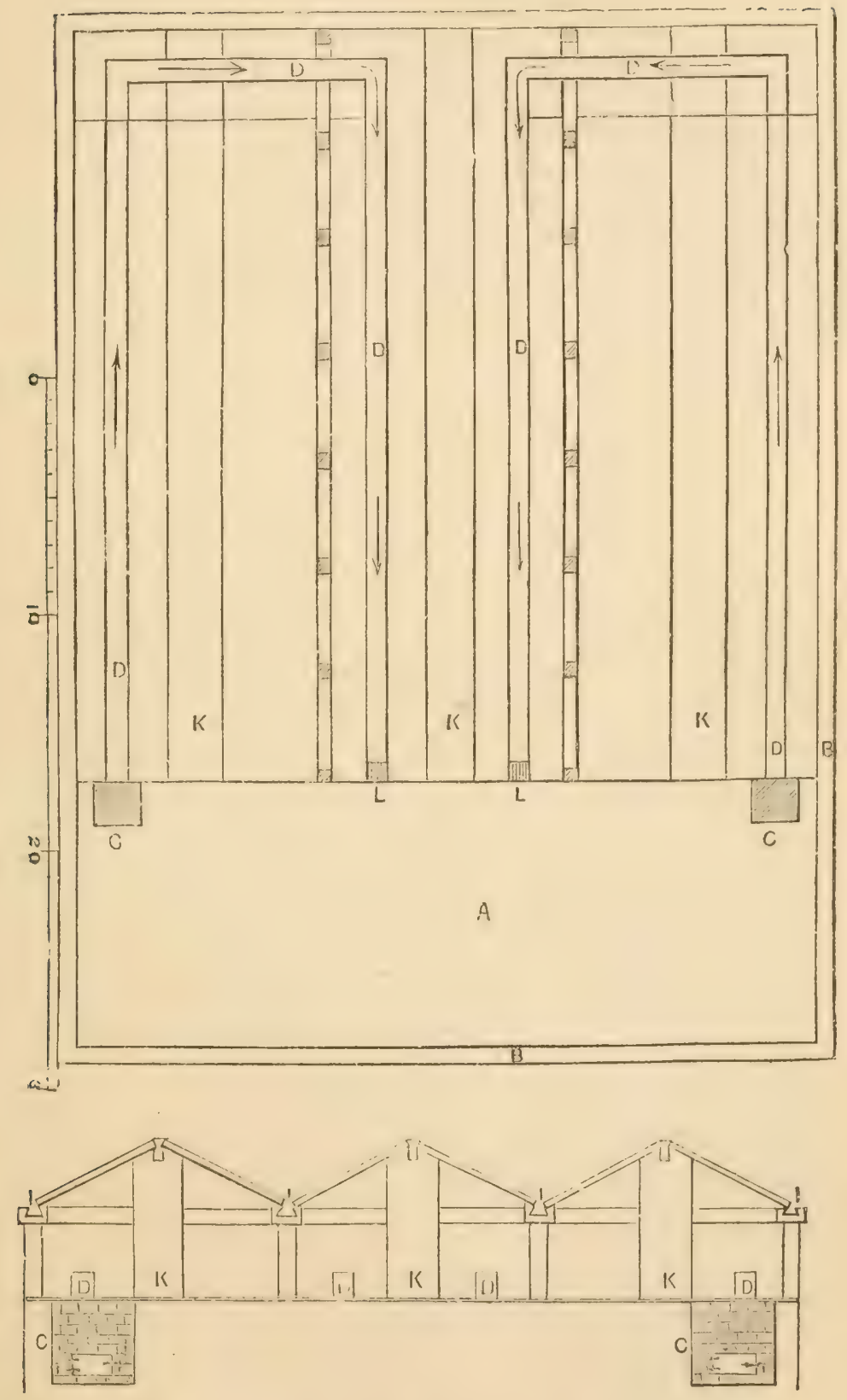

Fig. 8.-FND-SECTION AND GROUND PIAN OF FOROING-PITS IIEATED BY FLUE. 
results that hate been such as to make their huwiness a

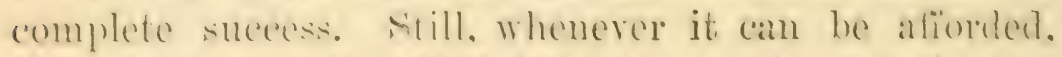
there is no yuestion that hot water or steam is the hest.

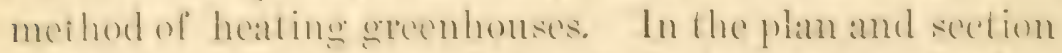
on the proceding page. $t$ is the shed enclesing the furnaces. (' C. from whieh pats the flues. I), in the direstion shown by the alrows to the chimmers, L. The benches are not shown here, but they are arranged as in ligure 6. 


\section{H A P'T E R X.}

\section{WIDE GREENHOUSES FOR}

FORCING VEGEIABLE CROPS.

Since "Gardening for Profit" was first written, larger experience has shown that greenhouse structures for forcing vegetables cannot only be erected cheaper when made twenty or twentytwo feet wide, instead of ten or eleven feet as then in use, but from the larger volume of air they contain, which when once heated better resists the cold outer air, less artificial heat is necessary. So well convineed were we of the advantages of the wider structure, that six years ago we removed all our old eleven foot houses (covering nearly an acre in glass) and replaced them with greenhouses averaging twenty feet wide by 100 feet in length. John Hudson, of Jersey City, New Jersey, one of the most successful of all our market gardeners in the vicinity of New York, constructed, the past scason, six greenhouses, each 150 feet long by twenty-two feet wide, plans of which are given in figures? and 10. 'The cost of these greenhouses complete, with rentilating apparatus, lieating, benches, etc., was about $\$ 10,000$,

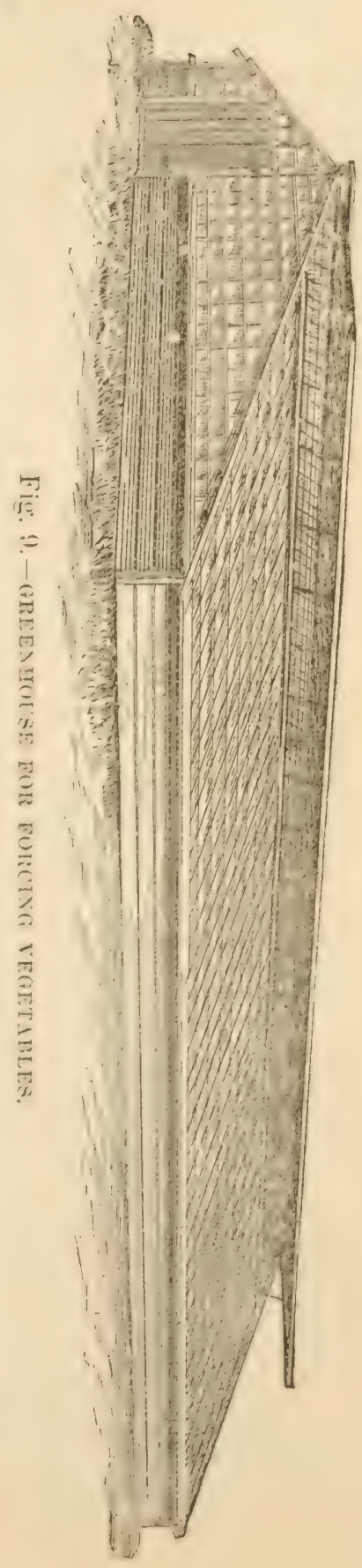


or about so pere rmming foot. 'flhe structure is very simple. 'ilhe walls front amel rear are comstructed of cedar posts, about tive to six inches in diameter, placed four feet alpart and simk three feet in the groment. On the outside sit these ane nated rough hemlock boards,

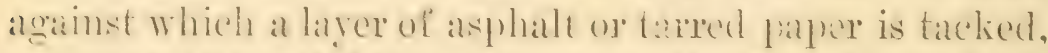
overe which is nated the orelinary weather boarding. Fuch a wall will resist cold hotter than an oight-inch briok wall, and will last twonty-tive rars it kept patited. I rery common errop is to build the wootan wall of a glemenhouse hollow and fill the spowe with sablust. This shombl nover be dome, as it is mote exponsile, and is by no meins so good as the plan here given. It will be

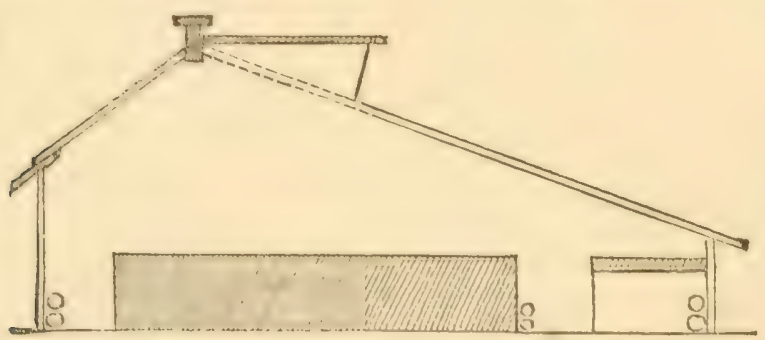

Fig. 10.-OROSS-SECTION OF FOLCING-IIOUSE.

seen by the engraving. figure io, that these ereenhonses of Ml. Iludsons atre heated whth hot water. the six (t)

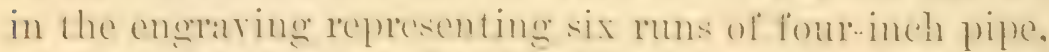
which is sullowent to gire a night temperalue of fortyfire or hilty degrees when the thememeter is tem below zoro. which is a sufficomt night temperatule in the win-

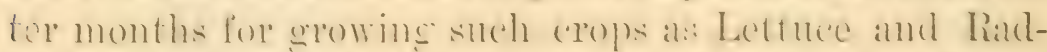
ishes. Of eompe in the day-time, when the sun shines. the fompreature of such a house will run filtere or t wenty

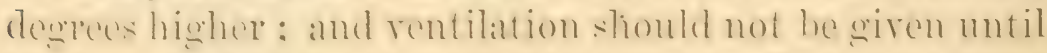

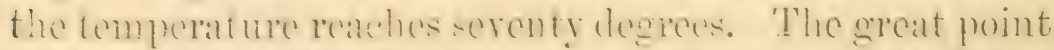

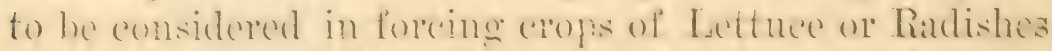
in ereenhouses is if possible. not to let the night temperiature creced tifty deneres. Of eourse this camnot be helped 
in the fall months, when the tomprature outside is often much higher than filty at night, hut in such catses, during the months of Oedober and November, the ventilating siahes should bo left up co as to kerept the temporature at night as low at practicable. Orten the entire first copeph of Lethace are lost for want of this precantion. Firthere cxiprience hats also taught us the nocosity of using glats of a latrere size. 'The size most nseat is twelre by sixteen, jut in the twolve inch way. The object of the langer glass is to obtain the gircalest amoint of light. In glaz-

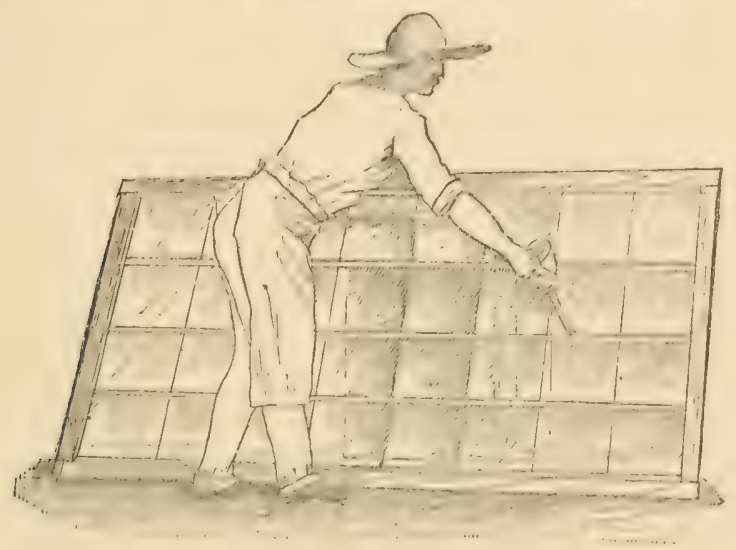

Fig. 11.-MMPizoved Met!IOI) ON GLAZING.

ing, the nothod now almost miversally arlopted is to berl the glass in putty and tack it on the upper side will, large glazing points, using no putty on top. 'The glaring points are triancular, one corner of which is turucel down, so that when it is driven in it lits agamst the lower edere of each pane and prevents it from slippong down. 1 great mistalie is often made in giving the glats too much lap. It should just he given enomoly to cover the colge of the pane below from one-cighth to one-quarter of an inch. If given much more the water gets between the pares and when it freezes cracks the glass.

It has been found that wheri the glass lies on the sathbars thus imbercied, the putty soon lots or wears out, 
and water geds in, and not only loosens the glass, but rots the har as well. I most simple plan to obriate this is to poul alone the jumetion of the bar with the glass a thin lime of white lade in oil. orer whold is shaken dry white samel. This harlens and makes a edement that

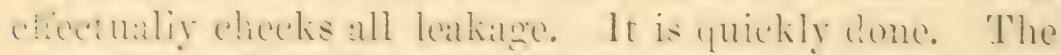

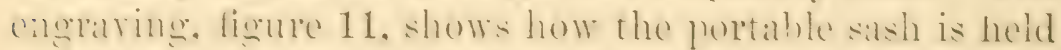
and the application mate liom the oil-ean comtaning the thin white leal. I havesen glass se exmented that has

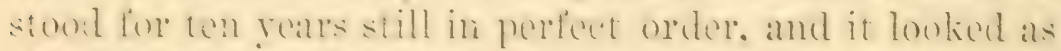
if it wailel stamel for ton rears mole without furthere repatr. 'lhis plan, which is hat linte kmown as yet. is of the ereates importame. Ilat I kinom of it thirty roars

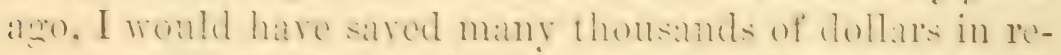
painde. hesiles having the plants meler this water-tight glazing in better condition.

It will be seen that two of the hot water pipes are

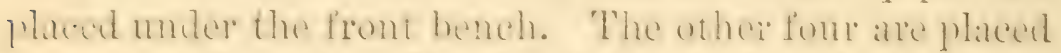

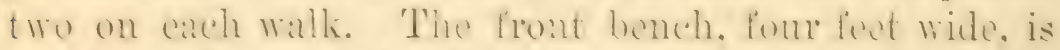
(omstruetalso that it will hold fice or six inches in depth of soil: hut the mithle or min bench. which is thintere

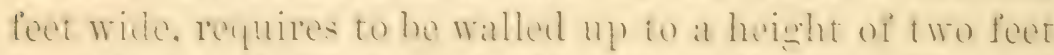
(so plam) and filled up to the top with soil. 'The sil

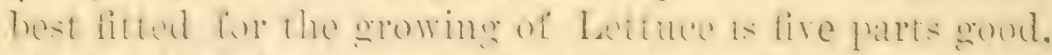
strome. fresh loam to ons part well-poten l cow dung. I

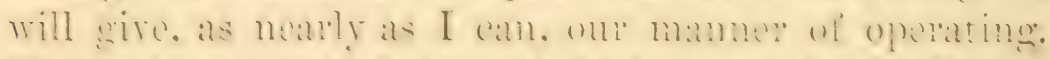

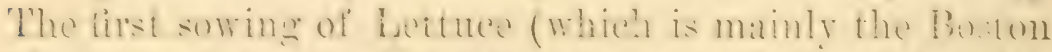

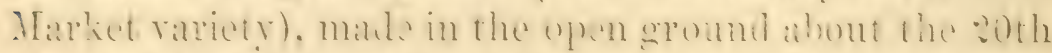

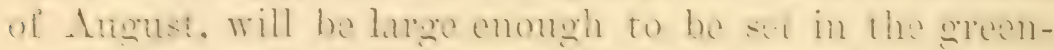

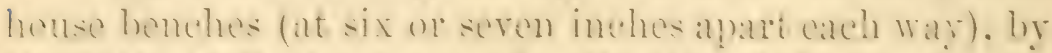

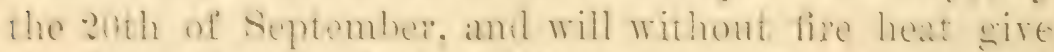
the hame by the first of Norember. For the seomed sucession. sowings are still made outshb about the ?uth wi Suptember. to replant the space where the tirst erep has beon ent out by the first wak in Foromber. Is the sanson is now watting ander the erop plantod by the tirst 
of November will not be fit for market until about the Christmas Ifolidays, at which time it usually sells well. for the thirel crope, to be planted in Jammary, the plants mate by the sowing on the deth of september should he

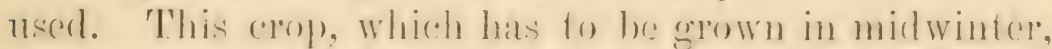
will not be ready, if planterd the first or serond week in January, until about the first of April.

One of the greatert pests in growing Isettues is the Grou Fly or $\Lambda_{\text {phis }}$ and the remedy must be preventive, for if it once gets a foothold on the growing plant, it cannot be destroyed. From its operations being mainly on the under side of the leaves, uothing can reach it; consequently every insect must be rest royed before planting. Tobaceo in any form is restructive to it. So before planting let the surface of the soil he sown orer with tobaceo dust, and aliog let the young plants be rinsed in water wherein tobaceo stems have been sterened long enonghe to give it the colsor of strong tea. By using these precantions there i:s little danger that the lattuce will be attacked by the insect, allhough, as a further measure of preantion, it will be well to strew the paths with refuse tohaceo stems, which will make a complete antidote against the $\Lambda_{\text {phis. }}$ There is another direase often affecting Letuce, with which, howerer, it jis not so easy to eope. It is first seen hy the leaves hardening and spotting brownish red, then gradually decaring towards the center of the plant antil it partly destrols it. The callse seoms to be anything that gives the plant a chack -any too sudden change of temperature, too much dryne:s or too much moisture. There is, I think, no remerly after the discase has once sturted, so our efforts mlist be for prevention. (See page 68).

Mr. Ifulson has used some of his greenhouses for growing the Early Rommel Thok Rerl and the SimallTopped Forcing Radish. which he finds better suitable for foreing than any other. These are first sown about the first week in October, sucession sowing heing 
mate on the same ground as catch crop is marketed, which, atecording to the salson, is from four to six werks

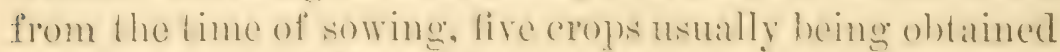
by the midlle ol May. The seed is sown thinly in rows three or forte inches aptert, and the rallishes thimned ont when an inch high to two inches between the plants.

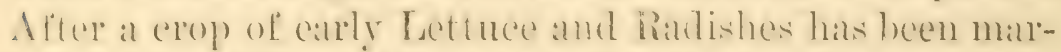
kefed (about the millde of Mateh), He hemehes are often

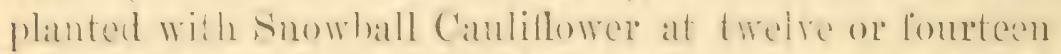
inches alpart each way, which is matreteal about the end of May, or two weelis before the omtetom arope is realy. Another, and rery often protitable, wse is mate of these

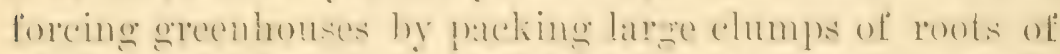

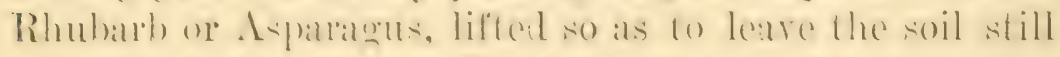
allering to the roots. 'These chmps can he sed as close?

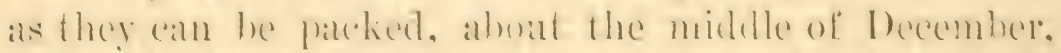
muler the front hench, as they require no light, and will

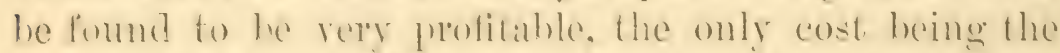
roots, which can ansily he raised, where ground is plontiful, in the open liold. hy soming the secel in lows cightern inches aprat, and thimning ont to a foot between the plants. It requires then yeits. howerer, to giow routs

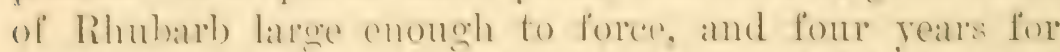
Aspalagus. There are olten ases where ole beds must. be remoled, where the rents, instabd of being theown away, would gire, by beingelosely jammed towether under

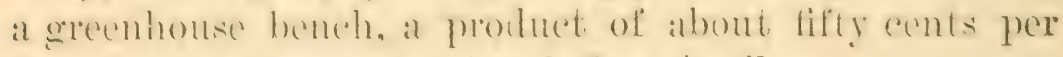
square foot, if sold any time before April.

It is not dasy to estimate the protits on such an invest-

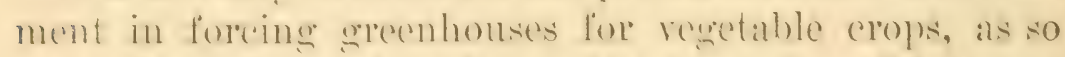
much depends on what the malliet alemands. Of eomser all the prodace in such a marliet as Xew York are sold at wholesale, and not infiaguently pass through sereral ditherent hambs before reathing the consumer; but eren thus sold, it is sale to saly that, with late arerage culture, shoh crops at wholesale lates will pay a clear net neotit of 
thirty per eent. ammully ; while there is but little dould that if the consumer could be reached direct, at least twice that amount conld be realized.

'The business is a particularly pleasint one, and is a great advantage, in all respects, over the hot-bed system, as one hat complete control orer the grecuhouse temperilture, both l:y night and hy day, if the heating and rentilating apparatus hare been properly constructed. 'These greenhouses are also well adayted for latising all kinds of vegetable plants. For the past six years nearly all our Cabbage, Cimuliflower, Lettuce amd 'T'omato plants have been raised in such grecuhouses at far less expense than in the old-fashioned hot-beds. When the expense of hot water apparatus camnot be entertinind, the same style of greenhouse can be heaterl by the horizontal smoke fluc, costing little more than half as mucle as the hot water apparatus, as the latter is abont one-half of the entire cost of the construction of such houses.

\section{FORCING CUCUMBERS.}

The wide greenhouses or forcing-houses, which we have described as being usen by Mr. IIudson for forcing Lettuce, Radishes and Cauliflower, can also be mate equally available for forcing ('ncumbers, either during the entire winter and spring season, or to be used to suc.. ceed the last crops of Radishes or Lettuce in spring. If wanted for the forcing of (ucumbers during the fall seasom, the seed should be sown in the greenhouse about October lst in small pots, three or four seerls in cach, thimning ont to one strong plant. These, in thirty days, will have become sufficiently strong to plant out at twenty to twenty-four inclies apart on the south side of the bencli, one row only. A trellis of galvanized iron wire is male with abont a nine-inch mesh, diamond shaperl. This, on the middle bench, should he kept two fect from the glas: but on the front bench it can only bo kept one 
foot from the glass, owing io its neinnes to the sashes. 'The elepth of soil should be, if on ratised wooden henehes, abolit tive or six inches: if on the solit enter bed, cightern

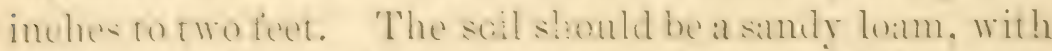

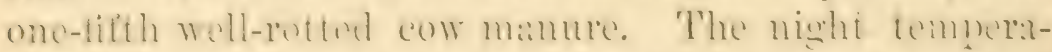
tare in the foreing-house for the fall, winter and spring

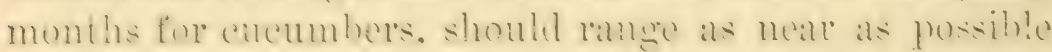
from sixty to sixty-five deseres. With a temperature on

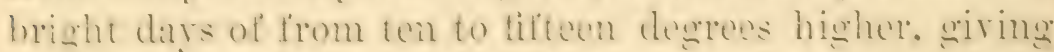

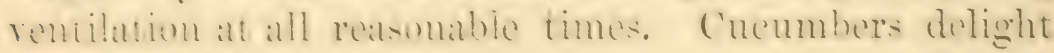
in a moist atmosphere, ame whemere the weather is bright and elear. water should be sprinklad on the pipes, wallis and umler the bomehes. I diry amosphere is certain to derolop the lied spider. Which is fatal to stecess. It maly also be here stated, -if c'uemombs are to lie; forcol during the winter mombls. that to hede up the

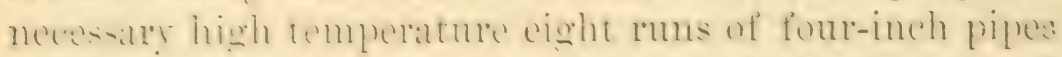

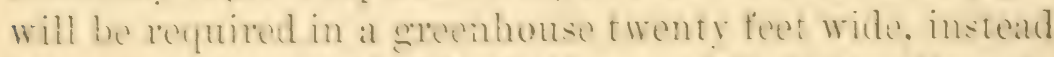

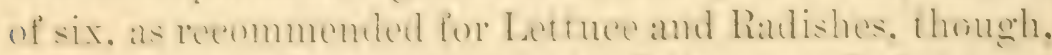

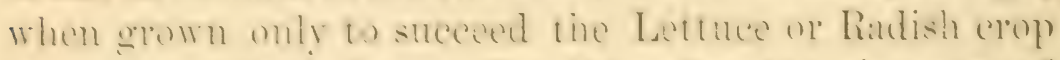
in spring. which is nswally the ease. the six runs of pipes at that season will be sufincient.

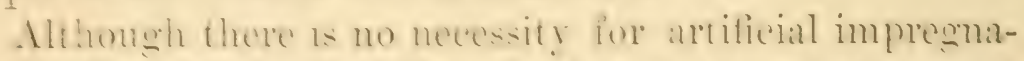
tion of the c'anmber thowers when grown in the open air, where the inserts ame wints do the work, yet, when grown in the foreme-house, it is absolutely needsalry. purtionlarty in midwinter. 'This is hest done with a camel's hair penteil, hy detahing the pollen. or fertilizing dust. from the stamens and applying it to the stigma. It will aloo facilitare imprenation on bright days to slightly

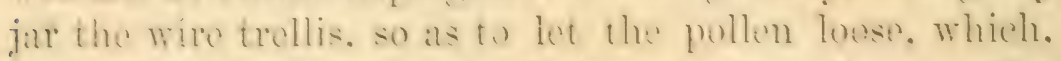
in Honting through the air. fattens on the stigma. Cucumbers from soled sown in Ociober will give a entinuous (rop until. Tume-of coutser. if woll hambled. When wanted only to sucered crops of Letmee or hamishes in

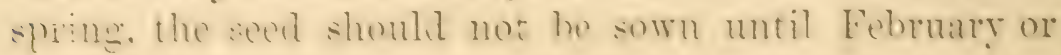


March. The variety for foreing which seems to be mo:t favorably received in our markets is "selected Early 1 h hite Spine," though, of late yeatrs, the beantiful long kinds, such as "Telegraph" and " Riambler," which are almost exclusirely used in Enrope, are beginning to be farorably received. Forced Cucumbers from December to May arerage, for best quality in the market of New York, $\$ 6$ per dozen, and, if the forcing is well done, this price will be found to pay very well. Southern competition, of course, seriously interferes with the forcing of cucumbers, as it does with nearly everything else in early regetables and fruits; but, like hot-house grapes, the bloom and fine appearance, together with the more delicate flavor, of the forced Cucumber, finds customers in all large cities who are willing to pay for the finer quality.

\section{FORCING STRAWBERRIES.}

The wide greenhouses, alreaty doseribed as being suitable for forcing Lettuce and Radishes or (ncumbers, are equally adupted, with slight modification, for the forcing of Strawberries. This modification is in having tho benches or talbles raicerl, so as to be as near the glass as it is practicable to have them, as shown by the sketeh, figure 13, of end section amnexed. It is also necessary that eight runs of four-inch pipe are used instead of six, as are in use for Lettuce and Rarlishes, as Strawherries require a somewhat higher temperature. The proper preparation of the plants for Stratwerry forcing is indispensable to success. This is best done by layering the runners in small pots, as describer under the head of Strawberry Culture. The layers may be placed in the pots at any time from the middle of July to September 1st. When the pot is filled with roots (which will he in about two or three weeks from the time the strawberry runner is pliced in it), it is then taken up and shifted ints a four-inch pot in soil four-fifth turfe lon to one- 
fifth rotted cow dung, to which miy be added a slight sprinkling of pure bone dust-say a handful to every bushel of soil.

When the strawberry plants have been shifted from the pots in which they were layered into the four-inch size, they should be set in the open sunshine, stimding the pots close together, and carefully watered as occasion requirs. so as to induce the best posible growth. All r'mners should he carefuliy pinched of as they appear, so that the whole force of the roots may go to derelop the main plant, or fruiting crown, as it is sometimes called. In four or fire weeks the four-inch pots will be filled with roots. and the plints must again be slifted into six-inch pots and treated as before. which will give, by the middle of October. the necesiary strong plants for forcing. As the season of growth stops about this date, water should be withheld to some extent, so that the plants may get a season of rest.

When they are placed in the forcing-house they may either be planted out on the benches at six or eight inches aprart, in soil five or six inches deep, or they may be forced in the pots, as may he desired. but, in any case, twice ats many plants should he prepared as will fill the honse, for, if desired, two crops can easily he raised in succesion. The first plants should be placed in the forcing-house about Norember 1st: these will produce marketable fruit by Jamualry or Fehruary. Plants put in in Fehnuary will be ready by March or A pril. Of course, it will be necesary to keep the reserve plants of strawberries in a dormint state. which is hest done in cold frames or pits, the pots being plunged up to the rims in dry leaves.

The best rule to follow in forcing any plant, is to keep as near as possible to its natural condition. We know that as the strawberry plant derelops its leares and flowcrs throughont May in this latitude in the open ground. 
that the night temperature will arerage, perhaps, forty degrees for the first two weeks in Mity and filty degrees for the last weeks, while for the first two weeks in June it will be about sixty degrees at night, and in all calses from ten to fifteen degrees higher in the day. This, then, is our rule for the forcing-liouses: Start slowly, jncreasing the temperature as the plant develops and ripens its iruit, just as nature does in the field.

Like Cucumbers, artificial impregnation is necessary for the Strawberry in the dull winter month.. This is best done by using a camel's hair pencil. twirling it from one flower to another-particularly from the staminate to the pistillate flowers-on clear days if posible, and allowing all possible rentilation. Sometimes lives of bees are kept in Strawberry and Cncumber forcing-honses, to assist in the impregnation.

Some judgment is necessury in watering until there are indications of rigorous growth. Water at the roots sparingly; at the same time, do not allow the soil to get too dry, and be careful not to water the plants orerhead when in bloom, as that will destroy the impregnation. When the fruit has "set," gire water freely whenever necessary, and throughout the whole scason of growth keep the atmosphere of the house well charged with moisture. in order to keep down the Red Spider, the insect which is quickly destructive to both Strawherries and Cucumbers.

The kinds of Strawberries which seem to have been the farorites for forcing are the Champion, a rather dark crimson berry of great beauty and of the largest size, with occasional trials of Jersey Queen, on account of the great size and beauty of the fruit. But the new variety, raised by Mr. Sermour. of Norwalk, Conn., and named in our honor, "The Henderson," from trials made with it, is likely to prove the most raluable variety for forcing purposes. It has what are known as "perfect flowers," and 
heme is cartain to " set " fruit. It is of the largest size. of beatiful form : color. a vivh shate of searlet erimeon. the surfue lowking as if ramished. In flaror it is msumased by any honwm variety, hesiles haring a rich

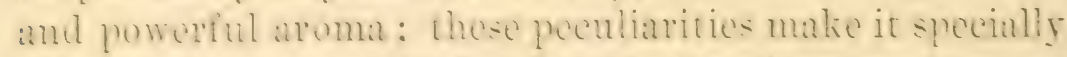

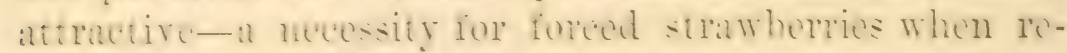
tailue at ahome tify conts a berry. for in the winter months. it must be rememberent. they soll at wholesale

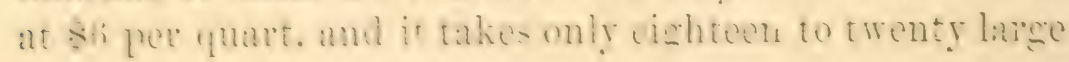
berries to make al quart.

To our rumal realers this extrambinary price paid for fruit may som incredible. but all lares vities contain pople who are rieh mough to athord these pricess not mily for fruits hut for Hewers. for it is no musual thing

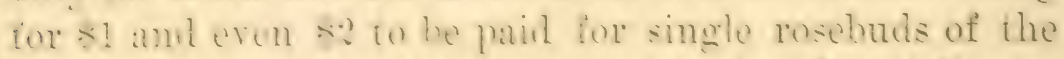

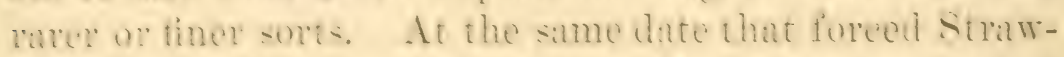
berriu are solling in Jew lork at se prer yuart. or forced Cuemombs at si pu domen. both strawberries and C'ucumbers grown in the sombern states are selling at onesixth the prices. but the quality of course. hears no comparison with the foreed commodities. He hare nerer ourselve formel vilher strawberries or c'ueumbers for murket. but quite a mumber in the rivinity of large oities make it a problable husines. In laet. there is compara-

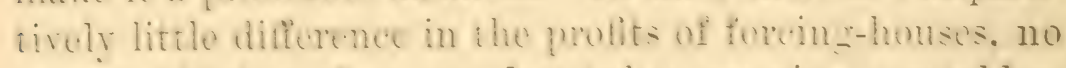
mation whether they are levoled to growing regetables, Pruit on Hower: : the pay well ror the invesment in all enses if the work is well rome.

\section{HEATIXY B FLLES,}

For bevinuers with small meare. when persomal attentim ean he giren to the fires by heating greenhouses with thes a werat suring in cost can be male-in fact. nearly half the cost of construction : for we find that the hot water heating apparates is usually half the post of owlinur! mommercinl grenhonses, while if hanted by Hes 
the cost of thee would not he more than ten prer echit. of the whole. A new methor of constructing flues (or rather a revived method, for it originated in 18:2,) has been in use for the past few years, which has such manifest advantages that many now use it who would no doubt otherwise have used hot water heating. Its peculiarity consists in running the flue back to the furnace from which it starts and into the chimney, which is built on the top of the furnace. As soon as the fire is lighted in the furnace, the brick-work forming the arch gets heated, and at once starts an upwarl draft, driving out the cold air from the chimney, which puts the smoke flue into immeriateaction and maintains it ; hence chere is never any trouble about the draft, as in ordinary flues which hatre the chimmey at the most distant point from the furmare.

By this plan, we not only get rid of the riolent heat given out by the furnace, but at the same time it insures a complete draft, so that the heated air from the furnace is so rapidly carried through the entire length of the flue that it is ncarly as hot when it cnters the chimucy as when it left the furnace. This perfect draft also does away with all danger of the escape of gas from the flues into the greenhouse, which often happens when the draft is not active. Although no system of heating loy smoke flues is so sitisfactory als by hot water, yet there are hundreds who have neither the means nor the inclination to go to the greater expense of hot water heating, and to such this revived method is one that will, to a great extent, simplify and clieapen the erection of gremhonses. Many old-estahlished florists, who have had the old plitn of flues in use, have changed them to the one here described, and with great satisfaction. The wonder is that such an important fact has heen so long orerlonked, for at the time it was discorered, heating greenhouses by flues was almost the only method in use.

Figure 12 (scale, onc-eighth oi an inch to the foot), 

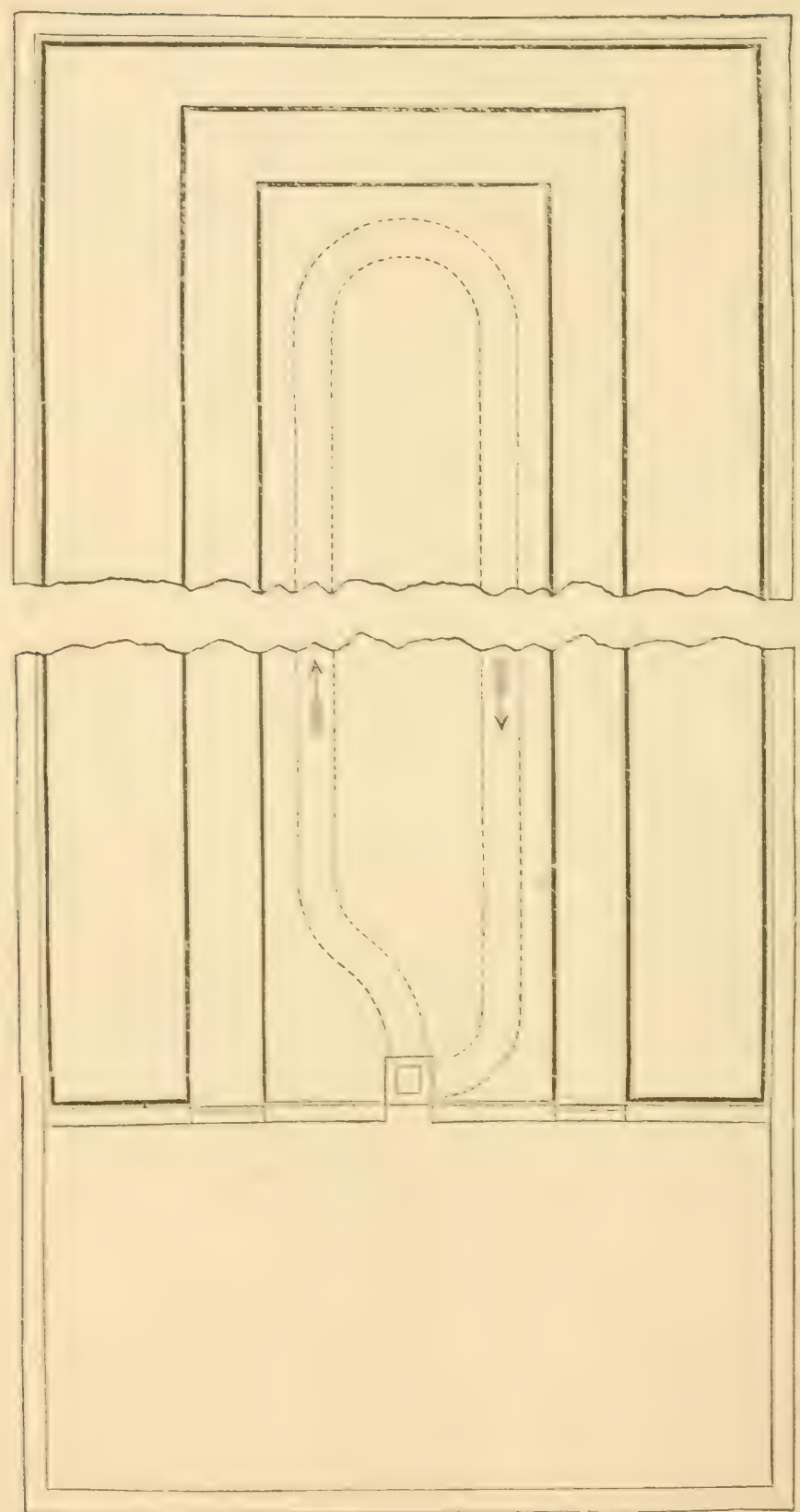

Fig. 12-HOCSE HEATED BY FLUE. 
shows a greenhouse twenty feet wide by fifty fect long, with furnace-room, or shed, ten by twenty feet. Here the flues are so dispeserl as to aroid crosing the walks, being placed under the center bench, but as near as possible to the walli on carch sicle, so that the heat may be erenly diffused throughout. If a difference in temperature is refuired in a house of this kind, it may be obtained by ruming a gass partition across the house, saly at twenty-five feet from the furnace end, which will, of course, make the latter end the hottest. It will be

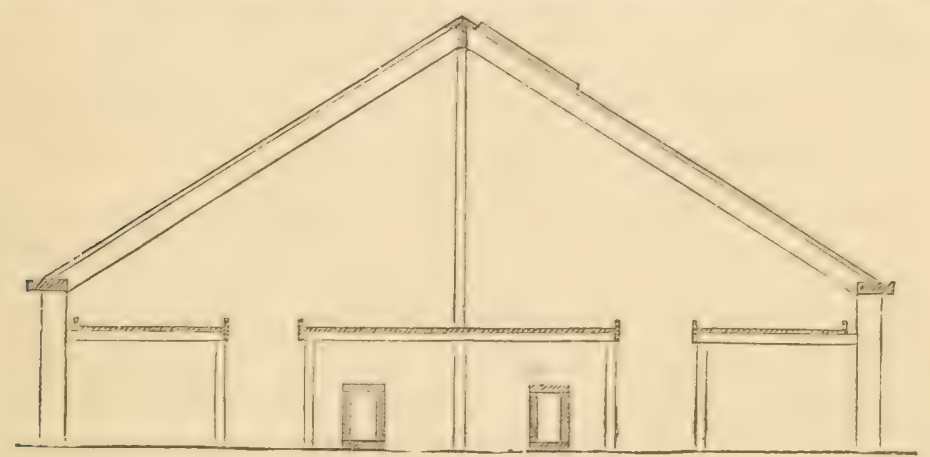

Fig. 13.-END-SECTION.

observed that the plan (figure 1:) shows by dotted lines this new or revired plan of the heating. Figure 13 (the same scale) is a section, showing the arrangement of the benches, etc.

In constructing the furnace for flue loating, the size of the furnace doors should be, for a greenhouse twenty by fifty, about fourteen inches square, and the lengtl of the furnace bars thirty inches: the furnace should be arched orer, and the top of the insice of the arch should be about twenty inches from the bar.. The flue will always "draw" better if slightly on the ascent throughout its entire length. It should he clevated, in all cases, from the ground on flags or bricks. so that its heat may be given out on all sides. The inside measure of the brick flue should not be less than aight loy fourteen 
inches. Ii tiles cam be combeniontly procureit, they are best to corer with: hut. if not. the t.ly of the flue may be contrated to six inches, and covered with bricks.

After the llue has been built of brick to twenty-lise of thirty foet from the furnatere cement or vitrified drain pipe, eight or nine inches in diameter, should he used, als they are not only cheaper, but ratiate the heat quicker than the bricks: they are also much casier eonstrueted and eleaned. Came shomld be taken that no wood-work is in contact with the flue at any place. It may be taken a.: a safe rule that wookl-work should in no case be noalper the flue or furnace than eight inches. In eonstrueting do not he influeneed hy what the methanies will tell rou. as few of them have had any experience in such matters, and are not able to jutge of the dangers resulting from woot-work heing in chese contact with the heated bricks.

The cost of such at ereenhouse, twonty hy filly feet, heated by fluc. when built alouc. would be, at present prices in this rieinity, about $\$ 1$ ? per ruming fout, or s800): hut if three wore built towether. cemnected at the futters, and thus sare the outer walls. as shown in the chapter on Fureing l'its and Gromhouses in another part of this book, the east of construction for thre houses heated by smolie flucs would not exeed s10 per ruming foot. or s1.s(n) for three houses cach twenty by tifty feet. 


\section{CHA PIER XI.}

\section{SEEDS AND SEED RAISING.}

If there is one thing of paramomet importanere in veretable gatroning it, is purity of seed ; and for this reason the seed oflered by seedsmen should be testod not only for its germinating qualities, but for its genumenesis of kind. The test of germination is asy enomgh, and theres is rarely any tromble with that ; but to be rertain that the variety is true to its lind, is a matter requiring tine and a knowledge of varieties.

In our own pracetice no important secels, such as . Meloms, Cucumbers, ('abbages, Caulifluwers, Lettuce, Colery, Radishes or Beets, are ever sold mutil tested in ond 'Trial Grounds, conseruently they are never sold mint they are? a year old, of aftere we have had an opportunity to prove, beyond any question, that they are genuine or true to the de kinds. But as all there reeds are just ats good four or five years old-some of them really better-this want of "Prohness," as some might frrm it, is no dicarlvantage whatever. It is quite a (o)mmon pratedice for matket

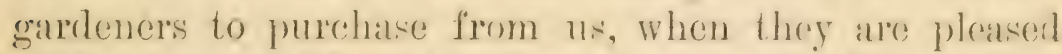
with some special strain of secol, as inureh of it as they will use for three yoars, so as to be certain bejond doubt that they have the kind they wan?.

Thirty years ago the market wardeners gerew nearly all their own seeds, as in these days we hard hardly any seedsmen that knew anything abont varieties. and (eomsequently the market gardeners dared not risk their arops in buying from them. I rememher on one oreasion the

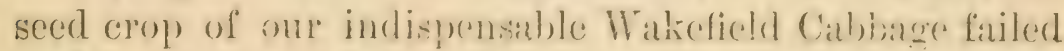
with nearly all of us. 'There was only onse man ammong us who had lat foresight enough to have a two years' supply; I offered him sofo pere pound, Int ande not pro- 
cure an ounce from him, and as no one cared to risk the

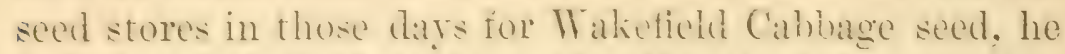
hat the whole fich to himself. He plantad nearly ten aldes with this variety, which coming in solne cight or ten days earlier than anything else. he mate a little fortume by his being ahle to have a momopoly of the seed. That i: now orer thirty rears age, hut I have never

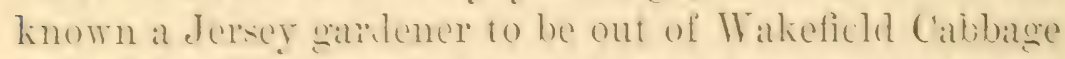
sased since, and rot linsw where to get it. Burere we adopted the system of proving sects in our i'rial Grounds, we often suffered serele luss's. I remember one getting from one of my neiphlors-al make garener-a pound of what he homestly thomeht wis silesia Lettuede hut which proved to he Corled India. I nsed it for planting in my forching-frames. which resulted in notrly an cutire lass of the crop). The India Lettuee is a summer variety. maturing in the hottest weather. and eonseduently almost useless for foreding. This blunder entailed on me a loss of orer a thomsand dollars. I yeare or two ago, we importal from England soo pounds of one of the leating kincls of celery, from a somere that in twenty yoars had always proved to be correct. ()ur Trial (ireund test showed it to he worthless, as it was lank growing and hollow stemmed : hat we not put it throngh the crucial

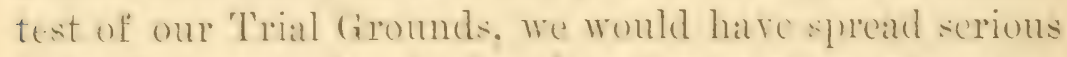
disitster amone humbleds of our market garten customers.

'There is hut little new to say of the mannel of raising sevels: the importance of selecting the purest sfecimens of each rariety, and of kevping plants that ane of the same fimilies apart as fili distant as the limits of the sround will andmit. is now well mulerstoul. It is not practicalnle, howerer. to lais all the sede wanted in our veretable vardens in one climats. and conseymently we have to raly on importation for sesds ol Broceoli. Camliflower. some rariotios of Cahbage. Ratishes. Peas. ote. 
But the great majority of seeds used are raised here, oul climate being particularly well adapted for maturing them. In the ratising of market regetab)!('s, near large cities, the nstual practice is for cach grower to grow only a few rarictice, and these of the sorts most purofitable to his location or ail. For example, we of New Jersey, in the immediate vicinity of Neir York, grow Beeds, Cabbages, Caulillowers, Cucimbers, Ledtuce, Radishes and 'Turnips as a first. crope, followed by Celerg, 'Thyme, Sage, Brocenli and late (ah) age as a second (erop) ; but in the more southem comntics of the state, where crops mature ten or twelve days earlier, but the distance greater from market, the bulkier and cheaper articles are not grown, and only the more portable and (when early) valuable kinds are raised, of which Tomatoes, Melons, Peas, Kidney Beans, Eirly 'Tumips and Becets are the staple articles.

seed growing, as practiced by market garrleners, is on much tro small a scale to make it profitable; in fact, there is hardly a seed raiserl, lut costs much more than what it can be purchased for from the seedsmen. Sieclsmen are supplied by regular seed growers, who make a special business of it; they are located in nearly every State in the Union, as the proper geographical distrihution of where seeds are grown, is found to be of the first importance; tropical seecis, such as Melons, Cucumloers, Egrg plants, and 'Tomatoes, doing better in higher temperatures, while Cabbages, P'eas, rite., do better in colder latitudes. California is becoming an important seed growing state, its climatic conditions beingr farorable for nearly all kints of seeds. Seerl growers, as a whole, are a highly responsible class of men, who thoroughly understund the business, and are now successfully competing with the English and French growers, from whom, only a fow years ago, nearly ail our sects were imported. By being able to get the sceds grown in our 
own comtry, we are able to supervise the growing of them, and, conseguently, the risk of error in getting spurious or inferior varicties is now rery small indecd. Henee there is now no necessity for the market ardeners to grow their own seeds, when they can be confident of setting what they want from the seedsman at half the price at which they can be grown by the market gardener; for while the sedsman contracts for toms, raised with all the appliances for saring secil in the hest manner, the market gardener cam only grow a few pounds on his ustally limited areat. Is a result of the malrliet girdeners erowing their own secels, may be mentioned the falct that the chinese gardeners in California, by reason of saving their own seeds, hare let rarietics so run down as to be hadedly recognizahle as the best types as now grown by our best Eistern market garleners. IHowever, no gambener should risk his (rop) without testing the secel, unless he has implicit contidenee in the souree from whence it has been purchased.

It will be muleretoul that of all ammual plants. such as Boms, Corn, C'ucumbers, Eger Plants, Lettuce, Mulons, Pous, Radishes. 'Tomatoes, ete., the seed is salved the seasom of plamting. and shomld be alwars taken from those first maturing, if carliness is an object. The secels of biemnial recetalbles. such as Beets, Carrots, Colerr, Cabbaloes, Onions. Lecks. Parsley, Parsnips, ete, are raised by selerting the best suecimens from those preserved orer winter, planting them out in good soil on the opening of spring, at distanees such ats are recommended for their growing.

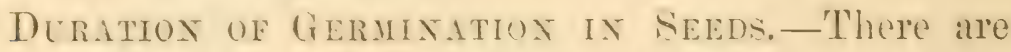
rery few seeds that will not germinate as freely the second your as the first, if properly kept in a cool place. and not exposed to either a too drring or too damp an atmosphere. With the exception of Parsups. Onions and Leelis, I would just as confilently sow seed two 
year's old as when fresh gathered; but there is a limit to the vitality of seeds, varying much in the difforent families.

Among those only safe for two year's are: Boand and Peas of all kinds, P'eppers, C'arrot, Corm, Lgg Plant, Okra, Salsify, Thyme, Sage, and Rhubarl.

Those safe for three year's: Asparagus, Endire, Lettuce, Parsley, Spinach, and Radish.

Those safe for fire years: Broccoli, Cauliflower, Caibbage, Celery, and Turnip.

Those possessing the greatest vitality are: Bect, C'ucumber, Nolon, Pumplin, Squash, and Tomato; the time ranging from six to ten years.

Market gardeners find this lnowledge very raluable; for example, in procuring the stock of a seed known to be good, of a rariety that does not seed the season it is markctable, such as Brocenli, Cauliflower, Cablage, or Celery, we procure enough to last at least two scasons. The first ceason only a little is sown, to test the merit of the variety, for we are never incautions enough to risk a full crop with one experiment. If it proves raluable, we have enough in reserve to sow for a full crop, knowing that it is sure to germinate. This was particularly the case with our New Dwarf Celery. On the recommendation of a friend I imported ten pounds of the sced, but, doubtful of low it would suit our market, only as much was sown as would furnish a few hundred plants. These showed so much superiority, in all respects, to the tall varieties that we had been growing, that the following season I put in half my crop with the dwarf seed. 'The thing was entirely new in our market, and so much superior that it sold for prices that would secm incredible. My ten pound bag was not half exhausted, and the next seatson I plantod my whole crop, fourtecn acres, containing nearly half a million roots, and made 
one of the bes hits 1 wer mute in gartening. But by this time me neighbors bean to taki an lanusual incerost in my colery crop and I conhel monopolive the variety no longer. 'T'he originater of our Xew White l'imme

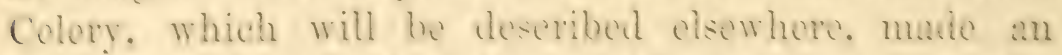
cyually gond hit bofore his noighbors waked up to the importamee of its merits.

- I ferquent somes of complaint is the firet of sceds failing to grominue durirg long contimed dry wenther. and it is very important that the gomdener should always apply oommon-suse to his work, and not simply follow rombue. for what will suit for one comblitum af soil or atmesplere would be nnuevesary. or cron wroug. for arother. I will gire a case to illustrate. About the fifth of Yay of isil. I sowed a large pateh of open ground with Colery seol, and another with Cabbage sect. The soil was in tine order, and the beds, after sowing. wore ruked-ihe Culery with a fime steol rake. the Cahbage with a large woolen rake, which covered the soved of anch to the regular degreh. The wenther was iry. with indicutions of its continuing so, and after soming I had both tho Cabbage and Colery bets rolled heavily. leaving. howeres. a strip of each mmolled, so that i conld elcarly show to some of my yount men what the result of this omis-ion would be if diry weather continud. Had a heary rain fallou within a day or two after sowiug. it would have compowet the soil and presduevel the etheot of rolling it. But we hat no rain for three or four weoks. and a burning-hot ammoshere. passing through the shallow. How corering of the swets. shriveled and dried them up so that it was implosible they could ever germinate. This little experiment re-

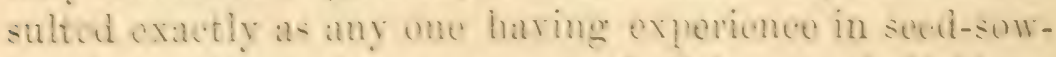
ing hnew it must our crop of cilery and cabbage planes were as tine as need be an the rollent bed, while ne! one serd in a thonsand of the Cilery. and not one in 
a hundred of the Cabbage started in the stribs where the soil was left loose.

In the sowing of Cauliffower, Cablatge, or Lettuce in September, the same precaution had better be lised. But in small beds, such ats are usually taken for these, if a roller is not at hand, after raking the berls the soil should be firmly patted with the back of the sparle; this not only produces quicker and more certain germination, but it leares the surface of the bed smooth, so that the plants come up staraghter than if the heds were left rough. We consider the practice of soaking sceds worse than useless. For fuller instructions on this, one of the most important of all garden operations, ses Chapter on the "Lse of the Feet in sowing and Planting." The greater part of this chanter hat been alrealy published in my book, entitled "How the Farm Pays", as well as portions of it in some of our secel catalogues. Believing it is of rital importance, I think it camnot be too often repeated. I have been writing on IIorticulture for nearly forty years, but I consider that I have benefited the farmers and gardener's of the Lniterl States more by the instructions given in the "Use of the J'eet in Sowing and Planting," than by any other article I have ever written. 


\section{H A P T R XII.}

\section{TIIE USE OF THE FEET IN SOWING AND PLANTING.}

[Read hefore the National Assuciation of Nurserymen, held at cleveland, O., by Petcr Henderson.]

It may be nseless to throw out any sugactions in relation to horticultural operations to such a body of pracetical men as is now before me. Yet I candidly atmit that, although I have been extensively chigaged in gardening operations for orer a quitrler of a century, I did not fully rablize, until a few years ago, the full importance of how indispensable it was to use the feet in the operations of sowing and planting.

For some rats past I hare, in writing on gardening mitters. insistad upon the ereat importance of * firming" the soll orer the seeds alter sowing, espectally when the soil is dry, or likely to become so. I know of no opereation of more implertante in cither the latm or garten, and I trust that what: I am alont to say will be read and rememberel he crepr one not ret allate of the rast importanee of the practice. I say " rast importance," for the los to the aterienltural and horticultural community

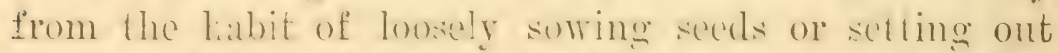
plants in hot and ary soils, i.: of a magnitude which fow will believe until they have witnesedel it: and it is a loss all the more to be regretied, when wo know that by "liming" the soil anomel the seed or plant, there is, in most cases, a certain preventire.

Particularly in the soming of sects. I comsider the matter of such great importance that it cammot be too often or too strongly told : for the loss to the agrienteral amd hortenlturil community he the neglect of the simple operation of limming the soil around the secel 
must amount to many millions ammualiy. For the mischief done is not confined only to the less importint garden operations, but even Corn, Cottoii, Wheat, 'I'urnips and other important crops of the fitrm often fail, in hot and dry soils, by being sown without being firmed sufficiently to prerent the diry air shriveling or drying the secrls. Of course, the use of the feet is impracticable in firming seceds on the firm, but a heary roller, applied after sowing, is an alsolute necensity under certain conditions of the soil, to insure perfect germination. From the middle of $\Lambda$ pril to nearly the end of May of this year, in many sections of the comntry, there was little or no rain. Such was particularly the case in the vicinity of New York City, where we have hundreds of market gardenres, who cultivate thousinds of acres of Cibbage, Cauliflower and Celery, but the " try spring" has played sar havoe with their sect-beds. Celery is not one-fourth of a crop, and Cabbage and Canliflower hardly half, and this failure is due to no othere callse than that they persist in sowing their seeds without eicu taking the precaution to firm the soil by rolling.

We sow annually alout four acres of C'olery, Calmage and Cauliflower plants, which produce probiatly five millions in number. and which we never fail to sell mostly in our immediate neighborhood to the market gardeners, who have, many of them, even better facilities than we have for rasing the plants, if they would only do as we do, firm the seca after sowing, which i: done thus :

After plowing, harrowing and leveling the lind smoothly, lines are drawn by the "marker," which makes furrows abont two inches deep and a foot apart; after the man who sows the seed follows another, who, with the ball of the right foot, presses down his full weight on every inch of soil in the drill where the seed has been sown; the rows are then lightly leveled longi- 
tudinaliy with the rake, a light roller is passed orer them, and the operation is done.

By this mathou our crop has never once fililed, and what is true of Celery and Cabbage seed is nearly as true of all other sects requiring to be sown during the late spring or summer months.

On July ad of 18 it, at an experiment, I somed twelve rows of sireet Corn and twelre rows of Beets, treading in, after sowing. every alternate row of each. In both arses. those troulden in eame up in four days, while those unfirmed remained twelve dars before starting: and woud not then have germinated had not rain fallen, for the soil was als der as dust when the seed was sown.

The result was that the seeds that had been trodden in wew freely from the start, and matured their crops to a marketable condition by fall; while the rows unfirmed did not mature, as they were not only eight dars linter in guminating. but the plants were also, to some extent. culeebled by being partially dried in the loose, dry soil.

This experiment was a most useful one, for it proved that a corn crop, sown in the ricinity of New York as late as July :d, could he made to produce "roasting ears" in Octoler, when they never fail to sell freely at high rates. but the erop would not mature muless the seed germinated at once, and which. wonld never he certain at that dry and hot season. unless by this method.

The same suason, in August. I treated sedels of 'T'urnips and Spinach in the same way. Those trodken in germinated at once and made an excellent crop, while those unfirmed germinated feebly, and were eventually nearly all burned out by a continuance of dry, hot air penetrating through the loose soil to the tender rootlets.

I beg to caution the mexperienced, howerer, by no nireans to tread or roll in seed if the ground is not di" $\%$ The soil maty often be in a suitible condition to sow, 
and yet may be too damp to be trodden upen or roiled. In such cases these operations may not be nocessury at all. ior if rainy weather en:ue, the seeds will germinate of enurse : but if there is any likclihogd of al continued drouth, the treading or rolling may be done a weck or more after the seed has been sown, if there is any reason to believe that it may sulfer from the dry, hot air. Another very important adrantage ganod by treading in the seed is, that when we have crops of Biects, Celery, Turnips, Spinach, or anything else that is sown in rows, the seeds to form the crop come up at once; while the seeds of the weeds, that are just as liable to perish by the heat as are those of the erop, are retarded. Such of the weed seeds as lie in the space betwon the rows where the soil is loose will not germinate as quickly as tho of the crop sown; and hence we can cultivate between the rows before the weeds germinate at all.

Of course, this rule of treading in or firming secds after sowing, must not be blindly followed. Very early in spring or late in fall, when the soil is damp and there is no danger from heated, dry air, there is no necessity for doing so.

Now, if firming the soil aronnd seed, to protect it from the influence of a dry and hot atmosphere, is a necessity, it is obrious that it is more so in the case of j)iants whose rootlets are even more sersitive to such influence than the dormant seed.

Experienced professional horticulturists, howerer, are less likely to neglect thiis than to neglect in the case of seeds, for the damage from such neglect is easier to be seen, and hence better understood, by the practical nurseryman; but with the insererienced amatenr the case is different. When he receives his package of trees or plants from the nurseryman, he liandles them as if thoy were glass, every loreken twig or roct calls forth a complaint, and he proceeds to plint them, gingerly 
straightening out earh root and sifting the soiv around them. but he would no more stamp down that soil than he would stamp on the evil of his mothers grare. sio the plint, in nine eases out of ten, is left loose and wah? ling: the thy air peretrates through the soil to its roots: the wimls shalie it: it shrirels up and fails to (now : and then come the anathemas on the head of the mortunate nurserman. Who is charged with selling him dead trees or plants.

Slout a month ago I sent a packiage of a dozen roses by mal do a lady in Savammals. She wrote me a woful story last work, saring that, though the roses had arived semingly all right. they had all died but one. and what was rere singular, she sald, the one that lived rats the one that Mr. Tones had stepped on, and which she hat thompht sure was crished to death, for Mr. Jomes weighs:on pounds. Now, thomple I lo not adrise any gentleman of ? on pounts putting his brogan on the top of a tember rose plant. as a practice conducive to it: health. got. if Mrs. fones eould have allowed her weighty lorel to press the soil against the root of eath of her dozen roses. I much denht if she would now have to mourn their loss.

It bas often heen a wonder to mamy of ms. Who have been workers in the soil for a generation. how some of the simplest methods oi culture hare not been practied until we were nearly done with life's work.

There are few of us but have hal such experience: persomally, I must say that I nerer pass through a year but I am confounded to find that some operation cammot only be done yuicler. hut done hetter. tham we hare been in the habit of doing it.

These imporements loom up from various causes. but mainly from sugerstions thrown out by our emplogees in chatroc of special departments, a system which we do all in our power to encourage. 
As a proof of the value of such improvements which have led to simplifying our operations, I will state the fact that though my area of ereenhonse surface is now more than double that which it was in $18 \% 0$, and the land used in our florist's business is one-third more, the number of hands employed is less now than in 1800 , and yet, at the same time, the quality of our stock is rastly better now than then.

Whether it is the higher price of labor in this country that forces us into lator-saving expedients, or the interchange of opinions from the greater number of nationalities centering here, that gives us broader riew's of culture, I am not prepared to state; but that America is now selling nearly all the products of the greenhouse, garden, nursery and farm lower than is done in Europe, admits of no question ; and if my homely sugrestions in this matter of firming the soil around newly planted seeds or plants will in any degren assist us in still holding to the front, I shall be gratified.

In the summer of 1886 I had a visit from one of the market gardeners of Norfolk, Va., who told me that he annually grows fifty acres of spinach, but that often by dry weather in autumn, only a partial crop wats obtained, owing to the failure of the seed to germinate. I arked him if he trod in the sech with the fert; he said no, that it would be cuite a big job to tread in rows at one loot apart on an area of fifty acres. $\Lambda$ little calculation showed that it could be done for less than s.on, and when it is known that a good crop of Spinach grown in Nopfolk will sell in the markets of New York for at least $\$ 300$ an ace, it will readily besecu that it would hardly be worth while to withlold $\$ 1$ per acre extra laloor, if it would, as it undoubtedly would in many casces, seenere a crop. Seedsmen hare more complaint of spinach seed failing to germinate than perhapes anything else, ats it has usually to be sown in hot, dry weather, but failure would 
raroly ooour if atere sow ing the sod the soil was carchully pressed down with the lect.

It was rathe an amusing incident that tirst bromeht to the attemtion o! a trath furmer of Charleston. S. C.. the impuranee of fimming the soil. It scems that a wenthman of color. has ing the emetitutiomal weakness for chickens peouliar to some of his race. got into a hen

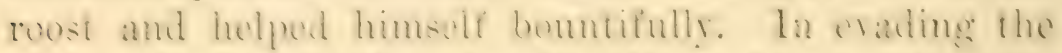
highroul, he struck a be-lime thromgh a nowly-own

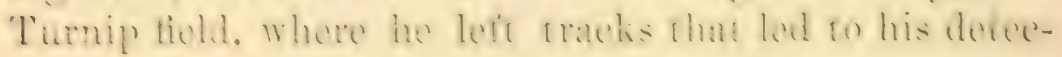
tion. But these trimks dit mone. i'hey showed to squire baneombe, whose ehichens had sulfered. that whereser the tow of the eolomed eirizen had fallen. Ihere

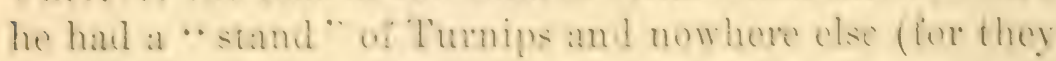
had beon loosely sown and the wather was ayy). The lessun shot home and has heen worth tens of thousume of dollars to the fimmers of south Carolina. who, it scens. Were neyer before sutticiondy allo to the impertame of tirming the soil until the mofortmats mere showed them the w:1y. The world has often ratsal monments to men who hare lone fal less to benetit their Whins than this pror negro meonsolously dat for the furmers of North Caroliuid. 


\section{CHA P'I R X I I I.}

\section{HOW, WIIEN AND IVHERE TO SOW SEEDS.}

As seced sowing is the starting point of cropping, a thorough knowledge of the conditions necessary for the germination of the different vardeties will go far towarels putting the tyro in gardening well on the way to suceess. The very general want of knowledge in this matter is ton often the cause of much undeserved censure upon the seedsman, for in nine cases out of ten the failure is not with the seeds, but results from the tince or manner of sowing. When the owner of a garden semds his order for seeds to the secemman, it is generally a complote list. of all he wants for the scason. 'They are received, and the interesting oporation of sowing is begme first in a hot berl, if ho has once often as ear!y ats the first week in Felpuary (which in the latitude of New York is a month too soon), and in go indiscriminately, at the sane date and monder the satme sash, his secels of Calphage. Cauli-

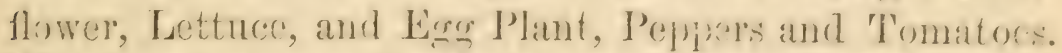
Yet eren in the waning heat of this early hot-herl, wheres a thermoneter woild posibly not indicate more than fifty degrees, he finds in a week or so his Cablated Lottuce, and Cauliflower "coming through" nicely, but as yet no Eog l'ants, P'erpers, or 'Tomatoes. Ife impiat iently waits another week, makes an examination, and discovers that instear of his 'Tomatoes and Egeg Plants beninning to vegotate, they are conmencing to rot. It is row plain to him that he has bern cheated the has been sold old seod, and if he does nothing worse, he forever after looks nyon the scedsman he hes patronized as a renal wretch, destitute of principle and honesty. But he must have 
'Tomatoes, Peppers, and Egg Plants, and he buys again, but this time from another seedsman, warranted honest. He renews his hot-bed-it is now a month later, and a bright March sun, with milder nights, give him the proper temperature in his hot-bed serenty or eighty degiees) - and his eyes are at last gladdened by the sprouting of the troublane seed. April comes with warm sunshine, inviting him to be in to "make garden" ontside. Ife has yet the balanee of the original lot of seeds that he boughi in February. But as he is still entirely befogged about the cance of his failure in the first hotbed, he begins his open ground operations with little confidenee in his sedels, hut ats he hats got them, they may as well be tricd. And again he sows, on the same day, his P'eas and Lima Beans, Raulishes and Pumpkins, Onions and sweet corm. Hardy and tender get the same treatment. The result must of meessity be the same an it was in the hot-bed: the hamely seeds duly vegetate, while the temder are of course rotted. Tlis time he is not surprixul, for he is already envined that seedsman No. 1 is a rascal, and only wonders how any of his seeds gerew at all. so he a a ain orders from seedsman No. 2 for the artiches that hate latiled. Here eiremuntanes eontinue

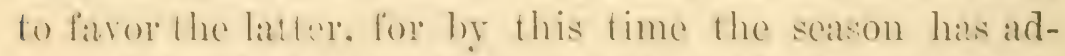
vinced in its temperature, and the seeds duly regetate. Every experiened farmer knows that in this lattitude he can sow Oats or Wheat in Mareh or April, but if he sows his (orn or Pumplins at the same time they will perish; this he knows, hut he may not know that what is true of the eropse of the farm, is equally true of the sarden. Henee the importanee of at knowledge of the siaton when to soy recetable seeds or set out plants. A most important case in point oceurs just as I write (May 1sth, 1sisi). A would-be finmer to whom we sold iffy bushels of sweet Corn complains that not a seed of the eorne which he had planted has werown. He had 
sowed it about May 1st, in Northern Indima, and thee weeks too early for that section; what made matters even worse, we have had a cold, wet May; the arerace temperature at night for the fortnight would probably not exeed forty-fire degrees. Under such circumstances the seed corn could no more have germinated than if it had been thrown into the fire. 'That the seed was good was certain beyond question, as our trials showed that ninety per cent. grew.

A decision was not long ago rendered in one of the Philadelphia courts against the claim for damages mate by a market gardener, who brought suit aginst at wellknown seedsman of that city for having solil him seed of Early York Cabbage that had "run to seed."

'The rentilation of such a matter is exceedingly instructive to those engaged in gardening operations, as was shown by the facts elicited on the trial, the gist of which was, that the prosecutor had sown the Gabbage seed on the 5th of September instead of the 15th, and that error, combined with an unusually mild and growing fall, practically lengthened the season, so that the Calbbage plants became "ammuals" - rumning to secel within the year of sowing-rather than forming heculs and acting as "biennials," as was expected of them. Now, just here an excellent lesson comes nith withother regetable. Many of our so-called scientific gardeners are English, Scotch, Irish, or Germans; they come here, most of them, with a thorough contempt for our rougher style of doing things (a practical style born of our neecssties in the higher cost of libur) ; and it is next to impossible to convince one in a dozen of them that there is anything in horticultural matters here that they need to he informed of. Accordingly, if he wishes to raise Celery, he starts his seed in a hot-bed in February, just as he would have done in England, and is astonished to find in July that mstead of forming a thick and solid 
stalk, as it would have done there, it spindles and runs to seed. If his knowledge of the art had been based on common-sense, instead of the blind routine practice acquired in a coldu climate, he would have known that our scason-from April 1st to July 1st-would sum up nearly the same mean of temperature here as it would there, from February 1st to July 1st; and hence it was not only unnecessury here, but dingerous to the welfare of the crop, to sow such biennial plant:s as Celery in any other place than in the open ground, and that not before April. It was just such an error that the market gardener made who sued the seedsman abore alluded to. He hat been following, likely, the English or German method, and paid the penalty not oniy of losing his crop, but losing his law-suit, by not alapting his practice to our conditions of temperature. As the matter of sowing the seeds of Cabbage, Camillower and Lettuce to malie plants to winter orer in cold-frames, is one in which there is a wide-spread interest. I may state that the time of sowing in fall, in a country haring such an area and dilference of latitude as ours, is somewhat diffieult to fix upon; but taking the latitude of New York as a basis, the safest time we have found to sow is alout the 15 th of September. Of late years we have eren sown some kinds as late als soptember 30 th, with excellent snceess. in warm, well-sheltered positions, in a rich, well-prepared soil.

Each kind of seed has certain limits of temperature, below or above which it eamot well germinate. Below the minimum heat it remains dormant; abore its maximum limit, its vitality is destroyed ; butween these two points is found the temperature most favorable to rapid germination. Practically it sufrices to divide our garcien seeds into two classes: natives of temperate and natives of subtropical countries.

The temperature best fitted for the germination of 
seeds of the leading linds, will be best understood by the tabular form given below :

Tigetable sects that may be sorm, in this latitude, fiom the midalle of Wereh to the end of April. Thermometer in the shade averaging 4 degrees.

$\begin{array}{ll}\text { Beet. } & \text { Lettuce. } \\ \text { Carrot. } & \text { Onions. } \\ \text { Cress. } & \text { Parsnip. } \\ \text { Celery. } & \text { Parsley. } \\ \text { Cabbage. } & \text { Peas. } \\ \text { Cauliflower. } & \text { Radish. } \\ \text { Endive. } & \text { Turnip. } \\ \text { Kale. } & \text { Spinach. }\end{array}$

Vergctuble scels that may be sown in the opxn ground, in this latitude, fiome the midulle of Hay to the mielale of June. Thermometer in the shade averaging 60 degrees.

Beans, Bush. Melon, Musk.

Beaus, Cranbery. Melon, Water.

Beans, Lima. Nasturtium.

Beans, Pols. Okra.

Beans, Scarlet Pumpkin. Runner. Squash.

Corn, Sweet. Tomato.

Cucumber.

It will be understood that these dates refer only to the latitude of New York; farther South operations should be begun earlier; farther North, later. So much for the time of sowing. I will now refer to suitable soil and the manner of sowing.

'The Crrorce of SolL wherein seeds are somn, when choice can be made, is of importance, the best being a light soil, composed of leaf mold, sand, and loam; the best substitute for leaf mold being well-decayed stable manure, or, better yet, decayed rafuse hops from the broweries-in short, anything of this nature that will tend to lighten the soil, the point to be avoided being a weight of soil, either from the nature or puantity of it. The nature of the soil is not of so much importance for the germinating of lirrge vigorous seeds, as Peas, Beets, Beans, Corn, ete.; but with the delicate, slow sprouting sorts, as Celery, Parsnip, Egg Plant, or Peppers, it is of much importance. Sceds of nearly every garden regetable should be sown in rows; the distance apart according to the variety, and the depth proportioned to the size of the seed. No better information can be giren in this matter than the ofl rule of corering the seed with 
about twice $e_{2}$ thrice its thickness of soil. but this should alwars be followed up by having the soil pressed closely domn. In our market gardens here we invariably tread or hare the ground rolled: or in frames or hot-beds, where the roller camnot be used, we pat the soil down evenly with a spale after sowing. This may not be of so much consequence in early spring, whan the atmosphere is moist. but as the season adrinces, it is of great importance. Another atrantage in rolling after seed sowing is, that it leares the surface smonth and lerel, thereby greatly lesening the lator of horing. Insteal of atopting the questionable pratctice of soaking seeds. preparatery to sowing in dry. lot weather. We prefer first. if rery dry, to thoroughly saturate the hed with water. and after it has dried enomgh. so that it can be raked without elogging. sow the secel. It is much better to do this tham to water the soil after the seed has been sown, as it hats a tendiney in most soils to cause the surface to bake.

Although direstions for sowing in hot-beils have been alrealy fully given in the Chapter on " Formation and Management of IIot-bels." and also moler the head of "Spring-rasing of Cabbage. ('anliflower and Lettuee," yet at the risk of some repetition I again refer to it here.

Sowixg is Hot-BEDs.- Ifter the hot-bed lias been formed-say the first week in Mren-let soil of the lind recommented be placel on it six inches deep. into which plunge a thermometer three or four inches. and when the temperature recedes to serenty-fire ur eighty dogress, you may then sow, giving air in mild weather as soon as the seeds begin to regetate. covering ul wamly at night with straw mats. Bat many that may reat this nerer sat a hot-bed. and are perhaps nerer likely to hare one: to such I would say that there is an excellent substitute on hand in most dwellings, in the kitehen or basement windows, facing south or East, inside of which is a temperatme usually not far from that required for the regeta- 
tion of seeds, and where plants from seeds of the early vegetables, or tender plants for the flower border, may be raised nearly as well, and with far less attention, than in a hot-bed. Instead of hot-beds, we use our greenhouses for the purpose, using shallow boxes in which we sow the seed; these are made from the common soap box, cut into three pieces, the top and bottom forming two, and the middle piece, bottomed, making the third; these form cheap, convenient boxes. Fill these nearly full with the soil recommended, and, after sowing, press nicely down level and make the surface soil moderately firm; keep moist in a temperature in the window of from sixty to seventy degrees, and your little tronble will soon be rewarded.

In this way sceds should be sown thickly, and after they have made the first rough leaf, should be again planted out into the sime kind of box, from one to three inches apart, according to the kind, and piaced in the window to receive similar treatment as the seeds; but as the season advances, in mild days the boxes should be set out of doors, care being taken that they are brought in before night, and that the soil in the boxes is never allowed to get dry.

I know what is usually the first thing the novice in gardening does if he gets any choice seed or favorite cutting; he has somehow got the belief that there is some hidden virtue in a flower pot, and he accordingly sows lis seed or plants his eutting in a pot, but in nine cases out of ten they are destroyed, or partially so, by the continued drying of the soil in the porous flower pot. If early in the season, let delicate seeds be sown in the kitchen or sitting-room window, in the boxes as recommended, or if late, in the open border; but seeds shonld never be sown in pots, as even in experienced hands they are much more troublesome and uncertain than boxes.

Rotation of Crops. - Cultivators of the most limited 
experience sonil discorer that the same kind of erop cannot be grown on the sime ground for many years in sueersion withoat deterioration. A great many theories hatre besn aldined assigning callses for this, but they alle as yet late from sattisfatory, and at this is not a book of theory but of pratetice. I will not further allude to them. The following general rules will be found uschul as a gouide :

1st. Plants of the same family should not be planted to sneceed each other.

sil. Plants which oecupy the glomel for a mumber of yours, such as lihubarb and Aspariagus, should be sileceeded by ammual plants.

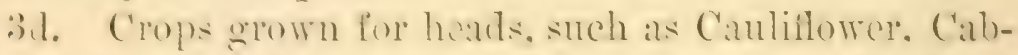

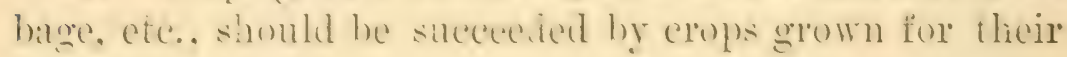
bulbs or roots.

It is hardly practicable to rary crope aleording to any set rule, the demand in different localities for certain articles being greater than in other: Cicnerally variety enongh is demanded to allow of suflicient rotation. Om system of heary manuring, deep culture. and taking two

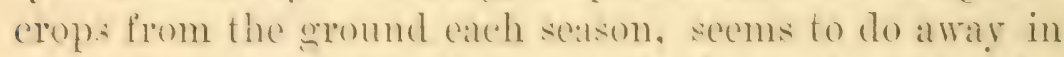
a great measule with the neessity for systematic rotation. which would often be found to be rery incomrenient. The erops of all of hers that we find most henefited by

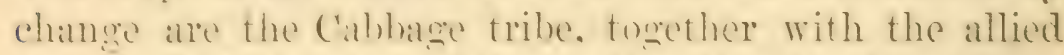
'T'umip, Raulish. ote. while, on the of here hamd. we have grown Onions sucersively on the same giound for ten

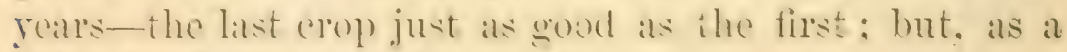
rule of safety, vary whenerer you can.

The best of all rotation for colops is to " rest" the land whemerer practicable from its continued manuring and cultivating, by sowing down to grass for one, two or three rears: this gives a renewen rigor and vitality that nothing else will impart. The farmers and marliet garchones of Tome Island, who grow truck to supply the 
great market of New York, are now excelling our IIurson County, New Jersey, market girdeners, whose limited areas and high-priced lands do not permit them to use this system of "resting" their lands by a rotation of grass or clorer. I have been so much impressed with the value of this plan, that, as soon as our cold frames have been emptied of Cablage and Lettuce plants in May, the ground is sown at once with Clover, Millet or Oats-it makes little difference which; this crop is cut off twice or thrice and by september it forms a good sod, which is turned down. It is rotted in thirty days and the land is in the rery best possible friable condition for the reception of the cold frame Cabbage, Caulillower or Letuce plants, which we begin to plant about the middle of October. Eren when only a few weeks ean be spared, we find it pays to sow the land with some green crop to be plowed in, rather than it should remain bare.

QuANTITy OF SEEDs PER ACRE.-The quantities given below are somewhat higher in some kinds than the usual estimates, our experience showing us that in weak regetating seeds, such as Parsnips, Carrots, ete, it refuires numbers, particularly on stiff soils, to force through plants enough to form a crop. More seed is recpuired when sown during the dry, hot months of summer than if sown in the cooler and moist seasons of spring and fall, henee quantities are regulated accordingly:

\section{QUANTITY OT SEED REQUIRED TO SOW AN ACRE.}

Asparagus 4 to 5 pounds.

Beans, Dwarf in drills 2 bushels.

Beans, Pole. in hills 10 to 12 quarts.

Bect in drills 5 to 6 pounds.

Cabbage. in beds to transplant

Carrot. in drills $1 / 2$ pound.

Corn in hills 3 to 4 pounds. Con (for soiling) 3 to 10 quarts. 
Cress, Upland in drills 2 to 3 pounds.

Kale, or Sprouts 3 to 4 pounds.

Mustard. broadeast $1 / 2$ bushel. Melcn (Musk) . in hills 2 to 3 pounds. Melon (IVater). in hills 4 to 5 pounds.

Onion in drills 5 to 6 pounds.

Onion, (for sets) in drills 30 pounds.

Onion, (sets) in drills

Parsnip in clrills

Peas in trills 6 to 12 bushels.

Peas broadeast 4 to 6 pounds. 2 bushels.

Potato, (cut tubers) 3 bushels. Pumplin in hills in drills Raclish in drills

Sage in drills

Salsify

Spinach in hills

Squash, (runniug varieties) to transplant

Tomato in drills broadeast broadcast. in lills 10 to 12 bushels.

Turnip 4 to 6 pounds. Turnip Barley -

Broom Coln 8 to 10 pounds. Clover (Red) alone 8 to 10 pounds. 8 to 10 pounds. Clorer (White) alone. 10 to 12 pounds. Clover (Alsike) alone 4 to 6 pounds. 3 to 4 pounds. Clover (Lucern) alone Grass (Mixed Lawn).

Oats. broadcast

Rye _...

Vetches . . . . . . . . . . broadeast. broadcast $1 / 4$ pound. 1 to 2 pounds. 3 to 4 pounds. 2 to $\$$ bushels. 8 to 10 quarts.

Wheat 15 to 20 pounds. 12 to 15 pounds. -8 to 10 pounds. Timothy, alone 20 pounds.

Orchard Grass, mixture. 4 to 5 bushels. Millet. 2 to 3 bushels. $11 / 2$ to 2 bushels. 2 to 3 bushels. $11 / 2$ to 2 bushels. $1 / 2$ bushel. 4 to 5 bushels. $1 / 2$ to 1 bushel. MIXTUE FOR פEEDING MOWING LANDS.

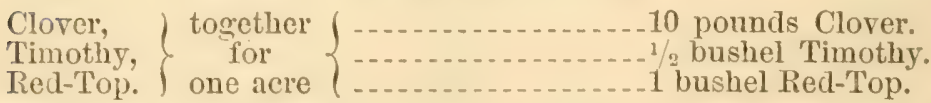

When drills are refereal to, the seed should be sown witi a seed drill. 
QUANTIT OF SEEDS REQUIRED FOR A GIVEN XUMBE? OF PLAXTS, NUMBER OF HILLS, OR LENGTH OF DRILL.

Asparagus, $1 \mathrm{oz} \ldots \ldots 60 \mathrm{ft}$. of drill. Beet, $10 z \ldots \ldots \ldots 50 \mathrm{ft}$. of drill. Beans, Dwarf, 1 qt. $100 \mathrm{ft}$. of drill. Beans, Pole, 1 qt ........ 150 hills. Carrot, 1 oz_.....150 ft. of drill. Cucumber, $10 z \ldots \ldots \ldots$........5 hills. Corn, 1 q t............ 200 hills. Dandelion, $1 \mathrm{oz}$. . . _ $200 \mathrm{ft}$. of drill. Endive, $1 \mathrm{oz} \ldots \ldots \ldots 150 \mathrm{ft}$. of drill. Leek, $1 \mathrm{oz} \ldots \ldots \ldots 100 \mathrm{ft}$. of drill. Melon, Water, 1 oz ...... 30 hills. Melon, Musk, 1 oz ........60 hills. Okra, 1 oz . . . . . . $40 \mathrm{ft}$. of drill. Onion, 1 oz ....... $100 \mathrm{ft}$. of dilill. Onion, Sets, 1 qt ... $40 \mathrm{ft}$. of drill. Parsley, $1 \mathrm{oz}$. . . . . $150 \mathrm{ft}$. of drill. Parsnip, 1 oz . . . . . 200 ft. of drill. Peas, 1 qt ...........100 ft. of drill.
Pumpkin, 1 oz . . . . . . . . 40 hills. Radish, $1 \mathrm{oz} \ldots \ldots \ldots 100 \mathrm{ft}$. of drill. Salsify, $1 \mathrm{oz} \ldots \ldots \ldots$...... $0 \mathrm{ft}$. of drill. Spinach, 1 oz ...... $100 \mathrm{ft}$. of drill. Squash, Early, 1 oz ....... 50 hilis. Squash, Marrow, $1 \mathrm{oz} \ldots \ldots 16$ hills. Turnip, 1 oz. . . . $150 \mathrm{ft}$. of drill. Asparagus, $1 \mathrm{oz} . \ldots . \ldots 500$ plants. Cabbage, 1 oz . . . . . . . 2.2,000 plants. Cauliflower, 1 oz _... 2,000 plants. Celery, 1 oz .......... 3,000 plants. Eg $\mathrm{g}$ Plant, $1 \mathrm{oz} . \ldots . . .1,000$ plants. Lettuce, $1 \mathrm{oz} . . . . . . . .3,000$ plants. Pepper, 1 oz _....... 1,000 plants. Rhubarb, 1 oz ........ 500 plants. 'iomato, 1 oz . . . . 1, 1,500 plants. Thyme, $1 \mathrm{oz} \ldots . . . . . .3,000$ plants. Sase, 1 oz ........ 1,000 plants.

TIIE NUMBEP OF ILAVZT, TZEEN, ETC., RLQUIRED TO SET AN ACRE.

\section{Distance.}

Nimbrr.

$1 \mathrm{ft}$. by $1 \mathrm{ft}$ $-43,560$

$11 / 2 \mathrm{ft}$. by $1 \frac{1}{2} \mathrm{ft} \ldots \ldots \ldots, 360$

$2 \mathrm{ft}$. by $2 \mathrm{ft}$. . . . . . . . . . _ _ _ _ _ 10,890

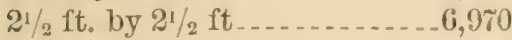

$3 \mathrm{ft}$. by $1 \mathrm{ft} \ldots \ldots \ldots \ldots \ldots \ldots \ldots$

$3 \mathrm{ft}$. by $2 \mathrm{ft} \ldots \ldots \ldots \ldots \ldots \ldots$

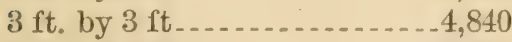

$4 \mathrm{ft}$. by $4 \mathrm{ft} \ldots \ldots \ldots$

$5 \mathrm{ft}$. by $5 \mathrm{ft}$.

\section{Distance.}

Number.

$6 \mathrm{ft}$. by $6 \mathrm{ft}$

$9 \mathrm{ft} . \mathrm{by} 9 \mathrm{ft} \ldots$

$12 \mathrm{ft}$. by $12 \mathrm{ft} \ldots \ldots \ldots \ldots 303$

$15 \mathrm{ft}$. by $15 \mathrm{ft} \ldots \ldots \ldots \ldots \ldots$

$18 \mathrm{ft}$. by $18 \mathrm{ft} \ldots \ldots \ldots \ldots \ldots$

$20 \mathrm{ft}$. by $20 \mathrm{ft}$............... 103

$25 \mathrm{ft}$. by $25 \mathrm{ft} \ldots \ldots \ldots$

$30 \mathrm{ft}$. by $30 \mathrm{ft} \ldots \ldots \ldots$

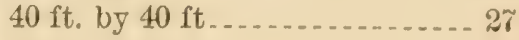




\section{H A P T R XIV.}

\section{TRANSPLANTING.}

Transplanting is an operation of great importanec; the condition of the plant, the state of the soil, and of the atmosphere, have much to do with its sucess, independently of the simple mechanical operation. It is not very easy to instruct the uninitiated as to what the proper condition of the plant should be: experience in this being, as in ererything else, the best teacher. Attention to keeping the seed-bed clear of weeds, the "topping" of plants when they get too tall, and eareful digging up of them so als to preserre the root fibres, wiil all sreatly assist. We camnot always get the soil in the proper condition of moisture to receive plants at the time tramsplanting should be performed. but to make up for the vant of moisture planting should be delayed always mutil late in the afternom, unless in clondy weather. It is al:so of great importance that the ground be freshly plowed; the moint soil thus brought to the surface will induce the formation of root fibres in one night in warm weather, after whicin the plants are comparatively safe; but if they be allowed to wilt before the new roots begin to be emitted. and continued diry weather ensues, then nothing will save them but having recourse to watering, which, howerer, should only be done in case of dire necessity. In planting, such plants as Cabbage, Lettuce and Celery, each man is provided with a boy, who carries the plants in a basket, and whose duty is to dron the plant on the line at the proper distance before the planter. In plunting, at hole is mate ly the dibber about the depth of the root: the plant being inserted, the soil is then pressed close to the root: the hole thus made by the displacement of the soil is again filled up by one stroke of the dibber. In dry weather lie still further 
firm the plant by each planter returning on his row and treading the soil around plants firmly with the feet. I am thus particular in describing a simple matter, knowing well that millions of plants are annually lost by inattention to this firming of the soil. The same rule is applicable to transplanting of all kinds, trees, shrubs, or vegetables. Instend of "puddling" the roots in mud, we prefer to keep the plants dripping wet during the whole time of planting, so that each plant, as it is put in the soil, puddles itself by the particles of soil adhering to the wet root. Besides, the leaves of the plant, being wet, will for some time resist the action of the dry arr.

Planting of Vegetalile Plants.-A year or two ago, abo:it the middle of ipril, the snow, after its long acquaintance with as during the past winter, intruded itself again in the spring and corered our newly-planted gardens to the depth of several inches, Veteran tillers of the soil could smile at this assindt, knowing it to be harmless. But conrespondents, still young in the business, wrote to me fearing their planted erops were ruined.

A snow, after planting in spring, I have neter known to injure plants of any limbl, unless, indeed, it was heavy enough to break them. 'i'he fear of snow, and of the slight late frosts, often prevents the setting of such plants as Cabloage, Lettuce, and even Asparaguis, among verget:bles, and of Strawberries and other small fruits, until the satson is so far advanced that hot weather comes on, starting the tops before the roots have her time to get a fouthold. There is rarely danger (when the ground is sufficiently dry to work, and it never should be worked until it is so), that such hardy or half-hardy plants as we plant in spring will be injured ly any frost that may come after they are put ont. 'This opening up for spring work watly begins here by the end of March, and I have nerer yet seen plants injured by frost after that time. 
To give an ideal what amount of cold Cabbage and Lettuce plants will stand without injury. I will relate an experience I had in my early days of market gardening. A particulary mild spell in the latter part of February hat led us io believe that spring hat come. Out went the teams. and the ground was manured, plowed, and planted with Cabbage and Lettues to the extent of two acres, which was all finished np by the obth of February. It was my soment rear in the insines. I was yot an inexperienced hamd. and my neishore predicted that my renture was a foolhardy one, and would result in total loss, no one having erer before planted such erops in this section at such an early season. But fortune farored me; the weather continued mild longe enough to allow the plants to ".strike root." and thomgh the thermometer alferward malked as low as fifteen degrees abore zero, and the ground was frozen for full ten days, so that it could not be again dug or plowed. yet the wild renture proved a suceess and I hat the satisfaction oi haring the first Cabbages fromis that Fubruary planting that were sold in market. I nerer after hat an opportunity of plarting so early. and wonde not do so if I had, for it was smonly farorable conditions that sared the erop. If the cold suap had set in immediately after planting. there is isut little douht the plants would have sutiered injury. But the experience was raluable in showing what sererity of frost such plants would stand withoul injerp. Ifuch depend: on the condition of the plants: if talien from the lot-buel or frame whout heing previour exposed, they might be in condition to be a.: ealsily injureal as a Tomato plant.

The past season I had the sashes taken off my entire crop of Cahbage and Lettuce plants on March 1st (they being hardened beforehand by rentilating), and nerer corered them again. They were twice covered up with snow, and the mereury sereral times marled on! twenty 
degrees above zero. Iet the harlly erer before had finer plants.

The sashes so taken of -nearly 1,000 in number-were used for our flower business, but, had we desired it, they might have been used on temporary frames, and grown a crop of Lettuce which in five weck from date of planting, March 1st, wonld have easily given s2 per sash. I mention these facts to gire confidence to the hundreds now engaged in market garitening, who, from dread of exposing their plants in spring, not only do them an injury, but lose the profit of a second use of their sashes. A third use of sashes may be had in groring 'T'omato, S'reet Potato, or Egg plants, aiter the crop of Lettuce is sold, or forwarding an early crop of ćncumbers or Melons. (See " Forcing Cncumbers.")

\section{H P T E R X V.}

VEGETABLES, THEIR VARIETIES AND CULTIVATION.

In describing the modes of cultirating the different varieties of regetables, I shall notice at length only those of the most importance, and the most profita'ile for market purposes, while for those of less ralue as market crops, the directions for culture will be sach as are adapted to private gardens only.

A limited number of kinds will be described, and such only as our experience has shown to posaess the greatest earliness and productiveness. Nothing is more perplexing to the beginner than to be bewildered by descriptions of perhaps twenty so-called rarieties of a regetable that in reality does not embrace four distinct kinds. For example, in early Cabbages, there are some hundred or more rarieties described; yet we find, after havins 
experimented with some seores of kinds in our time,

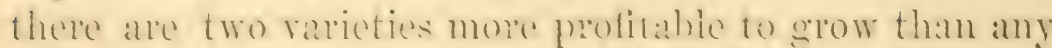
others-viz. thio dersey Waketielel am.l Early stmmer, Which are grown in this locality to the exchsion of all others. Howerer. some kinds are fomind to do bettere in some localites tham in ofhers-hemea ats ia fruts, no particular variety should be chamed to be nuirersally the best.

\section{ASPARAGUS̃-(Asparagus officinalis.)}

Asparagus being a har.ly peremuial plant. that ma!y be grown on the same gromel for twenty rears withont renewal. spectal care is required in forming the beds in which it is to grow. This is done sometemes by tronching to the depth of two or three fect. mixing each layer of soil. as lumed over. with two or thee inches of wellroit:d mamure: but for matret purposes, on a large scale,

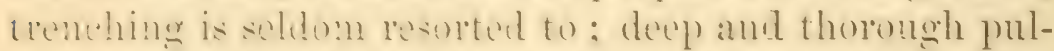
verizing by the p!ow and subsoiler serving instaul. 'The

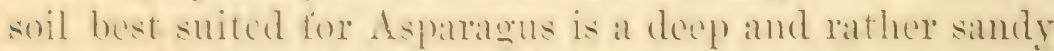
loalm, such at: is often to be found on the borders of meadows or on the matreins of lakes or rivers-lamed formed by the washings of the higher groumls, and known as allu-

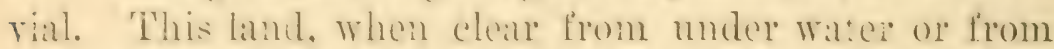
orerlow is by lat the hest sated for the growt th of all lime of regetateles and is. from the nature of the plants, particularly adapted lor Asparagus or Colery.

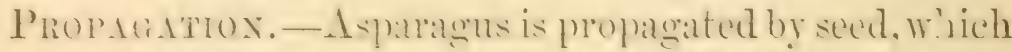
is sown in spring, als soln! ats the soil will atmit of work-

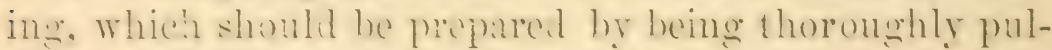
verized and enrideded with well-rotted mamure. 'The seed is sown in rows one foot apart. and if liept carchully hoed and clear from weeds, the plints will be in finc condition to plant ont the sueceeling spring. Striet attention to this will save a vear in time: for if the seed-hed has been mowhend, it will take two years to get the plants as large 
as they would be in one year, if they had been properly cared for. In consequence of this very common neglect of proper cultivation of the seed-heel, it is an almost universal impression that the plants must be two or three years old hefore planting. 'This is undoubterily an error, for almost all large growers for market purposis, in the neighborhood of New York, invariably plant one-yearold plants, and count on marketing a crop the third spring from the time of sowing. One pound of seed will produce about $3,(0)(0)$ plants; and to plant an acre of $\Lambda$ sparagus recfuires from 15,000 to 20,000 plants when planted close.

Plaxtrac.-The bad beng prepared as previonsly describerl, planting may he done any time for six or eight weeks from the opening of spring. 'T'he plant, from its peculiar succulent roots, is less susceptible of injury from late planting than most other regetables, although at the same theme delay shotild not oceur, unless unavoirlable, as the somer it is plinted after the gromel is in working onder, the better will be the result. When there is plenty of ground and the crop is to be extensively grown, perhaps the hest mode of planting is in rows three fect apart, the plants nine inches aprart in the rows. For private use, or for marketing on a smali scale, beds should be formed five fect wide, with three rows planted in each; one in the midlle and one on each side, a frot from the edge; the dietance of the plants in the rows, nine inches; the alleys between the beds shond be two feect wille. In planting, a line is set and a cut made a little slanting to the depth of six or eight inches, aceorting to the size of the plants. The plants are then laid against the side of the trench, at the distance alrcady named (nine inches), care being taken to properly spread the roots. The crown or top of the plant should be covered about three inches. In a week or so after planting, the beds should be touched over lightly with a sharp steel 
rake. which will destroy the germinating weeds. The raking had better be continued at interrals of a week or so, until the plants start to grow. when the hoe or handcultivator may be applied between the rows and alleys: the weeds that come up close to the plant must of recessity be pulled out by the hand.

In the first edition of this wor'i I gare it as my belief that we had omly one rariety of Asparatels. and that all the so-ralled “ (ibant" and “ Jammoth " ralleties were merely the results of superior soll or cultivation, which on being propagated by seceds or otherwise and plated in ordinary emelitions of calture. Would fitl hatek to their original or nomal condition : in short, that the syecies had never "broke," as we technically term it.

This belief necesilrily mate me skeptical to the daims of the ". Colosial " when that variefy wats first introduced. and I invariably replied to all inguirers ihat past experience in this matter led me to beliere that it was no different from the ordinary sort.

I was finally invited to pary a risit to the farm of Abraham Van Siclen. of Jimaica. Long Island, and there to inspect an are of the (Oyster Bay Asparagus (the ordinary kimel). and an alere of his." Colosill." which Mr. Van siclen hat planted in the spring of 1 stis. each then one rear old from serel. A thorotigh inspertion of the roots of each lot proved that they were of the same age when planted. 'The suil was next examined. and found to be as noar the same as it could weil be ret these two beds of Asparigutus showed a differenee that left me no longer a shadow of a doubt of their being entirely distinct varieties. In the old variety we fomnd no shoot thicker than one inch in diameter and averaging twenty shoots to a hill. while in the " Colossal " mamy shoots were found an inch and a hale in cliameter, and arelaging thirty-fire shoors to a hill-an enormous growth. when it is remembered the plant was only three years from the seed. 
Mr. Tan Siclen is well known als one of our best Long Island market gardeners, who has made the growing of Asparagus a specialty for twenty years, and who has probably in that time sold more Asparagus in the markets of New York than any other man. IIe was exeedingly enthusiastic in pratice of this varicty, believing that at a low estimate it would yield a profit of at least one-third greater than the ardinary sort, under the same conditions, besides coming to maturity two years sooner.

Mr. Tan siclen is method of growilg Asparagus is simple, and in some respects new to me. To begin, he sows his seeds in his rich sandy loam in $A_{\text {prill, in rows one }}$ foot apart and two inches in depth, droping the scerls so that they may be distributed erenly about half an inch apart; the plants are cultivated by hocing between the rows and kecping them clear of weeds by hand picking. In the spring following he sets his plants, now one year old, which are in his experience preferable to those two year's old. Inis mode of planting is somewhat different from the usual proctice, but for having a lasting Asparagus bed-one that will be as good at the end of twenty years as it is at eight-it is probably the best.

It differs in setting the roots much wider aluart tham usual ; his stand, six feet between the rows and four feet between the plants, making less than two thousand plants to an acre. In preparing the land to reccive the plants, he merely plows to the depth of a fout or so with the ordinary plow; his soft, sandy subsoil rendering the use of the subsoil plow mnecessary, but in soils less farored the use of the subsoil plow would be of decided adrantige. In preparing to plant he turns out a furrow with a double mold-board plow, so that at its decpest part it is nearly twelve inches deep; a good shorelful of thoroughly rotted manure is then placed in the furrow, at distances of four feet, so spread that it will make a layer of three inches or so ; an inch or two of soil is then 
thrown on the top of the mannre, and the Asparagus planted as shown in the cngraving, figme 11, and with its crown six or seren inches below the surface level. The plant is now only lightly corered up with the soil, say two or three inches, until it starts to grow, when the furrows are thrown in by the plow so that the whole surface is leveled, which places the crown of the Asparagus some six or seven inches under the surface. This would be, perhaps, four inches too deep in hesry soils, hut in light, soft soils it answers well. The first and second seasons after planting no Asparagus is cut for

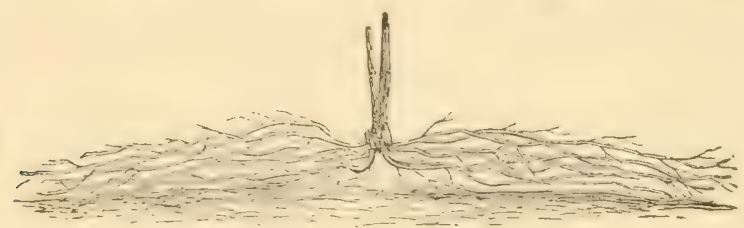

Fig. 14. - IINNER OF PLANTING ASPARAGUS.

mirket, as it weakeus the roots, but in the third year a partial crop is taken, although the beds are not considered to be at their best until the sixth or serenth year. 'I'heir productiveness may be continued for twenty years by this wide system of planting, recourse being had to manuring freely annully. ly digging or plowing it in around the roots before the crop has started to grow, or after it is cut.

Growixg Asparige's Froy SEED, without transplanting, is a method now fincling many adrocates. It is not only a much cheaper method. but in my opinion it is the best methor if the operator can have patience to wait a year longer for a crop. 'The plan is rery simple, and can be done by any one having even a slight knowledge of farming or gardening work. Prepare the land by manuring, deep plowing and harrowing, making it as level and smooth as possible for the reception of the secd. Strike out lines three feet apart and about 
two to three inches deep, in which sow the seed by hand or seed ärill, as is most convenient, using from fire to seven pounds of seed (which corts fifty cents per pound), to each acre. After sowing the seed and before corering tread down the seed in the rows crenly with the feet (see "Use of the Feet in Sowing and Ilanting") ; then draw the back of a rake lengthwise nver the rows, after which roll the whole surfice. As sowi as the land is dry and fit to work in Spring, the young plants of Asparagus will start through the ground stifficiently to define the rows in two or three weeks. At once begin to cultivate with hand or horse cultivator, and stir the ground so as to destroy the embryo weeds, breaking the soil in the rows between the plants with the fingers or hand weeder for the same purpose. This must be repeated at intervals of two or three weeks during the summer, as the success of this method is entirely dependent on keeping down the weeds, which, if allowed to grow, would soon smother the Asparagus plants, which for the first season of their growth are weaker than most weeds. In two or three months after sowing, the Asparagus will have attaine? ten or twelve inches in height. It must now be thinned out so that the plants stand nine inches apart in the rows. By fall they will be from two to three feet high, strong and rigorous, if the directions for culture have been faithfully followed. When the foliage dies (but not before), cut the stems down to the ground and cover the lines for five or six inches on each side with two or three inches in depth of rough manure. As the spring again returns, renew the same process of cultivation to keep down weeds the second year exactly as was done for the first, and so on to the spring of the fourth year, when a crop may be cut that will well reward all the labor that has been expended. Sometimes, if the land is particularly suitable, a crop may be had well worth marketirg the third year, but as a rule, it will be 
better to wait until the fourth year without cutting much, as it would tend to weaken the plants. 'To compensate for the loss of a year in time in thus growing Asparagus from seed, such crops as Cabbage, Lettuce, Onions, Beets, oi Spinach-all of which will be marketable before the Asparagus will have grown high enongh to interfere with them-can be sown or plinted between the rows of Asparagus the first year of its growth with but little injury to it: and as the ground for the Asparagus has been hearily manured and well prepared, such crops will, in a measure, make up for the year's loss in time, provided there is a market near enough for their sale. I had an old friend near Macon, Ga., who grew an acre of Asparagus after this plan. His ('pop was sold in the New York market and brought him all arerage of $\$ 1,000$ a rear for six years after it came into bearing, to my certain linowledge, my salesman having sold it for him. He died somo ten rears ago, and I prestme the bed was neglected, or it might still be in full bearing. 'I'here is no erop' so certain of sale and so eatsily shippert as Asparagus, from the fact that it has perhaps greater value for its weight than any other regetalhe, besides, it is ready at a scason when the temperature is low. so that whether shipped from the extreme southern sitates to our large cities in the Viddle states or reshipped to still further North, there is never danger from injury in transit. The reason of its heing profitable is obrions. The cultivator has to wait three or four years for a crop. The majority of gardeners either camnot or will not wait, and hence it becomes profitalble to the few who cultivate 1t. The varicty usually grown is the Colossal, but Mr. John Nix, a well-known commesion dealer of New Tork City, and who is also one of the largest trucker's in South Carolina, claims that the new valiety of Asparagus, "The Palmetto," is one which excels all other varieties grown at the South, in earliness, vield, quality and eren- 
ness of growth. It has not yet been extensirely tried at the North, but we have every reason to think that it will do equally well here.

The Applcatrox of S.lut to Asparagus as a topdressing is claimed to be of benefit in inland districts out of the range of a saline atmosphere, but is of little or wo berefit in the ricinity of salt water. When usted it should be aprylied in sing only, at the rate of half a pound per square yard, strewed on the surface; the rains will dissolve it and wash it down to the roots. Berides its benefieial effects upon the plant, it is to some extent destructive to the wire worm and other insects that are often troublesome to the Asparagus.

We have found Asparagus beds rery profitaljy benefited by the application of superphosphate of lime or pure bone dust as a spring top-dressing, applied at the rate of 500 pounds per acre, sown on the beds and hoed in. Experiments with this on alternate rows showed a difference of nearly one foot in height of the stalk in faror of the rows to which the superphosphate har bcen applied over those which had none; and a difference of nearly double the product when the crop was cut in the succeeding spring:

The fall treatment of the Asparagus beds varies with the locality; in cold regions, where, if left unprotected, the frost would ponctrate below the roots, a covering of three or four inches of rough manure or leares is necessary. Although an entirely hardy plant, it will start earlier and with greater vigor in spring if the root has not been subjected to serere freezing. In milder sections no such precaution is necessary; all that need be done is to clear off the stems as soon as they are withered in the fall, and clean the beds preparatory to giving a dressing of two or three mohes of manure, wheh had better not be applied until spring. We believe the common practice of top-clrossing Asparagus beds in fall to be a rery waste- 
Pul one. in districts where it is not necessary to provide

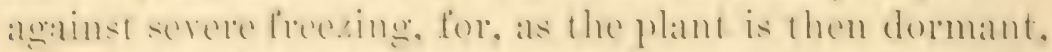
the juies of the mamure are either exaporated or else washed dow by mins belew the roots of the plant. I remember having three small deparagus beds under my wharge many gears aloo, on one of which I applied in Decomber twenty-five pounds of leruvian guano, dissolved in lifty gallons of water: in April the same applieation wats niate to another bet, and the other was left without anyihing. There was no presprtihle differenes hetween that to which the liguid hat bes applied in Desember and that ta which mone hatd bern given, hut on that which resered it in April nearly double the weight of crop was produced. Sinee theme all our pratetiece, cor-

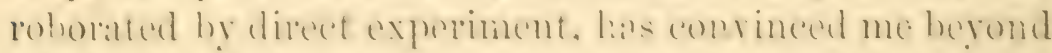
all doubt, that mamures citier liquid or solid, are mprofitably complosed when applied to plants in, the dormant state.

In wathering the erope eantion must be ned not fo injure the plants by continat or exessive eatting: for it

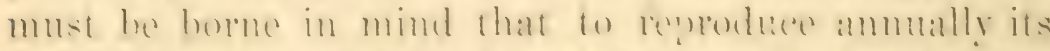
(rop of shouts in springe som thing mist bis le to to grow

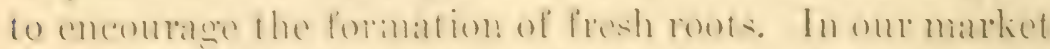

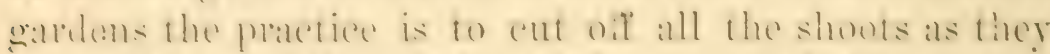
alre reads, until the midale of $.1: 1 y$ or ist of dune, when the showe hegin to show signs of weakness then all is left to grow and no more cut. In its perpalation for market the shoots are tied up in rensat bunehes. The size of the bunch is govemed someritiat by the abmatanee of the erope and is about four to fire inches in diameter and from seren to nine inches in length, in wight from

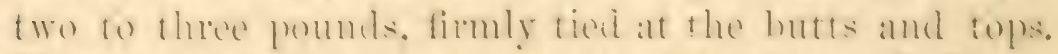
The wing material is the matting known als Raffial, ats that is soft. pliahle, and has the nicessaty strength. The

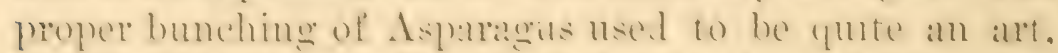
but the "Aspaltagus Buncher" (see implements) has ren- 
dered the operation so simple that any one can els it rapidly with a few minutes practice.

'This crop is suljecet to so many conditions that an arerage value cath hatrdly be given; some of our growers here yet claim that it pays an anmual clear profit of so) per acie, while others say that it does not pay them over $\$ 000$ per acere. Doring a period of ten ycars, connting from the time the berl was planted, it is sale to say that, in this reinity, the average profits per ace will be sesot). It is a crop that never fails to sell, is a iways poductivo if properly treatad, and having a great value for its weight -il ton often being worth from $\$ 200$ to $\$ 4(j 0)$ - it is, in all respets, a valabble "rop for the market gardener. In packing Asparagus for shipping it is best packed in boxes of a dopth equal to the length of the bunch or perhaps an inch deeper, because in packing, Asparagus is placed on ond, and some soft material, as mosis, cottrom, ol soft paper should be placer? on the top, so that should the box be turned upside down, the soft tops will not be bruised. The interstices between the bunches should also be filled in, so that the whole may he firm enough to not be injured by jarring. 'This is true of packing all vegetables for shipment; unles the box is pareded full and firm, jarring in the handling is sure to injore them.

In some localities, especially on Long island, New York, the Asparagu's Betle (Crioceris asyaragi) has injured the crop to such an extent as to caune whole plantations to be plowed muder. When the bectle first appears it may be controlled by picking it off and destroying it; but if allowed to become establisherl the task is hopeless. The engraving (figure 15) shows the insect in its different stages. The lower figure is a part of a branch, with the small black eggs attached by their ends; these are given of the natural size, and magnited. Fhe larva, or caterpillar, as well as the perfect bectle, is shown at the top of the engraving; the natural size ef these is in- 


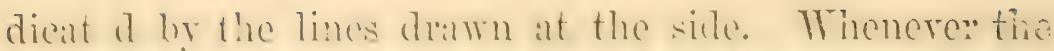

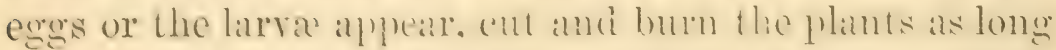
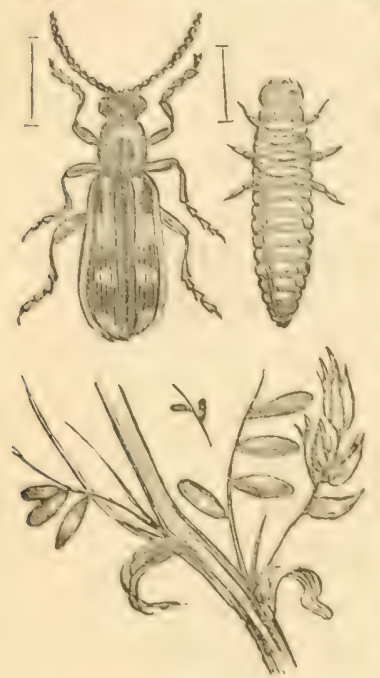

Fig. 15.-ASPdlitaUs BEETLE. as any traces of the insect are to be secn; this must be done if it destroys every restige of regetation. A remedy much in use in some sections is to coop up hens in the vicinity of Asparigus beds, and let the chickens out to pick up the larve and insects. A certain remedy against the Asparagus beetle, it is claimed, can be made by mixing one pound of Paris green in 100 giallons of water, sprinkling orer the plants twice each reek on the first appearance of the insect. 'The rarieties of Asparagus now are contined to the "Colossal" and the "New Palmetto," alleady describul. 'Ihe $\cdots$ Giant," formerly so much grown, is now nearly out of cultiration.

\section{ARTIOHOKE.-(Cynara Scolymus.)}

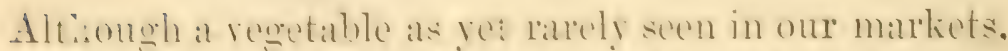
it is extensively used in Europe. particularly in France. the portion of the plant most used is the moleveleped flower-head. or rather those portions of the howor-hoad called the seales of the involuere. They are sometimes

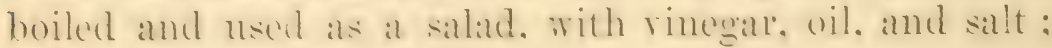
but more generally in the raw stat?.

Another ware of the diticholie is to hlated it. by tyine

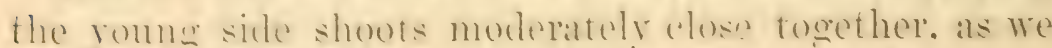
tie Endive. filling in betworn with soil to exelude the air until the shoots are hanched: this is what is kmown as "Articholic sialad," or "Articholie Chard;" it is used 
in this state in rarious forms of cookery, besides be ineg used as a salad.

It is a vegetable of casy cullure, originally proplatentel

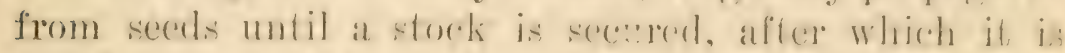

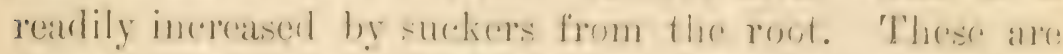
planted out in . 1 pril or May, in rows from three to four feet apart, and two feet between the plants, care being taken that the plants are well firmed in planting, and if the weather is dry, they must be freely watered until they start to grow. 'The plantation, the first season, will only give a partial crop; but, as it is a perennial plant, after being once planted the same bed will remain in bearing for years. 'The plant may be said to be entirely hardy south of Mason and Dixon's Line, but north of that it requires to be protected by covering between the plants

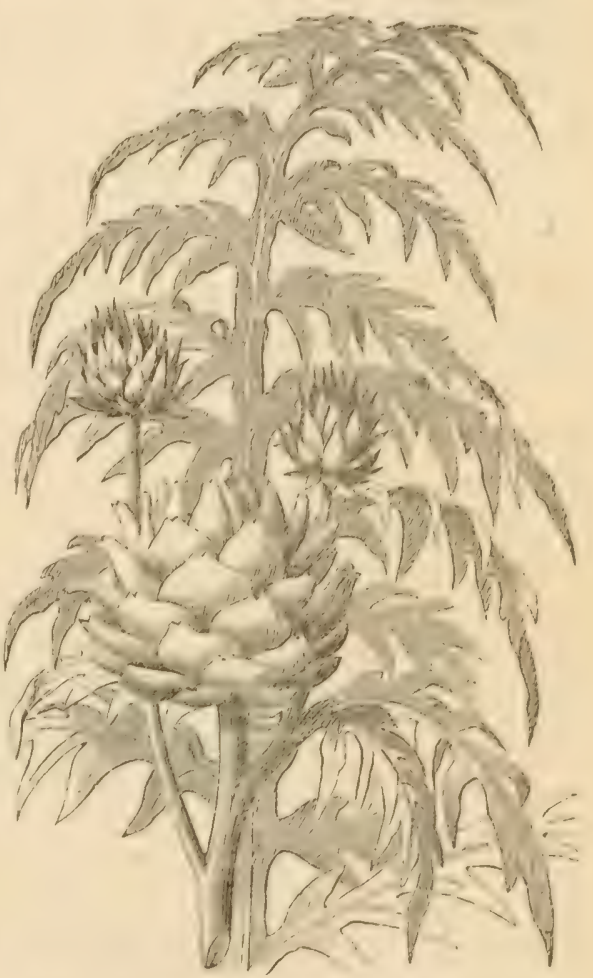

Fig. 16.-GREeN ar.oBe AITICHOKE. with six or coght inches of leaves or roatre manture.

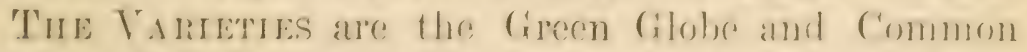
Green, rillereng but little, exerept in the form of thes

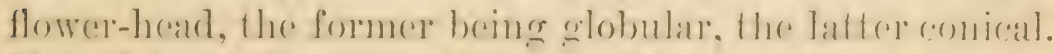
It is clained by some that the Common theren is mole hariy and productire, but we have grown thom side by

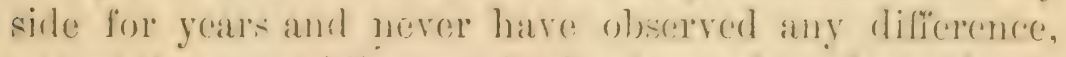
except the very trifling one in the shape of the flower-head. 


\section{ARTICHOKE,-JEnLsilem.-(Helianthus tuberosus.)}

This is an entirely different plant from the true Artichoke though rescmbles it somewewhat in flitrorhenee its name. It is a species of Hetienthus, or sumtiower, and the plant hats the general appearance of at small sunflower. 'The edible part of the plant is its tuber's. These are like the potato in alpearance, but when eooked. to the taste of most people, are very inferion in flavor. Their nutritive value is said, however, to be fully ergual to that of the potate. Leed in the raw state it is prekled like the enemmber. or sliced and eaten with vinegall as at salad. but als a culinary regetable it is but little grown, except for rariety or novelty.

Its culture is, in all respects, similar to the potato, but it is more productive, allays free from disease, will grow almo-t in any soil or situation, and will stand the winter on light soils wherever a l'arsnip (rop will stand;

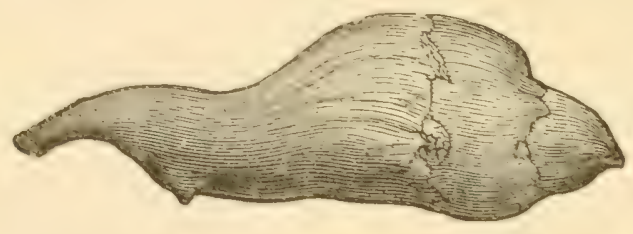

JERUSALEM ARTICHOKE.

for these reasons it is regarded as a valuable food for cattle or pigs, who eat it freely. It is planted largely at the IVest as food for swine, which do their own harresting.

There are sereral raricties, known as Recl, Purple, Yellow and White shinned. 


\section{EASIL_-(Ocimum Basilicum.)}

An herb of a highly almomatic orlor, and a strong flatror of cloves. It is used for flavoring somps, steres and salleces, and is hy some used in silats. Its culture is the same as that of other sweet heris. The seent should be solvin in the opern gromul and not in frames, which is the English pratetice, and necessary there liom their colder climate. Sow in rows one foot apald; when there or four inches high it maty he transplanted in rows one foot apart and six inches between plants. If a small quantity only is required, it maty be thimmed ont in the secel forws and left to grow where sown.

Where atre two species (aultivater, namely, the Common Ewat Basil (Ucimum Basilicum), and the Bush Busil (O. minimumi).

\section{BAIM.-(Melissa officinalis.)}

Another well-known aromatic herh which has a very agrecable Jemon-like ofme. It is used ats a tea for its soothing effect in irritations of the throat and lunges, and a century ago was used as a specific for coughs and colds. Its young shoots are sometimes nsed ats an ingredient in salates. It is rapidly proplagated hy dirisions of the root, which, planted in spring at one foot apart cach way, will form a solid mass by fall.

Besides the (oommon lind we have now in cultivation a heautiful variegated raricty, possessing all the properties of the other.

BEANS.-(Phasenlus vulyuris.)-Busif, Kinnex and Pole.

A leading vegetable of our market gardens, and extensirely cultirated in every section of the country North 


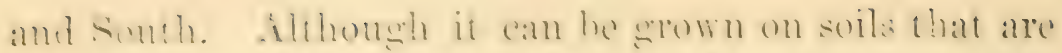
not enriched by mamme, yet, like almost every other resetable. it is more protitable when wown on highly cultivated limd. It is what wo term a " tender" plant: that is. one that will be killed by the action of slight prosts. henee is is not plamed untel late enomgh in the spring to secure it from the risk. As in a combtry pre-

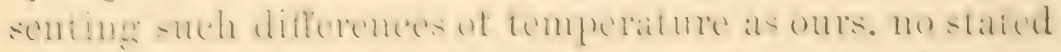

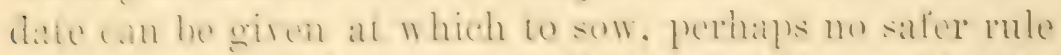

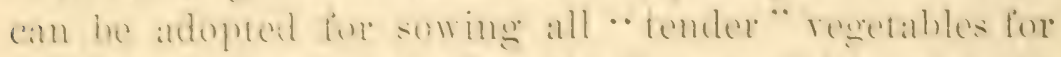

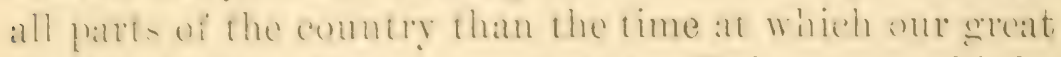
staple, Indian Corm, is planted. 'This rule will be cyually intelligihle on the inhabitants of Maine amd to those of south Camolina. for all plant corm. amb linow

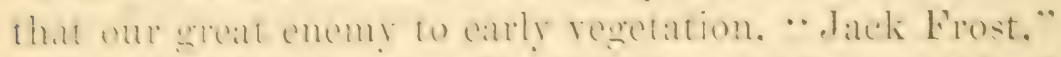

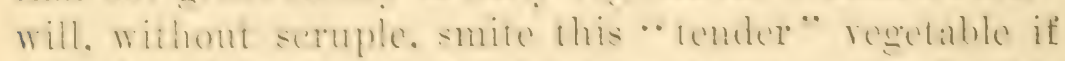

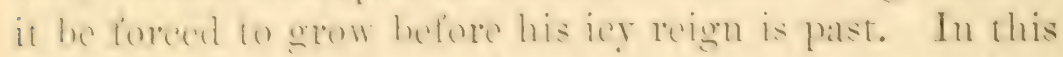
section we plint beans for first crop when we plant Oorn, from 10th to 20th Mar. But as the crop of

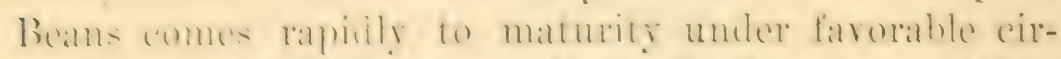
cumstances, in tîe or si werks, it maly he sown any time from Ihese dates muti July. Ansust, or september, atcording to the temperature of the distriet.

The enlune in markit garlens as simply to draw drills ahout thes inchesderp, and from eightern inches to two fort apart. aceording to the richness of the soil: the poorer the soil the closer they can be planted. The

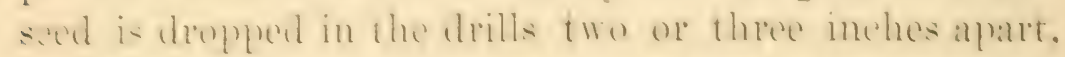
and the soil corered m on them with the teet: this we

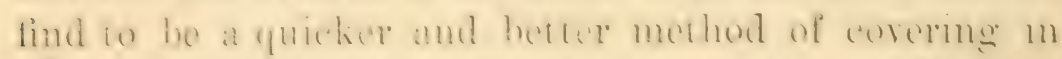
seeds of this size than by the hoe or rake. After the plants hate wrown an inch or two a culcivater is run between the roms. Whieh generally is all that is neecsing to be dome. until they are latree entem to have a hate

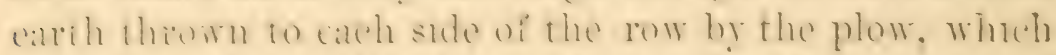

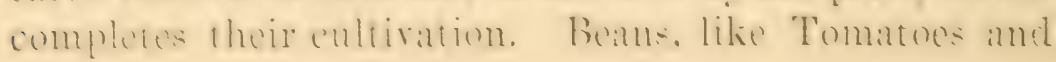


Peas, are easy of culdivation and not patrticular at th soil, and are, in consequence, rarely a profitable crop in the locality in which they are grown; hence the only way in which they are made profitable is by growing South and shipping North, they being easily transported. Large quantities are grown in early soils in Southern sections of the country and shipped to our large Northern cities, and meet a rapid sale at prices that must pay a large profit, if their manner of growing the crop is as simple as ours. It will be understood that this crop is almost exclusively sold in pod as snap shorts (in the green unripened state) by the hucksters, and rir'ely as a shell bean.

The varieties are now very numerous, but the following, placed in what we consider the order of their value to the market gardener, will embrace variety enough for all practical purposes.

\section{BTAN,-DWARF.}

Rarliest Red Valsutins.-This varicty is at least ten days earlier than the Early Red Valentine, which is one of the very best market varicties. On account of its great earliness it is largely grown by market gardeners; but except in the characteristic of extreme earliness, it differs in no other way from the Early Red Valentine next described. (See figure 1\%)

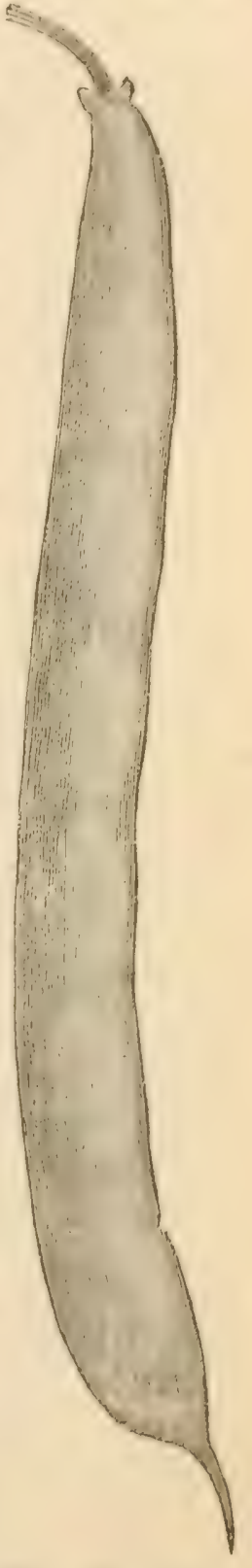

Fig. 17.-EARLIEST REI) VALENTINE BEAN. 
Early Red Valentane-- Equally desirable for either

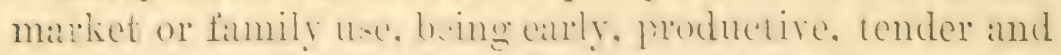
of exellent thatos. The pods alre round. somewhat curved, and the secels, when ripe. salmon speckled with purpitish rese. Tuis variety is usually ready to pick in six weeks from the time of sowing.

Early lohawk. A very moluetive early variety and one that will stand more cold than most of the bush varieties. Both this and the precenting sort alde larecly grown in the southern states for Aorthern markets. The pods are from the to six inches long: seds, when ripe, drab with purple spots.

long Vellow six Weelss,- barly, wery prolifie, and of excellent yuality. Pouls, six to right inches longe: sowls. when ripe, yellow or dun color.

Befuger or Thousand to one.- I rery prouluetive medium or late rartety. 'The roung pods alle tender and of the Hasor. 'This rariey is extensively grown for pickling. Seeds, speekled purple.

Gallega or large befuges. - This is of recut introduction and is a lapere form of the Refoger alnove de-

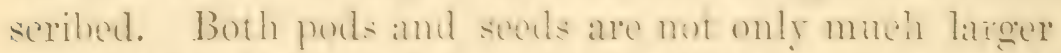
in sire than their parent rariety, hut it is also a much better yielder. Sicds. when ripe purples speckled with white.

White Marrowfat,-The variets so often grown for sale in the dry state. It is also ralued als a string bean, but is usul to a ereater extent at a shelled bean, either green or dry. Seen's large, ivory white.

\section{BEAN. - WAT.}

Black Was,- Then ripe the pods are yellow, areraging from six to nine inches in length. 'They are tender, 
and the quality is of the very best. The seeds, when ripe, are glossy black.

Golden Wax.-1 strong growing, distinct variety, at least a week earlier than the Black Wax. 'L'he pods will average six inches long, are brittle and entirely stringless. As a snap bean, it perhaps excels all others in tenderness and richness of Havor. Seeds, when ripe, are purple and white. (See figure 18.)

Pagcolet Wax.-The pods of this are very large size, often a foot in lengtin, exceedingly tender and sncculent, and enormously productive. It is equally good as a shell bean. I consider this one of the best of the Bush Beans.

BEAN.-(Phaseolus luncitus, te.)-Running OR POLE.

'These are more tender and require rather more care in culture than the Bush Beans. 'The soil best suited is sandy loam, which should be liberally enriched with short manure in the hills, which are formed, according to variety, from three to four feet apart, and provided with a stake fiom eight to nine feet in height, set in the center of each. This class of beans is particularly tender, and it is perfectly useless to plant the seeds before the weather has become settled and warm in spring, as they are

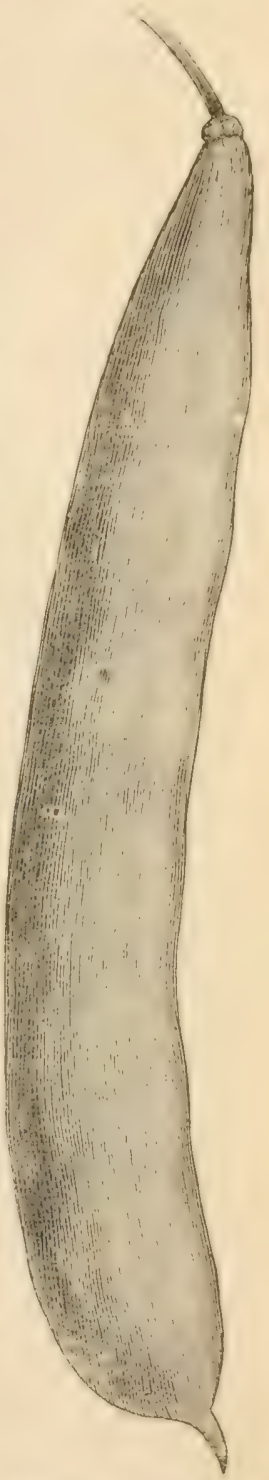

Fig. 18.-GOLDEN

WAX BEAN. almost certain to rot, and eren should they not, the plant malies no growth, unless in uninterrupted warm weather. 
In this distriet they should never be planted out until a week or more after the plauting of Bush Beans; if planted at the same time, 10th of May, they are almost certain to fail.

From five to six seeds are planted in each hill about tiro inches deep. Being a regetable reyniring considerable expense in growing, staking, picking, ete, it brings a correspondingly high price per acre in minket: but maturing during the heat of summer, the advantage of earliness in this erop is uot so manifest as in many others. The protits nele ace arerage about $\$ 100$, when sold for consumption in the locality in whoh it is grown. Shipled from earlier sections it. no doulst, would double the above amonnt. 'There are many varieties, but only a few of leading merit.

Latge White lima.- With nearly erery one the seeds of this variefy wher wreen or ripe are considered the most tender and dolicate of all the valleties of the bean, and it is therefore miversally arown, holle for matiet and family use. The ripe seeds are kidney shaped, and of a dull white color.

Jeruey Latra barly lima--(Sec figure 19.) d new variety, silul to beten diys carliel than any other sort grown in this rivinty. The pouls hare heen in the New York market as arly as July :30th, and sold at the rate

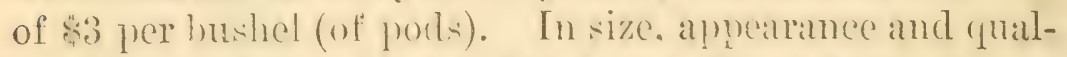
ity it is much the same as the Laroe II hite Lima.

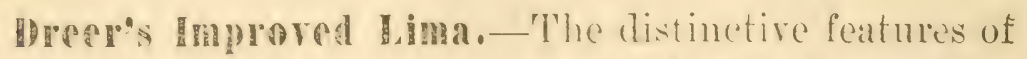

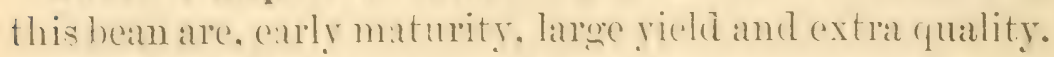
The bean itself is thick, and in shape more round than oval.

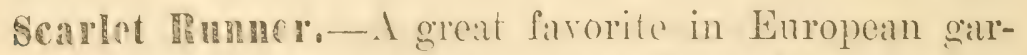
dens, both as an ormamental plant and a useful regetable. It grows to a height of nine or ten feet, producing dazzling scarlet flowers from July to October. Tsed both 
as string beans and shelleil. Seeds, when ripe, are lilac, mottled with black. A distinct species, l'haserolus multiflorus.

Giant Wax.-Tery productive, bearing pods from six

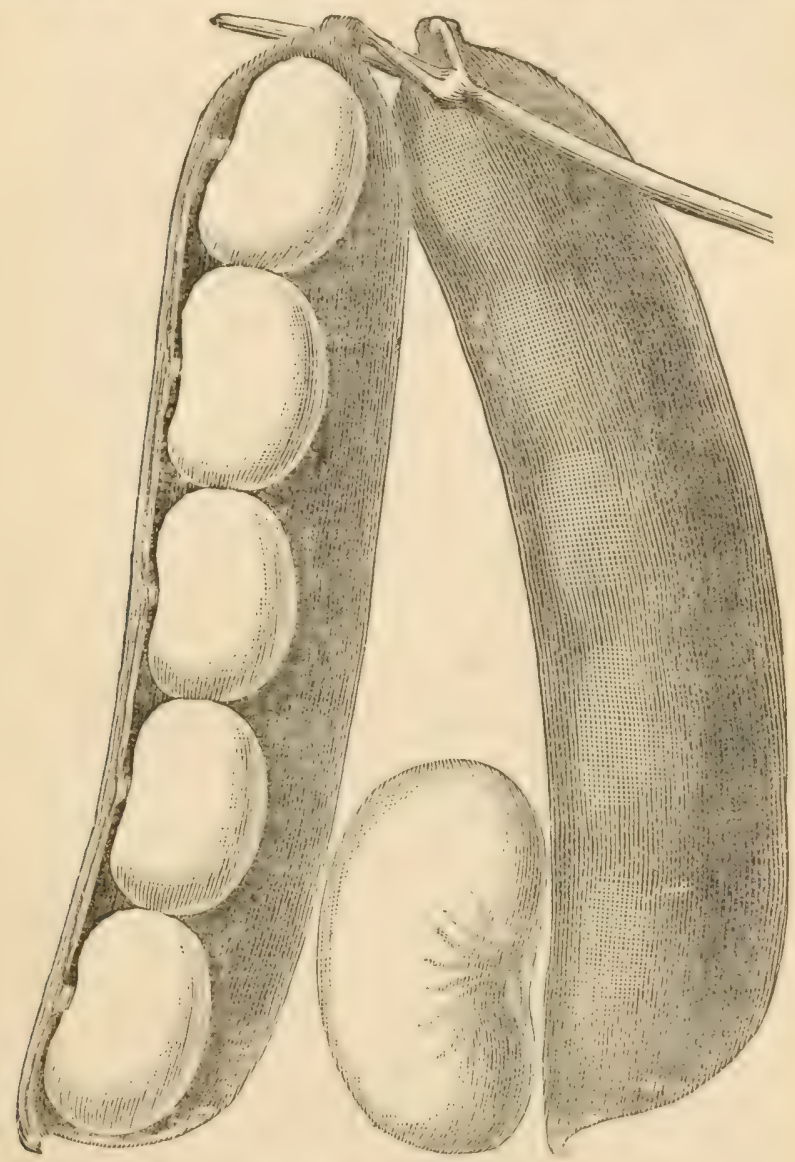

Fig. 19.-JERSEY EXTRA EARLY LIMA BEAN.

to nine inches long, of waxy color, thick ard fleshy, tender and of good flaror. The secels are red when ripe.

German War.-One of the best pole valrieties, producing large, flat pods.

Horticultural or Speckled Cranberry.-One of the best of the pole sorts for use in pods. It is rery produc- 


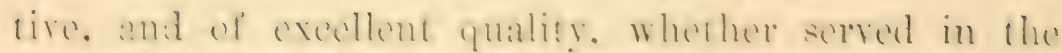

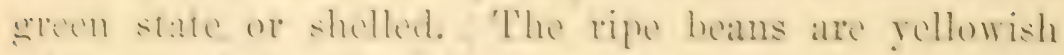
white. spotted with pink.

\section{BEET.--(Beta rulgaris.)}

This is ome of the leating and most valuable elops of

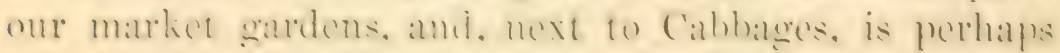
the most extensively arown as an early erop. The soil hese subed is that which is rather light than otherwise.

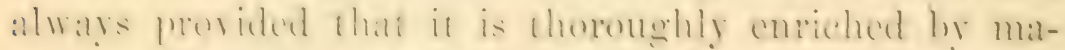
mure. Ite make litele ditterenes in the mamnere of werk-

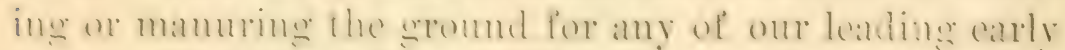
crops. The gromed must, in all cases, be thomonghly pulveriat by plowing. subsoiling and harrowing and when stable mamure am be procured. plowed in at the rate of serenty-fire to one hundred toms per alere. It

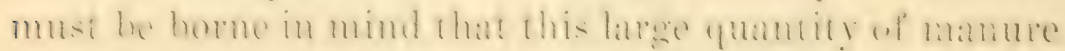
is used where two erops are taken oft the land in one seat-

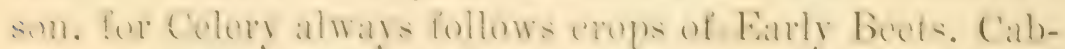

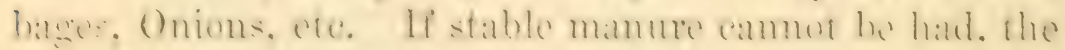
next best substitutes must be used in the qumbities

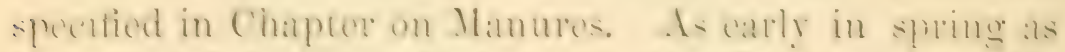

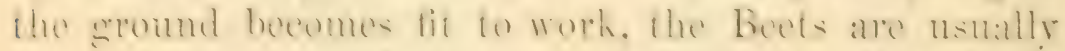
sown in rows one foot apart. mate by the " matker."

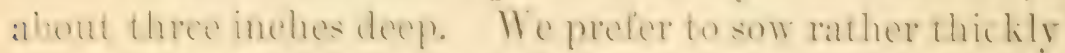

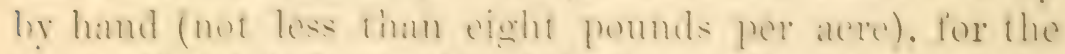
reason that late frosts of en kill ofle a portion of the young

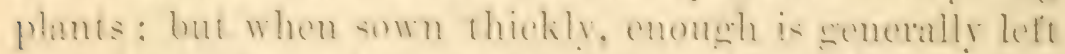
to make a crop whieh amply repays the diflowemes of a tew pounds of seed. Atter sowing. the sced is pressed in by the feet (see " Tree of the leot in sowing and Plameng." pare thi), and if the weather is dry. the whole surlace is also rollud, which firms the soil better aldomed

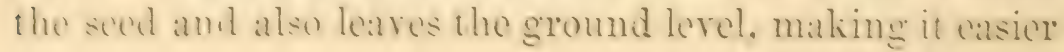


to be hout. This fimning of Beet seed is very important, as hundreds of acres, particularly of the Sugar lined, grown on the farm for stock, alle ammmally lost for want of

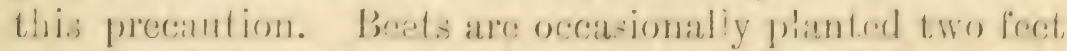

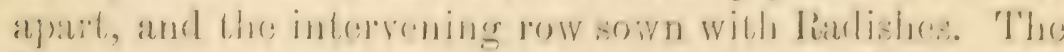

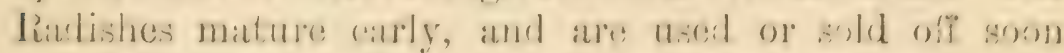

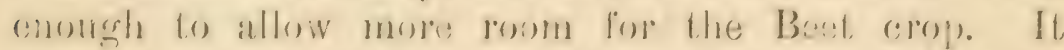
makes but lithe differences with us in the protits of the

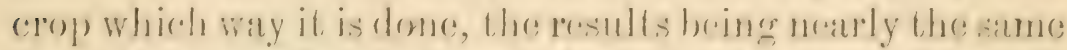

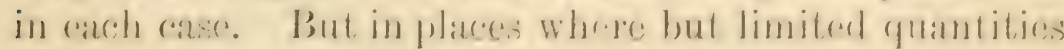

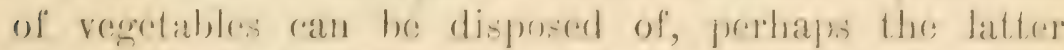
phan is the best. The youmer becis ale thimmed onte to six inches alpart. when the rows are one foot apart, but

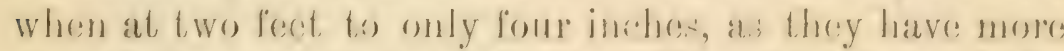
spare between the rows for air. The thinnines of the beeks are used like Spinateh, an!, whin carelully hamdled,

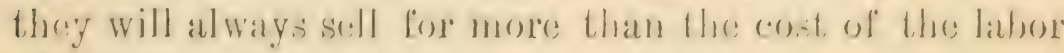
of thinning the clop?

In this noightortumet, Bocts somp lirst woek in April are begun to be malloted the fir:t week in June and entimely chared ofl by July 1 st, when the gromud is pro-

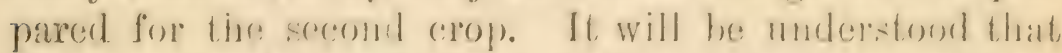
thry are, at this carly date, sold in an immature state,

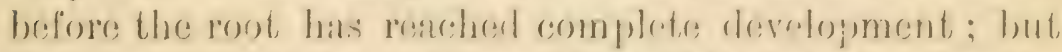
the great point is carliness, the public being well satisfied to pay more for it half-grown, if carly, than when full-grown, if late.

This crop I have always considered a very profital,

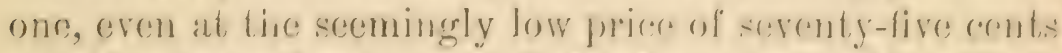
por 100 roots, the arerage wholesale price in New York markets. Lut, 80,000) roots ane guown pore aces when

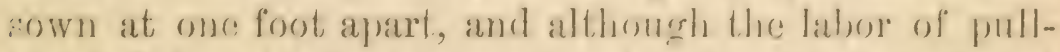
ing and bunching np is greater than in some corops, yot. at seventy-five cents per 100 it, will give an casy [nofit of $\$ 250$ per acre.

bects are an excellent article to ship, and the price 
paid in New York for the first lot.s from Savannah and Norfolk, etc., is often as high as $\$ 2$ per 100 roots.

The foregoing all relates to the crop in the green state for an early market, but they are also extensively grown for use in fall, winter and spring. For this they are usually sown later, often in some sections as a second crop, as late as July 1st, althongh in the Northern States the roots hardly develop enough when sown after June. The manner of saving them in winter will be found under the head of Preserving Vegetables in Winter.

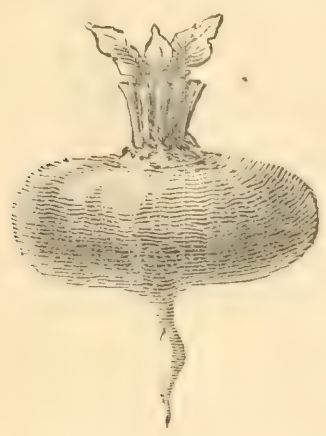

Fig. 20.-EgYPtiAx tURNiP BeEt.

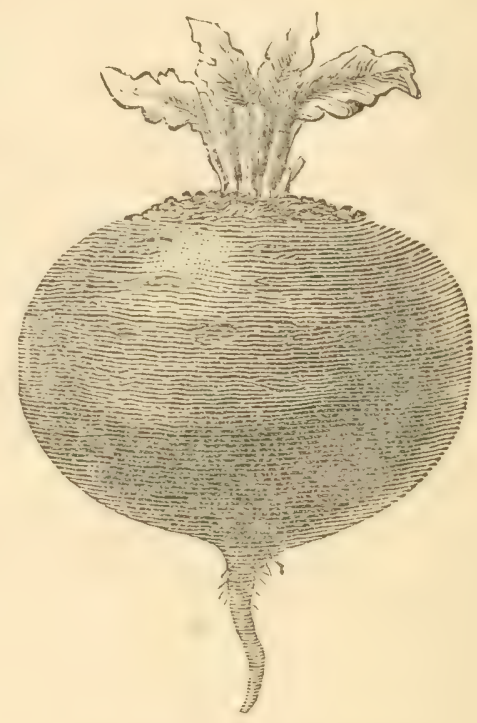

Fig. 21.-ECLIPSE BEET.

The really useful valrieties of Beets are very limited in number, and are embraced in the following. arranged as usual, according to their merit as market sorts:

Lgyptian Turnip.-(sce figure :0.) Now a standard sort. being from ten to twelve ditys earlier than the old Bhood 'Turnip. The roots are laree in size and of a rich, deep crimena color. From the smallness of the tops at least one-fourth more cam he grown on the same siace than of any other sort we have been in the habit of raising.

Eclinse.-(See figure?1.) A new variety that bids fair to rival the Egrptian as an early market sort. It is just about as early as the Egyptian, but is larger and of very 
much finer quality. It makes a comparatively small top and the roots are of the globe form shown in the illustration. Onr market gardeners in the ricinity of New York claim that it is bound to be the lealing market sort.

Bastian's Hood Wmpin. - After the Egyptian and Eclipse varietics, this is probably the earliest Beet in cultivation. In shape it is rery similar to the Early Blood 'T'urnip described below.

Early Brood Turnip. - i well-knom varicty, following the Egyptian and Eclipse in earliness. It is a deep red color, and of excellent quality.

Hewing's Inproved Blood Tornip.-This is simply an improved variety of the Early Blood I'urnip, with the roots of a deep blood-red color, and fine form and flavor. An excellent market sort.

Long, Gmoath Blogl.-(See figure D. A great improvement on the common Blood Beet, being less strong and freer from rootlets, besides being a week earlier. It is now grown liere to the entire exclusion of the other. The market demand, however, for early crops requires twice the quantity of round to that of long beets; for late sales of barreled roots exactly the reverse quantities are needed.

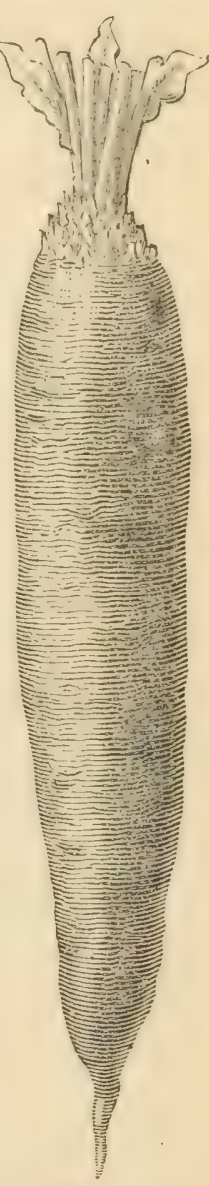

Fig. 22.-LONG, SITOOTH BLOOD BEET.

Swiss Chard.-A distinct species from the common Beet, which is grown for its roots, while the former is cultivated solely for its leares. The midrib of the leaf is stewerl as Asparingus, the other portions of the leaf being used as Spinach. The outer leaves are pulled off as in gathering Rhubarb. It is largely grown in France and Switzerland. In this coun- 
my it is now enltivated to some oxtent in private gare-

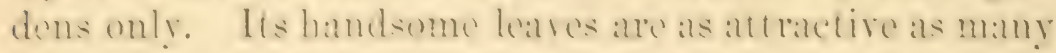
of our prized flower giurden "foliage plimts," and no chubt if wombl be much ralued if we conld only regard it without the idea of its being only a Beet.

\section{BORECOLE OR KALZ.-(Bressica ofmece. Fir.)}

A vardety of this. recoiring the rathere indedinite term of "sprouts." is extensively erown for the Northerm marhets. mamy ateres of it beme cultivated in the vieming of Xew Yorli. It is som in the month of september in

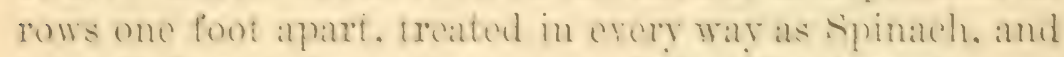

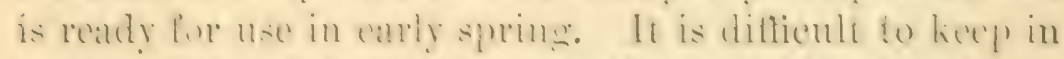
sume soils in winter : these of lather a light natule hemg the bes. When suecestully wintered oter, it is a vory

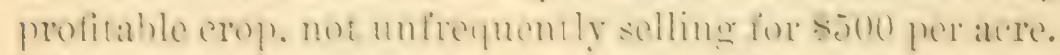

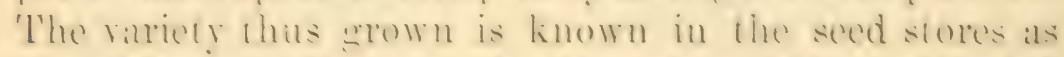

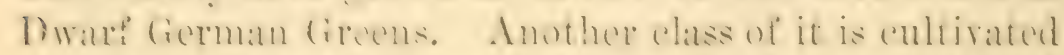
as we grom late cabhage : it is sown in the open eroment

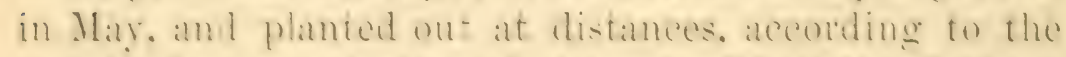

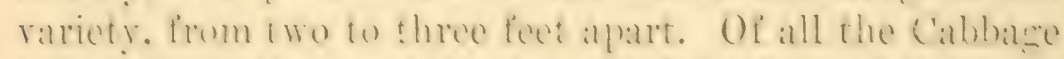
tribe this is the most temeler and delicate, and it is st.pprising that it has never yet hern wamted in yuantity

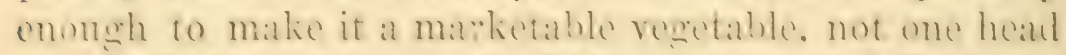

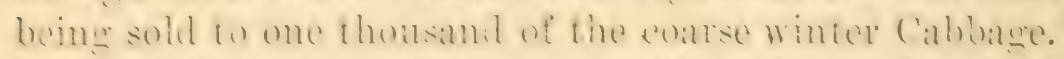
The varbeties ane rery numeroms ; those bulow described are all standard sorts.

\footnotetext{
"siberian liwari furled Gale." "Dworf German Grpens." or "spronts."-(sectigure -3.) The leaves are of a bluish wreem. resembling somewhat the poliage of the linta Bawa 'Tumip. It is of delicate llavor and in erery way desirable. It is the pupular market variety.

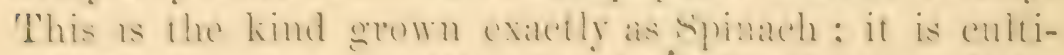

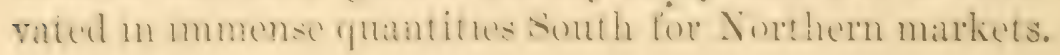


Very Early Dware $-\Lambda$ new rariety that is said to be of special cexcellenee. The leaves ane of a vellowith ereen color, very dwarf and finely curled. It grows very closo to the ground.

Dwarf Green curled seotch.-A dwarf variets, ramb exceding cighteen inches in height, but spreading out

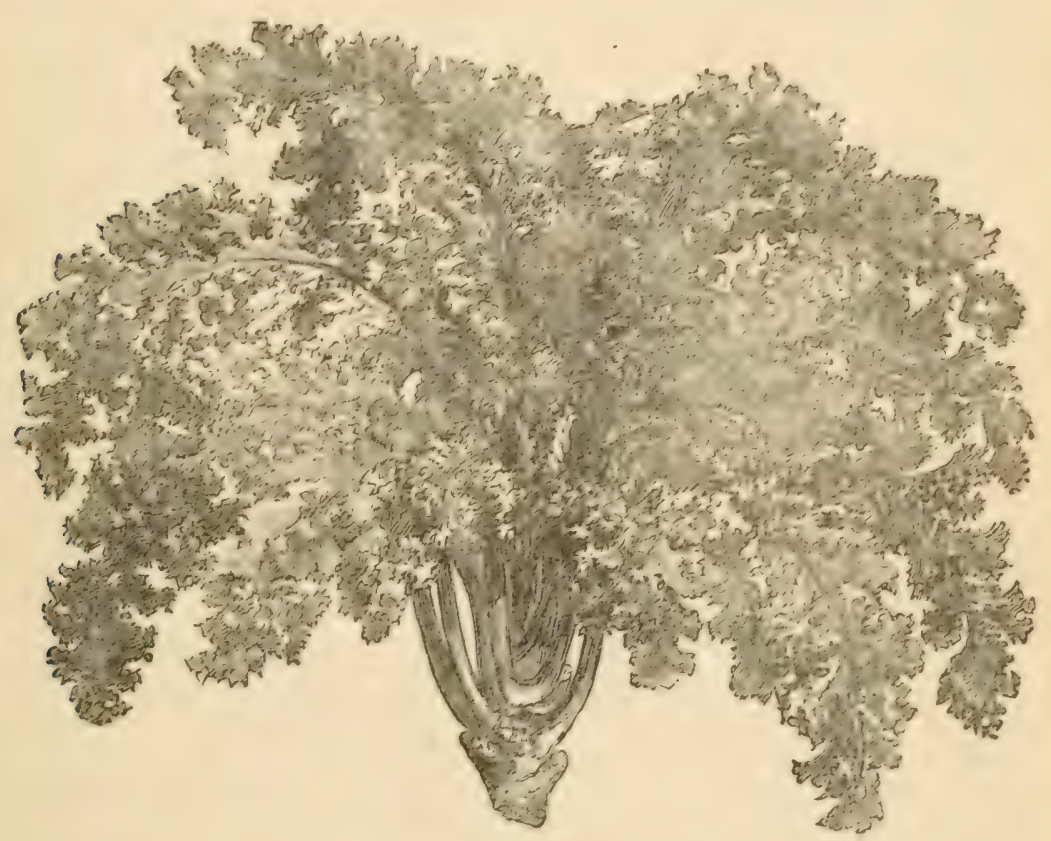

Fig. 23.-GERMAN GREENS.

under good cultiration to three feet in diameter. 'The leaves are beantifully curled and of a bright green. 'This variety is very hardy and will remain over winter in any place where the temperature does not fall bolow zero. It is most tender after being touched be sharp foret. 'This is the variety used in the fimous scotch dishe of "beef and greens."

Purple Borecole.--Similar to the abore in all respects except the color, which is a dunl purpole. This is the ra- 
riety most estecmed hy the Germans. It is rery hardy and is often seen in the markets of New York as late as January.

\section{BROCCOLI_-(Brassica oleracea. Var.)}

This renectable is a colosely allied to Caulillower that it serms absurd to have crer diviad them under different heall. Still. We persist in growing them muler the names of Broceoli and C'anlitlower. the Broceoli being planted for lall use. Cambitumer. on the ot her hand, heing mostly planted for summer use, although it is wall linown that their seasons might be reveroul without any mallied difference in the lesults. Like all of the calnhage tribe, Broceoli. to grow it in prefection, requires the soil to be in the hiohest posible denper of fertility. 'The seed shomld be sown, in this district. in the early part of May, which will give plants laroe enomeh to be transplanted in July. Fantherenth the sowing should be delayed until June or July, and the transplanting delayed aceorelingly motil Anfust, September. or Uctuber. There is no doubt that in parts of the country where the themometer does not fall below twenty or twenty-five deneres above zero, Broceoli ma! be had in prefection from Norember until March. A necessary condition of yerfect development is a monst and rather aod atmosphere; for his reason wo only eret the crop in fine condition, in this district, during the eool and molst monthe of eftalyer and November. Owing often. howerer. to heat or dryness in the month: of August and fintem? or. the eropl hecomes an entire faulure. and for this reatson. for market purposes, it is rather hazardoms. When a good (rop) is mate. howorer, it is very furolithle, rarely bringing les than \&s per 100, or alout sono per acre: but as the erop in this sectron fulls two seasons out of three, it is not considered a 
desirable one to plant. The plants of inost of the varieties are set out two and a half by one and a half feet, oi about 10,000 plants per acre.

In this district, for market purposes, we confine ourselves to the first two ralricties named below; some others, however, are occasionally grown for fimily use.

White C'ape.-Heads of medium size, close, compact, and of a creamy white color; one of the most certain to head.

Purple Cape.-Nearly similar in all respects to the White Cape, except in color, which is greeni:h-purple. This variety is rather hardier than the preceding, but its color renders it of less value in market, White Hearts of the same quality bringing $\$ 1$ to $\$$ more per 100. This is a mere matter of fancy in the buyer., howerer, as, when cooked, there is but little difference in its appearance from the White, and none whaterer in the flaror.

Warly Walchersu.-This variety seems to produce its heads earlier than the precening, but they are not usually so heary or compact. 'This varicty so closely resembles a Cauliflower that it is not easy to say in what respect it differ's from one. In England, where the Broceoli is much more grown than with us, this variety is sown every few weeks, in order to keep up a constant supply. 'The English catalogites enumerate some thirty or' more varieties, and each year adds to the list.

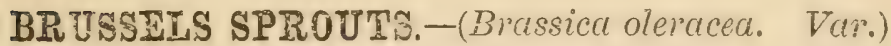

This regetable has nercr come into generial use in this country, probahly owing to its being too tender to stand the winters of the Northern States. Still, by sowing in April or May, and planting out in July, it may be had 
in finc condition until December: and, in the Southern stalde, may be hatd in lle from November to Mareh.

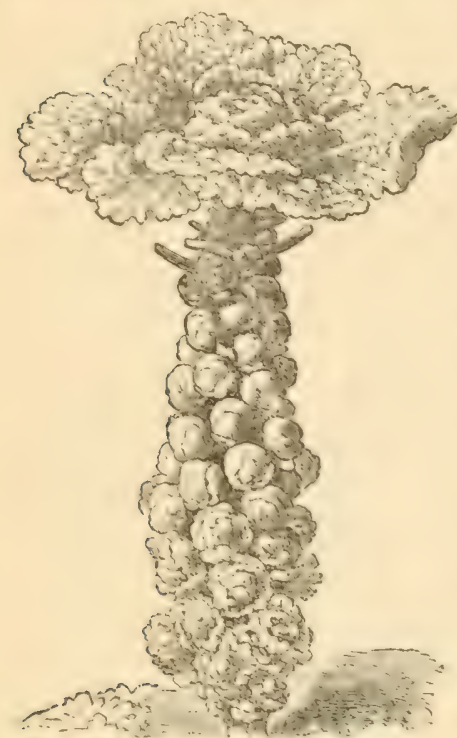
Even in England, where it is very extensively grown, it is not much raised for market, being mainly cuitirated for private use. Its cultivation is very simple, and it can be grown on almost any soil. Plant about two feet apart, and cultivate as for Cabbages.

Brussels Spronts are readily distinguished from all other varieties of the Cabbage tribe by the sprouts or buds, about the size of walnuts, which grow thickly aromel thestem. These

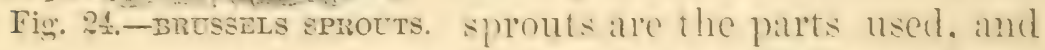
are equal in temelemess and haror to C'anlillower or Broccoli.

\section{CABBAGE AND CAULIFLOWER.}

Cabbage is moch easier managed than Caaliflower, and is eonserquently more certain of griving a erop), eren under mofarorahle comditions. The tirst eondition of suecess with the Cabbage crop. like that of nearly erory other regetable, is the right kind of soil.

'The hest soil for (Cabhage is a rather sancly loam, not

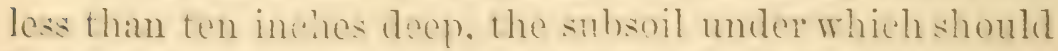

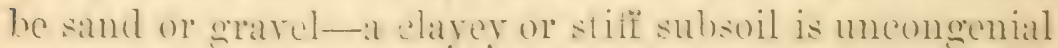
to almost "rery ('Pop). It may bus superfluous to say that mules the soil for (ahbare is drained artificially or uaturally (hy a siund or wavel subsoil), that sucess is innossible. 'This, of course, is true of nearly every crop grown. 'The propre pulverizing of the soll is a matter of 
the utmost importanee. Although many of the laree market gavedens in England are get dug with the sparle or clieging fork, it is ratre that anything olice is uses with us than the plow and harrow. We ourselves are so satisfied of the superionity of the plow as a pulrerizer of the soil orer the parde or digging fork, that we would not allow our grounds, for any purpose, to be duo, eren if done for nothing, and no digeing is ever d.ne on our gromuli in any spot where horses cail ha worked. Experience has shown us that it is always benenicial for the Cabbage erop to plow land in the fall, not only becanse when thus thrown up in ridges it grets pulverized by the action of the frost, but also that the mrning up of the soil exposes tho larre and egos of insecis also to the frost, which tends greatly to lessen their numbers the succeeding year.

Manille for the carly Cabbage crop should always be sprearl on broalcalst, and in quantity not less than 10is cart loaks, or seventy-fire tons to the acre, whict will leave it, when suread, about two or three inches in thichness. It is not unusual tiat much choice can be made in stable manure, but when such is the case, equal poitions of cow and horse manume are preferable, not that there is much difference in value, weight for weight, hut that it is adrantigeons to have the manure of the cow stablo mixed with that of the holse, so as to prevent the violent, heating of the horse manure, which, if not ropeatedly turned, will generate heat so as to cause it to "fire fang" or hurn, which renders it eompurative!y useless. Always bear in mind that the more tiroroughly rotted and disintegrater manne cam be hat, the better will be the results. When manure is thomonghly rotted and short, it may be turned in by the plow just ats it is sprear on the land, but if long, it is necessary to draw it into the furpow ahead of the plow, so that it is completely corered in. After plowing in the manure, 


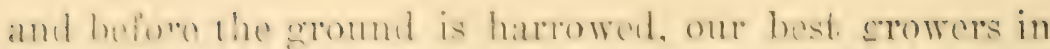

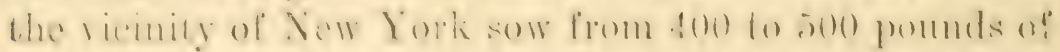
manme or home dest, and then harrow it in deoply, and

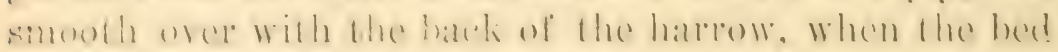
is ready to receiro the plimts.

In the vicinity of New York, and. in fact, now wher-

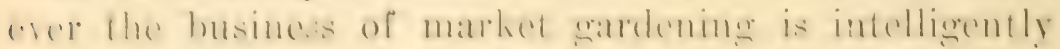

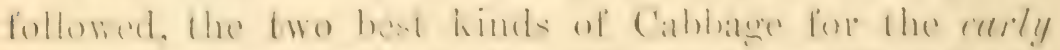

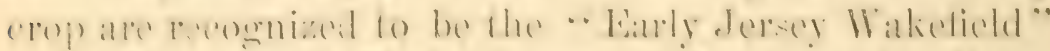

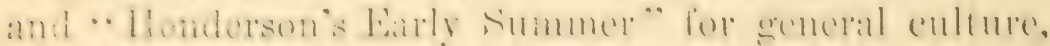

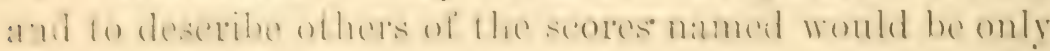
confusing. "Jorsey 1 takelichld" is the carliost and a

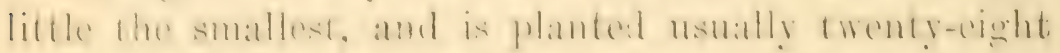
inches betwen tho rows and sixteen inches between

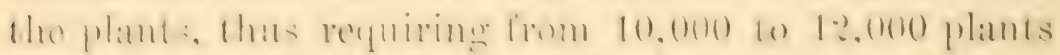
per ace. "Litrly Summer" girows a litte larger, and shombl be phanted thirl! imehes aflat and cightern

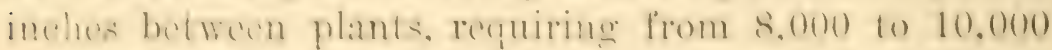

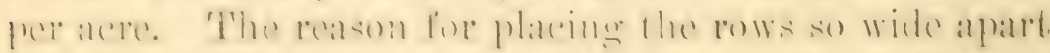
and the plants so close in the rows, is to admiti of a row

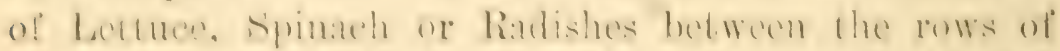

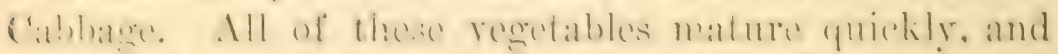

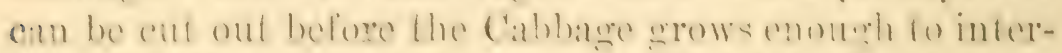

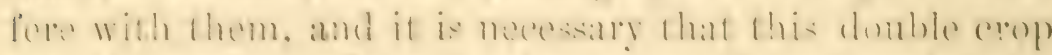
should be taken oft the limed so as to help pay for the

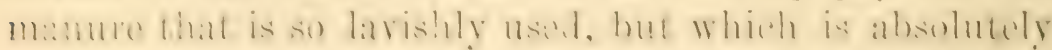
necessary to produce a good erop of Cabbares. Where

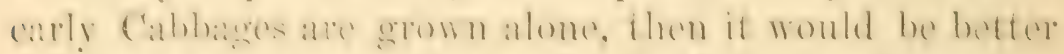
to plant about two or two am a half feet each way, so that cross enltivation can be done: and also in cases viere mamme in subirient quantiles is not allainable.

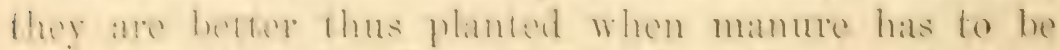
appliat in the hill. It applied in the hill, a good shor-

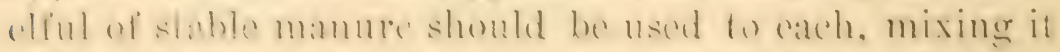

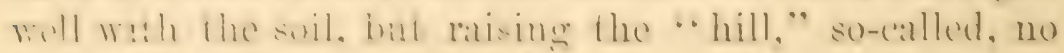
higher than the generail surface. 


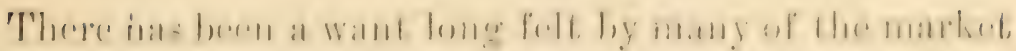

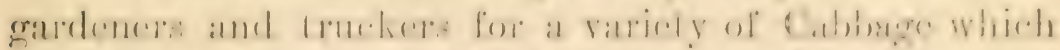

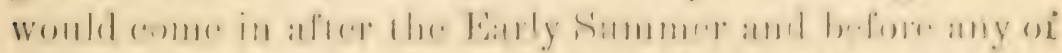

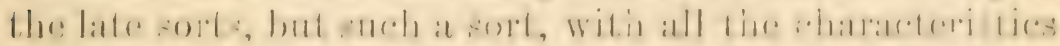

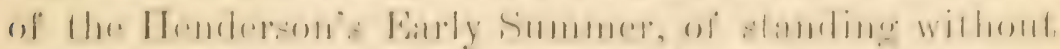

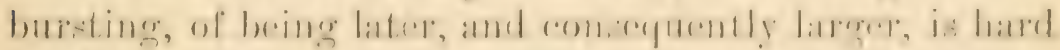
to obtain. 'ithough the medium, however, of the same

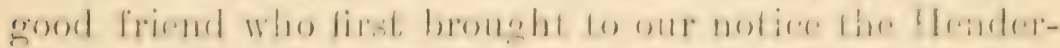

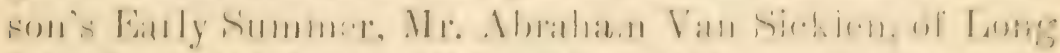

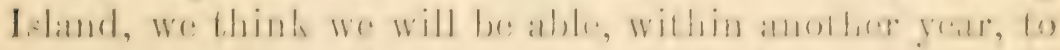
present to the public at variety of Cabbage which will

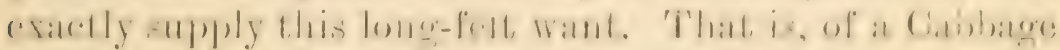

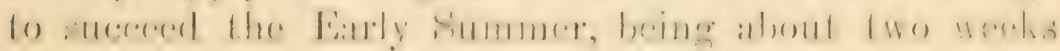

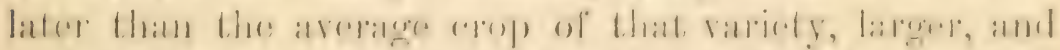

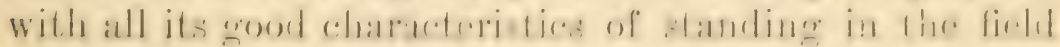

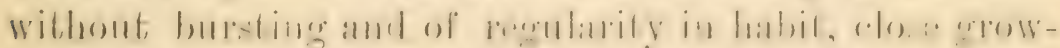

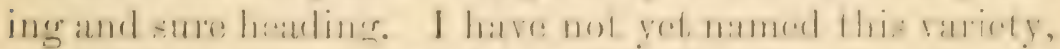
as I wish anothor soason's test of it belone dexiding io

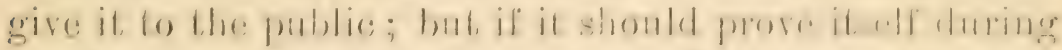
another season ats valuable as in the last two it will be a decided atcquisition.

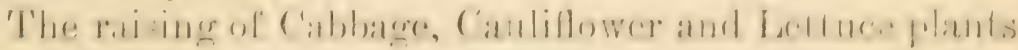
will, for "wintered over" plants, he found under the heatl of "Vores and Managrment of Cold Frame," and

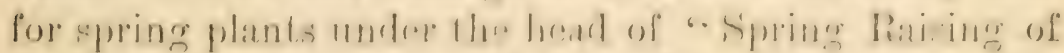
Cabbage, Caulilower and Lotuce Plants."

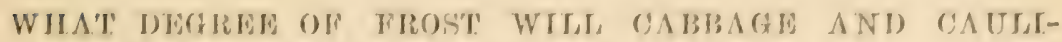

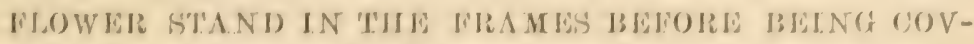
EREI) WITII TISE SASIT ?

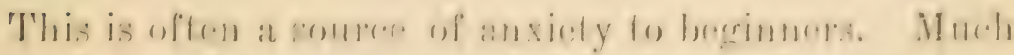
depends on the costition of the plante; it sometimess

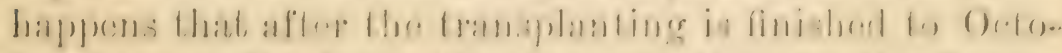

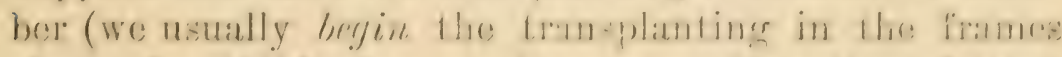
about the 15th), that we have a continuation of com- 
parative?y warm wouher. which induess a quick and solt growth in the plants. which, of entres, rombles them rery suseproble to injury from frost. When in that eomition we have sen them injured when the therme-

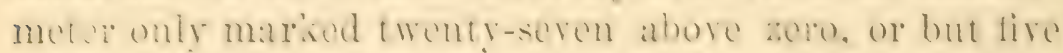

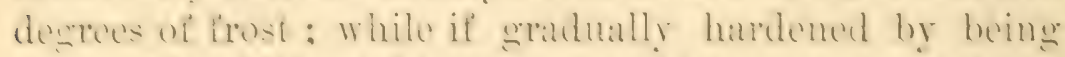
exposed to chilly nights, they would recoir no injury, eron when the themometer marksten or twelve ahowe gero. 'This will be well understood when we remembel' that in midwinter. when eorered with sals ahome, they

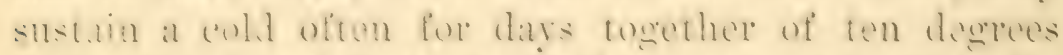

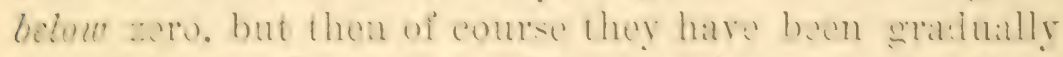

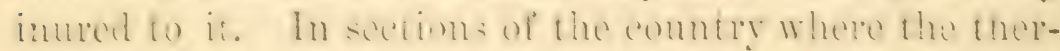

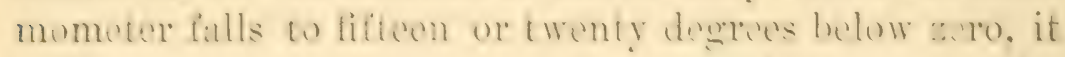
will be necesary to use straw mats or shutters orer the glas. It all time from the time of putting sathes on

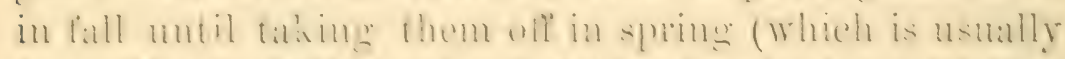

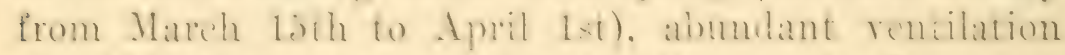

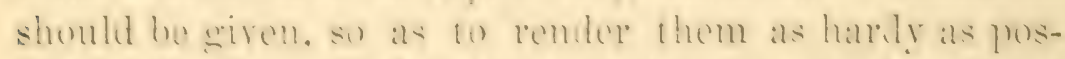
sible. The sme indieation that they are in the . prost

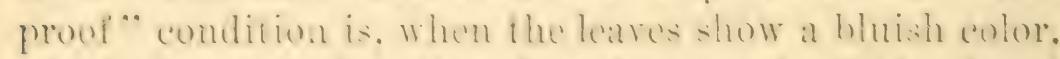

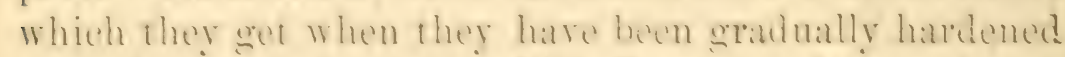

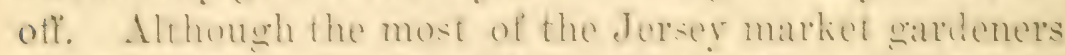
still use the cold frames for erowing the bulk of their

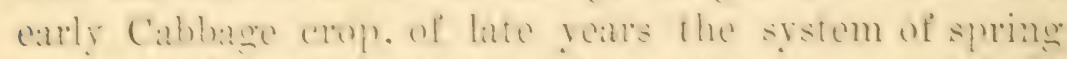
soming amb tramtplanting. amb somelimes wom wibout transplanting. is also used to a considerable extent. For

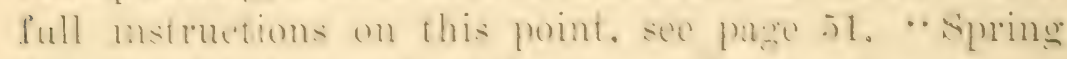
Raising of Cabbage, Cauliflowor and Lettuce."

In the laritule of New York. Cabbage planting is nsually begun about the soth of Mareh and finished by midalie wi April. It must always he home in mimel that Cablange boing a rery hamb plant. when wanted for an

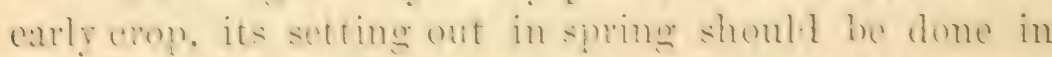
any section als soon ats the land is dry enough to work.

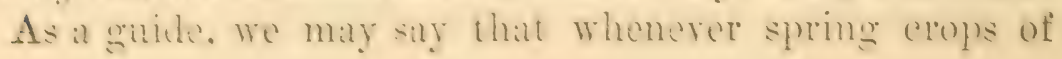


Rye, Wheat or Oats can ba sown, Cabbage may safely be planted in the open field, for if plants have been properly hardened they will not be injured after being planted out even by eight or ten derrees of frost.

The conditions in the difierent southern States are so varier that it is not casy to give directions. It may be taken, however, als a general rule that in any section of the country where the thermometer does not fill Ioner that fifteen abue zer\%, the seed for Cabbagr plants should be sown about Octolier 1st, left (without covering) in the seed-beds all winter, and transplanter to the open ground as soon as it is fit to work in spring, cay January or February. In sections where the fall weather contiunes fine into Norember, transplanting is done in that month ts where the crop is to mature. Cireat loss is often occasioned in milil seasons in the southern States, by Cabbages particularly the farorite variety"Early Summer" - rummeng to sect. As a remerly against this rlanger I wonld antrise sowing from two to four wecks later than the wsual time, in such a way as they could be covered in ci,ll niygls only with muslin, or, what is better, the new protecting cloth; these will answer all the purposes of sashes at one-tenth of their cost. I refur to this cloth more fully in another portion of this work.

After planting in the field, no (rop takes so kindly to l:ceing or cultivating as the Cabbage. In ten days after the planting is finished, cultivation should begin. If the Cabbages have been set two or two and a half feet apart each way, then the horse cultivator is the best pulverizer, but if a crop has been sown or planted lectween the rows of Cabbage, then a hand or wheel hoe can only be used-we ourselves now use the Planct Jir. Wheel IIne exclusirely, and find it a saring of three-fourths in labor, with the work better done.

The price at which early Cabbage is now sold varies so much at different dates, and in different parts of the 
conntry, that it is imposible to give anythiag like aceurute figures, the range leing all the way from $8:$ to $\$ 1$ ? per 100. Perhaps $\$ 1$ monld be a fair average for "Walivith" and so for " Varly summer", so that (a) unting 11.000 a the arerane frer aere of the former

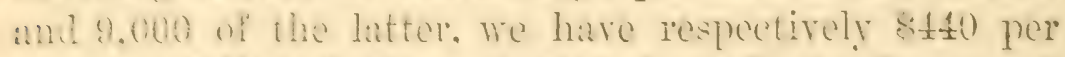
ane for * Wakdield" and stio for . Early summer." 'Thes: are the wholesale prices for latro markets like Now York. In smaller eities. where the prenduet is sold

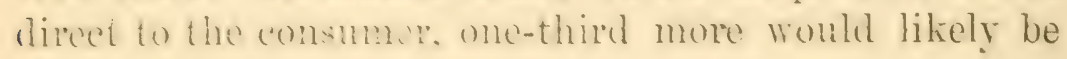
obtained.

\section{LATE CABBAGES}

are such as mature during the months of repermber, - Octobor and Normber. the soed for which is sown in

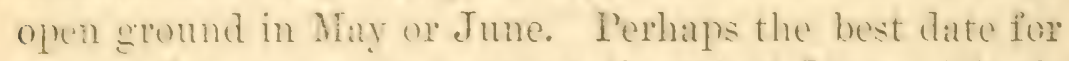
soring for main erop is about the list of Tunc. We alvalys profor to sow (ahbage seod for this purpose in pois ten or twolve inches apsirt, trealine in the seed with the flon, afur sowing and helore corering: we then level with a rake lengthwise with the rows and roll or beat down with the hatek of a spate. so as to exclude the atr lrom the sonl and irom the sect. Forn in this waly. Calbuage soel will ene un strongly in tho driest woather, and is less likily to be allieted with the hack flea tham if it mule a fecble growth. When the plants get ton tall. mow iwo or three inches off the tops. which will make them stoutur and stomerer rootert. As the

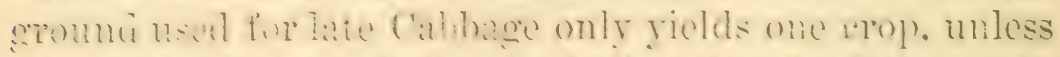
mamure is chanp and ahmulant. it will not often pay to nse it in the probusion peynired for carly cabhages, so that it is usmal to mamme in the liill, as is done for encly crons, if with stahte manme. but when that is not

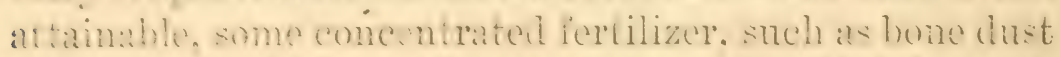

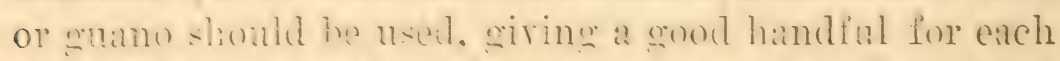
biil. but bing calienl, of course, to mix it well with the 
soil for about nine or tan inches deep and wide. In this way about 300 pounds per acre will be nerded, when 6,000 or $8,00()$ plants are ect on an acre. Th our practice we find nothing better than pure bone dust and guano mixed together.

In transulanting Cablbages from the secel-bed to the open field in summer, the work is ustally done in a dry and hot season-chd of June or July-and bere arain we give our oft-repeated warning of the absolute newerssity of having every phant pooperly firmed. If the planting is well done with the dibiber, it may be consugh, but it is often not well done, and ats a measure of afoly, it is always best to turn back on the rows after planting and press alongside of each plant with the fort. This is cyickly done, and it beider rests the planter, so that heo can start on the next row with greater vigor. In some sections of the comntry, preticularly in the Xicw Englend

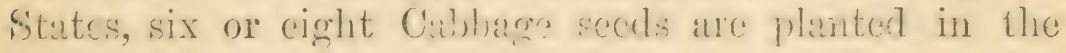
hills, and when of the heightef of two or three inches, are thinned ont to one plint in each hill. This we think not only a slower mothorl, but is otherwise oljectionalle, inemuch as it compels the manure to be plased for thres or cour weeks in the greund before the plunt can talice it up, to say nothing of the three or four wecks' culture necessary to be done before the secdings in the hill get to the size of the plants when set ont. The cultivation of late Cabbare is, in all respects, similar to that of carly, except as it is usually planter alone ; the work of caltivation is done entirely by the horse cultivator, the rowe ard plants in the rowis being, accorting to the kind, from twenty-four to thirty inches apart. There are a ment. number of kinds offered in the different ened lite, but experiencer cultivators confine themselves to but very few kinds. These we give in the order in which they are most approved: "II milemon's Salectel Flat Dutch," "American Drumheed," and "Marblehead Mammoth." 


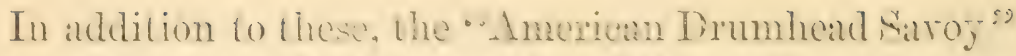
is crpown to a considcrublo cxtent, and it is really surprising that it is not erown t. the exchusion of rearly all ot her sorts, ats it attalias lo nourly at: much weight of clope is much more tomler, and thex in fhoror. The "Grow

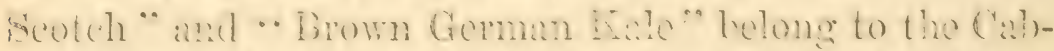

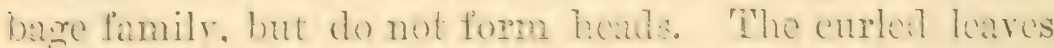
of tho whole plant can bo nsol, and anc, liks the . Saror," much finer in Raror than the plain heailed eab)-

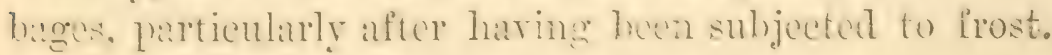

\section{KEEPING CADBAGES IN WIXTEM.}

It is best to ling linte Cabbares ont as late as posible. provided they ean la lifted before heing frozen in. In this latitude they can la safely left ont mull the third week in Norember. 'They are then dug on palled up. aneoreding to the nature of the soil, and tume i upside down-

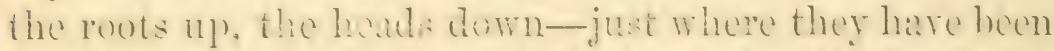
mowing. and the heads placiol choly towether in heds,

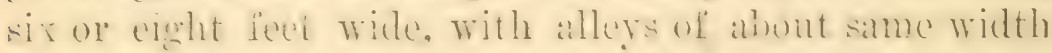
betwen, (atre being taken to hate the eround leveled, so that the Colmonges will sot crenly towether. They am be left in thi: way for thee or fom werks or as long as the mound lomans so that it can be cling in the alleys betwern the beals, the soil from which is thrown in on the beds of Cabonege, so that when finished they have a corewing of six or seren inches of soil. or sulficient to cover up the reots completely. Sometimes they are cor(red up imm diatsly on heing lifed, by plowing a furrow, shoveling it out wile enomeh to recoive the heals, then plowing so ats to corer up, and so on till bouts six or cight feet wish are thus foment. This plan is the quicliest. but it has the disulvantage, if the seasom proves mild, of having the cahbiges covered up hy the soil too soon, and hence more dingere of decaly. After the siond is frozen, stable litur, straw or leares, to the depth of 
three or four inches, should be thrown orer the Cahbago

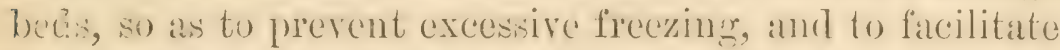
the getting at the Cabbages in hard wealler.

\section{INSECTS ATTACKING TITE CABBAGE.}

The insects thet attack the Cabiogo tribe are rarious, and for some of them we regret to say that we are almost helpless in arresting their ravages. Voung Cabbage flants in fall or in hot-beds in sprins, are often trombled with the $A$ phis, or, as it is popularly known, the "Green fly," or "Green lomse." This is easily destroyed by hating the plants dusted over once or twice with tobareco dust. This same insect, of a blue eolor, is often diststrons to the growing crop in the field, and, on its first appearance, tobalco dust should be applied, at of cource, if the Cabbage is hearderl up, it could not he used ; hencer, it is always best to apply it as a preventive remedy.

Another insect which attacks them in these stages is a species of stuy, or smail caterpillar-a green, glutinous insect, about one-fourth or one-half an inch in length. This is not quite so easily destroyed as the other, but will succumb to a mixture of one part white hellebore to four parts lime dust, sprinkled on thick enough at to slightly whiten the plants.

'This same remedy we have found to be the most efficulcious in preventing the latrages of the "Biack Flea," or "Jumping Jack" that is often so destructive to Cabluare plant: sown or planted in open ground during May and June, but in this case ics application may have to be repeated daily often for two weeks.

Another most troublesome insert is the Cablunge calerpillar, which often attacks the crop when just lergimning to head. This is the larva of a species of mall white butterfly, which deposits its geges on the cropl in May ol June. When fiells of Cabbage are isolatrol, or where neighbors can be found to act in mison, the best plan is 
to sateh the buthollics with an insed-atehing not as soon as thes show themothes. This is the most chodive

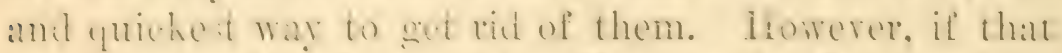

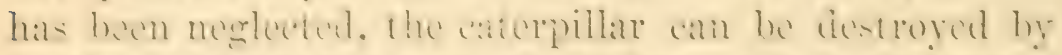

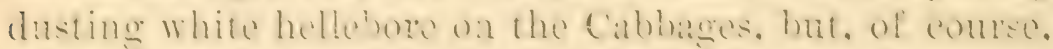

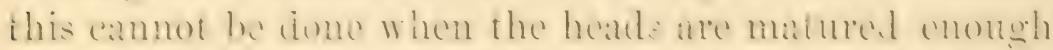
wo be reaty to use. as the hellebore is to some astent porsonous, lhomeh il used whon the phuns are about ladi

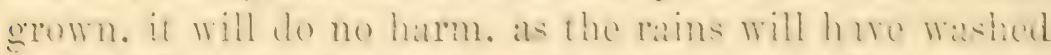
it off sullievonty by the time they head up. The inecets

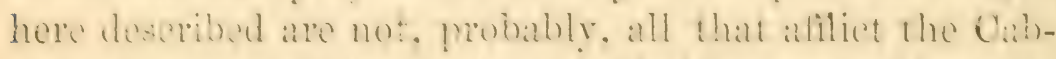

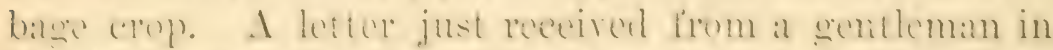

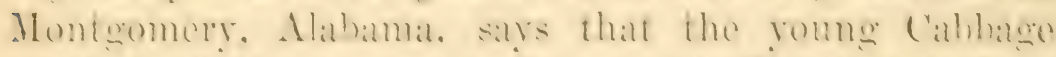

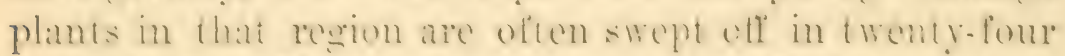

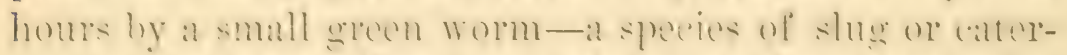
pillar. no loubt. 'The remedy lor all such is white holle-

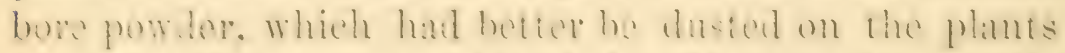

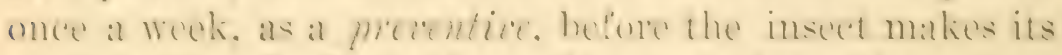

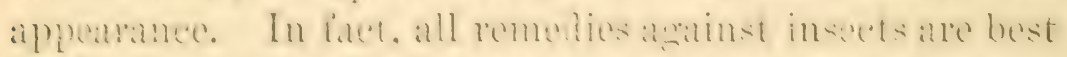

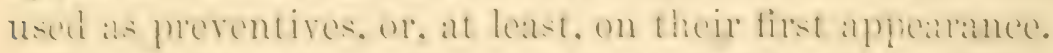

But the insect enemies that attack the roots of the

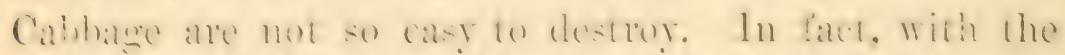

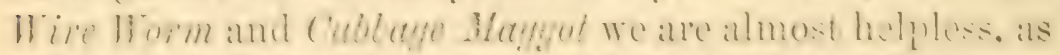

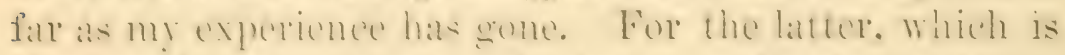
the worst cheme, a remedy has reomily been recommendod to me which ats ret I hate not listot. It is to make a hole with the dibber five or six inches deepe chose

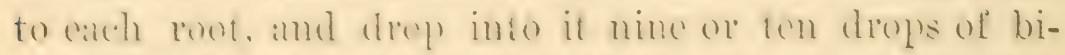
sulphide of carbon, closing up the hole again.

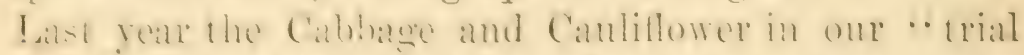

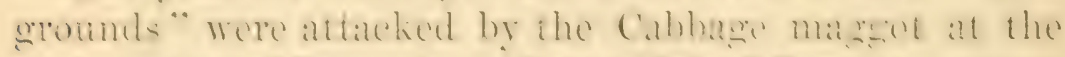

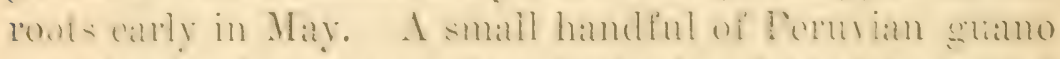

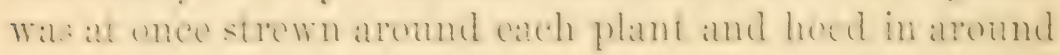
the roots: this at once started an musmal rigor of growth, which sustamed the plants until they matmed exesllont heads. Endersiand. the gramo did not injure 
the insect; it only enablerl the cabbage to outgrow its attack.

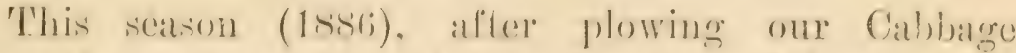
gromed, we gave it a hestry deresing of lime, thick anough to almost completely whiten the groment. 'This wat thoroughly harrowed in, and to further help against bhe attalek of the maggot, after the plants hat been set out three or four wedis, we removed the carth around the stem, and atrain sprinkled a little lime aromol it. This has completely stepleded the attake of the matgents, for, in a portion of a neighhor's field adjoining, the maggots have nearly destroyed the crop.

But one of the best pleventives against the magent is to plant carly, so that the plants get strong (onough to orercome their attark. One market, gatedenel's here rarely hate trouble with their main atrly chols, which are planted last of Alareh or first week in April. In onr own trial grounds, having to wait untit onr amples ("ams? in, we do not get our seeds of carly ('abluage and Cauljflower sown until first, weak in Mareh, which is a month ton late, hence the liability of the too tender plantis to the attack of the magerot. (One of the mot common mistakes of the incxperionerel market sardener is, fo delay the planting of carly Cablatge too late. Many of them in this latitude delay planting until kily, whireh, if the gromel is dry enough to work, had lar het tor be done in April.

For the destruction of the insect whirh calloses the

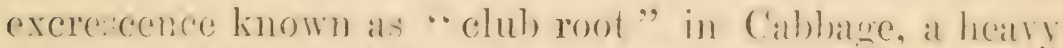
dresing ol lime in fall and spring will releck it to a seleat extent. In liat, on lands arljarent to the shoresof New York Bay, where the soil is mixerl with oyster slodls, "cluts root" is rarely seen, Cabluage having been grown on some fields, suceessively, for fift fears, without at fraces of it heing secen, showing that the inseret wheh catses the "club ront" camont cxist in contact with lime: for it is 


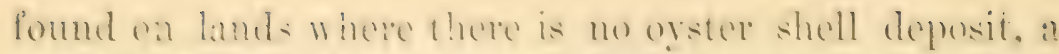

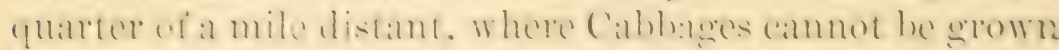

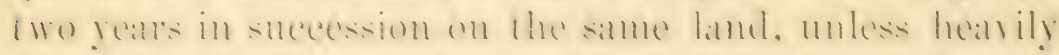
dressed with lime. and eren then, it is always deemed

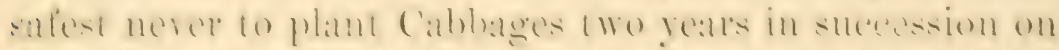
the same gromel : hor. While such crops as onions show

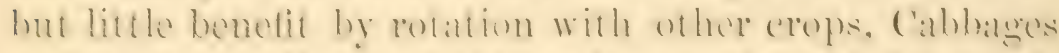

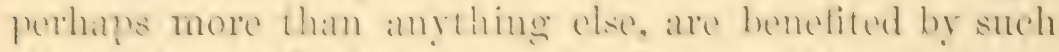
alternation, and when it and he dome, nothing is better

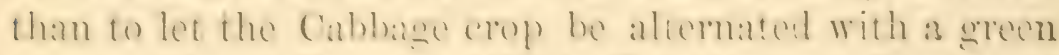

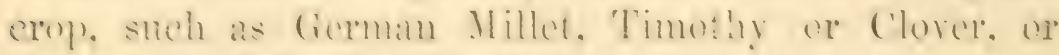
clse a crop of Oats or hye.

This is the meihend pursmed hy meny of the lames

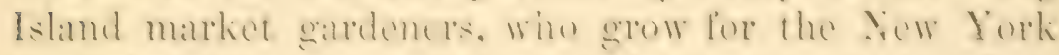

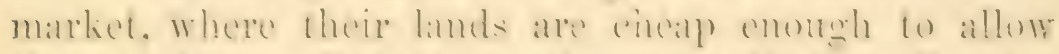

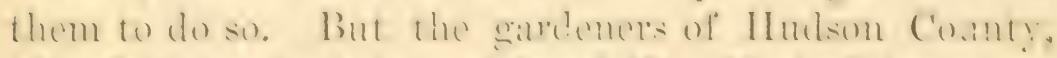

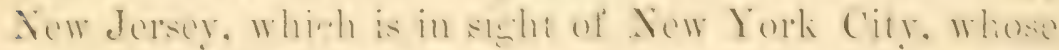
lamels now are limited in allad, and for which an arerawe of $\$ 50$ per acre rent is paid per ammum, cammot well

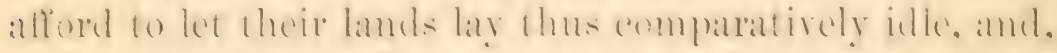

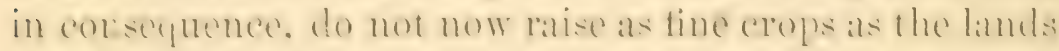
thus "rested" by the grass or grain erops.

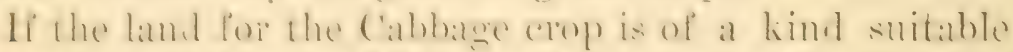

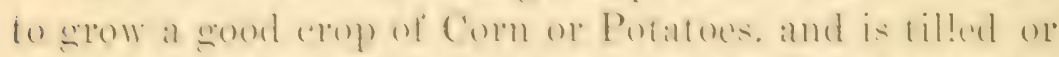
pertilized in the matmere atrised, it is rame inderel that a

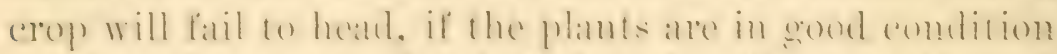

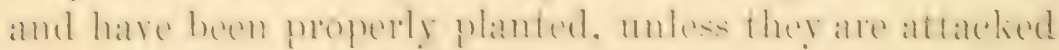
by the milggot or " club root." In our trial gromen, where oser a hombed different solts of cahbuger atre

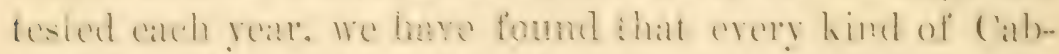
bage tested, early oa late. has produced solid heads, show ing that when the comtitions are right. ull himls of Cabbages witl head up and produce a corp), though, of

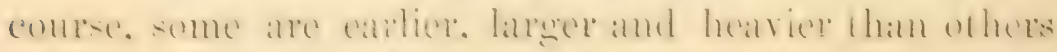
-henee, the value of known selected kinds.

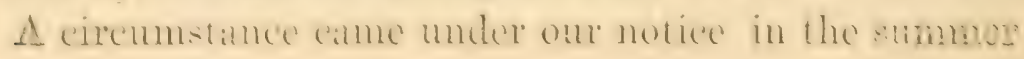




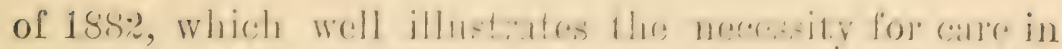

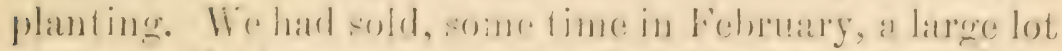

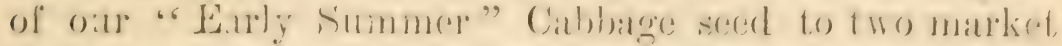

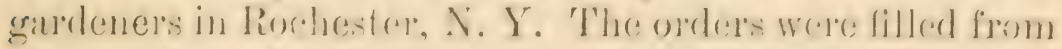

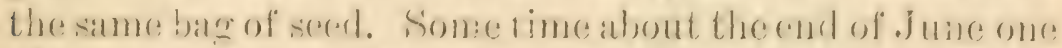

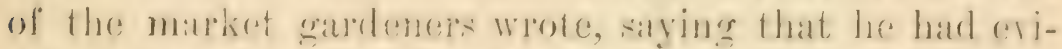

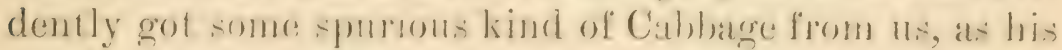
nejghbor was marketing his colop, while in his own ficld of ten alcres, he hat mot a head fit to colt, nof wate there any apporance of their over being :o, he thought. Invertigation showed that no Margent, "alub loot," of other inseret was alfecting the roots; the land was nearly idlen-

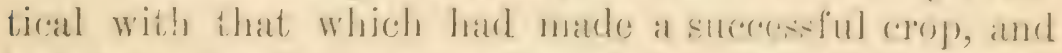
had been erpually well manured amel caltivated. Sis the only probable solution of the mattere wats that ihe plants in the case of failure hat leen lomsely planted and had fatiled to make a prompte start, as in the othere rase where the planting hat bern properly donse so that while

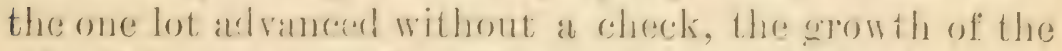

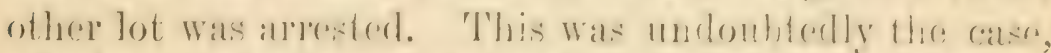

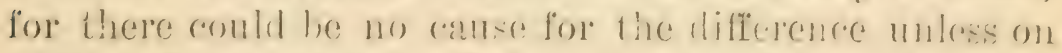
someruch hypothesis. But there was a fortumate seyurel to the casce. It luckily hapjened that a heary rainstorm occorred while the (abhages were yet in this mohrated condition. 'This started, as it were, a second growth,

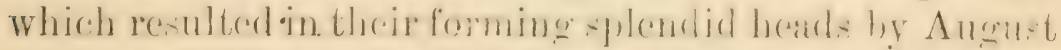
1st, at a time when Cabbages were scarce, which, luckily for the owner, bromght a much higher price flatn

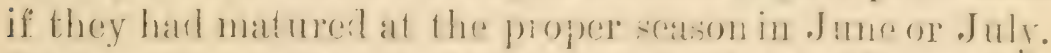

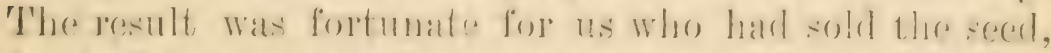

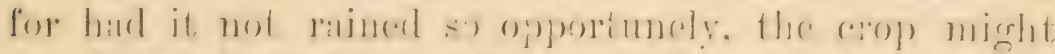

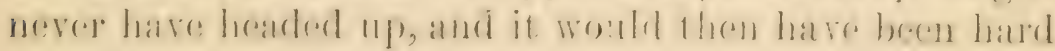
to convince the man that he had not been furnished.

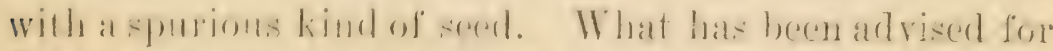
Cabbage crope, eithere carly or late, is esaletly the rolture, necessatry for a cropl of Cauliflower, exrept that Cambi- 
flower, being a plant of more dulicate constitution, it requires to be more carefully hambled f for. where the Caboage planis in the cold framse will safely keep orer winter in this latitule with no envering bit the glass sash, Caulifhower plants require the use of straw mats ore: the silsher as the plant is much more casily hurt by frost. In finet, in our increased experienee, we find that it is better not to lieep the plants throngh the winter; those sown in Eelruary and transplanted into cold frames in March, and planted in the open gromat in April, as recommented on the Chapter heated "Spring Raising of Cabbige. Canliflower and Letuee," doing rather better and costing much lo:s in lahor. The plants, however, must be stmerted early enough, so that they can be set out no: later than middle of April, for if not rooted well hefore warm weather sets in, they will cither" "buttm "- that is, form small stunted flowers-or elece bail entirely to heal up. Canliflower delight: in a cool atmosphere, and nerer does well when the seatom is hot and dry, mle is complete irrigation can be given when the plant is about half grown. If this can be done the (rop is certain. We ourselves gren in this mamner nearly an acre for many years, the crop selling for an areratge of 1,20 per acre ammally, and that wa: hefore we had introdued the now famons variefy known as: "Ifenterson "s Early Snowball." which is ahear of all other kints in its certainty to make a crop. The next in suceseson to this, is the "Early Erfurt," which is again sucecented hy the "Early Paris," but neither of these in any respecet is equal to the "Snowhall." For late crop, the varieties known as "Algiers" and "Erfurt" are the kinds usually grown. The plants are oltained by sowing at the same dates as

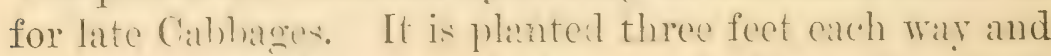
cultivated exactly at lite Gahbares and often sells as high as $\$ 25$ per 1 w in Norcmber and December. The are of 
the opinion, howerer, that the "Snowball," of which twice the number can be grown per acre, will prove a more profitalble crop even for late, than the "Algiers," as it is assureclly more certain to form heads. It is not once in twenty years that a variety of vegetables or fruit makes such an advance in earliness ancl quality a: this "Snowball" Cauliflower, and we have much satisfaction in the knowledge that we were the first to bring it into cultivation about five years ago. It is now grown to almost the entire exclusion of all other early kinds of Cauliflower in this country, and hundreds have succeeded, both North and South, in raising a crop from this variety, who had previously completely failed with all other kinds. In Cauliflower, as in Cabbages, it is folly to attempt the experiment of many kinds. Long experience has taught us that two or three of each for early and second early is all sufficient. Although our seed catalogues enumerate scores of hinds, gardener's who know what they are about, fight shy of all except those whose merit, has been prored beyond any question of a doubt. For this reason we only gire the names of such as we know to be the best.

As yet nearly all Cunliffuner: seed is imported, as we have not yet been suecessful in raising it here so as to give satisfactory results, our climate seeming to be unsuited for the growth of the seed. IBut Cubbage seed is almost exclusirely grown here. Though the imported seed costs less than half the price, we rarely have found it safe enough to risk it for market garden crops ; the American grown Cabbage seeds should be exclusively used. 


\section{VARTETIES OF CABBAGE-FAL:}

Early Jersey Walcelield, - The first nocorlety that this rariety attained was when we lirst orote "Gardening for Protit." 'lhat was nearly twenty years ago, and sineo

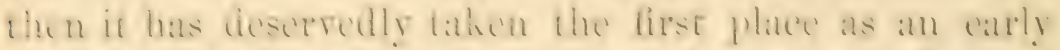
marthet variety. To most growers the merits and chatracteristies of the ruriety are so well homwn as to hamdly med reparting here, but lor the bemetit of those who maty not be familiar with is, ne would sty that it is mixers-

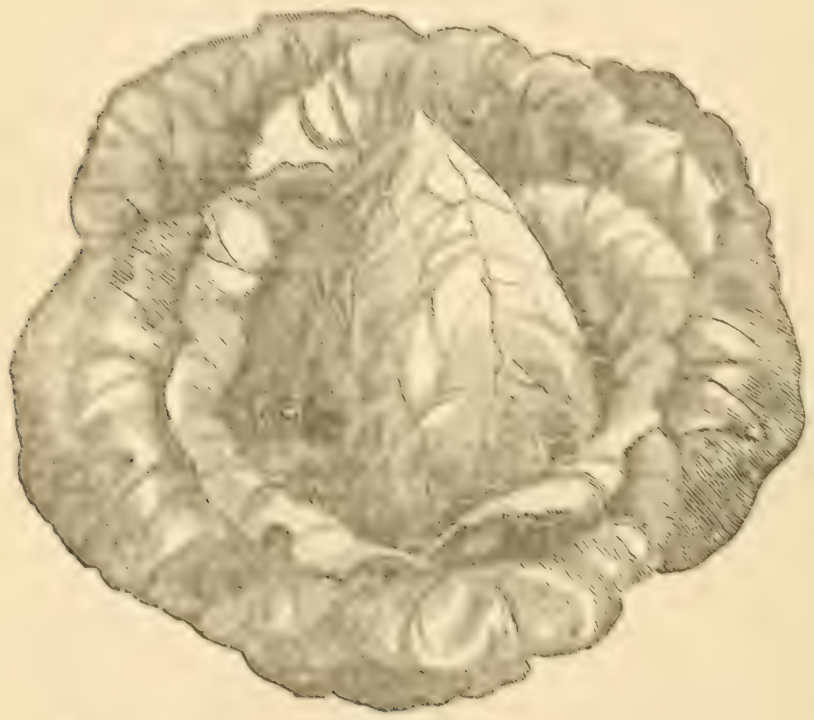

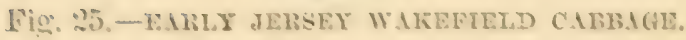

ally oonsidered the best early Cabbugo in cultuation. Among if merits mar be mentioned its large size of hemel, small ontsicie folinger. and its miformity in produeing a erop. The heots alre pyramial in shape, having a blunted or romded penk.

A fow years alter the introduction of the Malkefeld Cabbage, we foumel that it broke into orer a dozen subvariotes of rarsing sine of leat and shape of heat. and. wowse than all, of rarying carliness. No matter how 


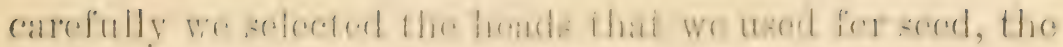
same dillienlty ocenred. A low miles inland, some-

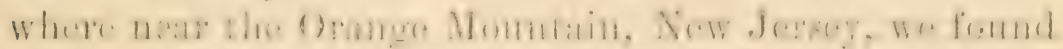

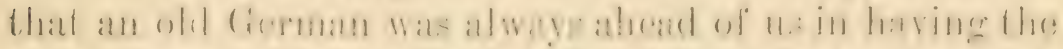

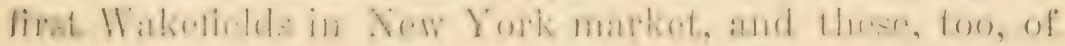
a unilormity in shape that none of us nearer the eity

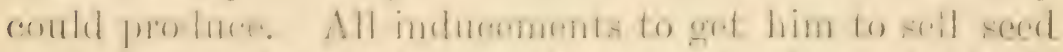

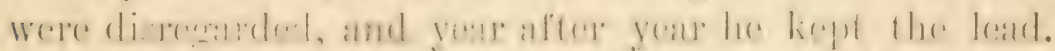

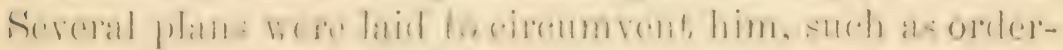

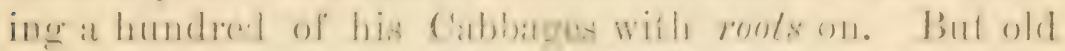

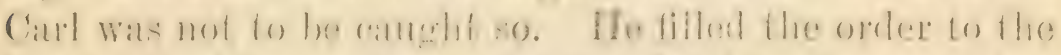
Iofter, making the hatyer pay rombly for the root:, but:

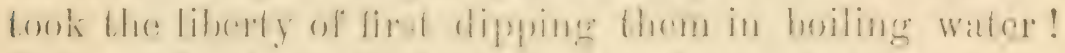

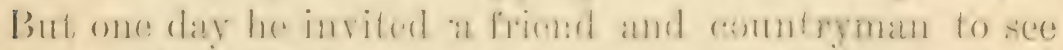

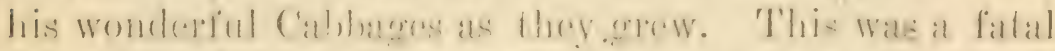

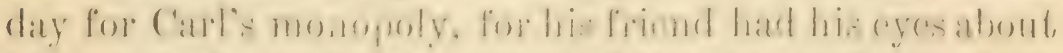

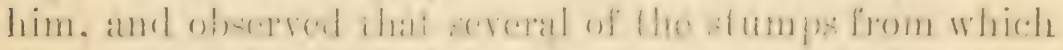

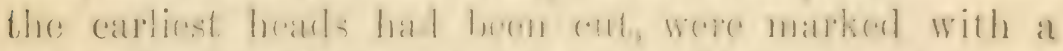

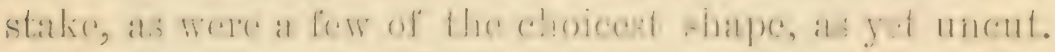

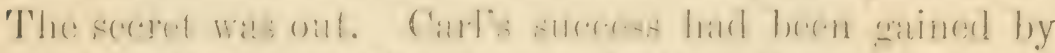

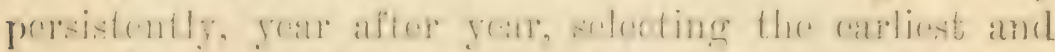

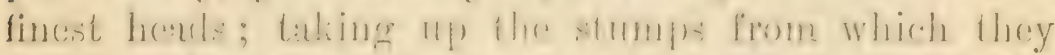

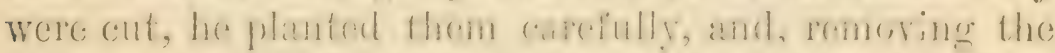

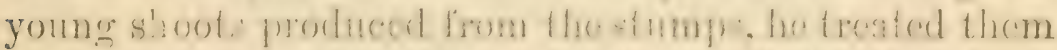

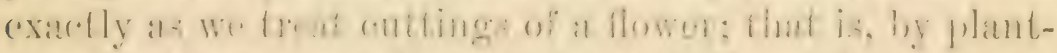
ing the alin in the woil, watering it lreety, and shatine it nutil it rooted. Alter these cuttings or shoots of the

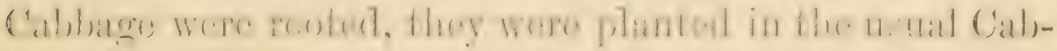
bage-frame, covered witl glass in winter, set out in spring, like a plant. from the sood, and noxh buly ripened

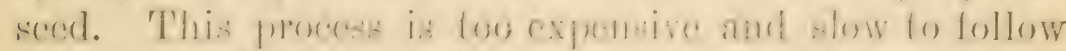

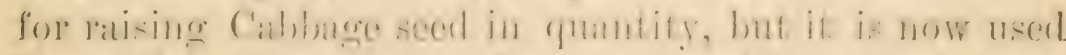
by careful arowers to produce puro and impored stock from which to raise secd. 
Henderson's Lardy Summer.-This peerless variety originated with . Jr. Jhraham l'an sicklen, of Jamaical, Long Island, N. Y.. (to whom I paid stivo for twenty pounds of the seed). but wats named and first introduced by me in 1sit. The barly summer heads about ten dalys later than the Jerwey Wakefiedd, but being of orer double the size, it may he classed ats the best large early Gabbage. In weight it is copual to most of the late valri-

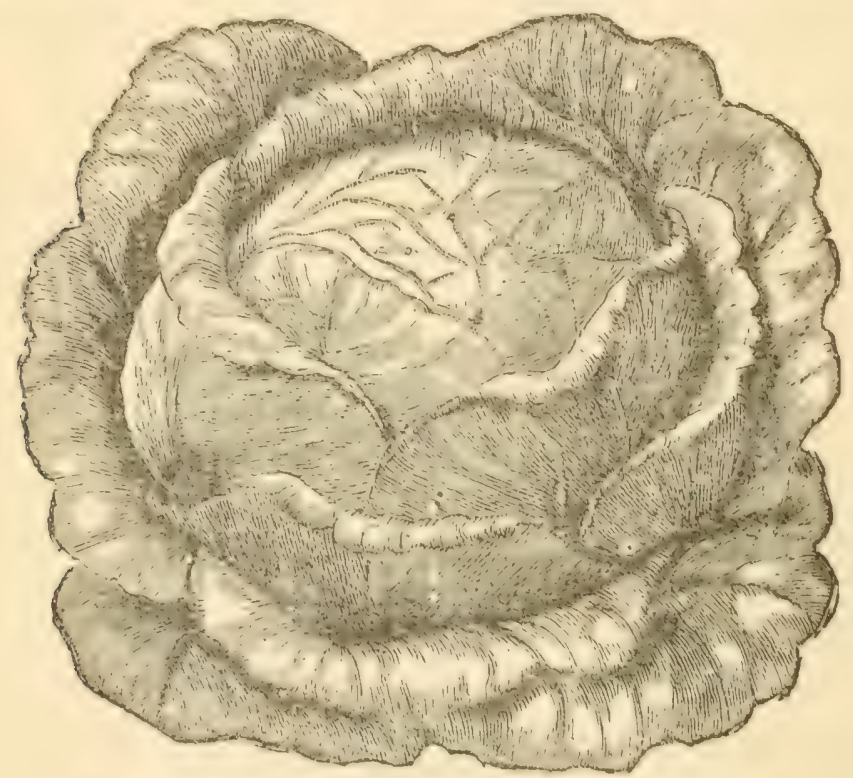

Fig. 26.- HeNDERSON'S EARLT SUMMER CABBAGE.

eties. and its short onter leares cmable it to be p'anted as

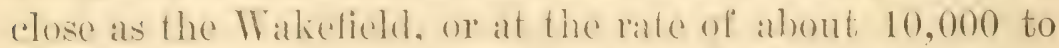
12,000 to the acere, while the Early Filat Duteh, Winningstadt, ete. producing no larger heads, can only be grown at the rate of s.060 to the alcre. It is equally raluable fo use as al late sort. als, when sown and planted at the proper time for late Cabbage to be used in winter, we consider it has no superior.

Prenier.-- I variety of quite recent introduction, execelingly sarly, and much valued ats a market sort. 
The heads are somewhat smaller than the Wakefied, but, as it forms very small outer leaves, it and be planterl onethird closer-fiften or eighteen inches apart each way, or from 14,000 to 16,000 to the acre.

Larly Winningstadt. - This is really a second carly rariety, coming in about three weeks later than any of the above. It is an excellent sort, however, where first earliness is not the olject, as it heads uniformly and is of large size, often weighing twenty pounds. It is a distinct variety; head pyramidal, the conter leares spiral and spreading. It requires to he planted wirler than the eariy sorts. For this reason, together with its comparative lateness, it is not a farorite in gardens where two crops are grown in one season.

Early llat butch.-A very dwarl variety, having large round heads, almost flat on topr. It is a very excellent variaty for a sucecssion crop, heing two or three weeks behind the earliest sort:, but is now almost supplanted by the Early Summer.

\section{CABBAGE-LATE.}

Selected late Flat butch.-(hee figure $2 \%$.) An excellent standard variety, making large flat heads, rery solid, and an excellent lieeper for late winter use. Although it grows larger than the "Early summer," yet as it has to be planted nne-third wider apart, it gives no more weight per acre. It is rery largely grown as an carly fall sort. It is rery tender and of excellent flaror, and is largely used for Sauer Kraut.

Fottler's Improved Brunswick, -1 second carly and late variety, used originally by the Boston gardeners, but which is now coltivated quite genemenly all orer the country. It produces large heads of excellent quality. 


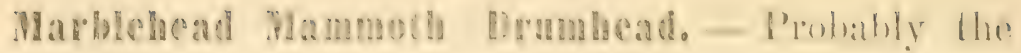
langest valrioty of Cabbage in cultivation, specimens olten growing an weigh sisfy pounds. In woost soil and

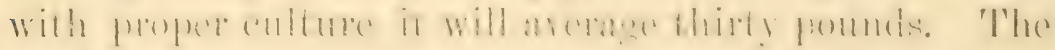
heads are round and somewhat irregular in shape. It

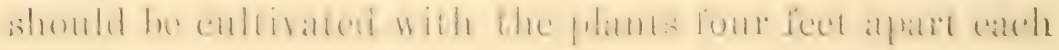
way.

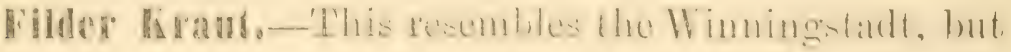

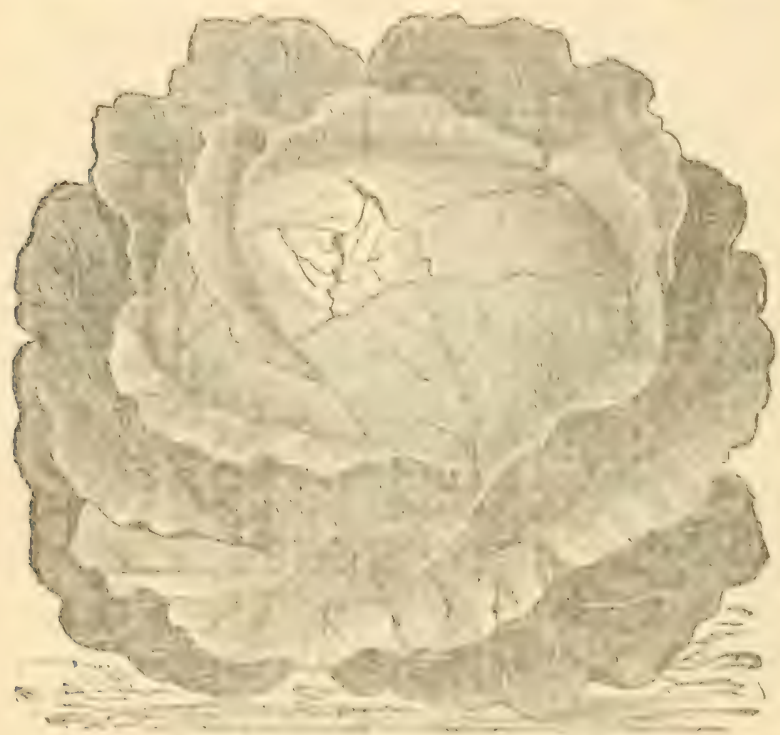

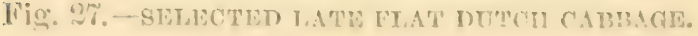

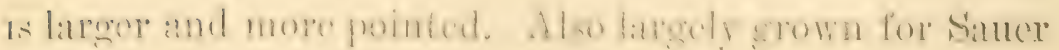
Krant.

Anerican Urambead Savoy, -..'The is the latrest of

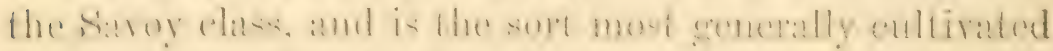
for market. The hend is large, spherienl, very solid,

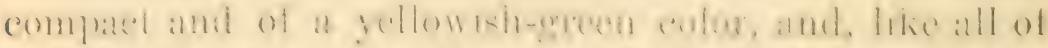
the sirvoy vametres is of oxoollent theror. far mupresing

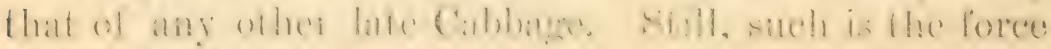

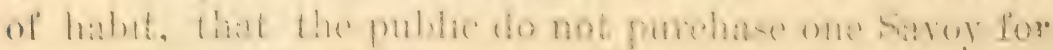

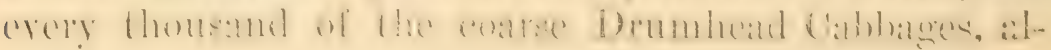


thongh the difierence in quality between the two is as great as between the lox grape of the woods and the cultivated Delaware.

Grown in fall and allowed to be tonched by frost, it is one of the most delicious of all vegetables. figure 28.)

lied Dutel.-This is used almost exclusively for pickling. It is one of the hardiest of all Cabbages, and when preserved as directed for the others,

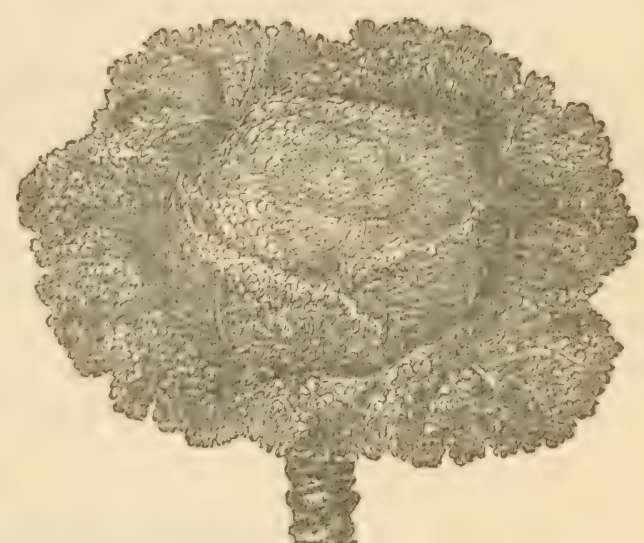

Fig. 2S. - AMERICAN DrTMIIEAD SAVOY CABBAGE. will keep later in the seasen than any of them. It is sow to malure, howerer, and repuires a richer soil for its perfoct revelopmert.

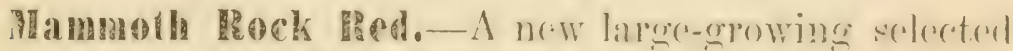
strain of the old Red (Ghbage thre hoads of which will average twelve pounds each.

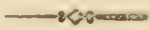

\section{CAULIFLOWER.}

As the cultivation of Cauliflower is almost identical with that of Cabbage, and as thece are two of the most important of all crops to the murket gardener, very full instructions are griven under "How to grow Cabbage and Cauliflower," on page 51.

denderson's Larly Snowball.-(See figure 2?). This . variety, introduced six years argo by mo, is now the leading early variety. We have found it to be not only the 
earliest of all Caulillowers, but it is more certain to make a head than any other variety we hare ever grown. Somn March 1st in our trial grounds in Jersey C'ity (which. horrever, is a month too late), at the same time and under the same conditions with other kinds, heads of the Early snowball measuring nine inches in diameter have been ready to matiet by June 10th, one werk before any other surt. From its dwarf growth and short outer leares, this rariety has been fund to be peenliarly well arlapted for forcing moler glass. and for this purpose no other valiety is now so latrely grome. It is also beginning to be used for the fall crop of Cauliflower, for which

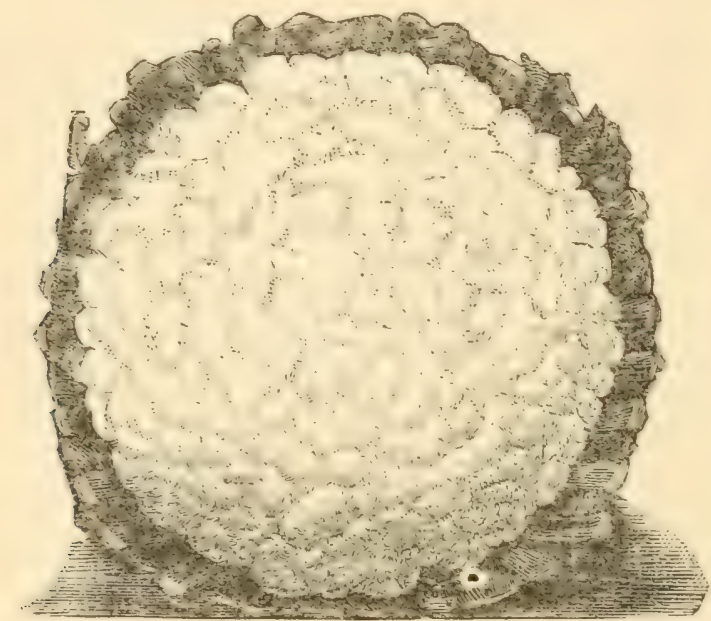

Fig. 29.-MENDERSON'S EAREY SNOWBAZT CAULTFLOWER.

it is equally well adanted as for the earty crop. From $1 \% .000$ to 13.000 alre planted on an acre. This rariety is a rery shy seerl-bearel, and the consequent high price of the seed has induced unprincipled dealess in many sectrons of the country to substitute sumions sorts. In - omr trial gromuds we fomnd that in a test of ten of these sumples piimportung to be the true "Snowball," not one was correct, and nearly all were worthless. 
Extra Early Dwarf Lrfurt.--'This fine sort is a dwarf, compact, growing kind, producing uniformly large heads. The leaves grow larger and not so close as the Snowball, besides it is not so early.

Lxtra Early Paris.-This well-known rariety is equally meritorious in all respects with the Erfurt, except that it requires more space to grow in, as it forms larger heads.

Half Larly Paris or Nomareil. - A useful raricty for succession crop. The dificulty with Canliflowers for market is, that the whole ('rop comes in and must he sold in a space of two or three weeks, unless we have a succession of varieties.

Le Normand's Short Stemmed.-A large late raiety, producing well-formed heads of excellent quality.

Large Late Algiers.-An excellent late variety, now coming into rexy general faror on Long Island, New York, and other Cauliflower-growing districts. Enormons quantities of this variety are amnually grown for market and pickling, with rarying results, sometimes selling as high as $\$ 25$ per 100 , and again as low as $\$ 3$. It is usually planted quite wide-three by three feet earh way-and worked by horse cultivation. It is a good plan to break and turn down the leares of Cauliflower over the head as it is dereloped. This not only keeps it whiter, but prevents its spreading.

\section{CARDOON.-(Cynara Cardunculus.)}

A regetable that is but little grown, and grown oftener as a novelty than for use. It belongs to the same family as the Artichoke, which it much resembles. The leaf stems, after blanching, are used in soups or in salads. It is cultirated by sowing the sects in early spring, 
thinly, in rows three feet apurt, and thimning out to eighteen inches between the plants. The plant attains its growth in early fill. When it is blanched by tying the leaves togother as a to calse an erect srowth, after which it is earthed up), and preserved exactly as we do Celery.

\section{CARROT.-(Daucus Carota).}

This may be clased more as a crop of the farm than of the garden, as a fir larerer are: is grown for the food of horses and eattle than for culinary purposes. Yet it is a salable regetable in our mirkets, and by no meams an unprofitable one to grow on linds not too raluable. It is not necessary that the land for this cropl should be highly emriched. I have grown on sod land (which had been turned orer in fall), ":00 barrels per acre, without a particle of manure, and three yours alter, and on the same lanrl, which had hen hrought up ti our market ganden standart of fertility, a very inferion cropl : the land beines too rioh, induced a reseth of toms rather than roots. In our market gardens. we sow in rows fourteen inches alyart, thinning out to three or four inches between the plants: but on farm lan ls, where surace is not so valuable, they should be planted eighteen or twenty-four inches between the rows, and worked with the cultivator. For eary crops, we sow at the beginni:g of our first operations in spring, in the same manner as we sow Beets, as soon as the gromul is thoroughly dry: but for later crops, they may be somn any time in this latitude until the middle of June. This is one of the regetables that requires a close watching to see that it does not get enveloped with weels, as, in its eariy stage, it is of comparatirely feeble growth, and nniess it is kept clean from the start, it is apt to be irrevocably injured. 
The usually prescribed quantity of seed per acre is fire pounds, bat I have always considered it safer to sow nearly double that quantity. In dry weather it germinates feebly, and not infreruently, when seed comes uj) thinly, it is scorched of hy the hot sun, and the saving of a few pounds of seed may entail the loss of half the crop. Vie prefir to sow all such crops by hand, though for field culture on a lurge scale, the seed drill sliculd be used. In all cases tread in the seed-see "Use of the Feet in Sowing and Planting," Chapter 12-to which, even at the risk of repetition, I again beg to call attention.

The Carrot, lile a'l otl!er root crops, delights in a sandy loam, deeply tilled. Considerable quantities of the carly varieties are sold in our marlicts in bunches, in a half-growin stat, at prices equal to early Beets sold in the sune manner. Sold in this state, they are highly profitable at the prices receired, but only limited quantities can be disposed of. In the dry state, during fall and winter, they range from $\$ 1.50$ to $\$ 2$ jer lorrel, according to quality, and at these prices will vield double the profit of Potatoes as a farm crop.

The rarictes in general cultivatian are limited. The favorite variety for all purposes is the

Early Fremen Foreing, - The carliest varicty, and one largely grown for forcing purposes. It makes a small, almost globe-shaund root, of an orange-red color.

Warly Scalet Worn.-An oll and farorite sort for an carly crop, but not large enongin to be suitable for general cnlture. It is one of the varicties that is bunched and sold in our markets in a green state. It matures eight to ten days earlier than the Long Orange, and is sometimes used for forcing.

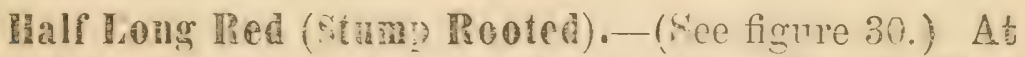
this time this rariety is more largely grom for the New 
York market than any other. and is the fimest of the carly sorts. It is intermediate in size and time of maturity betwern the Early searlet Horn and the Long Orange.

\section{Larly Ialf Long Scarlet} (Pointed Rooted).-The only difference between this and the preceding rariety is that it has a pointed instead of a stump or blunt root.

\section{Early Ilalf long Scarlet} Carentan.--A distinct variety, almost cylindrical, with few and very small roots. The skin is smooth, flesh red, and without any core or heart. It is excellent for forcing, and for fine quality and perfect shape can hardly be surpassed.

\section{Long 0range Im-} proved.-(See figure 31.) This is equally adapted for market and family

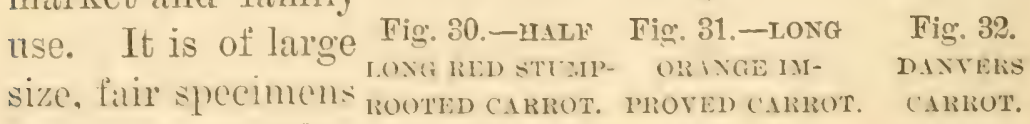
averaging twelve mehes in length. with a diameter of thre inches at the top: color, orange red, rarying in depth of shate in diferent soils.

Danvers.--(See tione 3\%) The color of this valuable sort, which is of comparatively recent introduction, 
is a rich shade of orange. In shape it is midwaly between the Early Scarlet IIorn and the Long Orange. Under the best cultivation, it is said to have yielded from twenty-five to thirty tons of roots per acre.

Large White Borgian.-Tlie most productive of all rarieties. The root is white; that part growing above ground, and exposed to the air, green. It is exclusirely grown for stock, bearing nearly twice as nuch in weight per acre as the Long Orange. IIorses do not eat it quite so readily, however, and it is said to be less mutritious than the red or orange sorts.

Yellow Belgian.-Similar to above; color, yellow.

\section{CHERVIL. -TURNIP-ROoTED.-(Choerophin'lum bullosum.)}

A regetable of recent introduction, closely allied to the Parsnip, which it resembles in shape. It is of a grayish color; the flesh is white and mealy, tasting something like the Siweet Potato. It is equally as hardy as the Parsuip, and in France, where it has beon cultivated to a considorable extent, is said to heve yielded six tons per acre. It is one of the many plants that were experimented with in Europe as a substitute for the Potato, when it was fearer that that tuber would bo lost to us by discase. Its culture is in all respects similar to the Parsnip or Carrot; it is entirely hardy in any latitude, and is rather improved by the action of the frost. It must be sown as early in spring as the soil is fit to work, it being slow to germinate if the weather becomes hot and dry. 


\section{CEABRY.-(Apium graveolens.)}

I know of no regetable upon which so much unnecessary labor is expended with such unsatisfuctory results as Celery. Many private cultivators still think it necessary to rlig out trenches, from sir to twelve inches deep, involving great labor and expense, and giving a crop rery inferior to that planter on the level surface, in the manner practiced on hundreds of acres by the market gardener's in the vicinity of New York.

Our manner of treating the Celery crop is now very simple. Instead of sowing the seed in a hot-berl or cold frame, which is the European plan, but not practicahle here (unless when on such soils as the muck deposits at Kalamazoo, Michig:un), owing to the tencency of plants thus sown to run to seerl, the seed is sown in the open ground as soon as that is fit to work in spring--here about first weck in April-on a level picee of rich mellow soil, that has been specially prepared hy thorough pulverizing and mixing with short stable manure.

I have had large experience in growing Celery plants, as our demaid for the plants often reaches $2,000,000$ of plants iul a season, and we nerel fail in getting a crop by rigilly adhering to the following simple method.

The bed being fined down by raling. so that it is clear of stones and ail inzqualitis, lines are drawn out by the "marker" eight or nine inches apart, in beds of eight rows in cacir, rubing ont every ninth mark for an alley, min which to walli when weeding, eto. The seed should be sown lather thinly, one ounce being sufficient for twenty feet in length of such a hed, or about 150 feet of roiv.

The seed is sown by hand in the rows : after the sower follows a mam who erenly presse; down the seed in the drull with the fect. That done, the back of a rake is drawn lightly tengthurese of the bet, which slightly cov- 
ers the seed to the arerage depth of something less than half an inch. After tils, the her is still further firmed and levelled by being rolled, or in small areas evenly patted down with the back of a spade.

As soon as the sceds of Celary begin to germinate, so that the rows can be traced, hoe lightly between the rows, and begin to pull out the weeds as soon as they can be seen. One day's work, at the proper time, will be better than a dozen after the secd-bed gets enveloped with weeds, besides inșuring much finer plants.

As the plants advance in growth, the tops are shorn off, generally twice before the time of setting out, so as to induce a stocky growth; plants thus treated suffer less on being transplanted. This plan of shearing off the tops we practice with Cabbage, Canliflower and many other kinds of plants to induce stocky growth.

The time of planting out in the Northern States may run from June 15th to the end of July, and in the Southern States from August 15 th to the end of September. In this section, we prefer to plant in July, as there is but little gained by attempting it early. In fact, I have often seen plants raised in hot-berts and planted out in June, fitr surpassed both in size and quality by those raised in the open ground and planted a month later. The great difficnlty experienced in the Southern States is, in raising the plants; for, if sown in March or April, as we do here, the high temperature and dry atmosphere either kill the plants outright, or so shrivel them up that they never start to make a free growth.

By sowing about the midrile of dugut in extreme Sontherie States, shading with the protecting cloth sashes, alleady referred to, in hot days from 9 A. M. to 4 P. M., and planting out the end of September, a fair crop of C'elery may be olstained in the late fall and early winter months. The plants are sometimes specially grown at the North for jianting at the south, but 
in all such easis ther mun be plants aroun from som ins

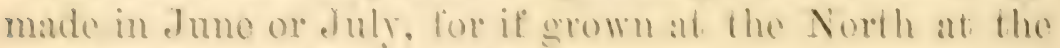

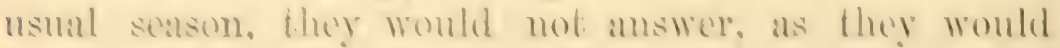

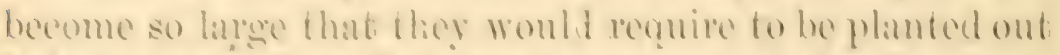
betore the end of duly, and in most of the southern States, if plantod then. flicy comlel not stand the longcontimod high temperatme ame dry atmosploro of August amel september.

It is dombeful if this sme tial growing of planes is liholy to be done, and ome liveneds at the somb must submit to

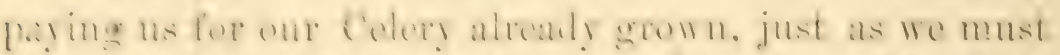

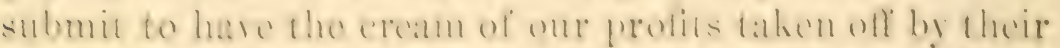

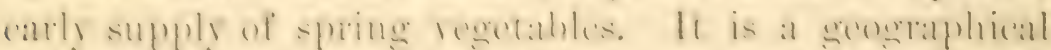
comedition of enlture that hoth sections must aceopt. In almost all the cally veretables, the tirst supplies eome from southern amdens, thus anticipating our crops by sone weoks: while colery is me of the rery low things

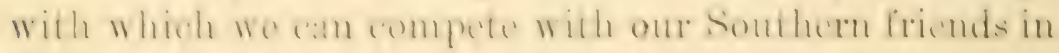
their own malliots.

Colery is a plant royulume a cool, moist atmosphero, and it is monsense to attempt to grow it carly in our hot

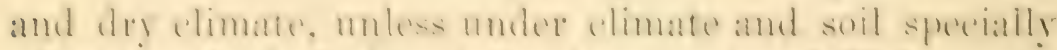

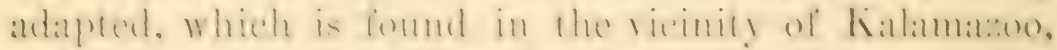
Michigan. Horse Heads, New lork, amel some other

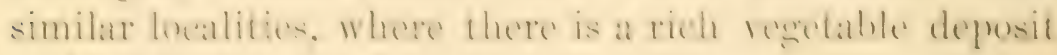
on level bottom limets.

But cren when gerown. it is not a rogetable that is ever very palatable mutil cool weather. 'This om market experience well pores, for, although we always have a

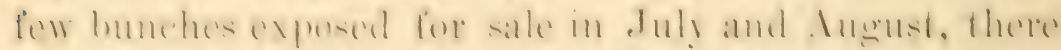
is not ome row solit at that time for a thensated that alle sold in Oetoler and Norember.

Celery is always grown by us as a "sceond crop;"

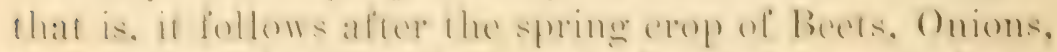

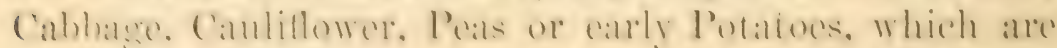

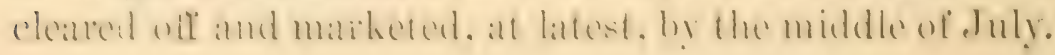




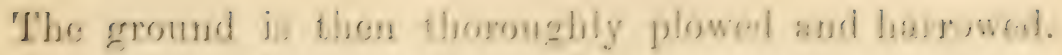
No additional manure is used, as enrugrie remains in the ground from the hrary coat it lias received in the spring, to carry throngh the crop of Celery.

After the ground has been nicely jrepared, lines are

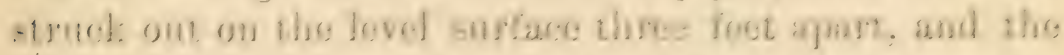
plants set six inches apart in the rows. If the weather is a fry at the time of planting. erreat care slowald be tabon that the roote are properly "firmed." Com castom is 6 turi back on the row, and prees by the ades of each plant

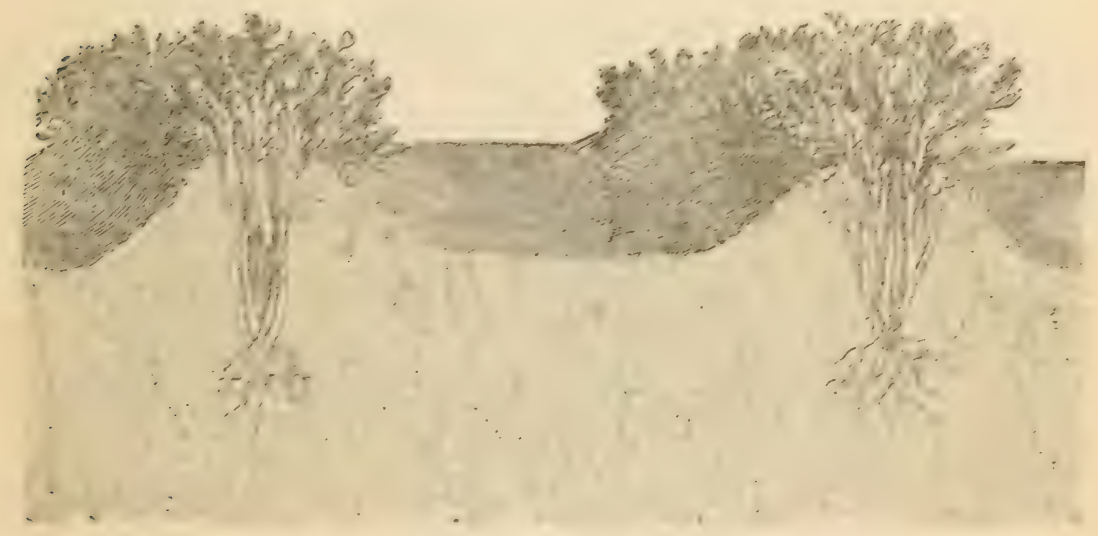

Fig. 3.3.CELERY AFTER "HANDIJNG."

gently with the foot. 'This compaces the esil and prertially excluber the air from thes root unil new mothets are formed, which will ueually be in forty-cight lomps, after wisch all danger is over. This prantice of preweinge the soil c.fosely aronmd the roote is esential in plantimg of all kinde, and millione of plant 4 are annually de troyed

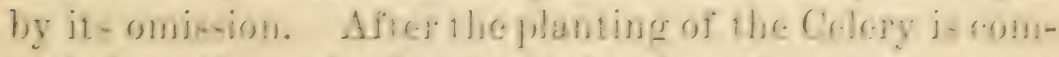
pleted, mothing further it to be dome for tix or aven werk s, exeepht running through between the rows with the cultirator or hoce and frocing the plante of wode until they gret stronge ensongh foregowd them down. This will bring ur to alout the middle of Auguet, hy which 
time we nstally hare. expecially at night, that moist and cool atmosphere escuntial to the gew the celery.

Then we begin the "earthing no" necessary for blanching or whitening that which is wanted for use dur-

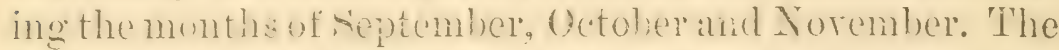
first operation is that of " handling." as we term it ; that is: after the soil has been dramu up arainst the plant with the hoe. it is further drawn close arombl cach plant hy the hand, firm (enough to liene the leares in an wexight

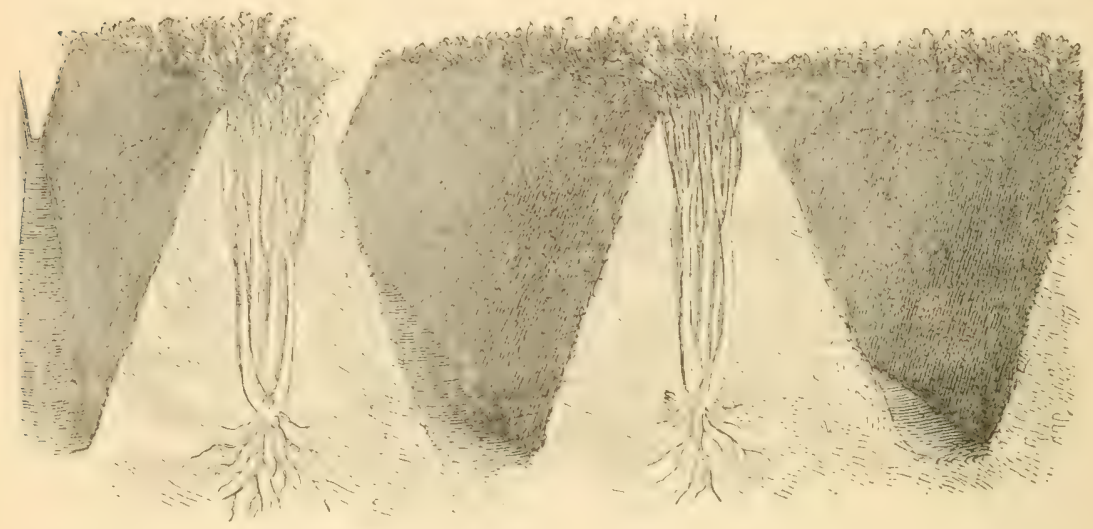

Fig. 3̊. -CELERY EARTHED UP.

positim. and prevent them from sureading. Which will leare them as shown in figure 33.

'ithis being done. more soil is drawn against the row, cither by the plow or hoe. ar ciremutances repuire, so as to keep the plant in this upright position. The blanching process must, howerel, be finished by the spade. which is done by digging ihe soil fiom between the rows and banking it up clear to the top on cach side of the row of Celery, as in figure 34 .

Three feet is ample distance between the dwarf varieties, but when "Seymonr"s Superi)," "Giant White solid," or other large sorts are used, thoigh they are now rarely grown, the width between the rows must be 
at least fonr and a half or iive fect, which chtails match more labor and loss of ground. For the past fifteen yours no Celery but the dwarf rarieties is grown in on vicinity, which sares in conserpence at least onc-haif in labor and one-third in gromml, while the arorage

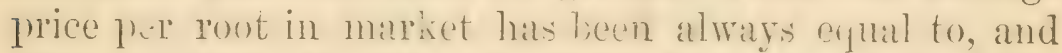
oceasionaly ingher, than for the tall growing sorts.

Neary all marlict wardeners inare at last got their eyes opened to the value of the drarf sorts, and I think that a few years more will suliee to throw the larege and coarse-flarored sorts, such at " irevmour"; superb" and " (iiant Thite Solid," out of our markets.

The preparation of the soil and planting of Celery for winter use is the same in all respects, except that what is intended for winter need never be "hanked up" "with the spade. It merely reyures to be put through the handling process to ling it into a complact and upright position preparatory to being stowed away in winter quarters. This should not be done before the midhle of september, or just long enough bufore the celery is dug up to keep it in the upright position.

We have, howerei, another method which we have found to answer very well for the late (por), and it is one by which more roots can he grown on the same space and with less labor than by any other. It is simply to plant thic Celery one foot aprat, cach uay, nothing farther being required after planting, except twice or thrice hoeing to clear the erop of weeds until it grows enough to cover the ground. No handling or carthing up is reguired by this method, for, as the plants strugele for light. they naturally assume an upright position, the leares all assuming the perpendicular instead of the horizontal, which is the concition esential hefore it is put into winter quistr.s. Th. Thethod is not quite so general with ns a: planting in rows, and it is, perhaps. hetter adapted for private sardens than for mairlict. Is the plant is 
more exchuled from the arre the reot hardly attains as much thiciness as by the other plan.

lie are oftern asked for the eatho of and remedy for

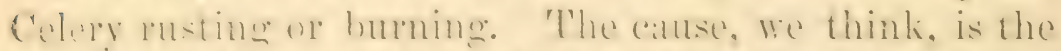

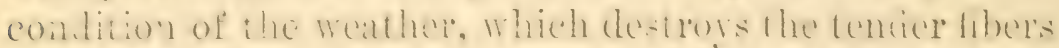
or what are calle the ". working roots" of the phamt. for we time it ustally worse in seatsons of extreme drouth or moisture, particularly in warm weather.

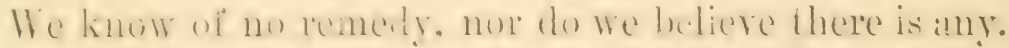

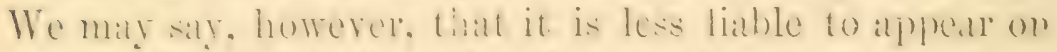

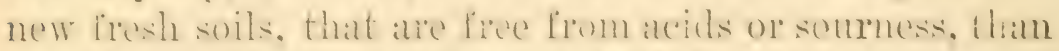
on ohl solls that hare been sureded with mamule and have had no rest.

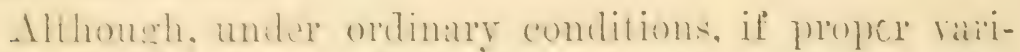

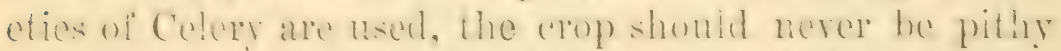
or hollow, yet we have foumd that now amb tiere eren the

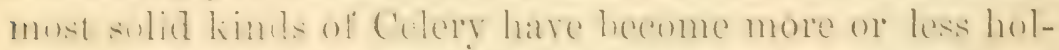
low when planted in soll loose soils, such ats rewhimed

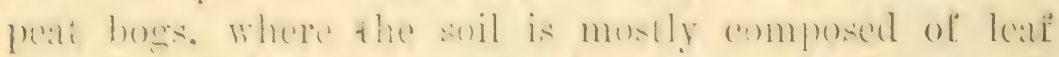

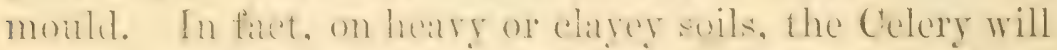
be specifically hearier than on lighter soils.

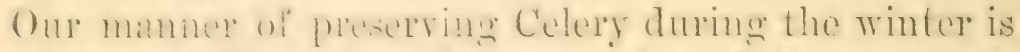
now very simple. but as the knowledge of the process is

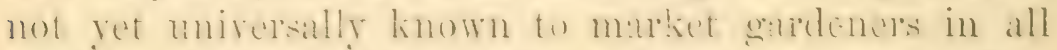
sertions of the entutry, I will molatrole to put it plain

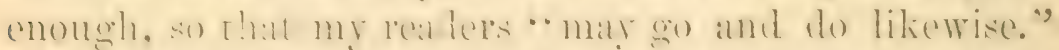
In this locality we begin to dig wy that which we intend

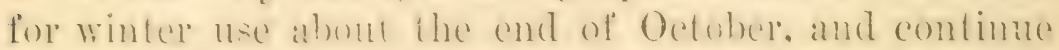
the work (always on dry days) until the enth or sith of Norember, wheh is as late as we dure risk it out for bear of frost. Let it be understood that celery will stamed

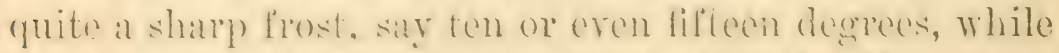
twenty or twenty-five degrees will destroy it. Ifener, ex-

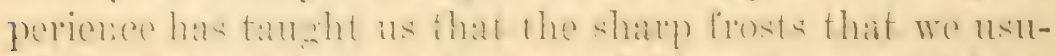
ally hate during the early part of Nosember rarely hurt it funless in late catse where we hate hat an unusual 
warm spenl succected hy shap frost), thomeh often cansing it to droog flat on the rround. mutil thawed out by the sun. It must, however, nevel: be touched when in the frozen state, or it i. almort certain to deary. "he

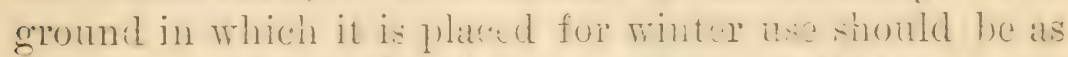
dry as possible, on if not diry, so arramered that no watter will reman in the tremele. 'l'he tresteh should be the as nallow as posible, not more than tern or twelve inches wide, and of the depthe caretly of the herght of the Celery; that is, if the plant of the Celery be two fect in length, the depth of the drain or mench should be two

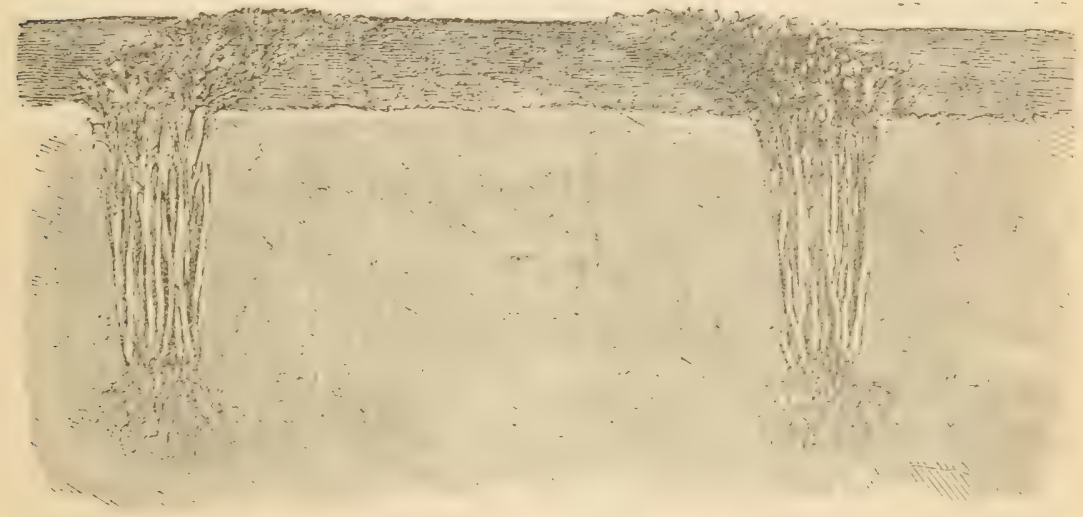

Wir 35.-CELERY STORED FOR WINTER.

fect also. The Colury is now placed in the trench as nearly perpendicular as poseible, si) as to fill it up entirely, its green tops being on a level with the top of the trench. Figure 35 represents a section achos trenches fillet with Celery in the manner just deseribed. No carth whaterer is put to the roots other than what maly adhere to them after being alug up. It being closely parkol torether, there is moisture enough aliars at the hotom of the trench to lieen this plant. at the cool season of the rear. from wilting, and also to induce it to form new white roots, which must he formed lodone the Celery will blanch. That which is put in trenches about the esth 
of Octuher is usually reatly to he talien up for use about the 1 st of 1 lecember : that a comble of weelis later, ly lst on January a and the list (which we try alwars to

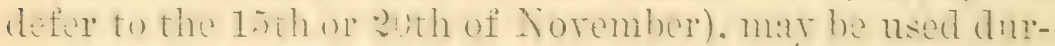
ing the winter and until the 1 st of April. For the first lot no covering is repaimed, but hat for nse duriag the winter monthe must he ematually corerel un wntil the

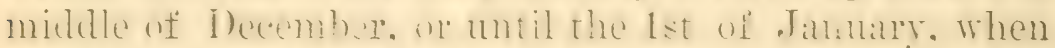
it will require at leats a foot of covering of some light. dry material-hay. straw, or leaves-ihe latter perhaps

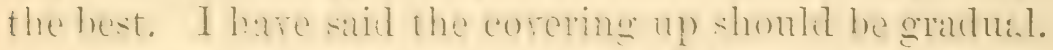
This is rery important; for if the full weight of coreling is put on at once it presents the passing off of the

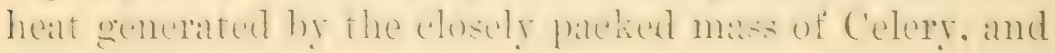
in consequence it to some extent "heats," and decay takes place. Corered up in this mammer, it can be got ont with wase during the coldest weather in winter. and with perfect saftety. These dates of oplations. like all

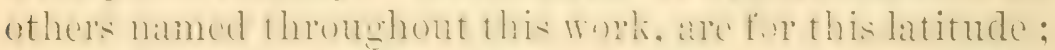
the cultivatol must use his judgment compully in this matter, to suit the section in which he is located.

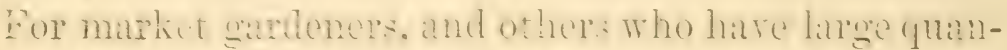
tities. this is the lust mothod of storing : lont lor smaller

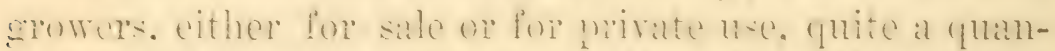
tity ma! the preserved in any conlar where there is no

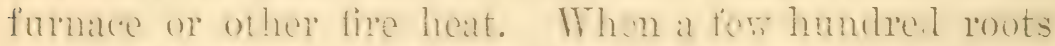

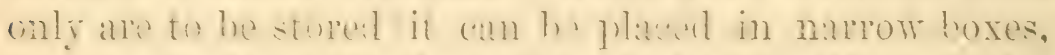
sas nine inches whle. fom on six loes in length, and of a Gepth a litile lese than the height ot the celery. I few Biaches of sand or soil i: plated on the bottom of the lux. lut nome must le put lotweon the stallis of the

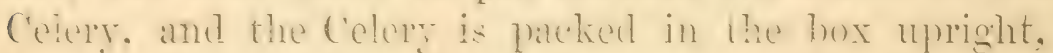
the roots being placed on the sind at the bottom; the colery must he packed in as tight as possible. but withont brusing. Buxes thus packed and stood on the co.s floce of the cellur, if put away in Norem- 
ber, will be "blancher" fit for ure ciaring Jannury, February, and Niarch. If put in sooner than November it will blanch carlier, and if stored later it will kenp later. If larger culuntitics are to be kept in the ceilar, the cheapest practicabie way to do so is to begin at one side next tile wall, furthest from the entrance, and ereet boards across the cellar, nine inches from the wall, and of a height a little less than the length of the Celery-that is, if the Celery is twenty-four inches in length, the hoarding may be eighteen or iwenty inches high. In this nurrow division the Celery is parked in upright, as above described for packing in bose.. As soon as the first tier is filled, erect another board trench or division at nine inches distant from the first, and so on until the whole space to be used is filled up. It will be understood that no soil or sand is packed between the stallis of Celery, only two or three inches loeing strewn on the floor, on which the root: are placed. Simultaneonsly with the formation of the white rootlets the hanchjng proces begins, which is simply the plant making an efiort to nrow in the dark, and thus becoming blanched or whitened. We have sometimes complaints that Celery fail: to blunch or whiten. In all such caces the roots mast hure been in some way injured by being frozen or driet too much while being lifted from the field, but this should never happen with ordinary care. A cellar or root-house twenty by twenty feet, so packed, will hold from 3,000 to 5,000 roots of Celery, according to their size. Caro must be taken not to get the board partitions forming the trenches, or divisions between the tiers of Celery, more than nine or ter inches apart, for if at much greater distance the stems and leares would be in too large masses and would generate heat and rot.

$\Lambda$ s the cellar or root-house is usually a damp and dark anarment, there will generally be no necessity to water the Celery after it is packed. Erery means of rentilation 


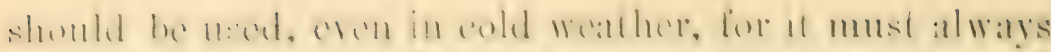

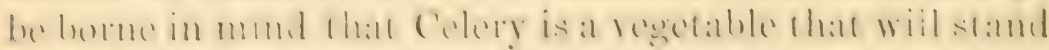

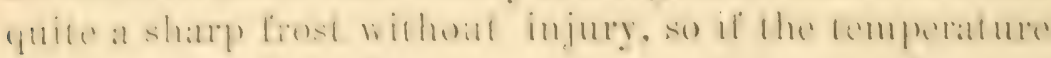
of the collar dalls live of six degrees below the freezing point, no injury will to donc. When Celery or other

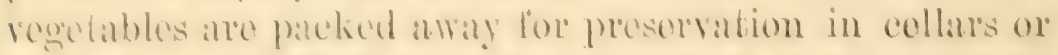
in the opren licht, it is indisponsable that no water he allowed to lodere in the pit or trench: so that in the "vont of using a cellate or root-houso for his purpose, a

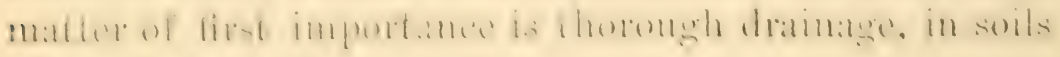

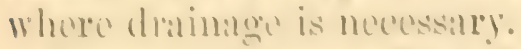

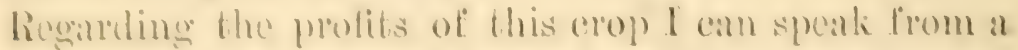

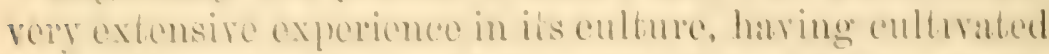

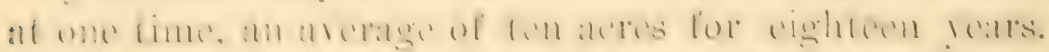
Hor mamy yours, in the carly part of that time, it was by no ma:ans what we wontal now rall a protituble crop. liy persisting in ratsing the latro growing sorts, and the

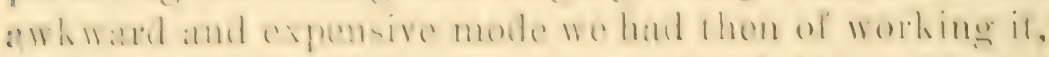

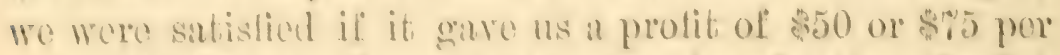

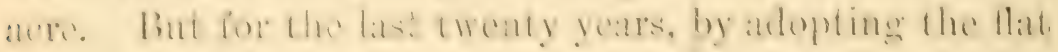
enthur, and the drain or fromeh system for winter stor"age, it has dome much bether, and is now a vory protitable

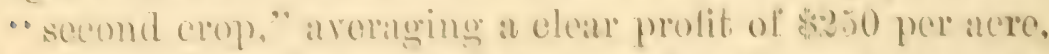
Honeh it rably brings here orer s.0.50 per 100 roots.

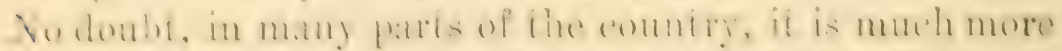

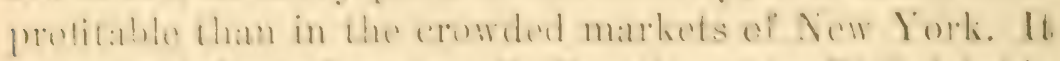

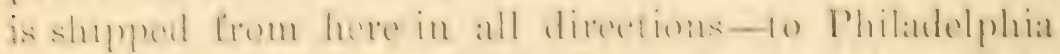

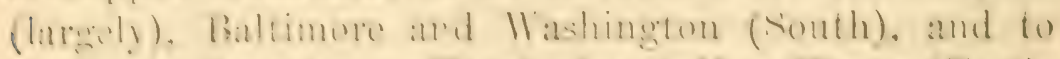

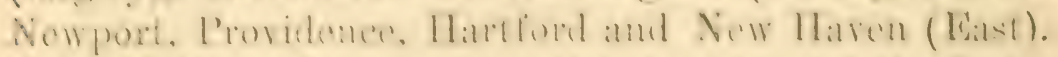

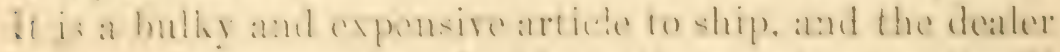

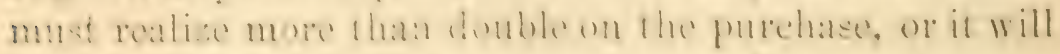
not pay his risk. It must thus cost tho consmmer, in

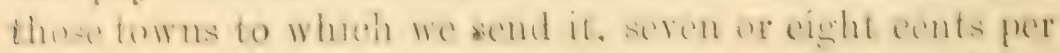
heat. a price at which it woald pay a cleall prodit of $\$ 1.0000$ or $\$ 1.0000$ per acre.

If the anhared and laborious systems of cultivation 


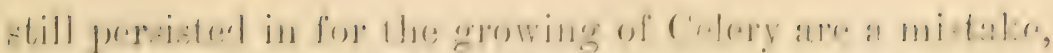

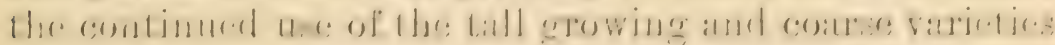
we believe to be even a far grealer one. 'The kinds that

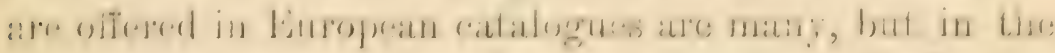
whole list there are but fow that are desinable for the market gardener or for private gitldens. 'The climate of Hingland is much more favorable to the growth of Gelery than that of our country, and every year new varieties are ollered there, of which only now and then one proves of permanent value, but with the majority the differences ale mainly in the name 'The following kinds, some of them of very recent introduction, are great implovements on the sorts grown a dozen years a(co:

IIendroson's goldan brarf.-(Sec figure

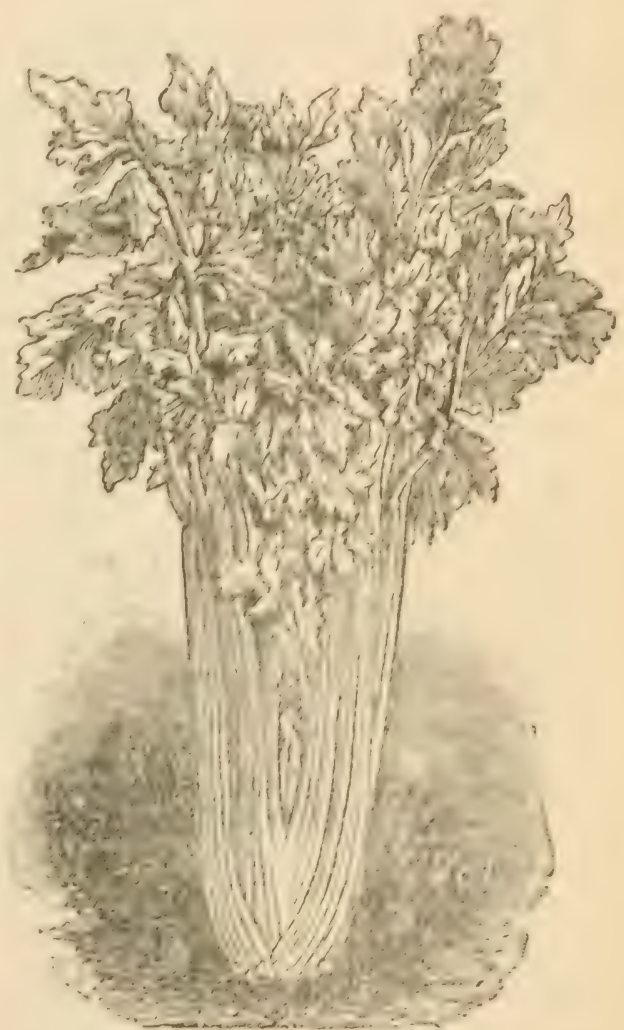

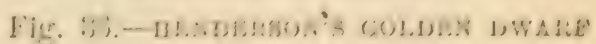
CDILETY. 36.) 'This is now the learing varteis, not only around New York. but in nearly all parts of the enomtry. In the grent Colery-gerowing dirtrict of Katamazoo, Michigan, it is the varaety that is planted al most exclunively. In sime and habit of erpowth

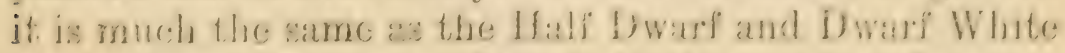

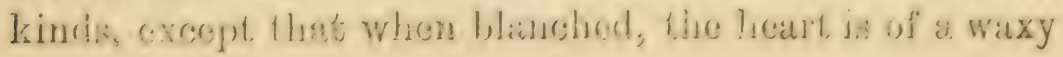


The soil best suited for Corn for an early crop is a wall enriched samily lonm. The planting should never be dome until the weather is settled and warm, as heat is indispensable w the healthy growth of com. We make our first plautings in this ricinity ahout the midale of May, and continue simession plantings orery two or three weeks mutil the tirst week in July, which date. in this latitule. is the latest at which we cam plant and be sure of a crop of "roating cars." In more sontherly latitudes planting is begun a month earlier and contimed a month later. The crop is hardly profitable enough for the market gamtence where land is high in priee, hut the farmers realize double the price for sweet Corn when sold un the greens state in our markets, that they do ferr lipe Com, besides, as the groame cam be cleared whon the ears are thus sold in August, it can be used afterwards for 'T'urnips.

Ahout twentr ratrs aro I cam! int pusassion, alhout the let of Mar, of a four-atere plot that hat lain for many rears in sod. It was then too late to be ahle to break it $u_{1}$ for planting any of the finer kinds of regetahles. so I decided to plint it with sweet ('orn. Acecordingly. I hat the soll plowert over that in such at manner als would best rot it. I was careful to have the furrows straight, and at erery five feet where they lapped towether I diropued siweet Corn at four or tive inches aprart. so that when it started to grow it stood in regular lines five feet destant. The Corn was planted about May and, and hoed aromed the line as it grew, the space between being rum orer lay the harrow enltivator. By the midale of June. from the action of the eultivator. the space between the rows of Corn was m fine friable condition, and celery was plinted on double rows, ten inches apart. The shate given by the Corn was of no injury to the Colery at this carly stage of its growth. and as the Corn crop wats sold and the stallis were cleared off 
by the midale of August, the growth of the C'elcry was not in the slightest impaired. The whole transation was quite satisfictory; the Corn crop sold (ereen), for about $\$(50)$, or $\$ 150$ per acre; the Celery at about $\$ 400$ per acre, which was exceedingly low, not much more than one cent per root for erery root planted; in some subseruent years the price would have doubled that for the same funantity. No fertilizer was used, except it slight sprinkling of bone dust for the Celery. A profit now of from $\$ 50$ to $\$ 15$ is usually realized per acre from Sweet Corn. The best varieties now are :

Varly Marblehead.-(See figure 41.) (Certainly as early, if not a little earlier, than any of the other sortis of Sirect Corn. In appearance it resembles the better known Early Narragansett. The stalk is dwarf and it sets its ears very low down, which are of fair marketable size.

Cory.-Equally early as the preceding, and said to be larger in size.

Carly Minnesota.-(See figure 4\%) Very early and desirable alike in the market and family garden. II eight of stalk, four and a half feet; cars of fair size and good quality.

Crosby's Early Sugar.-Early, and a great favorite in the markets of all large citien. Ear's rather small but productive, and of excellent quality.

Henderson.-This varlety is of medium earliness and is valued alike in the market and family garden, or for camning purposes, for which latter use cnormous areas of it are now grown. The ears are twelve rowed, straight and handsome; quality of the very best.

Squantum Sugar.-One of the swectest and most valued varieties I know of. It is rather eariy and wonderfully productive. Rows irregular, but setting four and five cars on a stalk. 
most of the linge surome sorts in weight of bunch when grown under the same conditions.

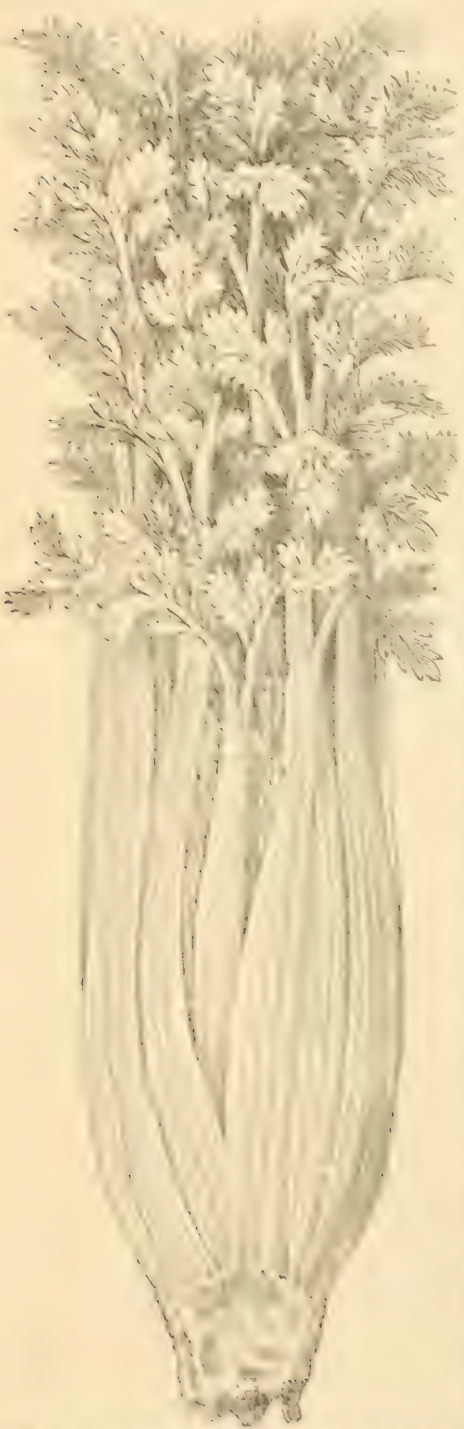

Sanoringham.- - Tnder good cultivation this variety attains a height of two feet and a circumference of twelve inches. It is perfectly solid, the stillis halli romd, the latres and stems being rather light secen. When blanched it is a yellowish white, crisp. temker and of very fine flarol. 'The great adrantage of thise as weil as the other dwart sorts, over the lare kinds, is that nearly every part of the plant is fit tocat when blanched. For instance, if in the dwarf rarieties the length is only two feet and in the large sorts three feet, the extra length of the large sort is mutit for nse, being nsually only an elongation of the onter leares. the lieart or edible part rincly rising more than eighteen inches in the large sorts, while the dwain sorts maly be said to be all heart. 'I'his rariety in this section seems to have more tendeney to blight or rust than any other kinds: but where it can be grown with-

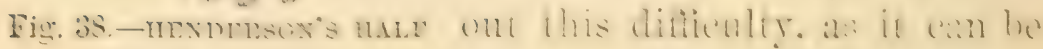
DWARF CELEMY. in such soils as at Killamazoo, Michigun, I think it has no equil.

Bostou Marhet.- I great farorite aromol hoston and 
similar to the Dware White, hat rather more molust.

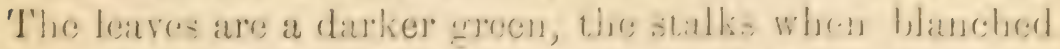

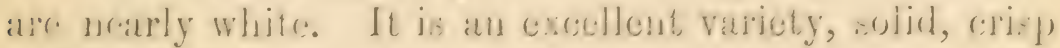
and tender.

diant While Solde. There brest of the lapere growing

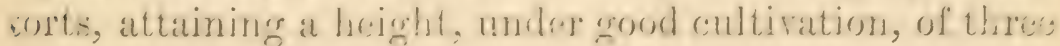

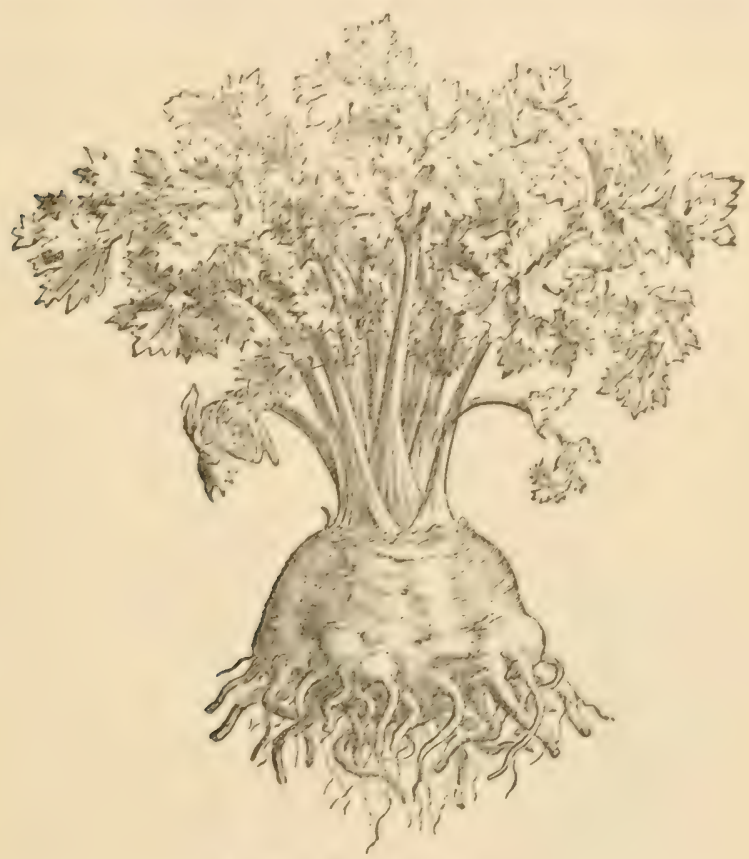

Figr. $3 \%$-CELERIAC.

feet. It should never be planted chosse than four foct between the rows, on it cannot he properly worked. For southern sections of the conntry this variefy $i=$ more suitable than the diwarf sort: as it grows freer in a hot and dry atmosphere.

Irendrrson's liose.-The supcrionity in flavor, as a rule, of the red or rose Celerice orer the white sorts, is much better understoon in England (where the majority of (colery greswn is red), than with lis. For some unexplained reason, the red Colcries have not sold 
will in our markets. 'This camnot long be, howerere as when one greow they will never be given up, not only

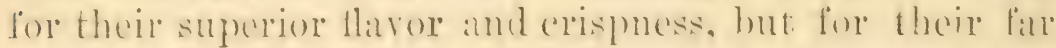

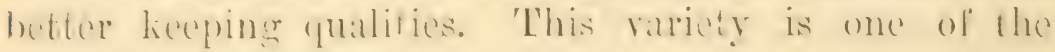
best I have ever seen.

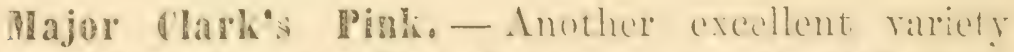
amomer the red solts. It is of medium erowth, stiti, aloce

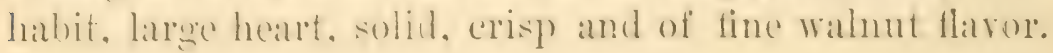

\section{CELERIAC, OR TURIIP-ROOTED CELERY.}

\section{(Apium graveolens. Var.)}

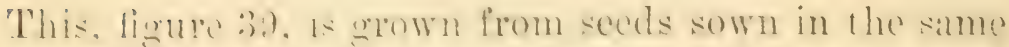
manner, and planter? out at the same times as direceted for Celery; but as it repuires but a slight amthine

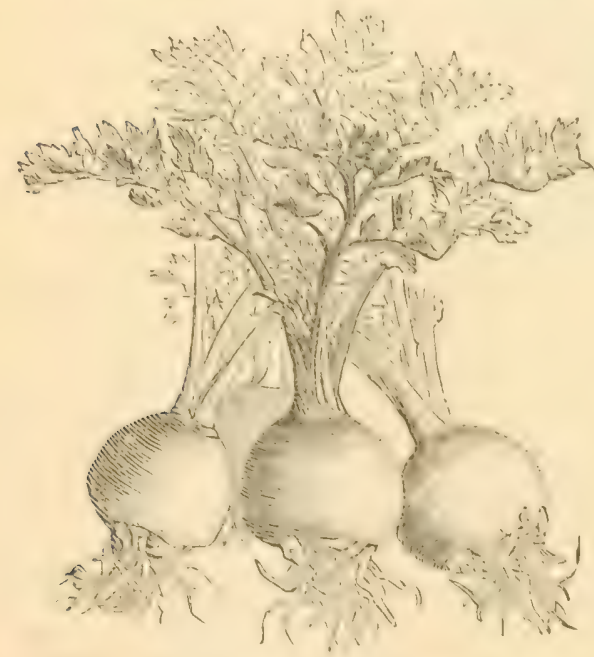

Fig. f0,-DWATE a PPLE-Sinaped CDIEIIU. it is planted closer than ordinary Celery ; eightcen inches between the rows and six inches between the plants. It is preserved for winter use in shallow trenches, and corered up as the scason advances, as directed for Celery. It is as yet grown to but a limited extent here, being used only by the French and Germams. "The turnipm like root is cooked, or it is sliced and used with vinegar, making a most excellent salad.

Dwarf Apple shaped.-(Fice tigure ti). This comparatively now varety is now the main kind grown. 


\section{CHIVEST-(Allium Schcenoprasum.)}

A small bulbons-rooted plant of the Onion tribe, entirely hardy and of the cascist culture, ats it will grow on almost any soil for many years without renewal. It is propatated by division of the root, and may be planted at nine ol ten inchess apart; the leaves are the parts used. which may be repeatedly shorn oil during the early summer months. 'T'hey are sometines used in soups, but more generally in the raw state.

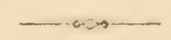

\section{CORIJ SALAD, OR FETTISJï.-(Fedia olitoria.)}

$\Lambda$ vegetable used as a salat and sold to a comsiderable extent in our markets. It is sown on the first opxening of spring in rows onc foot alpart, and is fit for use in six or eight weeks from time of sowing. If wanted to come in early in spring it is sim in september, corered up with straw or hay ats anon ais cold weather sets in, and is wintered over exactly as Spinach. 'The covering is remored in March or April when it stants to grow, and is one of our first green rergetables in spring. It is also grown to a large extent by the ferman gardeners on New York Island in cold frames.

\section{CRESS, OR PEPPER GRASS.-(Lepiclium sativum.)}

Another carly spring vergetahle, used as a salart, and of easy culture. It is sown in early spring in rows one foot apart; at: it runs quickly to seed, suceession sowings should be marle every right or ten days. There are several varieties, but the kind in eneneral use is the Curled, which i.s userl for gambhing as well as for salarls. 


\section{CRESS-WATRR.--(Nastutimm onficinule.)}

'This is a well-kmown hatrly peremnial alpultic plant.

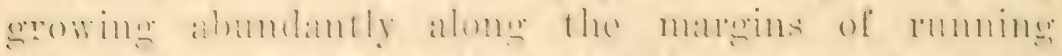
streams, diffhes and pombls amb sold in immense quantities in our malkets in spring. Where it does not grow natturally, it is cacily introdued by platuling alone the

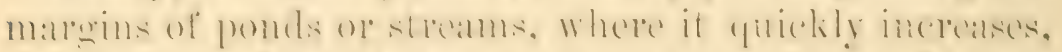
hoth by sprealine of the root and by soding. Mamy a

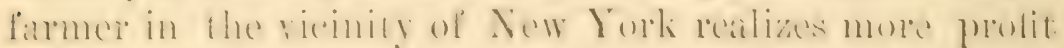

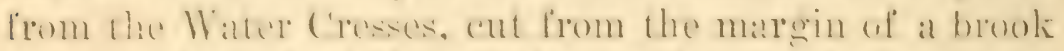

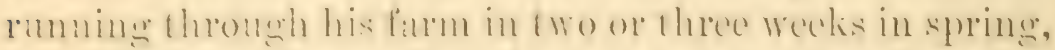

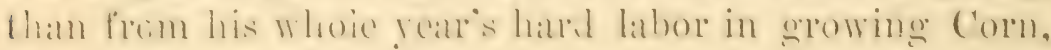
Hay or Potatoes.

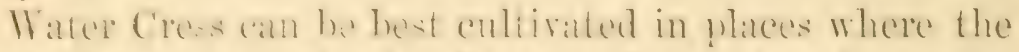
streams run thromeh a leveltract. Supmosing thestream

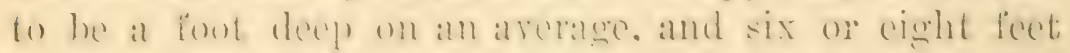

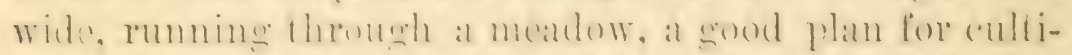

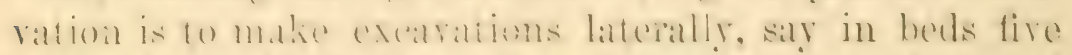
fort wille (with firo foot alleys hetwoun). lo a dephlo of

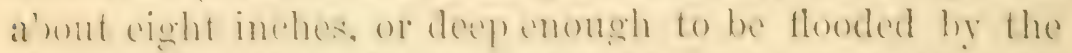
strain when it is of arelage height or when shallow. hy damming it up so as to flood the beds.

'The alvantage of having the huis excavaled at rioht

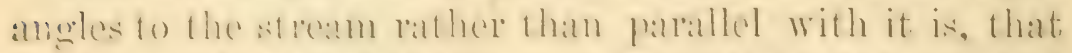

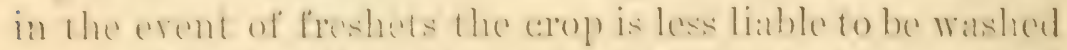

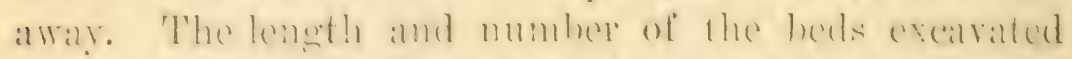

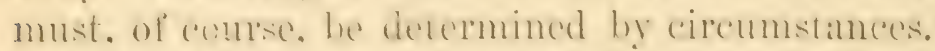

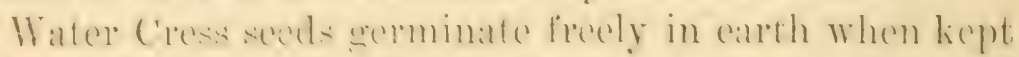

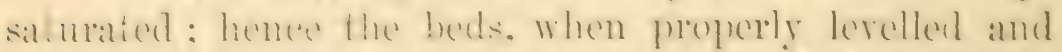

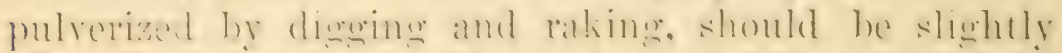
flowhel-enoweh to only saturate the soil until the sceds

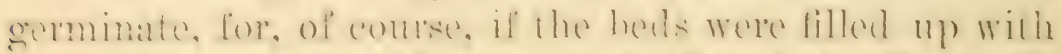
Water, the souls would be washed oft. After the sede linse have startod so as to show grem, the water maty be gradually let on as they develop.

Whe hest time of sowing the seed for the latthite of 
New York, for spring, is about the middle of $\Lambda_{\text {pril }}$; for fall, about the middle of August. I arloceate that seceds of all plants of this description should be sown in rows a foot or so apart, as the seed is small and germinates frecly, so that three or four pounds will be conough for an acre. It should be cultivated exartly as Spinarde is.

When Water Cress is found growing naturally, the beds can be marle by setting the plants six or twelve inches apart each way. When the cultivation is once fairly begun, there is no difficulty alont forming new bed; as few plants grow more rapidly when proper conditions are present.

After the (rop) is planted or sown, in two montles it will have sprearl all orer the hert. The streams heing full in antumn, the heds will he fully flooded 80 as to protect the plants cluring winter. It is always foind growing hest wild, in clear, shallow, slowly-rumning water, with a mandy or gravelly bottom; and as nature is always the surest guide to successful cultiration, the nearer it can be imitated the better the success.

I find it is one of the plants the culture of which is not very easy to give by writing, as so much must be determined by the circumstances of locality. Wherever a suitable stream is at eommand, the cxperiment of growing Water Cress is worthy of trial, especially when we know that it in many caseses pays, for a given area, six or eight times more than any other vegetable cultivated, provided it can be sold in the markets of New York or Philadelphia.

It is usually sold in baskets contuining about three quarts, which sell, when first in market, at filty cents each; 200 or 300 such are carried in an ordinary wagon, so that from a single load of this simple vegetable, s10.) to $8: 20()$ are realized. The Water Cress has a particularly pleasant pungent taste, arrecalble to most people in cariy spring. 
It is a aid that when Sir Joseph Banks first arrived in England after his rovage around the rorld, among the first thing he asked for were Water Cresses, well knowing their value as a purifier of the blood: and that he afterwards presented one of the lirgest Water Cress grower's for the Loniton market, a Banksian Iredal, for energy shown in the businss. beliering that while he had henefited himself he had benefited the community.

I hare no doubt whaterer that in situations where irrigation could be nised at p? casure, and regular plantations made, as for Cranberries. that. gromn in this way, julging from the enormous price it sells at. piclier ip as it is in the present hap-hazard way, at present prices. an acre would sell for $\$ 1,000$ to $\$ 2,000$.

To gire some idea of the immense quantitics of Water C'ress sold about some of the cities in Europe, we may state that a recent number" of "Corent Garden Gazette" states that Water Cresses to the value of $£ 50,000$ are anmually consumed in Paris, and in London to the extent of $£ 30,000$ annually.

\section{UPLAND CRESS.-(Barionea valgaris.)}

This has recently been introduced as a new regetable by a Mr. Beyer, of Iowa, and Mr. Beyer may be well pardoner for believing it to be new. for he sars that he is informed by the largest seed firm in Paris in a letter written in 188., that in their belief it is " new in France."

Now, it is not " new," but a very old plant, as I well remember it in $m y$ "prentice days, when it was grown as spinach, and ised exactly as Water Cress. In fact, it so much resemlles Water Cress in taste that the difference is scarculy discenible, and the wonder is that its use has not become more general, as it is of as easy 
culture as spinach; indecd, easier, for it is a peremial plant, and can be grown casily for two vears without resowing, and it yieds comormons crops. The sered should be sown in April, in rows tweive to fiftecn inches apart, and Mr. Beyer, who has been experimenting with it in the climate of Iowa, says it has stood a temperature of five dergees below zero, and still keeping greern. Ho belieres that its great value as a salard will som bor aprprociaterl here, and, besides, as cattle eat it stecrily, it may, in some sections, prove a valuable forage plant.

\section{COLLARDSี (SOUTHERN).--(Brassica oleruere. Irer.)}

Iost of the Collards as grown in this section. are nothing more than sowings of any early variety of (ab)bace in rows abont one foot apart, which are cut off for nes when six or eight inches high. The Southern (collarl is a distinct variety of vigorous growth, attaining a heirht of five or six feet, and grown in portions of the South where the ordinary kinds of Cabluge fail to hearl. Suring sowings may be made every two week at two feet aprart from February to May; and in fall from soptember as late as the soason will admit.

\section{CORH_-(Zea Mrays.)}

The rarieties known as "Sweet" are the sorts most cultivater for culinary use in the green state. It may be either sown in rows four and a half feet apart, and the seeds planted at eight or nine inches in the rows, or planted in hills at distances of three or four fect each way, according to the variety grown or the richness of the soil in which it is planted. The taller the rariety or richer the soil, the greater should lue the distance apart. 
The soil best suited for Corn for an early crop is a wall enriched sandy loam. The planting should never be done until the weather is settled and warm, as heat is inclispensable to the healthy growth of Corn. Tre make onr first plantings in this vicinity about the middle of Nay, and continue succession plantings every two or three weeks until the first week in July, which date, in this lititude, is the latest at which we can plant and be sure of a crop of "loasting cars." In more southerly latitudes planting is began a month carlier and contimued a month later. The crop is hardly profitable enough for the market gardencr where land is high in price, but the farmers realize double the price for Sweet ('orn when sold in the green state in our markets, that they do for Ripe Corm, besides, as the ground can be cleared when the ear's are thus sold in August, it can be used afterwards for 'Turnips.

About twenty years ago I came into possesion, about the 1st of May, of a four-acre plot that had lain for many years in sod. It was then too late to be able to break it up for planting any of the finer kinds of regetables, so I decided to plant it with Sweet Corn. Accordingly. I had the sod plowed orer flat in such a mannel as would best rot it. I was careful to have the furrows straight, and at erery five feet where they lapped together I dropper Sweet Corn at four or fire inches apiut, so that when it started to grow it stood in regular lines five feet distant. 'The Corn was planted about May 20th, and hoed aromin the line as it grew, the space between being rm over by the harrow eultivator. By the middle of June, from the action of the cultivator, the space between the lows of Corn was m fine friable condition, and Celery was pianted nu double rows, ten inches apart. 'The sinade given by the Corn was of no injury to the Celery at this early stage of its growth, and as the Corn crop was sold and the stallis were cleared off 
by the middle of August, the growth of the C'elery was not in the slightest impaired. The whole transaction was quite satisfilctory; the Corn crop sold (green), for about $\$ 600$, or $\$ 150$ per acre; the Celery at about $\$ 400$ per acre, which was exceedingly low, not much more than one cent per root for every root planted; in some subsequent years the price would have doubled that for the same quantity. No fertilizer was used, except a slight sprinkling of bone dust for the Celery. A profit now of from $\$ 50$ to $\$ \%$ is usually realized per acre from Sweet Corn. The best varieties now are :

Larly Marblehead.-(See figure 41.) Certainly as early, if not a little earlier, than any of the other sorts of Sweet Corn. In appearance it resembles the better known Early Narragansett. The stalk is dwarf and it sets its ears rery low down, which are of fair marketable size.

Cory.-Equally early as the preceding, and said to be larger in size.

Early Minnesota.-(See figure 42.) Very early and desirable alike in the market and family garden. Height of stalk, four and a half feet; ears of fair size and good quality.

Crosby's Early Sugar.-Early, and a great favorite in the markets of all lirge cities. Eai's rather small but productive, and of excellent quality.

Ilenderson.-This rarety is of medium earliness and is valued alike in the market and family garden, or for canning purposes, for which latter use enormous areas of it are now grown. The ears are twelve rowed, straight and handsome; quality of the very best.

Squantum Sugar.-One of the swectest and most valued varieties I know of. It is rather eariy and wonderfully productive. Rows irregular, but setting four and five cars on a stalk. 
Egrptan.-The cars of this rariety are of large size. the fluror peouliarly rieh and sweet. It is gromin in eynally large quantities for hoth camming and for selling in the ereen state. Like all the other larese varieties, it matures late-perhaps the best late sort.

stowell's Lrergrecu,-(Sectigure 4:3.) Now recognized

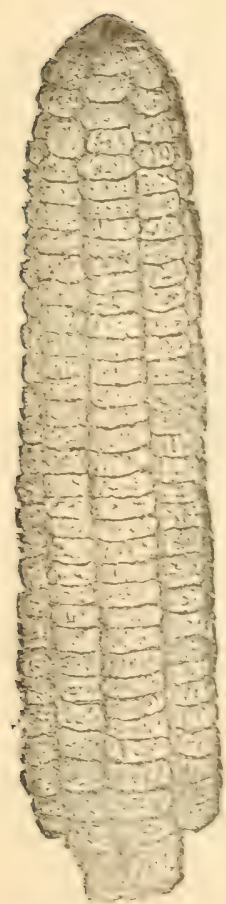

Fig. 41.-MArbLE- Fig. 4.-Mrissot. HEAD CORN.

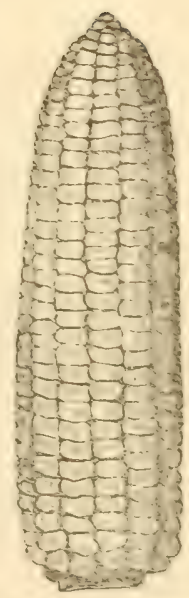

cois.

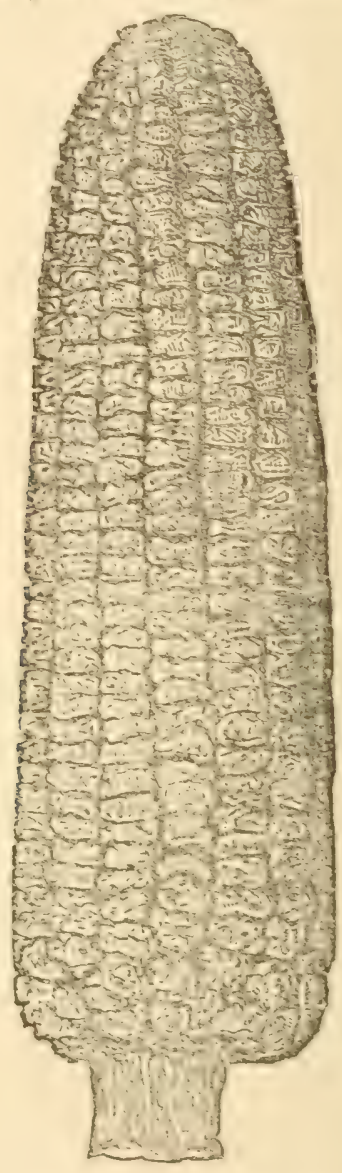

Fig. 43.--sTotrLL''s

ETERGREFN CORY.

everywhere as the standard late vartety, and hatring the pecullarity of remainmg longer w the green state than most other sorts.

Mammoth Sugar,-A late variety and a sort that pro- 
duces ear's of very large size and fine flavor. It is unusually productive, and is the variety almost exclusively grown by New York market gardeners for their late crop.

\section{CUCJMBER.--(Cucumis sativus.)}

'The growing of the Cucumber out-of-door's is, in most places, attended with a great deal of annoyance and loss, occasioned by the attacks of the "Striped Bug." When the seed is sown 11 the open gromul. repeated sowing's are often utterly destroyed by this pest, despite all remedies. To avoid this, and at the same time to forward the crop at least a week, we have long adopted the following method with the greatest suceess: About the middle of May (for this section), we cut from a pasture lot, sod.s two to three inches thick: these are placed with the grassy sile down, either on the benches of our forcing-house, 1 an exhausted hot-bed, or minde of a colll frame; at that season of the year any one of these will do as well as another. The sods being fittel together neatly so that all crevices are filled up, they are then cut into squares about three or four inches in length and breatth ; on each of these are planted two or three seeds of Cucumber, and over the whole is sifted abont half an mch of covering of some fine rich mold. 'They are then sprinkled thoroughly from a rose wateringpot, and the sashes put on and kept closed until the seeds begin to germunte, which will be in three or fom rlays. As soon as they are up, the sashes must be raised to armit arr, else the sun's rays, acting on the glass. would rase the temperature too high; at that season of the year the sashes, as a rule, may be tilted up at eight or nine oclock in the mornmg, and shut dowin by three or four $0^{\circ}$ (lock in the afternoois. By the time the Cu- 


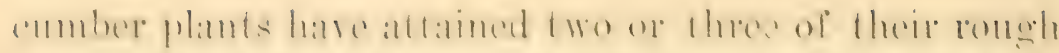
leaves, which will be in about thee weoks from the time of sowing they aro planted ont in the open eround in hills thee leet aprat each way. The hills should have

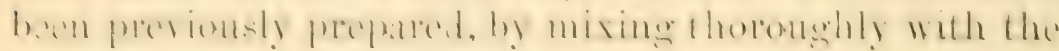
soil in oach, a shovellul of well-potted mamme.

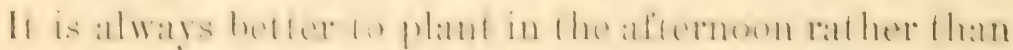
during the early part of the dian ats the coolness and moisture at night enable the plants to reenperate from the oftects of removal. It the weather is hot and dry, it

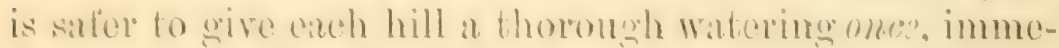
diatcly aller phating. I hatro recommended sods in preference to llarer-pots ior statims. the Cucumbers, inasmuch as they are not only proenrable in all places. but our experience shaws that the son is eren better tham the flowerepot: it betiter retains moistme, and there is a

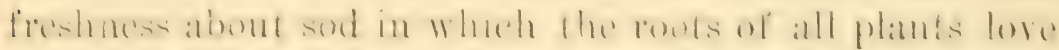
to revel, and which no eomposts we call preprate an ever copmal.

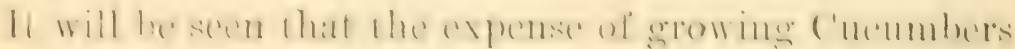
in this minner is considerable ; to grow enough for an

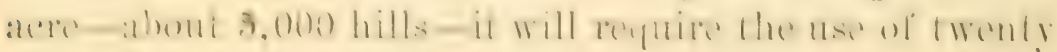
three by sax loot sishes, and the preparation of the sods amel attention in airing, ete., until they are fit to plant, will involve ten times mom expense than simply sowing the seed in the hills: but all such expenditures are well retumed, for it is salde to saly that the protits would always be at least three times more by this plan than by the other. 'The arerige receipts are 8500 pere

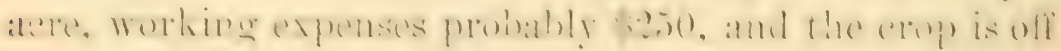
m tome lor 'l'umips or Spinach ats a second erop.

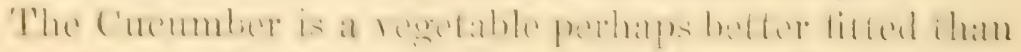

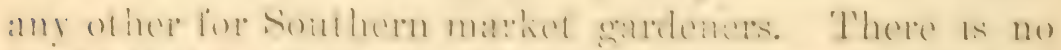

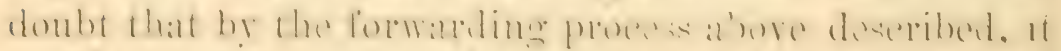

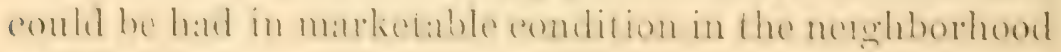
of Charleston or sarammah, at least a month bofore it 


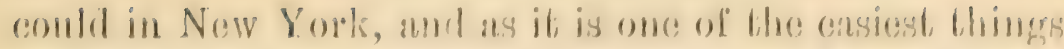
wo have to shipe a profitahle busionse combl be mate of

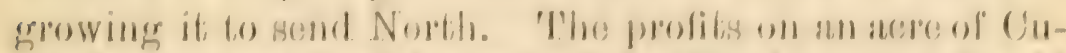

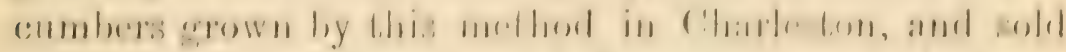
in Now York in June, womld, I lhink, axcesed the noop-

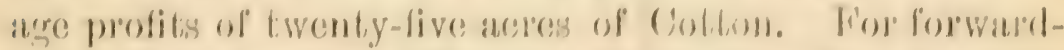

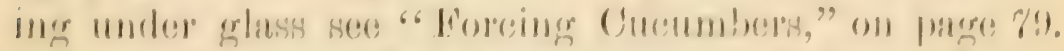

Cucumbers aro also extensivaly raised for piokling,

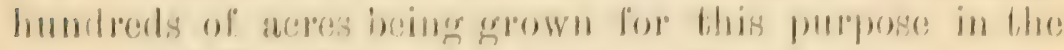

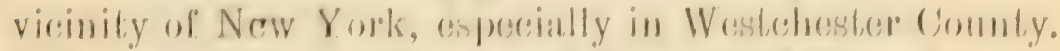

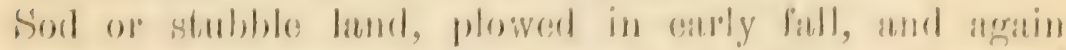

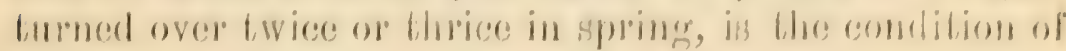
soil manally ehosen.

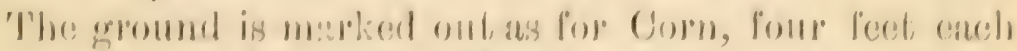

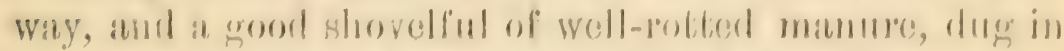
at the sugle which forms the hill; thes seod is solvo-

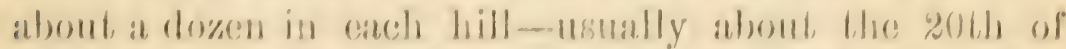

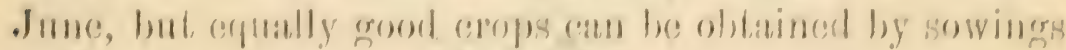
made as late as the mildle of duly.

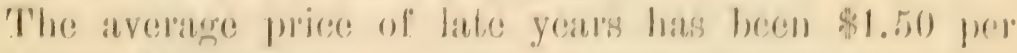

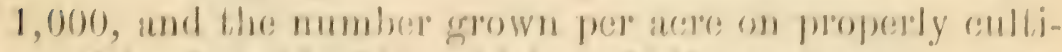

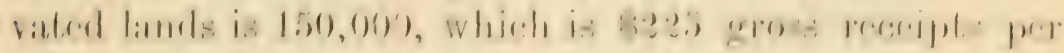
acere. The expense of rasing is said to be ahtomb onse-half.

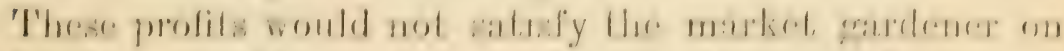
his low valuable aceres neale tho city, but, no doubli, anes

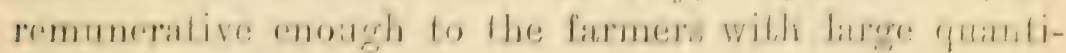
lies of (dowe lamd.

The variedies are mumerous and ambrace many very

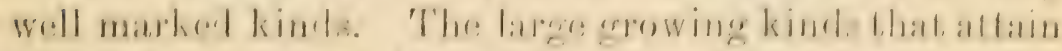
t.wo feet or more in length lave nover become fiavoribes in our Amorican markets.

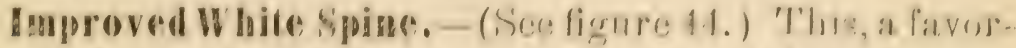

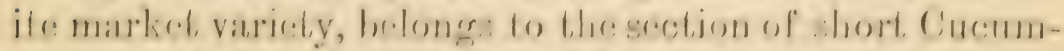

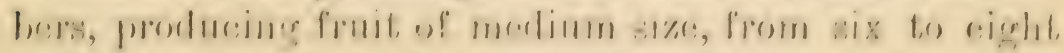

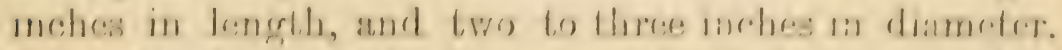

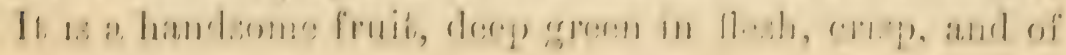


finc flaror. This is one of the varieties gromn for folcing:

Michol's Medium dreen.--This new raliety is excellent as a pickle sort. and for forcing there is none better. It is rery productire, of medium size. and always straight and smooth. C'olor, daris green ; Hesh, crisp and tender.

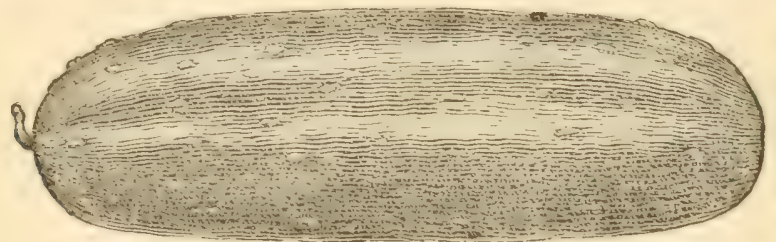

Hig. 41.-TMPROVED WHITE SPINE CUCUIBER.

Larly clasifr, - I much cstemed carly variety, groming in clusteris and extremely productive. Its color is bluish green, shating lighter at the extremities.

Larly Hassian.-(Nee figure 4.).) This is the earliest raricty. coming into use about ten dars befor the Early

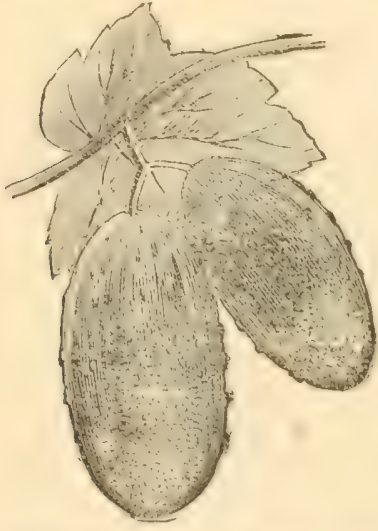

Fig. 45.-EARLY RUSSIAN CUCULBER.

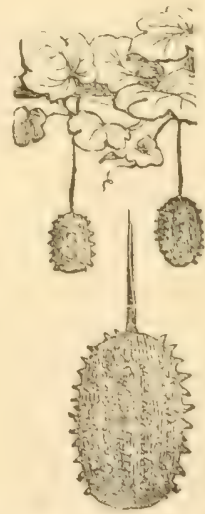

Fin. $46 .-$ WEst INDIAN GHERKIN OR BURK CUCUMIBER.

Cluster, which it resembles in some respects. but is smaller and shorter. 'The fruit is generally produced in pairs, and is from three to four inches lone, hardy, productive and fine flarored. One of the best vilrietics for private gardens. 
Green Prolific. - As a pickle raricty it is unsurpasser?. Its characteristics are its rery uniform growth, hardly ever yielding Cucumbers too large for pickling, and it immense productiveness.

'Tailby's Hybrid.-Dark green and glossy in color, good yielder and fine flavor; resembles the English forcing varieties, with one of which it is a cross.

West India dinerian or Burro-(See figure 46. ) This variety, which is exclusively grown for pickling, is a species distinct from the common Cucumber (Cucumis Anguria). It is very small, length from two to three inches, a strong growing sort, and shoild be planted fire feet apart.

\section{EGG PLAIT,-(Solanum Melongena.)}

The cultivation of the Egg Plant, from its extreme tenderness, is, in its early stage, attended perhaps with more trouble than any vegetable of our gardens. A native of Tropical America, it at all times requires a high temperature. For this reason, in this latitude, the seeds should not be sown in the hot-bed until the first week in April ; even then a stearly bottom heat is necessary to a healthy derelopment, and there should be a warm corering at night orer the sashes. I hare always found that with tender plants of this kind, not'ning was gained by starting carly, even though by great care the plants are carried through the cold season. By the time they can be planted in the open ground, alout Jnme 1st, those started the 1st of March would be no larger than those started 1st of April, besides being harder both in roots and leares, in which condition they are far inferior to the rounger plants that have been raised with less than half the labor.

A correspondent from an inland town writes that, for the first time, the Egg Plant has been grown in his sec- 
fiom this seisom, amb that it has beens a romder to the

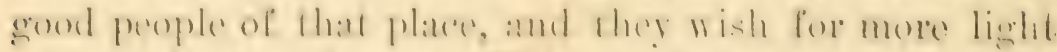

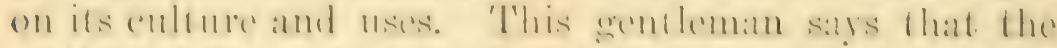

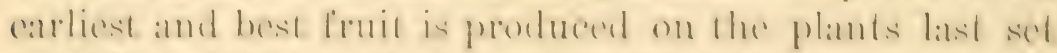

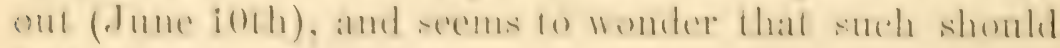
bo the case.

His experience here teaches a loreible lesson on the

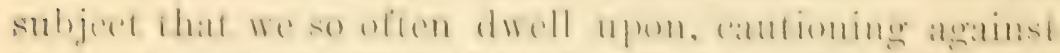

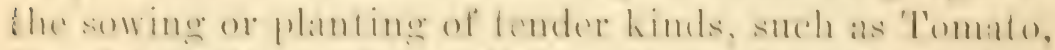

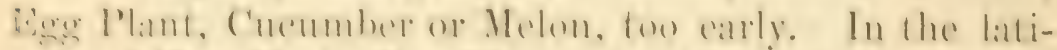

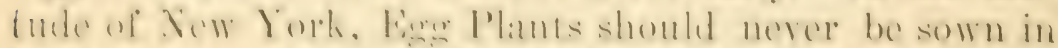

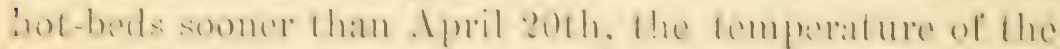
hot-bod to be not less than seventy dogrees at night.

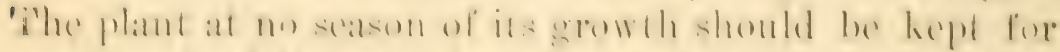

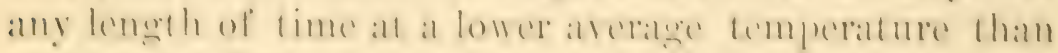
serenty deserees.

The experiment of my eorecpondent demomstrited than his plants, plantent in open air on Maly lah. wore inferior to those set ont on June 10th.' Foge Plants,

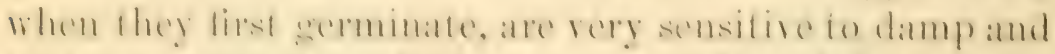
to being chilled, and the amateme often fats to rase them, eron wibh his hot-bed. Liat as they aremow grown in all barge towns. Hose wishing to try them, and rot

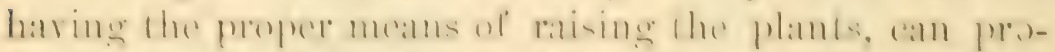

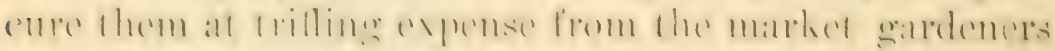
or florists of their mentest town. The soil in which they

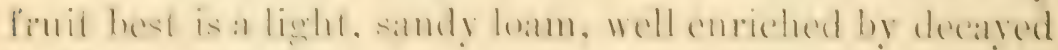
stable mamure.

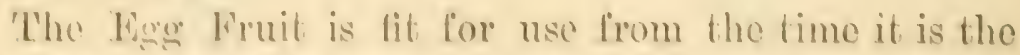
size of at turliey's egerge motil it is full grown, saly five inches in diameter: but it is mot so good when the suds

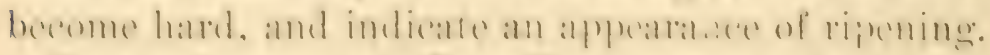

The soil in which Wege Plants are to be grown ean

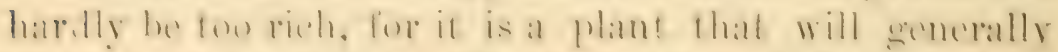
repay good treatment. 'They are planted from two to

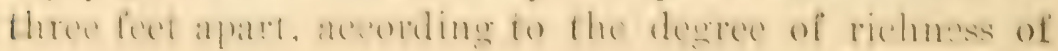


soil ; in the fortite marlied aurens never lese than there

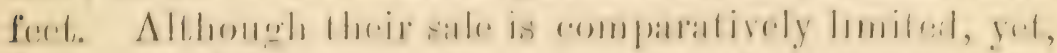
from the difficulties oflen experienced in masing the plants, all that are offered are sold at good prices; the

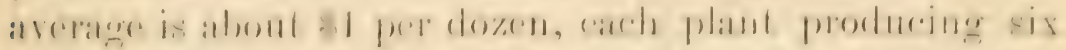
fo nime full-sizal fruil. It is mom impmetant with thi:

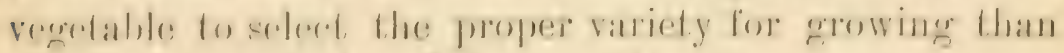
witi any other that I linow; for that reason we are

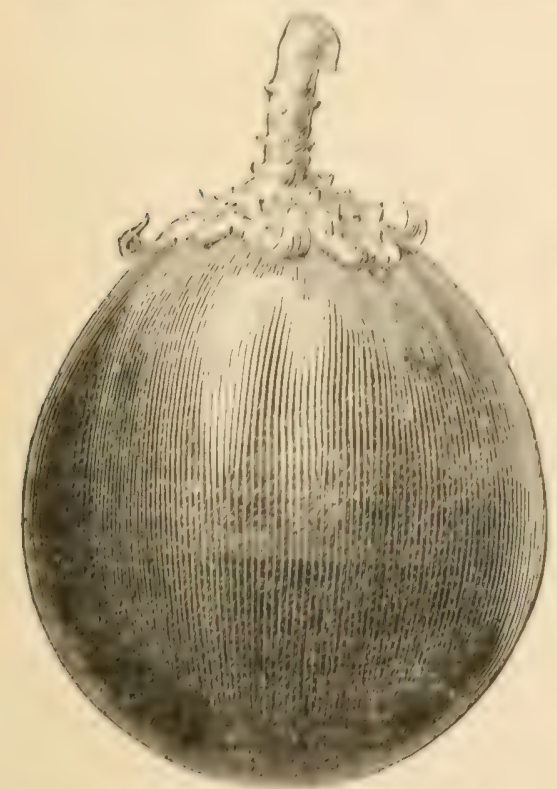

Fi.. 47. - NEW YOLK MMPIOVED EGU I'I, A, N'I'

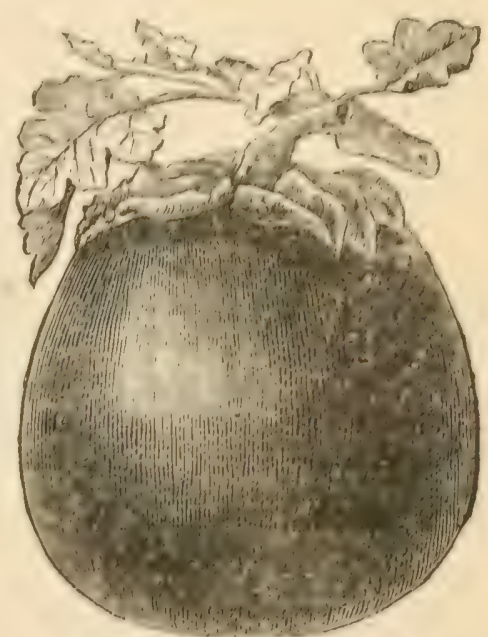

Fig. 48. - BT.ACK JERTR RGG J'A.A'I'.

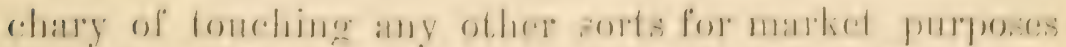
than the "Now York Improved" and "Blatck Pokin."

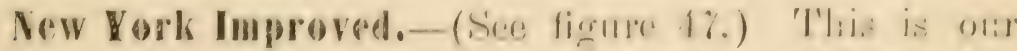

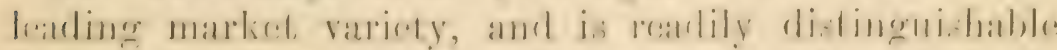

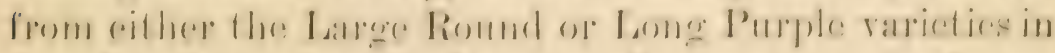
the plant being more robast in all its parts, flue leatses and stoms aleo lecing thickly studded with ginos, which are not formed to any gereat extent on fles other ratretices. A productive and excellent variety. 
Long Durple.-Difierent in shape from the ioregoing: sometimes deep purple. and andin pale, with white or rellowish stripes. Eirly, productive, and of eaty culture.

black Fokin. - (Fee figme 18.) A comparatively new rariety of superion excellence; fruit glossy, deep purple, almos black of globular form and very solid. It is carlier and more productive than the New York Inprored, and much superior in flaror. and is now selling rather better in our New York markets.

Whiterfuited Egg Plant.-Gimilar in arowth to the Long Purple. hut the fruit is Tarerer, and of an irory whiteness. It is goon when cootied, ?nt much less productive, and, like the scallet. which is almost identical except in color, is grown more for curiosity and ornament.

\section{ENDIVE.-(Cichorium Endivia.)}

The cultivation of this regetahle for market purposes is not ret extensive. it being used by few except our German and French population. It is. howerer, offered now he the wagen load, where a few rears ago a few basketfuls would have supplier? all the iemand. Like all other regetalbles that are grom in limited cumatities. it commands a high pricere and the few who do raise it find it very profitable.

Like Lettuce. it may be sorw at any time. from early spring until August. and perfect its erep the season of sowng. As it is usert almo-t exclusively in the fall months, the main sowings are made in June and July, from which plantations are formed, at one foot apart each war, in August and September. It requires no special soil or manne, and, after planting, it is liept clear of weeds hy howng and weeding, until the plant has at tained its full size, when the process of blanching begins : for it 
is never used except when hlanched, as it is harsh and bitter in the green state.

Blanching is ellected by gathering up the leares, and tying them up by their tips in a conical form, with bass matting. 'This exclutes the light and air from the inner leaves, which, in the comrse of three to six weeks, acording to the temperature at the time. become blanched.

Another method cf blanching is much simpler and quicker, and is the one mostly practiced hy those who grow Endive for market; it comsists simply in corering

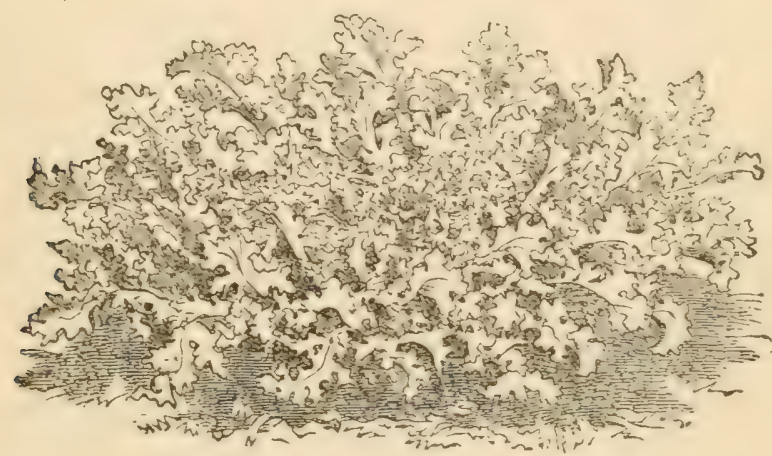

Fig. 4\%-GREEN CCILLD ENDIVE.

up the plants as they grow. with slates or hourds, which serves the same purpose, hy exchding the light, as the tring up. The arerage price during the months of Octoher, Norember and December is fifty cents per dozen.

'The best sorts are the following :

Green furled.-(See figure 49.) This is not only ore of the most nseful as a salad, but is highly ornamental from its delicately cut and curled leaves: it is much used for garnishing.

Hoss curled.-This rariety is now common, and is being extensively cultivated. From the density of the foliage, the pliant is heavier than the Green Ciurled, is 


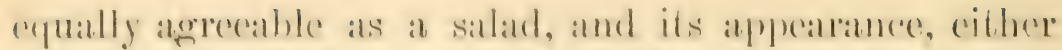

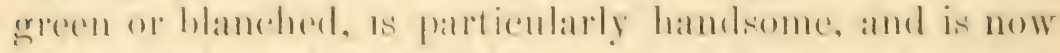
boing moneh used for gamishme on ome best hotels.

Broad-Ieaved Batavian.-A loose growing variety, formine hut lifte hear. As with this blanching can

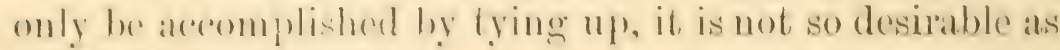
either of the preceding.

\section{GARIIC. -..(Allium sativum.)}

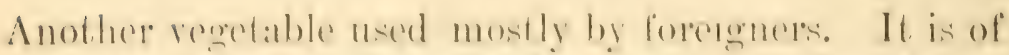

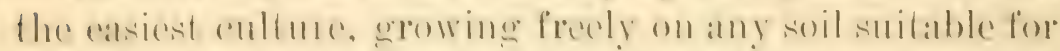

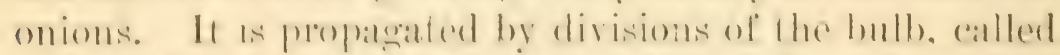

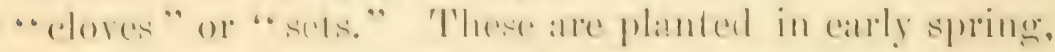
in rows one foot apalt, and from foul to six inches hetwern the plants in the rous. 'The (rop) matures in August, when it is harvested like the Onion. It is always sold in the diy state.

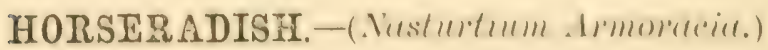

This root is an important crop, upwards of five

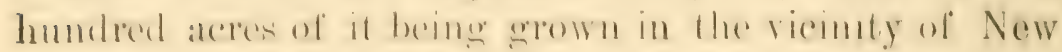
York alone, and for the last twenty years there has berts nothing grown from whoh wo hatre realized more

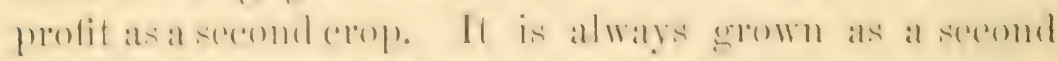
erop in the following mammer :

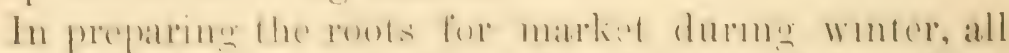
the small routlets ale broken oll and resered for plantme, leaving nothme hut the matn ro.th, which is molally from twelye to difuen inches lomg, and weghong about

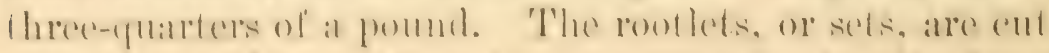
unto piecess of liom lour to sax molnes in length, from 
one-quarter to onc-hall an inch in diameter; these are tied in hundles of from lifty to sisty, the top end hering

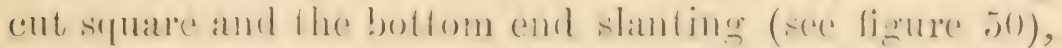
so that in planting there will he no dangere of senting the root upside down : for althemphe if would grow if planted thus, it would not makic a handsome root.

The sats. when prepared, are stowed away in boxes of sand, care being taken that a sufficiency of sand is put between each layer of bundles

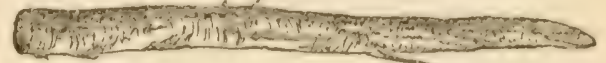

Fig. 50. - HOISERADISU SET. to prevent their heating. They may either bo kept in

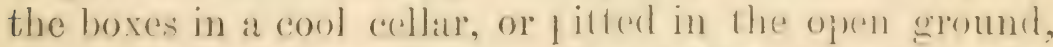
as may be most convenient. He prefer the openground, when the weather will permit.

I have raid that Iorseratish is always cultivated ats a secomd crop. With us, it usmally suceededs om Early Cabbatere, Cambiflower or Bucis. Thhus we plant Early Cabbater lining ont the gromed with theone-foot marker ; on erery alternate line ale first planted Farly Cabbatges, which stand. when phanted, at two feet between the rows and sixteen or aighteen inches, between the plants. We always finish onr (ntire planting before we put in the IIorsuradish, which delays it generally to about 1 st of May. It is then planted between the rows of Cabluace, and at about the same distance as the Cablotge is in the rows, griving about 1:,000 of $1: 3,000$ plants per atere.

The planting as perfomed hy making a hole alonte erght or ten noches deep with a long planting stick or light crowhill, nuto which is dropred the Horaradish set, so that it: top will be two or three inches under the sulfare; if the sots should be longer the hole should be made proportionally deep, an that the top of the set is not nearer the surlace than two or three nu. hes ; the carth is presed in alongside the set, so as to fill up the hole, as in nediuary planting. 
'ithe main raison for planting the set so fiar moler the

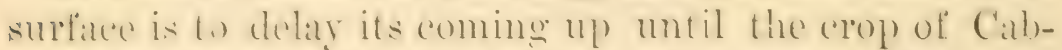

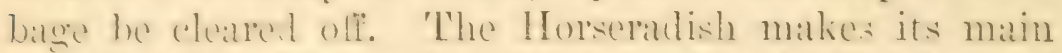
arowth in the lall. so that it as no injury to it to kecip et. from arowing until July; in finct, it often happens that by heing llanted tor neall the surface, or tor cally, it starts to grow so as to interfore with the ('abhatge elop); in

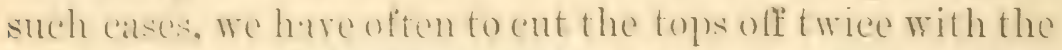
how before the Cabbage is realy, but this does not injure it in the least.

It is a crop with which there is rery little babor during

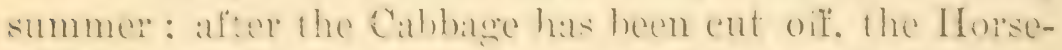
lanlish is allowe / to wow at will, and ats it quickly callers

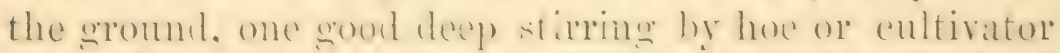

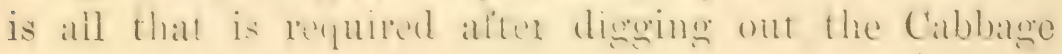
stumps.

When grown hetween Fariy Beets the culture is, in all lespects, the sime. only it is mome probitable to have the

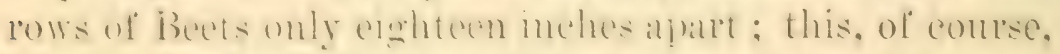
throws the Horseratish nearer. so that when wrown be-

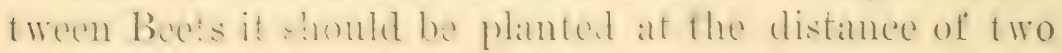
feet hetwern the plathes in the rows. making atont the

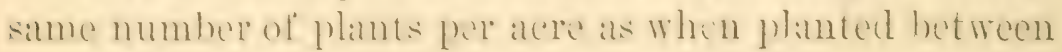
early Cabbages.

Is it is an entimely hardy plant, it s one of the list

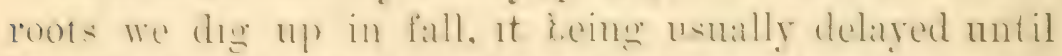
becember. Here diegring the small routs are usually holien ofle on the fold ant : fowed awaly in hoxes, so that

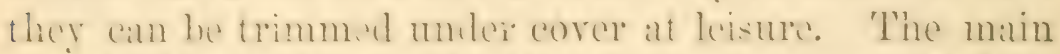

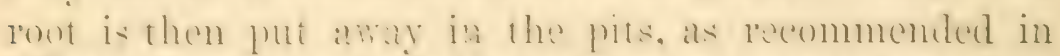

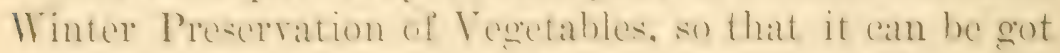

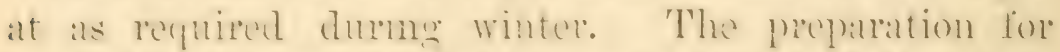

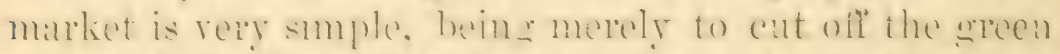
tops and small pontlets, learme the mam rout only, as representel, in refluced size, hy figure $\mathrm{s}$. It ss sold by weight. and is erencrally washed. whele is done sufti- 
ciently by rinsing a quantity of it together in a larece tub.

Oul manner of growing IDorscratish in this district, we clain to be a great atrance on the methois generally practised. All American writers on the subject that I have seen, follow in the same track, and recommend planting the crouns. This would not only destroy the most salable part of the root, but when planted thus, the crowns will produce only a sprawling lot of rootlets that are utterly unsalable in the market. 'Thoy also tell us that "after two seasons growth the roots will be fit for use." Now, my experience in growing this root has most emphatically told me that, after two seasons growth, it is entirely unfit for use, or at least unfit for sale, which I suppose is about the same thing. 'Iwenty years ago, one of my neighbors had a patch of about two acres, whish from some cause or other he had neglected to have dug until late in spring, and concluded, as it was then rather late to sell it, he would leave it to

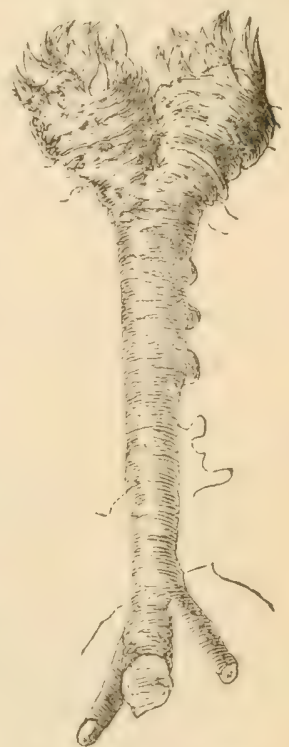

Fig. 51.-HORSER.DISH. grow orer until next scuson. On commencing to dig it the next fill, he fonnd that the main root, instead of beging solid, as it is at one one year old, had become partially hollow and of a wooly, stringy nature, and when offered to manufactners it was refused at any price. So there was no help for it but to dig up and throw away his entirely worthless crop at a most musual expense, as its two year's arowth had massel the whole soil with roots. Fhis experiment of my neighbor was a loss to him of certainly not less than $\$ 1,500$, as the price then was higher than now.

Crown in the (lec) rich soil of our maket gardens, 


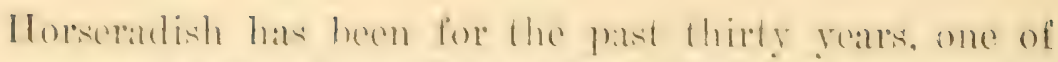

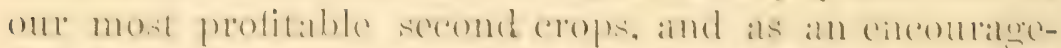

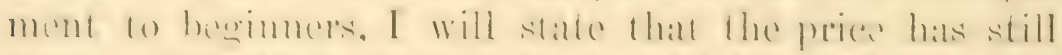

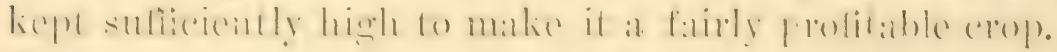
Our arexige weight per are is fire tons, or al little over threc-quarters of a pound per root for 12,000 planted. Its arerige price is now about $\$ 100$ per tous. But there is one thing to be remembered : these heary erops are

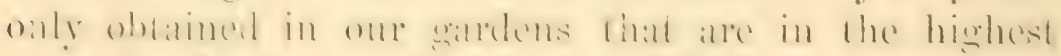

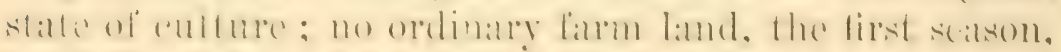

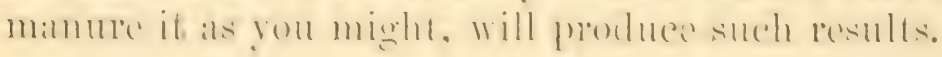

\section{KOHLRABI, OR TURMIP-ROOTED CABSAGE.}

\section{(Brassica oleracea. Var.)}

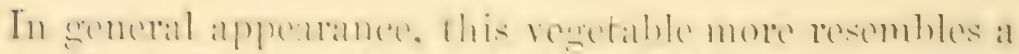

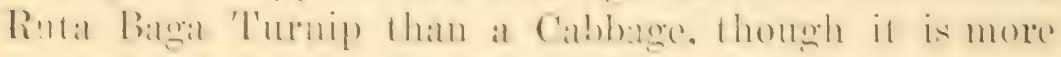

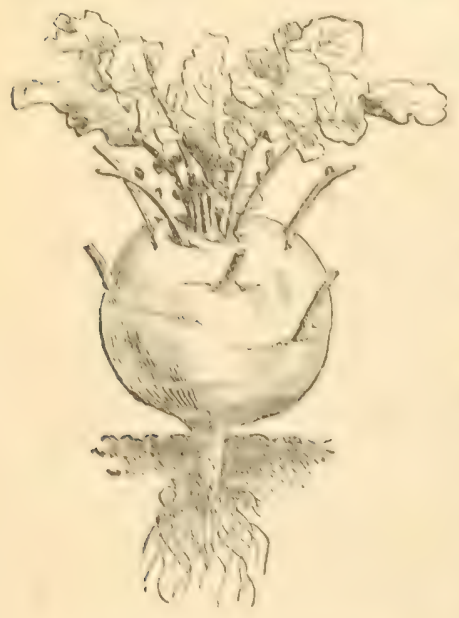

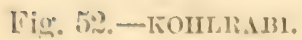
generally elassed with the latter. It is best cultivated by sowing the seeds in lows in May, Jume, or eluly, aceording to lintitude. In this district we sow thromghout June, for succession in rows eighteen inches apart, thiming out to about eight or ten inches between the plantis. It is rather diflicult to tramsplant, and we generally prefer to sow the whole erop) from sect, and thin ont where it stamels: although when the veather is suitable, the thinnimes mas be planfed at the distaness above named.

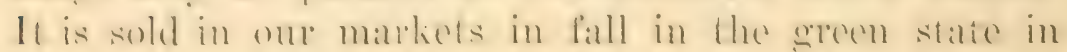
bunches containing thee roots, at an arerace pries of 
seventy-five cents per dozen bunches. As it is not in general usre, its sale is limiterl. The varictics mostly cultivated are :

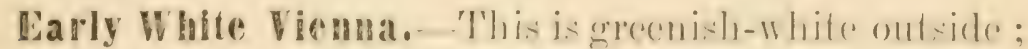

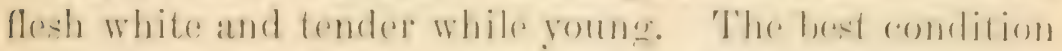
for use is when the root is from three to four inches in

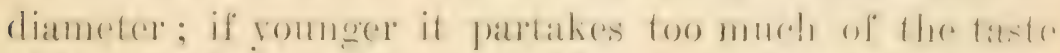
of the ('aldbatere and when oldere it is dry and stringer. 'T'he best market sort.

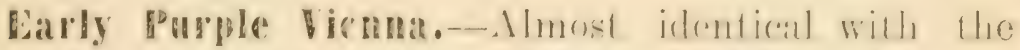

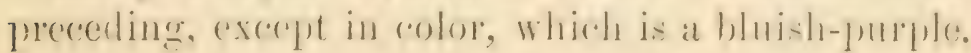

\section{LEEK.-(Allium Porrum.)}

The Leek is another reoctable that is axclusively grown as a second crop. The seed is sown in April in rows one foot apart in gromed woll prepared, as reom-

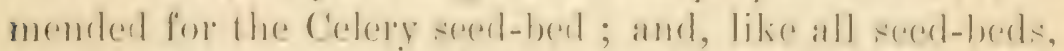

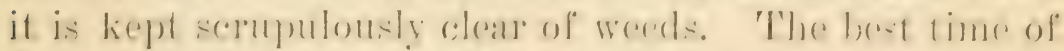

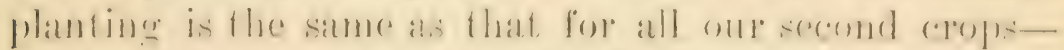

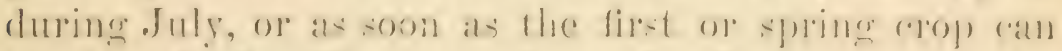

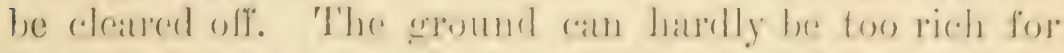
Lecks, and, when time will allow, we always rentldye to

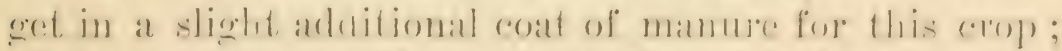

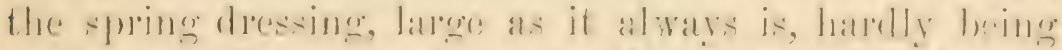

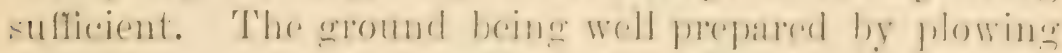

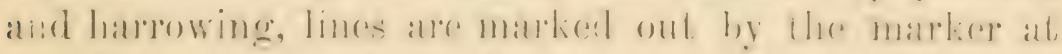
one foot apart, and the Leeks planted on each line at

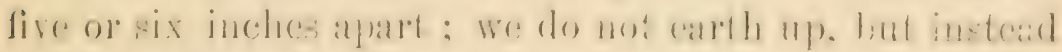
plant rather deeply. $\Lambda$ s it is a plant the foliage of

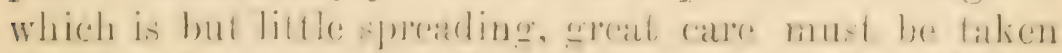

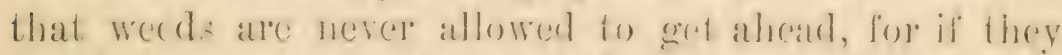
do, they maty som entirely envelop the crop to its total destruction. 


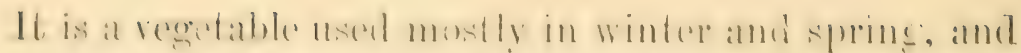

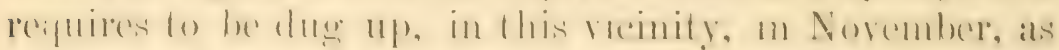

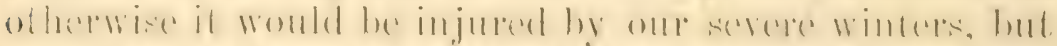

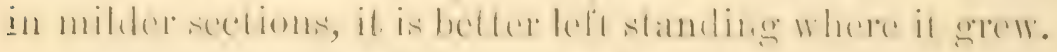

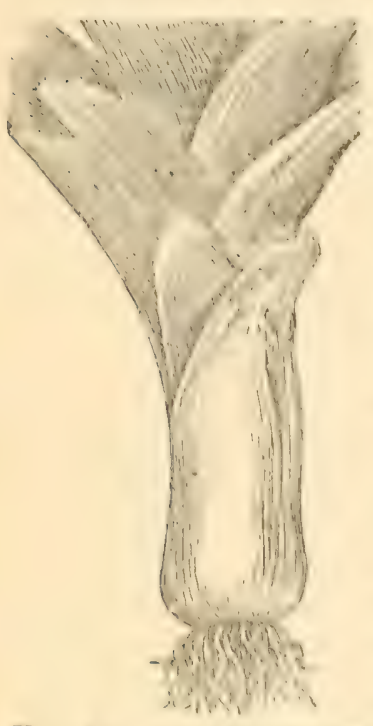

Tig. 53,-Mugseluzuram I.ENK. It is quite a handy regetable, so that twenty or twenty-five degrees below lecering will not injure it. It is preserved by the marliet girleners here in trenches, exinctly ats Colery is prescived (see Chapter on Celery.) Lamere quantities are sold in om Northern marketsat tairly remmerative rates, although, from the nature of the plant, if requires perhaps more labor than any other regetable to mepare it for market. Figure 5̌3 represents the Musselburgh Luek, trimmed p)'evious to heing bunched up for malket. from six to eight roots are ticil in each bunch, which bring in the market upon an average, inrongtum the scason, about, lifty emts per dozen

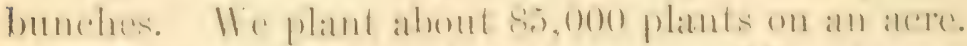

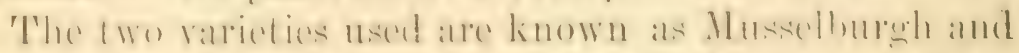

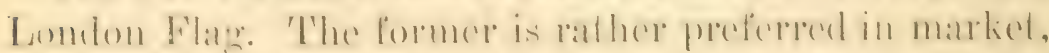

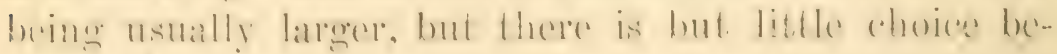
tween them.

\section{LETTUCE-(Lactuca sativa.)}

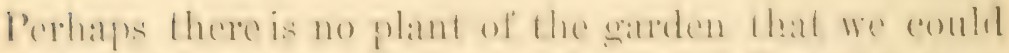

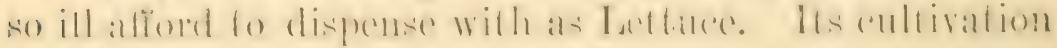

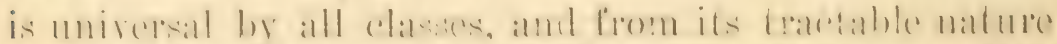

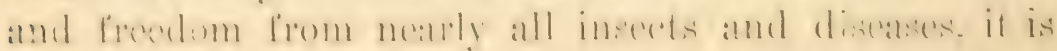
mamareable in the hamds of every one. In a well-ap- 
pointed market garden it i, the most important vegetable

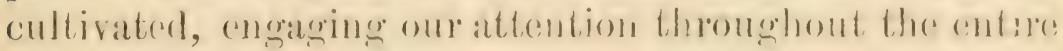
year, cither in the open esentmet in semmere, in foreing houses or hot-beds in wintere or in cold fralluse in spering. As our mote of growing it molder giases is sufticiontly dreceriber in treating of pits, frances, ete., I will in this plice confine myself to our system of cultivating it out of doors.

For our main carly cerpe, that is sold from the open gromend in the lither part of Maty ore first of Jume, the secel is sown the previous season in the open grommel, from the 15th to gith of Seprember. I'inese plants are usually large (rnough to be planted in frames foul or five wecks later, as recommended for Cabbatge plants; about fore or fo() are planted undere a there by six sath. Occalsonally we sow seed thinly in the frame in fall and do not transplant them, ats it sates at oreat amonent of labser, but they are not quite so good plints as those transplanted, ats it is dillicult to sow them so that they comes 1i!) at the regular degree of thickness. The winter treatment of latuce plants in every way similar to that described for Cabhowe plants. In dry, well-sheltered spots, by rovering up) with latres or litter. late in thr season, saty midille of Decomber, Lethuce plants, particularly of the more hardy kinds, such at Boston Mar. ket and butter, may be saved overe winter without glasis covering, in southern parts of the eomutry withont ditficulty. Like most, plants that we term harly, twenty derereses of lorest will not injure them. 'Tlue plants for setting out in spring are also sown in cold foumes in

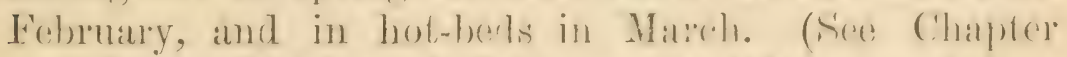

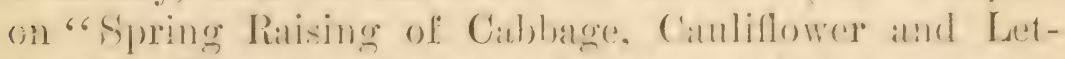
tuce.") 'To economize notonly in slater, hut i!n matume,

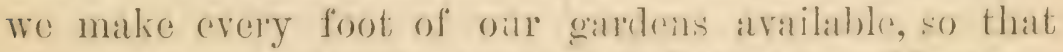
when we come to platit ont our Letituce in Mirehor Auril, instran of sotting at in a hed asclusively for 
itself, it is plinted at the same time and between the rows of Eirly Cabbage or Camblilower, which are set at two fent ipmot. Whe Lettuce matures its crop in half the time that it takes for the Cabluare, and is eons?quenie all cut off and marketer before the Cabbate i: half grown. If it were not so, they (entel not he both grown at once on the same oround. for, when the Cal)hage crop attains its growth, it repintes the full space allowed-two feet-for its development.

'This early crop of lettuee from the open ginound is considered lather an amxiliary than a main one ; it meets with a rapid sale at an arerage of $\$ 1.50$ per 10u) heads. Rather a low prico, it may be a hought: but growers hat-

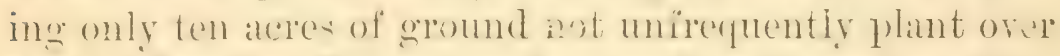

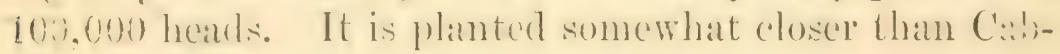
bage, usually about 15,000 per acle.

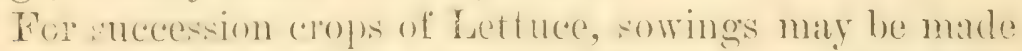
in the open grommel as arly as spring opens until only. Vinen hat planted hetween Cabhatge, they are set at one foot ayat wach way. They are sold to some extent throughout the whole summer, hut the wreat weight of the crope is sold about the first weok of June in New Tork mathess. The smmmere price ol Idetuce is rery

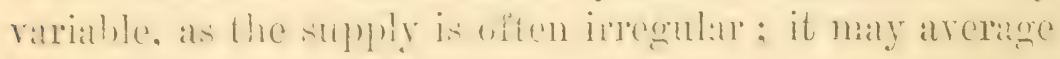
$\$ 2$ per 100.

'The pusenger in Elavated Rabiland atrs going from

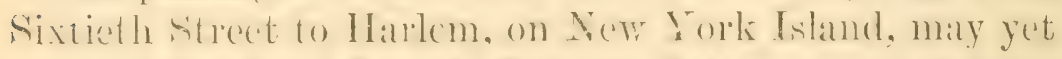

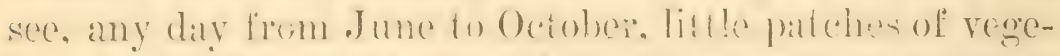
tation of dilferent sharles of grane remged in uniform and regular lines. There aro the . - valad pateles," cultivateil manly by forman marlict gatreners; they range

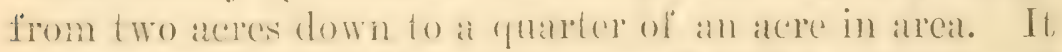
secuns a wonder that the cultivation of such a small plot of

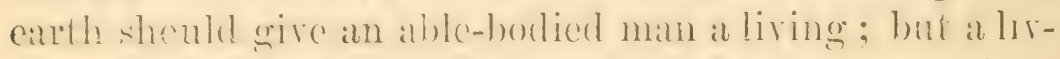
ing it deres give in nearly all cases, and some have quite a resnectible sulplus for a "rainy day." 
The manner of growing the Lettuce for the first or early erop, is the same as that practiced by the market gardener's of New Jersey or Long Island, namely, using plants from seed sown in lall that have been wintered over under satshes, whit planted out as early as the groment is fit to work, which, in these warm nowis (in mosi caises at the base of rocky elevations), i: often as carly as the first week in Marcli. In some particularly farored spots the Lettuce is planted out in the first week of Octolser, and, if it remains unscathed during winter, comes in 1 . such fine condition for market in May als to well repay the risk. The rariety used for this purpose is the "Brown Dutch."

In any section of the country where the thermometer never falls lower than ten degrees above zero, Lettuce sown the first week in Sertember and planted out the first week of Octuber in shaltered spots in dry soils, will be almost certain to "winter orer," and give a crop in spring earlier than if treated by any other method.

A plan of recent introrluction for the summer growing of Lettuce, is to mark out lines one foot each way across the bed, and at the intersection of the lines six or eight seeds are plantel, pressed down and slightly covered. 'These in the summer months germinate in a few dars. When the plants are an inch or so high, they are all talien out but one plant. This is a quicker and beter plan than planting in het summer weather, as the Lettuce plant at that season is somewhat difficult to tramsplant. Succession sowing slould be made erery two or three weeks.

T'o return to the New York City growers. The varieties grown under glass and first plinted out in spring are msually the "Butter" and "Curled Simpson," both white and black seeded. As soon as the crop is planted out, sowings are made for a succession; this tima of tha "Sallamander" and the "New York," the "Simpson" 
being unfited for the warm wather at which this sowing would mature.

'The (arop planted out in Mallech, matures hy the end of May or 1st of Jume, and ats soon ats it is cut off, the groumd is plowed or ciug orer, and the plants from the. March sowings ale sot. Another sowing is male for plants to suceed these again, and so on during the entire season, the rule being to sow seed at each time of planting. Four crops of Lettuee are usually taken from Jume to October, or nearly a crop each month.

The plants ale set about a foot alpart each way, amel will arerage one exut pre heall, so that the four erops

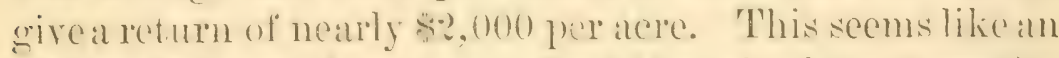
immense return for an acere, but though the not protits are respertahls, there are some serious disalliantages attending the coltivation. Few, or none, of these mentere owners of the lan 1 in Yer York e'ity nor in hardly any instance hare they a loas. 'They are trants at will, and

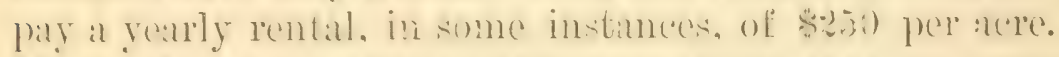
Miny of ond comntry rialers mily think that an cxtrat

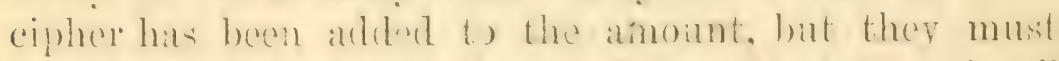

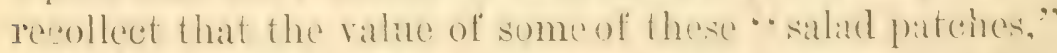

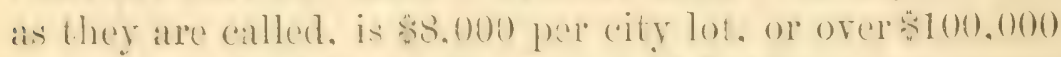

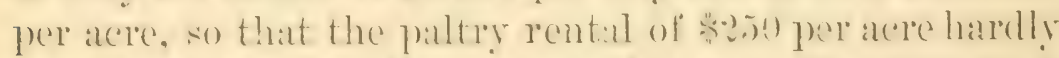
pays the interest on the amomot of taxes. The following figures were given me by one of the best and largest growers, whose patch was two acres:

Rent $\$ 100$

Mannice 250

Labol of three men for six months

Horse keep and incidentals 750 450

$\$ 1,850$

Four crops Lettuce, estimated at $\$ 4,000$

Expenditures 1,850

Annual profits for two acres.

$-\$ 2,150$

This was in $18 \%$; ; it is pobalible that now the profits would be quite one-third less. 
A pretty good proit, but deservelly enrned, for to attain this result the grower works carly and late. It must not be suplosed that five aeres entld be cultivated by one man with the abore profit. The loss from inalequate hired labor, and the difilieuties of selling larece quantities of a quickly perishable crop, would be likely to make the attem, to larrely increase the area cultirated a failure. Bisides, Lottree is on!y used to a Jimited extent in the summer and fall months, and if grown in the quantities that it is in spring, could not be sold, yet in all large citios it is used more or less at all seasons:, and commands, for limited quantities, usually a higher price than in spring, the season of its greatest consumption. No doubt the system of our New York City Lettuce growers might be suceessfully and profitably followed in the neighborhood of many other cities and large towns.

The varieties of Lettuce used for the difierent pruposes of forwarding and forcing; and for out-door culture in spring and summer, are of more importance than with most regetables. I once lost almost my entire crop of Frame Lettuce, from planting the Curled India, a summer variety, instead of the (nrled Sim?pson, which I had got from

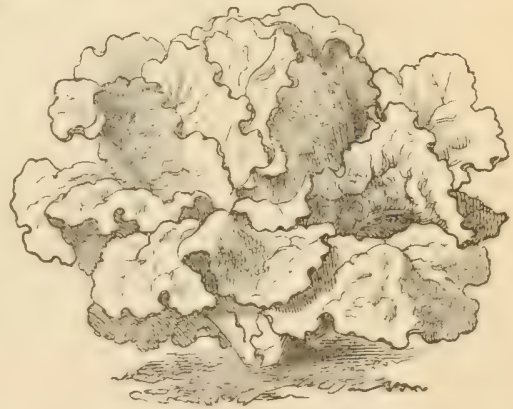

Fig. 54.-E.tri.y C'liLd simpson LETTUCE.

a well-meaning but not rery laurucd friend, whose hieroglyphics had got transposed.

Larly furled Simpson,-(Sce figure 5-1). This is still the most generally useful variety for all purposes, and so I place it at the hearl of the list. Properly speaking, it dons not head, but forms a close, compact mass of learce, which are of a yellowit shate of reen and much curled. 
This peculingity allows it to matme quicher than varicties that form tim heads, and gires it its ereat desiderattum-citrliness. It is the lind that is litregely plintert in cold frames, although not so larerely as the boston

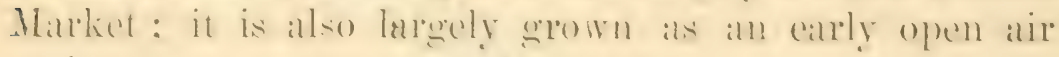
variety betreen the rows of the Cabbage crop.

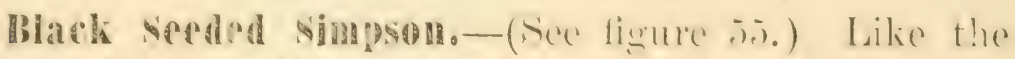

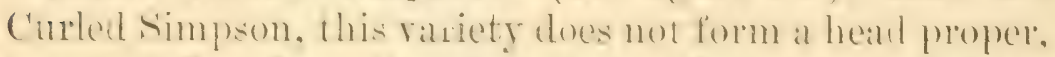
hut it dillers froni the preveling in being much lighter colored, the leares being creamy yollow; it attains a size

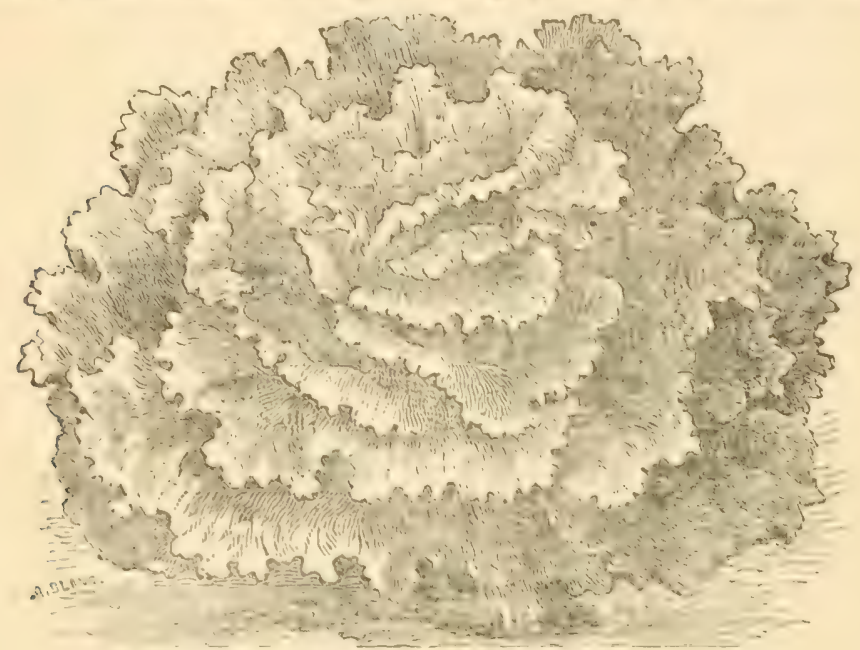

Tig. 55.-BLACK SEEDED SIMISON LUTTUCE.

nearly domble that: of the Ourled simprom. It stames the

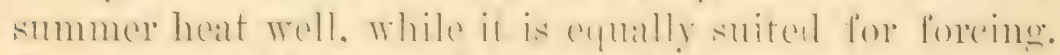

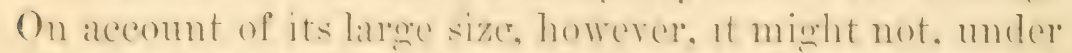
some eirementances. prore so profitable as a strictly forcing sort, such as the Boston Market.

Black Gefoled Tennis Ball,- I lavorite foromo vamcty. andi. as the name indicates, foming a hard hear. It makes tew onter leares, and for lhes reason wan be

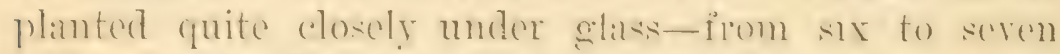

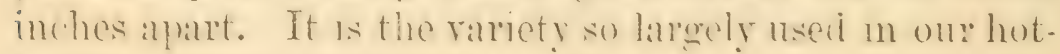
beds and forcing-pits un greenhouses. 
Boston Market, or White seeded 'Tennis Ball.-This is an improved rariety of the 'T'ennis Ball which attains a larger size. It grows very compact, is beautifully whito and crisp, and is one of the rery best varieties for forcing; in our opinion it is preforable to Black seeded Temnis Ball.

Salamander.-(See figure 56.$)$ i grind Lettuce for summer use, forming good - sized, compact heads; in color it is light green outside and white on the inside. Its great merit is that it will withstand drouth and heat, and remain longer in head without bursting, than any other

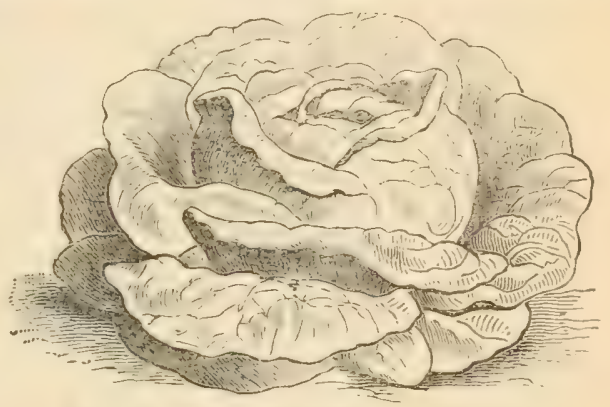

Fig. 56.-DALAMTANDER LETTUCE.

variety except the "New York." Is largely grown for Philadelphia and New York markets.

Vellow Seeded Butter.-Like the Salamander, this stands the summer's heat well. It is a very distinct sort, making a large, denke, yellow hear, very crisp and tender, and of excellent flaror. Its beantiful yellow heart gires it a very handsome appearance.

Iarge White Summer Cabbage.-One of the rery best late rarletics for summer; heads of goor size, close, and well formed. It is a splendid market variety.

New Vork.-(See figure ji.) This is a remarkable stummer Lettuce introduced in the spring of 1886 ; the size and solidity of its hearl are unmial. Te have seen it eighteen inclies in diameter and weighing nearly four pounds, with heads almost as solid as an Early Summer Cabbage, which $m$ form it somewhat rescmbles. It blanches itself naturally, is crisp, tender, and ot excel- 
lont llavor. It will not do tor loreing, but is almost

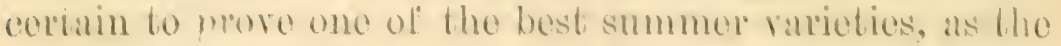

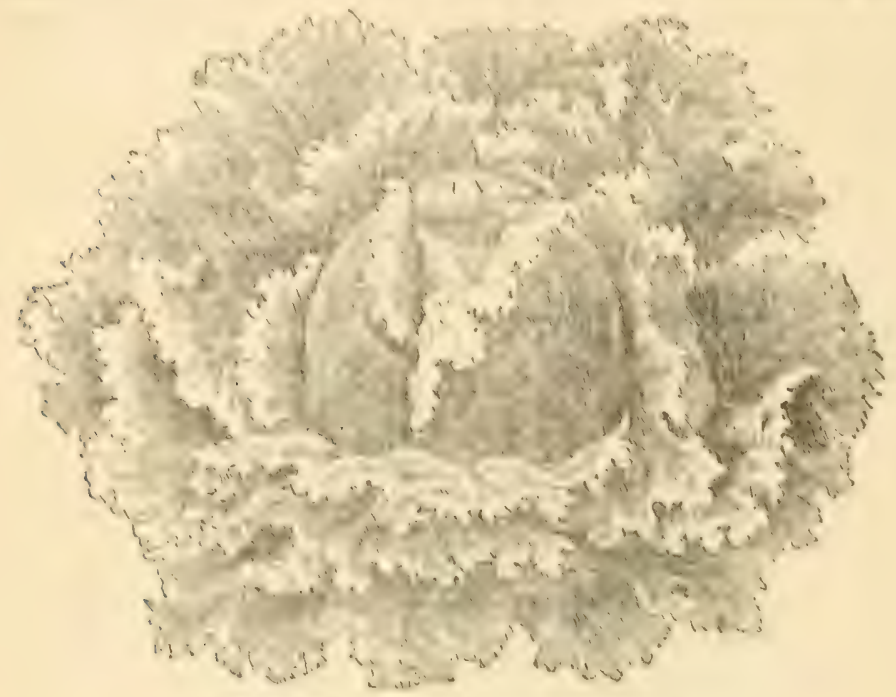

Wig.

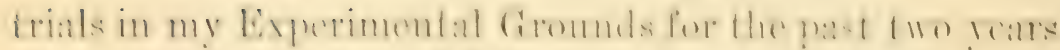
show it to bo tho last oi filty kinds to rmo to secel.

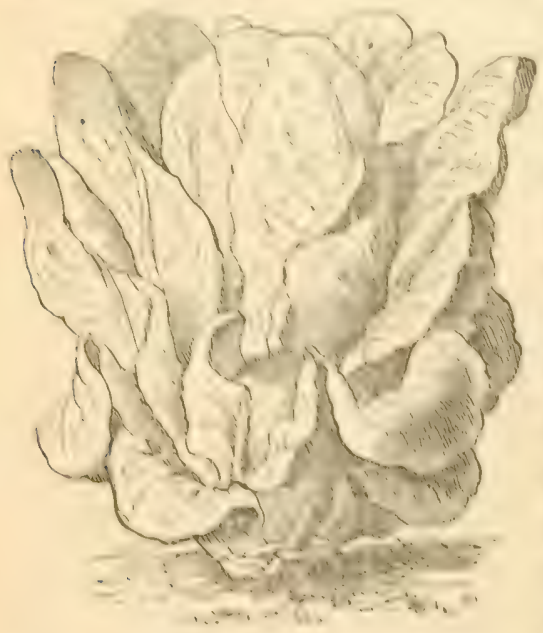

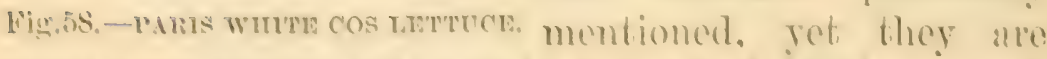

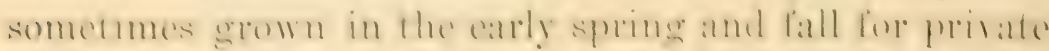

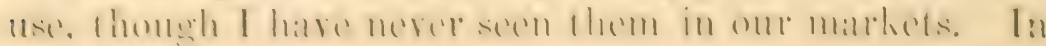


shatpe they difier materially from the other varieties, the

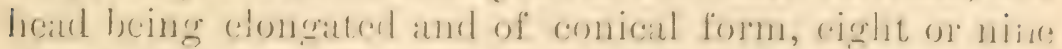
inches in height, and ti:c or six inclues in dianeter. 'ill color of this varicty is yellowish-green. 'T', be harl on prefoction, it resuires to be tied up to ensur\% blanching. Millions of this rarioty are annually grown to supply ting matrets of Londen alone, where it is preferred to all others.

\section{IIARJORAM-SWEET-(O)'igumum Marjiram.)}

A well-known anomatic lespl), grown to a consistrable extent for market purposes; but ats it is of less importance than 'Thyme, which is grown very latredy for sal., the reader is reforrel to that had for all information regarding its calture, price, ctc., as in the particulars they are entirely identical.

\section{MELON.-MUSK-(Cucumis Melo.)}

The II Ion is not culivatel in the vicinity of New York in the market gardens nopler, hut to a larse extent in what may be called the fiam garidens of hong Island and New Jersey. 'There it is grown alnost in the same manner as they grow Corn, planting about the same time and cultivating in the sane monner, and often with but very little more profit per ace than a cropof corn. but the Melon is a fruit ansily s!ijpger?, and roisen grown by the forwarting procens we detal for cucumbers-by planting the soeds on cods under erass-there is no question but that it can be male equally profitable in all repecte with the Cucumber, when grown in southern latitudes for our northern markets ; aithough, like many other fruits and regetahles so asily ratised, it cam 
never be expected to be very profitalle if sold in the district in which it is grown. It is a plant not at all particular as to soil. provided it be not wet or heary. Ioldutely enriched, light soils, are those most congenial to it.

For open field culture. M[elons shoula be planted in hills sis feet arch way, incorporating well with the soil in each hill a comple of shorelfuls of thoroughly rotted manure. Siow four or fire seeds in each hill, * and cultivate afterward as for Corn.

A clover soul is especially faromable for Melons. The main point is to push the crop forward as rapidly as possible, suas to catch the high prices which usually rule for an early crom. One of the Melon growers of Hackensack. New Jersy, atmitted to me that he had lost the whole of his late (rop) hy witholding the exponditure of s.5 or s:30 for guano on his fieia oi tweive acres, which, if used at the planting. Wonld have pushed tie crop forWall six or eight dars and would thus have sared it from an carly fill frost. For this leason, a dressing of wnatno or bonteineal. Well mixed with the soil, should always be used ii we would attain the most profitable lesult: It is a crop that can be as casily raised as a crop' of ('oru, and when sold at wholesale, it is salfe to say, will always pay a prolit of at least $\$ 100$ per acre. The variety most preferred for this section is that known as Hackensack. Which is grown by the hundreds of acres for the New York market. 'The most successul growers greatly increase the yield of this erop by a system of

* The term "hill." when usad here and elsewhere, meaus but a slight eleration of the surfa.... ant is usel onl s as a courenient term to denote where the seet or nlant is to be plante l. Bui from the sirnitication of the worl, it natarally lat ls the norice in warienin? into very serious ewor, by causing him to thin's he must litaralls raise a hill on which to sow or plant, ad in consaqueace me too fricuently see plants elevater on little knolls a foot or more abore the general silface from which the rain slides, and on which the sum beats to their utter destruction. 
pinching the main rine, so a: to encourage the lateral shoots upon which the fruit is borne. A large grower in the vicinity of Lackensack. Aew Jereer, a noted locality in this respect, gires the following details of the culture:

Melons are a special ciop which needs praticular care and culture. In some localities they an grom for market in great quantitics. It is silid that, on one evening in 1885,160 twu-horse wagon loads, each of about 1,000 Melons, crossed by one ferry from a suburb of New lork City. And this was by no means an extra occasion. The Melon saran lasts from Juiy into October, so that some ilea may be gained from this of the magnitude of this business. The crop is a rery profit. able one when slilfully cultirated, and often realizes $\$ 500$ to $\$ 1,000$ an acre, and more rarely eren as ligh as $\$ 1,500$, when the Melons are the first in the market and bring the highest price of the scason. But as with other products, these large profits are only realized by those growers whose long expericnec and skill gire thom more than usmal advantages. The methods. howerer, are no secret, and any one who will fullow them may just as easily meet with the same success.

The most suitable soil for lielons is a rich, warm, deep, sandy loam. haring a southern or southwesteru exposmre. The latter is preferable, as it gets the last rays of the sum and the soil is thus warme? np for the night, and, being sheltered from easterm and northern winds, retains this warmth until the morving. This may make sereral dars difference in the ripening of the crop, which may be erquivalent to $\$ 300$ or $\$ 400$ an acre in the ralue of the fruit. 'The manner of culture is as fullows: The soil is plowet in the fail or carly in the spring and is cross-plowed the first dars of May, about twenty loads per acre of mamure being plowed under, in addition to the special manming for cach hill. The ground is then well harrowed and furrowed out six feet 
apart cach way. I pood shovelful of mixed fine manure and night soil. together with a small handtul of guano, is used in each hill. heing mixed with the soil. for nine inches deep and tweily-foul inches wide: six or eight seeds are planted in cach hill. Whe first planting is early in May : other plantings may be continued through June. The hill is raised tro or three inches abore the surface and is male about two feet broad and quite flat. When the plants appear abore the surface they require protection from cut woms. which would otherwise cut the stems and destroy them : and as the rough leares apreat, the weaker blants are thinned out and only thee leit. A gool methou of protecting the plant: aymst the cut wome is to make a ring of thick papere aibut a for in diameter and inree inches hroad, and pridee this around them, so as to form an olstatele orer ntich they camnot climb. The afier cultivition (onnsists of decle plowing at intervals. at lasis twice. and freduent cultivation, until the rines begin to run, when the termina? huts are pinched ofi to canse the growtli of the lateral bianches. The main rine produees chictly male or barren flowers, and if this is left to run, the laterals would not push out and there wonla be little or no fruit. 'The lateral shoots liar the feriale or perlect flowers, and to cucourage the growth of these, is one of the secrets of Mclon culture mpon which the profits depend. The same peculiarity of growth is found in all the courd tribe, and

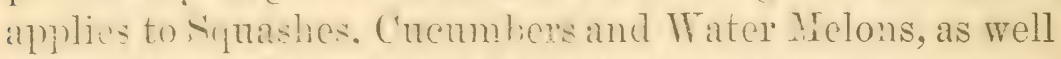
as to Mnsk Mclons, (areful atention to which, other things being right, makes succoss certain.

The pests of the Biclon are lice, the striped beetle, and the syuash bug. Th" lice anpear on the under side of the leares and anc diticilt to get at. so that the simplest and most cifecotive remedy is to prich off the affected leares or the patt of the rine and carry it awar and hurn it. If left undisturied. the lice from one hill will quickly 
spread orer sereral square rods and completely destroy the erop. A sure preventive against the lice or Aphis is tobicen, which, if cither in the form of refuse stems or dust, is strown on the hill, the lice will nerer appear ; it will also act as a preventive against the striped loug. I'he striped beetle is the worst enemy to deal with. It lays its egges on the stem at the ground, and the small gruls work their way to the root and feed upon it. 'The first indication of their presence is the witing of the laves- "going down" of the rines, the growers call it -and vine alter vine thus goes down, until at times the largil part of the crop may be destroyed when the Melons are half grown. 'T'he remedy for this pest is to apply strong tobacen watri aromin the stem on the first appearance of the small striped beetle and repeat it in a feo days, and to repeat it agin as suon as the wilting of the first leaf is noticed. 'The fruit hegins to "net" about two weeks before it ripens, and the indications of ripeness are the fragrant secht, the soltness of the blossom end of the melon, and the cracking and easy parting of the stem.

Too much care camnot be used in sowing the sceds of all plants of chis class, als they cross very readily; for this leason, when seeds ale to be sared from any particular variety, care must be taken that it is widloly removed from any othel--not less than 300 yallis. If sesl is not wanted, impropor crossing will make no ditference to the fruit that season, hut the seed-the prodirct of that crop-will be affected therebr, and it.s impurity developed in the fruit raised from it.

From the facility with which the Melon intermixes, it follows that the varieties are rery numerous, and for the same reason it is difficult to retain rarieties pure. The following seem to be the most fixed in chaliacter, and are the varieties in general use:

diary Uachenack.-This is an improrement of recent 


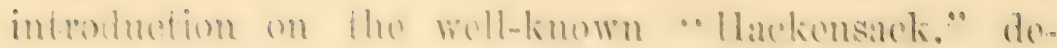

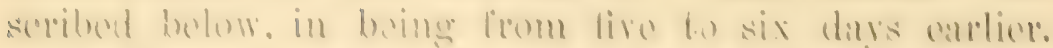

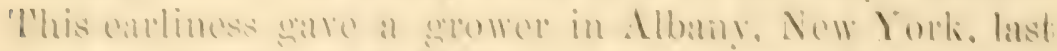

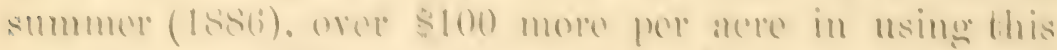

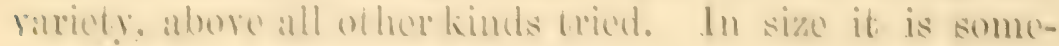

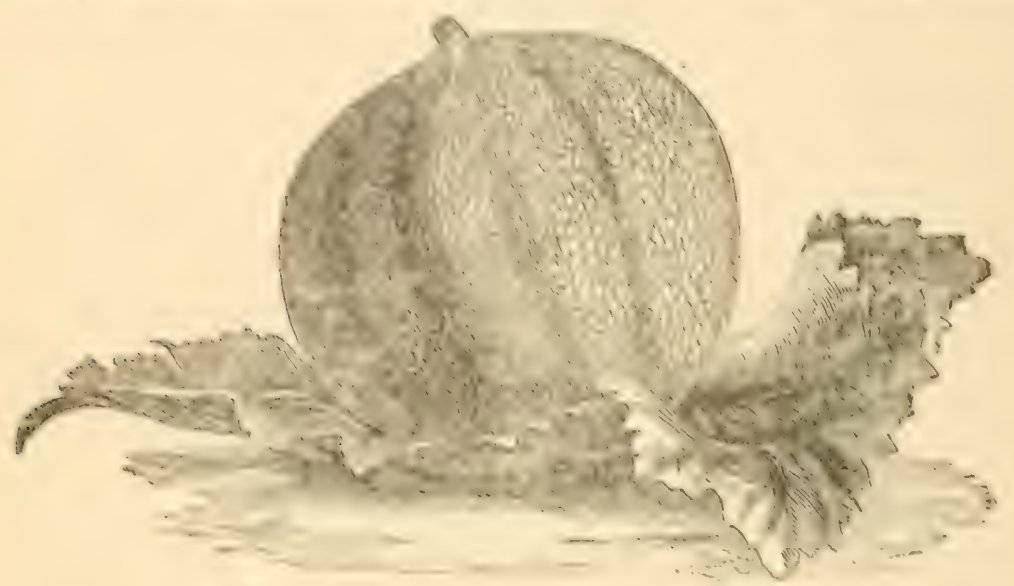

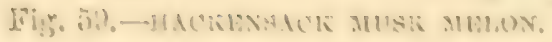

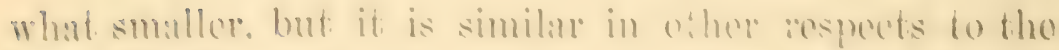

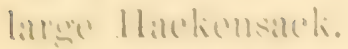

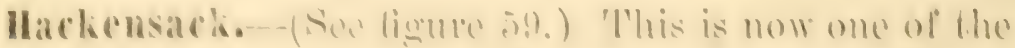

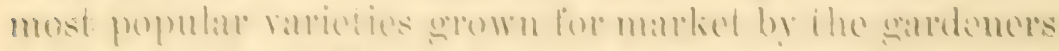

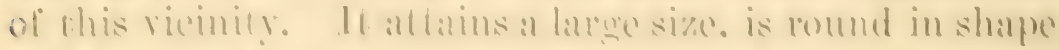

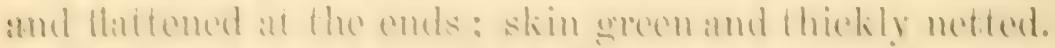

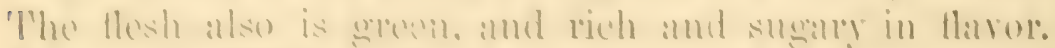
It is momderlully pouluediro.

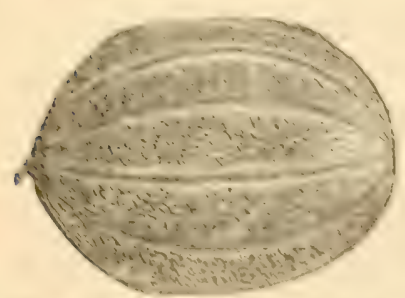

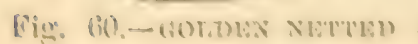

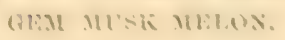

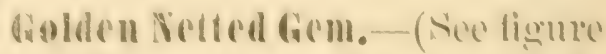
(i). This is ome of the carliest. ame no dombet the hest small Melom

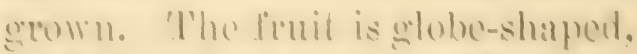
milom in size. woighing from one and a quartel to ome promed and a hall' cilch. 'The hesh is lightweren, and of time havor.

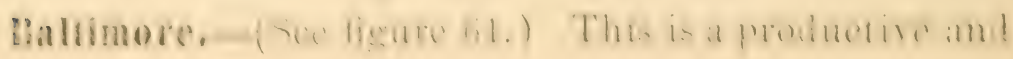




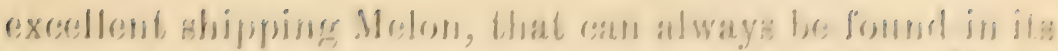

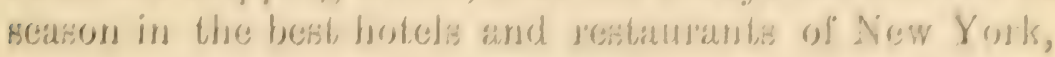

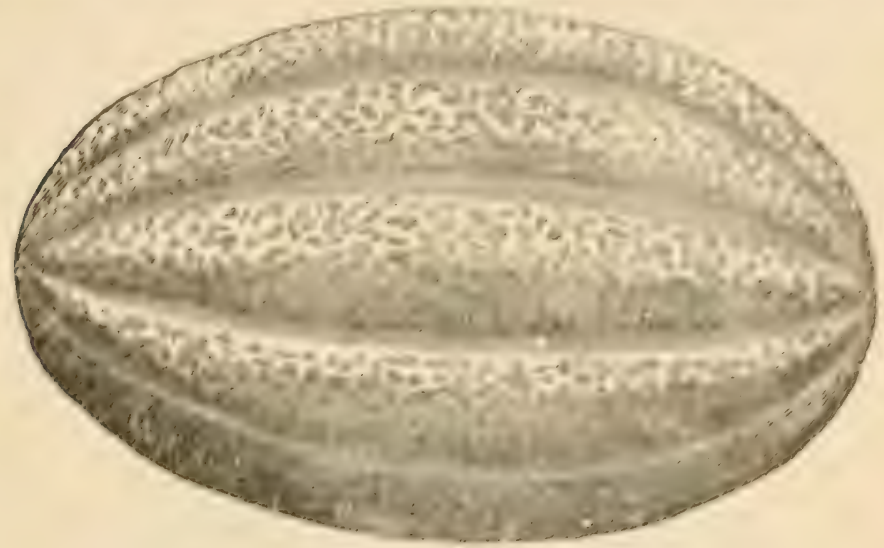

lesp, li1, -

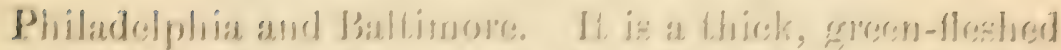

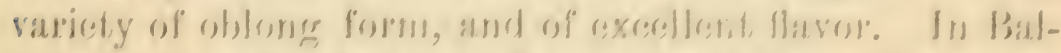

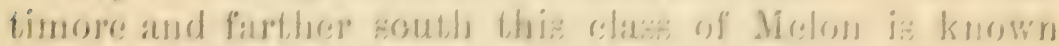
a's Ciantalonims.

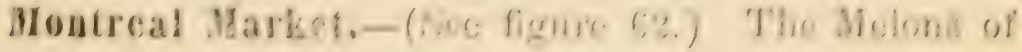

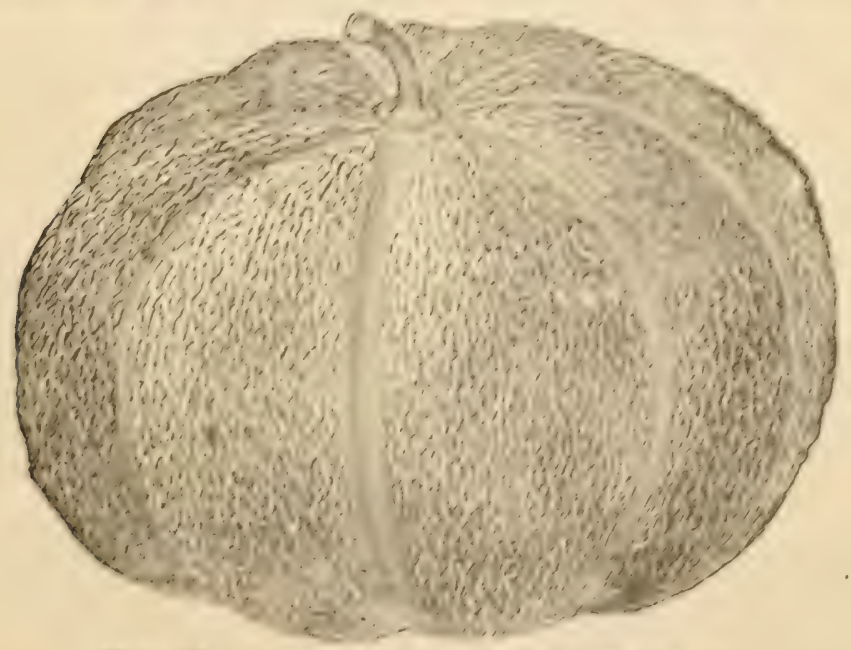

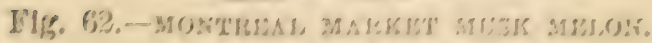

this coxcellent varicty are of the larecest sizo. We bave 


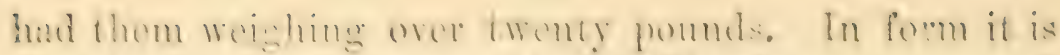

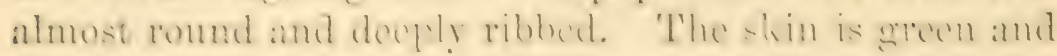

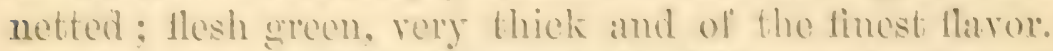

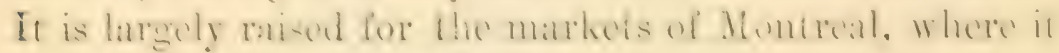
is justly highly csteomod.

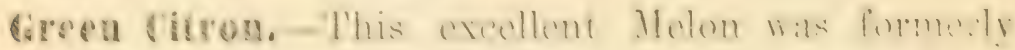

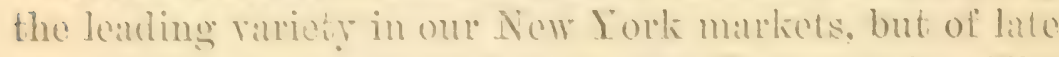
gears it has been supurseded by the Harelemsanek. The irmit is of medium sine cheply methed, of globular shaph

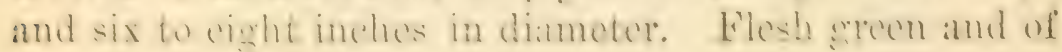
time flitror.

\section{MEEON. -WaTwe-(Citrullus vulgaris.)}

Tike the Musk Molom. When enltivated for sille. this is essentially a plant more suited fore the firm than the garden, as it repuires eren more spree in which to grow. 'Tho soil best suited to it is a rather sambly loam. heatrier

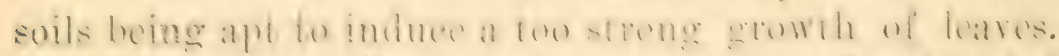
It should be flamtad about the same lime amd enla isated

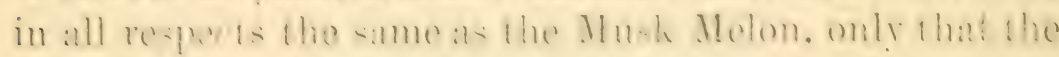

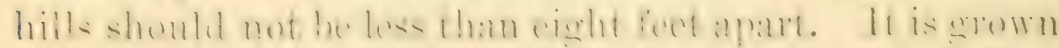
in immense yusmtition on the liche samels solk of New

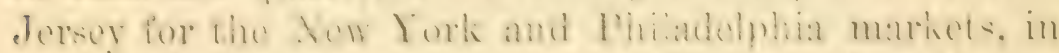

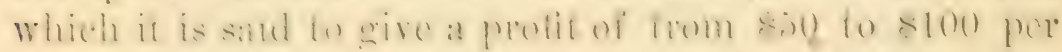
acre. But it is in the ricinity of our Southern eities-

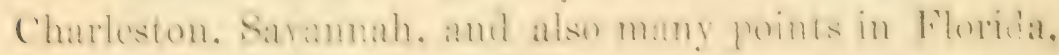
ete. where we have regular stcamboat communication, that these trophical fruits cam be grown at a high rate of piolit to the eultivator.

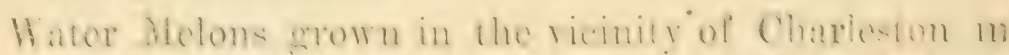
July aresolet hy the tens of thousamis a Xis Jork to the consumer at $\$ 1$ meh. white these wewn in tombern

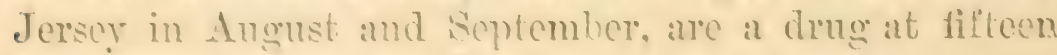
and twenty-firo conts. 'The leading rarieties alle: 
Phimeg's Darly,--Verg ratly, productive, of modium size and quality.

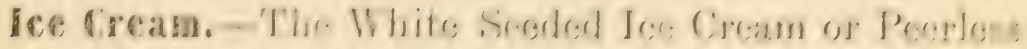

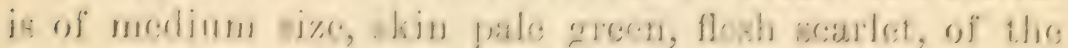
best quality.

Moundain Sweet. - An old favorite. It is of laverelize,

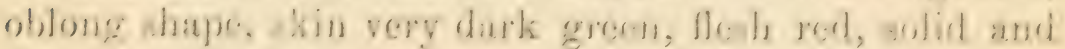
very sweet.

liallemuake or dypsy.-(Bec figure (6.).) Now jurhape: the |riblung mariset varjety. 'The Melone are chlong

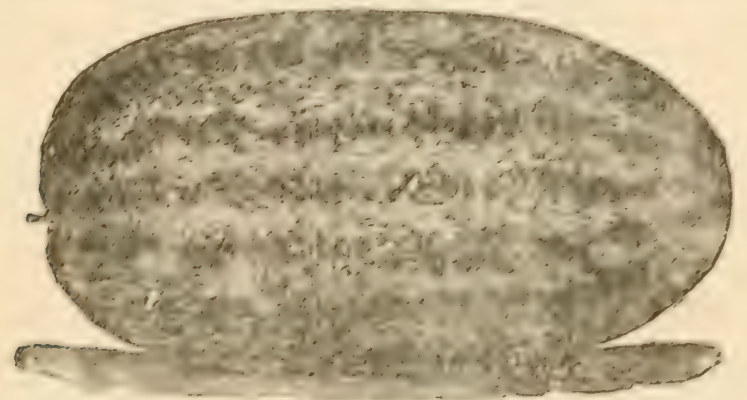

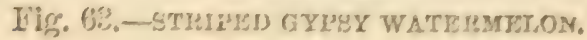

in shape, the rind is lightit green in color, with wavy stripes of darte green; flowh bright rest and of fion flaver. One of the very best Mlolons for shiproing.

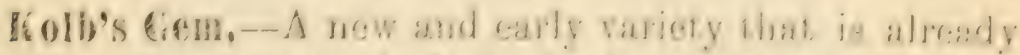
largely grown, particularly in the Bonth, for ahijument is

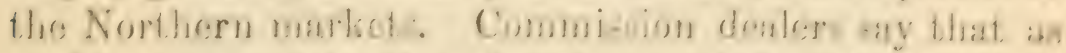

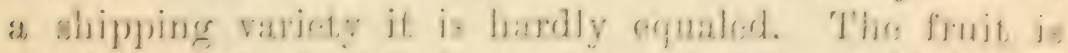
noarly round, rind das! corene, fomewhat marbled with lightres ahalea. The Mloloma wibl asp from iwenty-fives to fifty pounds each in weight.

Mammoth fronclad.--This wately is of manmoth size, specimens ofien weighing righty promeds and njwards. Ther rind is masked with regular strijes of lighe and dark grenon. It is a very showy rariety of fair quniity. Shape olslong. 


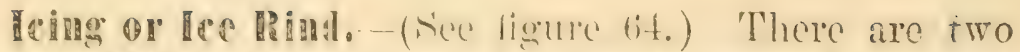
tynes of this Melon-dirk and light, both of excollent

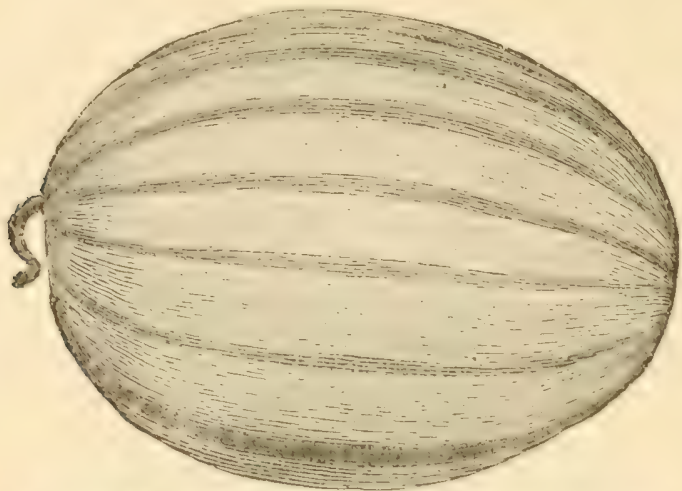

ㅂ.

flatror. This is the lavorite rariety of the mollet gardeners of South New Jersey.

Back Spanish. Fruit mediume size, almosi round;

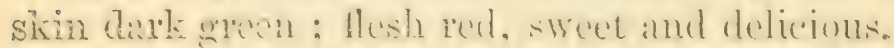

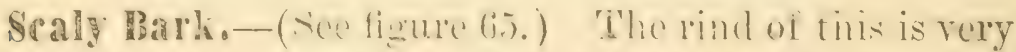
thin, and got so lough and stroing that it will hear any

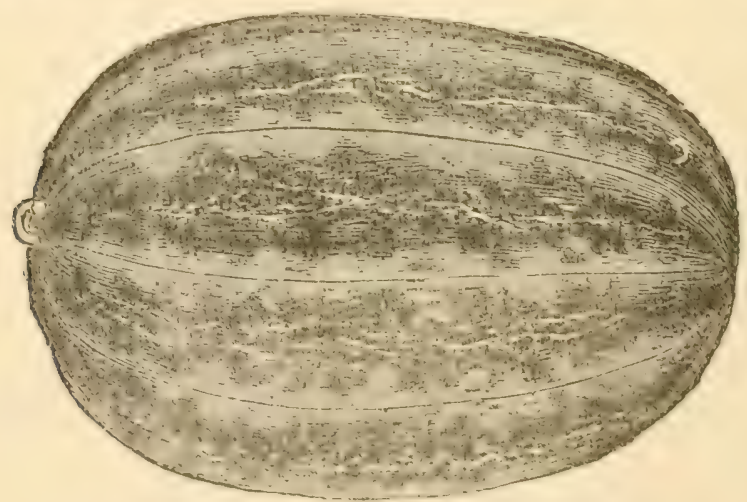

Fig. 65.-SOALT BARK TVATERMEION.

amount of handling before hursting or cracking open. This characteristic wires to the variety special value for shipping purposes. The llew is light scarlet in color, and 
of excellent flaver. 'T'o give some idea of what prestrie this variety will bear, we state the fict that, in 18s.1, a specimen of this variety left at our office stood a pressure of 1 , D.jo pound before breaking. 'T'here are numerous other varieties constantly being ofiered by seedsmen, a few of which are meritorions, althengin the majority of them are worthles. Besides the sorts alleady given, the rariety known as Pride of Georgia is worthy of mention.

Oitron.-Outwally a rery handsone Melom. The fruit is of small size, but not worth growing ats a ripened fruit. It is used to some cxtent for making sweetmeats, for which purpose it is alone cultivated.

\section{MINT.-(Mentha viridis.)}

A hardy perennial plant. fond growing in abundance along the roadisides in many ulaces. It is often grown in gardens, however, and is used in sonps, sances, salarls, etc., very generally. It is of the casiest culture. It is increased by divisions of the root, and planted at distances of a foot apart. It quickly forms a mass, which may be cut from for many rears without renewal. It is grown to a considerable extent in hot-beds and forcingpits, in the same way as Letence, and sold in the markets in early spring:

Its treatment there is very simple, being merely to lift up the roots in solir mass, placing them on the three or four inches of earth in the hot-led or bench of the forcinghouse, and water freely as soon as it begins to grow. The sale is not large, but growers realize about $\$ 10$ perp sash (three by six), for what is thus grown throughout winter and spring. 


\section{MARTYNIA.-(Nortynia proboscidea.)}

A regetable used to a consilerable extent for pickling, the pods or fruit of which are grodued in the areatest abmulance. It is cultivated by sowing in open ground in April or Mily, and transplanting to two lect ratch way in June; it is fit for use in July and August.

\section{MUSTAID.-(Sinapis alba, and S. nigra.)}

Is used for culinaly purposes ats a saldal. usually in conjunction wit? Gess. For this purpose it may he had throughout the entipe scason, hy sowing during winter in hot-beds or lopeine-pils, and, on the opkning of spring, in the open eround. whire, by sowing at intervals of

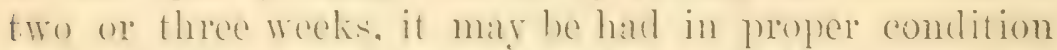

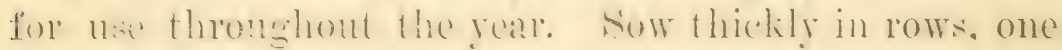
foot apart, on any soil.

White Mastaglo--Chis is the variety mostly used as a salad: the secols aro hrieht yellow, and are used in the manufacture of the Mustard of commerce.

Bhack Mustand.--This valiety is hardly distinguishahle from the prexeline. exeept in the color of its sects. which are dirk-brown: they are used for menticinal purposes, and also in manufacture of Mustard.

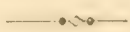

\section{MUลHROOM.-Agaricus eampestris.)}

I know of no reogetahle which has such a novelly and interest to the beginner as the cultivation of the Mushloom. In all other regetables hesecs something tangible to start with-seeds, plants or roots ; but here we may cimost say he sees neither, for the seeds camot be seen 
with the naked eye, and it reyuires an unusual effort of the imagination to beliere the white moldy substance we call spawa to be cither plints or roots. There are so many different systems of glowing the IIushroom, detailed in most of the works on gardening, that the rearler is too often bewildered in choosing a ande. In this I will only detail one methon, which I have plucticed for many years with unfailing success.

'I'o make the cultivation of the Mushrom profitable, it must be done in a bulding, either surectly erected for the purpose, or in some shed, stull)!e or cellin already on the premises, and which can be converted to that use. 'The most, suitable place, in establishments having greenhouses, vineries $\mathrm{or}^{\circ}$ forcing pits, are the bas:sheds, usually erected orer the boiler pits, such as are shown in the plans of forcing-pits in this woris. But such a structure is not indispensable. Any

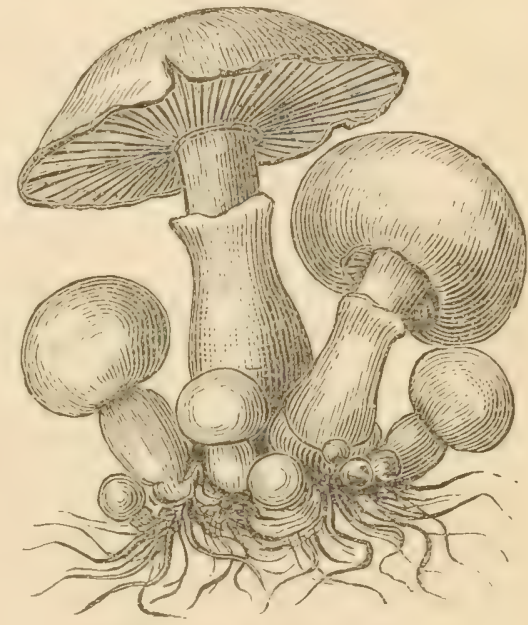

Fig. 66.-Musilrooms. place where a temperature of from fifty to sixty degrees can be sustained during winter will suit. We have also grown then under the stages of our greenhouses, but our "modern improvements" of late years allow us no longer room for the operation there. The time of beginning may be any time during winter. We hare usually begun our preparations ahout December 1st. which brought our beds into bearing about February 1st, at the season that Mushrooms berin to be most wanted.

Our method of growing Mushrooms is very simple, and can bo accomplished to a certainty by any one conforming 
stretle to the following diredions Lat preh horse

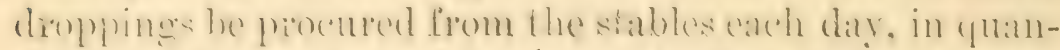
tity not les. perhaps, than a good batrow loal : to wery

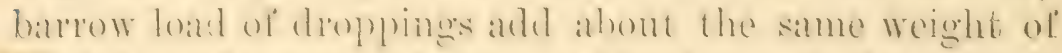
fresh lom from a patsture or sod latud. or soil of any kind,

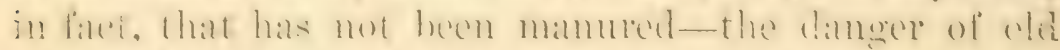

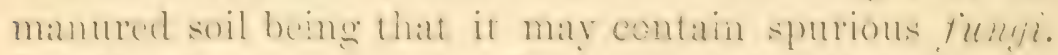
Let the deplones and soil he mised towether, dary by

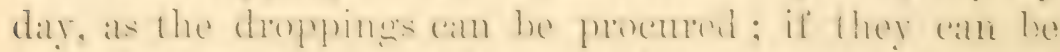

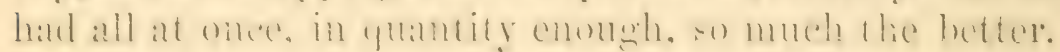
Let the heap be turned every day, so that it is not allowed to heat violently. until you have got quantity

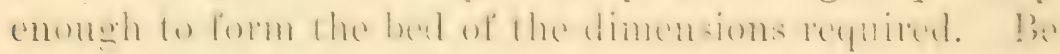
careful that your heap is under cover, so that it cammot possibly get wet.

The most convenient size for a bed is from fom to five

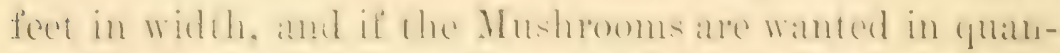

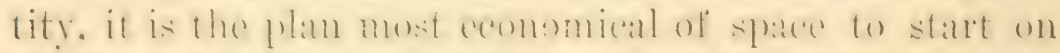
the lloor of the bonse with the lirst hed. the ad litional ones

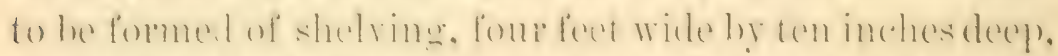

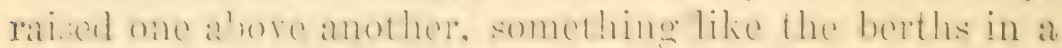

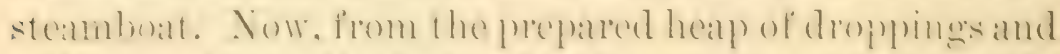
soil. spreat orel the hed a thin taryer ; pomet this firmly down with a herele : then another layere pounted down as before and so on until it reaches a depth ol cight inches. Be carcul that it he no mone nor less than eight inches; mole would ramse the mass to leat tor violontly. while

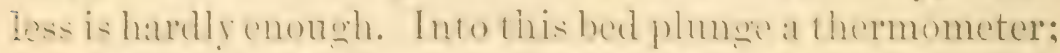
in a day or two the bed will heat so that it will run up to

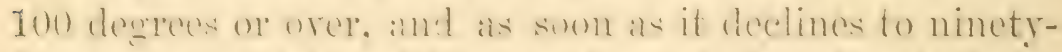

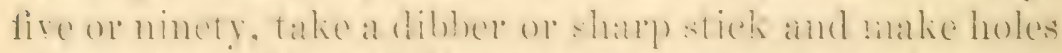

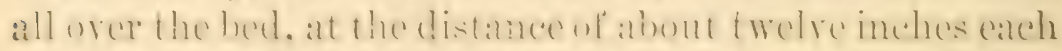
waly, to about hall the depthe of the bed. Into calde hole

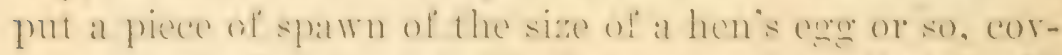

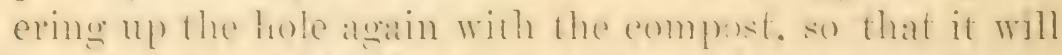
present the same lerel firm surface as hefore the spat wa was 


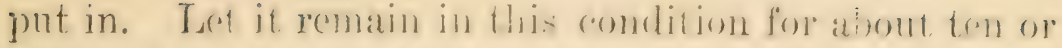
twelve days, by which time the spawn will have "lun"

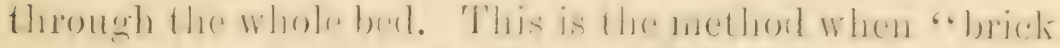

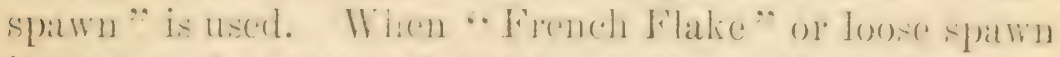

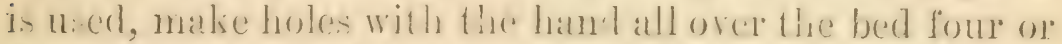
five inches deep and wirle, in whish place a handful of the loose spawn, and again beat it down to its oroginal fimm-

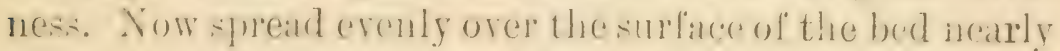
two inches of fresh loan, firm it down morlerately with

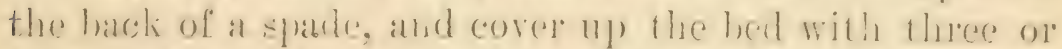
foilr inches of hay or straw ; this completes the whole

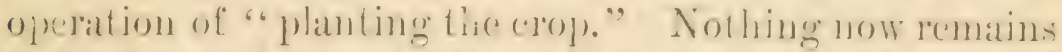
to he done hut to give attention to the propere degrees of heat and moisture.

If you can rontrol the means of heating so that the plare can be liept uniformly at a temperature ol sixty degees, all the better, but if not, it maly lange from

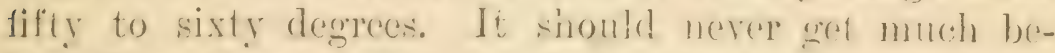

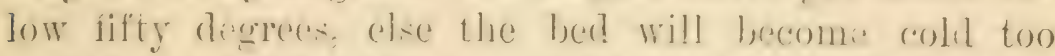
quiblily, and delaty the clope until too late in the season to be profitalule. Unlese the air of the houre has been mun-lally dry, the Mushooms will apjear before any watre is repuirerl. IBat examinationshould be marle, and if the surface of the bed appears dry, a sent le sprinkling

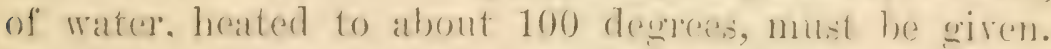
With this tratment. berginning in I)ecember, our firet crop is rarly for use in Felnotry, ant as the Mushrooms

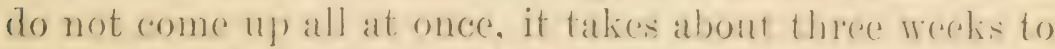
gather the (arop). which is fit to gathere when the Mlushrooms have got to he an arerage of about thee inches in riametre, the under side haring a relicate pinds color. In gathering the crop, it is best to give the Mushrooms a slight twist, so as to disturb as little as possiblo the young ones which usually (o)me up) in dense clustres as shown

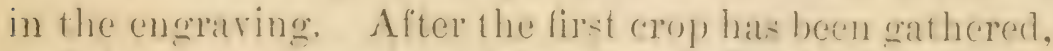
a slight desesing of fresh soil. of about hall an inch in 
depth. is spreat orer the hed, and again beaten down with

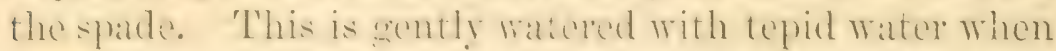

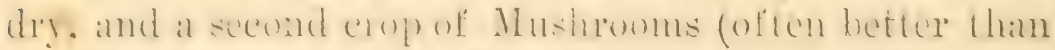
the first), is gathered in March.

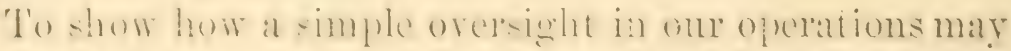
defeat the whole work, I will state that, in my tirst altempt at Mushroum elowing. I labored lor two gears

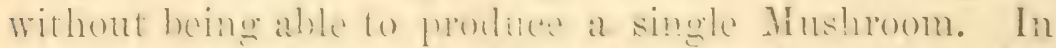

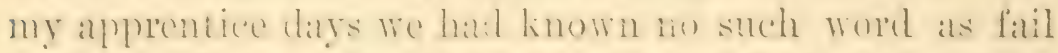
in so simple a mallier. hall here. on my lirst altempt on my own respensibility. I was met hy total falilure. Every althorit! was onsultat, all the valdous methods tried, but with no betien sueces. In all such calses something must be hamed, amel l prommoned the spallu ats worth-

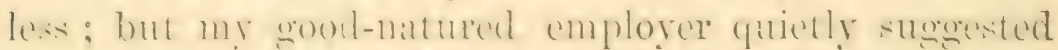

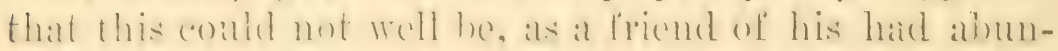

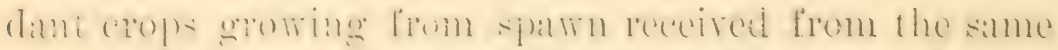
somper. I piven buto a eomer by this information. I male

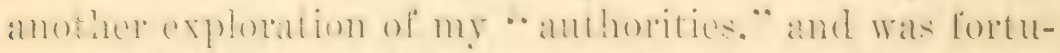
nate to thed in one of them at single sentenere that at once

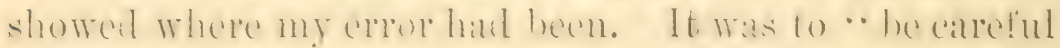

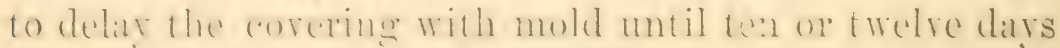
aitor the bed had been spawned."

Now. In all the different molhots I had tried. I had in

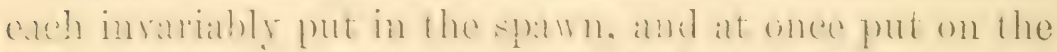

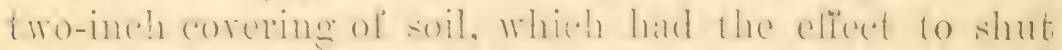

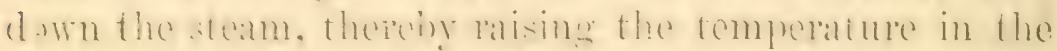

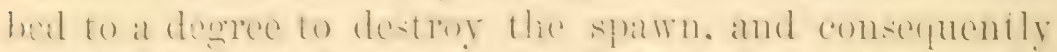

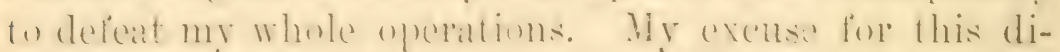
aresion is to show the imm mater of what miwht otherwise be thought mmecessary details.

'The plan of one of our most suecesful Mtushroum growers in the neighborhoud of Xow Yore is practically that of my own just given. exerent that he makes a ditfersmee in eovering. Insteat of using the two inches of loose soil. as was my method. he nsen old complat sod, 
cut two inches thick, placeing the grassy side townwarl. This he has found in his experience to be the bert method, which his extraordinary suceess secms to well atiost.

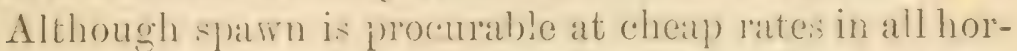
ticultural stores, yet to such as desire to make it themselves 1 give the following brief directions. Take equal prortions of horse driplunger, cow dung and fresh loam ; mix the whole thoroughly together, as you would malie mortar ; then form it into cakes about the size of large bricks; plate these on edge, under corer, until they become half dry; then insert into each a piere of spawn half an inch or io sfuare; let the bricks remain mutil they

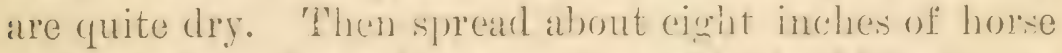
dung over the floor of the shed, on which build the brickis in a pile three feet wide hy three feet high, keeping the side in which the spawn has been plit uppermost ; then crover them over with sulficient stable mallures so ds to give a gentle heat through the whols. In two or three ireoks the snow will have spread it:alf thromen the whole mass of each brick. Ther are then remorecl to a dry place, and will retain their rital properties for many year:- There is not the least question that the cultivation of Mushrooms for market, foreed in the mannere detailed, will give a lareer profit for the lohor and calpital invested than that from any other regetalile. 'Tho supply has never yet been half enough, and soller's have lian prices almost pretty much as they pleased.

I know of no house in this ricinity-there are some, I heliere, in Canalit--that have been especially erected for the purpose, and the markets have heen supplier from berls formed in out-of-the-ray corn swe, giving only an nucertain and irregular supply, very disconarging to buyers. I have no doubt whaterer that Mnshrom houses, roughly built, but exclusively devoted to that purpose, would, in the vicinity of any of our large cities, pay a profit of thirty per cent. per annum on cost of construc- 
tion. I am oflen asked if it will pry to ratise Mushrooms

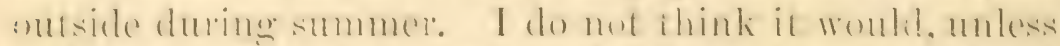

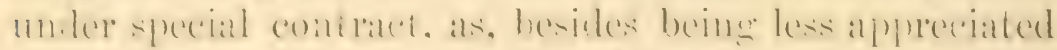

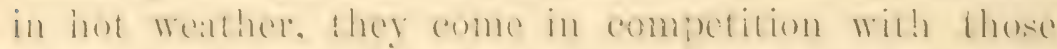

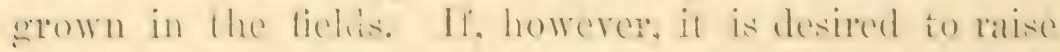

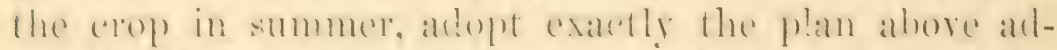
rised : all that is necessalty to sere to is, that the beds are? male in the shate and proteded against rain.

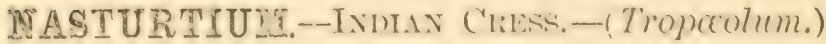

A plant at once highly omamental and nsteful. The shoots and tower buds are somed imes used ats a salat, but it is prom for its secel-pods, which are piekled in rin-

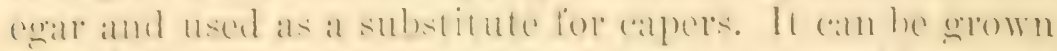

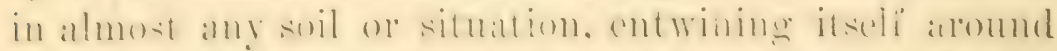

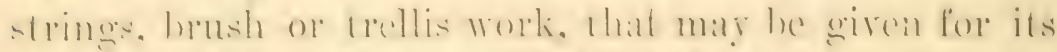
smplutert. It maty he som thinly in drills an inch or so

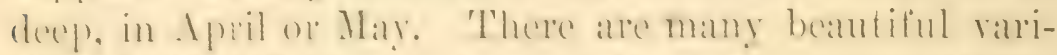

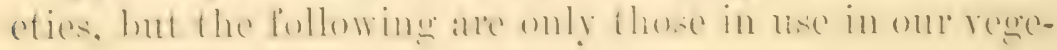
tible girritens.

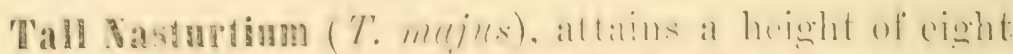

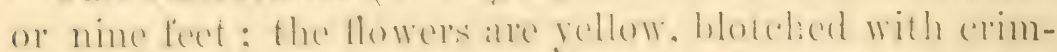

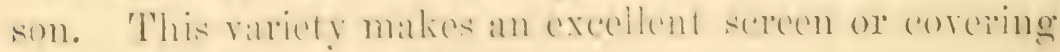
for unsightly places in the garten.

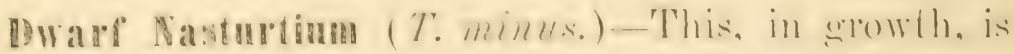

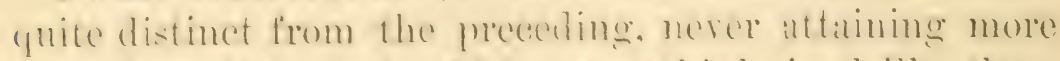

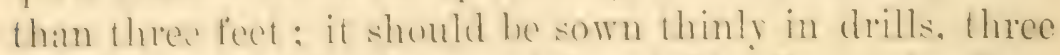
foet wille, and staked up whh brush like Pats. Its flowars are hamisome, bright yelow, hlotehed with scarlet. 


\section{OKRA OR GUIMBO.-(.16elmoschus esculenelus.)}

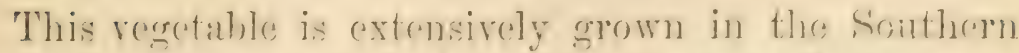

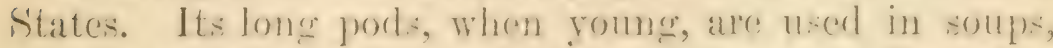

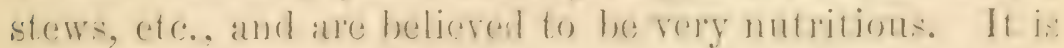
of the casicet colture, and grows froely. hearing alsen-

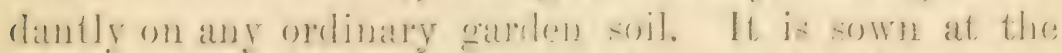
netlal tome of all tender rewetables-in this distrot in May-in drilis fwo inches derple and from rigliteen to twenty-four incles: alpart in the rows for the dwarf sorts ; for the tall, noarly domble that willh. There are now the following sort: : Now Dwart P'olife, Dwarl IIhite, Dwarf Green and 'T'all Green.

\section{OTION.-(Allium Cepa.)}

Next to Cabbages, porlape Onions are the most mofitable cersp of ous market gardens, in which they are grown from sols and noarly all sold in humelese in the

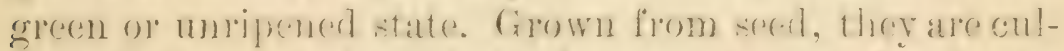
tirated almost excelusively by farmel's as mon who devote farm land to this pulpose alone. Thus erown they are soid in the dry stalie, and forin an important article of commerce.

I will first describe the manner of cultivating in our market gardens. 'To prosture the "sets," or small hulbs, that are plantent to give early onions to be sold grereme a poor piece of gronur is chosen as early as it is fit to work

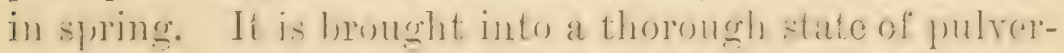
ization hy plowing, harrowing and raking, so that the surface is level and free of stonces. I line is then stretcherl, and lines are marker out by the nine-inch side of the marker. In these the seet is sown m herls of sis rows wide, rubbing out rery serenth row marked, so that it forms an alley cighteen inches whe. For this pulpowe 
the seed is sown quite thickly, and on poor soil, so as to produce the "sets" as small as powsible, for we find that whenerer they much exceed half an inch in diameter, they will rum to seed. It matters not how small the bulb is: even when of the size of the smallest Peas, they malie an equally good if not a better crop than if of a larger size. 'The sets are taken up in August, well dried, placed with the chaff among them in a lolt of a stable or barn, about four inches deep, covered up) by six inches of hay on the approach of hard frost, and left thus until wanted for setting out in spring. 'This is the usual method of raising Onion sets.

But few market garlenex can grow them in the ordinary manner, unless at a cost greater than they can be purchased for from those who make a husiness of growing them. But the price paid for sets the past six or eight years has been so high that many market gardeners have abandoned growing Onions from them.

For Onion sets the best soil of the garlen is chosen. manured with short, well-rotted mamure, plower in at the rate of serenty-five tons to the acre. When only concentrated mammos an he obtaned, crushed bone is preferable to gumo (for quantity see ('halpter on Manures). 'The ground is lurther deply harrowed, finishing with the smoothing harrow (see Implements), or, if on a small scale, smoothed fine with the rake. 'The line is now stretched along the bed, and the nine-inch marker again makes the drills, six in each ber, with the seventh rubbed out for an alley. The sets are now planted in the drills at a distance of two to three inches apart, pressing aach bulb down firmly, so that it will keep right side up. The row is then closed in by the feet or a rake, so that the set is entirely coreled up. The ground is then rolled over, so as to render it still more compact around the bulbs; as soon as the lines can be tracef, by the Onions starting to grow, the hoe is applied between the rows. 
and the soil broken between the plints by the fingers, where the hoe camnot reach, so as to destroy the germs of the weeds. If attended to in time, twice going orer with hocing and weeding is sufliciont until the crop is fit for malrket, which it besins to be about the first weck in June, and is usually all gathered by the first week in oluly, so as to give us time for second crops.

When we first begin to send them to market, they are usually not more than half grown, and are washer and ticd in bunches containing from nine to twelve Onions; later, when full grown, from six to seven. This crop is one requiring considerable labor and expense to get it in shape to sell, taking cost of sets, labor, manure, etc., probably not less than $\$ 300$ per acre, fol the pust liften years; but the receipts have been correspondingly high, averaging in that time quite $\$ 500$ per acre.

Onions, planted irom sct., rarely lixil to gire a crop on any kind of soil, provided it has been well manured ; and althougin they are sold lyy the market gardeners in the green state, they are equally gond, ripened and dried, when raised from sets as from seerl. I'lie quantity of sets required per acre is from six to tom bushels, aceording to size. At present prices, they cost to per bushel.

Another plim to get early (Onions to sell green, is to sow the seed in fall in rows from nine to twelve inches apart. The time of sowing is of great importance, and varies, of course, with the locality. In the latitude of New York they may be sown from 5th to :oth September ; they do not always stand the winter well here, but it is well worth the risk, as the cost of seed is trifling. compared to cost of setting, and when they stand well the crop is usually better than from sets. A clry, well sheltered soil in this location is a necessity to enable the crop to stand the winter.

'The following instructions are given for lating Onions as a farm crop to be sold when mature: 


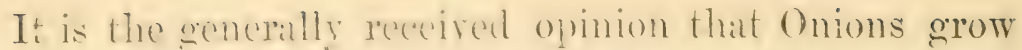
best in ol: arount. This wo think is an crore ; it is not

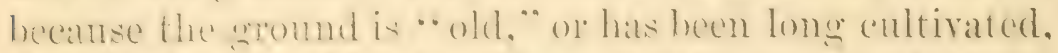

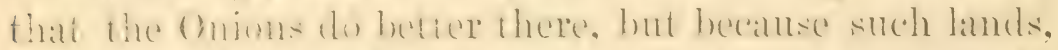
from their long cultille. are usually heter pulverized;

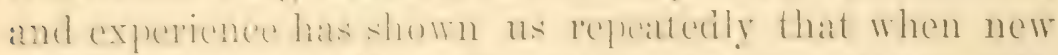

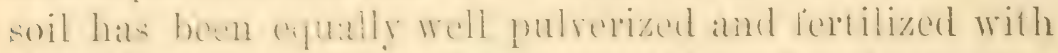

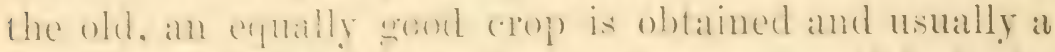
(erop mope sempit from rust. Is a matter of fact, the fincet crop of thions we ("Fer heheld was on samely swamp land, which had heen first thoromghly drand and broken up. In fatel, new soils, particularly when

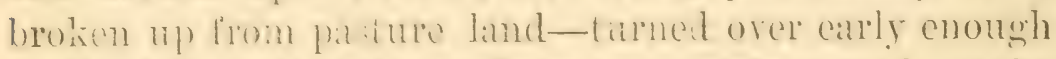
in the fall so that the sort is completoly rotted-make

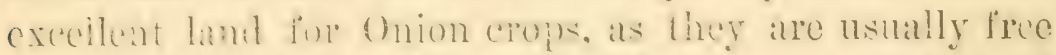

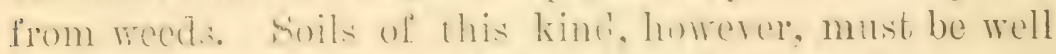
pulverimel hy the now of the plowe. A rme ame smoothing harrow, or good pesults may not follow. Mach depents on the yuntity of such soil. If rather sandy loam, it will, of course, be mueh easere fo pielrerize than if stiff

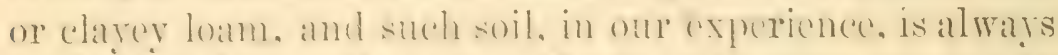

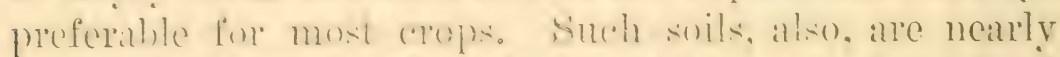
always free from molep water, ramely reguiring artificial

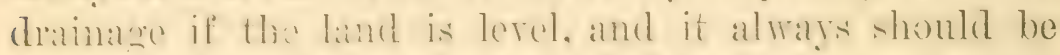

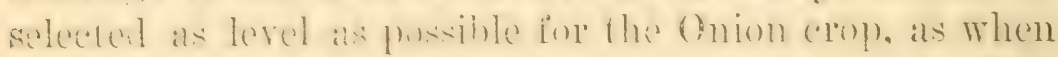
land slopes to any areat extent. much dimmage is oftem done by wathing ont. Ihe Onicn roots being near the surface, conscyurmily ammot so woll resist floods, as crops that root deeper.

Many onion growers who malie a specialty of the business, find it is ceonomical to altemate the onion erop with a veren once smeh as Geman Millet, which cam be cut for hay in ernly. the "stuhbe" piowed down in August. giving a lich fibrons soil clear of weats for the (H)ion crop to he somm next spring. It is not elaimed

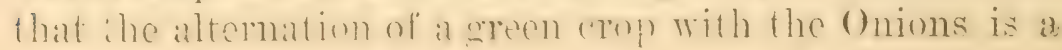


necessity, as it is well known that the ()nim is one of the very few crops that do not seem. benefited by alternating; but it is claimed that it gives almost entire freelom from wects, as aitcr a crop of Millet, which has been cut before its seed is riph. few tromblesome weeds will come up the next year.

\section{MANURES.}

I have alwars held the opinion that when well-rotted stable manure, whether from horses or cows, can he procured at a cost not exceeding $\$ 3$ per ton, delirered on the ground, it is cheaper and better timan any kind of concentrated fertilizer. It should be julfed in at the rate of thirty tons to the acre. The concentrated fertilizers in the marixet are now so numerous that it would be invilious to specify particular hrands. We ourselves, except in using occasionally the "bluot and bone furtilizer," which we have proved to be execllent, nece only pure ground bone and Pewrianguano, which, for Oni:ms, we prefer to mix in erpul parts, sowing it on the lant. after plowing, at the rate of at least one ton per acre of the mixture (when no stable manure has been used), aftur sowing to be harrower in, as described in "Prepuring the Ground."

Une of the most valuable manures fur the Onion crop;

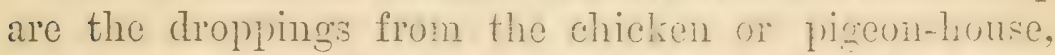
which, when mixed with twice their weicht of line, coal or wood ashes, so as to disintersate and pulverize, may he sown on the land after plowing. to los harrowed in at the rate of three or four tons per acre of the mixture. Night soil, when mixed with hry muck, coul ashes, chin'coal dust, lime, or lime rublish, as absortents, and splead on after plowing, at the rate of six or eight tons per acre, and harrowed decriy in, the mixtme will never fail to prodace a hoary clop) of Onions in any suitable soil.

There are mung other mannes that will answer the 
purpose, often to be had in special localities, such as the refuse hops and "grains" from breweries, which should be used in the same mamner and in similar quantities as stable manure; while fish gumo, whalebone shavings, or shavings from horn, when pulrerized so as to be in proper condition for plant food, are nearly equal in value to ground bone. Wrood ashes alone, sprear on at the rate of five or six tons per acre, will usually give excellent results.

It is well to keep the fact in mind that it will always be more profitalule to fortilize one acre of Onions well, than two areses imperfectly. If thirty tous of stable manure or one ton and a hali of concentrited fertilizer are used to an acre, the net prodits are almost certain to be latrer, than if that quantity hat heen spread orer two aceses for in all probahility nearly as much weight of crop would be produced ment the one well-manured are as mpon the two that hind been imperfectly manniod. besides the saring of secel aid labor in cultivating one acre instead of two.

\section{PREPARING THE GROUNI).}

In preprang the sround for the reception of the secel (if it has been plowed the fall previous). plowing shoukl be becun als soon als the land is lery enounh to work, first having spreat orel the land well-rotted stable mamme, at the rate of thinty tons to the acre. rhis should be lightly turned under, plowing not more than five or six inches deep, and covering the manure so that it will be three or fom inches muler the surface. For this reason the manure must he well rotted, otherwise it camnot he woll covered by the plow. If concentrated fertilizers are to he nsed, it is hest to plow the land up ronghly, sow the fertilizer at the rate of one to two tons per acre, according to its fertilizing properties ; then harrow thoroughly, 
so that it is thoromghly incorporated with thesoil. After harrowing with an ordinary toothed harrow, the surface should be further levelel with a Smoothing or Dise harrow. The revolving dises pulverize the soil to a depth of three inches much better than it can be done by raking, and the smoothing board, which follows in the wake of the revolving wheels, makes the surface, if free from stones, as smooth as a board-far better than it can be done by rakiug.

'The ground being thus prepared, the next thing is the sowing of the seed, about six pounds being used per acre. This, of course, now-a-days, is always done by the seeddrilling machine, of which there are many in the market; we oursclves give preference to the Planet Jr. In sowing the first row, a lne must be tightly stretched so as to have that row straight, after which the marker can readily regulate the other rows. 'The farorite distance apart for Onion rows is fifteen mches, though they are sometimes sown as close as twelve inches, loavmg out every ninth row for an alley, thus forming beds of eight rows each. Where there is reason to beliere that weels may be troublesome, this plan of forming into beds has the advantage of the alley (twenty-four inches wide), into which to throw the weeds.

We so fixedly believe in the valie of firming in the secds after sowing, that we advise, in addition to the closing and firming of the sceds by the drill, to use a roller besides, particularly if the land is light, or where the soil has not been sufficiently firmed down.

There 1 s no other crop where the adage of a "stitch in time" is so applicable as in the Onion crop, therefore, just as soon as the lines can be seen, which will be in ten or twelve days after sowing, apply the scufle hoe between the rows. There are a great many styles of hand enltvators, many of which are exceedingly useful when the Onions get strong enough after weeding; for the first 
hoeing, alter the serel shows the lings, we prefer the Planet J1. Double Wheel Hoe.

'The distance at which Onions should stand in the rows is from one to two inches, and if the erop) is sown evenly and thinly, few require to be taken out, but whether it is weads or onions that are to he romover, one thing should never be lost sight of-that when this operation is done, erery inch of the surface should be broken. 'This is best done after locing. hy using a wooden lawn rake all orer the land, raking lightly aross the rows. It is one of the mos common mistalies in a laborer when weeding or hoeing, if he sees no weeds, to pass orer such portions without lowaking the rrust. By this negleet, not only is it most likely that he preses another crope of weals in embryo molder the mbroken arust, but the portion mbrolicn loses the stirring so necessary for the wellbeing of the erop.

In our long experience in farten opelatioss, we have hat more trouble to keen our workmen up to the mark in this matter than in any other : and I nerer fail, whon I decorer a man grublty of surh negligence, to set him back over his work until he does it properly and if he again fails to do so, promptly dismiss him.

'The Onion (rop) is usmally fit to hamest, in this section, form oth to zoth of Angust; that is, when the secel has been sown in eirly spring, which shomld he not later than May 1st, if posible amd if by April 1st all the better. It the seed is sown too late, it may delay the lime of ripening, whioh may result in a complete lose of the crop, forl, if the bullus are not ripened by dugust, there is danger, if sutembur we wet. that they will not ripen at all, henee the oreat no....sity of corly anding in spring.

If the Onion crop is growng rery strong, it will facilitate the ripenng process if we henel down the laves with the back of a wooden rake, or some such rmplentent. 
so as to "knee" them, as it is calleit, at the neck of the bulb; this chectis the llow of sap, and tends to ripen the bulb.

After the tops of the Onions become rellow and wither up, they should then be pulled without umecessary c?cl:1y, for if there is continued wet weather, and we delay the pulling too long, a secondary growth of the bulls may be developed, which would seriously injure the crop. After pulling, lay the bullos in conrenient rows, so as to corer the ground, but not to lie on cach other. By tuming them erery day or two, in six or erght days they will usually be dry enough to be carted to their storage quar. ters, where the shriveled tops are cut off, and Hac Onions stored on slatted shelres to the depth of six or cight inches, in some try and ary place. It is of importance to have the bottom of the shelres slatted, so as to leare spaces an meh or so aprart, that air can be admitted at the bottom as nell as the top of the hegp. The shelve: when all the space at hand is to he mate arailahlo, may be coustructed one alove another. But if to. he liept through the winter. the Onions must he protected in some building capmble ol resisting severe frost, of the must be corered with hay or straw as a protection andinet extreme cold. For, although the Onion will staisd a moderate degree of frost, any long continuation of a zoro temperature would injure them. When frozen, they should nerer be hindled, as in that condition they are easily blemished, and would rot. When liept in barre?s. holes should be hored in the sides for rentilation, and they should he left unheaded until shipping times is permit the escape of any moisture that may be generater.

For the insectis and ot?er enemios that attack tho Onion crop, I am much afraid there are few if any efiectwe rementies. Every year' a experlence with the enemies that aitack plints in tio open fie?d convinees me that we can successfully cone with rely few of them. The rem- 


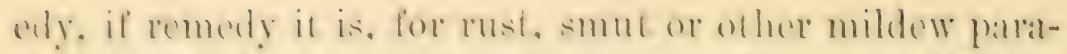
sifes, must, in my opinion, be al preventive one : that is. whemere pratedeahle, use new lamel, of reme the old

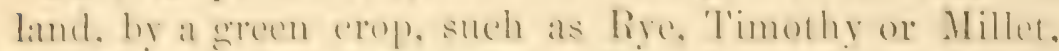

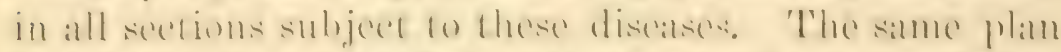

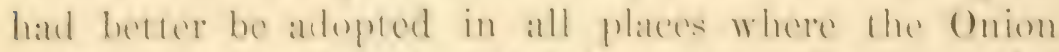

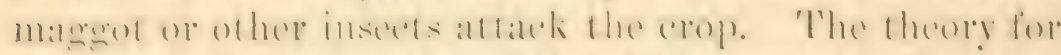

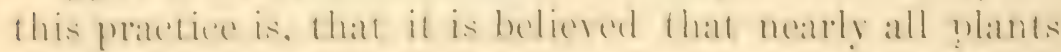

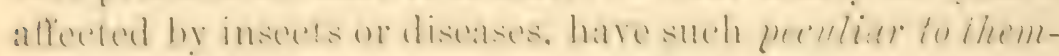

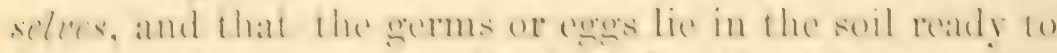
fisten on the same (rog), if planted withomt intermission on the sime ground, while if a season intervene, the

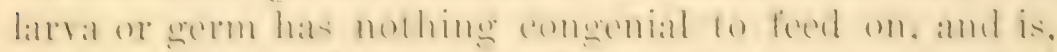

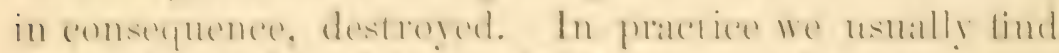

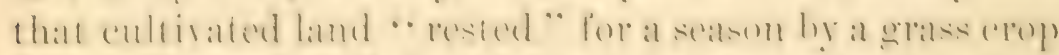

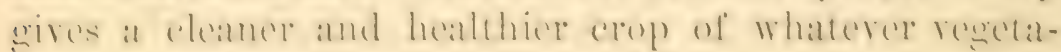
ble maty follow it.

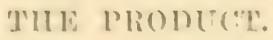

The product of the averace Onion crop varies very

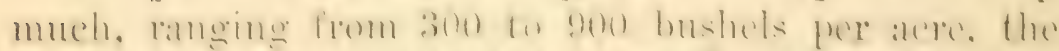

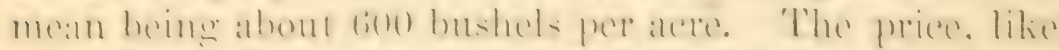

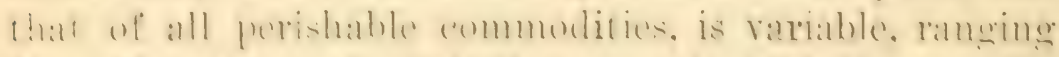

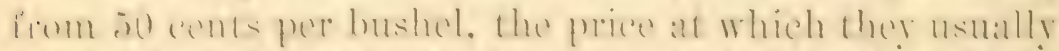

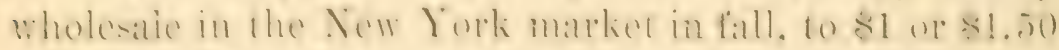
per bushe for winter and spring pries. The estimate. then. of protif per ace may be given about as bollows:

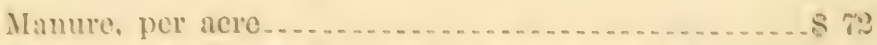

l'lowing, weoding and hatresting crop), per acre . . . . . 100

Six pounds seed, average s.2 per pound ............. 12

lient or interest. on land, per acre................. 9)

Marketing erop, per acre......................

Cost

Six hundred bushels per acre, at 50 cents ........... . 300

Protit 


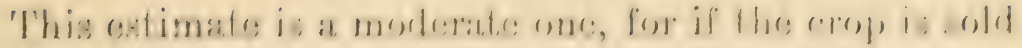

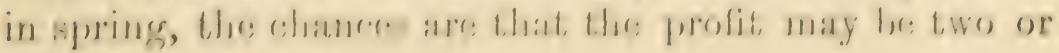
three times as great.

'J'ho leading kinds of ()nions ance:

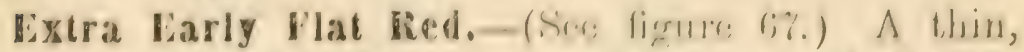
rablher light-colored Onion, a gond liceper, and the ratliest of all.

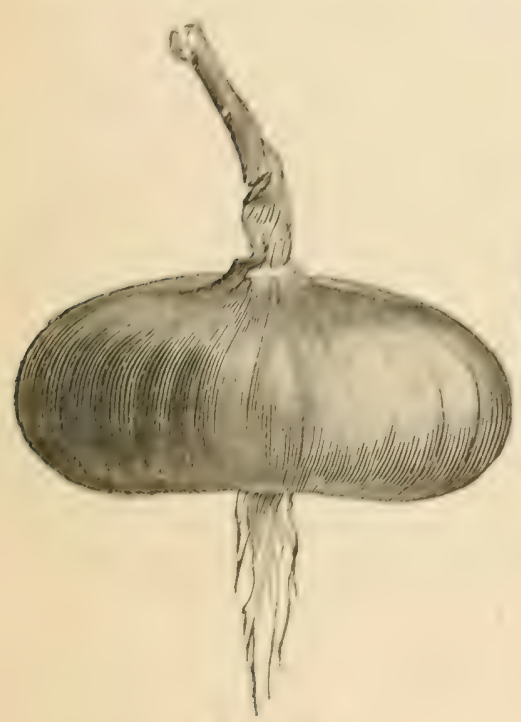

Figr. 67.

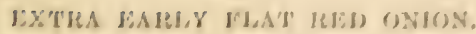

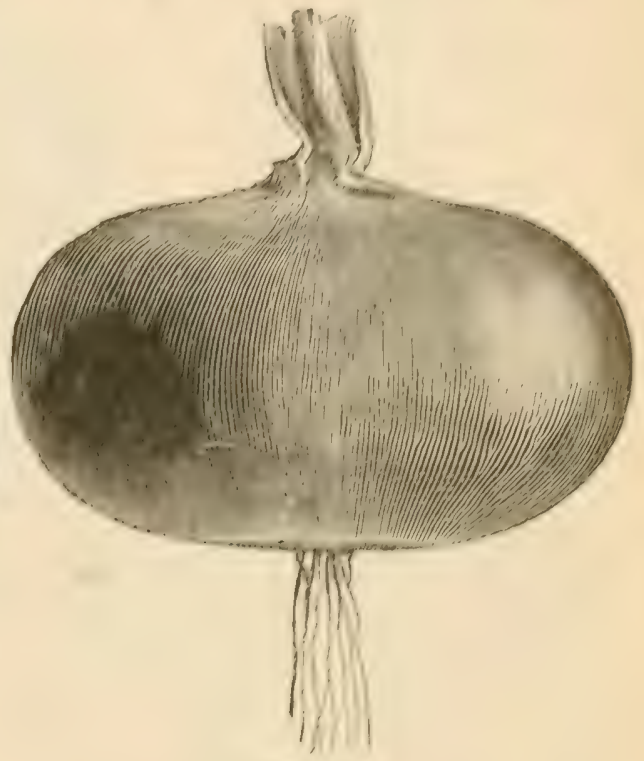

Tiger. 68 .

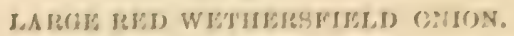

These cuts, which ale haddy half the average natural size, are given to show whe shape and relative sive of the different kinds.

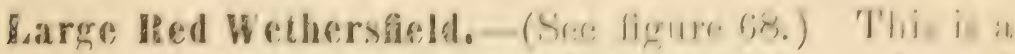

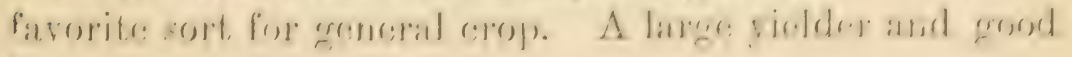
kecper.

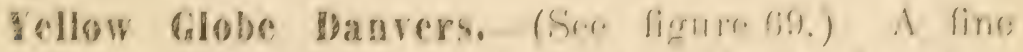

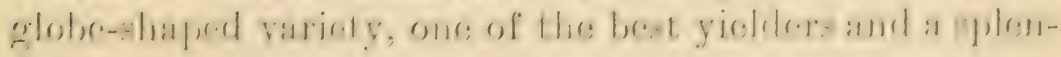
did keepel.

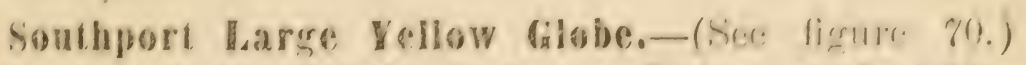

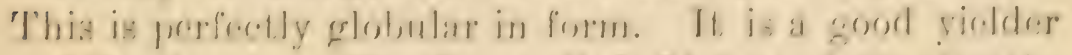

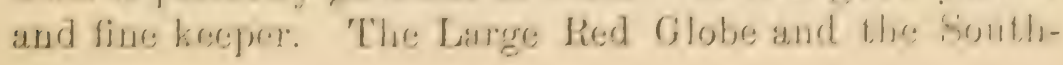




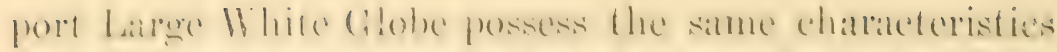

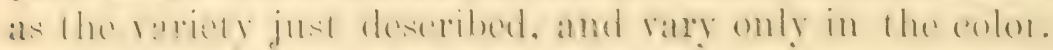

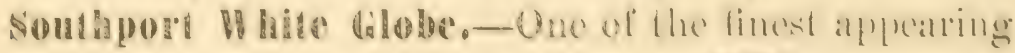

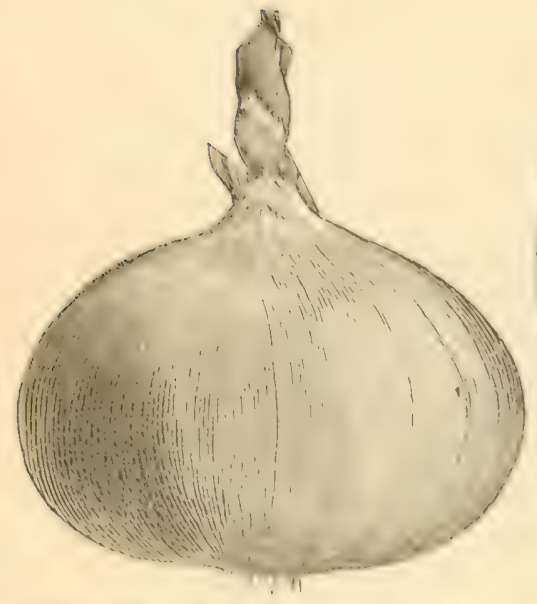

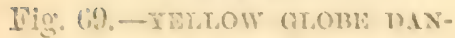
VRHA ONION.

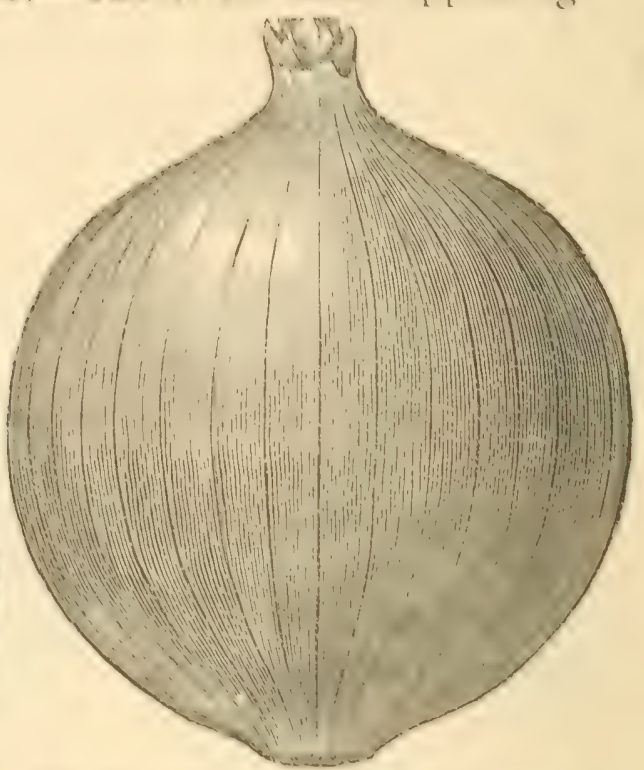

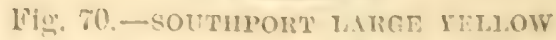
(7.) (OBI: ONIUN.

and most salcable sorts we have; pure white, fine flaror amd in every way desirable. It is not quite as good a keeper as some of the colored sorts, but it is a great firsorite in the New York market.

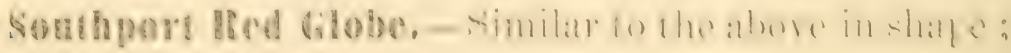
color, a decp real : ar good keepere

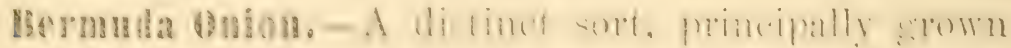
in the Istand of Bermuda, althomeh the seed cimmot be erown there. 'There are two varieties of it, the II hite amel the Pale Red. They are both very carly, and are the varicties from which as high as 200,000 bages of Onions have heen shipped from Bermudir in one seatson. It is now being extensively inpuired for by the truckers in the south, for the reason that it can? be

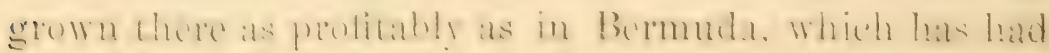




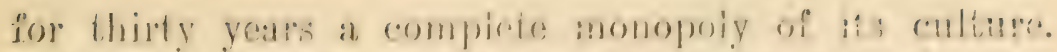

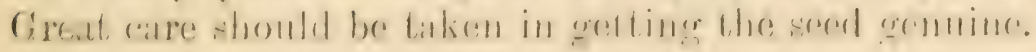

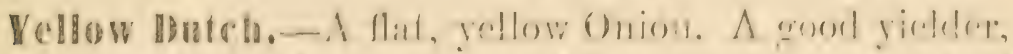

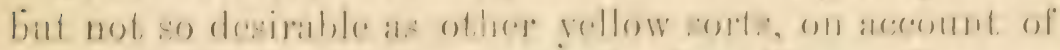

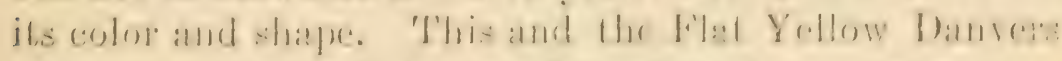
are very similar. It is one of the heaviest ceropers.

Whate portugal or silver skin.-(rice figure il.) One of the learling -orta of white, flat, Onions. A most, rexcellent keeper and good yielder.

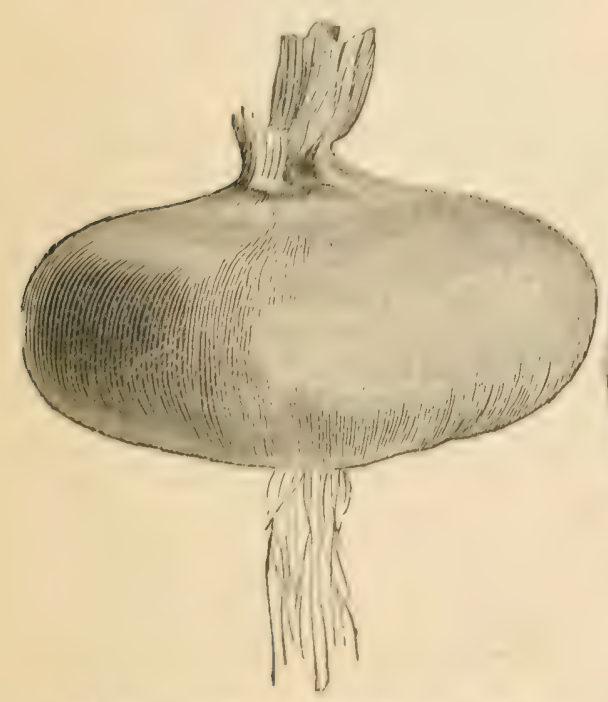

Fig. 71.-WIIT's IPRTYGAT ONION.

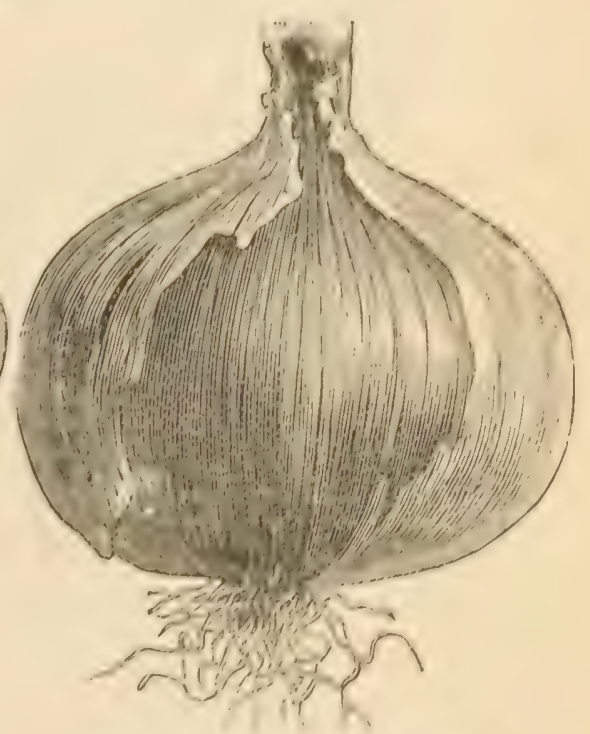

Fig. 72.-GIAN'T HOCOA ONION.

The following sorts are Italian varteties, and are woll adapled for growing in the Southern State:

Queceno-This is the rarlirst, of the Jalian sort, small, flat, white and mild-flavored.

Neapolitan Marzajola.- $\Lambda$ n carly, white, flat Onion, of line flavor.

Giant Rocea.-(Sec figure r2.) A very large-growing shobr-shiped variety, of a reddish-brown color; flaros: mild and sweet. 


\section{Large White Italian Tripoli and Large lied Italian} Tripoli.-(ser figure i3.) These grow to a large size, and are hater than cither of the preceding.

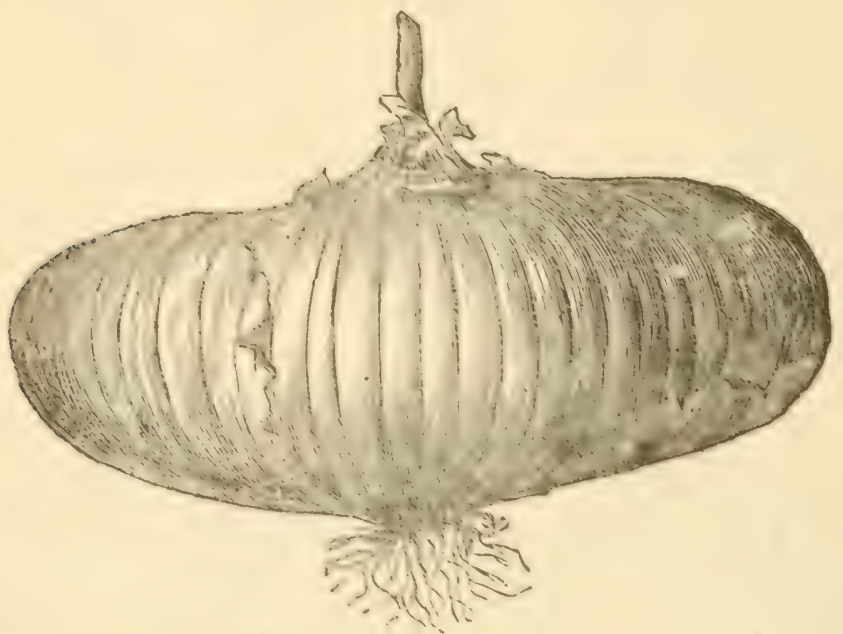

Fig. 73. - WHIte tRIPoIr oxios.

Potato Onions are inereased by the bulbs as it arotrs. splitumg into sir. oight or ten sedions. which form the crop from which the "set," or root for next season's planting is ohtained. These are planted in early spring. in rows one foot andat. three or four inches betreen the onions, and, like the Guinas raised from sets, are gencrally sold green, as in that state they are rety temder, while in the dry state they are leses deviable than the ordinary Onion.

Top Onion-s so-called, are propagated br the peendiar growth of this rarietr. Which protuess a cluster of smatl bulblets on the Oniom stalk, a eluster of bulblets heing formed instead of thowers and sededs. In all respects its culture is the same as the Potate Onim, only that, as the bulbs are smaller, they can be planted eloser. 


\section{PARSLEY.-(Petroselinum sativum.)}

$\Lambda$ regetable in more gencral use for gamishing than any oflure plant of our gardens; it is also extersively used in somps, stews, ote. Its cultivation forms yuite an important item in market gambens, parlicularly under glass. 'The manner of cultivating it thus is by sowing it

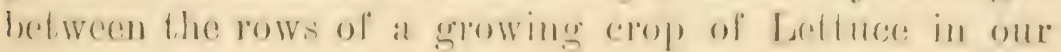
cold frames in April. As it is low fo germinate, if only

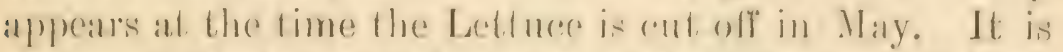

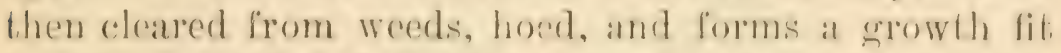
fo rolt a month before that sown in the open enroment. After the first culting has heen marle in Jume, it is erancrally so low in price as not to be worth markelinge so it is allowed to grow thromgh the smmmer motil the first.

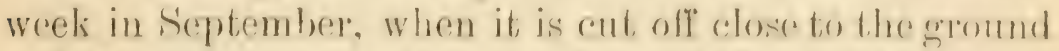

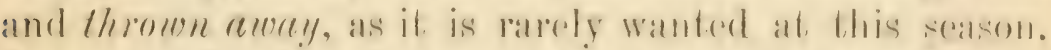
It is again hocel, and ats at this time it makes a short,

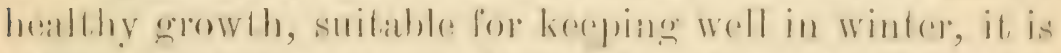
stowed away in narrow, shallow trenchese cxartly in the same manner in which we preserve Celery.

'This way of growing Pansley is, I holieve, mainly oomfinced to the vieinity of New York, hut as the consmomption of such an article is neressitrily limiforl, this matiet; has been oversupplied of late years. Formerly it has

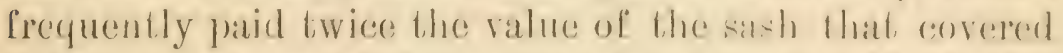
it in one season-\$6 for a three by six satsh. No dould, in many places, this systen of erowing would be as profitable as it used to be with us. When not grown mudor glass, it should bo sown thickly in pows a foot apurt in carly spring in the open gromut. Where greenhouses are nsed for foreing vegetables, Parsley can be nicely grown under the benches, at least as far moler as thore is partial lichto T'his is best done by sowing the seced in boxes (three or four inches derep, eighteen inches wide, anrl two feot in

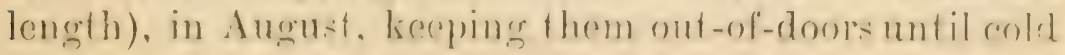


weather in November, and then plandere them under the benches of the grenhouse, but alose to the walli, where

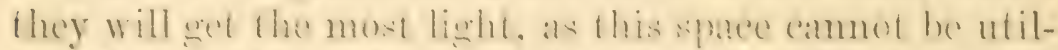

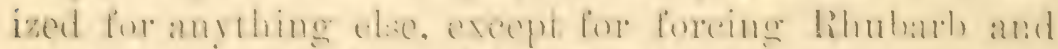

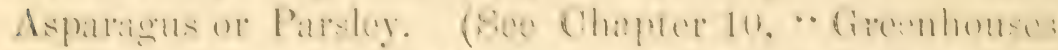

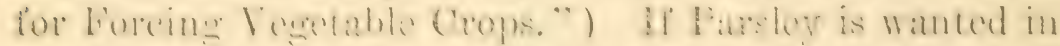

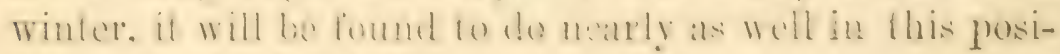
tion as in the full light.

the varletics are.

Dendorsen's lincrald.-(Sw: fiome it.) The finest

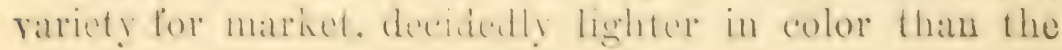

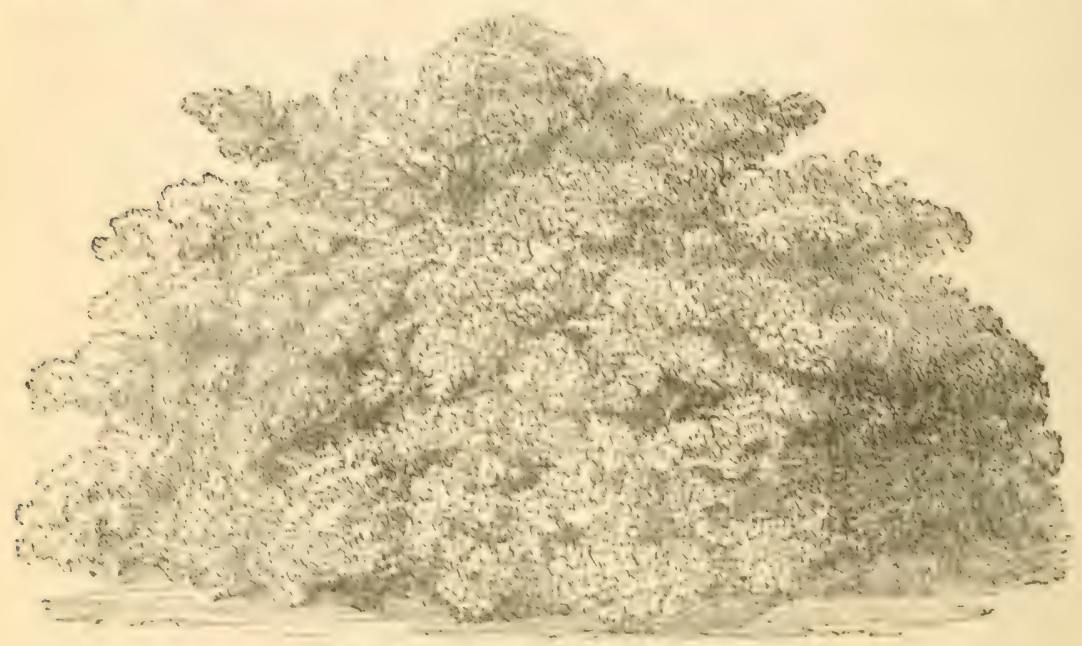

Fir. 74 -enterate parslex.

Donble amd Mose curled variotices Is particularly

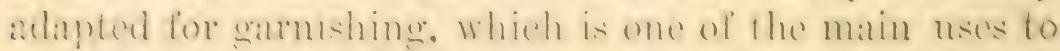
which latroley is put. It is now the mann sort erown by the market gardeners of New Iork.

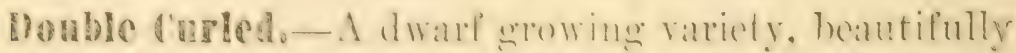

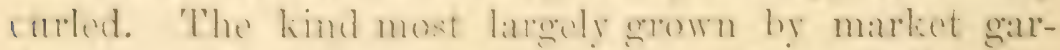
deners, until the introduction of the " Emerald."

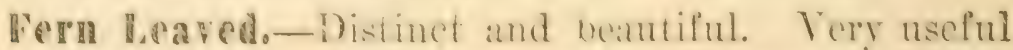
for tabhe decoration, as it afpears more like a crested Forn or Moss than like Parsley. 
Plain. Oô this variety the leaves are plain. It is lasdier, however, than any of the curled sorts.

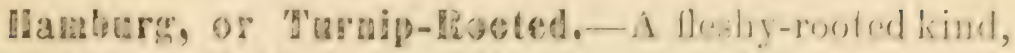
the root: of which are uecel for flaworing soup s.

\section{PAISNIP.-(Pastinaca sativa.)}

Of late years our mark of gatien grounds have breome too raluable to be we in erening this regetable, the competition from weli colidvated farm land having

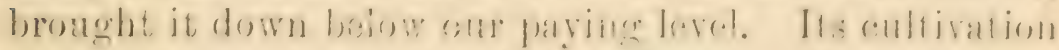
is, in all mopecte, simiar to the Carrot. The onil mo-i,

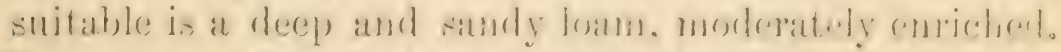
It is sown rather thickly in our gardens in carly spitine,

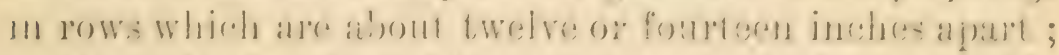
on farm lands at cighten or twenty inclues, of wide

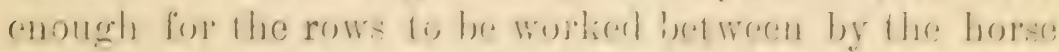

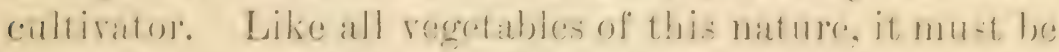
thimned ont to a distanere of about theres os four inclues

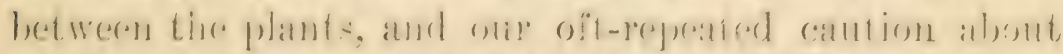
weeds is here again enjoined. Poarsmps are uend almo-t exclusively in winter, bat in our Northern states what is

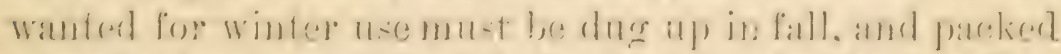
at way in the manner deceribed under the leead of " Preserving Vergetahles in Winter." What are wantrod for

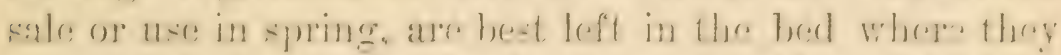

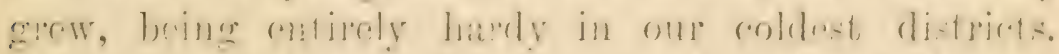

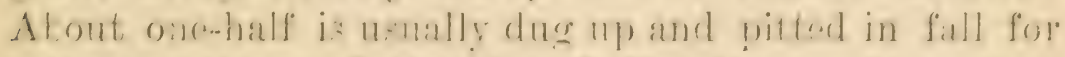
sale in winter, and the ot tror half left over for spuring. Put it sometimes happens that the winter supply is corhansted before the frest is ont of the erround in spring

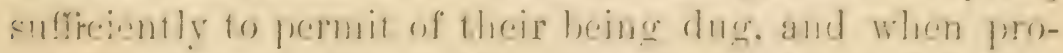
carable at such times, they command almost faldritons 


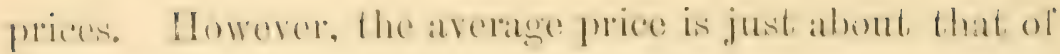
Carrotis.

The varieties are conlined to the

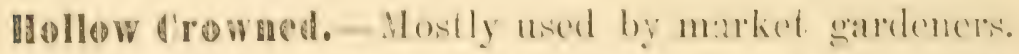
Whe stadent.-Girowis a littlesmaller, hut hats a more delicate llarol.

Larly Round. - A small round early sort.

\section{PEA.-(Pisum sativum.)}

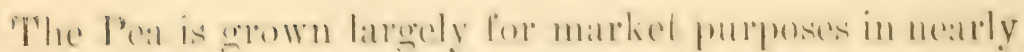

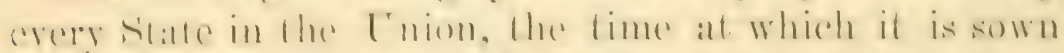

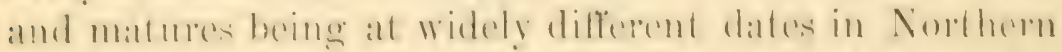

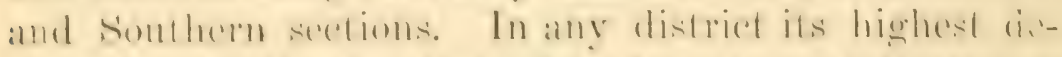

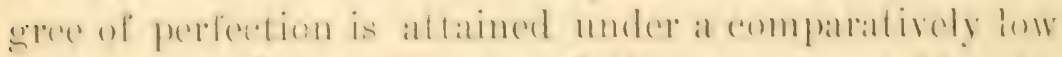

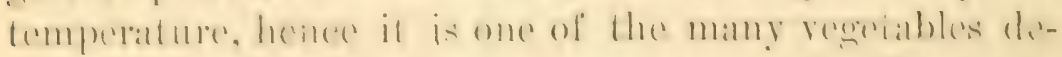
seribed as best to ba sown in "early spring." 'ilue, it is sown for a succession erop throughont the summer

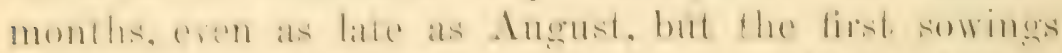
every where always produce tho best results, and it is

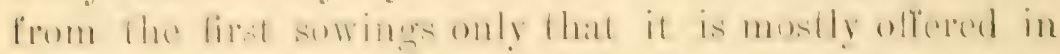
market. For market pruposes it is more a erop of the

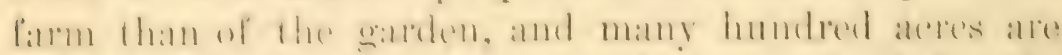

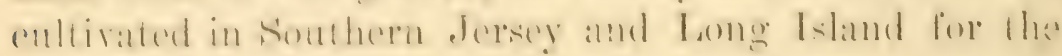
New Yorki market.

II arm, light sobls, molerately amriehed by stable mat-

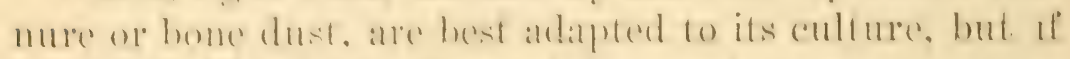

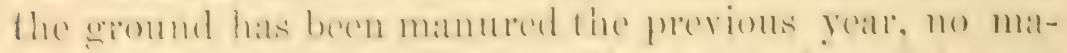

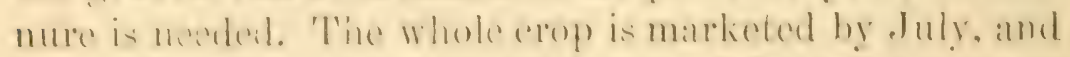

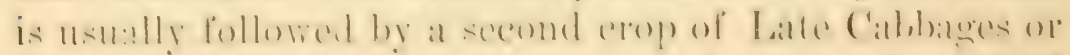
'Tumips. The two erops together arerage a profit of

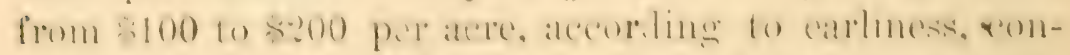

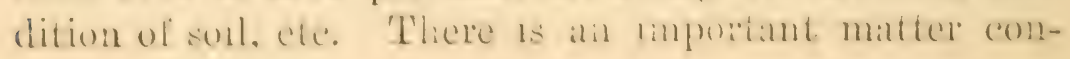


nected with growing l'as, that confines lheir enlture fo the vicanity of a town or villawe-it, is the necessity of

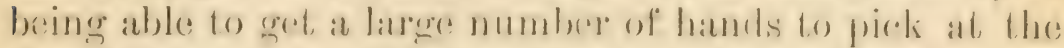

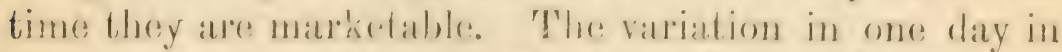

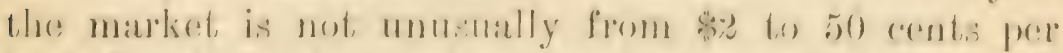
bushol, which shows the great importance of an arly

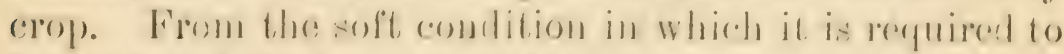

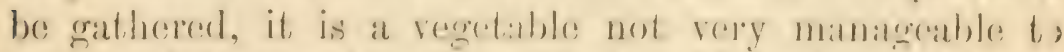

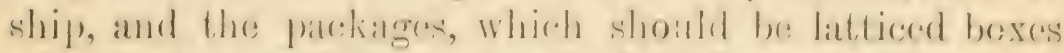

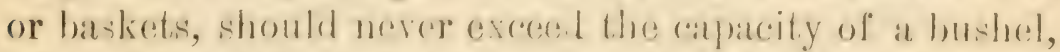

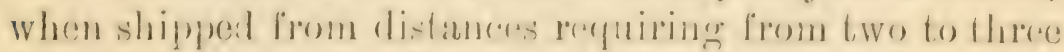
days in the transit. But eren this expense and ande are well regatd by the high rates for which the lir-t lots ares

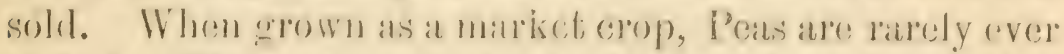
stalied. 'Tluey are sown in single rows about two inches

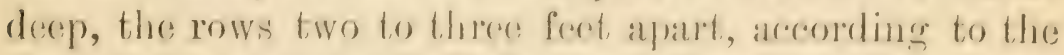

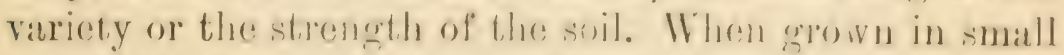
quantities for private nse, flory are genorally sown in double rows, six or eight inches apart, and staked un hy biush, for the taller growing kinds.

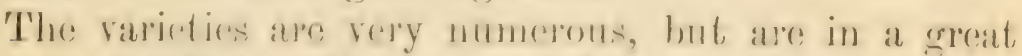
state of confusion, the rame kind hering oilen sent ont

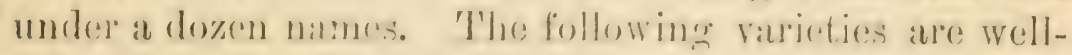

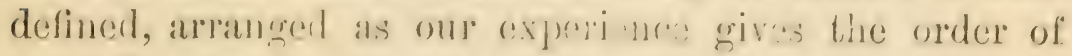
merit for this locality.

PEAS - EXTRA WATIY.

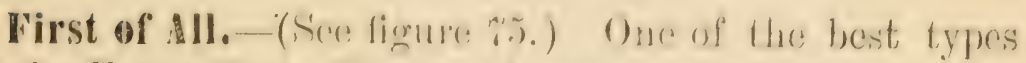

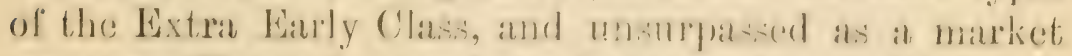

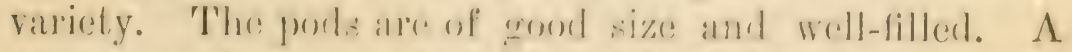

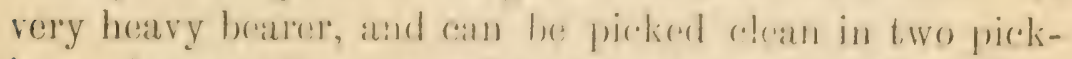

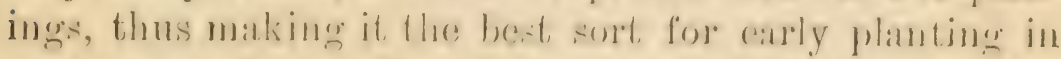
market gardens. It is aleo very hardy, and when

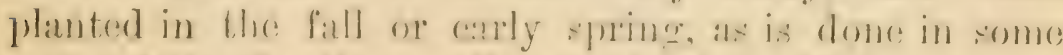

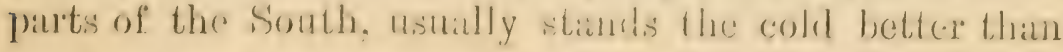




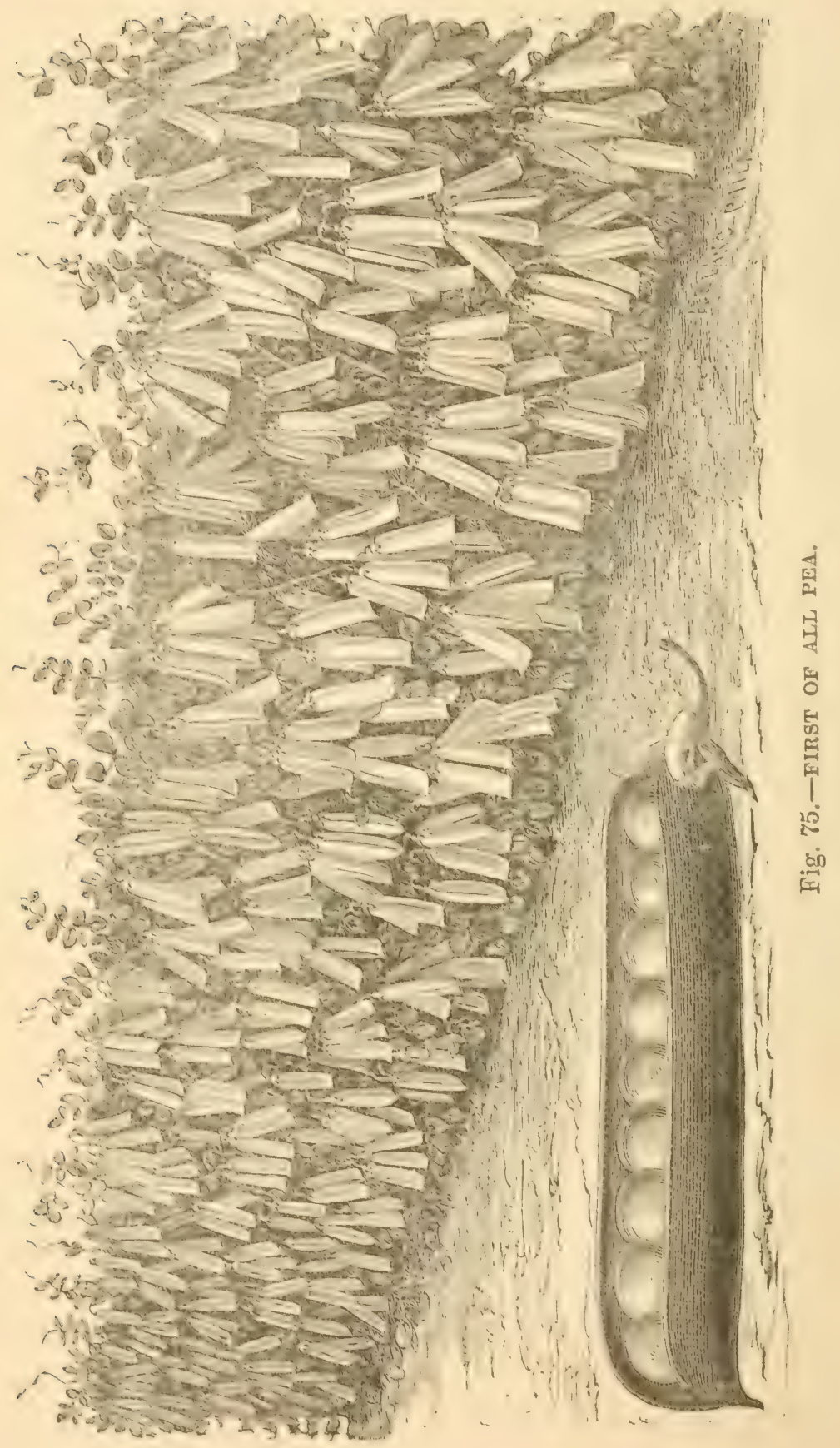


any other sort. One bushel and a half of eced i: required per acre.

\section{Improved Daniel do'lourke and Lxtra Larly.-The:e} are excellent carly varieties and great farorite: in all parts of the country, but are not so regular in habit als the Firet of All. These, ats well ats the First of $\Lambda 11$, should be sown for a field crop in rows of from two to two and a half feet apart, about one and a half bushel of seed being required for an acre.

American Wonler.-(See figure ifo.) Ole of the best acquisitions of this generation, but a variet y perhal s beter suited for private we than to the market gardener. It is early and very productire. The peats are winkled, and its distinctiveness consists in its extremely alwarf growth, which rarely escereds ten inches in leight. Can be sown at eighteen inclies aplart; two bushels of seed is required for an acre. Like all wrinkler peas, the flaror is much snjerior to the round, or first carly linds.

Maska.-Tery distinct and first carly; folinge rery light green, vines sender. In our trials this year (1886), it was shown to be very productire.

Preminn Gem.-A green, wrinkle: marrow, that comes into use just a fow days later than the First of All or Improved Daniel O'Rourlie. It grows from twelve to eighteen inches high, is rery productive, and of excellent flavor.

Fentish Invicta.-About five days later than the First. of All and Danicl O'Rourke. Tery productive, and possesces fine flaror. Althomgh it is one of the liest for canning puryses, it is also largely grown fur marlict.

MeLean's Adrancer.-A second early rariety, and now a great farorite with marliet growers in this neighborhood, among whom it is often linown as the Early 


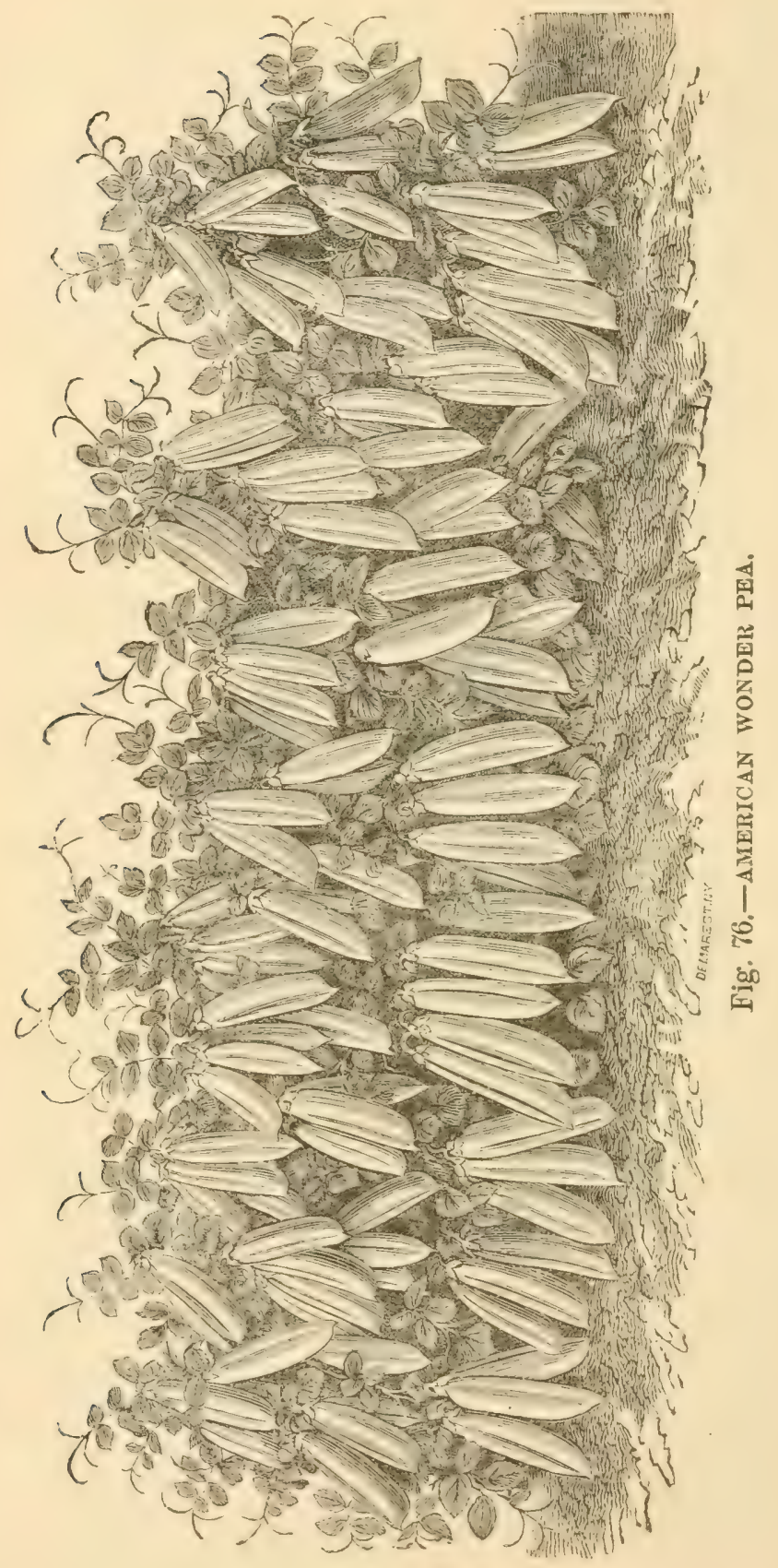


Champion. It is a green wrinkled varicty, of delicions flavor.

FOR THE GENERAL CROP.

C'hampion of Eugland.-This is still, hy general consent, acknowledged to be the best of the late sorts. It is a tall-growing lind, attaining a height of four feet or more, and requires to be staked. The pods and peas are of the largest size.

Stratagem.-(See figure \%\%.) Is a newer variety, and by good judges considered one of the best Peas raised in recent years. It is a dwarf-growing, wrinkled, blue marrow, and produces large, well-filled pods.

Yorkshire llero.-A splendid wrinkled green marrow Pea, of a branching habit, and an abundant bearer. Seedsmen on both sides of the Atlantic find their sales for this variety constantly on the increase.

T'elephone.-A newer tall, wrinkled marrow, with enormous pods, which are not always well-filled. In spite of this, it is becoming a favorite market garden sort.

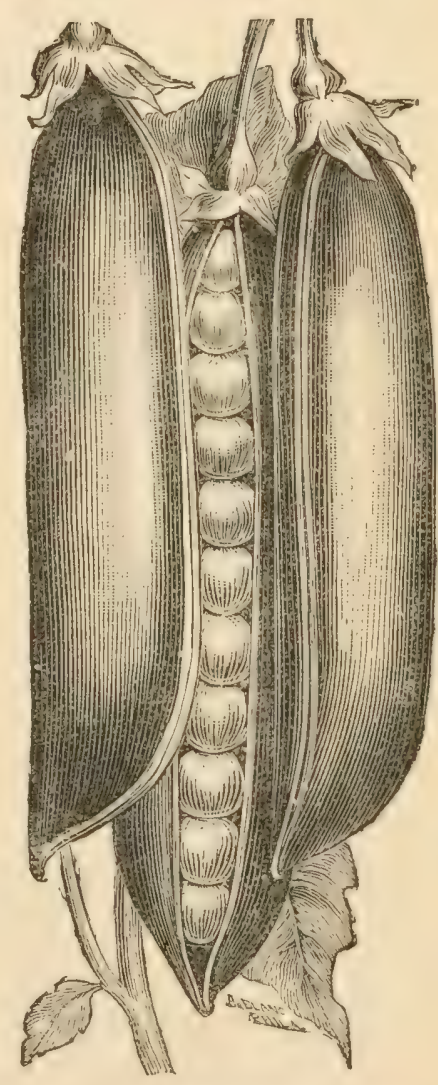

Fig.77.-S'rRATAGEM PEA.

IBliss' Abundance.-Remarkably productive; grows from twenty-four to thirty inches high.

Bliss' dverbearing.-Also rery productive; grows 
from elghtecn to twenty-four inches high. Should be planted thinly, and is moted for a continuance of bearing:

Pride of the Marlint.-Also a new sort, strong growing, and a wonderful hearer. It grows only from eighteen to twenty-four inches high, prodilcing large pods of Peas of exceptionally fine flaror.

Back-Eyed and White Narowfat.-These are both productive and hardy rarieties. (xtensively grown as field Peas, to he used dry. 'They atre also, from their great prodnctiveness, grown largely in both private and marliet gardens, but they ale not of so fine flaror as most other varieties.

\section{$-0.00$ \\ PEPPER.-(Capsicum annuนm. $)$}

A tropical plant, that requires to be started in hot-beds or forcing-ints in the Northern States. The most conmon methon is to sow in hot-beds in March, and treat in all resperts as directed for the cultivation of the Egor Plant. Light sandy soils are rather best suited for its giowth, but it will arow tolerinly well on any soil. When cultivated for market they are planted in rows two feet apart and fifreen inches between the plants. The crop is only moderitely profitable, but it is not grown in laroe quantistes, the main consumption of it being by the pickle factories.

The varieties are:

I.arge IBell ar Rull Nose.An early variety, of mild flaror, and a farorite sort both for pickling and for use in the natural state.

Sweet Momatan or Mammoth.-Similar to the Bull Nowe, but larger and milder in flaror. U'sed to make stuffed pickles. 
Ruby King. - Intweluced two year's ago, and at decidest acquisition. The preples grow from four and a half to six inches long by three and a hall to four inches thick, are bright-red in color, and are mild and pleasunt to the taste.

Squash or 'Elomato-Ghapd,-Gencrally grown for piekling, hardly io carly ats the Bull Xase, hut very productire, and the lealing market valriety.

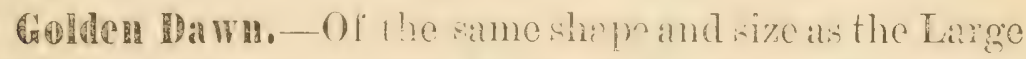
Bull, but of more cielicate flaror, while the color, wis the name indicates, is a beautiful golden yellow.

Cranbrry, - One of the best for pickling. The fruit closely resembles the Cramberry in appearance.

Long lied fayenne.-The rariety of commerce. Pods small, cone-shaped, scirlet when ripe. It is quite a late variety, but the pods are as frequently used for pickling green as when ripe.

\section{P0TAT0.--(Solanum tuberosum.)}

The soil acknowledged to be best suited for the Potato is sandy loam; in ali heary soils it is more subject to disease, and the flaror is also much inferior: this. howerer, is true of nearly all regetables, heary land inducing a watery insipidity of fiavor. Like all robust-growing regetables, Pototo sesn be grown with rarying success on soils of all lindis and in all conditions of fertility, but it is every way most profitable to use an abundance of manure when it is at all attainable. In breaking up good pesture land. the decarying sod answers sulficiently well for the first year in lien of manure. Manure is applied either in the rows or hills, or broartenst orer the surface, and plowed in ; the latter plan being in all cases pre- 
friable. when mamure can be ohbined in sullieiont quantities.

l'otatoes, whin grown lor marliet at the North, are

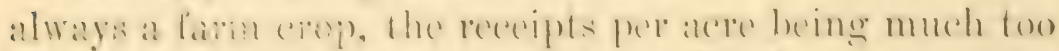

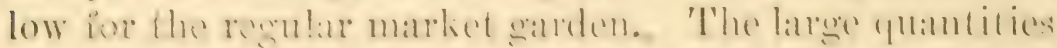

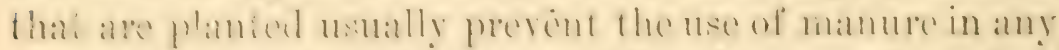

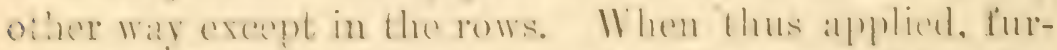

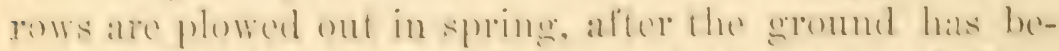

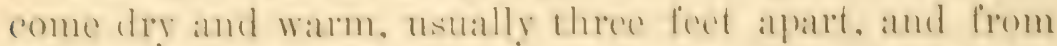

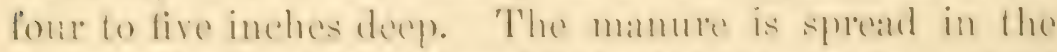

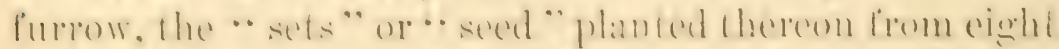

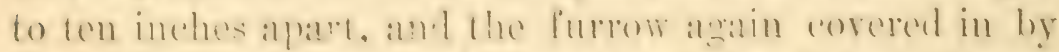
the plow. Is som as the shouts are sect above ground

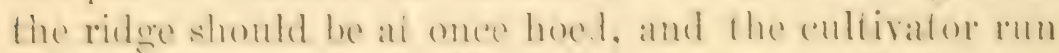

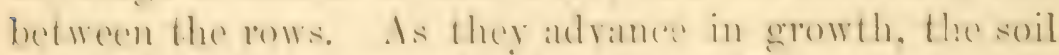

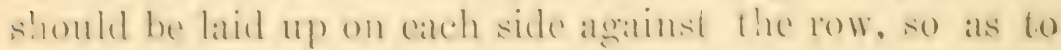
form a slight ridere.

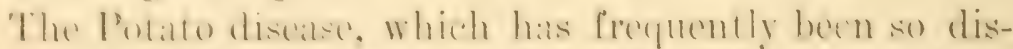

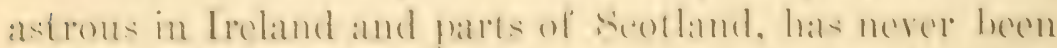
bry devastating here. It is now woll known to he a pall-

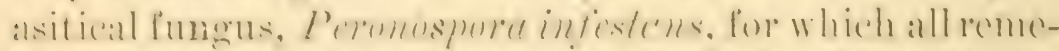

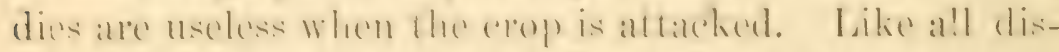
eases of this himd, the only help wh hate is prevention. As lar ats oxperiments hate game. they hare shown that

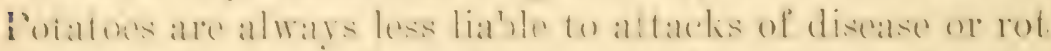
if planted in new land. broken mp from the sod, or at least that. which has not been lomg in cultivation. Inother ememy to this crop is the well-known Cohtomde

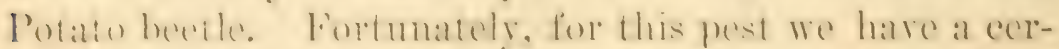

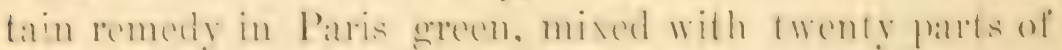
Homr. applied hy dustme while the dew is om the leaves in

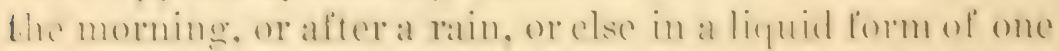
ommer of Paris when to tom gallons of watcr. But whicherre way it is applied, bi should be begum at lhe rery tirst.

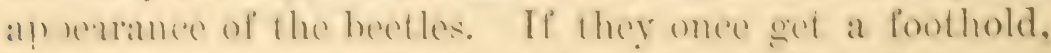
they increase so rappidly that the erop is oftem destroyed 


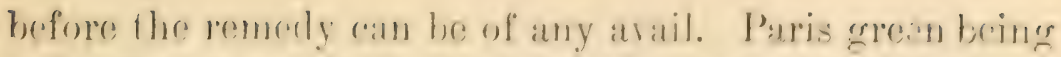

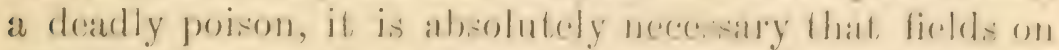

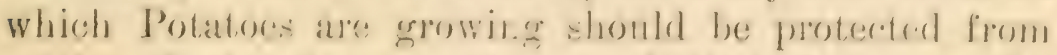
catte. It is sometimes smplesed that danger miglit. arise from the $11 \mathrm{se}$ of the Paris green afferefing the Potato tubers. 'There need be no feall of this, ats the lubers do not in any way absorb it.

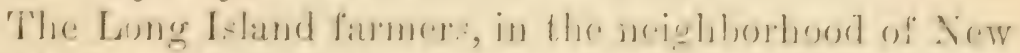

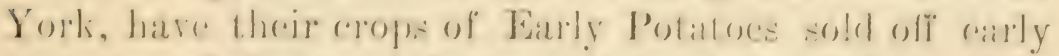

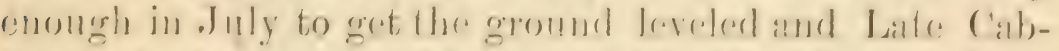

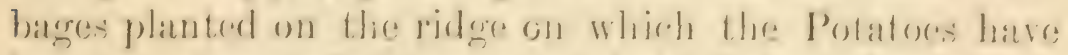
been growing, suflicient manure being left in the gronud

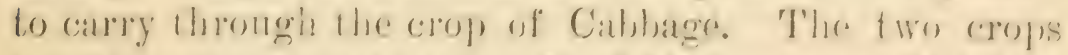

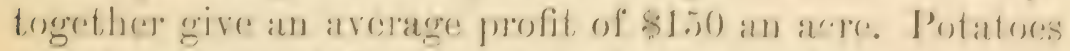

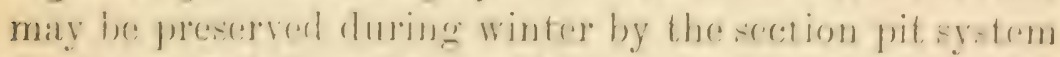

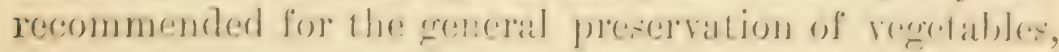
or in a frost-proof cellar.

The varieties of the Potato are rely numerous, many of them havingonly a lomal reputation, sol that it is colme-

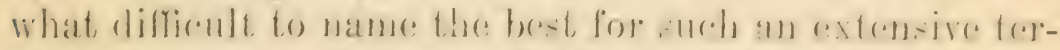

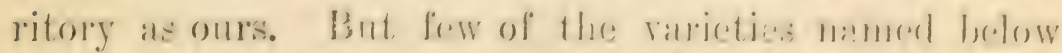

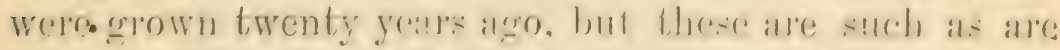
now in very general demand, whirele indirates that they are the best for general cultivation.

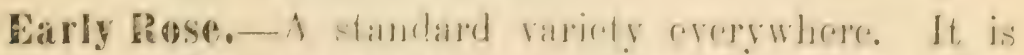

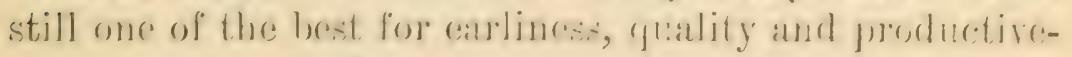
ness yet introdueed.

Vauguard.-Bstremely early, perlads the carlicin of all. (quality unsurpased, but rot, quite en loway a yielder as some others.

Pearl of Savog.-1 good yielder and a rory rexcellent

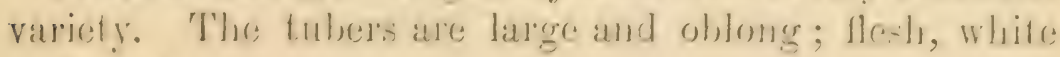
and mealy.

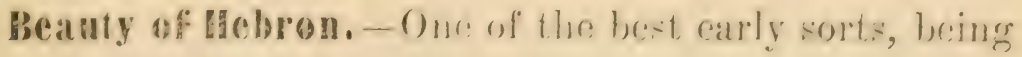
very productive and of fine quality. 


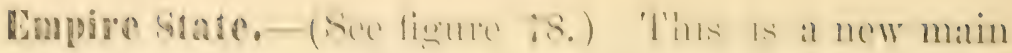
crop ranety, very productire, and in the estimation of

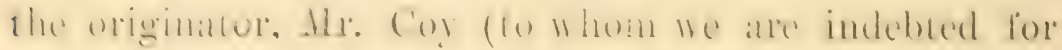

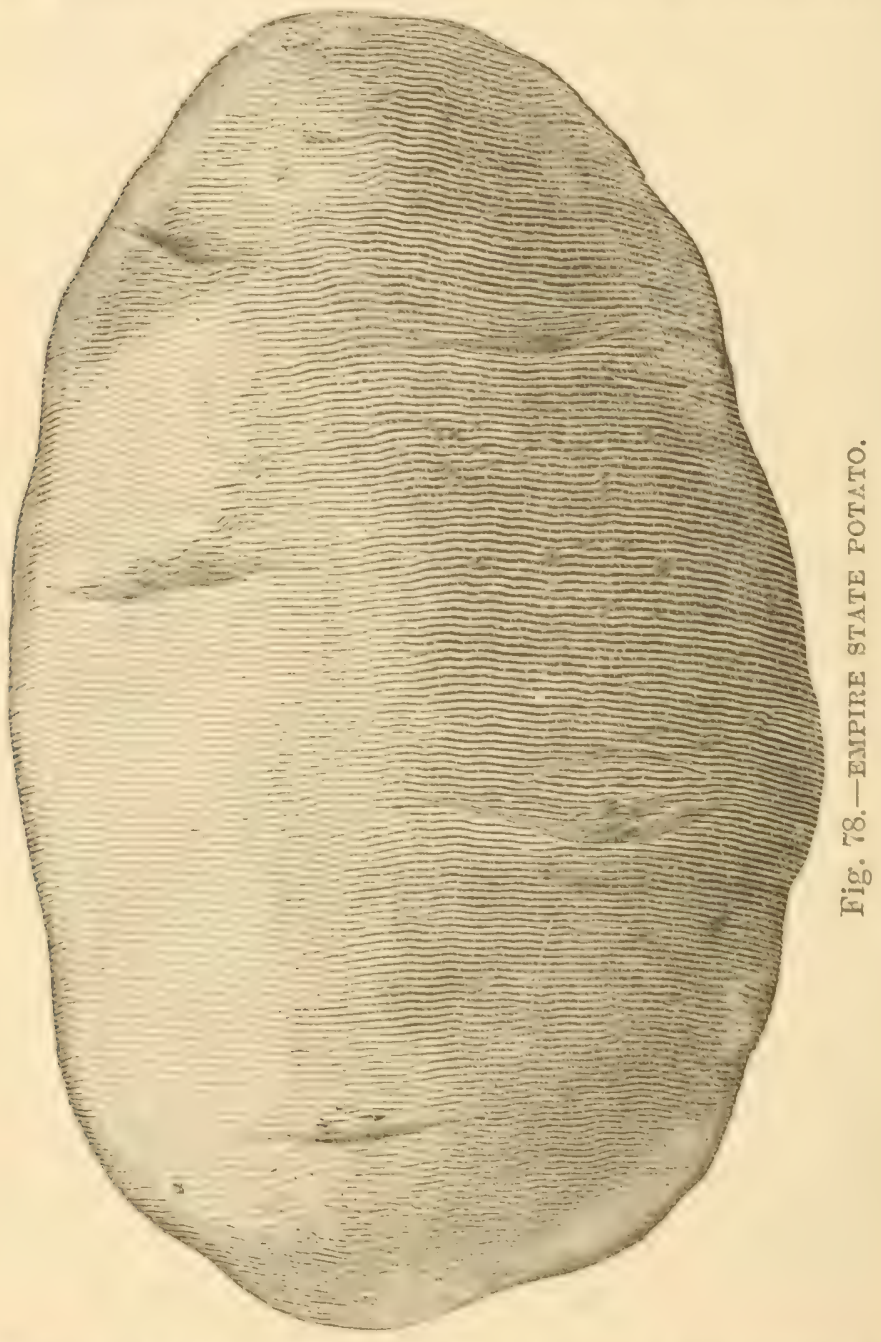

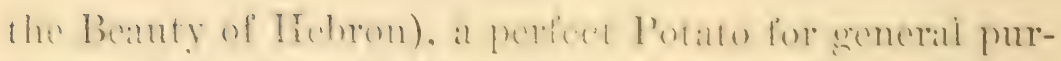

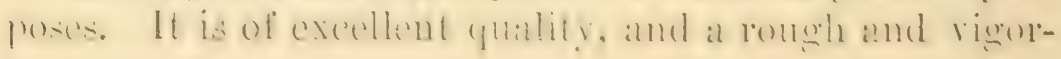
ous crover.

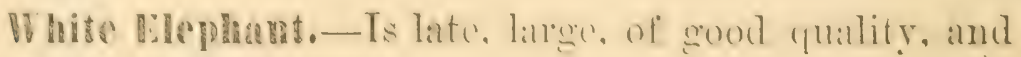
enormously productive. 
Clark's So. 1.-(Sere figure o.9.) This: is and to be

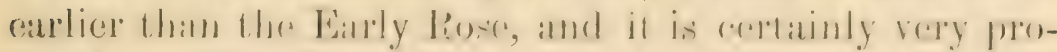
ductive. 'The flator is excellont, and it cooks dry and

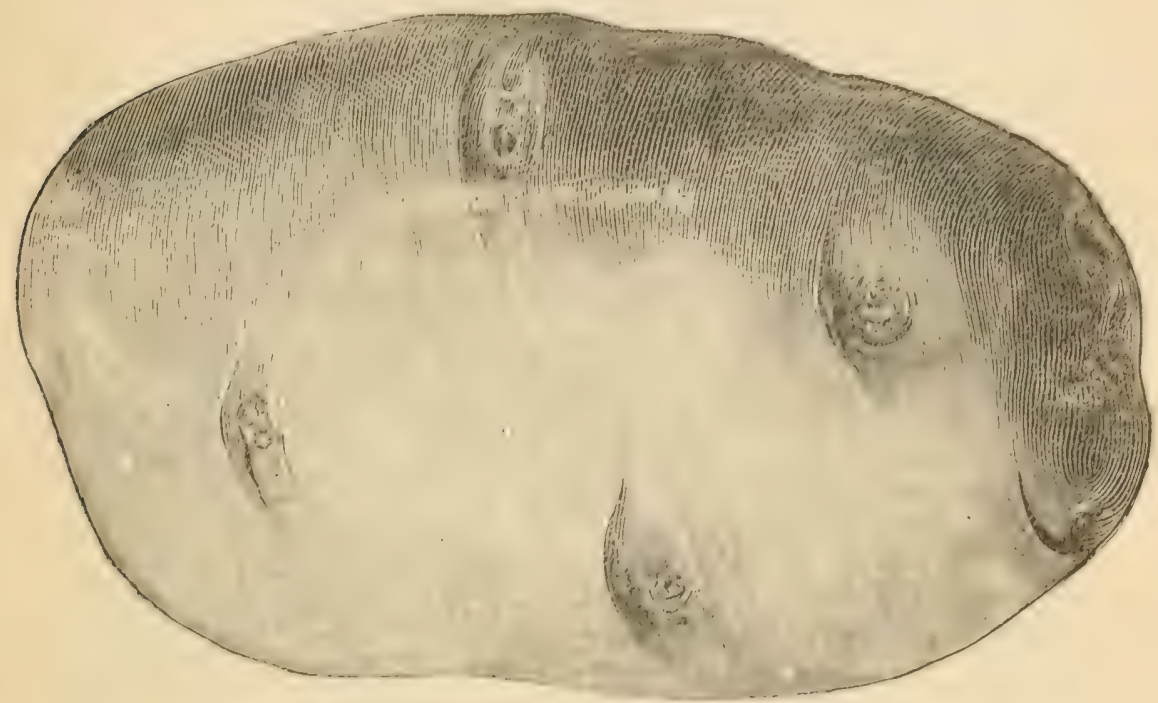

II

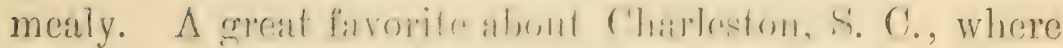
it is grown for the Northeru markets.

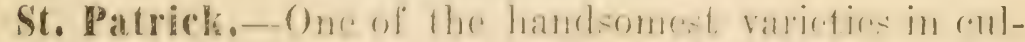
tivation. The tubers are smooth, with very fow and shallow eyes. I gond yiolder, and of the bost quality.

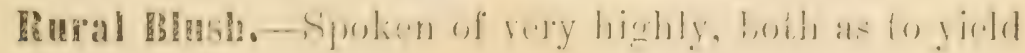
and quality.

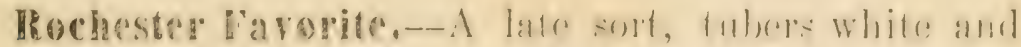

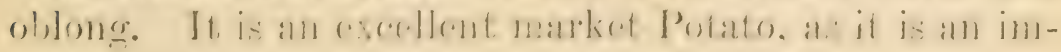
mense yielder.

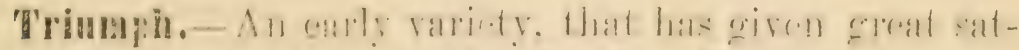

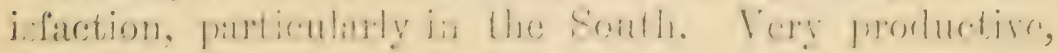
and of good ruality.

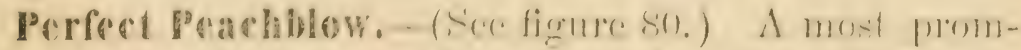

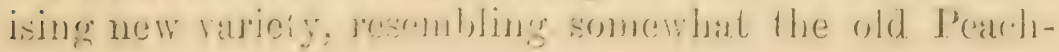




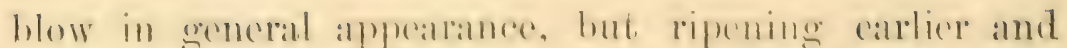
rooking through rery quickly and arenly, a chatrateristie

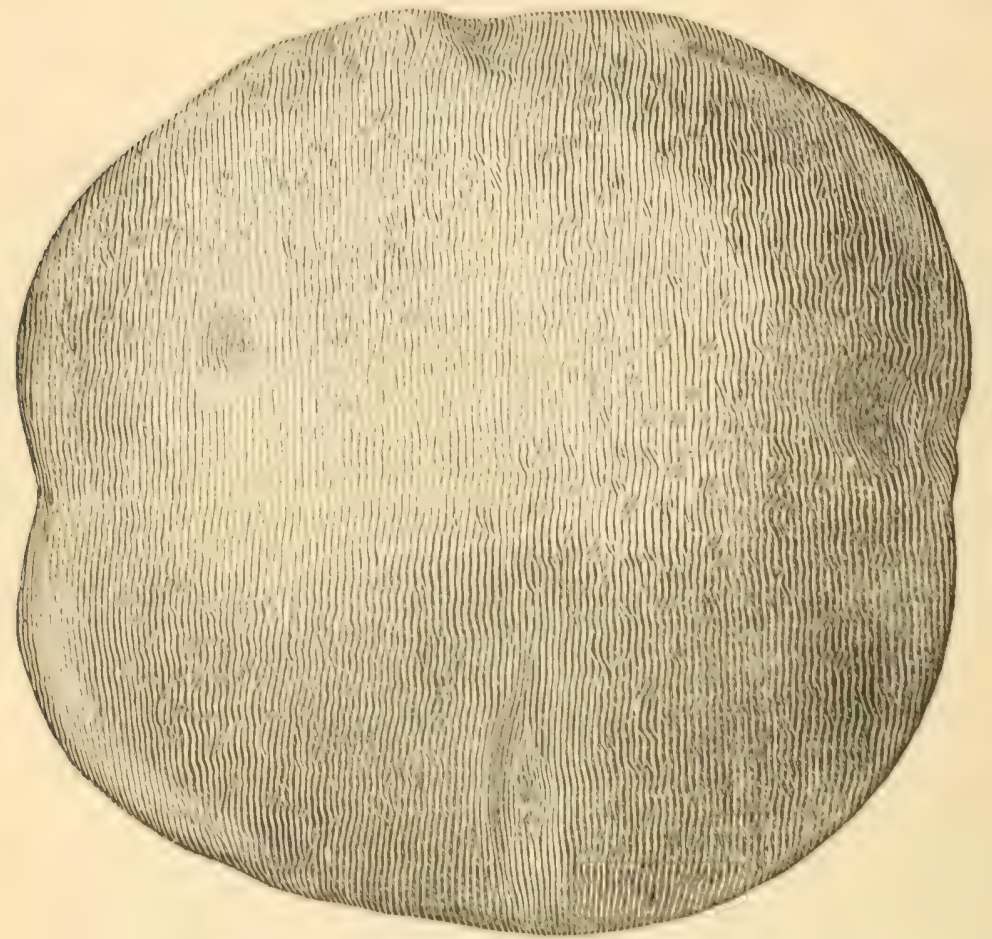

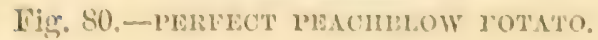

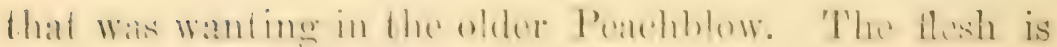
pure white and the quality execllent.

Comsiderable discussion has at varions times ocenred

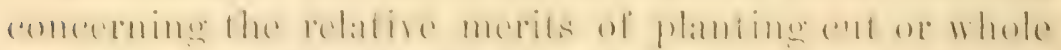

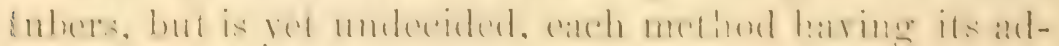
vocates; a lact which goes far to prove that it is of little eomsequence which way is followed. The best; rule, in om experience is, to plant the whole small mbers it fully maluad, and ent the larerer ones, but in oither ease leaving enough in bulk of the potato to give subieienti sustemanee to the plant:

The smperintemente of ome of the state Evperimental 
Stations, in a recent, repmet on axperiments matre with Potatoses, gatese it as his opinion that loy contimually

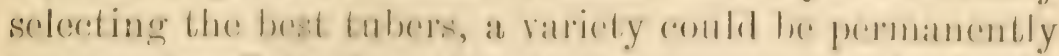
improverl. Belioving this to be an errole which shombl

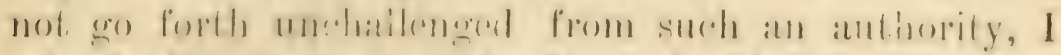
take the liberty, at the risk of a slight digresison, lo grie

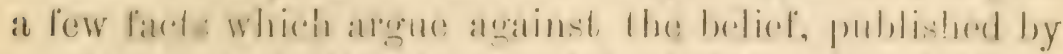

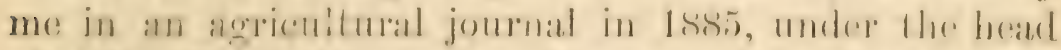

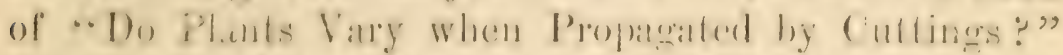

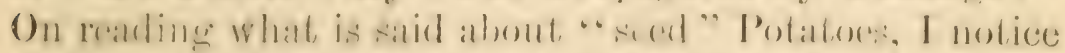

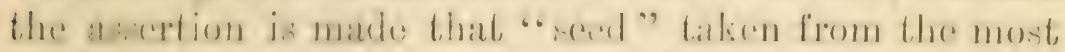

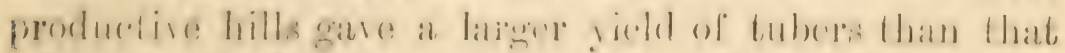
taken from the least productive. I :m inclined to

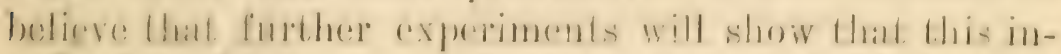

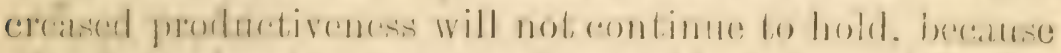

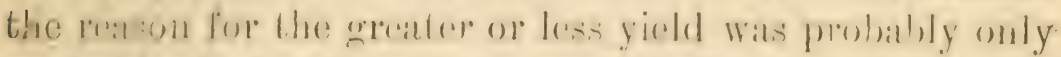

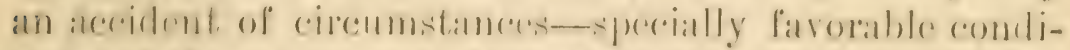
lions of the sed mate lo form the hill, or by boing highly

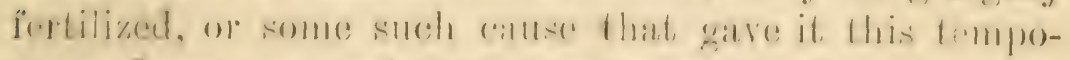

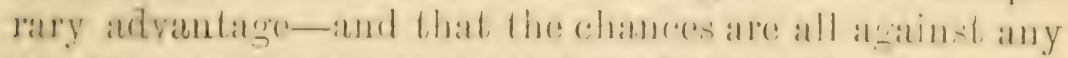
permanent improvement, being mate by sureh seledions.

'T'1e Potato is said to have been introduced into Europe in 1581. If the opiginal tubers hat hat the highed cultivation that lhe still of man rould grive, it is

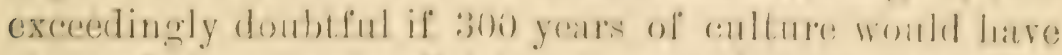

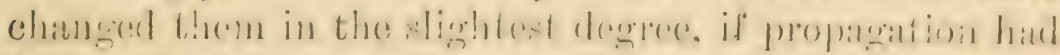

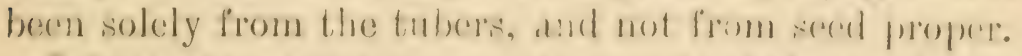

I base this opinion on a rery extended exprerence in the cultivation of plants from cultings blandersy plank bakon from any woll known kind, such as Silatrje.

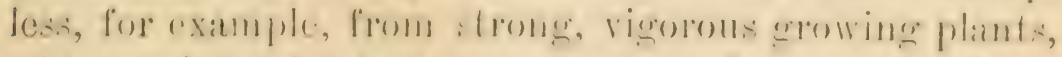

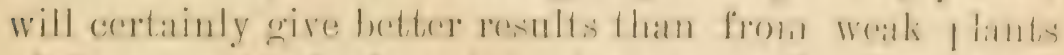
of the ratme kind planted in the same soil. lint if the progeny of the stereng and the weals plante atre atgath

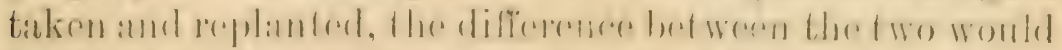

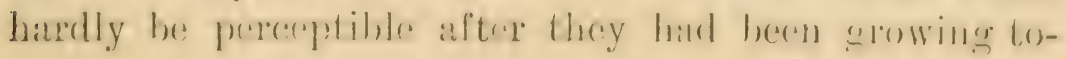


getiner under the some comlitions. Every now amd then we hear of varieties of fruts or flowers, sild to be de-

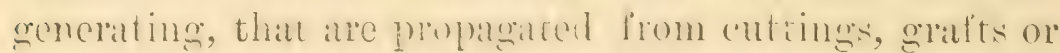
roots. I beliere there is no and thing as fermanent degeneration of any fruit, flower or rewetable that is ratised

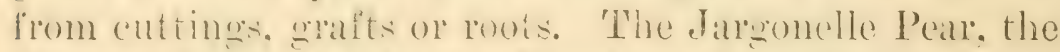
libibton Pippin Appla. the Hamburg (rlape or the Kecn

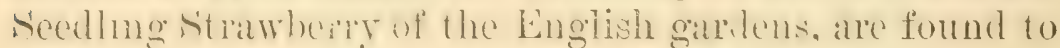
look just as gond and as bat. under dilferent onditions ol colture, at they were fifty or 100 yearsage, and that

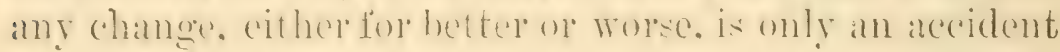
of cire motances. ant temporaly. For. he it remembered, that when a plant is raised from cuttings, as in the

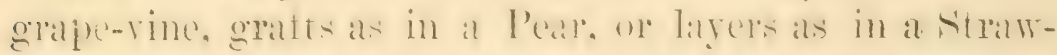

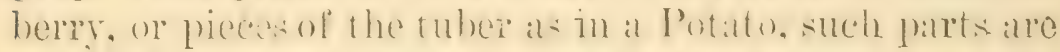

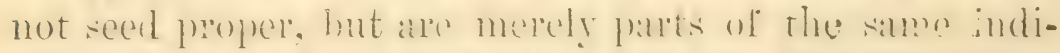
vidual that was tirst cilled into existenees. The Early Rose

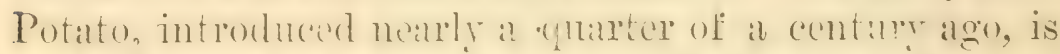

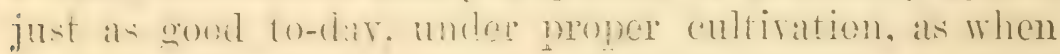
first introdnced, but it is certainly no better. It is

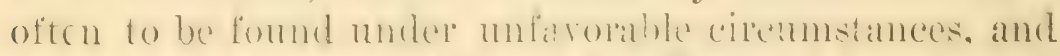

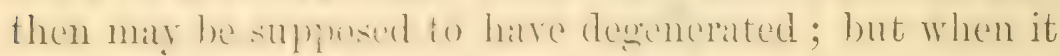

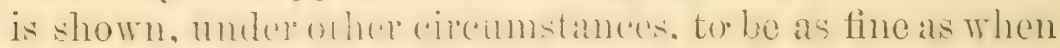
first intruluevt. how (an the atsortion of permanent degeneracy be admitted ?

Permanent improrement. in my opinion, in variotics. can only be male by the celection of the fittest specimens that have inem labed from sed proper. ILere we have, as in the Fialy lose I'otato, the sharpless stratw-

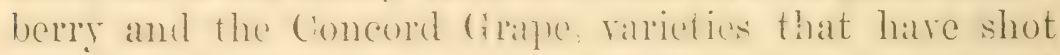
ahear of therip follows. having merits that the general pulsic recognizs. But all the ant of man cannot further improre these, so that their "progeny" (to use a conrenient. though, perhajw, not a strietly colrect term), when increased by "sets," "layers" and "cuttings," will la permanenty bettep ol worse than when first 
called into existence. It is a very common error, when a luxurlant crop of anything is secin srowing uncler specially good culture, to imagine that cuttinges, liosts ol grafts from such plants must necessarily give similar results when the same couditions to gruw such crops well are not present. Not long ago buston was famer for its Rosebuds, and even expericnceil florists paid double price for stock from such plants, only to find thas in their laads these plants would not prodnce Boston Ruscouds. Now the case is changed. Miadison, New Jersey, as a whole, heats Boston ir Ro:e culture, and the demand has changed fiom Buston to Madi:on, and, of course, with the sume losults, for, if the purchasers of Maiison lioses cannot give Madison eulture, there will be no Madison Rosebuds. While we admit the adrantage of a healthy stock, and eren, perhaps, the va!ue of a change of stock, what I claim is, that no culture will permancnt?y change the variety from its normal condition, and that the only adrance that can be male is by selecting the best sperincres, hybridizing these from their seed, again se?ecting, and so on forwarl.

To be sure, we hare in rare instances what are known to gardeners as "sports", or what Darwin has called sbud variation," which mar he improvements on the original variety or the reverse ; but culture, good or bad, has nothing to do with such anomalous cases.

Whe ofeen sne it asserted as a mitter for wonder, that the wild Celory of English marshes, or the wild Carrot of the liedge rows, have attilued their present high condition by "cultivation." If cultivation means that man has through generations "selected the fittest" of these again and again, taking always the "flower of the flock," :o as to have attained the present perfection, then that is true ; but if by "cultivation" is meant that "domestication" by high culture, manuring, ete., in a garden or a ficld has caused such results, then, in my humble opinion, it is not true. 


\section{PUMPIIN.-(Cucurbita Pepo.)}

The Pumpkin is yet offered in large cuantities for sile in our marlicts, but it ought to be binished from them as it has for some time been from our gardens. But the good people of our cities are suspicious of all innorations in what is offered ticem to cat, and it will be many yeals's yet before the inasees will understand that the modest, and sometimes lincolith looking, Squash is immeasmrably superior, for ail cuinary purposes, to the mammoth, rotund Pumpkin. 'The Pumplin is an excellent agricultural plant, of great value for cattle, but I only allude to it here, to denounce its cultiration or use as a garden vegetable.

\section{RADISH.-(Raphanus sativus.)}

Radishes are consmmed in immense quantities, and are one of the regetables which we deem of no little importance as a market crop. To have them early, a light rich soil is the best; heary or clayey soils not only delay their maturing, but produce crops much inferior, both in appearance and flaror. They are grown by us by rarious methods ; the most common is, after sowing at crop of Beets in rows fourtecn or fitecn inches apart, to sow Radiches between. The Radishes come up quichIr, and are gathored and sold ustraly in six weeks from the time of sowing. The Bects at this time have only become large enough to be thinned, and will not be ready for at least a month later, so inint the Radish crop is taken from same ground with little or no injury to the Beet crop. Another method is, to sow them between the rows of Early Cabbages or Canliflowers, where they also are gathered off so soon as not to interfere with these crops. 
These are the methods practiced in our gardens here, where land is so raluable that we must make it always carry double, and often treble, crops in al season. Radishes are also grown in some places very extensively, on land deroted exciurively to that purpose in spring. 'Their culture thus is exceedingly simple. The ground being plowed and harrowed well, the seed is sown, anr? the harrow again run orer, which places the seed at the proper depth. But though the field cultivation of this regetable is simple, the labor of gathering, tying up, and washing, freparatory for market, is great, which detracts largely from the profits. Perhaps the average receipts are $\$ 300$ per acre, but the expense, before this is realized, is probably one-lialf that amount. It must be remembered that, in many cases, it is an auxiliary crop, interfering but little with our main spring crops. It is one of the regetables conrenient to ship, and the early samples from Noriolk, Tirginia, arerage $\$ 5.50$ per barrel, of poo binches: or abont \$ro per acre, which should be a great inducement to soutliern cultivators, as there is but little danger of glutting the markets with fresh regetables shipped from a southern to a northern port. For forcing ladishes und glas', see Chapter

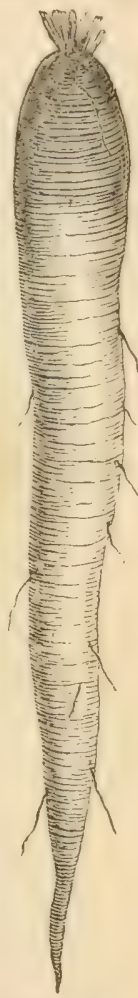

Fig. 81. LONG SCARLET SHORTTUP. 10, on "Crenhouses for Foreing Tegetable Crops."

Wood's Early Wrame. - This is a farorite with market gardeners, as it is at leavt ten dars earlier than the Long Searlet Radis?, which it rery much resembies, although it is not hardly as long.

Long Scarlet Shart-TwD.-This variety is grown the country orer in rather the largest quantity as from its shape (when tied up in flat bunches). it is best suited to 
shipping. In rich, light soils its arerage length is about nine inches. (See figure 81.)

Beclert's Chartier Madish.-This, shown in figure

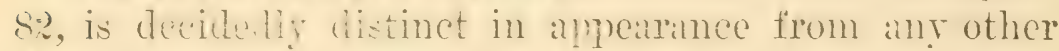
Tadish in caltivation. Its form is well shown by our

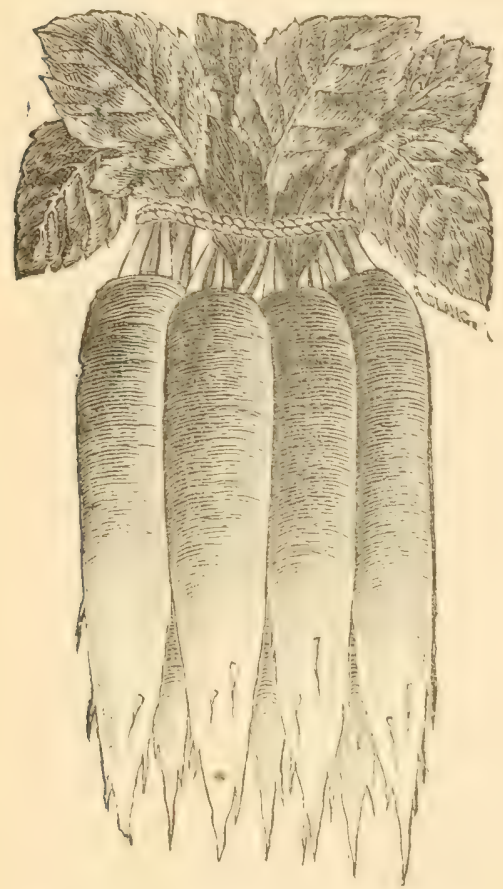

Fig. 82.-BECTERT'S CHARTIER RADISH. engraving, the color at the top being crimson, running into pink about the middle, and from thence downward it is a pure waxy white. It will attain a very lisge size before it becomes unfit for the table. In fact, at nearly all stages of its growth the quality is excellent. It sold rapidily in market during the past season.

Early Scarlet 'Tunip.More delicate in flavor than the above, and for this reason more in demand for home consumption. By allowing it sufficient time to grow, it attains a size of three inches in cliameter,

but it is always gathered at half this size.

Early Romnd Darie Red.-The shupe is the same as that of the Early Scarlet Turnir, and it diflus only in the skin, being darker in color, and in maling much smaller tops. On this aecoment it is now rely langely uset for forcing in both frames and grecnlinuse. This and the preeding rariaties are the sorts that are crown most largely for carly marketing. (fee fignre s?.)

Red Foreing maraip.-The tops of this rariety are the smallest of any of the early laddishes, which, with 
its extreme carliness, make it especially raluable for strictly forcing purposes.

White ripped Scarlet Turnip.-(See figure S4.) An

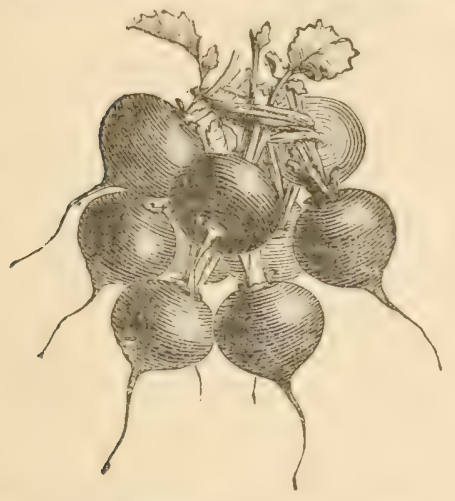

Fig. 83.-EARLY ROUND DARK RED RADISH.

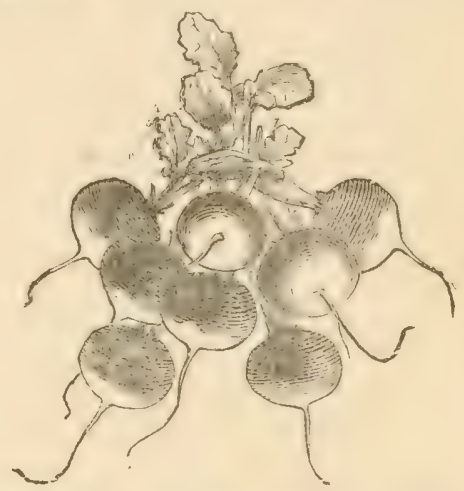

Fig. 84.-WHITE TIPPED TURNIP RADISH.

early varicty of medium size, rery handsome in appeaance, and of excellent flavor.

French Rrealifast.-(See figme 85.) A rariety of quick growth, very mild and tender, and one of the best

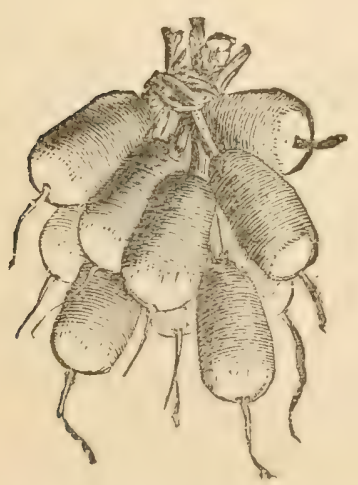

Fig. 85.-FRENCII BREAREAST RADISH.

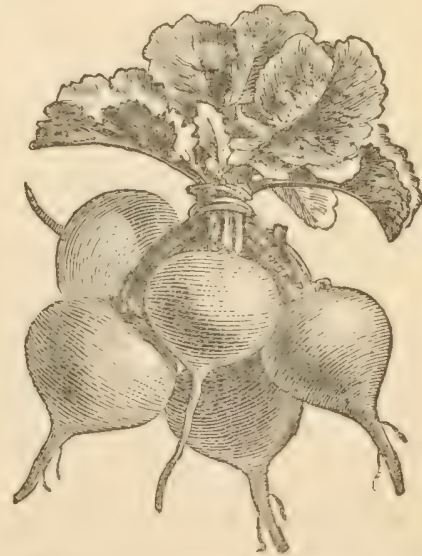

Fig. 86.-TELLOW STMMEIR TURNIP RADISH.

for forcing. Of oral form; color, scarlet, tiplped with white. 
Olire-Shaped searlet.-Ofohlong shale: flesh, rosecolor, and a good summer variety.

Later varieties, grown for fall and winter use :

Vellow and faray sommer tomipo - Varricties well suited for summer use, als they stamb the heat better than the early sorts. Both alle mild in fiaror. The yellow rariety is shown in figure sto the other is like it, save in color.

chinese loese-colored Winter.-Exellent for winter use; flesh, firm; skin of a bright rose color.

Long and Bbound black spanish.-Fery hardy varieties. They are often preserved, kecping an well as any other rogt, in simel. until miel-winter, in al cellar or roothouse. They are of latrge size, but ruther hatrsh in flavor. Color, grayish-black.

\section{RHUBARB.-(Rheum Rhaponticum).}

Rhularh is mow cultivated latrecty for market purposes in the ricintity of and bane cities, and fow private gandens are without it. Its culture is of the simplest kind. It is a plant that adapts itself tio almost any soil, prorided it is well drained, artificially or otherwise. The preferable soil for Ithularbla als for most regetahles, is a deep, sandy loam. Whaterer the soil, it should be

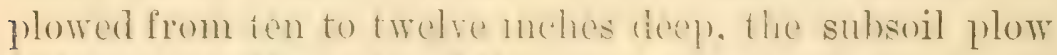
following in the wake of the other. at trring to the depth of ten or twelve incles nore: alter plowing, harrow deeply and thoroughly.

After the soil is prepared. lines are struck ont by the plow four feet apart rem each side of the tield or plot, so that they will intersect at right angles. At these points the plants ane set. first mixing with the soil three or four shorelfuls of well-rotted manure for each plant. 
The time of planting in the Northern or Western states may be either in the fall or spring; at the South the fall is preferable.

Rhubarl) is usually propagated by division of the old roots; aach eye or bud, when broken alpart with a root attached, forming a plant. But malking a plantation of any great extent in this way is expensive to the beginner'; as the roots are rarely to be purchased nender s50 per 1,000 eyes, and as alhout 3,000 plants are required for an acre, quite an outlay is necessary.

This expense may be obriated ly increange the plants by seeds, instead of by division of the roots. In the Northern state:, the hest time to sow the seen is about the middle of April, in the open ground, in rows a foot apart, if the plants are to be again transplanted; if to be left where sown, the row's mist be three feet apart, and the plimts thimed ont in the rows to one foot apart. But as this latter plam requires the occupation of the land too long, the usual way is to sow closely and transplant. Care must he taken that the seed is well trodden in with the feet, as it is rery light and rather slow to germinate. The soil best suited is a rich sandy loam, which should he thoroughly pulverized, and the surfiace made completely level before sowing.

The plantis may be transplanted from the seed-bed either in fall or spring.

The first season after plantmg, no stalk should be pulled, but the next year a full return may be expected if proper attention has been given to cultivation.

It is execedingly duffieult to name the amnual profits from an acre of Rinularb in full hearing, as crerything depends upon earlinests. Even here, in the ricinity of New York, growers vary in their statements from $\$ 100$ to $\$ 300$ per acre. The difference of a week in earliness often makes a difference of $\$ 150$ and $\$ 200$.

It may be safe to say, however, that it will arerage, in 
this vicinity, a profit of $\$ 250$ per acre amually from the date of planting; in many places where there is less competition, no loubt double or treble that amount may be realizerl. Rhubarb is a most simple and convenient plant for forcing, which may be done in the following manne: ' lin roots are dug from the open ground in fill, put ciose together in a box or barrel, and soil sifted in to fill the interstices betwewn the roots; they are then placed in a situation where the temperature will range from fifty-live to about serenty-five degrees, with a mollerite amonint of moistur. By this treatment Rinbarb may be had Irom January to April. The roots mat be placel wherever there is the necessary temperature. Light is not at all necesiary : in fact, the stalks of Rhubarl) are much more crisp and tender when forced without exposure to direct light; hence the roots may be placed in the furmace room of a cellar, under the staging of a greenhouse, or in an sarly forcing grapery. A florist in Boston told me a few years ago, that he had soll enough Rhuharb, grown unter his greeihouse stages, to pay his conl hill (over $\$ 100$ ), besides having all he wanted for his fanily use. Rhubarl is foreed quite extensively by some of on malrket gindeners; the method pursuci by them is to lift the roots from the open ground in the farl, lulue them as closely torether as possible in such pits or frames as are usel for hot-bels, hut about two feet deep, sifting in soil so as to fill the spaces butween the roots. On the approach of cold weather, the whole is corerel orel with a foot or so of diry leares, and so remains until about Fermary first, when the leaves are removerl and sashes placed on the frames. Sometimes this is not done until Marcl, the sashes being then used which have been covering Cabbage plants through the winter. But little rentilation is giren to the frames at this cold season, as it is necessary to raise the temperature of the frame by the action of the sun's 
rays, so as to forward the crop. It creatly aids the forwarding if the sasthes are corered up at night by straw mats or shutters. Rhubarly so forced matures about one month before it is marketable from the open ground, and averages about \$10 for each three by six fout sish. It must be borne in mind, howerer, that forcing com-

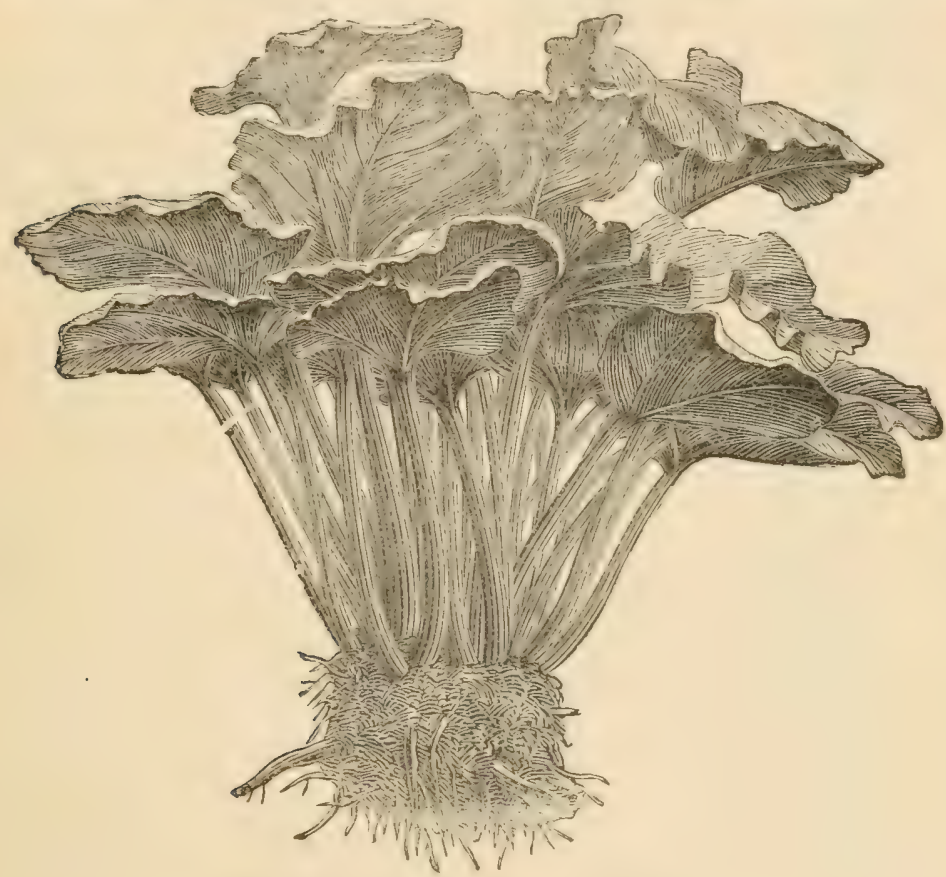

Fig. 37. -ST. MARTIN'S RHUBARB.

pletely destroys the roots, and for that reason it is only practiced by those who have a surplus that they would otherwise throw away.

The principal varieties in cultivation are:

St. Marting-(See figure 8\%) A new London rariety, which is by far the hest, being of rich spicy flavor, enormously prodnctire, and of the largest size of stalk.

The other" two well-known kinds are "Limnæus" for early, and "Victoria" for late crops. 


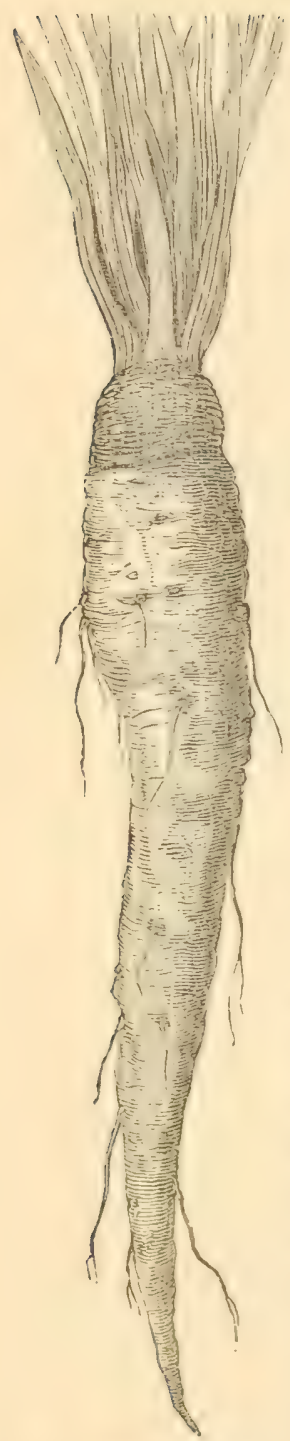

Fig. 88.-SAISIFY.

\section{SAGE-(Salvia officinalis).}

See 'Thyme, and other Sweet Herbs.

\section{SALSTIE, OR OISTER PLANT,}

(Tragopogon porrifolius).

This regetable is coming rapidly into general use ; patches of an acre in extent are seen in some of the more extensive gariens here, that a few years ago grew only a few rows. It should be sown in early spring. Its culture is in all respects similar to that of Carrots, and although its consumption is as yet limited, for what is grown of it, the prices are high and rery remuncrative. It is moreorer a safe root to cultivate, for, being entirely hardy, there is no risk whatever of its being injured by frost, should it so happen that the digging up is neglected in the hurry of fall work. It is generally better, howerer, to dig it up and put it away as we do Parsnips or Carrots, so that it can be had at any time during winter. It wsually sellas at higher rates in spring than in fall or winter; but eren with the adrance in price is less profitable to the grower when sold in spring, as that being a busy season, the labor expended in digging it up and gutting it reaty, is then of much more value.

As this regetahls will be monown to many. I will state that it is used in rarious ways, but generally boiled or stewed. like Parsuips or Carrots. It is also msed to 
make a somp, which has a decided flaror of the oyster. It is also eaten as a salad, sliced and dressed with vinegar, salt and pepper. There are no varieties.

\section{SCORZONERA-BLACK SALSIFY.}

(Scorzonera Hispanica).

Very similar to the above in general character, and of the same culture and use. It is not, howerer, so generally esteemed its the Oyster Plant, and is not grown except for private use, and even for that purpose sparingly.

\section{SEA KALE-(Crambe maritima).}

This regetable is much esteemed and grown largely for market purposes, both $1 \mathrm{~m}$ England and France, and no private garden of nny extent in either comntry is considcred complete without it. Here, howerer, even yet we scem to make but little headray in its cultivation. I have rarely seen it offered for sale in our markets, and its culture is practiced in but few private gardens.

There is an impression that it is difficult of culture in our climate; this is not so by any means; it is equally as easy to grow it here as it is in England, only thatt. like all regetables recuiring artificial heat for its perfection, its cultiration is attented with more expense than that of regetables that we plant in the open ground, withoni other care than to keep them clear of weels.

It is mereased cither by roots or by seed; when roots can be obtamed to start with, they are quicker. The manner of operating with them is as follows: In fall, a few old plants of sea Kale are dug up, and the roots cut in pieces of from two to three inches in length; these are placed in boxes of sand in a dry cellar until 
Fohruaty or Mande ; they are then sirewn on the surface of a hot-bed, where, in a week or two they will emit roots and tops; they are then potted or planted in

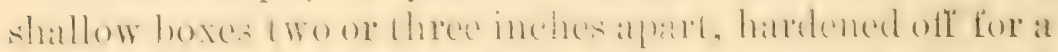

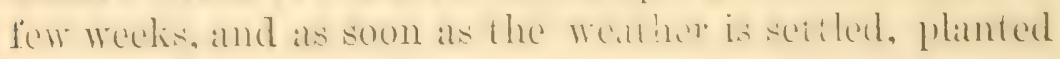
ont in rows three lect

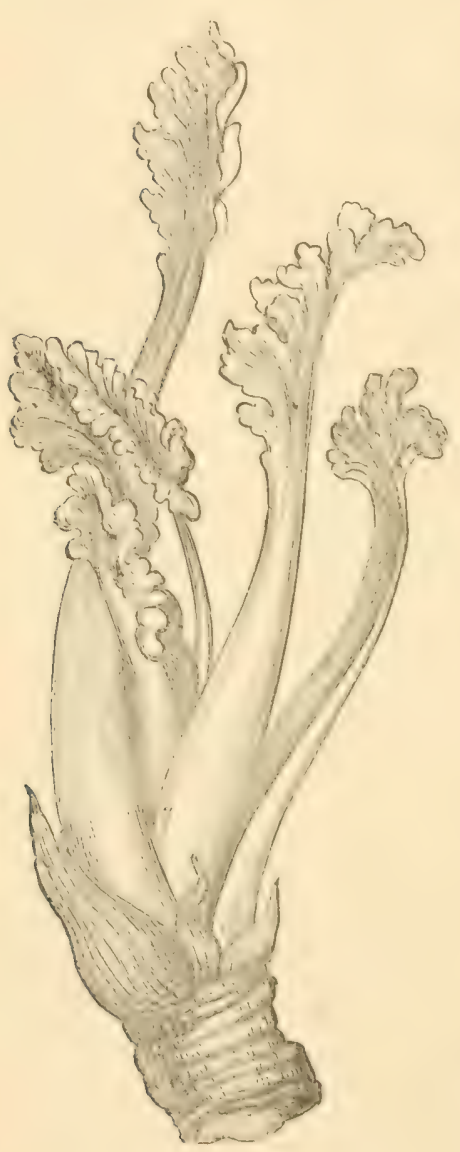

Fig. 89,-SEA TALE. apart, and two feet between the plants. If the ground is in the condition that it should be, Sea Kille, thus treated, will produce crowns strong enough to give a crop the next season alter planting. When grown from seed, the seed should be sown in hills at the above distances apart, in the early spring, each hill being thinned out to three or four plints. In our colder latitudes, the crowns should be covered by four or six inches of mamure or leares as a protection from frost.

Sea Kiale is only fit for use in the blanched state, consequently on the approach of spring", the "crowns" should be covered with some light material, such as sand or leaf mold, to the depth of twolve or fifteen inches, so that the young shoot, being thus excluded from the lieht, wall become blanched in erowne through this covermon: or sometimes cans, matce for the puxpose, or inverted flower pots ane used, the only oljoct being to 


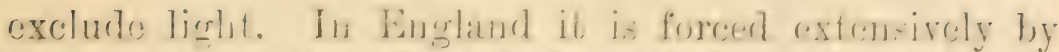
corering over the whole lieds with leater, manure or

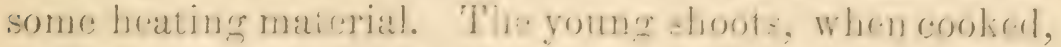

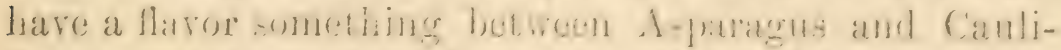

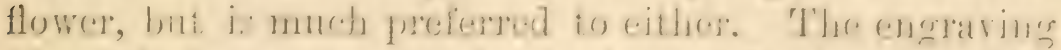

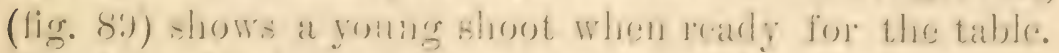
I'le fully developed leares are large aisd polust.

\section{SHALIOTS.-(Alium Ascalonicum.)}

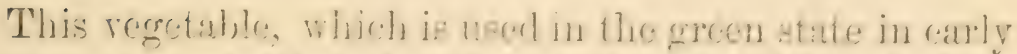
spring as at substitute for Onirone, 14 planted by rlividene the bulbs in septrinsey, and planting an rows one foot apart and six inceles between the flants: it makes a slight growth and forms its poots in the fall. (Bn thes opening of spong at dorelope rapiolly, and the singte

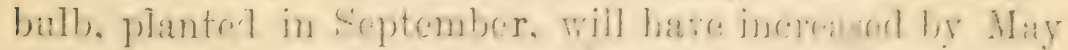

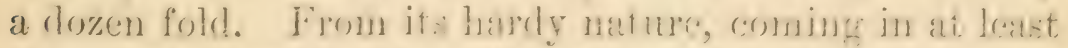

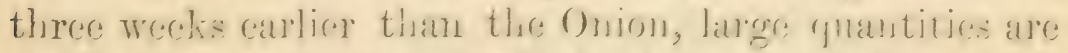
sold at rates corresponding with thowe of (onions raicod

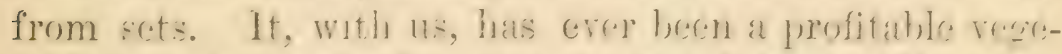

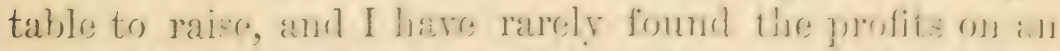

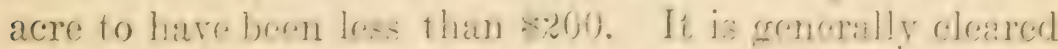

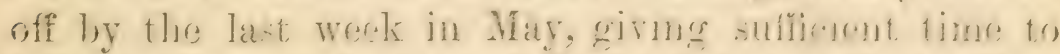

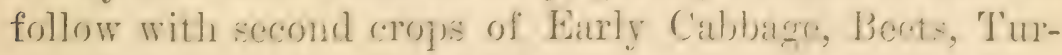
nips, ctc.

\section{SORREL-(Rumex Acetosa).}

A woll-known preronnial plant, (onltivatrel to somm oxtent with us. It $1:-11 \times 0+1$ ins somys and sancos, mo-tly by

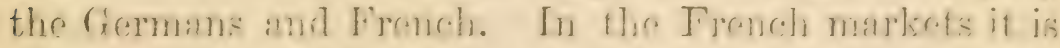

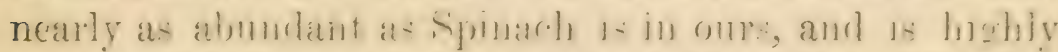

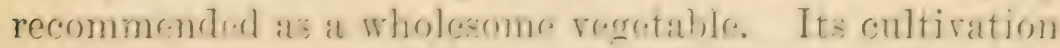
is very simple. Serols, orwu thinly now row in rarly 
spring, will give a hary crop of leaves in Jume ant July ; when the flower-stalli of the Sorrel starts to crow, it should bo cut out. Which will adh greatly to the levelopment of the leares. The cropl may be laft two sea: ons, but is more tonder when anmully raised from seed.

\section{SPINACI.-(Spinacia oleracea.)}

This is a rery important crop in our market gardens, hundiects of areres of it being cultivated in the neighborhood of New York. It is one of the most manageable of all regetal, les, reyuiring but little culture, and may be had fit for use the entire season.

In onl market gardens it is sown in early spling as an

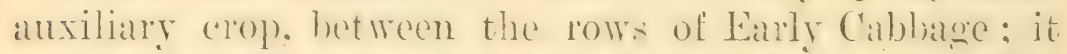
comes to perfertion msualy in four or fire weelis after sowing. At this seasom, it sells at a low proce, uslatly about B̂fty cents per bal'ele ; but it requires but little labor, and generally palys about \$ô per ace of profit. 'The main and important crop) is sown in drills one foot apart, in this section from 1st to bith september. or late cuough in fall to git about half grown before cold wather sets $i: l$. It is sometimes (mored np in exposed planes with straw or salt hay during winter, whin preFoists it being ant with the frost: hit in sheltered fichts here there is no necessity for coyering.

Any soil that will grow a good ('om eropl will grow Ginale, though, as is the case with all other regetables in which the leat or stem is the part used, the land an hambly be made too rich. Oar practice ss to erove it on one best suils, applying not lose than fiety tons of wellrotert stable manure to the acrear or in licu of stable manure, one ton of bone dust: or about $1 .: 200$ pounds of enano sown after ploweng. and decply harrowed in. The rows are male with the ordinary garden " marker," 
at the distance of twelve or fifiecn incies apart. The seed is sown rather thickly; we prefer to do it always by hand, uning from ten to filteen pounds per acre; when thickly sown the plants can he thinnerd ont, so that a much larger yick will be griven. We sow here from the ith to the 15th of September, and anite frecpuently sell, by thiming out, filty or serenty-fire barele from an acre, which usually in october and November sells for $\$ 1$ per batrel. This thimnes out, which is done by atitting out the plants where thickest with a knifo, if carefully performed, cioes not at all injure the main (rop, which is to stand over winter until spreing. I may here caution the inexperienced of the necessity of trealing (i)wn the soil on the seed, if the land is dry : the crop is often rained by the want of this precantion, in emtinued hot, dry spells that are frecruent with us during september. If the soil is left loove, the hot air shrivels up the seed so that it will never germinate. The best way is to tread in each row with the feet, and in addition to use a roller. Probably one-half of all spinach seed sown in fatl fails to germinate, and from no other callice than the failure to thus firm the seed. The same precaution is necessary in the sowing for Cabbage and Lettuce plants; at this season these are often lost from the same cause.

Fair crops give a yield of 200 barrels per acre (average price, \$2 per barrel); at a high estimate the expenses; will not exceed popere so that it is safe to claim a net profit of s15is, althoug's extrandinary crops often do much more than this. 'ilhe pround can be reared early enongh in May to follow the spinach with a crop of Flat Dutch or Early Summer Cabbare. Apinach is hardy enongh to grow in almost any part of the conntry ; but in districts where the thermometer falls below zoro, it is necessary to cover it up alont Christmos whth hay, straw. or leares, to the repth of two or three inches; it 
is best done just as a snow storm is setting in, as the

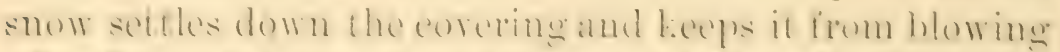

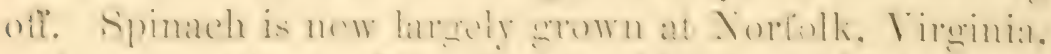

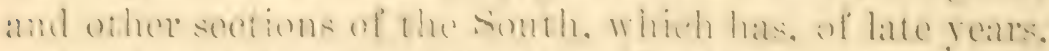
sorionsly interfored with the Northom grown erop.

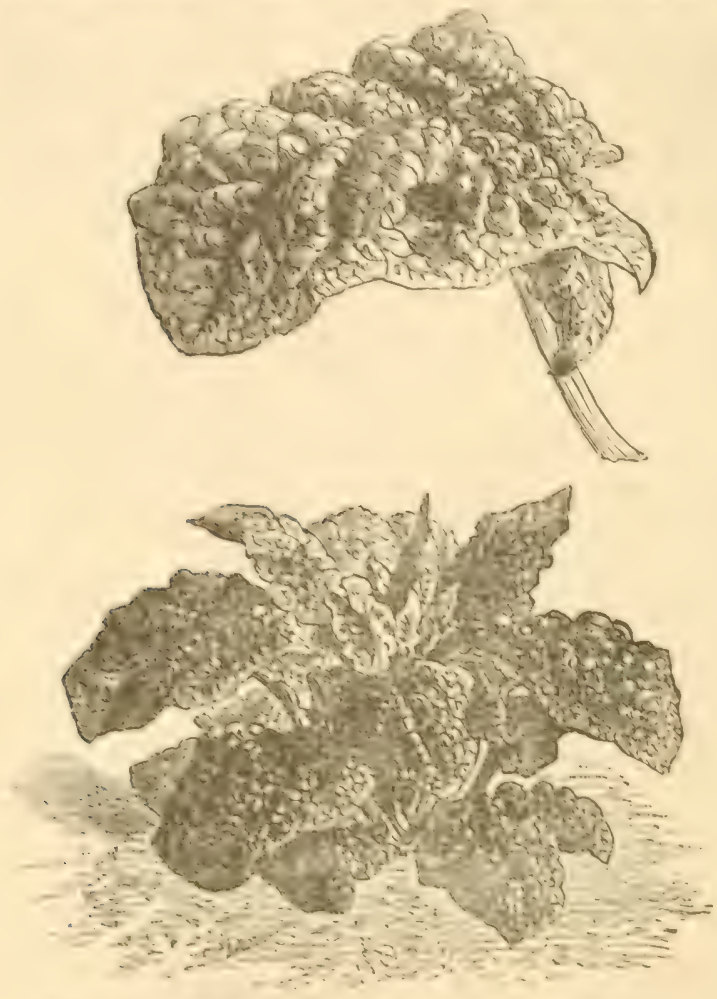

Fig. 90.-NORFOLT SATOT-LTATED SFINACI.

'The quanticy of sod per aree is fomm cioht to twolve

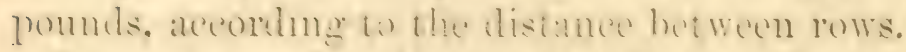

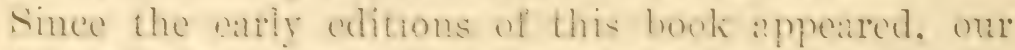

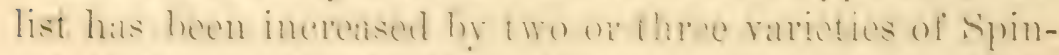
ach that are not only distinet in ampeatrance. but which. in many sections of the comntry, are now grown to the

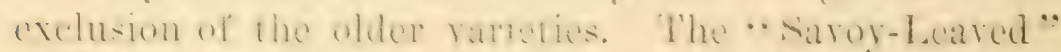

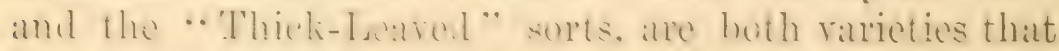
have secured this popularity. 
Norfolk Saroy-Leaved.-(Sce figure 60.) This produes nearly twice the weight of crop of the older varic-

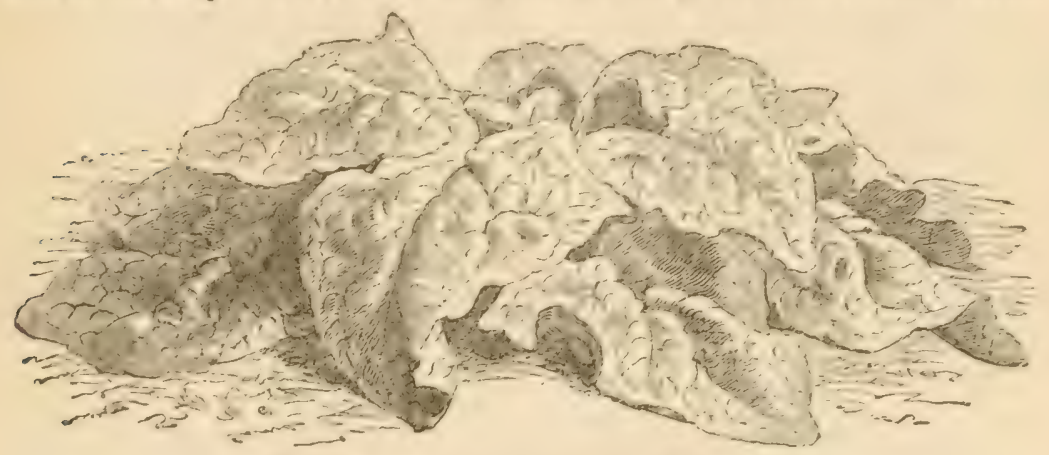

Fig. 91.-THICK-LEAVED SPINACH.

ties, and has a further value in the fact that it is the hardiest of all varieties of Spinach. In appearance the leaf is wrinkled in the same manner as the Saroy Cab-

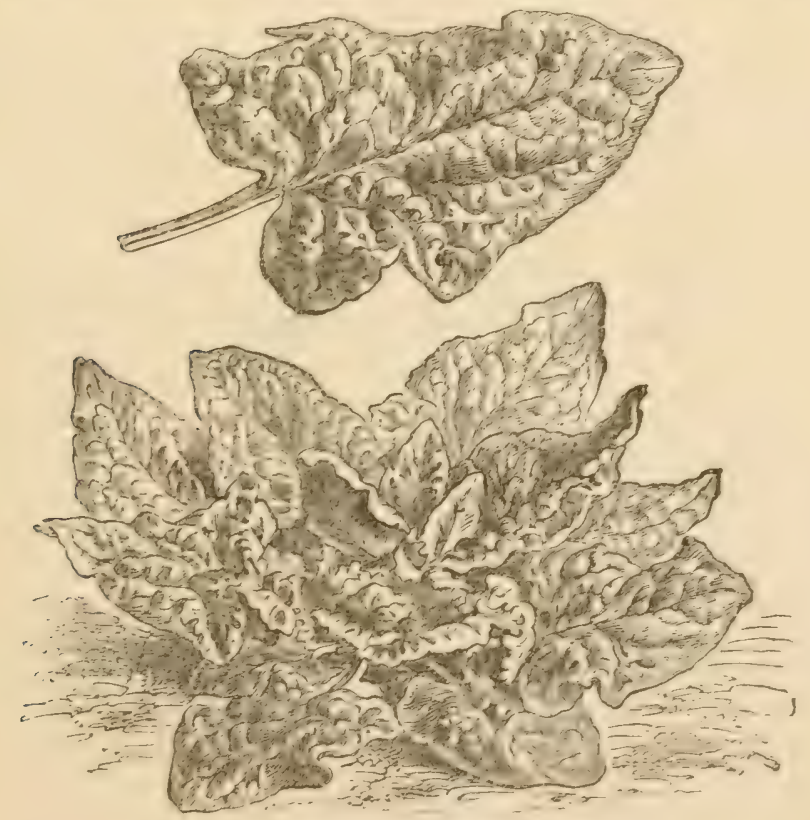

Fig. 92.-LONG STANDING SPINACH.

bage, hence the name. From the tendency of this sort to run to seed, it should never be sown in suring. 
Thiok-Leared.-(son fisum ?1). This is whe of the best matket sorts. If produces a liarge, thiek, strong. green leat, somewhit crumpled, and possesses the valuabe quality of stmoing a lomer timo before rumning to seed.

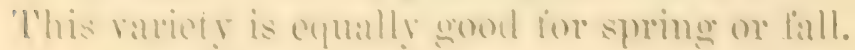

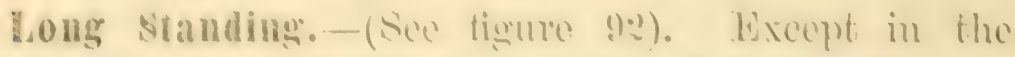
perentiarty that it stands at long fime before rumning to

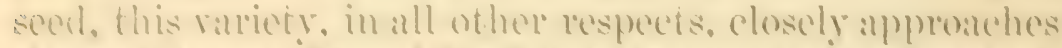

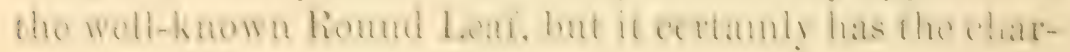
acteristic of not rumming to secel.

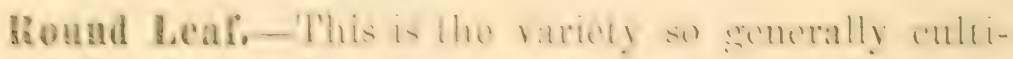
rated for winter nse, boing rery hardy, standing our sererest winter's with little injury.

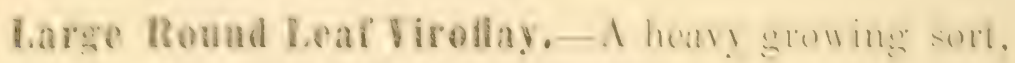
resombling the 'Thick-Leared: hardy.

Priskly. - dlihough this rantety is msually sown in the spring and summer. it also stands well in winter, but gives less bulk per ace tham the others named.

\section{SPINACH.-SCRSTITTTES FOR.}

As Spinach will not endure the hot suns of summer, it ruming up to seed at onee if sown in hot weather,

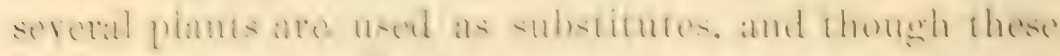
are not grown for market, they are very convenient in the limmily gitriden.

One of these is the swiss Chard, mentioned under Bove, seremal forms of whieh are sold ats sirnateh beet and Porpotnal spinueh. Perhaps the thes suhstitute for Spinach in the summer months is the

New Realand spinach.-(TRergona cxpensa).- 1 plant of the same character and uses, hut of a different genus, and used only in private gardens. It is a remark- 
ahle plant, of hew branching labit, growing with worr-

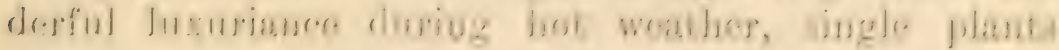
often measuring six feet in diameter. The leares alle userl ewactly as common Spinareh; it jos bost glown by gowing the seeds after the soil is well wamerl, and thansplanting to three foct ajorat in resy rich, wasm sojl.

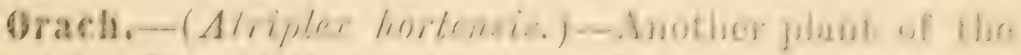

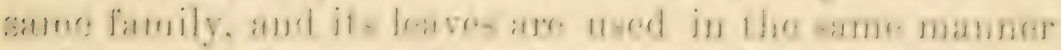

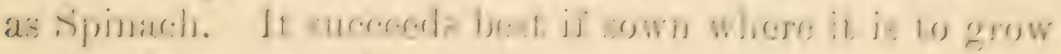
-in rich, mojst soil.

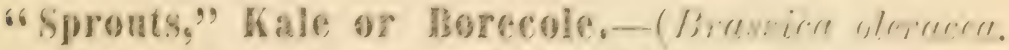
Var. Sabellica.) I form of the Cabbage grown in all

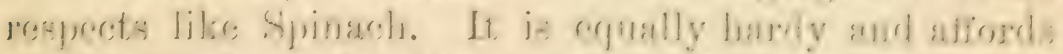
amilar profits moder like conditiona. Jake gyimarsh. if

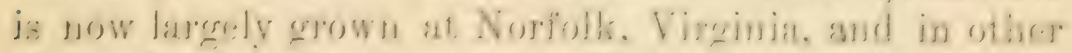

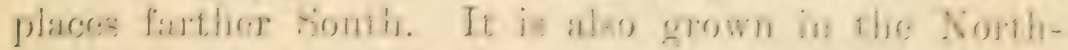

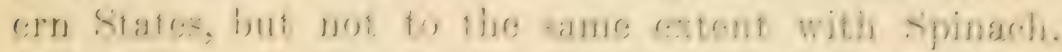

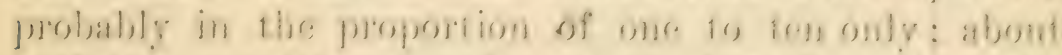

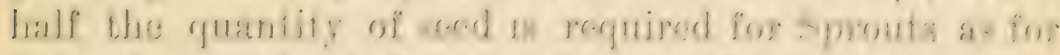

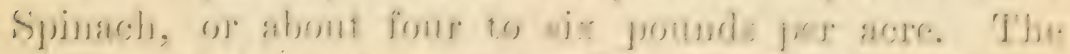

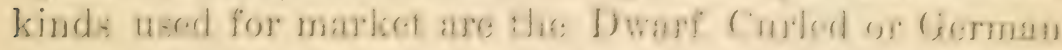

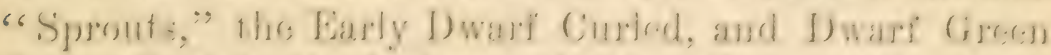

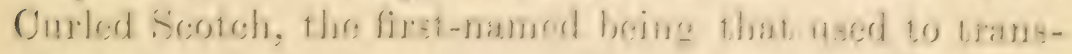
plant the others, being grown like Spinach.

\section{SQUABH.-(Cucorbila Pepro, and C. maxima.)}

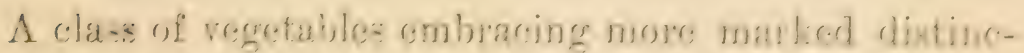

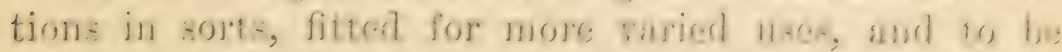

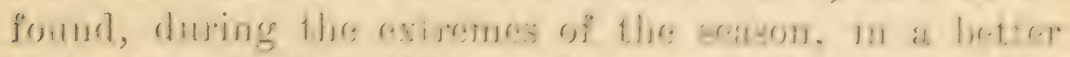

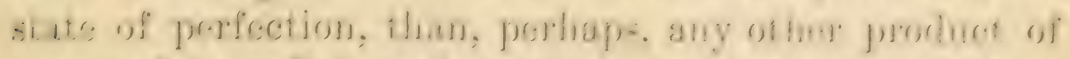

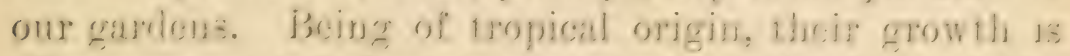

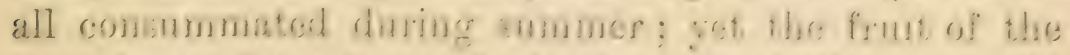
"winter varietice" may hre lept. with a lntle care, nutil May. Theer are all of hoxuriant and vienorie erowth, 
ame a?tlough they will grow reatily on almost any soil, Yit there is harlly anything cultivated that will so well

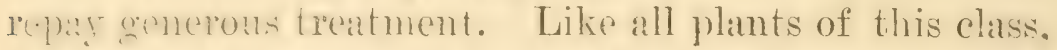
it is uscless to sow until the wealther lias become setted and ramm: next to Lima Beans, Squashes should be the litst regetahle planted. Liglit soils are best suited for their growth, and it is most economical of manure to prepare hills for the seeds in the ordinary manner, by incorporating two or three shorelfuls of well-rotted manure with the soil for each hill; for the bush varieties, the hills shomld be from three to four feet each way, and for the running sorts from six to eight feet. Eight or ten secds shonld be sown in each hill, thimming out after they have attained their rough leares, leaving three or four of the strongest plants.

'They are extensirely grown for marlict, but are not, sulficiently profitahle for our highly cultivated gardens, and are therefore grown rather as a farm-garden. crop. Whey vily in prolit, in our vicinity, of from $\$ 100$ to s.) per alce. 'The carly varieties are grown quite extensirely in the vicinity of Norfolk, Charleston and Sarannah, and shipred North, from two to four weeks earlier than they can he hat here, and, like all such commodities, bring three or four times the price of those grown in this ricinity, in quantities that glut the market.

The rarictics are very numerous, and from the facility with which they will cross, it is very difficult to retain the different kinds pure.

\section{SUMMER VARIETIES.}

Yollow and White Bash Scalloped.-(See figure 93.) These rarieties are the two kinds that are considered the carlicst, and are grown almost exclusirely for market for first crop. From the hard texture of the rind, they are well fitted for shipping, and are grown exclusively at 
the South for that purpose. Plant three to four foet apart in hills.

Bush Summer Crook-Neck.-A much estecmed rariety in private gardens. Somewhat similar to the proceding in growth, but rather more dwarf. The fruis is orange yellow, cosered with warty excreseences. It is considered the best yielder of the sumber varietis.:

Boston Marrow.-This rariety may be termed second early, coming in about ten days after the bush and crook-

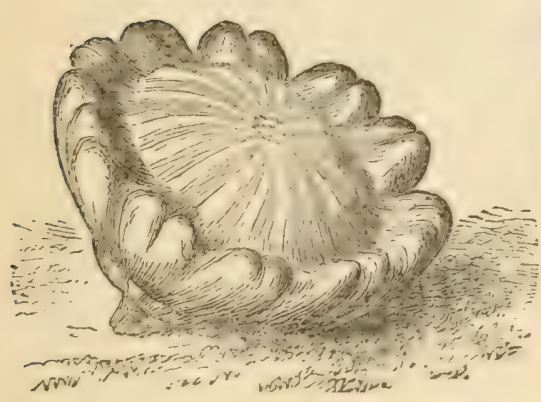

Fig. 93.

WHITE BUSH SCALLOPED SQUASH.

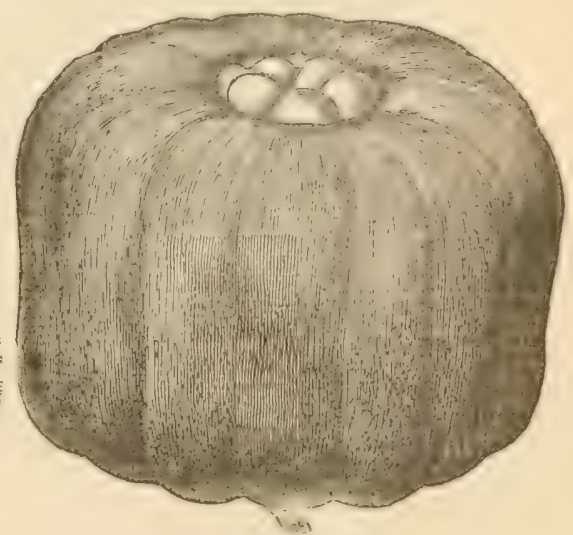

Fig. $3 t$.

ESSEX HYBRID SQUASU.

neck sorts. The skin, which is of an orangerellow rolor', is very thin, the flesh being dry, finc-rained. and of unsurpassed flaror.

\section{FALL AND WINTER VARIETIES.}

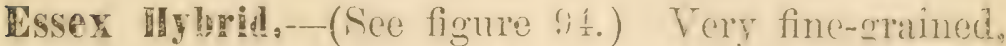
rich and sweet, and a splendid keeper. The flew is very thick and solid. Ass a siquash for winter hesping it is unsurpassed.

Hubbard.--(See figure 95.) A ceneral farorite, and more largely grown as a late sort than any other. It is of large size, often weighmg from nine to ten pounds. 
Color, hluish-ereen, oreatsonally mathed with brownish-

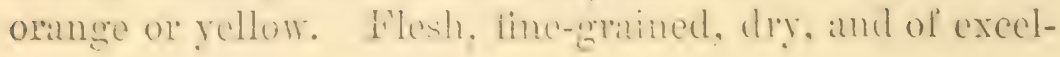

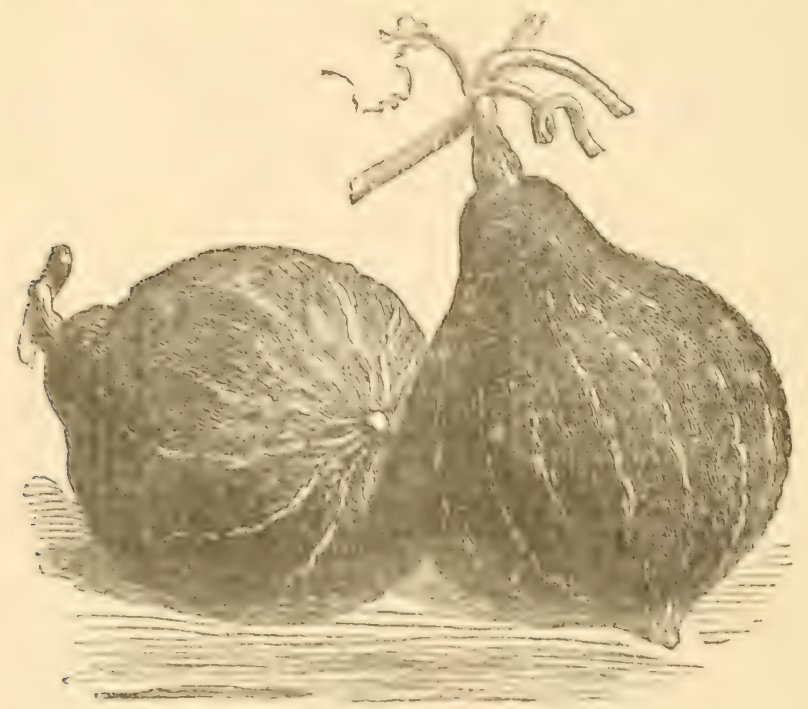

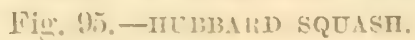

lent flavor. It wan he ham in we lrom september to Nay. Plant in hills eight foet apart.

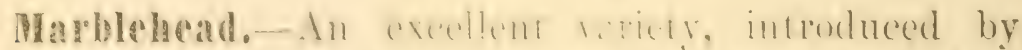

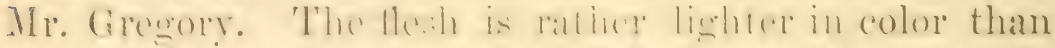

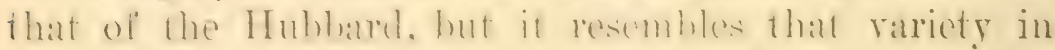
shape, although it has a hapeler shell. It is productive. of rich and excellent flaror, and a time herper. Plant eight feet apart.

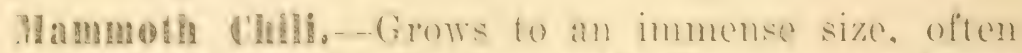
livehing :00 pounds. Exeollent lor all purposes. Plant nine feet apart.

Winter crook- Veck.-A rariety largely grown in some wi the Eastern siates, where it as ofien liept the entire winter. sing, rohlish-pink when matured : flesh, closeseramel and sweet. Plant in hills nine fort alpart.

Pegetablo Marow. - filvorito linglish sort. 'The

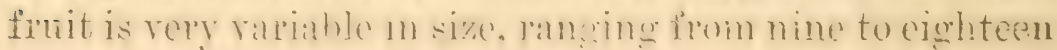




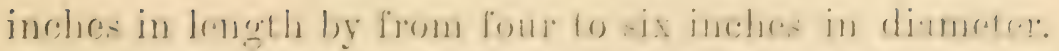

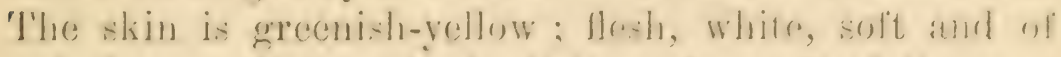
rich flavor. It is cutirely distincet from all of the for ceding. Plani eight fect apart.

SWEET POTATO.--(Ipomea Bretritus.)

The Sweet Potato requires a rich. Jight, warm orsl. It is more groneraily grown in thr. Somthern states than the ronmon lotato, as there the eoil and climate are mores eongenial to it. We lawe often diflimalty, in this dis-

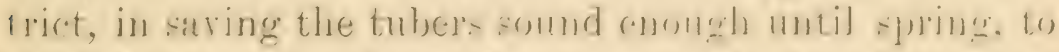

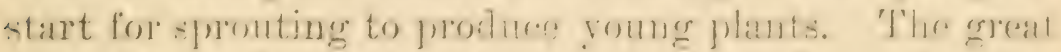

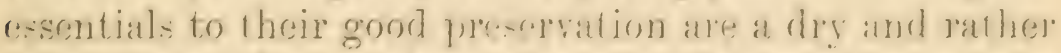
warm atmosplere; the collats, suitable to preserve the

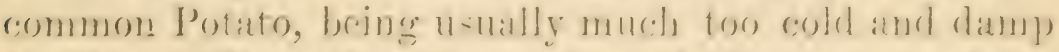
for this. Where there is no place of the necentery high temperature, it is best to get them in spring direct. from

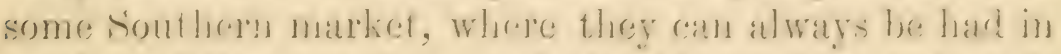
good condition: or they an be kept by parking in bareds

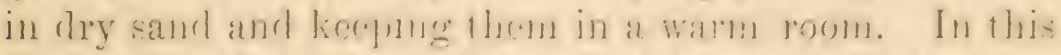

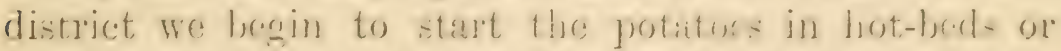
foreing-pits about the mirlale of April, laying whem thickly together on a two-inch laver of sand and leaf

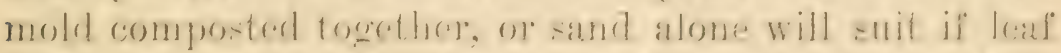

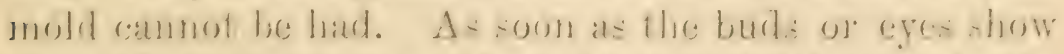
sigus of starting, cover the roote enmpletely overe to the

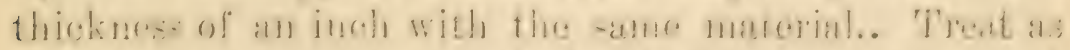

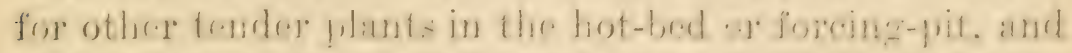

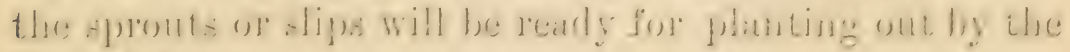
first of June.

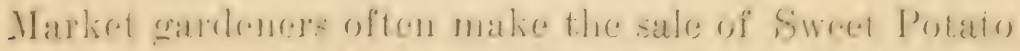
plunts a rery profitable operetion, immener quantitires of 
them being sold to private growers at the planting seatsom. Is the sprouts from the potatoes coms np rery

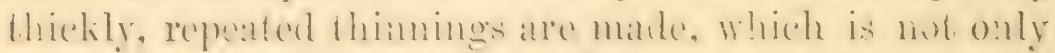
profitable to the grower, but of great alvantage to the remaining plants, hy giving them the nexestry loom to grem. One eromere in this viemity informed me that list

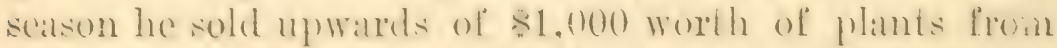
150 salshes, which were sold att an arerage of 81.95 pere 1,0iv). The protit from the entivation of the plant in the field is ammething less than that from Tomatoes, hut mole than from the common Potato.

In Somthern Now Jexey and further south, these heds are not covered with glass, but with a light corering of straw or collse hay, to retain the warmith, hut the hed: must not be ihus male before the lirst week in May, in New Jersey. 'This is removed when the plants

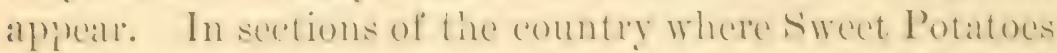
are grown eren to a small extent, there are geremerally men who make a business of growing the plants, which are oftem to be bought as low as $\$ 1$ pex 1 , (100), and it will be forma better for the erewere to purehate than to ratise them himself, if he has not the proper convenience of satshes and hot-beds. The plants alle sed ont in rows three or four foet distant, and about two feet alpart in the rows, using a woul shovelful of woll-rotted manure, mixed in, for each hill. 'They are always planted in light, sandy soil, heary soils being entrely monengenial to the nature of the root. As they atrane in erowth the rows are hilled up with the plow in the sime manner as ordinary Potaloes, care heing talien, howerere. to prevent the vines as the hamg ored, from rootinge in the siml. 'This is dome by rmming alome the vires. oceat sionally under them. with the hamed fo hreak the young roots and liepe them from striking into the soil. If this were not dome it wombl diredt the gerowth from the main root, and the putatoes would be small and nearly 
worthless. In the Northern States, Sweet Potatoes must al ways be used previous to Itecember, unless they can be kept in a warm place.

In the sontinan states they are kept in pits in the open groumd in much the same way as we keep ordinary Potatoes at the North; but the temperature of the soil i.s of course much higher in Floridat and other extreme Southern States than at the North. MInst of the Swect Potatoes that find their way to our Northern marisets in the winter and spring months, are grown in cieorgia, South Carolina and other southern states. They are preserved in the South ly storing them in hoases specially built for that purpose. The Potatoes are packed in boses not more than eighteen inches deep, which are placed in tiers one alowe the other, leaving spaces between for ventilation. Isut in extremely cold weather it is necessary that the apartment should be heated in some way so that the temperature at no time is allowed to fall below fifty degrees. There is no necessity for packing anything around them; if the heat in the apartment is sulficient, they will keep by the air circulating around them among the shelves or boxes in which they are placed. Probally the hest temperature at which Sweet Potatocs can be kept in winter is sixty degrees. The following are the sorts mostly grown:

Nansemond.-This is the earliest sort ; tubers large, from three to four inches in diameter at the thickest fart, tapering to cach end, and from five to eight inches long; flesh dry, sweet and well flavored.

led skinned.-This variety is claimed to be hardier than the preceding, but it is donhtful if this is the carce. It is a long, slender variety, mostly grown in private cardens, and is thought to be of a richer flayor than the yellow or white sorts.

Vollow skinned.-This sort is manly cultivated in the 
Southern states. Where it attains neary the woight of the Namsemomel : it requires a lomger season tham that varietr, and is not so suitable for the North. It is of

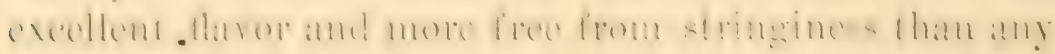
othere solt.

\section{$\rightarrow \infty+\infty$

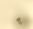 \\ TOMLAT0.-(Lyenpe?sicun esculentum.)}

This regetable is onc of the most important of all galden products: humbed of acoes are now planted with it in the vicinity of all lange eities, and the lacility with

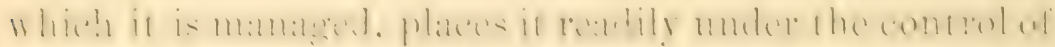
the least oxperioned. It is now erom here almost entimely by those who gaw Peas, Potatoes, Melons. and

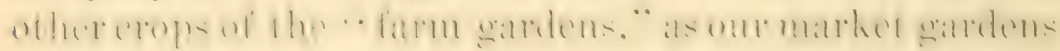
proper ane too highly amichad and much too limited in

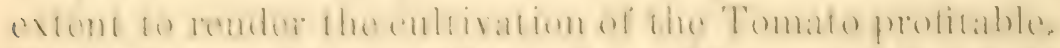

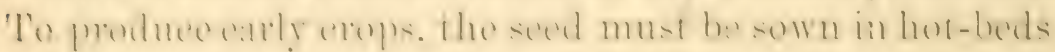
or foreme-pits, about ten weeks before the plants may be safely put in the open gremed. 'Thus, in this distriet. We sow in the hot-bed about the first wote in Mirch: in April the plants are fil to be sed out. at a distance of fom or live inches apart, in another hot-bed.

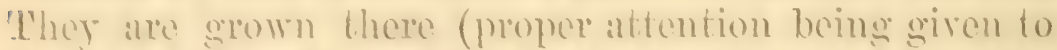

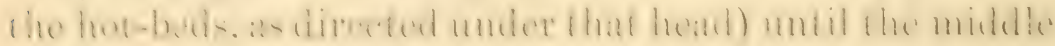
of Mar, when it is salfe to plate them in the open eround.

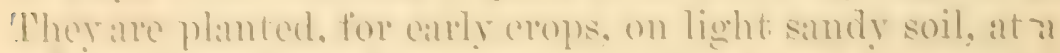
distamese of there lewt allate in hills, in which a good shotollul of rotited mamme has berem mixal. ()n heavy

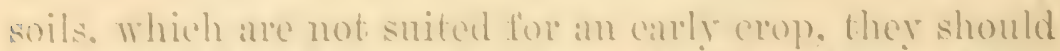

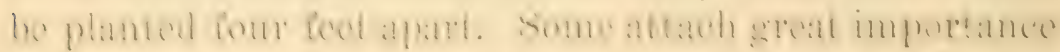
to topping the leating shoos of the 'Tomato, so that it

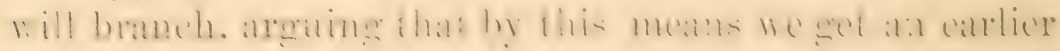




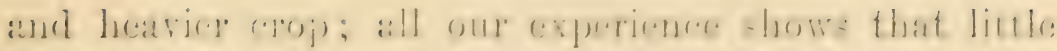

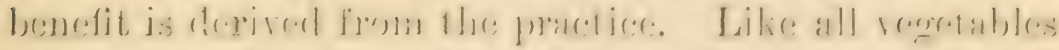

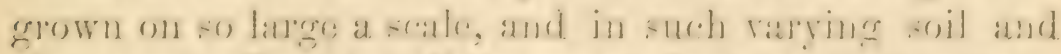

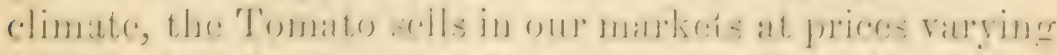

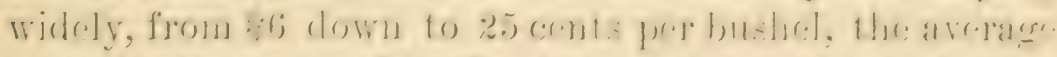

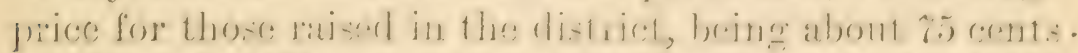

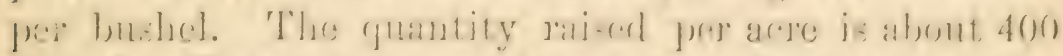
batsels. This may acem at first glance to be quice a profit-

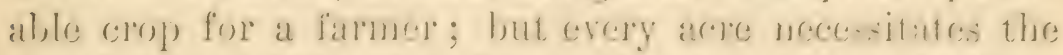

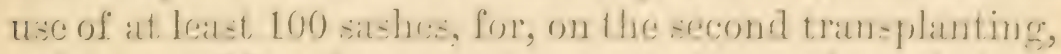
only alorut fifty liant : cibll be grown to a sa-h, and athout

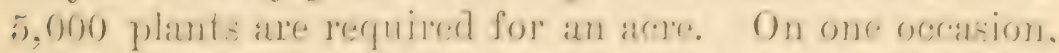

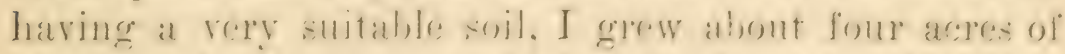

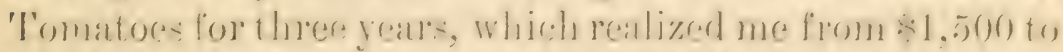

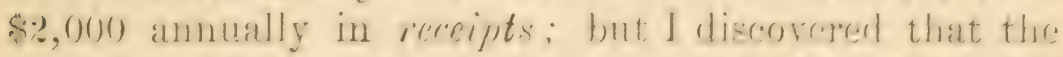

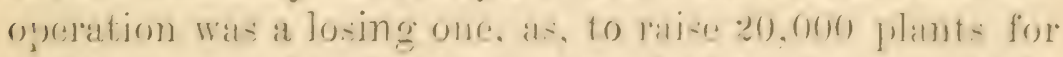

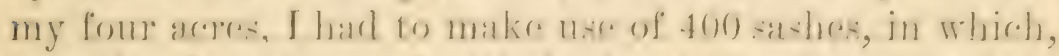

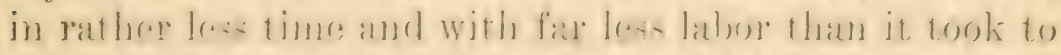

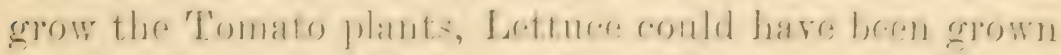

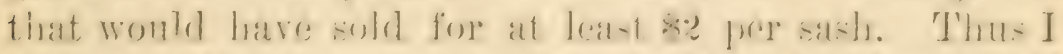

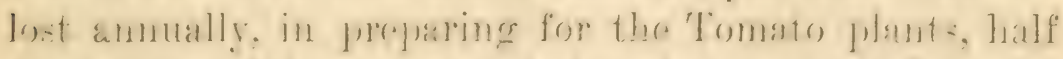
the receipts of the erop exen before they were planted out. but there are many partso of the enontry where Letturee,

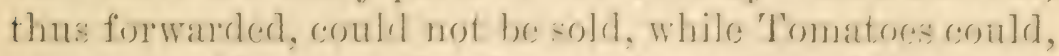
which would matcrially chandere the asyocet of the operat-

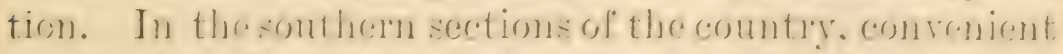

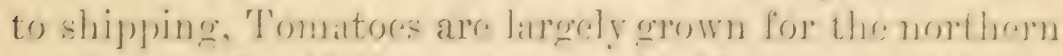

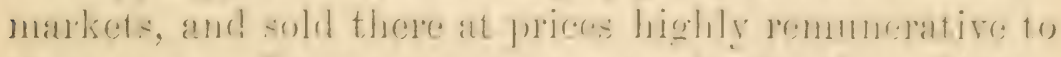
the grower. In many instanese in the fonthem thatse,

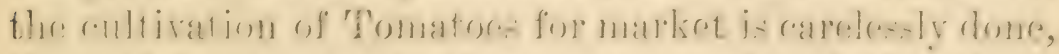

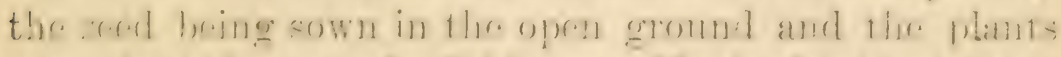

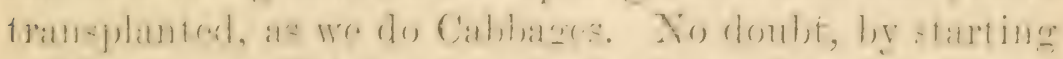

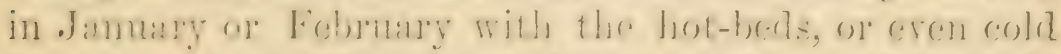
frames and planting one in Marels or April, thry could

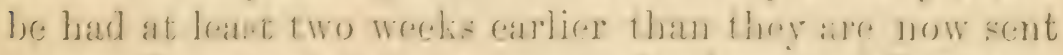

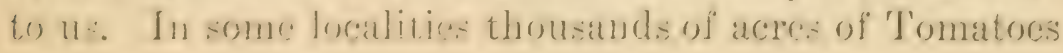


are now

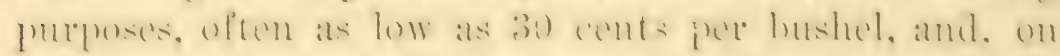
suitable land, oren this low price will pay better than most furm crops, as there is usually no necessity for having the crop cally for camming.

'l'here are alwatys some one or more varieties, said to

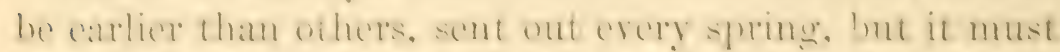

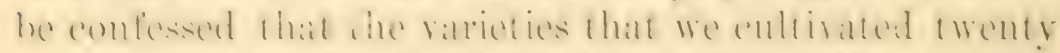

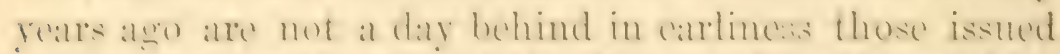

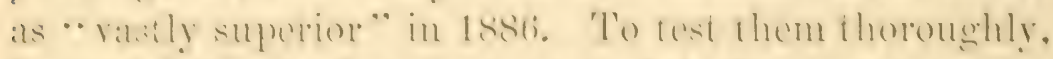
I planted twenty-five plants aboh of the lour most populate

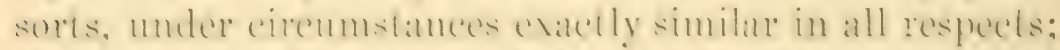

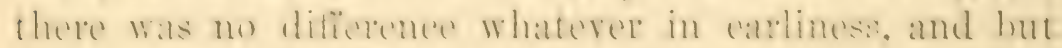
little pereeptible dilierence in productireness.

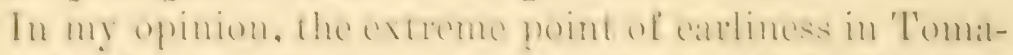

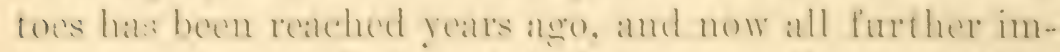
provements must he in promt of sine, smouthness and solidity: and lhall any one laying elam to hay ing good

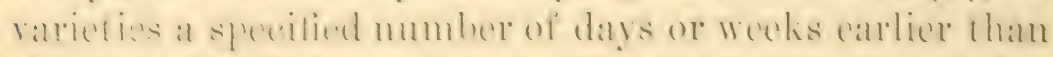
those we alreaty have, doesse without havinga how ledege of the subjert, ar wh ith the desire fo impose on the publie. 'The 'Tomme i a plant roquiringat all times a certain high

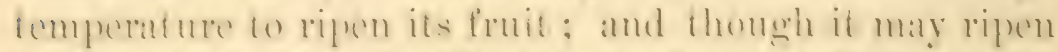

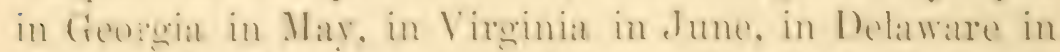
duly, or in New dersey in August, it repuires the simme

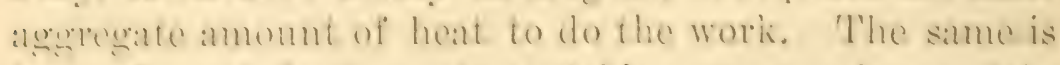

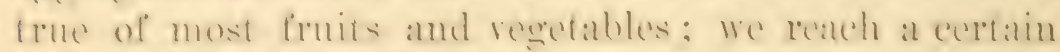

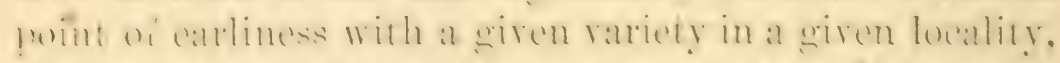
when the tomporature tois us we must atop. If improme-

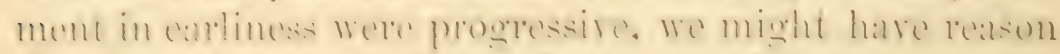

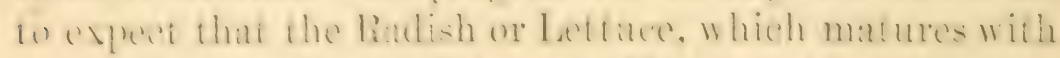
us in the open ground here in May, would yot matme in April.

I heleve that one orimaty methots of saring 'Tomato amel all ather sexds, in liat. do mueh to provent us from

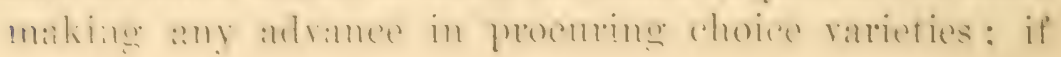




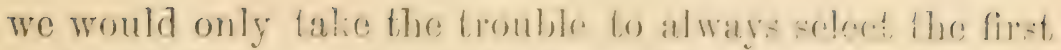
matured fruits, and the bert specimens only, for cored,

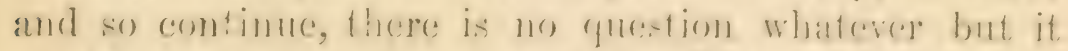
would amply repay the trouldire Sout the erower for

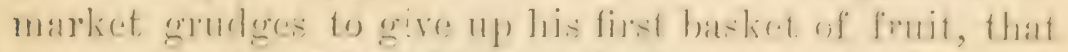

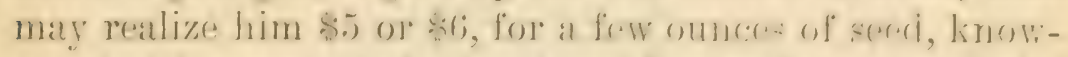
ing that he can got plenty when his copop in not worth the gathering for market. Eut, depend upon it, hro makes at mistake, for the soed from his first fruits would, porthajes, pay him a hundred times better, if n-ed for sowing the next year, than any price he might get for it in the markot.

In private wardens, where suace is often limitrel, a greater quantity of frut will be obtaned by olovating the branches of the Tomato from the gronend with hrosh, such as is used for sticking l'uats or by tying fo laths nailerl argainst a board fence: or, what is neater yet, the hoop training system as jractisod in France. Ihut fon market purposes, on a larges scale, it would rerpuire too much labor.

'The following, at this date, are the leading kinds:

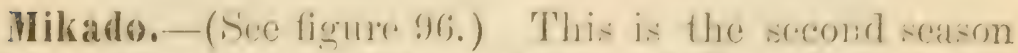

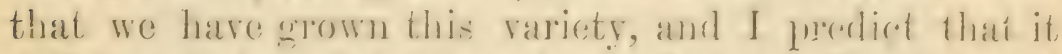
will be certain to become a stambarel sent. It is one of

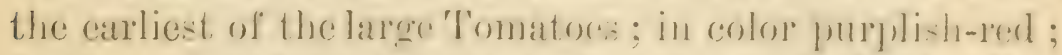

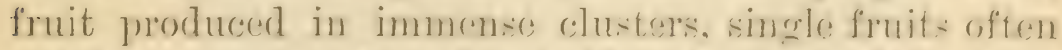
wojghing one pound and a half rareh. The Mikarlo is contirely distinct in foliage from any otlere Tomato, whireh allows it to always be distinguished.

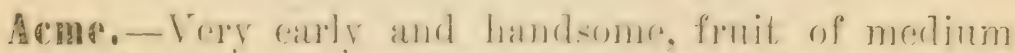
size, porfectly smooth and reoular, very solir, and a good kerpere Color distinct, being armorn with a pintish tinge. In some markets the color would be a drotrinient;

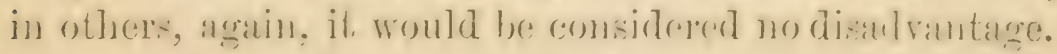

Paragon.-The deserjetion of the Arme will answer

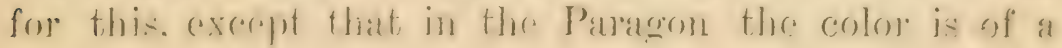




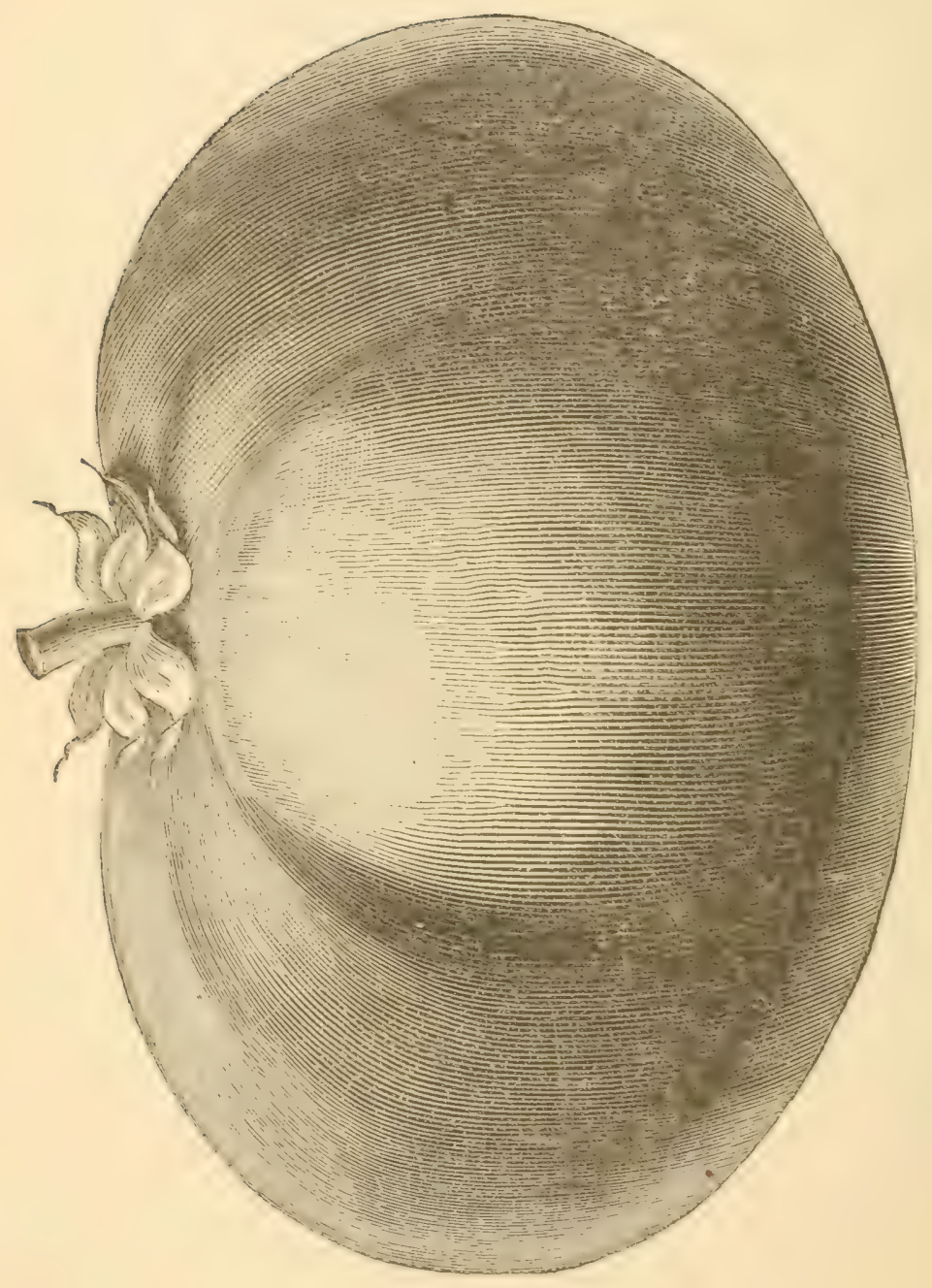


bright, glowy riaton!, and antirely frec from the pinkish tinge that characterizes the Acme.

Perfection.-(Soe tizure 3\%.) Colog blood red. It is as early as the Cimbrla lintor (one of îhe first to ripous),

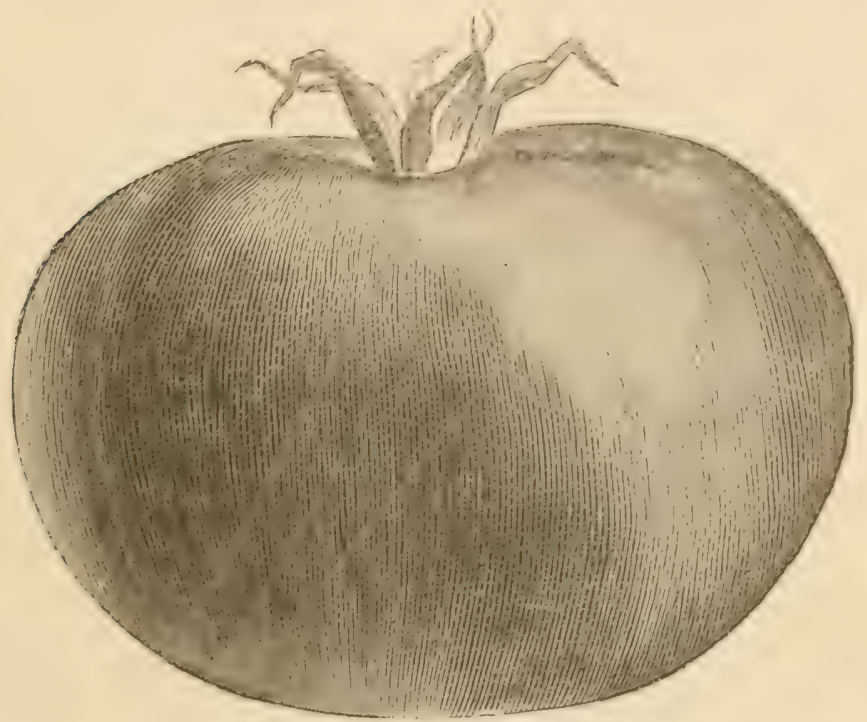

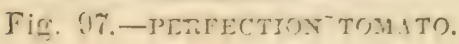

almost round in shaje. perfect ly smosth, and very solid. Of the best quality and conomously productire.

Canata Victor.-One of the carliost. of merlinm sizo, bright red, and very symmetrical in shape.

Tropley. - No Tomatn orer introrluced created the furore that this dir when it was first hrought ont. It is mompased in size, flawel, and productiveness, but is now supereded hy other's in carliness and smoothness.

Ceneral frant.-Whe fruit of this is large and of good quality, and ripens evenly and thoroughly.

Illathawag's Excelsior. - An early raricty, of medium size, smooth, wery solid, and of recellent quality.

Iefed and Vellow Plum Tomato.-Beantiful rarieties, never exceerling two mobus in lencth by ons inch in diameter. Mainly used for pickling and preserving. 


\section{TURNIP.-(Brassica campestris.)}

The cultivation of the Tumip as an emly crop for market purposes. sold bunched in the reren state. is in all resperets the same at detailed for Early Beets. 'The' protits of the (rop) are alse similar. 'The T'monip. howerer, for carly cropse, is rather more particular alout soil than the Beet. and cam lost he pirolnce l early on light sundy or alivelly soils, highly endehed with mimure.

For lute croms, sowing may be mate, for Rilta Bagas, forom May to feptember, in the ditferent sertions of the conntry: here, the thest roots are obtained by sowing about first werk in olune. For white and rellow variethes as they come quicher to maturity. sowing should he delayed forir or fire weels later. Here. we sow from the middle of July to the middle of August.

I'umips. Whether for early or late crops, should always he sown in drills. about fourtecn of eightecn inches apart. In large quantities. they are sown hy the machine, when che pound of seed will be enomia for an acres. In the Northern states it is neaseary to take them np on the approalch of serout weather. when they are best preserved during winter by being pitted. at: recommended for other roots. The late crops of l'urnips are by no means so protitahle as the early. rarely realizing to the grower more than sis per acre ; but like most other late crops of the garden or farm. they cam be grown with less manure. are less perishalle if not immediately sold. and are conseypently grown by the farmer on hi: less valuatle but more extensive glounds. Again let me reiterate the neesity for firming the soil arement the seeds of the Tumip erop, sown in the dry. hot weatlee in Angust. Thousands of acres fail to germinste from no niher callse, while in Enchand in 1885 fully onc-half of the crop scemert to me was lost, solely from lack of this pre- 
caution. There had been no ruin, even to lay the dust, for a period of eight weeks in smmmer-atn experience almost unprecedented there, and no provision had been mate for firming the soil overe the seerl, and as a consequence it was shriveled and dried, and failed to grow. We here hrve nearly always such hot, dry weather when

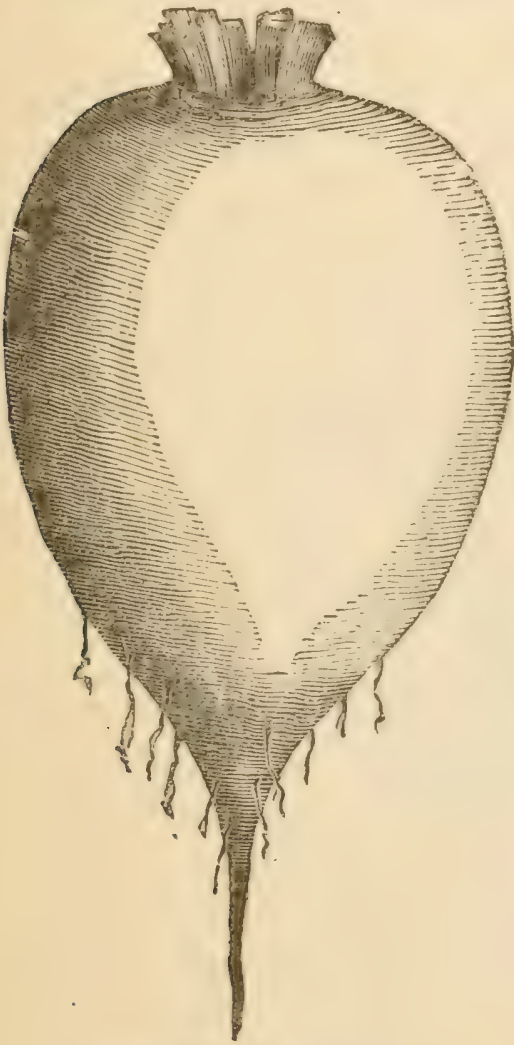

Fig. 98.-

WHITE EGG TURNIP.

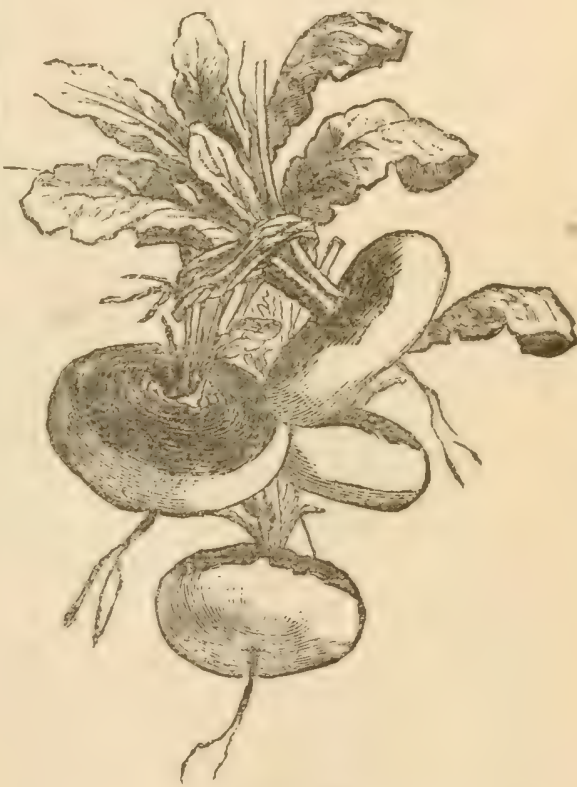

Fig. 99.-

EXTRA EARLY MILAN TURNIP.

Turnips are sown for late crops, and hence the necessity of always firming the soil.

'The following are the lealing varieties grown :

White Exgo-(kee figure 9s.) This in shape, is nearly oral or egen its fiesh is firm and finc-graned. skin thin and smooth. The flavor is mild and sweet, rendering it. 
very lesirable for table use, while its attractive appoarance makes it a most salcable variet y for market purposes.

Lxtra darly Milan.-(See figure 9!.) This is an carly stralp-leared variety, coming into use a week or ten days before any of the ordinaly carly sorts. The bulbs are white, with a purple tol), round and solid; flesh pure white, sweet and crisp.

lied-Top strap-leaf-A ripid grower and of mild flaror. 'The most popular varicty for early use, grown either for the table or for stock.

Purple-Top Whita Globe.-(Fee figure 100.) A rery heary cropping, cally variety, of glohe shape. It has a

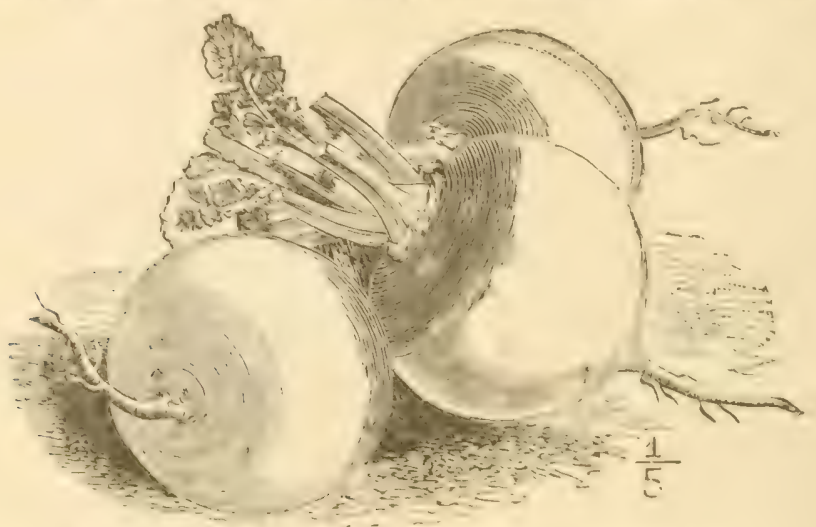

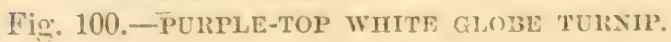

very handsome looking bulb, and is rapidly taking the lead orer other vameties for market garden purposes.

Amber Globe.-In ereat favor in the South. Attains a latree size, flesh solid and sweet, hardy, and a good keeper.

Golden Ball.-T'his has no superuor for table use, being of excellent flavor, elobe-shaped, and of a beatiful yellow color. It is a very rapid grower.

Suowball,-I round, pure white rariety, of superıor flavor : excellent for market. 
Snow-White-Olive-shaped, very hardy, quality the best.

Seven-Top.-This is the variety so largely grown in the Southern states for 'Tumip salad or grecins.

TURHIP.-RUTA BAGA OR SWEDISE.

Improved Anerican (Purple-Top).-(See figure 101.) This is the leading variety; very hardy and productive;

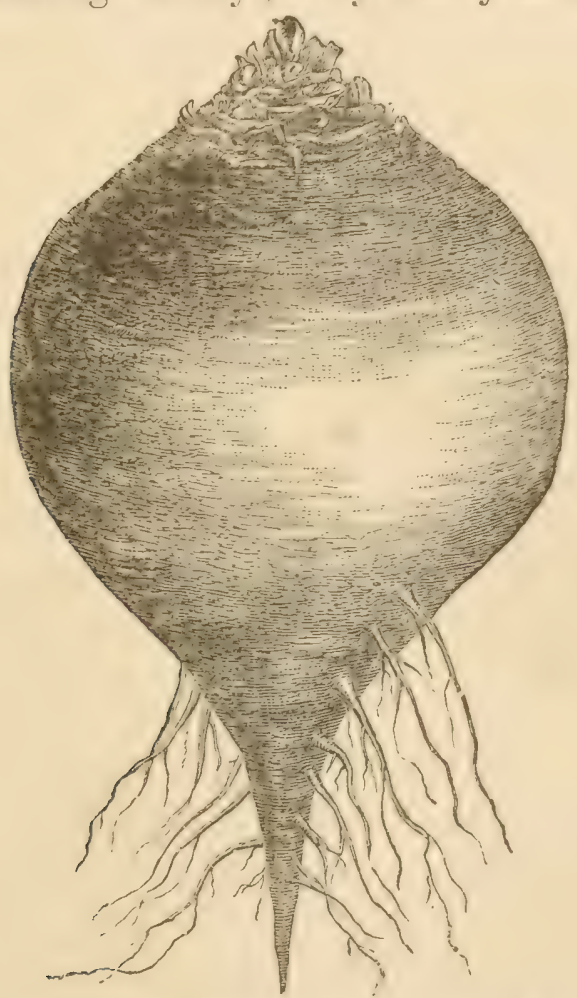

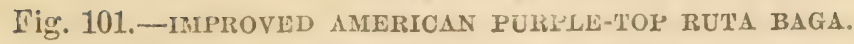

flesh yellow, solid, sweet, and fine flavored; equally good for stock or table use; the principal rariety raised by market gardener's on Long Island, and the hest of all yellow 'Turnips. In onl trial grounds we find American-grown seed, of this variety, to yield bettershaped and reaner 'Turnips than does imported seed. 
Shamreck - One of the finest purple-top rarieties in cultiration; forms a handsome bull, with small top and very few leares; an excellent keeper and good for stock or table use.

Large Whito Trencle- 1 superior variety for table or stock: flesh firm, white and solid ; attains a large size, and hats a very rich and sweet flaror; a very popular variety.

\section{THYME, SAGE, SUMMER SAVORY, AND MAR- JORAII.}

I believe even yet the enltivation of Sweet ITerhs, for moret purposes, is hut little lonown in this eomtry, $\mathrm{ex}$ cept in the regotable gardens in the ricinity of New York: there it is practised to an extent of perhalps 100 to 1.50 alcres, a fair average profit of which would be about sosen per acre. Like the erops of Celery, Spinach, or llorseradish, they are grown only as second crops, that is, they alle planted in July, after an early crop of P'als. Calbiager. Bects, or Onions has heen sold off. The kinds ate thyme, sige, Summer sarory, and sirect Marjoram, the formex two being grown in the ratio of ten acres to one of the others.

The soed is sown in rows in April in rich mellow soil, carchully liept clean from weeds until the plants are fit to set out, which maly be done any time that the gromel is ready from middle of June until end of July. As the plantis are misully small and delicate, it is necessary that the ground be well fined down by harrowing with the dise halrow, or laking before planting. The distance aluart, for all the kints. is about the same, namely, twelve inches betweent the rows, and eight or ten inches between the plants; the liness are marked ont by the "marker." "This is the "marker" used for many other frurpores: in lininge nit the rows for Fitrly Cab- 
bages, for instance, every alternate line is planted, thus leaving them two feet apart, their proly. distance. (See Implements.) In eicht or ten days after the herb crop hats been planted, the ground is "hoed" lightly over by a steel rake, which disturhs the sitrface suficiently to destroy the cropl of weents that are just beginning to germinate; it is done in onc-third of the time that it could he done by a hoce, and answere the purpose quite as well, as deep hoeing at this carly stage of planting is perfectly useless. In ten or twelre days more, the same operation is repeater with the stec! rake, which usually effectually destroys all weents, the reeds of which are near enough to the surface to errminate. We use the steel rake in lieu of a hoe on all our crops, immediately after planting, for, as hefore said. deep hocing on plants of any kind when nevrly prtenterl, is quite unnecessary , and by the steady application of the rake weeds are easily licpt down, and it is great oconomy of labor never to allow them to start. By the midalle of September the herb crop usually cover's the ground completely, looking like a fieid of clorer. Allow this mass to grow for another month as it is, and you would not increase the weight of leaves; the plints would grow taller, keeping the green and marketal,le leaves on the top, but only yellow and withered ones and plenty of woody stems below. But by cutting out every alterinate row (each plant making about two bunches), the remaining rows are allowed light and air, and in three or lour weeks will hare spread so as again to corer up the entire surface, from which half the crop) hes.s alreally been galherect. We treat siage in all respects the sance as Thyme; and I have seen both these herbs on rich soil not only meet when left two feet apart, hut when every other row at two feet apart was cut out, almost meet again at four feet apart.

By this method of cutting out every other row, fully a 
double crop is taken, and of a quality superior to what it would be were it allowed to grow without being thus thinmed out. Dhout thirty years aco I wats lucky cuough to diseover the importance of this plam of doubling our

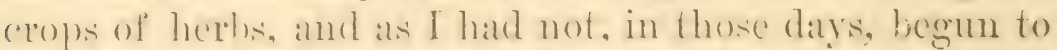
toll " what I know about gardening," I liept my own (coumsel for some yeal's before my neighbors discovered the plan. Heros are regaredert as a sale erope for the marliet gardener : they are less prishable than anything else grown. fore, if there be any infermption to their sale in a areen state, they can, il necessiry, be dried and boxed up and sold in the dry state, months alfer. The price now is from soti to sto per 1, (100) huncines, and wo always pre-

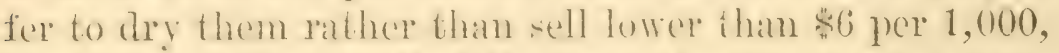
experienee telling us that the market will usually so regulate itself as to handsomely pay for holding batck the sale. The cost of wetting the crop rated and marketed will arerage about sis() per alcre, one-half of the expense bing in tying it in bunches. But with many of our industrious German gambleners it does not cost half that, as the tying wp is mstally done by thein wires and children.

I'here are but few rarieties among Herbs, lut of 7 hyme there ale sereral, and it is rery important to plant only what is known as the "sprealing varioty ; " an upright "sort, sometimes sold, is worthless as a market erop. The Sage, known as the Broad-leared, is the best.

I am often asked. by correspondents at a distance, in relition to the best waty of selling hophs in New Jork City. I will here say, that there is no certain sale that I know of, muless they are in a green state. The season for selling is October, November and Derember ; and if shipped in open clates so arranged by divisions of slats that not more than cight or nine inches of a latere would be togrether, they could be shipped at that cool season to distances repuiring filty or sixty homrs in the transit. The arerage reseipts per acre is now ahout 8400 . 


\section{II A P T E R X V I。}

\section{WHEN TO SOTV AND PLANT IN THE SOUTHERN STATES.}

We have hundreds of letters each season making inquiries on this subject. From the great variation in latinde, soils, shelter, ete, it is impossible to give accurate information on the subject, for the date that would answer for Charleston, Sonth Carolina, or Jackisonville, Fla., would not do for Norfolk, Va., or Knoxville, Tenn., but at the risk, in some few cases, of repeating instructions already given, I will endearor to approximate as nearly as possible to the dates at which regetables should be sown and planted in the Southern states. The instructions for culture vary but little fron what is practised at the North, so the reader is referred to each article under its proper head for cultural instructions.

Asparagus. - iThether raised from seed or from plants, had better be started in the fall months, varying, according to latitude, from the 1st of October to the 1st of Decemoer, earlier, as at Norfolk, Tirginia, to the latest date in South Carolina, Florida, Lonisiana, and Texas. The plant is hardy, and consequently will have made roots enough to sustain itself through the cool season, if sown at these dates, and be ready for vigorous growth as soon as vegetation starts in spring.

Beans; Bush or Pole.-Are of tropical origin, and consequently belong to what are classed as "tender" vegetables, and when wanted for eurly crop, as nearly all Southern regetables are, should not be sorn until all. danger from chilly weather is past-not before the night temperature will arerage fifty-fire degrees. Perhaps one of the best rules is to delay sowing or planting in the open ground until such date as corn can be safely planted. 
Bets.-Are of infemediate hardiness ; not sutheiently hardy to be sown and wintered orere like Aspanagers or

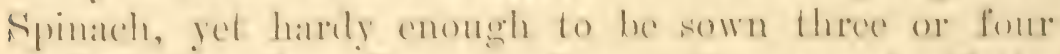

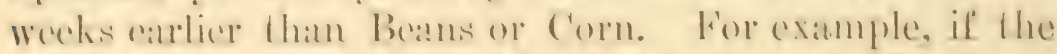
Germ-planting seatson is March in extreme southern points, bects maly he sown al the samm plate in Edortary.

Cabluage.-Is perhatps the most important of all Somlhern crops ratised for Ihe Northern matred, and much-

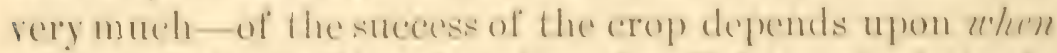
sown and the quality al seed used. 'T'aking the latitude

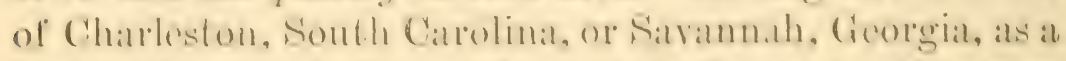
basis, the ustall time of seming Howe in the opern

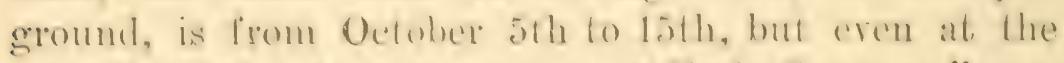

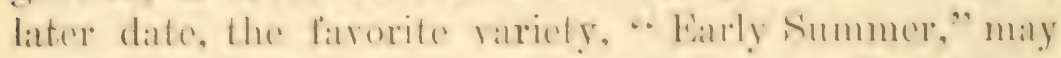
run to sod if the scison is mild : so we stromgly advise to sow, at latst a pertion of the crope lan datys latter-sity

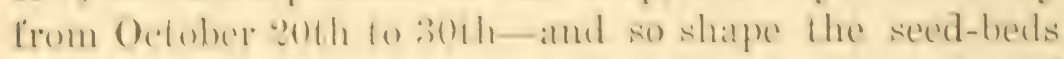
that they cam be covered up) by "sashes" made of muslin, or the protediug cloth alremly alluded to, on rold nights-uxposing them, of comse, lo the light, on warm, bright days.

Cauliflower.-Same as for Cabbage.

Gedery. - being a winter weretable, is never shipped

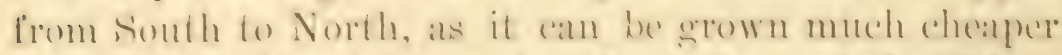

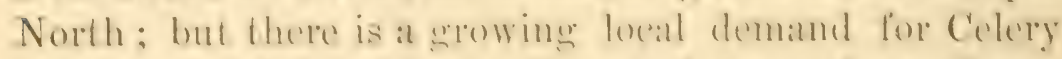
at many sumthern points. 'The secd, to produce plants. cammot salfely be sown sollth in the spring for coleryyrowing als in most instances. from the lomger scalson, it

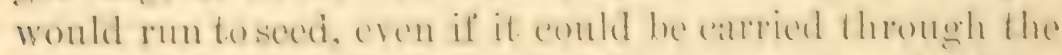
hot weather. My atries would te to sow at ditherent periods, saly brom the midelle of dume to the midelle of Anewst, using the protertime choth "sashes" alrealy

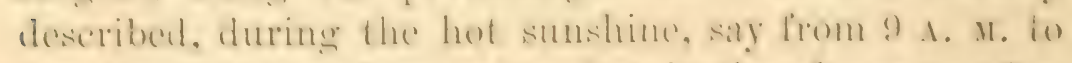

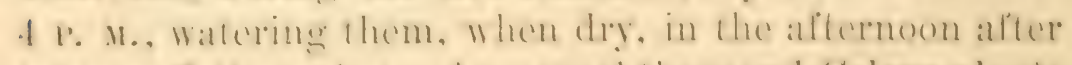
takimg oll the sishes. Is several thomand Celery plamis 
can be grown under a three by six foet sath, it will repay the labor in such places ats this, where protecetion aganed the sun is a necessity.

Collateds.-Reyuire to be sown alout the same date atis Spinach, which see.

Corn.-Swect Corn is a valuable crop in some soetions Sonth, to be sold in one Northern markets. It is one of

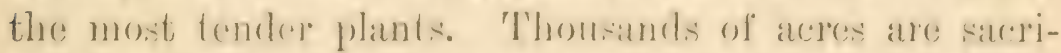
ficed every season by impatient cultivators, who, delonded by a lew warm lays in spring, plant too carly. No date cam be given with silfety, only, als a rule, one will be sater to be a little behind his neighbor than before him. If the nswal date is the 1st of the month, you will be certain to catch up if you wait until the th or 5th, as it is a crop casily checkerl even by a slight chill. It may be forwarled sis or coght days by whing in pieces of sod under sashest, ats recommended for Cucumbers.

C'uenmbers.-Another "tender" plant, repniring the same conditons for vigorous growth as Swect Comm. It may be sown on pieces of inverter sol, cut in sections of three or four inches; these, if placed in frames and covered with the protecting coloth, or better still for this purpose, glass sashes, may be started two weelis sonene than they can be sown outside. In alout a montle after sowing (if not bersun before the temperature would atrerage fifty-five degrees at, night), they will have grown two or three inches and have matter the pieces of erod full of roots; the tomperature now should be ten derres hishoi, and they may then be set in the open field and will grive a crop) at least a week carlicr, which will well repay the extra labor.

Eggr Plant.-The same rules may be applied to this, rememberine, however, that this is an retra "tonder" plant, and at least five degrees higher will be necessiary. 
Greens, dierman or Sprouls.- Samc as Spinach, which sec.

Infuce.-The same rules as lor Cahlage and Cauliflower will apply nearly as well to luettuces.

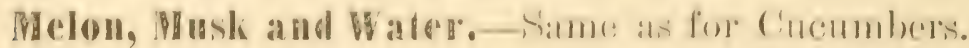

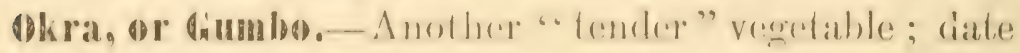
of sowing the same as for Beams.

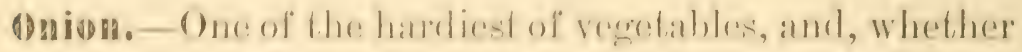

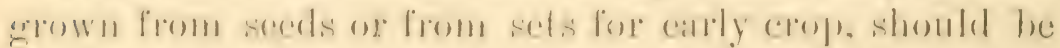
sown in the fall, alomet the dates alvised lor Asparagus, thomgh if wanted for a later spring resop, or for drying, may he sown in spring, at the date arlvised for Bects.

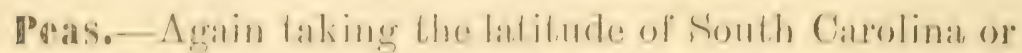

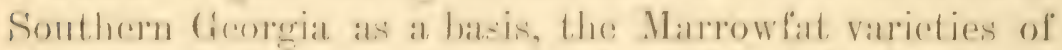

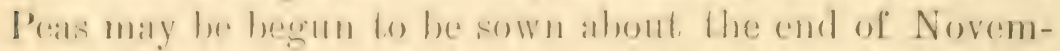
ber, following with the early kinds for sucension (erops every week or ten days to January 1 st.

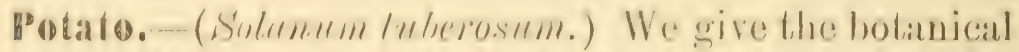

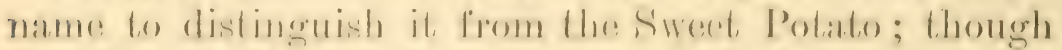

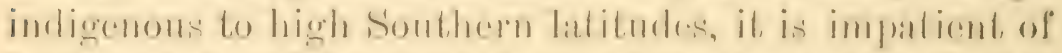
heat, and shomld be planterl as early in the rarrous Somthcro slates as the ground is in complition lo work; in parts of filorida as early as Jannary 1st, while Folnuary lst will he proper at Charloston of Salsammah, and nearly a month later in Southern Virginia.

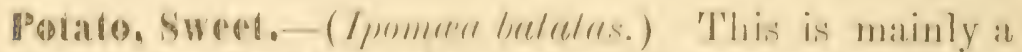

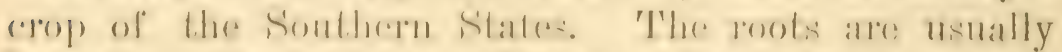

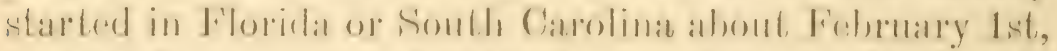
in cold frames rovered with grass, or in warm borders in the open air. 'The "sets" or "draws" will msually be

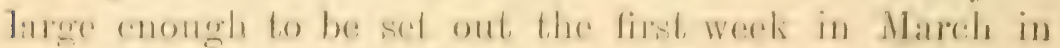

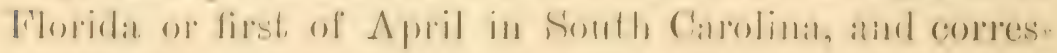
pondingly later as we move north ward.

Radish.- Same dates as for beets. 
Rhubarb, - Same date as for Asparagus.

Turnips,-For fall sowing, the Sweet or Strap-leared kinds of 'Turnip should be sown from September to October, while the Ruta Bagas, requiring a longer time to mature, should be sown a month carlier, For "spring sowing," January to February for the extreme Southern States.

Spinach.-A hardy regetable, and a valuable crop in many sections of the South. Maly be sown from september to October at Norfolk, Virginia, and from Norember to December at Charleston or Savamnah ; but as it is slow to germinate in dry weather, sce what is said in relation to it at pare 101, under the head of the "Use of the Feet in Sowing and Planting." At the extreme South Spinach is not much grown, as it does better in such latitudes as Virginia or Delaware.

Squasil.-Same as for Cucumber.

Tomato.-A most important regetable grown at the South for the Northern markets. It is usually set out by first raising the plants under glass, often in hot-beds, when great earliness is desired. The reader is reforred to "Construction of Hot-beds," which will be necessary in most sections for the first sowing for the seedling plants. An ordinary three by six fect sash will raise from 1,500 to 2,000 seedling plants. These if sown, say, February 1st, will be large enough to transplant at three or four inches apart, again under the protection of sashes or of "sashes" of the protecting cloth, until fit to set out in the open field. As it is also a most tender plant, easily hurt by chill, the same rules apply here as for Cucumbers. 


\section{H A P'I E X X II.}

\section{PACKING OF VEGETABLES FUR SHIPIING.}

This is a mather for which it is not very as a to give directions, as the distance, season, and atioles to be pareked will greatly detemine the mammer in which it, is to be done; but a lew general directions may atrist the inexperienced.

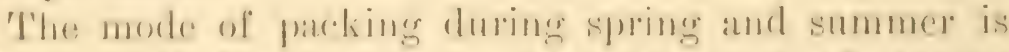
almost antionly the reverse of that practiond doring atrtumn or winter, for the datson that, when the temperealure is high, provision must be mate in the patekage for

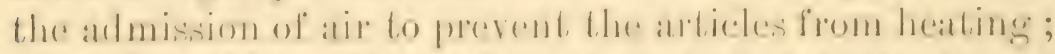

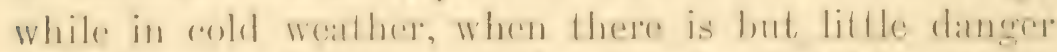
from hraling, hut more fo he alpmelended from lrost, close packages must be used accordingly.

As rarly regetables are always shipped from a warm

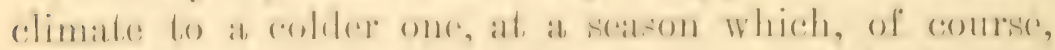
must, loe Warm to mature fleme, open work baskels of

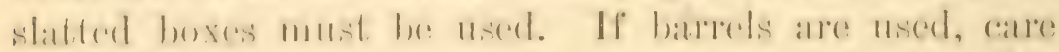

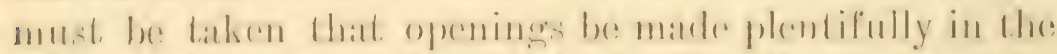
sille, so that air maty he atmithed. For distances requiring a delaty of more than lorty-ejeht hours in the transit,

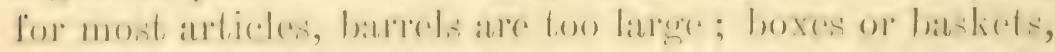

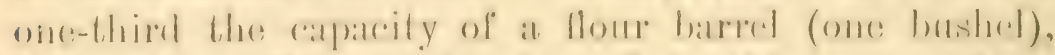
being salfor. 'The articles shippeal in this manner from Southern ports to Northern matrels, are: Asparagus,

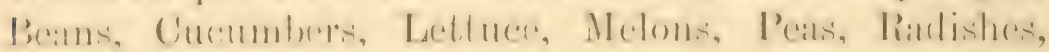

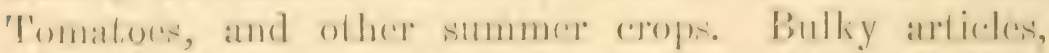

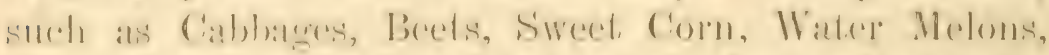
'T'urnips, are of ten shiped loose on the decks of steamers,

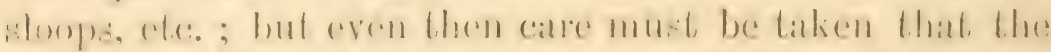
leaplas are not too large, else they may be injured by heat-

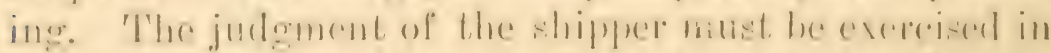

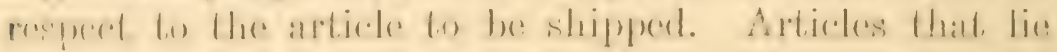


close will require to be shipped in smaller packares than those that lie so loosely that the air an pats amnours them; for example, Melons may be safely packed in a barrel, while if 'Tomatoes were so packed, they would be utterly destroyed.

'The winter or fall shipping of vegetables is the reverse of the summer, for then we semel from the North to the South, our colder and dampxre atmospliere beingr more congenial to the growth of late crops. Close packages are now used, hut still not too larese; barrels boing hust suited to such articles as Beets, Carrots, Celery, Onions, Parsnips, Potatoes, or 'T'urnips, while (abhages and Cauliflowers maly be shipped in crates or in bulk.

\section{H A P E R X VIII.}

\section{PRESERVATION OF VEGETABLES IN WINTER.}

Our mamer of preserving veretalble roots in winter is, I think, peculiar to this district, and is very simple and effective.

After taking up such cropos as Bects, Carmots. IIorseradish, Parsnips, 'T'umips, Potatoes, cte., in fill, they are put in temporary oblong heaps, on the surface of the ground on which they have heen growing, and covered up) with five or six inches of soil, which will kecp ofl such slight frosts as are likely to occur, until time car be spired to store them in permanent winter puarters; this is done in this section, usually, during the first part of J december,

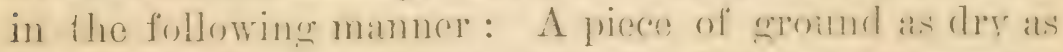

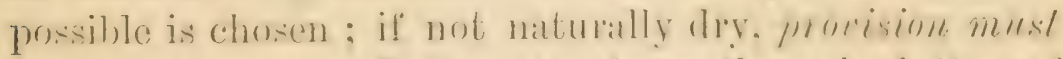

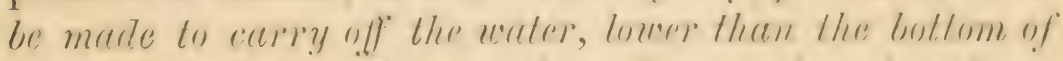

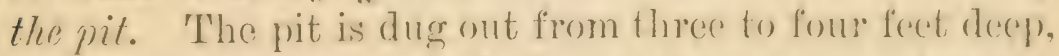
about six feet wirle and of the length reguired t the roots 
are then packed in, in sedions of abont two foed wide aroses the pit, and only to the height ol the gromed level.

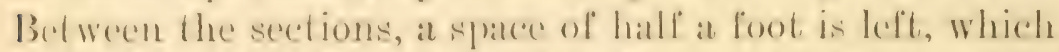
is filled up with the soil lerel to the for); this leatres thes pit filled $11 \mathrm{p}$ in secelions of two feet long, with roots, and hall at loot of soil, and so on, until the whole is linished. 'The ald antage of this plan is, that it is morely a serices of small pils, holding loom there lo live hampers of roots, which ean be taken ont for mathed whlosut aposing the mode section, ats it is closed oli hy the six inches of soll

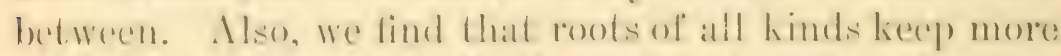
salloly when in small bulk than when latere numbers ance thrown inle one pit together. In eotering, the top is romeded so as fo throw ofl the water, with a layer of from

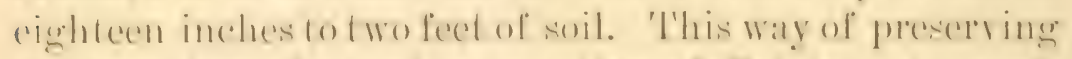
roots, with prothes the exception of Potatome is moch moluable fo kecpines them in a collate or root-house, as

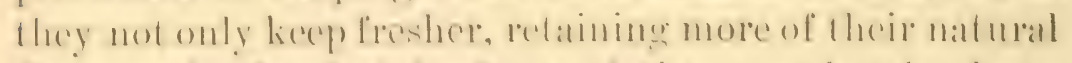
flaror and color, but fall lawere of them are lost hy deraty than when exposed to the air and varying temperatme of

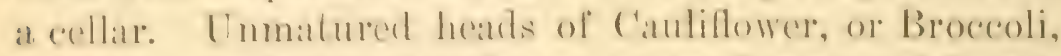
howerer, alle best matured in a light rellar or eold lrame. by being planted in close togenters in this way, good heads maly be had to danmaly. For the kereling of (al)hatges, Celery, and (Bnions, see instructions in the chatpter

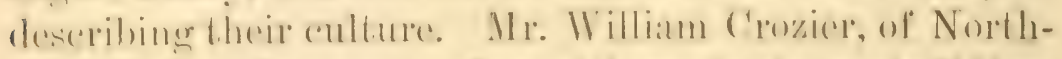
port, 1. 1., who is aro-inthor with me in the work " IIow

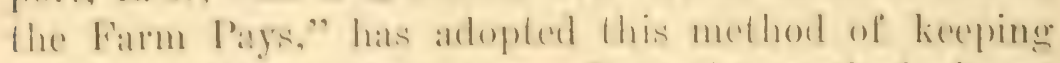

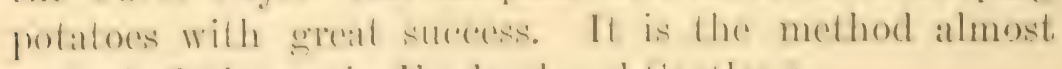
arelusively in use in tingland and ścotlande. 


\section{H A P'T E R XIX.}

\section{INSECTS.}

We have but little trouble with insects in our lighly eultivated grounds; what with continued moving of the soil by plowing and harrewing corery for, from three to four times each scason, incessant hoeing, and the digging

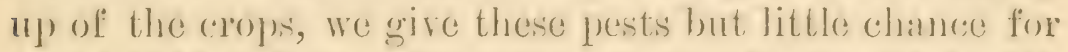
a foot-hold. He are, however, oceatsionally trouldarl witit

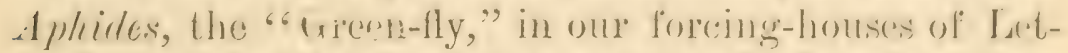
tuce. Another kind of aphis, closely allied to the croenen,

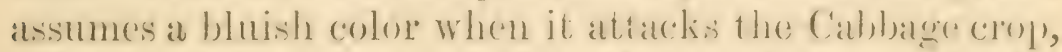
either in frames or ontide. A complete remedy for either pest, in its (ally stages, is tobaceostoms sterped in water to give it about the colol of strong toa, and alpplied with asyringo or watering-pot, or tobateco dust, ar, in fact, tobacese in any form that it can he applicel. "Jumping Jack," os the T'umip-fly, occasions : ome trouble with late sowings of Cabbages, 'T'urnips, and Radishes, but we find an excellent preventive in dusting lime orer the berls ats soon as the secrls begin to germinate. It is of the utmost importance to use preventives in the case of insects, for if once they get a lodgment, it is almost useless to attempt, their destruction. 'The striped C'ncumber-bug, which, with us, attacks late sowings only, we have found to yield readily to a few a prplications of bone dust, which serves the domble puryose of disturbing the inseret and encontraging the growth of the crop). But our most formidable enomy of the insect tribe is that whireh attacks the roots of the Cabbage fannily, causing the descructive dizatio known as the ". (elub)root." There is a general miscrenception of the canse of this disease; happily our peculiar location here gives me the means, ! belirere of thoromethly dispereing some 


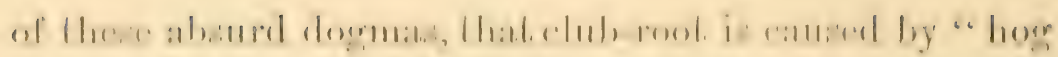

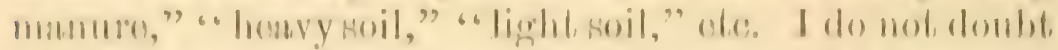

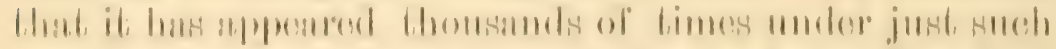

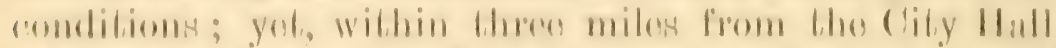

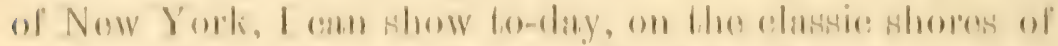

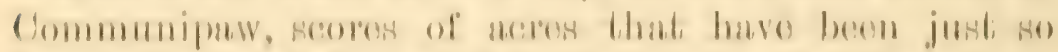

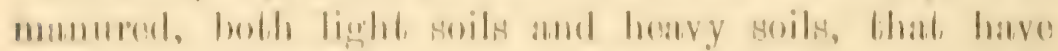

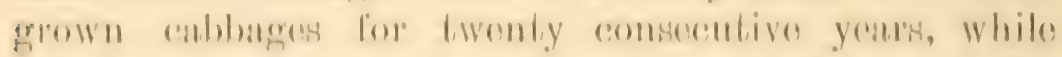

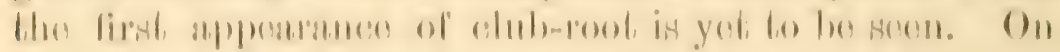

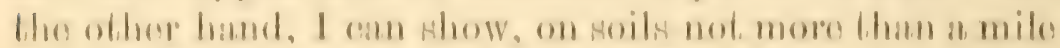

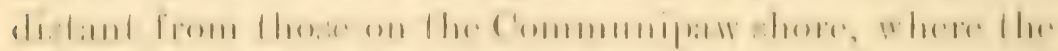

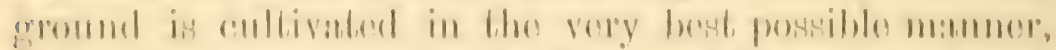

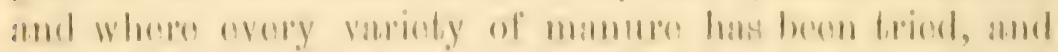

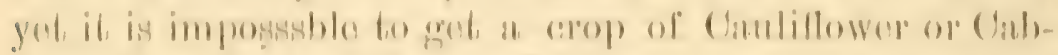

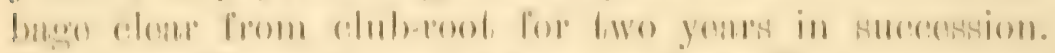

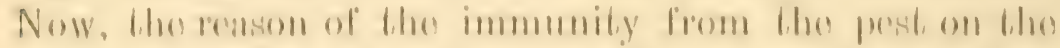

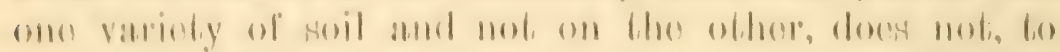

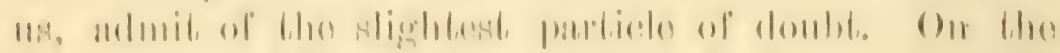

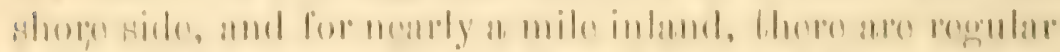

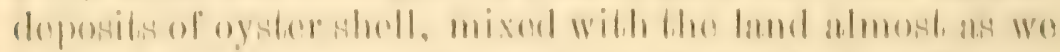

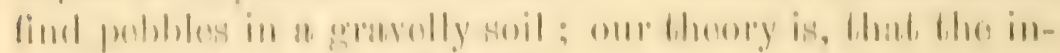

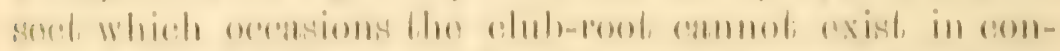

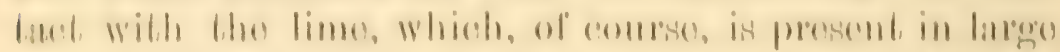

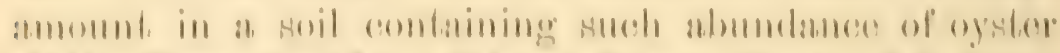

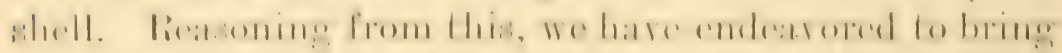

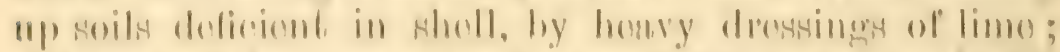

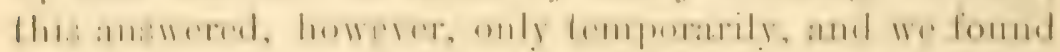

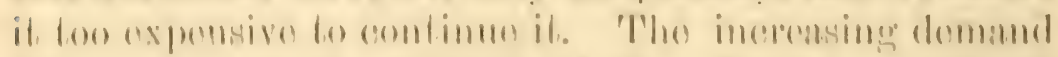

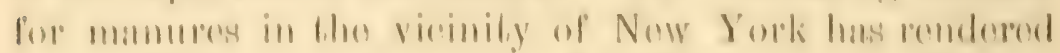

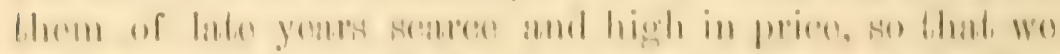

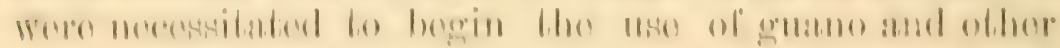

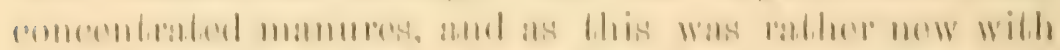

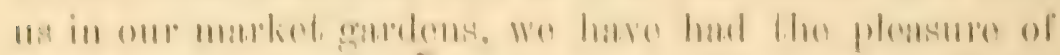

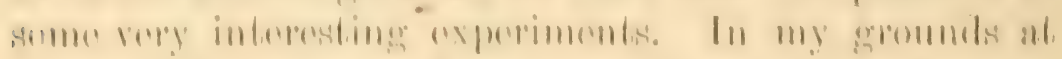

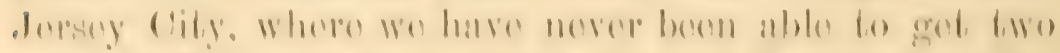

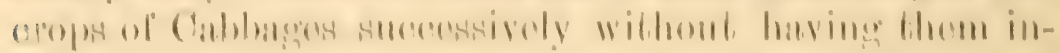




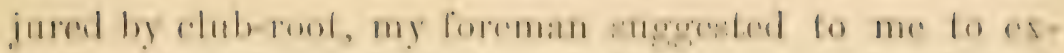

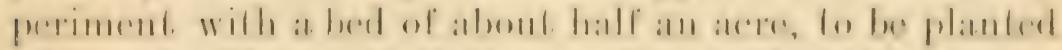

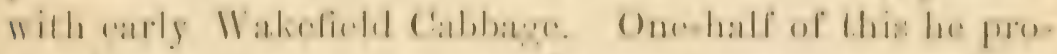

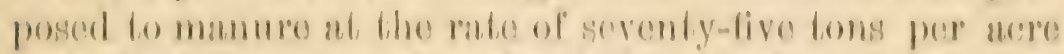

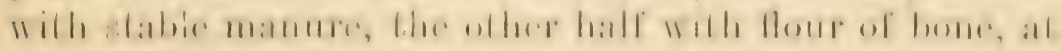

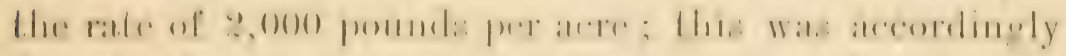
domo in the usmal way, hy sowing the bono dost on the

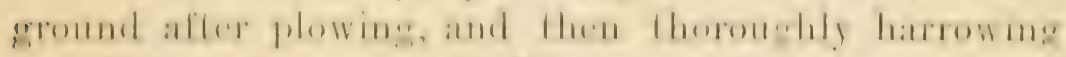

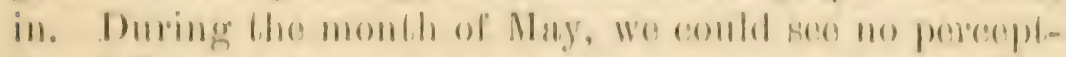

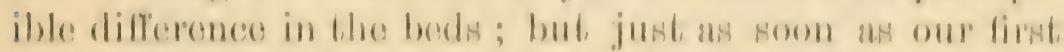

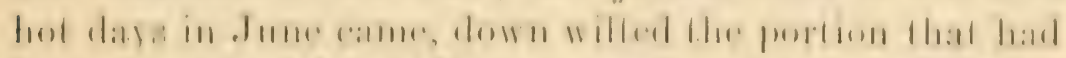

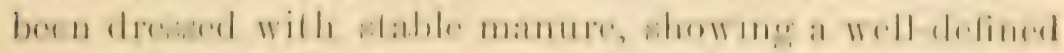

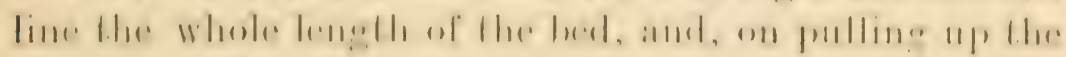

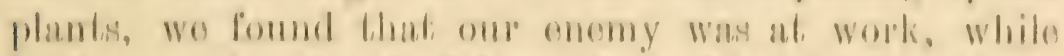

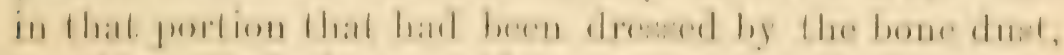

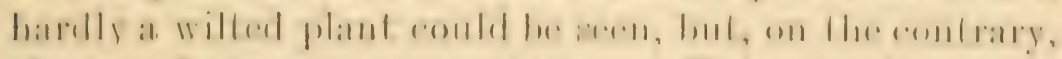

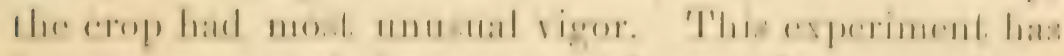

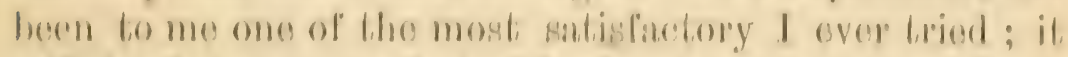

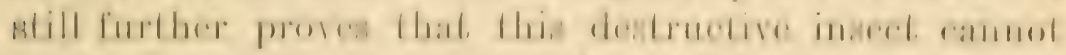

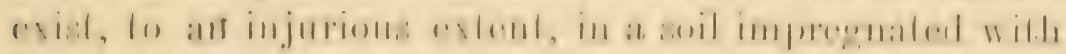
lime, and also provess that wo have a most allecelive

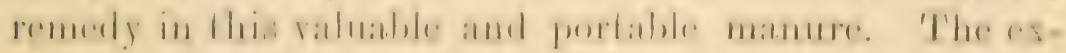

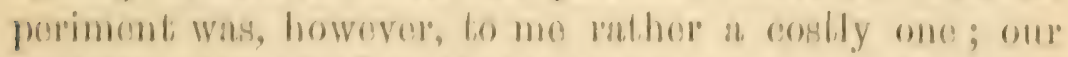

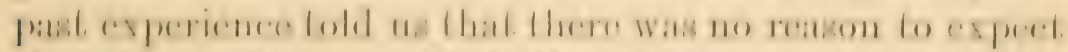

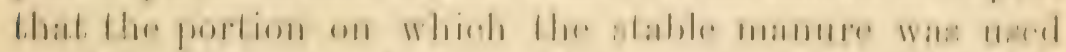

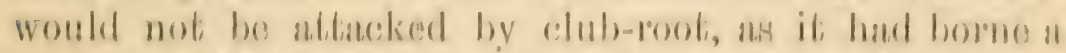

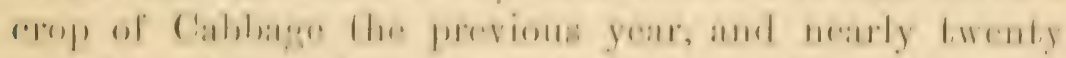

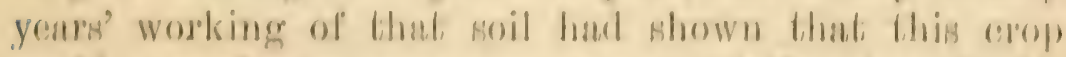

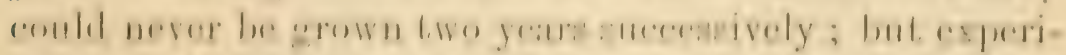

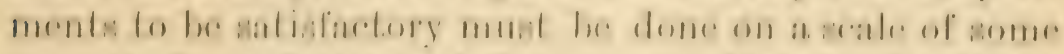

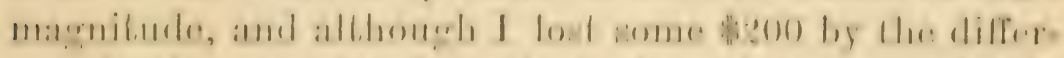

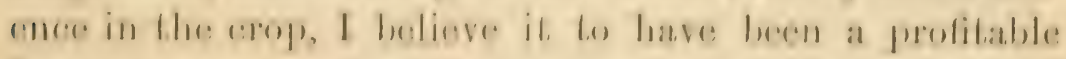
invostimentio

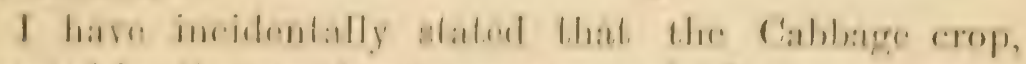

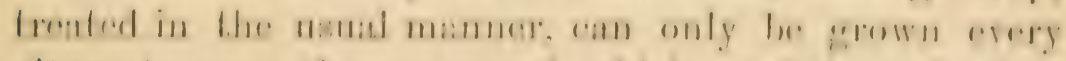

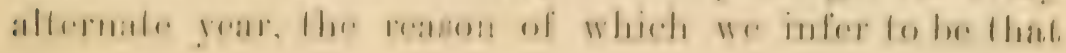


the insed to hambless to the plant when in the perfect

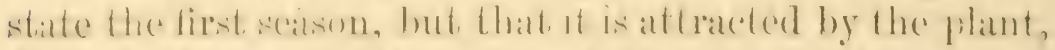

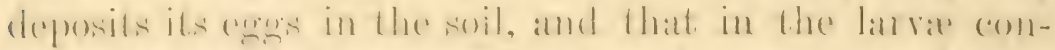

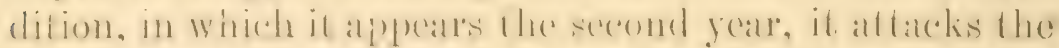

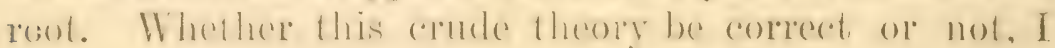
will not presume to say, but il not, how cain we ale(a)tut for the fated of our being ahle to grow this plant frew trom its ravages every alicrualle gear, while if we

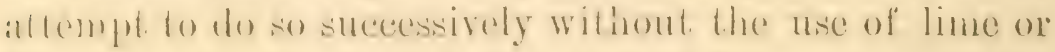
bone dust, it is certain to be attalcked?

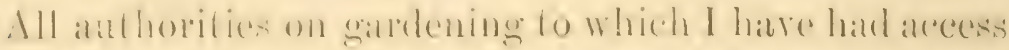
serm to be matwate of the lated that chub-root is never

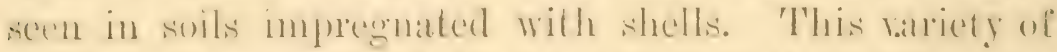
soil is mot common. I hatre nerer seren it angwhere ox-

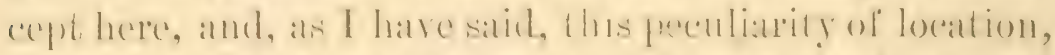

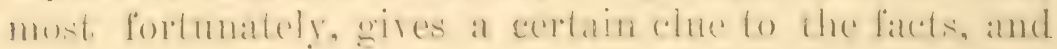
directly points ont the remedy, whish, I think, we hate

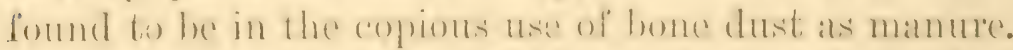

Another coneng of the (athlatere plant, and one that, is

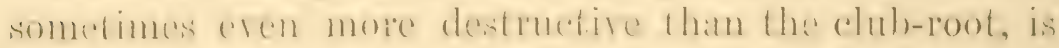

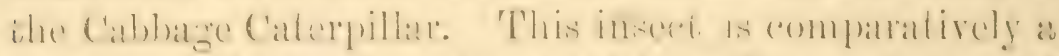

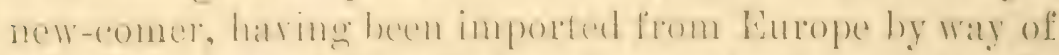
Calmatal. It is produced by the small white butterlly

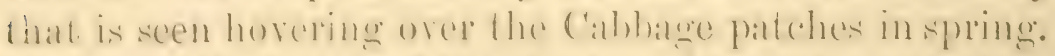
It attackis the leatres of the plant, and is stleh a rolateints

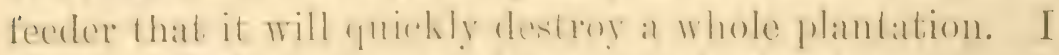

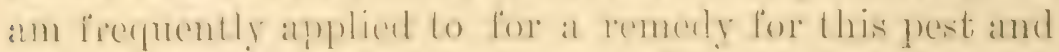

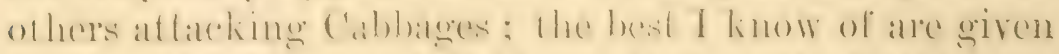

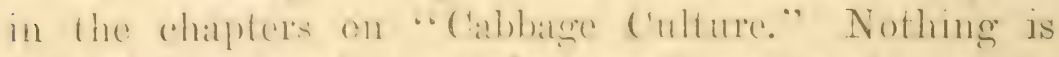
more dimieult and mosalistarefory than the attempte to

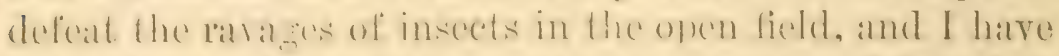

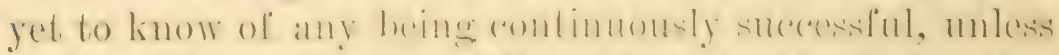

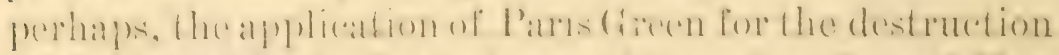

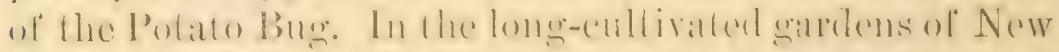
Jersey and fong Istame we do mot sulter much from the ravages of either of the abore pests. The soil is so re- 
peatedly turned over and disturhed that I presume the maggot is not left long enough at rest to develop itscle in sulficient numbers to produce any great injury; and the luxurious growth resulting from the continued and heary manuring, secms to be less mviting to the butterfly to deposit her erge thin the feeblex growth of less fertile soils. Or, it may be that the increase of English sparrows is helping us 11 both these cases, by destroying the fly that prodices the maggot, or the small white butterfy that produces the caterpillar, or it may be that they fecd on the caterpullar itself, as I know they do mpon the rose-slug. At all erents, the farmer will gain by enconraging and caring for the sparrows. A few years age the street trees of New York, Brooklyn and Jersey City were festooned by myriads of the " measuring worm; now, since the advent of the sparrows, they are scarcely ever seen. The sparrows wll live in any section of the country if properly honsed and fed in winter, and if such (are were general we should hear fewer complaints of insect ravages. True, the hirds might exact wages for their services, in requiring a little grain, but of the two crils, better submit to that done by the birds than hy the insects.

I will relate an experiment to destroy the Cabbage Caterpillar, which occurred during this month in my intmediate neighborhood. One of my neighthors found that the pest was attacking his Cahbages; he canne to me and asked what I thought of his nsing shaked lime to dust orer them. I told him I had but little faith in it. But he was resolved to try it, and put it on at the rate of four or five barrels to the acre, carefully dusting it on each plant. This was about the list of June. On the 1'th he came to me in triumph, saying that the remedy had been effectual, and that there was hardly a caterpillar to he seen. Unfortunately for the experiment, but fortunately for truth, another neighbor, whose Cabhage patch 
had been attacked at the same time, but had receired no lime, was also entirely clear of the caterpillar! The cure waik traceathe to another cause. We had had a deluging riin that surept of the caterpillars, and started the Cabbages into luxuriaut growth at the same time. Had the insect come in the legions it does in some places, had there been no railis, and had the dry, hot weather continued, the lime dust would probubly have failed.

Last : nmmer, I hid with great care nurser along in my greenhouses, for many weeks, a collection of rare varieties of Germanstock Gillyflower's, a plimt belonging to the same natural order (Crucifere), as the ('abbage. Upwards of two thousme plants were set out in June, on rather poor soil; by the middle of July they had malde plendid plants, one foot across, and just as they were bursting into bloom we observed the little white butlerfly moring amongst them, and knew what might be expected to follow. Lime dust, solutions of carbolic sone, whale oil soip, and sundry other things were used, all to no effect, and by middle of August, the plants were literally eaten $n$ py by the caterpillar. There is nothung more innlealsint than to tell any one suffernng under a calamity that there is no eflectire remedy; but it is infinitely better to do so than to delude them with a false one. I have been a worker of the soil since my boyhood, and every reall" experience conrinces me of the almost. helplessness of remedies against insects or other blighting plagnes that attack vegetation in the open field. It 1. true that the amateur gardener may save his dozen or two of Cabbages or Roses by daily picking off or destroying the mects: but when it comes to broad acres, I much doubt if ever any remedy will be found to be prasticable, mnless in rare mstances, such as P'arris (treen, as as an antidote against the Potato Bug. We have one consolation, $m$ knowng that these pests are only perrodical, and never continue so as to permanently destroy. 


\section{H A P E R X X.}

\section{CULTURE OF SMALL FRUITS.}

Complaint has heen made that in the former colitions of this work, no allusion was made to the culture of small fruits, which, in many sections, is as nuch a matter of interest to the market gardener as is the culture of regetables, as, in many places the two have to be combined so as to supply the local demand. The most imjortant of all the small fruits is

\section{THE STRAWBERRY.}

The same general rules for soils, drainage, manuring, ete., are generally applicable for Strawberry or other small frut culture as for regetable crops. Our method of obtaining a full crop of strawberres by "pot lavering," which we here give in detail, we have practised for the past fifteen years with unvarying success, and if we were growjug Strawberries for market, no matter on how large a scale, we rould follow no other method. 'To obtain a crop in June from the plants that were planted out the previous August, or in ten months from date of planting, the plants must be such as are layered in pots, and the sooner they are planted out after the 15th of July the better, although, if not then conrenient, they will joroduce a crop the next season, eren if planted ats late as the middle of September; but the sooner they are planted, the larger will be the crop. They may he sut ilrom prot layers either in beds of four rows cach, twelve inches apart, and twelve inches between the plants, leaving two feet between the beds for a patin way ; or be set ont in rows two feet apart, the plants in the rows twelve incless aprert; and if the plinits are proper y set out (care being taken to firm the soil around the plants, which is best done by pressing the soil against each plant with the foot), not 
one in a thomsand of Strawherry plants that have heren struck in joots, will fan to grow. lion the first three

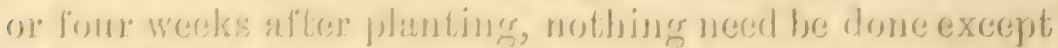
to Joe the beris, so that, all woeds alle kept down. be raleful lo do this onee in every ten days ; lon if the weeds once set a statet it; will treble the Jabos of keepines the ground colous. In about a month after planting they will hergin to thow out; runners, all of which must be

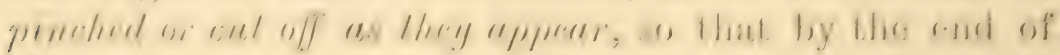
the growing soason (1st of Novernbero), each plant will have formed a compulete bush one foot on mole in diametes, loaving the necessasy matured "corowns" fol next

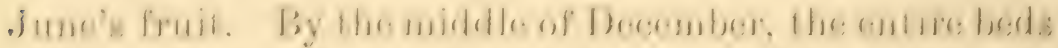
of Strawherry plants shondel be covered up with salt

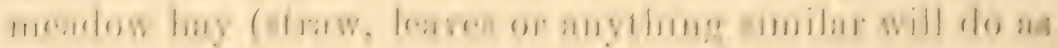
woll), to the depth of two or throes inchess, entirely covering uje the plants and soil, so that nothing is socen but the hay. Iis A pril, the planty wo protereted will khow indications of growth, when the hay over eaceh plant is

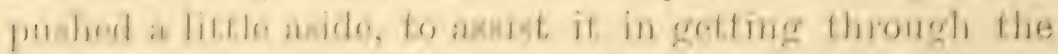

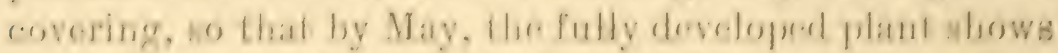
on the clean surface of the hay. This "mulching," as

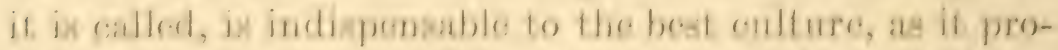

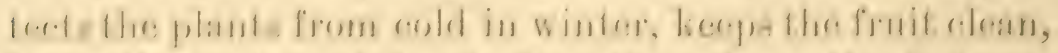
henge the rents eool by sharling them from the hes sun

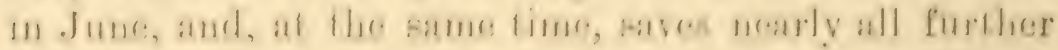
labos after being once put on, as few weeds can push

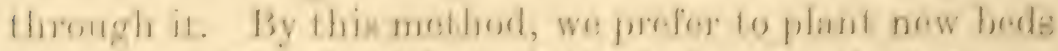

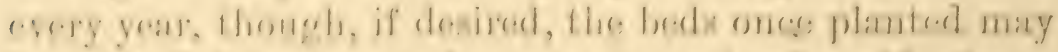
lec fruited for two of three yeare, as by the ofd plane;

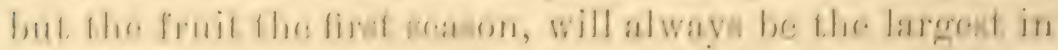
nize, if not proatest in quantily. Anoflece artuantage of

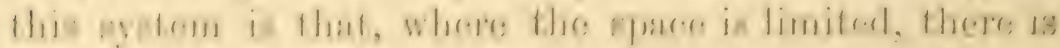

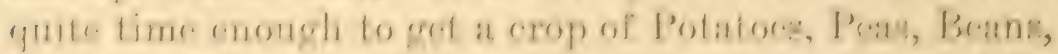

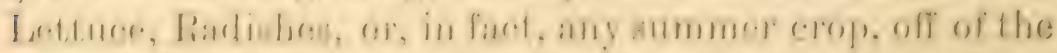

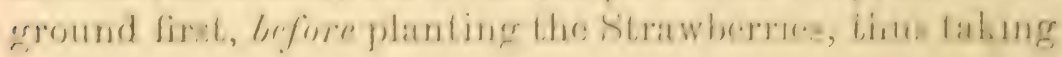




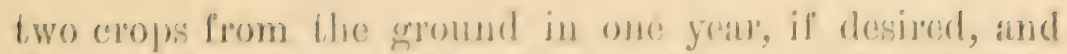

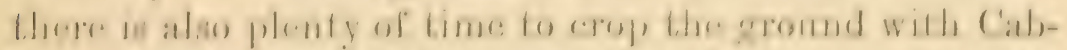

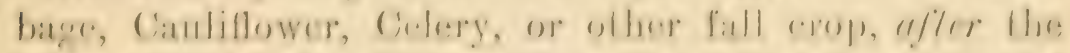

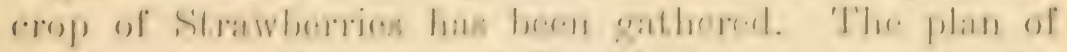

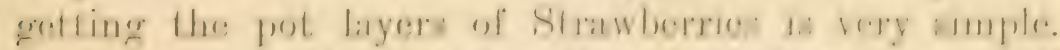

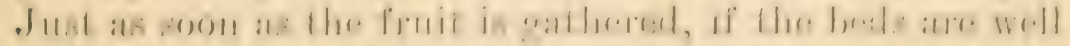
forked up betweren the row , the rumbert, or youmg planta.

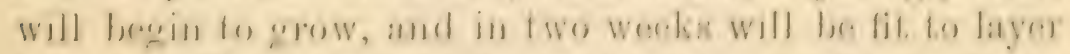

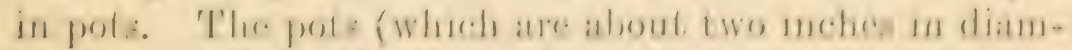

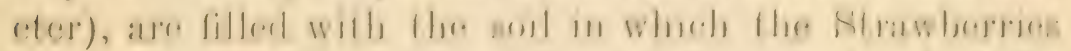
are growing, and "plunged" of sumk to the level of the

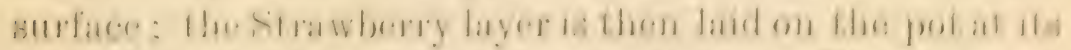

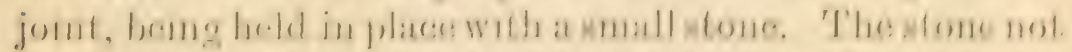

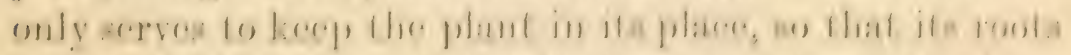
will trike inte the pot, lone it alke merven to mark where each pot is ; for, bemgr sumk to the level of the surfacen,

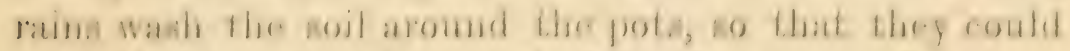

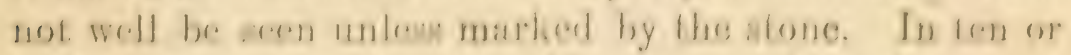

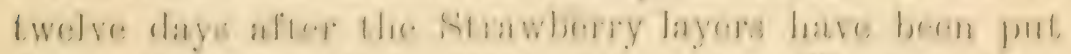
down, the pote will hes tilled walle roots. They are then

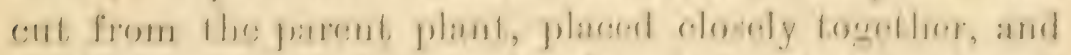
shadrel and watront for a fow days before bring planted out.

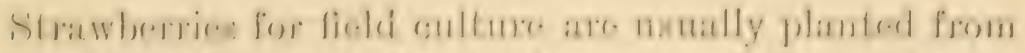

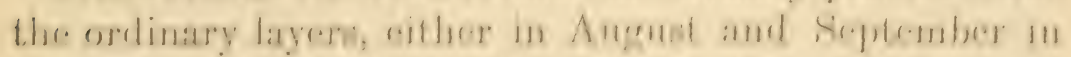

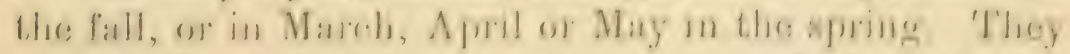

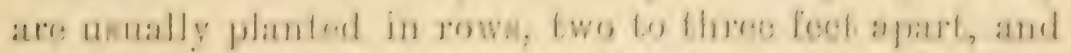

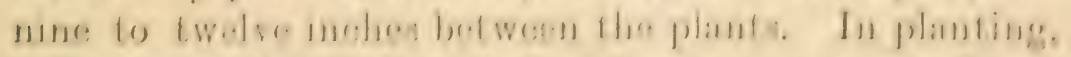

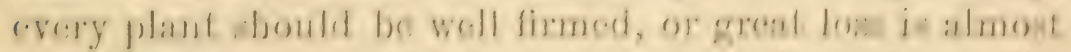

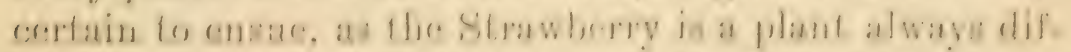

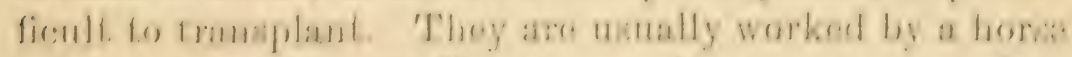

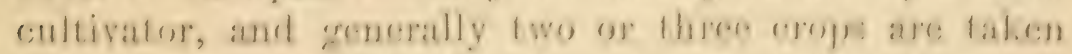

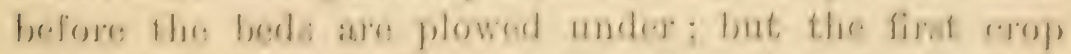

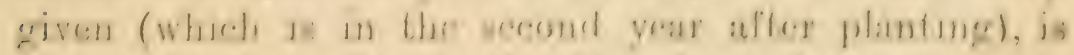

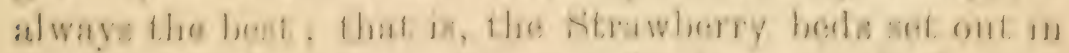

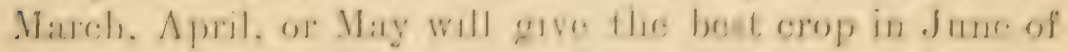


the next your. 'The sume care must he talien as in planting the pot layers: the gromel must be liept clear of weeds. and the rumbers pinched or ent ofl to malie fruiting elown. I3y the usual field method of crilture. it will be seen that there is a loss of one satson in about three: for in the your of planting of course no fruit is produced. Our own pratetre is to set aside enomgh to produce ealy plants. so that pot lapers can be obtained to set out by the Loth of July; thus a full crop of the finest fruit is hat erery season, and with less eost, we think: for the only labor, after planting, is to kecep the gromed clean and pinch off the rlinners. from July in October. with the rertainty of getting a lull erop next June, or in less than a year from the tme of planting. while by planting by ordinary layers, if set out in dugust. We have three months of fall culture, and six or seren monihs of the nuxt summer's culture, before a crop) is produced. Again. if the crops is continued to fruit the second or third rear, erery one who has had experience with the nature of the plant linows that the labor of kecping the plants free from weels is enomous: while by the pot layering methou of taking a fresh crop each year, much of such labor is dispensed with.

There are hardly two sections of the country, 100 miles apart, where the same varieties of stramberrics are grown. We can only offer those grown in the ricmity of New York as our standard.

The Henderson.-(See figre 10:.) This new Strawbery originater with Mr. Georese Seymour. South Norwalk, Conn.. in 1883, who named it in homol of the author of this work. It is dombutul if there is another Strawbery in cultiration having such a (a)mbination of good qualitics as the "Menilerson." The fruit is of the larowet size, rich, glossy crimson in color, looking as if ramished, enty and exceedingly productive, but its excelling merit is its exquisite flavor and aroma. Thether for family or mar- 
ket ase, the "Henderon " is almost certain to become a standard sort, and its strong and lealthy growth will

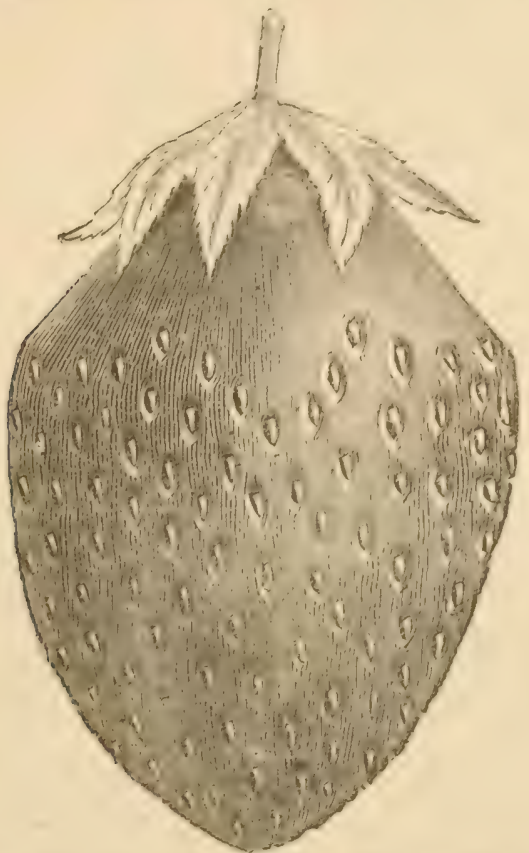

Fig. 102.-THE HENDERSON STRAWBERRY.

adapt it to almost every coil. It is a perfect-flowered variety, and, therefore, nerer fails to set its fruit.

Crimson fluster.-(See figure 10.3.) On the 10th of June, 1886, I examincel this Strawhery on the grounds of the raiser, Mr. E. W. Durand, and found :3,ofor) plants that had been planted on the 15th of August, 185.5, which, in less than ten months from the date of planting, were producing a crop that would arrage fully a quart to each plant; :3,000 quarts from the 3,000 plant:s, or at the rate of orer 20.000 quarts per acre. The crop was so immense, and the size of the berries so larere, that the pickers who were paid two conts per quant, averated twenty-five quarts prer lonur, or 85.00 jer day-a fact beyoud question, and which could he attested by a doren affidarits. At the first picking, every yard of row 


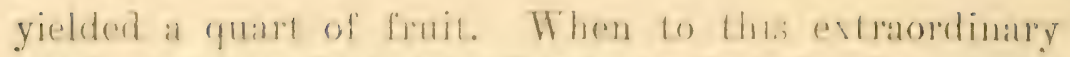
production we and the further lacts, libet h his Strawberry is of the richest erimson color, borne in immense clusters (hence the mamo), and that it is ono of the carliest as well as the lalest - as its great vigor prolonge its saason of fruting-nombined with its exrollent. qualily, there is every lation fo think that it, is boumd to be the mo-l, valuable Straw werty ever ratised hy Mr. Durand.

On the 10th of July, ons month after m! first exami-

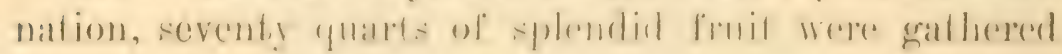

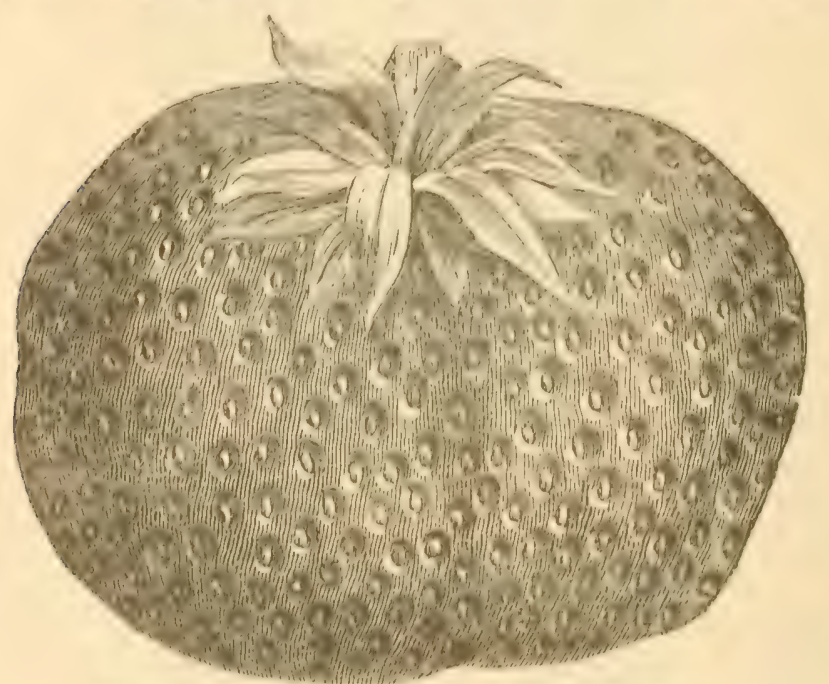

Fig. 10\%,-ORIMSON OLUSTEIR STIRAWIBRRY.

from the :, 000 plants above refered in, and furthermore, to show it still kept. on lruting. Mr. Durand sent, me a large eluster of berrine in all stages of development on the 30th of July: something entirely unlinown in a Strawhery that hat alleady giren an immense carly (arople

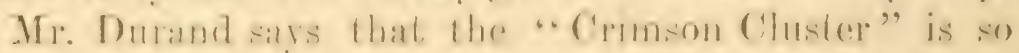

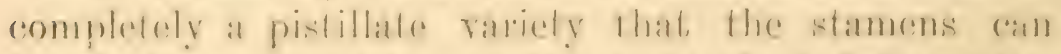
hardly be seen, get he says it may be planterl five miles away from any ofler sirawbery and get merer fail fo produce enormous crops. He lurthere silys that he has grown it in frames moler glass in enly spring, where it 


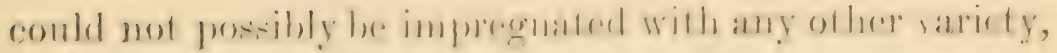
with the same results-an abundant clop.

He thinks that this laret, fo a creat estent, uperets the very prevalent notion that perfect flamens and pisits on

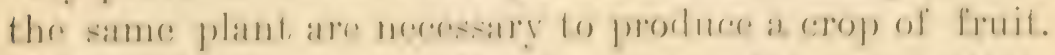

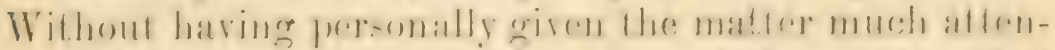
tion, I have lome believel, fom genelal ofservation, that theres was mores importance grien to the nexeraty for "perfocet flowers," at thry are ralled, in stranberries than jesults warlanted.

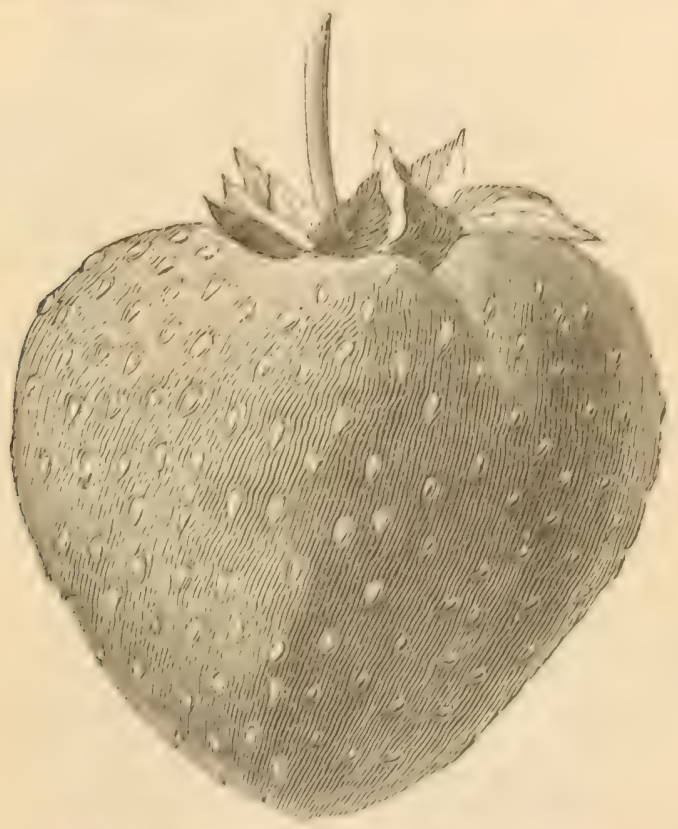

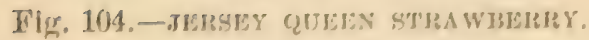

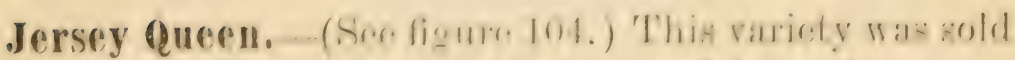

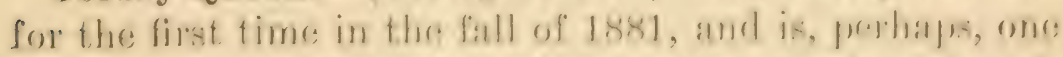
of the very hrat late Strawberries thus lar introduced. The size is immenes, often measuring wis inches in eir-

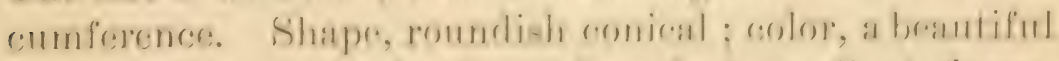

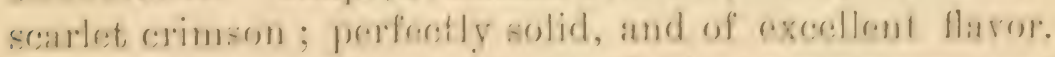
It is an enormouth bearer, many plants averaging a quart. of first quality fruit. It is orme of the latest Strawlerries, 


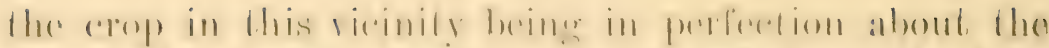

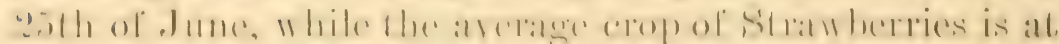
its best by the tisth ol: Jume.

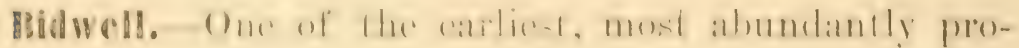
ductive, of medimn sige, excollont flityor, and light scatrlet in rolot. I'lants set out from potiayers on August. 5h, 1880, hat lomit ripe dune 5th, 18si, ten months

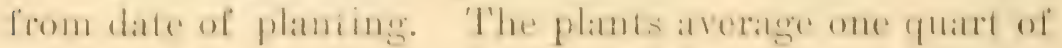
fruili anch.

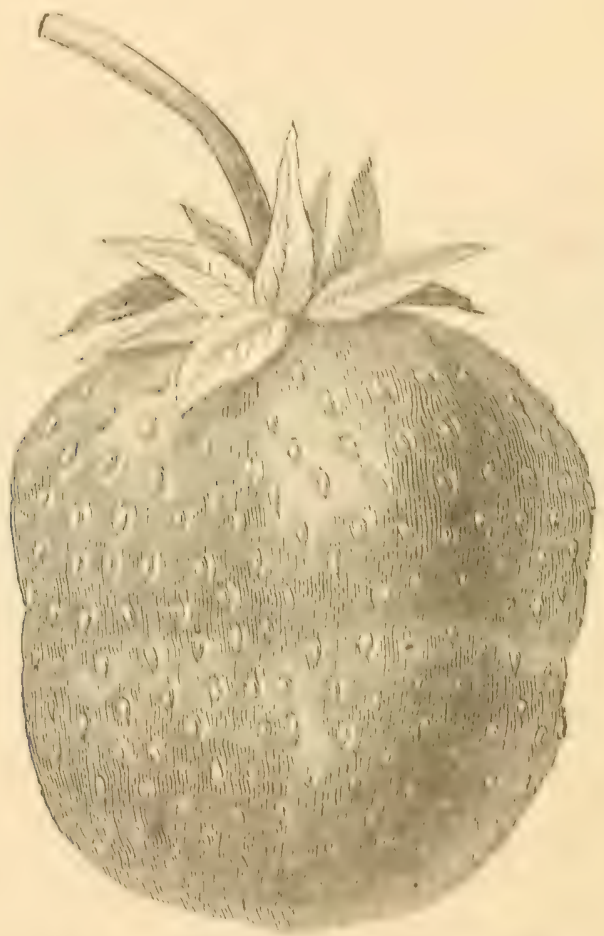

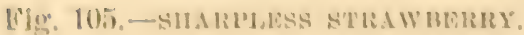

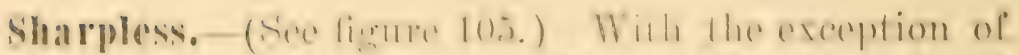

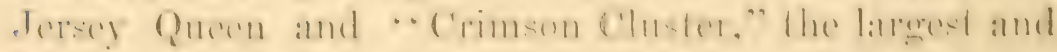
one of the homiest borries of this eollodion. It is of lino Hallor, a good he:mer, amd has 130 hecome al stamdard sort.

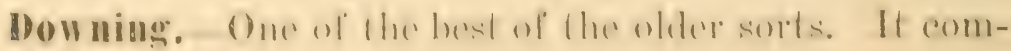




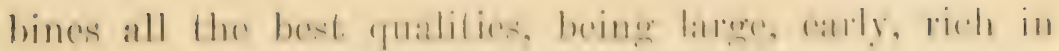
color and flavor, and abumblantly froductive.

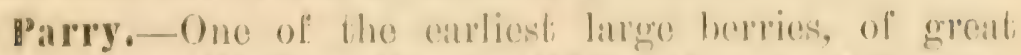

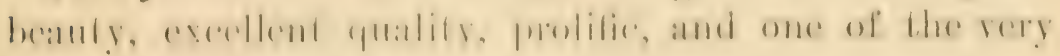
hardiest and strongestigrowers.

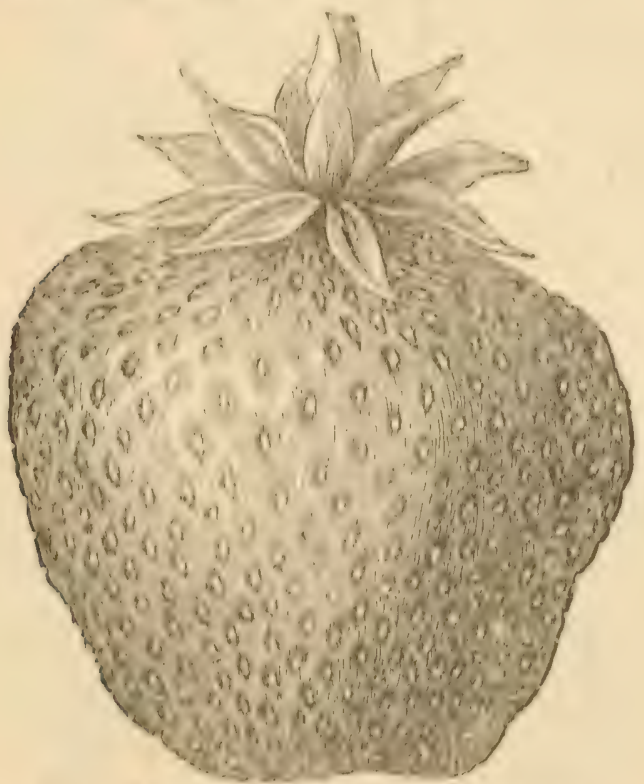

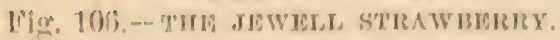

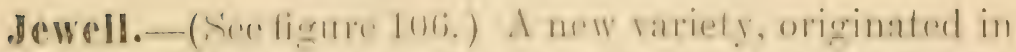

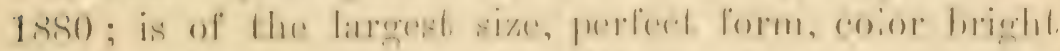

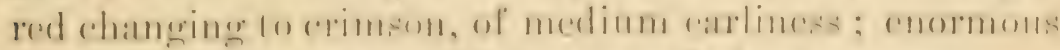

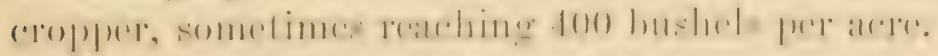

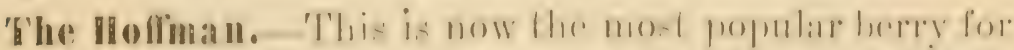

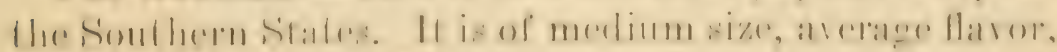

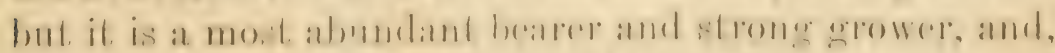

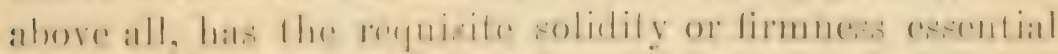
for distant carronge.

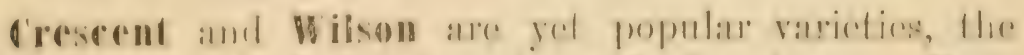

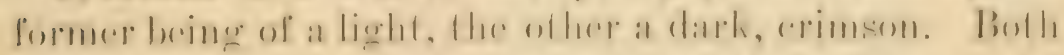
are inforior in sire and pualigy lo any of the larger varietres above describerl. but they ne both early, stromer 
growing, doing well on nearly all soils, and are often userl as early market sorts where the market is not critical as to quality.

Strawberries rarely sell at less than an arerage of $\$ 8$ per 100 quarts, and when retailed to the consumer, arerage one-third more. As about 20,000 plants are giown on an acre, and an average crop nuder good culture will give at least 5,000 quarts per acre, the crop, when sold eren at lowest rates, is a fairly profitable one. But it is a crop that must be promptly attended to in hoeing and weeding. It nerer can be made profitable muder slipshod culture, for, from the nature of the plant, it cammot defend itself against weeds, and if neglected will quickly get orerwhelmed and destroyed. Thousands of acres of strawherrics are planted ammally, which, from the want of prompt work at the proper time, are allowed to be destroyed by weeds. At a small cost in labor, at the proper time, such crops might have paid a handsome profit.

\section{BLACKBERRIES.}

Although Blackberries are found in a wild state in almost all sections of the country, yet the rarieties are so much inferior to the cultivated kinds, that it is poor economy to depend on them for a supply, no matter how abundant they may be. Cultivated Blackberies comprise varieties which are not only double the size of the wild kinds, but have the adrantage of ripening in succession throughout the season, from the middle of July until the last of September. The distance apart to plint Blackberries may be, if in rows, five feet, with the plants two feet anart in the rows; or, if in separate hills, they may bo set fire feet apart each way. In either case they should be supported by strong stakes driven into the ground, having a height of irom four to fire fect, 
to which the canes or shoots should he tied. "ithey may be set either in the fall or in the apring. If in the fall, a covering of four or five inches of rotted manure, leares or soil (if eorered with soil it is best to cut down the plants to four or fire inches and cover up the whole), should be spread over the roots, to prevent them from being frozen too much. The plants of Blackberries set out either in fall or spring will not give fruit the first sealson, but, if a good growth his been made, they will give a full crop the next year.
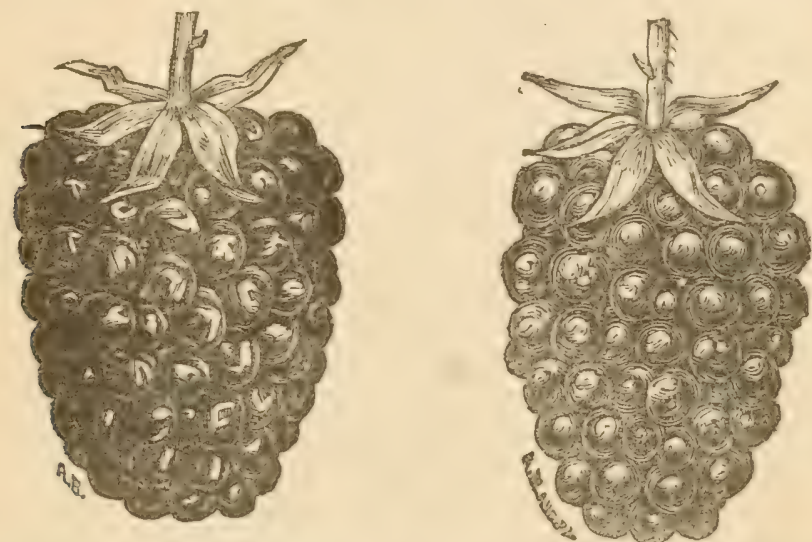

Fig. 10\%.-Wilson blackberry. Fig. 108.-Tittatinny blackberrer.

That is, if planted, for instance, abont the middle of April, 1886 (or the previous fall), by the middle of July in $185 \%$, a full crop should be obtained. After the fruit has been picked the old canes or shoots should be cut out to give the new ones a chance to grom, about four or five of which only should be left. As the new shoots are very rigorous, when they reach a height of four feet or at most fire feet, they should be checked by pinching of the tops. This will cause an abundance of side shoots to start, which are to be pinched when about a foot long. This treatment increases the productireness of the plints and keeps the fruit within easy reach for gathering. The bushes should be carefully tred to the stakes. Of 
the varicties, that known as Wilson's Eurly comes in a week before any of the others. It is a deep black, large, and of excellent quality, being destitute of that hard centre so peculiar to most wild sorts. The Kittatinny connes next in succession. It is an immensely large berry of fine flavor, of a deep) shining black color-one of the very best. It is somewhat given to rust, which may be checked by removing all the rusted young shoots as they appear. The next is the old Lawton rariety, which is hardly as good as either of the others, but has the merit of coming in after they are nearly done fruiting. 'There are a number of other kinds of Blackberries offered, but the varieties. above named are as ret standarl sorts in most sections of the country. Any one growing Strawberries to.supply a local demand, must of necessity, have such fruits as Blackberries to succeed them as the season adrances, and in most localities they will be found equally profitable with. Strawberies, although, perhaps, for local demand, they could not be sold in as large quantities.

\section{RASPBELRIES.}

The culture of the Raspherry is almost identical with that of the Blackbery, except that they may be planted one-third closer, and that m some sections, the Rasploerry is not quite so harly, and it is better to take the preculltion of laying the hoots down close to the ground in the fall, being careful not to break them, and cover them up with corn stalks, straw, leares or litter. This should not be done, howerer, until the weather is quite cold, say, in the latitude of Now Iork, the first week in Decenber. The covering may be from three to six inches thick, and should not be removed in the spring until the middle of April, as, if remored too soon, the shoots, which would then be beginning to start, might be hurt 
by the late spring frosts. Raspherries are of three colors -red, black and yellow. Of the red, Cuthbert, Hanesl and Indson River Antwerp are the farorites. Of the black varieties, the Gregg is of the linrgest size, an enor-

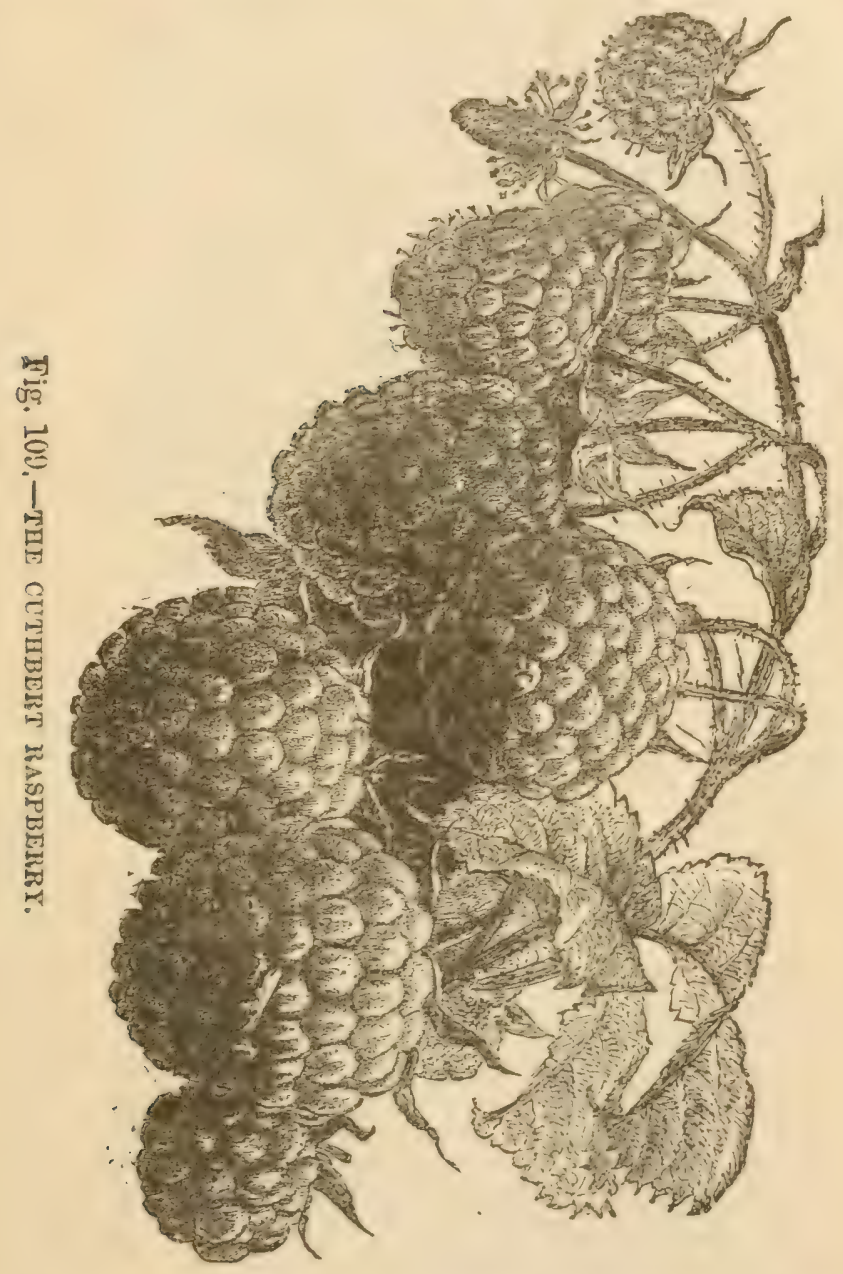

mous producer, of excellent flavor, and should, perhaps, be grown to the exclusion of ail others of the "Black Caps." A ycllow varicty, known as "Caroline," is of rich orange color, entirely liards, and of excellent flavor. Another yellow kiml, known as "Brinkle" Orange," is 


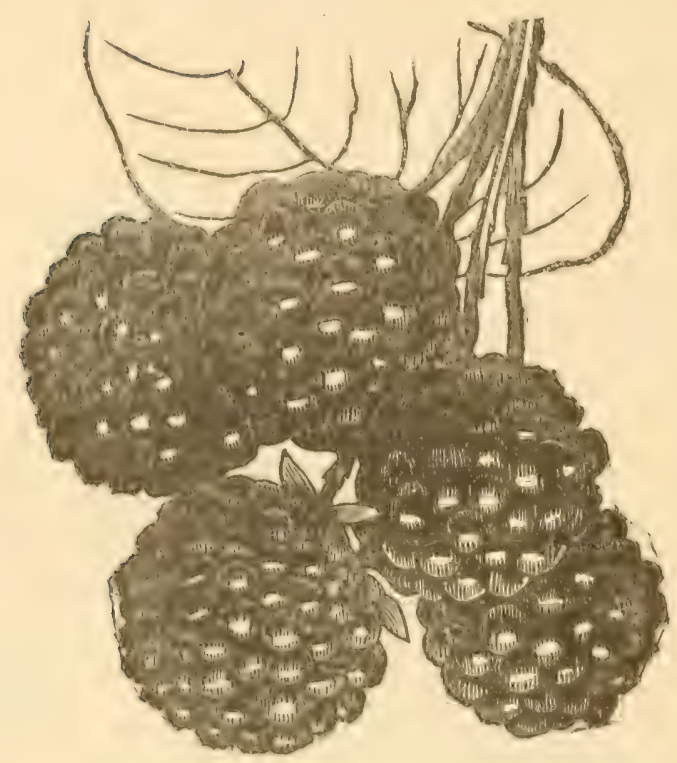

Fig. 110.-TIE GREGG IZASPBERRY.

of the most dolicious llaror, but it is mot hardy unless in well sheltered spots.

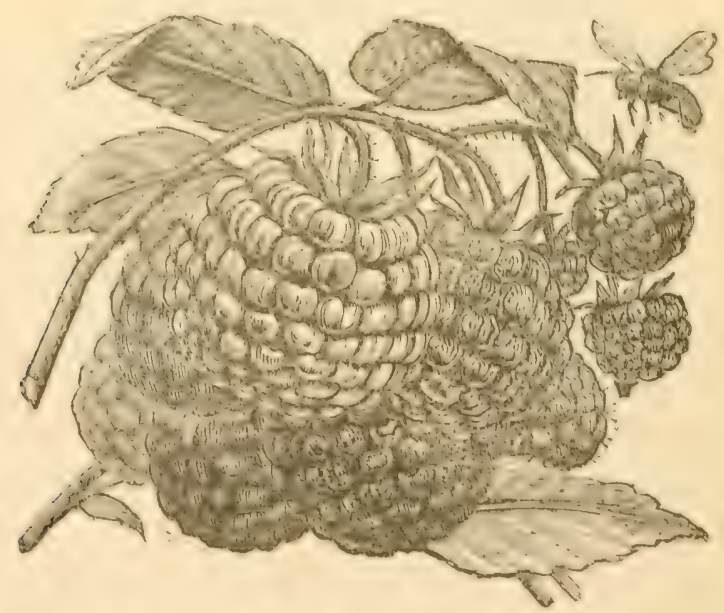

Fig. 111.-THE WANGELL RASPBERIR. 


\section{CURRA N'TS.}

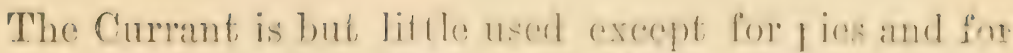
preserving purposes. There is, perhape, mo of the small fruit that will give more weight of crop for the space it aceupies than the Currant. However, as it is moly urat for these special purposes, and is but very little caton ot dessert, in an moneolied state, compraratively fow are required. The plants should be sed, ond in the gatraten in rows about four feet alpart, and three feet be lwern the plants; for market purposes, these distanees may be inereasent one-hall. The young shoots reyuire to be pruned in the fall, cutting ofl abont one-thiret of their growth, and thinning out the old shoots when they become too thick. They are all trained in bush form, to a heighte of three or four fect. 'The best red varieties grovin are known as the Fay, Reel Dutch and the Cherry. Oif the white kinds, that, known as the White Duteh is the bes. It is of a yellowish-white color. This vartecty is swecter than the reds, and for that reaton is better for deresert purposes. Black Currants are but little grown, and then exclusively for jams and jellies. They should be cultivated in the same way as the whites and reds, altiongh they are an enturely different plant, belongrng to a different species.

\section{GOOSEBEURRIES.}

The Gooseberry is but little orown in this climate, as our summere is entirely too hot for it, and it $\mathrm{i}$ rarely seren in geond condition, ats it ripens just in the luan of summer, when the weather is the hottest, thus forrenge it unnaturally to maturity, so that the fine flavor chtained in milder climates, such as Great Lritain, is nescr found hore. For that reason it is not much grown, except to be used in a green state for pies or tarts, and is 
in but little demand. Miany of the English varicties are offered for sale here, but they areso subject to mildew, lint they rarely do any good. Of the native varieties, that lnown as the Downing is of a greenish-white eolor whon ripe, and of very lair quality. We have also a red

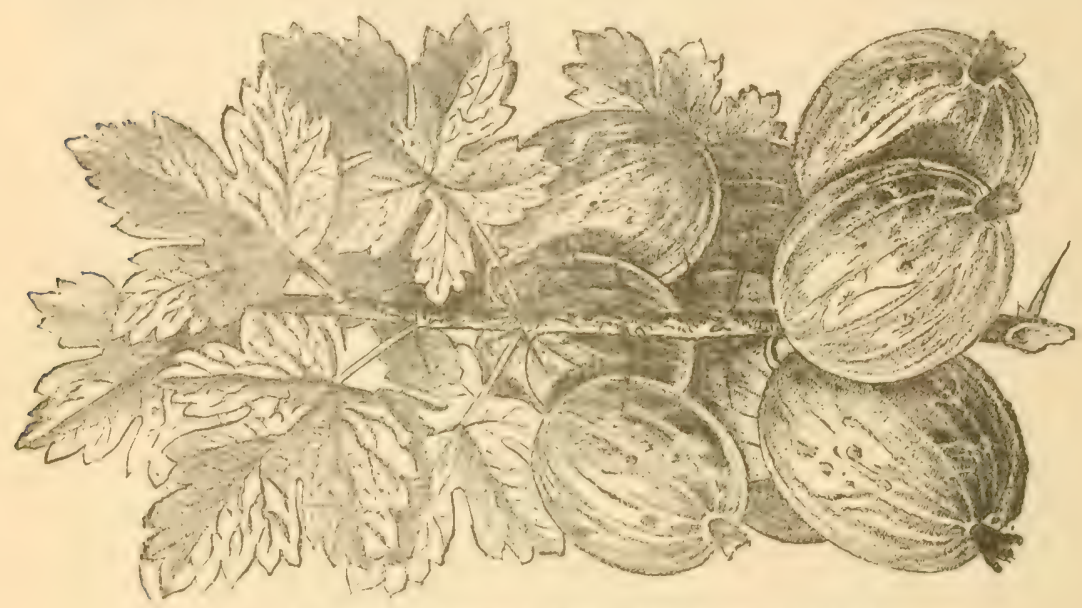

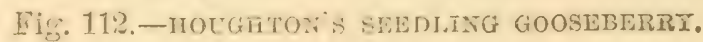

mative seedling known as Inoughton's, which is of arerarn size and flavor. The culture is same as that of the currant.

\section{GRA PES.}

Althongh grape-vines can he grown in almost any soil, yet if a position can be obtained on a sloping bank, facing sonth or southeast, rumning at a slope of ten or fitem degres, where the soil is stony or shaly, they will usnally be found to do better than when planted on level lansis, particularly if they cam be mamured. All the finest vineyards in (termany and France are so located, and the fruit is always hetter flavored and freer from mildew and other diseases than when on the level. However, such conditions are not always to be obtained, and the vines, of course, are not so casily worked as when planter on the level. There is now so much advance 


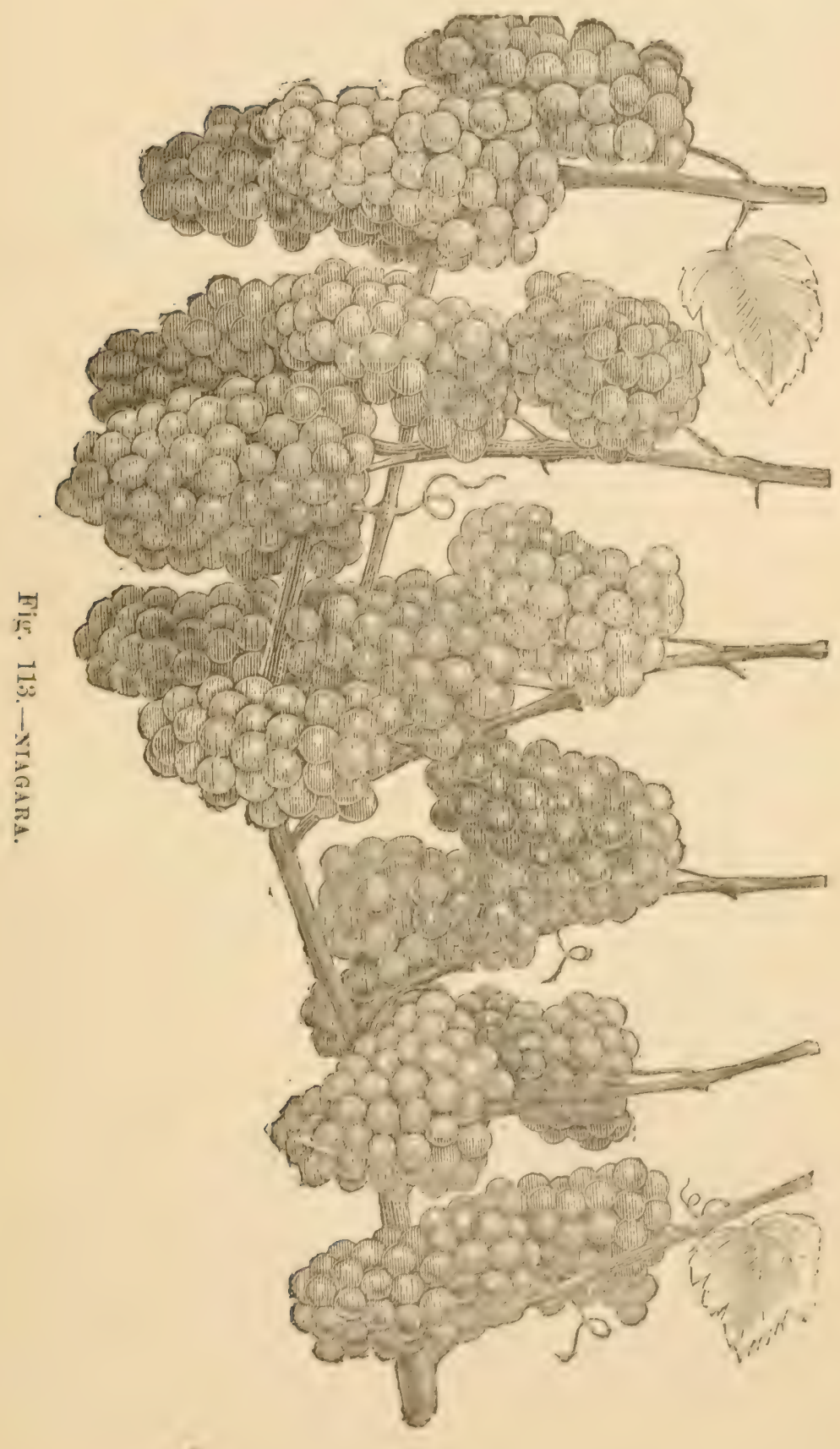


made in our hardy varieties of native Grapes, that those who have not had opportunities of secing them will be smprised fo lind the rast improrement that has been made in this deiceions fruit within the last ten or fiftecn fear. He have now erapes of the linest flavor, of all

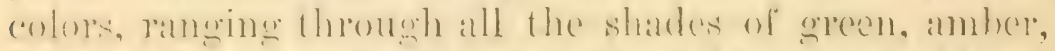
red and hack, ripening in sucession from the midrle of Augut until the miklle of Ocholer. Immense areas are now leing plantud with the kinds that have proved most protizable for market purposes, and as they can be saldy shipherl to almost any distance, there is no need of heing dependent upon a local market. There is much mirconception as to the age at which a grape-rine shonld be planted. It is the general impression that they should always the three or four years old. This is a populate crear, for no matter how latrere a glape-vine may b, it will never frut lo anyextent the same season it is planted, and the langere it is the more it will suffer in heing lifted and transplanted. 'Therefore, I always recommend purchasers to buy yommer plants, which not only can be bought at one-third the prices of two or three rear old ones, but alle usually better, eren at the same price. If a irellis is made for them, they should be planted at a distance of six foet aluat. The trellis may be any height from six to twenty fect, as desired. If planted in rineyarel style in the open fiedd. without trellises, they may je sed six feet hetweren the rows and three or four leet between the plants. and tied up to stromg stakes.

'The fir:t rear alter planting, if with rineyard eulture, they homld he ant down, and on!y one shoot left to reach to the top of the dive or six loot stake. If it has grown strongly and ripened well, that shoot will give a few bumches the recond real and may be pruned elose, so as to resemble a walling stick, hut with the lateral shoots ent halek to one eye only-that is, the main shoot is allowed to stand, and the side shoots or laterals are 
frimmed to one hed or eye. This is what if caller the: Sipur System, and will be fomol to be ilos most oomse-

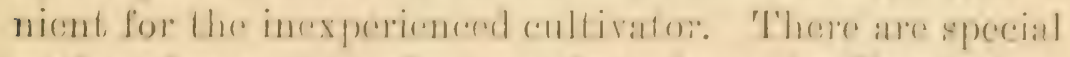

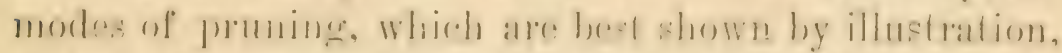

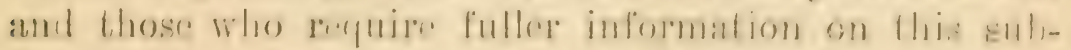

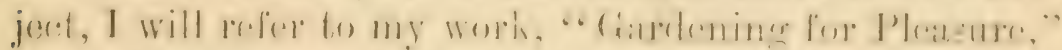

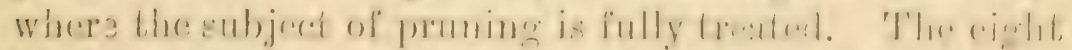
kind: which we would recommend for groneral en! wre ane the following:

Mooress Darly, - This varichy has large and compacel

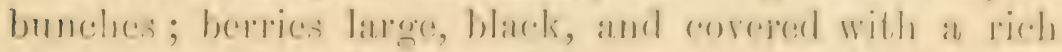
bloom ; excellent flatror, and is one of the carliest rifuen-

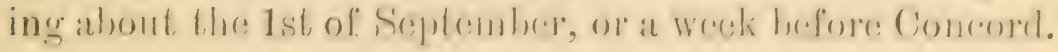

Champion. $-\Lambda$ nothere excellent, blarek; modimm a.ely.

Niagara.- Is of eqeeni h whito color, somelimes linted

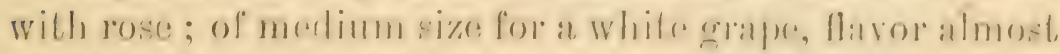

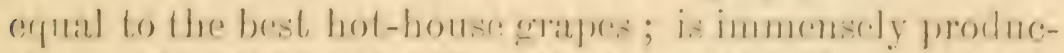

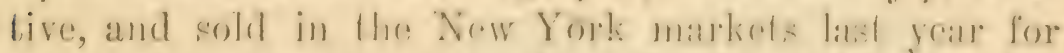
twonty-five cents per pommit, while comeorel and other

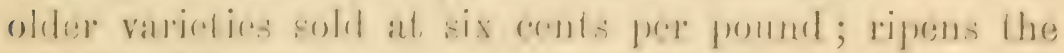
middle of September.

Hartha, - Anothere white; not, so enoul in quality, but a strong grower, which mirrht snit, in places where Niagara would firil.

Wibler.-Has herres of modium ize ; color rendish bronze; berry of expuide flavor, ripening middle of September.

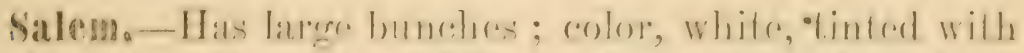

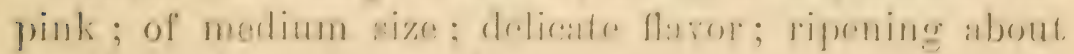
Ist of October. $\Lambda$ gland varicty.

Breghton.-Color reddish hronz, bunch and berres of

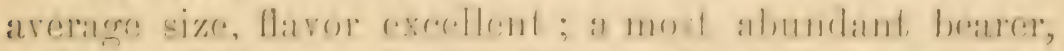

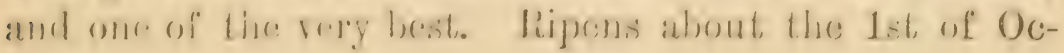
tober. 
Concord, the last we name, is one of the best linown of all the sorts. It is mueh inferior in flaror, but it hals the valuable quality of seldom failing to bear abundant crops, and is indispensable in any collection, and if but one grape is grown, this should be chosen.

\section{H A P T E R X XI.}

\section{IMPLEMENTS.}

The tools or implements ancually repuired for the market garden are comparatirely few. The most important implements in los in the regetahle garden are flow and harrow, which should always be neel to the

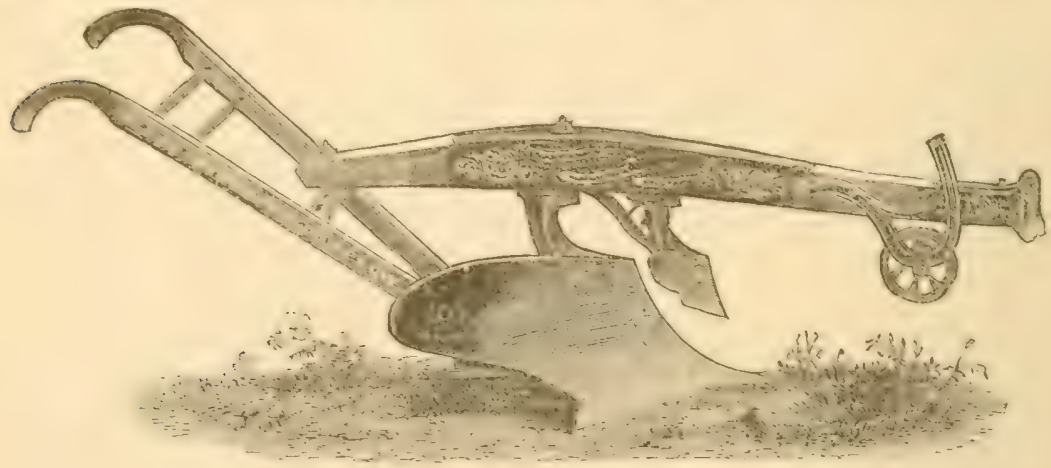

Fig. 114,-ROLAND CUILLED PLOW.

cxelusion of the spate or dieging fort. whenerer it is practicable to do $:$ o. No digrging in the ordinary way (an pulrerize the soil so thoreughly as an he dome hy the plow and harrow, nor does trenching by the spatce. much surpass in its results, that dome by thoromgh subsoiling.

Figure 114 represents a plow now larely used hy manket gardenexs and known as the lioland Chilled Plov. So superior are its pulverizing pores's to those of the 
spade that we linow of no marliet gardener who would allow his ground to be dug, even if it were done free of cost.

'To aroid the frequent chancre of shares, and the extra

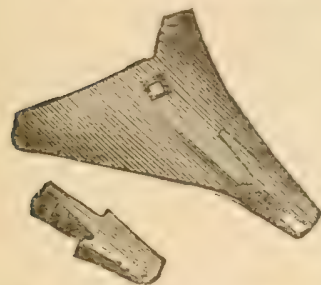
cost of replacing them, a reversible, self-sharpening slip point (see figure $115)$, is now made. When the bottom of this point is worn, and the plow tends to run out of the ground by reason of the rounded point, the slip point Fig. 115.-SLip STARE. is taken out and reversed, and thus doubles the length of its useful life.

Miner's Gold Hedal Subsoil Plow (figure 116), is the best subsoil plow we know of. It involves new principles, and accomplishes the work of stirring, loosening and draining the soil bencath the furtow of the common

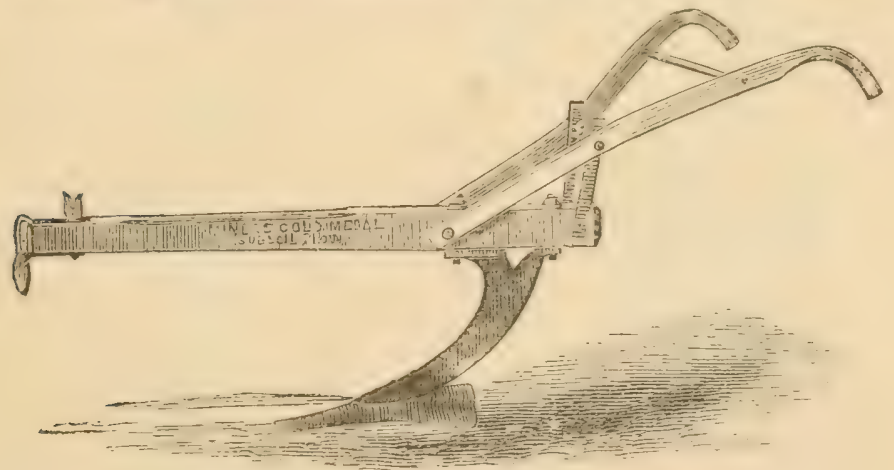

Fig. 116.-MINER's SUBSOIL PLOW.

plow, lifting and lnealing (but not turning) the subsoil to the depth of fifteen to twenty inclies, as may be desired. On rery stiff soils, we use the subsoiler once in two years; in lighter soils not so often; although if time would always permit, there is no doubt but that it would i,e beneficial to use it whenerer piowing is clone.

The Garden Harrow (figure 11i) we find is wall suited for garden work. It contains some forty tecth about ten inches long. 'These and driven through the 
wood-work, leaving tire or six inches of the sharpened end on the one side, and one and a half to two inches of the blunt end on the other, as shown in figne 11\%. After

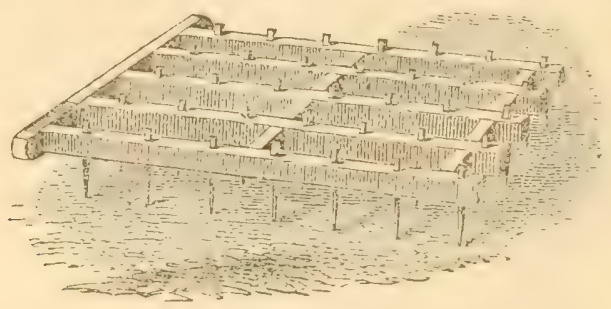

Fig. 11\%.-GARDEN BARROW.

the ground has been thoroughly pulverized by the teeth of the harrow it is turned upside down and "backed,"

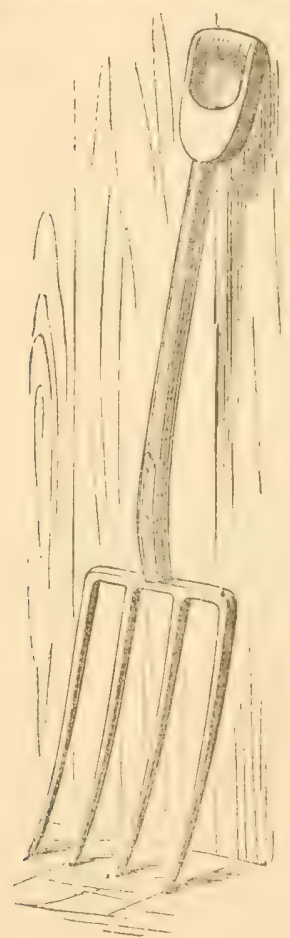

Fig. 118.-DIGGING FORK.

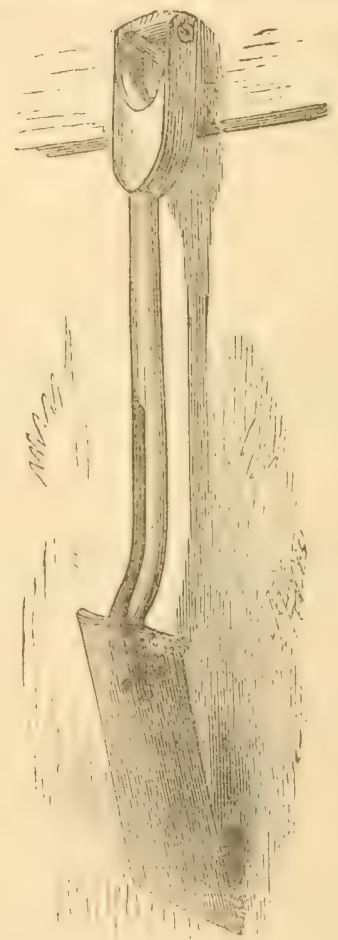

Fig. 119.-ATIES' FIRST QUALITY.

as we term it, the short blunt tecth further breaking up the soil, and smoothing it to a proper rondition to receive the seeds or plants. 
But there are many spots in the garden that it is impracticable to plow, such as our frumes, borders, and necasionally between rows where the space is too narrow for a horse to walk. Such places must be dug, and here we use the Digging Fork, represented by figure 118, in

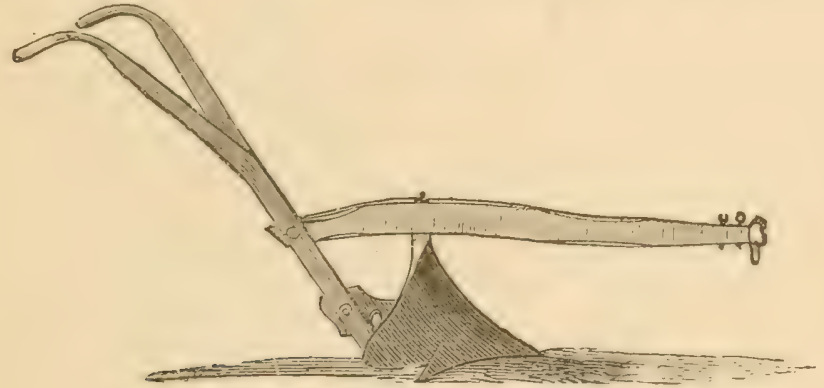

Fig. 120.-SKELETON PLOW.

preference to the spadc. Its prongs enter the soil more easily than the blade of the spade, and by striking the turned orer soil with the back of the fork, it pulverizes it better than can be done by the blade of the spade. Still there are many operations in the garden, such as the digging up of roots, earthing up of Celery, etc., for which the spade is indispensable. For such purposes the

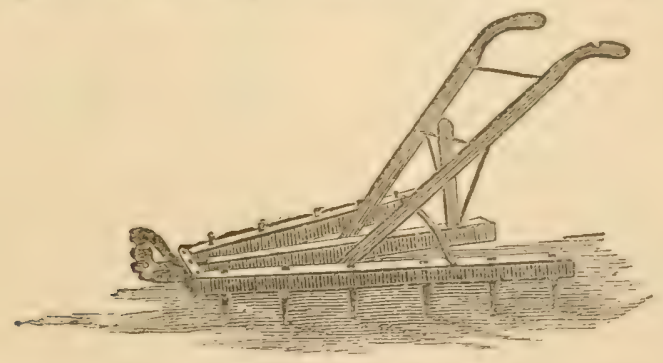

Fig, 121.-TRIANgULAR ADJUSTABLE HARROW.

one remresented by figure 119, and known as "Ames" First Quality," we find the best.

For stirrng between narrow rows of Cabluage, Celery, etc., we use a small one-horse plow before using the cultivator. This is represented by figure 120 , and is knomin 
as the Skeleton or Cibbage Plow. Following this, is our main implement for cultivating between rows, which is simply a Triangular Adjustable Harrow, represented by figure 121. 'This implement, we prefer to any variety of culivator we hare ever used, on gromed where there are

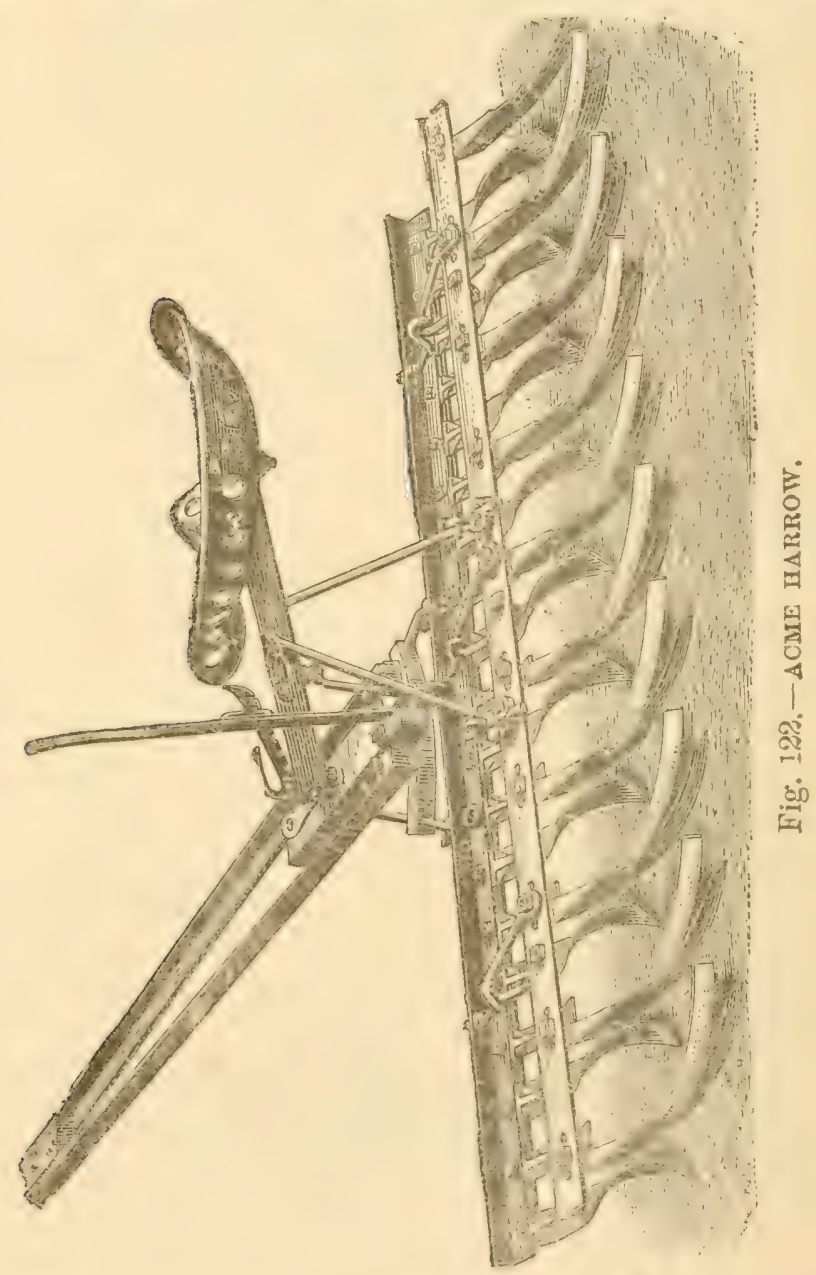

no weeds, as its teeth sink from three to fonr inches deep if liept sharpened: when extla depth is wanted, a weight is put on to smk it reeper. Anotherexcellent implement, which we have used to great ad rantage in onr market gar-

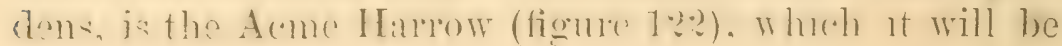


seen is of an entirely difforent construction from the harrow just desclibed. A; $:$ mulverizer ol leveler we liare found it one of the rely hest implements we have? ever used lor these purpowes : fol it is not only a harrow, but, muler certain conditions of the soil, it is to all intents and purposes a ging of small plows; or, in other morels, in a solt or light soil you can plow the gromel just as thoroughly for six fect wide as you call (lo it wath the ordinary pho eight inches wide. Although this implement has heen recommended especially for farm work, onr own experienre with it convinces us that it is equally valuable in the market garden. Still another excellent smoothing haprow is that known as the I)ise, which consists of some sixty sharp (listes, plinced on levolving shafts so as to cut the soil to a depth of thice inches by one

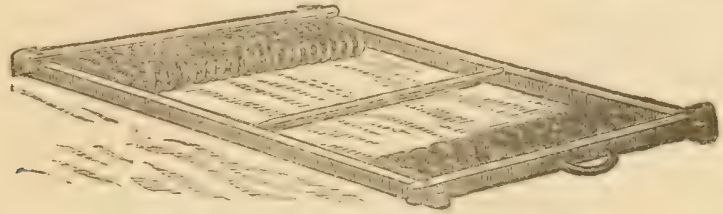

Fig. 123.-DISC HARROW.

meh in width, which levels the gromud as completely as can be done with a sted ralie in the hands of an expert workman. The use of this implement has sared us an immense deal of labor, which previonsly was donc by hand rakes.

In all hocing operations by hand, the Steel-Prong Hoe (figure 1: 4 ), is used in preference to the old-fashioned blade hoe; yet superior as this implement is to the blade hoe, it is not much more than twenty years since it came into general use. A man can do fully onethird more work with it, do it hetter, and with greater ease than with the hlade hoc. 'True, it is not so good for cutting weeds, but weeds should nerer be seen in a garden, whether it ha for pleasure or profit; it is shortsighted economy to delay the destruction of weeds until 
they start to grow. One man will hoe over in one day more ground where the weeds are just breaking through than ix will do if they be allowed to grow six or eight inches in height, to say nothing of the injury done to the ground by feeding the weeds instead of the planted cropus. Another benefit of this carly extirpation of weeds is, that taken in this stage, they, of comrse, nerer seed,

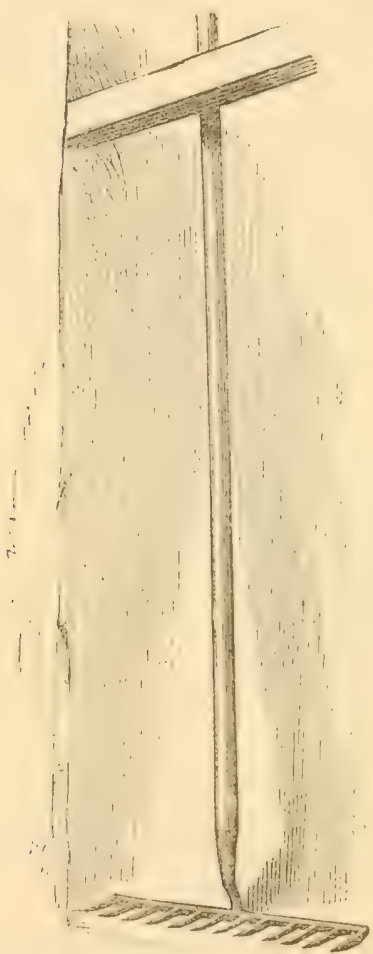

Fig. 125.—STEEL RAKE.

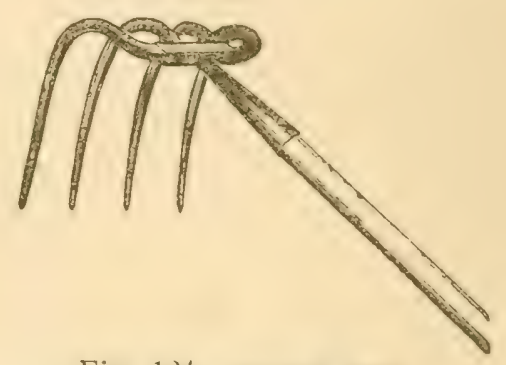

Fig. 1:t.-PRONG Hor.

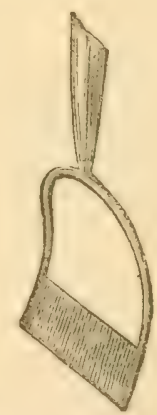

Fig. 126.-SCUFFLE HOE.

and in a few years they are almost entirely destroyed, making the clciring a much simpler task each succeeding year.

Another tool, used in place of the hoe, is the Steel Rake (figure 125), which we use in various sizes, from eight inches to twenty inches in width. Nicarly all our first "hoeing" is done with rakes. That is, the ground is raked over and leveled in from two to three days after 
planting. This destroys the germs of the weeds. In from fire to ten dirys, according to the state of the weather, the ground is again gone orer with the rakes. I am no believer in decp hoeing on newly plimted or sown erops; it is only when plants hegin to grow that deep hoeing is beneficial.

For using between narrow rows of crols just starting from the ground, the Push or Scufle IIoe (figure 126), is a most effective tool. Wie use them from six to twelve irches wide. They require to be always about three inches narrower than the rows; thus, in rows nine inches apart, we use the six-inch hoe. Another indispensable implement is the Rolier (foure 1:i). It is of great importance, not only in brealing lumpy soil, but in firm-

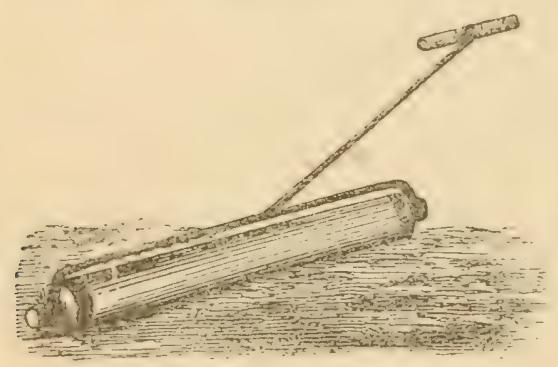

Fig. 127.-GATZDEN ROILER.

ing it properly around newly sown seeds; besides, the ground leveled by the roller is much cisier hoed than if the surface were uneven or irregular. The roller we use is made of hard wood, and is five or six fect long and nine mehes in diameter. 'The roller is bored through its whole length, and through this hole is put a bar of two-inch round iron. This bar gives the necessary weight, and its projecting ends afford pomts to which to attach the handle.

The Double Marker (home-made), figure 1:8, is used to mark six or eight lmes at once, as may be requireal, the spaces hetween the teeth being twelre inches on one side, and nine mehes on the other. Where rows are re- 
quixed only of thece wilths, "ropy row is, of course,

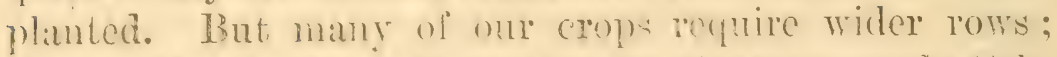

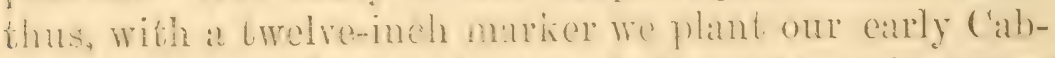
bueres at twenty-fonl inches aprat, the interening rows being plinted with Lethee at the smme time; or, with

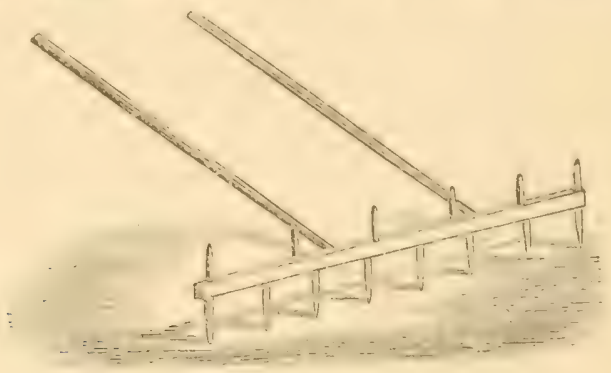

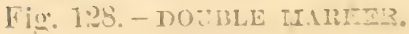

the narrow side of the marker, every ros nine inches aprat is planted with Onion scis, or, in such a crop is Buets, every alternate row only is lised, making the rows cighteen inches part. This is the marker that has been

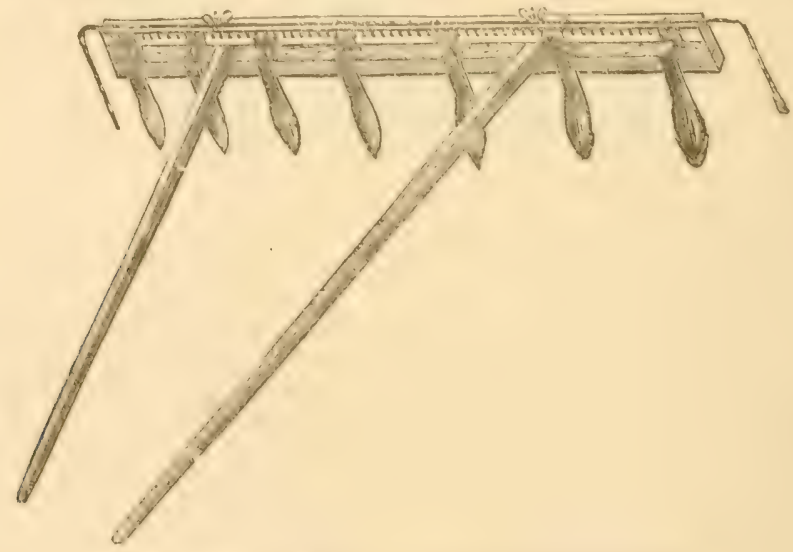

Fig. 129.-RAPP'S ADJUSTABLE MARTER.

ia tase for many year. Within the last year, however, a new implement, linowr as Rapp's Adjustable Ground Marker, has been offered, and a laree number of than hare been sold to the best market cardeners in our vieinity, all of whom, without cxeention, sily that it effects a 
great saving in time and lathor, compared with the old

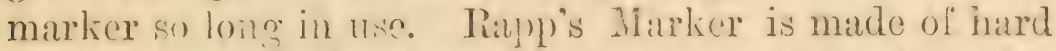
wood and iros. By mom- of thumb-nuts it is al juatable

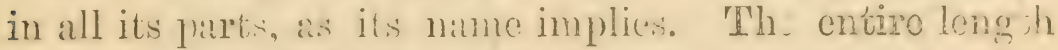
of the he: : is divided into inches. phanly marked : thus

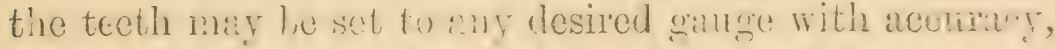
while the derith of the trenches is rewhend by bwo in:m

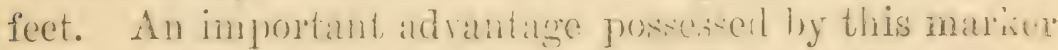
over the old one is, lhat h: rai: ing the handle slightly the weight of the machine is thrown on the feet, thus allowing a shallower tiench to be dug, and relioving the operator of the necenil y of carrying the mathine, as heretofore. Mhis Harken, an illustration of winch we give

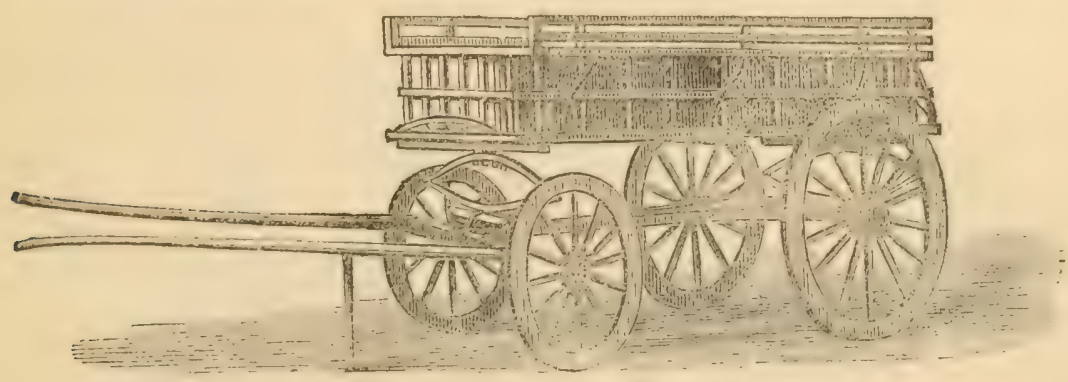

Fig. 130. - MATIKET WAGOZ.

in figure 129, can be ohtained from most of the sece $\mathrm{Ci}$ implement houses.

The Market Waqon (fignre 130), is made aficr various patterns in different scetions of the country. That shown in the engraving is the kind used by us, and is usually drawn by one heary horse. It is stronely made, weighing ahout 1.400 pounds, and is capalble of carrying from 2,000 to 3,000 pounds.

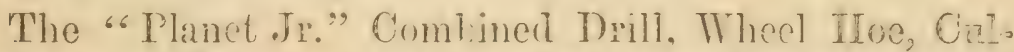
tivator and Plow is really a most excollent and raduable implement, eombining in one, three implements, all nearly a.t efiective as any of them would be semaritely. The change: are easily and quickly adiustahle. Fie have 

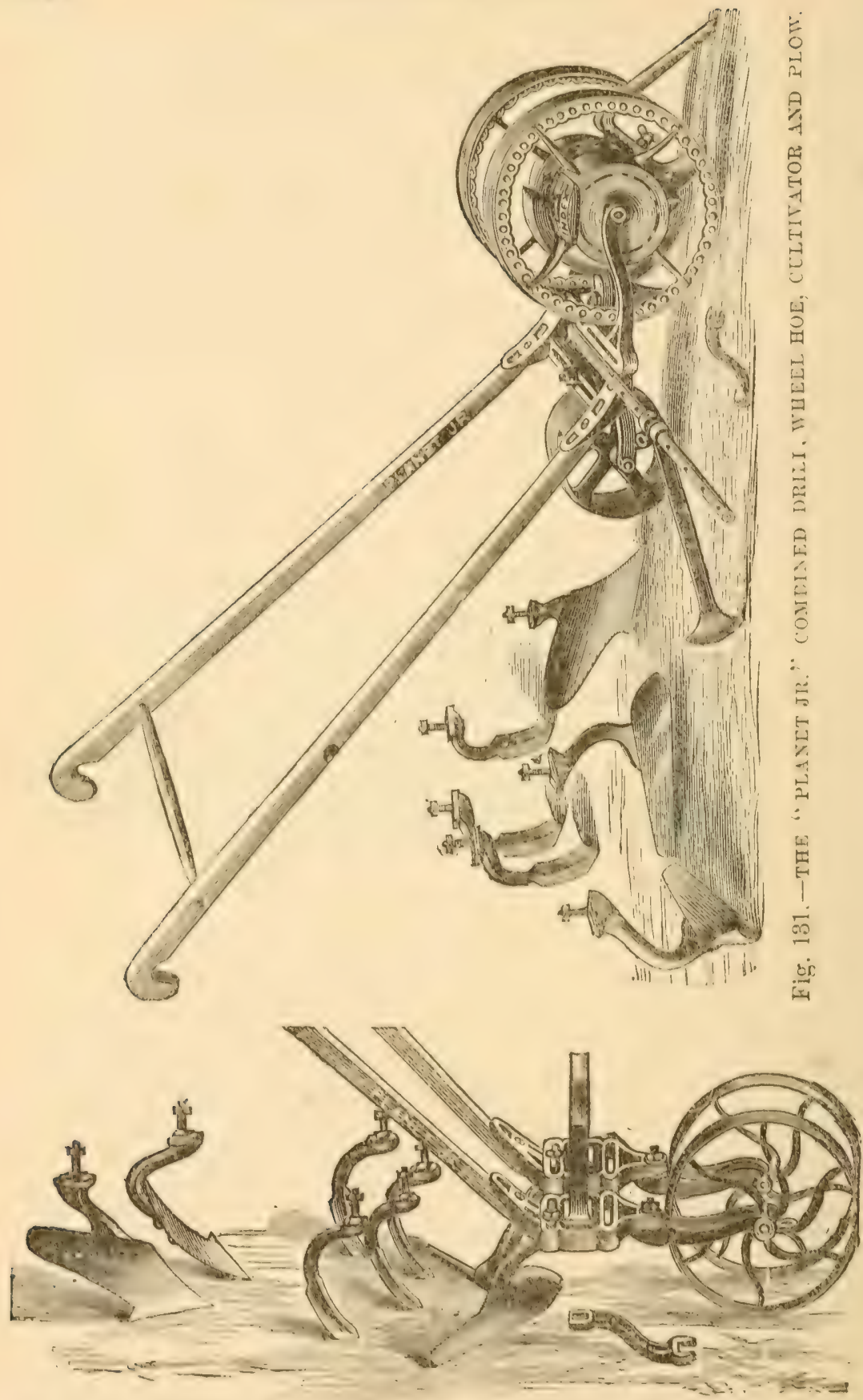

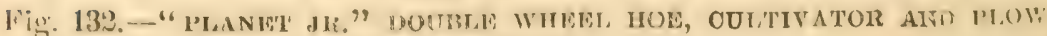
CO.1131NL1). 
used this implement, for the past, two years with great, satisfaction and profit.

Planct, Jr. Fouble libeel Hoe, Cultivator and Ilow is on the same principle as the preceding, neariy identIril, escept Wanting the seed Drill Attachment.

'Ihe Asparagus Kulle (ligure 1:33), is a tool intomeled for cuttug the $\Lambda$ sparagus below the surtace of the soil,

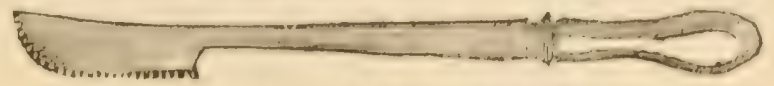

Fig. 133.- - SPARAGUS KNIWE.

the saw teeth being used whore there is diuger of injuring the edge of the knife.

'The Asparagus Bunchur, shown in figure 134, is the only implement of the kind that we know of, and while it is an improvoment over the old process of tying by hand,

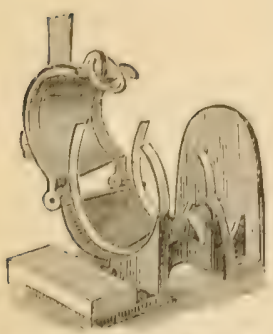

Flg. 134.-ASPARACUS BUNCILISR. it is not as perfect as it might be.

'The Garden Line Reel (îgure 135), is best described by our ent. 'The best sizo wo heve used is one that will carry 150 feet of line.

Iigure 136 represents a Horscridish Grater, and

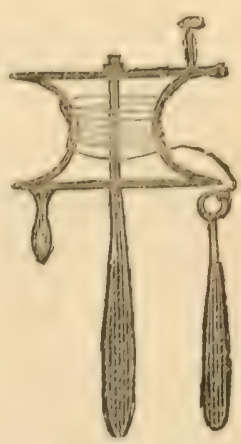

bis. 125.GARDEN TATIE REEL.

this machine is perhaps as convenient to noe as any that can be fommel. It is easily operated by ome presom. The cylinder is covered with heary perforaled tin, and the roots, first cleancel hy scerapinge alle hold up aganost: it and grated off in that way. Sinch a gratere as we show will grate about filteen pounds an hour.

The Dibber (figure las), is a very simple but indis-

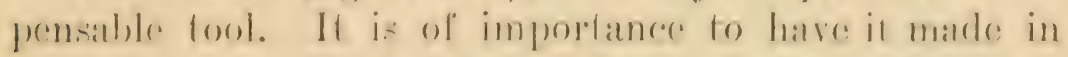

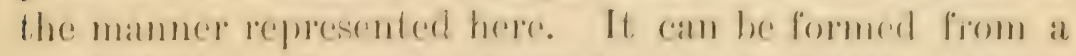

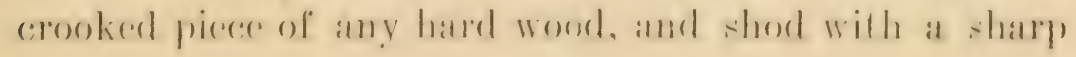


iron point, which gives weight to it, besides it always heops sharp. Dibbers are too often raude from an old

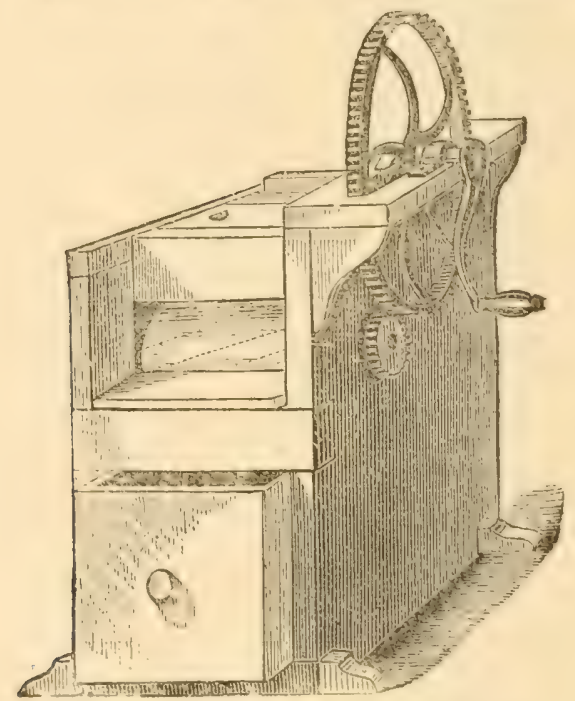

Fig. 13ü.-HORSERADISI GRATER.

spade or shorel handle, when they are awkward and unhandy affairs.

Planting is an operation that often reyuires the most rapid movement to gist the cron in at the proper time, and the best appliances in working are not to be disregarded. With a Dibher of this style an espert planter with a boy to drop the plants, as we invariably practise, will plant from 6,0:00 ta 10,060 per day, according to the lind of plants or the condition of the ground. I have on many occasions planted in one diay three areses of Celerv, holdmog about 90,(0)0 plants with ten men, each of whom had a boy from ten to fourteen years of age, to drop the plants down before him. This plan of using boys ls not generally adopted, but I have repeatedly proved that, by thus diricling the labor, a boy and a man will do more Fig. 137. pianting than two men would do if plantugg singly, and each carrying his own plants. 
Another valuable marke garden tool is the Planet Jr. IIorse IIoe and Cultivator. The frame will expand to twenty-four inches, or close to five inches, or it can be

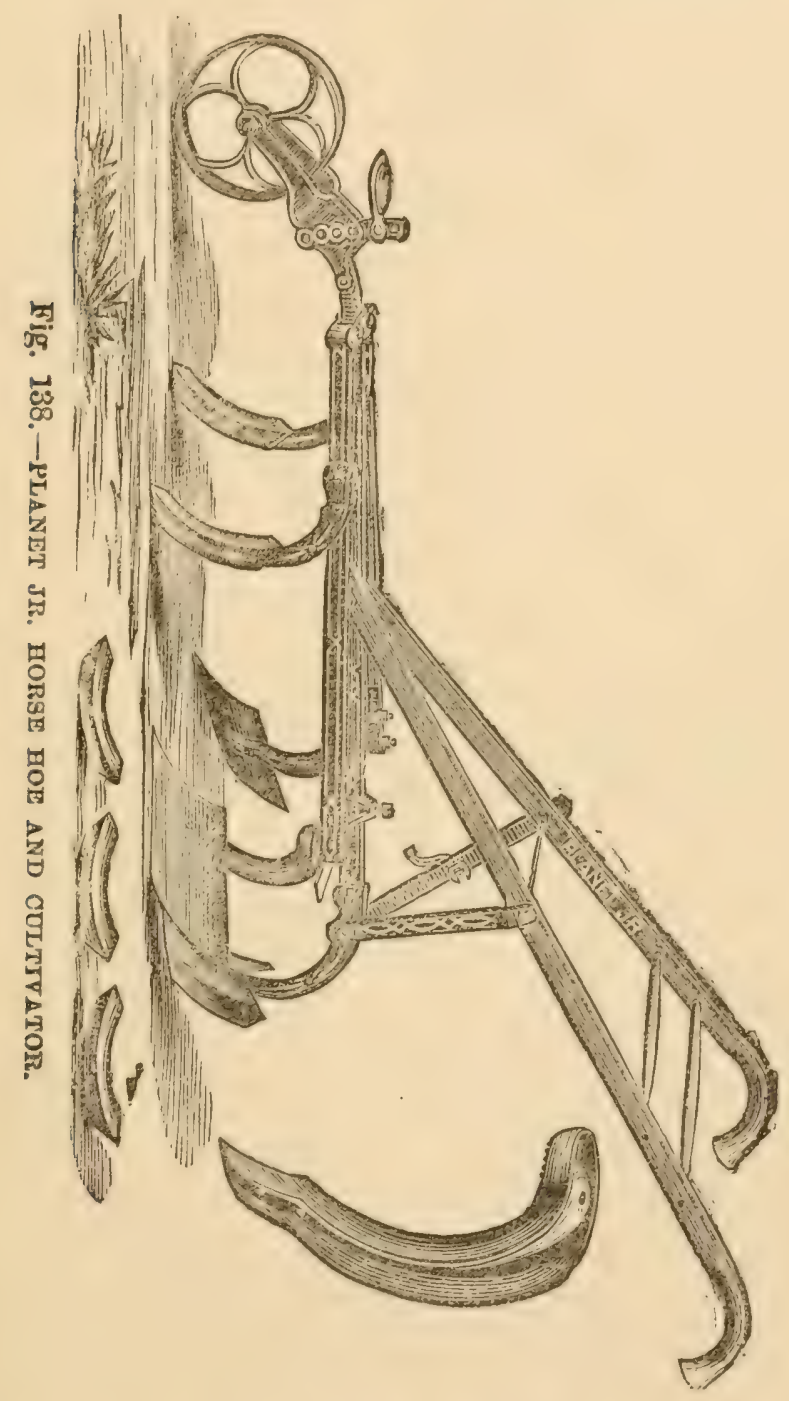

adapted to almost any wiath of row. The value of this tool is lingely due to the peculiar shape of the teeth, which will be understood by referring to the engraving. 


\section{MONTHLY CALENDAR.}

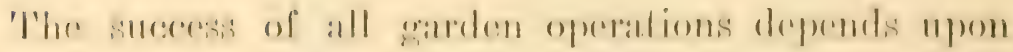
prepambory monsures; for this reason the beginner in

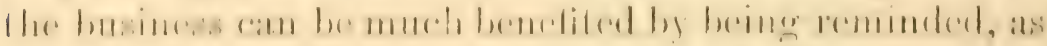

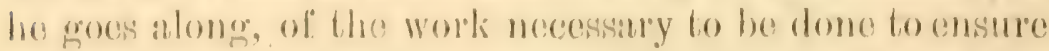

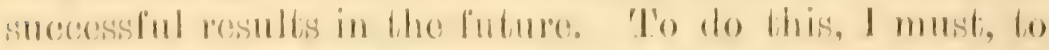
some oxtent, repeat directions given in tho body of the work, but as they will be presented here in a condensed form, they will not lax the timo of the reader. As in all othor reforences made to dates, the latitude of Now York is taken as a basis, that being not only the point;

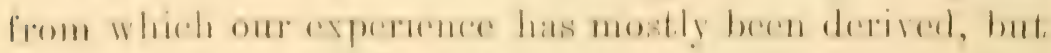
also ono that will besti sutit the majority of reardor's

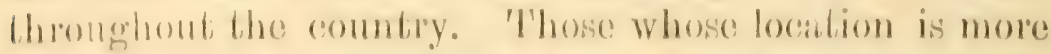
somblerly or mortherly must, use their judgmont in adapting the directions to suit their locality.

I ANUARY. - Vegedation in om Northern Shates is eompletoly dormant during this month, so that, as far as

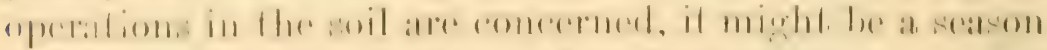

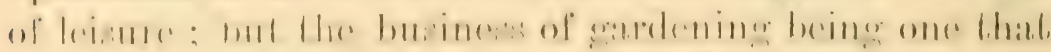

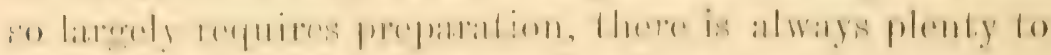
do. Tho ground boing ustably frozen, and giving us

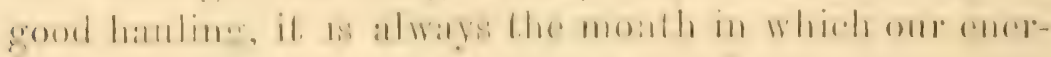
gies are given to gotting manno, muck, lime, ote., into consenient, plices for spring work. Oanes should be

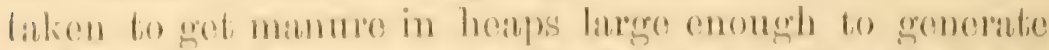

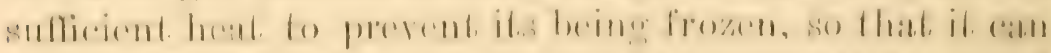

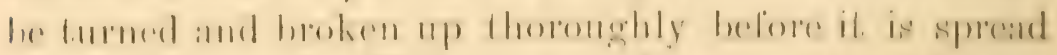
npon the gromol. 'This work is often very stovenly per- 


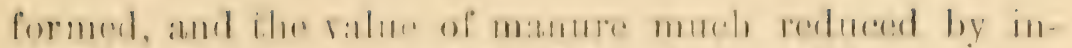

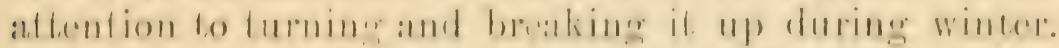

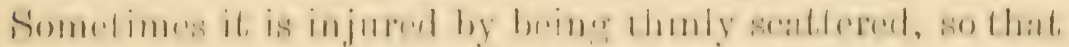

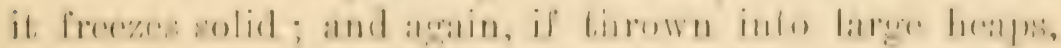

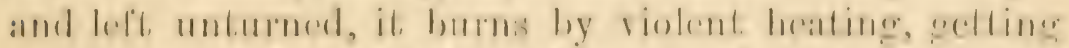
in the condition which gardenere call "lime lanerel."

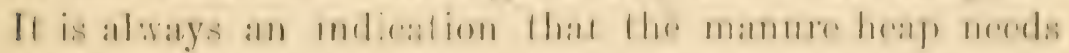
turning when it is socm to emit, vajur, no malter how

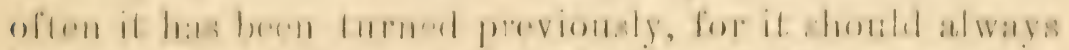

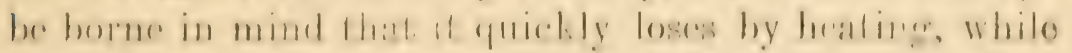

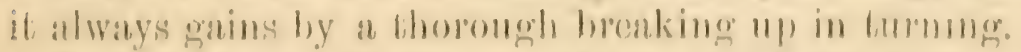

January is usmally tho month in which we havo oms houvest snow stopms. Which often entail on 118 an im-

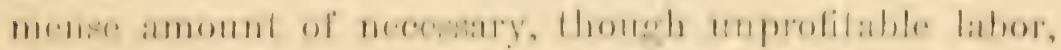

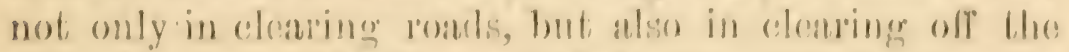
snow from ond cold frames and foomerepepits, for even at

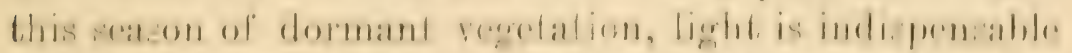

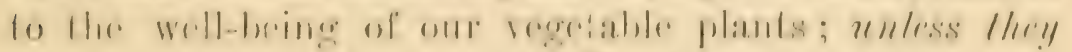
are in a frozone comdilion, that is, il wo have had a conlimmation of zoro weather, all onr plants of Cablatge,

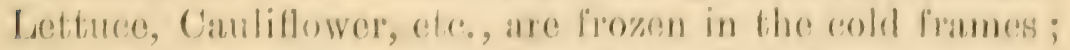

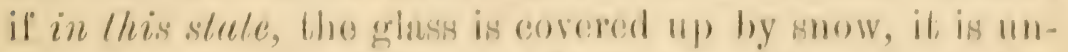
necessary to remove it, even lor lwo or lhree weoks, but,

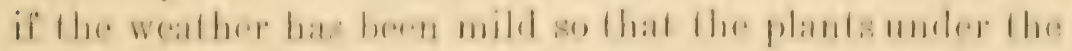
sashes have nob been fromen when covered by snow, liten the snow must be reloured forom the grass as soon ats practicable. In the greanhousess, hot-beds, or foreinerpits, where antificial heat is used, bhe removal of the

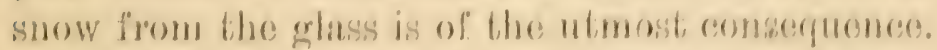

If not done in December, the dinal covering ung of (cel-

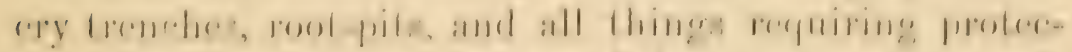
tion from frost, should be attended to in the tiost week of this month.

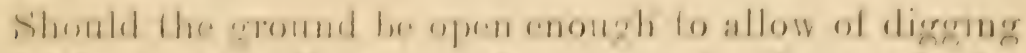

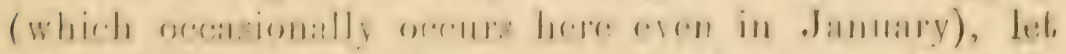

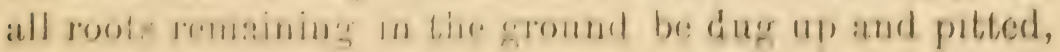


as another chance is not likely to oceur before spring. Cold frames and forcing-pits, particularly the former, should be ared wisenier the weather will perment, for it is necesary to carry them wity though until spring, that they may be propeily harched. we Chapter on

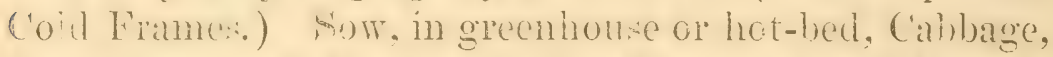
Camlillower and Lettuce. (sec Chapter on "Ilow to Inise ('ab!)age, Canliluwer and Lettuce," page ji.)

Februar. - The gardening operailons differ but little fion ino:e of Junuary, except that in the latter part of the month, as the days leugthen anci tie sun gets brighter, more air may be giren to irming and forcing-pits. Hot manne shor! I now be cot forward to be prepared for hot-heds, and if decmert, some mä be formed this month. (Sce Chapter on Ilot-ber?.) Inive all tou? marchased or repirerl, so that no time may be low:-in the more valuable days of next month. It is importants always have spare tools of the loading linels, so tint num mut not be

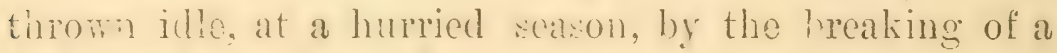
fork, suate, or hos. In harness and implements, con nente! with the teams, it is of great mpentance to have som parts to replace thoce liable to be broken; otherwio, half a day i frepuently lust hy the bieaking of a w'alle-tres, or plow share, camsing more loss ly delay than then wr four times the cost of the articte. Sow, for suceserion crops, Cablage, Cimlillower and Lettuce in gieenhouse or hot-beds.

Maren i; oas of the busiest months in the year with 11: Ilot-beds are made and planced or somn, and Let-

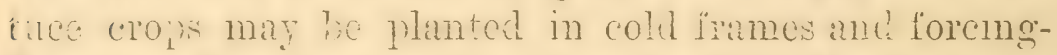
pits (se dircetions mence the heads). In the latter part of the month wa ften berin, on diry suls, the sowing on planting in the oper gusum of weh hardy regetables as Horkeradish, Cabban, Lettuec, Onions, liadishes, 'Turnips, ete., ete. Although we gain but little in carliness by starting before April, yet it forwards our 
operations, so that it equalizes labor more than when startrig late in spring. Enthisiastic becinners must aroid the too common crror of begimning out-door operations too soon, when the soil is not sulieciently dry ; for, lit the soil is dug or plowed while wet, it is highly injurions, not only destroying the preasit crop, but infuring the land for yearis after. Gou for sucestion, if wanted, Cimbage, Canliflower, or Lettuce, in hou-beds, greenhorse, or cold frames.

New plantations of Asparagus, Rhubarb, Sea Kale, aud Aricholies may be made, and old beds top-dressed by dirgug in short manure close around the plants; we cinsiden it more economical of manure to do this in spring than in fall. (See Asparagus.)

Such roots as Cabbage, Carrot, Celery, Leek, Lettuce, Onion, Parsnip, etc., planted to produce seed, may be set out the latter part of this month, on soils that are warm and crers, drawng earth up around the crowns so as to protect them from sharp frosts; in hoeing, in April, this soil is remored.

Where extra laborers are wanted for the garden, I have always considered it economy to scenre them in the early part of March, even a week or tro before they are really needed, for if the hiving of them is delayed until the rush of work is unon us, we often have to pay higher rates for inferior hands, and have less time to initiate them in their duties. To such as require large numbers of hands, and look to such ports as New York for emigrunts, let me caution my fricnds from the rural districts not to believe too implicitly in the promises of these pro pective American citizens. Much rexatious experience has tanght me that one out of erery thee men is either worthless, or will rum awar, so that for many years back, if I wanted four hands, I marte one jol, of it and hired six, well knowing that before a week had passed, my foree would be rednced to the required number. 
APRIL brings nearly all the operations of the garden mnder way; the planting and sowing of all the hardy varieties of vegetables is completed this month. (See table in Chapter on Seed Sow ing). Look well to the hotberls, cold frames, or forcing-pits; tiey will require abundance of air, and (where artiliobil neat is used), plenty of water : we have now bright sunshine, promoting rapid veretation under glass, and to have heary crops, they must not be clinted in water. Hot-beds are particularly critical in this monih an hour or tro of neglect, in giving air, may cuickly scorch the tender plants that you have been numing with so much care for a month previous ; and a balmy April day may terminate in a stinging frosi at night, making short nork of your hot-beds if they are not well covered up by straw mats.

Plantations of Asparngus, Rhubarl, ete., if not mate last month, shonld now be done, as those set out later than April will not make such a vigorous growth. Succession crops of Lettuce. Bects, Ciblunge, Onions, Peas, Potatoes, Radishes, Spinach, 'Tumips, ete, my be planted or sown during the latter part of the month, to sucesed those planted in Mareh and carly part of April.

'The early sown crops should be hoed, and the ground stirred close to the young plants, so as to dentroy the germ of the weeds now appearing.

MAY. - Although the bulk of the hardy regetables is now planted, yet the tender varieties are still to come; they require more care, as they are more susceptible of injury, by too early or injudicious plauting, than the others. In the early part of the month, the succession crops. named in April, may be yet planter so as to produce good crops, and the tender rarieties, such as Bush Beans, Corn. Mclou, Okra. Pepner, Squash, 'T'omato, may he sown or pianted after the middle of the month ; but Egeg Plants. Swcet Potatoes, Lima Beans and Peppers had better be delayed to the last week in May or 1st of 
June. The first produce of the spring plantings will now be ready for use. Lettuce or Radishes, planted in cold frames in March, are matured from sth to 20 th May, and if covered up by straw mats at night, ten? days earlier. In warm situations, on rich, light soils, the Radishes, Lettuce, Turnips, or Peas, planted in Mareh, are fit for market. Rhubarb and Asparagus are also fit to be gathered, on early soils, the latter part of the month.

Additional labor is now beginning to be required, the marketing of crops occupying a large portion of the time, while the thimning out of sown crops, and the keeping down of weeds which are now showing themselve's everywhere, entails an amount of labor not before necess:rry. 'T' $\mathrm{G}$ withhold labor at this critical time is shortsighted economy, whether by the owner of a private or market garlen; for let the crops planted and sown once get enveloped by weeds, it will often cost more in labor to clean the crop than it will sell for. It is not at all an uncommon occurrence to see acres of Carrots or Parsnips plowed down, after being carrefully manured and sown, from neglect or inability of the owner to procure labor at the proper time. The rapid derelopment of weeds is, to the inexperienced, rery deceptive; a crop of Carrots, Parsnips, Beets, or Onıons, may appear to be easily manageable at a given day in May; but a few days of continued rain occurs, and the crol' that could have becn profitably cultivated on the 15 th is hopelessly overgrown on the 25th.

IUNE is one of the month in which we rean the reward of our operations in the market garden; at this time the bulk of all the early crops matures in the Northern States. So far. nearly all has been ontlay; now, we recerve the returns. In this district our early crops of Asparagns, Beets, Cauliflower, Cabbage, Lettuce, Onion, Peas, Radislies, Rhubarb, Spmach and 
'i'mrnip are sold off, and the ground plowed for the sccond crop (except in the cases of Asparagus and Rhubarb), by the end of the month. For private gardens (w in special cases for local markets), succession crops of Berts, Bush Beans, Cabhages, Cucumbers, Lettuce, Peals, Raudishes and Potatoes may still be planted, but, at a rule, it would hardly be protitable for market purposes, as it would oecuny the dand wanted by the markit gardener for his second crop, besides the market bayer of the cities will hardly touch a regetable or fruit behind its sea:on at any price. He will pay ten cents per bunch for Radishes in May, and will pass by a far better article of the same lind in .July or August, though offered at one-fifth the price. He will give fifty cents per quart for 'I'omatoes (half-ripe), in June, thit he conld not be induced to touch in Octuber, if he could buy them at twenty-five cents per bushel.

The Cucumbers, planted in cold frames and forcingpits, are also marketable in the latter part of this month. Great care must be taken to have them abundintly watered in diy weather; inattention to watering (partimainly of all regetables under glass), is sure to entail low on the cultivator, by giving an imperfect or partial (rop). Watering had better be done in the erening, linle:s chully, whenever the surface appears dry, not by a mere sprinkling, but by a thorough soaling-not lese than a gallom to every square yard of surface. As soon as the Cucumbers are all ent from the frames, the sathes should he piied up at the erids of each section and covered with a shuter. and a weight of some lind put on the top, to perent these from beng blown off by high winds.

JLLF, - The remaining part of the spring crops are cleared off m the carity ditys of this molith, and by the mudle of $i t$, mless the season is unusually dry, all the ground a planted with the second crois of C'lery, Sage, 
Thyme, Late Cabbage, Broccoli, Caulifower, or Leelis. Little is done to these crops this month, as lun little growth is made during the hot, dry weather, and newly planted crops are merely stirred between the rews with the hoe or cultivitor. Some of the other later crops are now maturing for market. Bush Beans, C'rcunibers, Potatoes, Aquashes, and, in early places, "iomatoes: also succession crops of Peas, Beets, Onions. (ahbares, ete., such of these as only mature during the cnet of the month, render the second crops rather litte, linless for the later crops of Celery and Spinach.

AcGest. - Except the months of Jannary and Furmary, August is a month requiring less labor in the market garden than any other. Usually all the planting has been done in July, and the long Girouths, common at this season, stagnate the growth of eren our most luxuriant weeds, so that in this month, of all others, the garden ought to be clean.

Late plantings of Celery may be made to the mirdle of the month, and still gire fair-sized roots for winter. Spinach may also be sown for an early crop, to le cut ofí in fall. Rula Baga 'Turnips should be sown early in the month, and the white and yellow raricties during the later part. Be carreful row, if the land is dry, to firm after sowing. (See "Use of the Feet in sowing and Planting.") If the "Ay" attacis them, it may be kept down, so as to do but little ham, by frecuent aphinations of lime dusted lightly orer the rows. Bush Beans and Peas may still be sorvn for late crops. For Peas for late sowing, we found onr "First of All" rariety the best. In 1886, a crop sown 20th of August was marketed late in October, and sold at excellent prices. The Onion crop will ripen ofi during this month, and when conrenient to market, shon!t be offered for sale as soon as gathered, as the price received for those first sold is frequently double that of those coming in ten days later. 
September. - The cool nights and moist atmosphere of this month begin to tell strikingly on the crops planted for fall use. Celery, Cabbage and Caulifiower now grow lapidly, and require repeated stirring of the soil wih the plow, cultivator, or hoe. Celery that is wanted for use towards the latter part of the nonth may now be "handled" or straightened up, and the eartin drawn to it by the hoe; in a week or so afier it may be "banked up " by the spade to half its herght, allowed to grow for another week or more, until it lengthens out a little further, when the banling should be continued as high as its top. In ten days (at this season), whenthus finished, it is blanched sulieiently to use, and should then be used, or it will soon spoil. Care must be taken that no more is banked up than can be sold or used, as it is not only labor lost, but is decidedly hurtful to the Celery by making it hollow. The practice recommended by most athorities, and still followed by private gar. deners, is to keep carthing it up erery two weeks from the time it begms to grow; this is utter nonsense, resulting in making tough, strugg, and rusty Celeryutteriy unfit to cat. Whule the expenditure in labor would be twice more than the price it would usmally bring if soll : for further mfoumation on this important subject. sec Chapter on Celery. 'The seeds of Caulillower, Cabbage and Lettuce should be sown this month, from the 15 th to the 25 th, for the purpose of being pricked out in cold frames to be wintered over. It is rery important that the sowng should be done as near these dates as possible, for if sown much before the 15th the plants may run up to seed when planted out in spring; if much later than the 25th, they would be too weak to be wintered over. Shallots aud Onons should also be plinted the month, and Spmach and German Greens, or "Splouts," sown to be wintered over, all now for spring use. 
OCTOBER. - This month corresponils in part to June of the summer months, being that in which the returns from the second crops come in. Celery that has been banked or earthed up, now sells freely and in considerable quantities. All the crop should this month be "handled," and, as much as possible, eartied up. Cauliflower is usuatly scarce and dear in the eariy parti of this month, but unless the fall has been unu. dally moist, is generally not matured until towards the end of the month. Thyme, sage and all Sweet Herbs should now he sold, from the beginning of the month, cuttung: out only every alternate row, as it gives the crop time to grow, so that the remaining rows spread sufficiently to fill the space. (See article on Thyme, etc.)

The crops planted or sown last month must now be carefully hoed and the weeds removed; for, though weeds are not quite so numerous in variety as in summer, Chickweed, now very abundint, is one of the most expensive weeds of the garden to eradicate.

The plants of Cabbage, Cauliflower and Letcuce, recommended to be sown last month, are now fit to be pricked ont in the cold frames. (See detail of the process, page 45.)

Noreaber. - This month warns us that winter is approaching, and preparations should be curefully made towards securing all products of the garden that are perishable by frost. 'The process of putting away the Celery crop in trenches for winter use (see Celery article), should be begun about the 5th or 10th of the month in dry weather. 'That put in trenches then will be blanched sufficiently for use in six or eight weeks, but when sufficient help can be obtained, it will always pay well to bank or earth up a large portion of Celery by the spade, clear to the top; this will usually keep it safe from injury from any frost that we have in this month, and thus protected it need not bo put away into winter 
quarters-the trenches-before the end of Norember. Put away thus late. it will lieep usually without the loss of a root until Narch or April, whon it is always scarce and high in price. The great diticulty most persons have is from stowing it away and corcling it up too cariy; this practice of carthing it up to the top roughly in Forember we have only recently practived, hut find the extra labor well repaid, as we are enabied thus to save this rery valuable crop without loss. There is rarely need of alplying any covering of leaves or litter to the trencile; this month, and it camot be too ofen told that the covering up of regetables of all kinds in winter quarteris should be delayed to the reiy last moment that it is salfe to do:0. Beels, Carrots, Cibbages and Cauliflowers must be dug np and secured tils month in the manner recommended in "Preserving legétables in IInter." Horsuradish, Silsify and Paisnips, being cntrrely hardy and frosí proof, need not necessurily be dug, although from the canger of their being frozen in the ground next month, if time will permit the rork had better be progressing.

All clear ground should be dug or plowed, and properly leveled, so that on the openme vi spring operations cain be begun with as little cielay as possiule. If diruming is required this is the most convenient time to ro it, the ground being clear and not yet much frozer.

Mowards the end of the month the sashes shomld be put on the Cabbage and Lettuce plants in cold nights, but on no account should they be kept on in ay-time, as it is of the nimost importance that they be not mate tonder at this time by being "drawn" under the sashes. I may again repeat that these plants are half hardy, and it is kiling them with kndness to protect them from sigyt freering. Cubbare and Iettuce plants maty bex. posed in any prace without glass or other protection where the themometer runs no lower than ten ahore 
zero. Rhubarb and Asparagus beds will be benefited by a covering of four or six inches af rough manure, or any other litter, to prevent the sererity of the frost: the crop from beds thus covered will come in a few days earlier, and will be stronger than if left muprotected.

Deceriber.-Occasionally we have the ground open, so that digging and yowing can be done to nearly the end of the month, but it is not safe to calculate much after the first weck; though by covering up the roots, still undug; with their own leares or with litter, we are often cnabled to dig our Horscradish or Par'snips very late in the month, and, like all other regetables, the later they remain in the soil they grow in the finer is the quality.

Celery trenches should receive the first covering early in the month, if the weather has been such that it has been unnecessary before. 'The corering should not be less than four or five inches of litter ar leaves, only taking care that the material is light; weight or closeness would prevent eraporation too much at this season, while the weather is not yet serere. 'The find covering should not be later than the end of the month.

'The crops of Spinach, Kale, Onions, Shallot, ete, that have been plinted or sown in September, should be covered up with hay or straw if their position is much exposed ; if not, there is no particular necessity. Fihen all has been secured safely in winter quarters, attention must be energetically turned to procuring manture, muck, and all available kinds of fertilizers. There is little danger of spending too much in this way. if you have it to spend; depend mpon it, there is no better investment if you are working your Garden for Profit. Straw and rope for straw mat making should always be on hand, so as to gire employment to the hands in stormy weather. 


\section{N D E X.}

Capital Required.............

Climate, Ours Different from England

Crops, Rotation of

Cuttings, Variation of Plants from

Drainage

Drain, Board

Flat Stone

Rubble -..............

Tile

Fertilizers (See Manures)..... Application of .......... Comparative Value of ... Preparation of Special

Forcing Pits .

Frames, Cold, and Hot-beds.. Airing:

Cucumbers in ..........

Frozen Plants in

Lettuce in

Protecting Cloth for- - -

Seed Sowing in

Shelter for

Snow upon

Spring Raising of Cabbage Plants, Etc

Ground, Preparation of the ... "Hill," Meaning of the T'Term Hot-beds

Ero. Plants in

Frame for

Forcing Lettuce in ........

Manule for .............

Pepper Plants in .........

Sashes for ..............

Straw Mats for. .........

Sweet Potatoes in ........

Sowing in . . . . . . . . . . . . .

Tomato Plants in ........

When to Plant in .......

Importance of Ventilation 10.)

Houses, Forcing and Greenhouse Buildings and Appurtenances ..........

Greenhouse for Forcing - John Hudson's.......

Ileating of

Heated by Flue

$(3 \% 0)$
Heating by Return

Flue ...........

Flues, Danger from ......

Flue, How to Build_... _ 70,87

Greenhouses, Profits of _. 69

Pump for....... 66

Rotation in ....... 67

Soil for _........... 76

Vegetable_........... 24

Watering in _.... 66

Sashes, How Fastened 65

Sashes, How to Glaze 75

Wells _............. 24

IMPLEMENTS.

Buncher, Asparagus _. . . . . . _ _ 355

Dibble or Dibber............. . 356

Drill, Planet Jr. Combined.... $3 \check{3} 4$

Fork, Digging _............... 346

Grater, Horseradish . . . . . . . . . 356

Harrow, The Acme........... 348

The Disc _... . . _ _ _ _ _ _ 349

Garden ................ 346

Triangular Adjustable ... 347

Hoe, Hor'se, and Cultivator. .. 357

Prong ................. 350

Push _................ 350

Seuftle _.............. 350

Single Wheel, Etc . . . . . . 358

Knife, Asparagus .......... . . 355

Line, Garden, and Reel_...... 355

Marker, Adjustable . . . . . . . 352

Plow, Cabbage ............. 347

Roland Chilled ......... 344

Slip Share for........... 345

Subsoil _... . . . . . . . . . 345

Skeleton -... 347

Rake, Steel .................. 350

Roller, Garden ............... 351

Spade, Ames' First Quality _. 346

Wagon, Market ............. 353

Laying Out of Garden........ 24

Location of Garden .......... 23

Manures (See also Fertilizers) 33

Alternation of ............ 35

Ashes, Wood ............. 43

Bone Dust .............. . B̃

Comparative Value of ... $\quad 36$

Cotton-seed Meal ........ 42

Gas Lime ................ 42

\section{(n)}

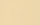

(1)

(n)

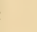

4


Manures, Green Crops as..... 37

Peruvian Ginano ........ 34

Preparing Guano, Ete.... 33

Hops, lieiuse......... . 33

Horu Shaving's.......... 34

Horise . . . . . . . . . . . 33

Line . . . . . . . . . . . . 42

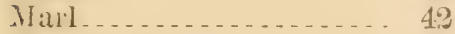

tiluck . . . . . . . . . . . . . 40

Night Soil ............. 35

Plaster ............... 43

Poudrette............ 40

Silt at................ 40

Sugar-louse Seum . . . . . . 31

Whalebone, Refuse ..... . 34

Men Suited to Gardening.... 13

Monthly Calendar, January _- 358

February - . . . . . . . . 360

March ........... 360

A pril ................ 362

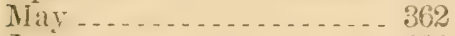

June - . . . . 2. . . . 363

July . . . . . . . . . . . . 364

Aumust .............. . .

Septeniber . . . . . . . . . 360

October . . . . . . . . . . . . . 398

Novembed . . . . . . . . . . 367

December . . . . . . . . . . . . . , i,

Number of Plants to an Acre 113

Plants for Frames, When to Sow _.................

Plants Propasated from Cuttings, Do they Vary? . . . . . .

Profits of Garlening . . . . . . 20

Rosebucis, Boston ......... 27:3

Rosebuds, Madison _....... 673

Seeds and Seed Raising . . .... 89

Cabbase become Annual_ 105

California, Seed Growing in .

Celery, Success in Sowing

Failing to Germinate.....

Feet, Use of, in Sowing - -

"Firming" the Soil over" Seeds

How, When and Where to Sow

91

94

9.

93

93

Indiscriminate Sowing ... 103

Quantity to Sow an Acre - 111

Quantity for a Giren Numbel of Plants........... 113

Soaliing of ............. $9 \check{0}$

Soil for Sowing . . . . . . . . 107

Sown in Dry Weather ... 94

'Testing' ............. 89

Vitality of, Duration of .. 92

Wrongly Blaming the Seedsmen.

Situation of Garden.........

\section{1}

Blackberries ............... 334

Culture of . ........... 325

Kittatimu ........... 336

Lawton ................ 3336

Wilson's Early_.......... 336

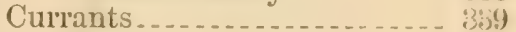

Black ................ 3:39

Cherry_ _ _ _. _.

Tay _... _. _.......... 339

Red Dutch .............. 339

White Dutch ............. 3is?)

Gooseberries _............. $3: 39$

Downiug ............ . . 340

Houghton ............. 340

Grapes_... _........... 340

Age of Vimes . . . . . . . 340

Planting .............. 31 ?

Brighton ............. 343

Champion - . . . . . . _ 313

Concord .............. 344

Martha ........ . . . . 343

Moore's Early ........... _ 343

Niagara. . . . . . . . . . . . . . 343

Salem ................ 343

UVililer. . . . . . . . . . . . . . 343

Raspberries . . . . ........

Covering in Winter ...... 333

Brinkle's Orang'e........ 337

Caroline _.............. 333

Cuthbert _............. 337

Gregg (Black-cap) _...... . 333

Hansell _... _... _ _ _ 337

Hudson River Antwer' _ . . 337

Strawberries, Forcing ........ 81

Forcing, Kinds for ...... 83

Layering in Pots . . . . . . . 327

Open Culture ........... 325

Stratwberries, Varieties of ... . 328

Bidwell _............... 332

Crescent …_.......... 333

Crimson Clister......... 329

Downing -

Henderson _........... 328

Hofman ............... 3is:3

Jersey Queen ............. 333

Jewell _................... 333

Parry _................. 333

Sharpless _............. 332

Wilson ….......... 333

Soil, Preparation of ........ 31

Resting the ........... 110

Selection of ........... 25

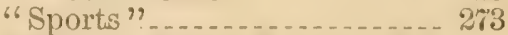

Southern States, When to. Sow and Plant in ........... 311

Asparagus .............. 311

Beans ................. 311 
Beets ... . . . . . . . . . . $31: 3$

Cabbage ............. 312

Candiitower ............ 31:3

Celery ............... 312

Collards ............... 313

Corn ................. 313

Cucumbers . . . . . . . . 313

Eiger l'lint . . . . . . . . . . 31:3

Girechs, (ielmill _...... . 31 .

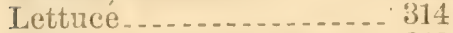

Melon, Musli and Water _ - 313

Okra or Gumbo . . . . . . . . 314

Onion _................ 314

Peas _............... 314

Potato, White ......... . . 314

Potato, Sireet............ 314

Radish.................. 314

Rhubarb _............ 315

Turnips_... . . . . . . . . . 315

Spinach _... . . . . . . . . 315

Squashì _................ 315

Tomato ................ 315

Transplanting ................ 114

Variation in Plants.......... 273

Vegetables, Hardy .......... 107

Vencetables, 'leuder ... . . . . 107

Vecetable Plants, How to Plant 115

Vegetable l'lants, IIow Much

Cold Will They Lndure .... 116

Varieties of Vegetables-Too

many ................. 11 .

VEGETABLES, VARIETIES OF :

Artichoke................. 129

Char (1 . . . . . .

Common Gieen ........ 129

Green Globe . ........... 129

Artichoke, Jerusalem ....... 130

Varieties_............. 130

Asparagus ................ 118

At the South . . . . . . . . . 124

Beetle _............... 127

Buncher _.............. 126

Fertilizers for........... 125

Gathering the Crop . . . . . 126

Planting _........... 119

Profits of _............. 127

Propagation ............ 118

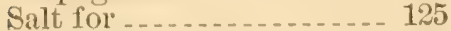

Van Siclen's Method .... 120

Without Transplanting-_. 122

Asparagus, Varieties of _..... 120

Colossal ................ 120

Giant .................. 128

Palmetto _............ 124

Balm ..................... 131

Basil ........................... 131

Bush ................. 131

Swcet ................... 131
Benns, Bush, Kinney and Pole 131

Beans, Dwarf Varieties....... $1: 33$ Earlicst Red Valentine . . 1:33 Early lied Valentine ..... 134

Early Mohawk. ......... 131

Gallega ............... 1: 134

Large Refugee . . . . . . . . 134

Lone Yellow six-lrectis. . list

liefugee .............. 13:t

Thousand to One........ 134

White Marrowfat . . . . . . . 13t

Beans, Running or Polc ..... 135

Lima, Dreen"s Implored _ 136 Jersey Extra Early . . 136

Large White ........ 136

Giant W $a x \ldots \ldots 137$

German Wax .......... 137

Horticultural _.......... $13 \%$

Scarlet liumner.......... 136

Speckled Cramberry ...... 137

Beans, IVax, Black. ......... 134

Flageolet ............... 13ij

Golden _................ $13 \tilde{5}$

Beet ................ 138

Bastian's Blood Turnip _. _ 141

Dewing"s Improved Blood 'Turnip _........... 141

Early Blood Turnip . . . . . 141

Eelipse ............. 140

Egyptian T'urnip . . . . . . . 140

Long Smooth Blood . . . . 141

Swiss Chard ............ 141

Borecole, or Kale ........... 142

Dwarf German Greens.... 142

Dwarf Green Curled Scotch ............... 143

Purple................ 143

Siberian Dwarf Curled ... 142

Sprouts _................ 142

Very Larly Dwarf........ 143

Broccoli _.................. 144

Early Walcheren ........ 145

Purple Cape ............ 145

White Cape_............ 145

Brussels Sprouts _........... 145

Cabbage and Cauliflower ..... 146

Aphis........................

Black Flea _........... 155

Butterfly ................. 155

Caterpillar .............. 155

Club-root in . . . . . . . . . . . 157

Green Fly on .............. 155

Insects ................ 155

In Southern States ....... 151

"Jumping Jack" . . . . . . 155

Keeping in Winter ....... 154

Kinds for Early Crop _. . . _ 148

Late, Culture of ........ 152

Louse ................. 155 
Calibage, Mamgot .......... 150 Plants, What Cold They will Endure........... 149

Seed ................... 161

Slug _.............. 155

Soil and Manures ........ 147

TVire Worm _........... 156

Cabbages, Early _.......... 162

Early Flat Dutch . . . . . . . 165

Early Jersey Warefield_. 162

Early Winningstadt ...... 165

Henderscn's Early Sum-

mer................ 164

Premier.............. 161

Cajbages, Late ............ 165

American Drumhead Sa-

roy ................ 166

Felder Kraut_............ 166

Fottler's Improved Bruns-

wick _.. 165

Mammoth Rock Ped . . _ 16r

Marblehead Mammoth _ _ 166

Red Dutch _............. 167

Selected Late Flot Dutch_ 165

Tumip-rooted ............ 212

Caritoon .................. 169

Carrot ................... 170

Danvers ............ 189

Early French Forcing .... 171

Early Half-long Scarlet Carentan _.......... 1\%?

Early Half-long Searlet (Pointed Rooted) ......

Hali-long Fed (Stump Rooted) ............. 1 r1

Large White Belgian ..... 173

I.omg Orang, Imiprored. - 17?

Yellow Belgian .......... 173

Caulillower ................. 167

Extra Early Dwarf Erfurt 169

Extra Early Paris ..... . . . 169

Half Early Paris ........ . . 169

Henderson's Early Snowball

Large Late Al cicrs . . . . . 109

Le Normand's Short stemmed.............. 169

Celery

Nonpareil . . . . . . . . . . . . . 169

Close Planting ......... 179

Dwarf Kinds Preferred ... 179

Farthing up ............ 178

"Hanciling" .......... 178

Planting Out_........... 176

Profits of ............... 184

Rust on ............... 180

Shipping of . ............ 184

Sowing the Seed ........ 17t

Storing for Winter ...... 180
Celery, storing in Trenches . . 180 In Cellars........... 182

Celery, Varieties of........... 185

Boston Market........... 188

Giant White Solid........ 189

Henderson's Golden Dwart_............ 185

Henderson's Half-Dwarf - 18r

Henderson's Rose_....... 189

Major Clark's Pink ...... 190

Sandringham .......... 188

Turnip-rooted ........... 180

White Plume ........... 186

Celeriac ................. 190

Dwarf Apple-shaped .... 190

Chervil, Turnip-rooted ....... 173

(hives ... . . . . . . . . . . 191

Collards (Southern) ........ 195

Corn Salad ................ 191

Corn, Sweet.................. 195

Planting _.

Profitable Crop of _...... 196

Corn, Sweet, Varieties of _ _. _ 197

Coly _............ 197

Crosby's Early Sugrur-_... 197

Early Marblehead _._._... 197

Early Minnesota . . . . . . 197

Egyptian _............. 198

Henderson ............... 197

Mammoth Sugar ......... 198

Squantum Sugar......... 197

Stowell's Evergreen _..... 198
Cress

Upland ................. 194

Water _................. 192

Profits of _.......... 194

Cucumbers ................ 189

How to Plant ............ 193

The Pickle Crop ......... 201

Cucumbers, Varieties of . . . . 201

Burr ................. 203

Early Cluster ............ 202

Early Russian............ 202

Green Prolific............. 203

Improted White Spine ... 201

Nichols' Mediurn Green .. 202

Erg Plant ................ 203

Black Pekin . . . . . . . . . . . 206

Long Purple . . . . . . . . . . . 206

New York Improved . . . . 205

White-fruited .......... 206

Endive _................... 206

Broad-leaved Batavian . . 208

Green Curled ............ 207

Moss Curled _........... 207

Fetticus ..................... 191

Garlic ............ 208

Gherkin, West India ........ . . .

Greens, Dwarl Gorman...... . 1t2 
Gumbo

Horseradish

The Sets.

Planting

Profits of

Intian Cress

Kale or Borccole ........ 142;

Kohlrabi

Early White Vienna.....

Early Pumle Vienna .....

Leek

London Flag-

Musselburgh

Lettrice

Forcing in Hot-beds

New York"Salad Príches"2..............

Profits of . ...............

All the Yeal Round ...... . 22:2

Lettuce, Varieties o1 .......... 219

Black-seeded Simpson _. . . 2:0

Black-sceded Temnis Ball_

Boston Marliet .......... . 221

Early Curled Simpson _...

Large Thite Summer Cab-

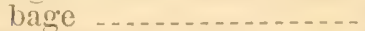

Tiely Yoils

Paris White Cos......... 222

Silmamiler

White-seeded Tennis Ball 221

Yellow-secled Butter ... . 221

Marjoram ........

MIarjoram, Sweet........... 2:23

Martyuia .................... 234

Miclon, MIusk_............. 223

Cuiture of . . ............. 224

Profit of . . . . . . . . . .

Soil for _. . . _ _. _ _ _ _ _ 225

Insects Injurious to . _ . _ 226

Melon, Musk, Varieties of ... _ 227

Baltimore............... 228

Early Hackensack . . . . . . . 227

Golcen Netted G'cm....... 228

Green Citron............ 230

Hackensack _............ 228

Nontreal Market......... 229

Melon, Water............. 230

Profits of . . . .

Melon, Water, Varieties of _. _ 231

Black Spanish . . . . . . . . . . 232

Citron _.............. 233

Gypsy _................ 231

Ice Cream _. . . . . . . . _ _ 231

Tcing .... . . . . . . . . . . . 232

Ice Rind . . . . . . . . . . . . 23. 23\%

Kolb's Gem .............. 231

Mammoth Iron-clad _.... 231

Mountain Sweet. . . . . . . . . 231
Melon, Water, Rattlesmake _. 231

Phinney's Early ........... 231

Scaly Bark ............. 232

Mint_.......................

Mushroom _............ 2it

Making the Bed . . . . . . . 336

Making the Spawn ....... . 239

Preparing Manure for _ _ _ 236

Spawning the Bed _. . . . . 236

Mrustard ... . . . . . . . . . . . . 2 2:4

Black................. 234

White ............... 2

Nasturtium _...

Dwarf _............... 210

Tall _................... 240

New Zealand Spiuach ........ 290

Olira........................ 241

Onions.................... 241

Harvesting .............. 249

Insects Injurious to ... . . . 249

Farm Crop, As a ........ 243

Profits of . . . . . _ _. 250

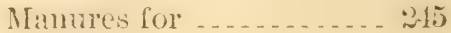

Planting . . . . . . . . . . . 2 219

Preparing the Ground... 216

Protits of .............. 243

Sowing the Seed _. . _.... 247

Sowing in Fall ........... 213

Sets _... . . . . . . . . . . 24:

Storing the Crop _........ 249

Weering the Crop _......... 247

Onions, Varieties of ......... 251

Bermucla .............. 25.3

Extra Early Flat Red. . . . 252

Giant Irocea ............. 253

Large Red Wethersfield _. 251

Large Red Italian Tripoli. 254

Lorge White Italian Tripoli 245

Neopolitan Marzajola _ . _ 253

Queen _... . . .......... 253

Southport Large Yellow

GIobe ............ 251

Southport Red Globe_... _ 252

Southport White Globe .. 252

Silver-skin _............... 253

White Portunal ........... 253

Yellow Dutch ............. 253

Yellow Globe Danvers _. _ 251

Onions, Potato_........... 254

Onions, Top _.............. 254

Orach..................... 291

Oyster Plant _............. 282

Parsley, in Winter.......... 255

Parsley, Varieties of . . . . . . . . 256

Double Curled.......... 256

Fern-leaved ............. 256

Hamburgh _........... 25\%

Fenderson's Emerald .... 256 Plain ................. 257 
Parsley, Turnip-rooter.

Parsnip Early Round

Hollow-crowned . . . . . . . 258

The Student _............ 258

Pea, Varieties of . . . . . _ . 258

Alaska................. 261

American Wonder ...... 261

Black-eyed Marrowfat. . . $26 t$

Bliss' Abundance ........ 20.3

Bliss' Everbeuring........ 206;

Champion of Eugland . . . 263

First of All _........ _ 260

Improved Dan'l O'Rourke 261

Kentish Invicta _. . . . . . _ 261

MeLean's Adrancer...... 261

Premium Gem ......... :

Stratagem ……....

Pride of the Market_.... 264

Telephone _............ 263

Yorkshire Hero .......... 263

White Marrowfat _....... 26-1

Pepper, Varieties of ........ 264

Bull Nose.............. 264

Cramberry …........... 2605

Golden Dawn............. 2635

Large Bell ... . . . . . . . . . . . 264

Long Red Cayenne....... 265

Mammoth _........... 261

Ruby King ............ 265

Squash _............. 265

Sweet Mountain . . . . . . . 264

Tomato-shaped .......... 265

Pepper Grass .............. 193

Potato .................... 265

Diseases of ............... 266

Colorado Beetle......... 266

Tubers, Cut or Whole . . . 2\%0

Potatres, Varieties of . . . . . . .

Beauty of Hebron ........ 26\%

Clark's No. 1............ 2(19

Early Rose . . .......... 267

Einpire State............ 268

Pearl of Saroy .......... $26 \%$

Perfect Peach Blow . . . . . 269

Pochester Favorite . . . . . . 269

Rural Blush_........... 269

St. Patrick _............ 269

Triumph _... . . . . 269

Vanguald _............. 26\%

White Elephant......... 268

Potato Onions .............. 254

Pumpkin .................. 2\%

Radish as a Succession Crop. . 2 : it

Forcing ...............

Radish, Varieties of ......... $2 \pi 5$ Beckert's Chartiel ....... 276

C'hinese Rose-colored, Winter
Radish, Early Round Dark Rea :2 6 ; French Breakfast ........ $27 \%$ Gray Summer T'urnip .... 278 Long Black Spanish _..... 278 Long Scarlet Short-top... 2\%) Olive-shaped ............ 278 Red Forcing Turnip _... . 279 Round Black Spanish _. _ 278 White-tipped scarlet Turnip _.............. 277

Yellow Summer Tumip _ 278
Rhubarb $\ldots . \ldots \ldots$ 279 281

281

281

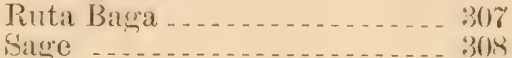

Salsify _............... 282

Salsify, Black _.......... 283

Savory, Summer _........... 308

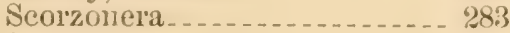

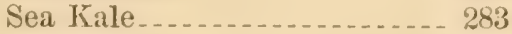

Blanching - ............ 284

Shallots _............... 285

Sorrel _................. 285

Spinach_. _...

Profits of _.............. 28r

Spinach, Varieties of ....... 289

Large Round Leaf Viroflay 290

Long Standing........... 290

Norfolk Savoy-leaved _... 289

Prickly ................. 290

Round Leaf ............ 290

Thick-leaved............ 290

Spinach, New Zealand ...... 290

Spinach, Substitutes for _.... 230

Sprouts ................ 142, 291

Squash, Summer Varieties. . . 201

Boston Marrow _. . . . 293

Bush Crookneck ..... 293

Yellow and White

Bush Scallo er..... 202

Fall and Vinter Varieties:

Essex Hybrid ....... 293

Hubbard ........... 293

Mammoth Chili _. . . . 294

Narblehearl _......... 20.4

Vegetable Marrow . - 291

Winter Croolrneek _.. _ 294

Summer Savory............. 308

Swedes or Swedish Turnips_. _ 307

Sweet Herbs _............. 308

Sweet Marjoram _...........?3, 30s

Sweet Potato _............ 295

Starting the Plants...... 297

Sets or Draws _... . . . . . _ 296

Nansemond ........... 297

Red Skinned ............ 297 
Siveet Potato, Yellow Skinned. 297

Swiss Chard (See Beet)....... 141

Thyme _.............. 308

Tomato _................... 298

Earliness in .......... 300

Prolits of .......... 299

Saviug Seeds of . . . . . . . . 300

Tomato, Varicties of ........ 301

Acme ................ 301

Canada Victor . . . . . _ _. 303

Gencral Grant ........... 303

Hathaway's Excelsiol . . . 303

Mikado _............. 301

Paragon _............. 301

Perfection _............ 303

Plum, Red ind Yellow ... 303
Tomato, Trophy _... . . . . . . . . 303

Top Onions _............. 254

Turnip, Varieties of . . . . . . . . 304

Amber Globe ............ 306

Extra Barly Milan _. . . . . 306

Golden Ball ............ 306

Purple-top Strap-leaf _. . 306

Purple-top White Globe_. 306

Red-top Strap-leaf . ...... 306

Seven-top _.............. 307

Snowball _............ 306

Snow-white _.......... 307

Turnip, Ruta Baga Kinds .... 307

Improved American ...... 307

Large White French ..... 308

Shamrock............... 308 


\section{Alphabetical Catalogue}

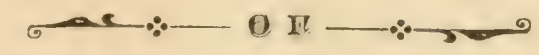

\section{Judd Co., David W. Judd, Pres's',}

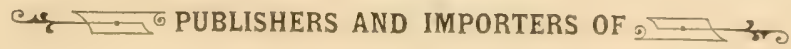

A11 Works pertaining to Rural Life.

751. Broadway, IVew Torls.

\section{Agriculture, Horticulture, Ete.}

\section{EN Q}

Allen, R. L. and L. F. New Americnn Furm Book........... 2.50 American Farmer's Hand Book ......................... Asparagus Culture. Hlex. Cluth.................. . . . . . . . . .

Bamford, C. E. Silk Culture. Pinper..........................

Barry, P. 'The Fruit Garelen, New and Revisid Edition......... 2.00

Bommer, Method of Making Manures ...................... .2.

Brackett. Farm 'l'ulk. Papel 50e, Clot! ................. . . . . . .

Brill. Farm-Gardening and Seed-Growing... . . . . . . . . . . . . 1.00

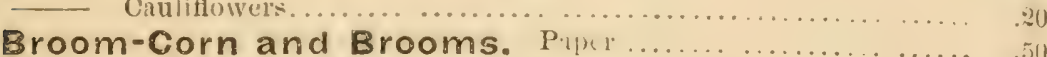

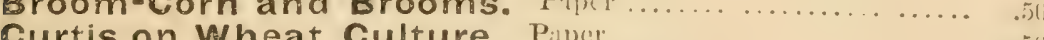

Curtis on Wheat Culture. Pitper ........................

Fmerson and Flint. Manual of Agricultur............. 1.50

Farm Conveniences ...............................

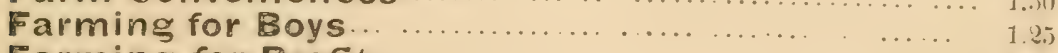

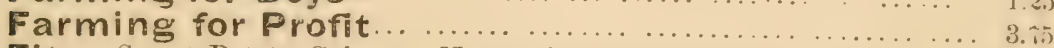

Fitz. Sweet Potato Culture. New and Enlareded Edition. Cloti. ... . . (i)

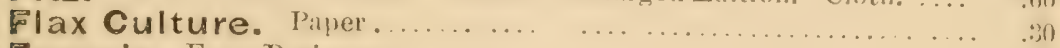

French. Farm Drainage . . . . . . . . . . . . . . . . . . . . .

Fuller, A. S. Practical Forestry .......................... 1.50

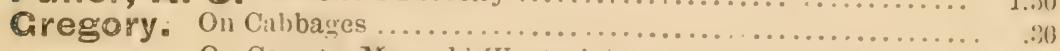

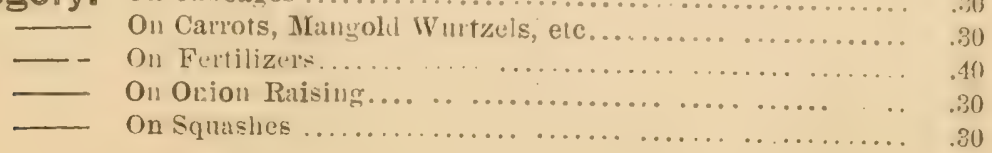


Marlan. Farming with Green Manures .................. 1.00

Harris. Insects Injurious to Vegetation. Plain \$1. Col’d Engravingrs. 6 5)

Marris, Joseph. Gardening for Xonng and Old... ... ......... 1...;

'Talks on Manures. New and Revised Eution... 1.\%

Henderson, Peter. Gurdening for P!easure............... 1.50

Gatrening for Protis. New and Binlaraed Eibition. :.00

Garden and Farm 'Topics... . . ............. 1.50

Henderson \& Crozier. IIow the Fim Paly.............. 2.50

Hop Culture. New and Revised Elition. Palper... ........ . . 3

dohnston. Agricultural Chemistry....................... 1. .

Johnson, M. W. How to Plant. Paper.................... . .

Johnson, Prof. S. W. IIow Crops Feed ............... . 2.00)

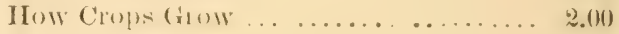

Jones, B. W. 'The Peantit Plant. Paper................. . .

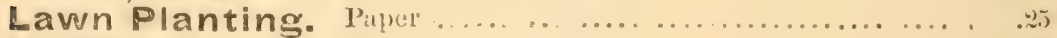

Leland. Firm Homes, In-Doors, and Out-Duors. New Edition. ... 1.50

Long, Elias A. Ormmental Girdening for Americus ........... 2. (10)

Morton. Frumer's Calendar ......................... 5.00

Nichols. Chemistry of Farm and Sca................... 1...

Morton. Elements of Scientitic Aericulture.................. . .5

Oemler. 'Thuck-Farming at the South...................... 1.50

Onions. How to Raise them Profitably.......................

Our Farm of Four Acres. Pappr.................

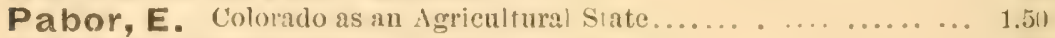

Pedder. Land Measurer fir Famels. Cloth.................... .6)

Plant Life on the Farm ................................ 1.0

Quinn. Money in the Garden ........................ 1.50)

Register of Rura| Affairs. 9 vols. Each.............. 1.50)

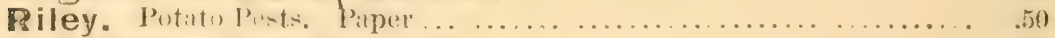

Robinson. Facts for Farmers.......................... 5.00)

Roe. Play and Potit in my Garden ...................... 150

Roosevelt. Five Acles Too Much... ... ................ 1.50

Silos and Ensilage. New and Eularmed Edilion......... . . .50

Starr. Farm Echoes................................ 1.00

Stewart. Irrigation for the firm, farden and orehard . . . . . . . 1.,0

Ten Acres Enough.... .......................... 1.1(1)

The Illustrated Dictionary of Cardening. Vol. 1 .. 5110

The Soil of the Farm..... ......................... 1. . .

Thomas. Farm Implements and Machinery. .... ......... 1.50)

Tim Bunker Papers; or, Yankee Farming ......... 1.50

"Tobacco Culture. Palper..............................25

Treat. Injurious Insects of the Farm and Garden............. 2.00

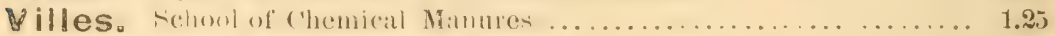

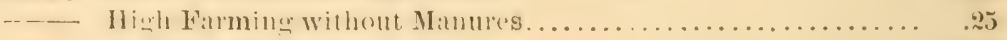

Artificial Manures............................. 6.00

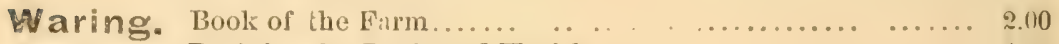

— Draining for Profit and Health. ................ . . . . . .

—Elements of Agriculture...................... 1.00

-

—_ Sauitary Drainage of Houses and Towns. . . . . . . . . . . 2.00

Sanitary Condition in City and Country Dwellings......... .5i)

Warington. Chemistry of the Farm ........................ 1.00

White. Gardening for the South ...................... 2.00 


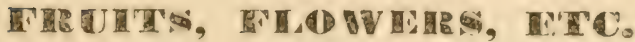

A merican Rose Culturist........................ .30

American Weeds and Useful Plants ............. 1.i.

Boussingault. Rural Economy ........................ 1.t0

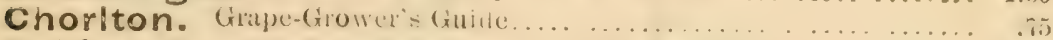

Collier, Peter. Sorwm, its culture and Manulature............. : of

Common Sea Weeds. Buards .............................

Dovnning: F'ruits and I'ruit 'Trees of America. New Edition........ 5.,00

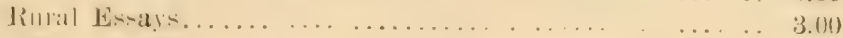

Elliott, Hand Bouk for Fruit-Growers. Palper foc. Clowh.... . . . . 1.00

Every Woman her own Flower Gardener........... 1.00

Fern Book for Everybody ...........................

Fuller, A. S. Grape Cullurist......................... 1.50

Illustrated Striwberry Culturist $\ldots \ldots \ldots \ldots \ldots \ldots \ldots$. 20

Small Eruit Culurist. New Ellition. . ........... 1.50

Fulton. Peach Culture. New anci Revised Edition ............... 1.50

Heinrich. Window Flower Gaten..........................

Henderson, Peter. Hund Book of Plants... . ............. 3.00)

Hibberd, Shirley. The Amatemes Flower Garlen .............

The Amatem's Greenhouse ami Conservalory. 250

+ The Amateur's Rose Book................ 2.50

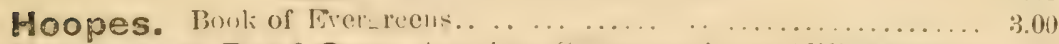

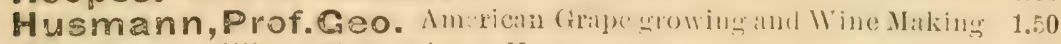

Johnson. W'inte: (ireeneri st Home...................... 1.00

Moore, Rev. J. W. Orange Culture..................... 1.00)

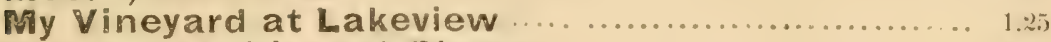

Origin of Cultivated Plants ......................... 1.i.

Parson3. Ont the Ruse ............................... 1.50

Quinn. Pear Culure for Prolit. New and Revised Editim. ....... 1.00

Rivers. Miniature Fruit Gard

Rixford. Wine Press and cellat . . . . . . . . . . . . . . . . 1.50

Robinson. Ferns in their Homes and Ours ................. 1.50

Roe. Success with Small Fruits........................... 5.0

Saunders. Insects Injminns to Frnits.................... ; 10

Sheehan, Jas. Your Plants. Paner...................... .40

Stewart. Sorch"m and Its Products....................... 1.50

Thomas. Amerim liruit Culturi-t.....................

Vick. Flower and Vegetable Garden. Cloth. . ............... 1.010

Warder. Ifedges and Evergreens ........ ............. 1.50

Webb, Jas. Cape Corl Cranberries. Paper. .................. 40

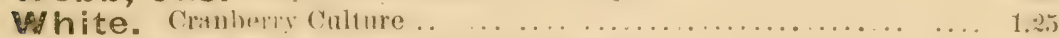

Williams, B. S. Orehil Grower's Mantal................ 6.50

Wood, Samuel. Moderu Winduiv Garkning.............. 1.25 
Mayhew, E. Illustrated Horsc Manacement. 8vo... ......... 3.00

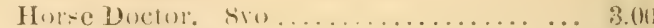

WeClure, $\mathbb{R}$. Diseases of American Horsus. $12 m 0 \ldots \ldots \ldots \ldots \ldots .2 . .10$

American Gentlenan's Stable Guide. 12mo........ 1.00

Miles, W. On the Horse's Font. $12 m(1) \ldots \ldots \ldots \ldots \ldots \ldots \ldots \ldots \ldots . .75$

Rarey. Hotse l'amer and Farrier. 16mo.................. .50

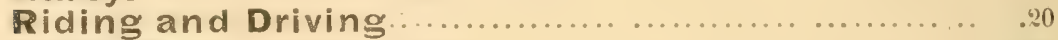

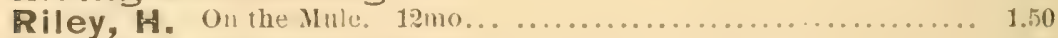

Russell. Scientific Horse-Shocing...................... 1.00

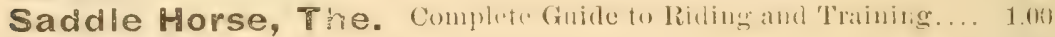

Saunders. Horse Bredine. 12mo..................... 2.00

Stewart, R. American Farmer's Horse Book. 8vo ............ 300

Stonehenge. Every Horse Owner's Cyclopedia. Evo.......... 3.75

On the IIorse in the Stable and the Field. Enylish

Ellition. $8 v 0 \ldots \ldots \ldots . \ldots \ldots \ldots \ldots \ldots \ldots .3 .50$

On the Horse in the Stable and the Field. American

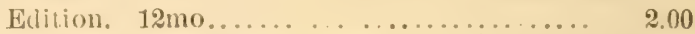

Tellor.' Disenses of Live Stock. Cloth, 2.50; Sheep............. 3.00

Wallace. American Stud-Book. Per vol.................. 10.00

Milliams. Vitrinary Medicine..................... 5.00

Vererinary Surcery ..................... 750

Woodruff. The Trotting Horse in Am rica. 12mo........... 2.50

Moods, Rev. J. C. Horse and Mn......................50

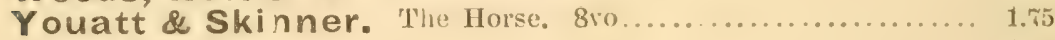

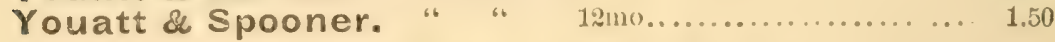

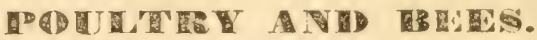

Burnham. New Poultry Book........................... 1.50

Cook, Prof. A. J. B.e-Lieper's (anideor Mantal of the Apiary... 1.2.

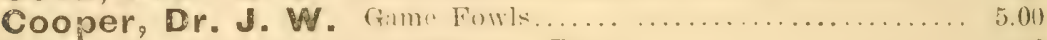

Corbett. Poultry Yard and Market. Paper................... .50

Felch, I. K. Poulty Culture......................... 1.50

Halsted. Artifial Incubation and Incuhator's. Palper.......... is

Johnson, G. M. S. Pratical Poultry Keeper. Papre......... .50

King。Be-Keeper"' Text Book... ....................... 1000

Langstioth. On the Honey and Hive Bee................

Poultry. Brenling, Rearine, Feeding ete. Bumis ........ ... .50

Profits in Poultry and their Profitable Manage-

ment. Most complete Work extant.................... 1.00

Quinby. Mýteries of Bee-Keeping Explained (Editod hy L. C. Rut). 1.50

Penwick. Thermostatic Incubator. Paper $36 \mathrm{c}$. Clorh........... .56

Root, A. I. A, B, C, of Bee-Culture....................... 1.25

Standard Excellence in Poultry ................... 1.00

Stoddard. An Eq⿳-Farm. Revised and Enlarged............... .50

Wright. Illustrated Book of Poultry..................... 8.00

Practical Ponltry-Keeper....................... 2.00

Practical Pigeon Keeper......................... 1.50 


\section{ARCHITEOTURE, ETO.}

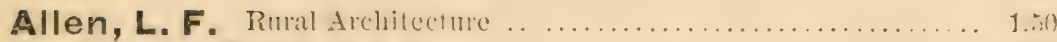

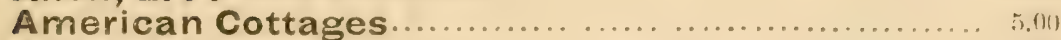

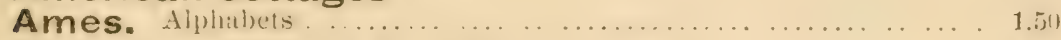

Atwood. Comtry and Sububan Houses................. 1 ;0

Barn Plans and Qut-Buildings ................... 11

Bell. Carpentry Made Easy............................... . .

Bicknell. Cottage and Villa Aichitecture............... $4(00)$

Detril Cottage and Constructive Arrhiteciure........... (i.)

—_Modirn Architectural Designs and Details.............. 10.00

- Public Buildings. New................... . 2.50

- Street, Store, and Bank Fronts. New............. 2.50

Sthool-Honse and Cinuch Architecture............. 2.50

Stables, Out-buildiuers, Fences, etc.............. 2.50)

Brown. Building, Table and Estimate Book.................. 1 50

Burn. Drawing Books, Architectural. Inlusurated and Ormanental.

8 Vols. Eirch............................ 1.00

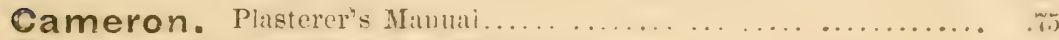

Camp. Huw Can I Leam Architecture.................. .50

Copley. Plain aud Ornamental Alphabets ................... ; 10

Cottages. Hints on Economical Buildiugr... ................ 1.00

Cummings. Architectural Details...................... tico

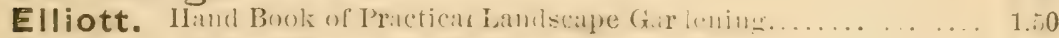

Eveleth. Schonl-Ifonse Architucturc..................... 4. . .

Fuller. Artistic Homes............................. 8.50

Gilmore, Q. A. Roads and Street Parements.............. 2.50

Could. Anerican Stair-Builler"s Guile. ................... . 250

Carpenter"s and Builder"s Assistant.................. 2.50

Hodgson. Steel Squnre .................................. 1.

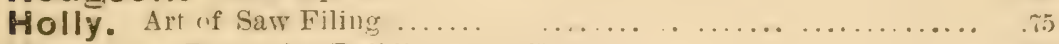

Harney. Bums, Out-Bnildin-s, and Fences ................. 4.00

Hulme. Mathematical Drawing Instruments. . . . . . . . . . . . 1.50)

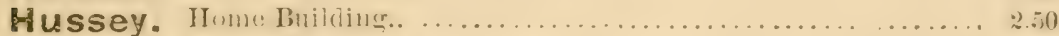

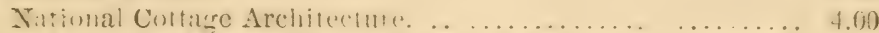

Homes for Home Builders. Just Puhlished. Fuly [ilumatin. 1.50

Interiors and Interior Details........................

Lakey. Village and Country Hollses ....................5 (1)

Modern House Painting ...........................

Fifonckton. National Carpenter and Joiner .............. 510

National Stair-Builder.................... 5.(11)

Painter, Cilder, and Varnisher's Companion.... 1. II

Palliser. American Cottage Homes............................ (n)

Ilodel Homes. . . . . . . . . . . . . . . . . . . . . . . . . . . . 1010

Lscful Details............................ $\quad 2.10$

Plummer. Carpenters' and Builders' Guide................. is

Powell, Fomblations and Fomciation Walls....................

Reed. Cottane Ifon

Ifouse Plans for Everyboty. .

Dw.llin...... . . . . . 


\section{Our Very Latest Publications.}

Through the Yellowstone Park on Horseback. By

GUN. (… W. WINGATE ............................ 1.50

Fly-Fishing and Fly-Making. By KEENE............. 1.50

How to Mandle and Educate Vicious Horses. By

O. R. Gleason..................................... 1.C0

The Law of Field Sports. By Geo. P. Suiti ........... 1.00

Bridle Bits. A Trealise on Practical Ilorsemanship. By CoL. J. C.

Battersux. ................................. 1.00

The Percheron Horse in America and France .. . 1.10

Profits in Poultry. Usclul and Ornamental Breeds... ......... 1,i0

Cape Cod Cranberries. By James Webi. Paper......... . 50

How to Plant. By M. W. Johnson......................... .50

The American Merino for Wool and Mutton. By

STEPHEN I'owER................................... 1.75

\section{$\longrightarrow \infty+\infty$ \\ New and Revised Editions.}

Hallock. Sportsman's Gazettecr.......................... 3.10

Stewart. Irrigation for the Farm, Garden and Orchard............ 1.50

Farm Implements and Machinery. By THoras...... 1.50

Egg Farm. By Stoddard. "Cloth....................... .50

Play and Profit in Garden

Silos and Ensilage ................................, ${ }_{50}$

Send Postal for Complets Catalogne of our Publications regarding Ilorses and Ilorsemanship, Innting, Fishing, and all other Out-Door Sports and Pastimes.
0. JUDD CO.
DAVID W. JUDD, Pres't,

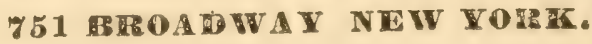






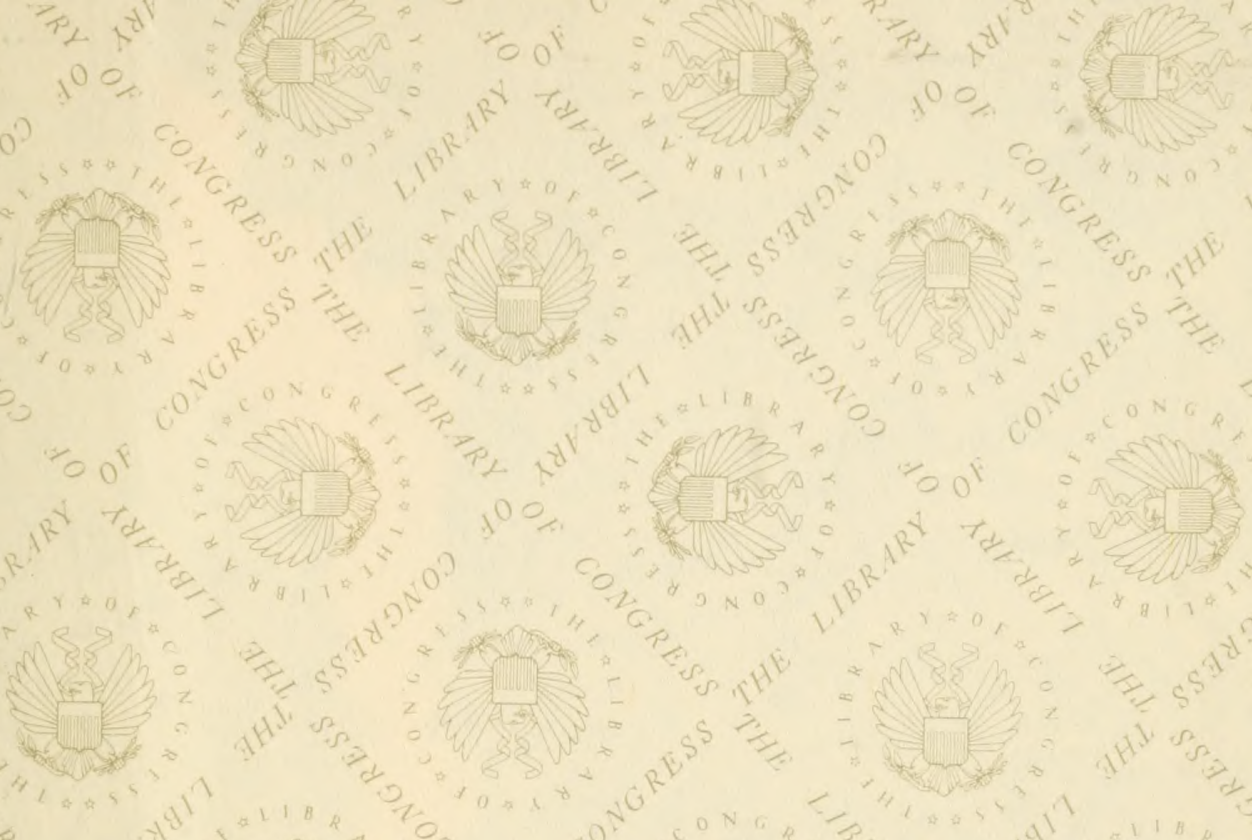

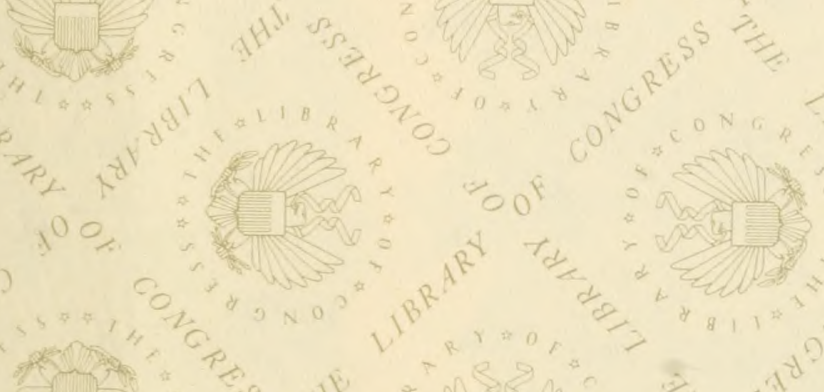
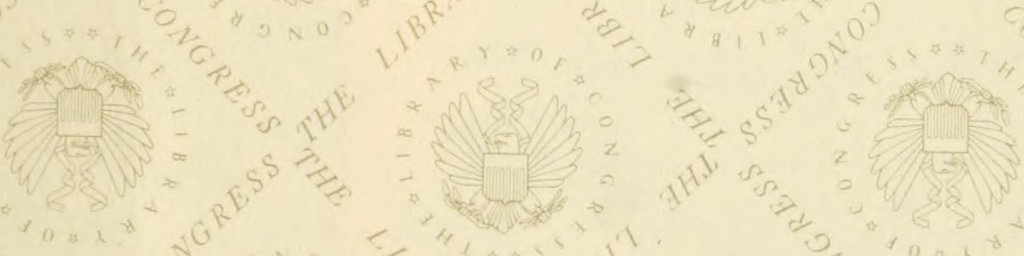

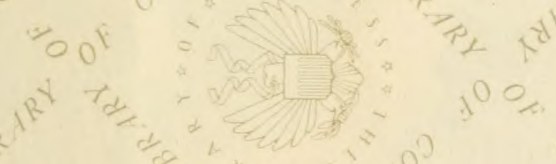

$0^{\circ} \mathrm{CON}^{\circ}, \mathrm{O}_{\mathrm{s}}$
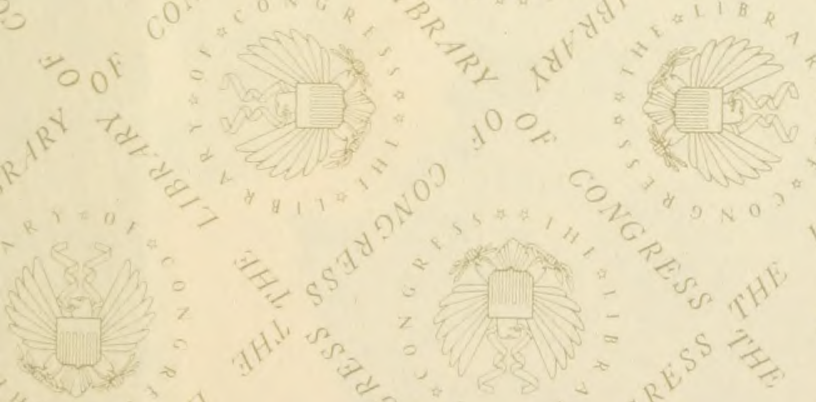

$\pi$,

, 00

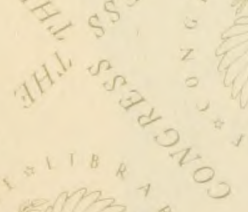
P

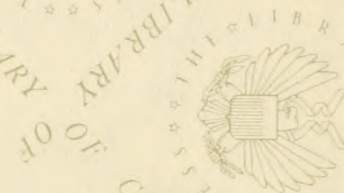




\section{LIBRARY OF CONGRESS} ||||||||||||||||||||||||||||||||||||||||||||||||||||||

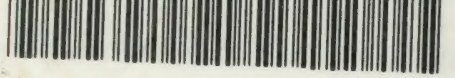

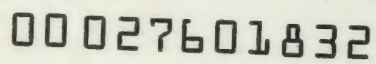

。

(1)

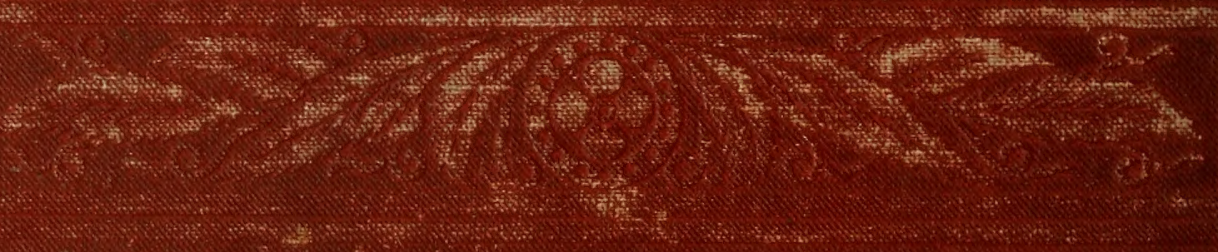

